STATE OF ILLINOIS

DEPARTMENT OF REGISTRATION AND EDUCATION

DIVISION OF THE

NATURAL HISTORY SURVEY

THEODORE H. FRISON, Chief

Vol. XIX. BULLETIN Article III.

\title{
The Plant Lice, or Aphiidae, of Illinois
}

BY

FREDERICK C. HOTTES

AND

THEODORE H. FRISON

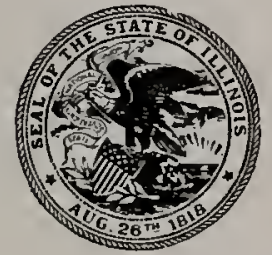

PRINTED BY AUTHORITY OF THE STATE OF ILLINOIS

URBANA, ILLINOIS

SEPTEMBER, 1931 
STATE OF ILLINOIS

DEPARTMENT OF REGISTRATION AND EDLCATION

M. F. WaLsh. Director

BOARD OF NATURAL RESOURCES AND CONSERVATION

M. F. WALSH, Chairman

WILIAIM TRELEASE, Biology

Henry C. Cowles, Forestry

Edsox S. B.istix, Geology

William A. NoYes, Chemistry
Johx W. Alvond, Engincering

Charles M. Thomrsox. Representing

the President of the University of

Illinois.

STATE NATURAL HISTORY SURVEY DITISION

THEOnork H. Frisox, rhief

H. C. Orstring. Entitor

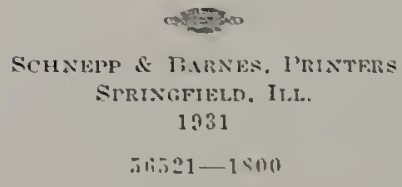




\section{CONTENTS}

\section{PART}

Introduction

.

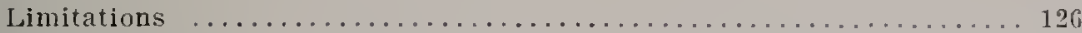

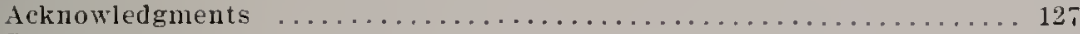

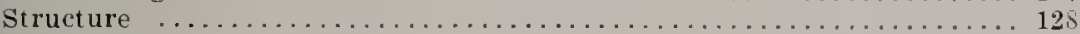

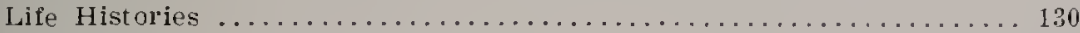

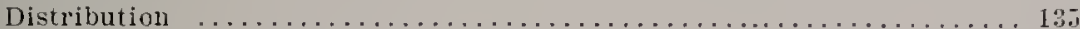

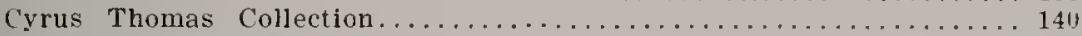

Designations of Types.............................. 141

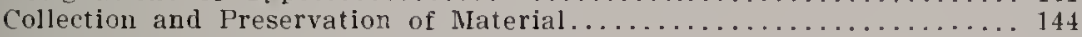

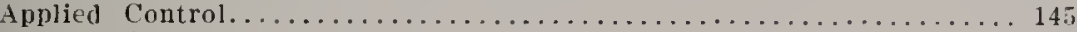

Natural Control and Interrelations...................... I 4 ?

\section{PART II}

Family Aphiidae ( ith Key to Subfamilies).................. 148

Subfamily Aphinae (with Key to Supertribes) ............... 149

Supertribe Lachnea (witl Key to Genera).................. 150

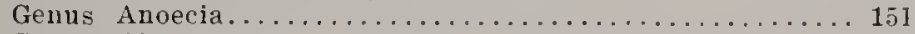

Genus Cinara............................... 158

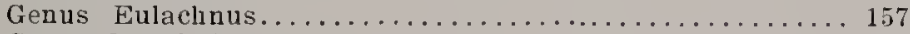

Genus Longistigma......................... 157

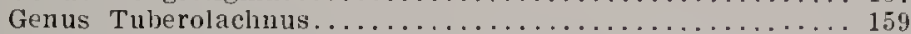

Supertribe Chaitophorea (witl Key to Genera)............ 16)

Geuus Amphiceridus........................... 160

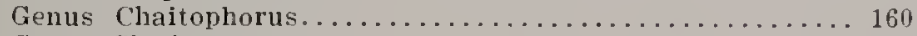

Genus Clavigerus............................ 165

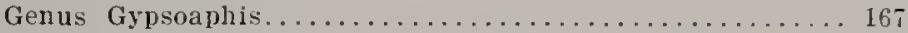

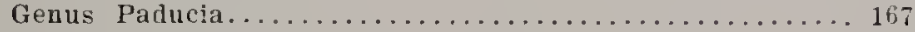

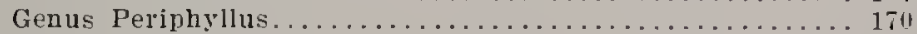

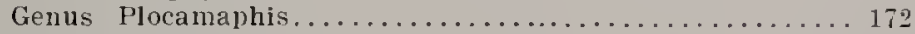

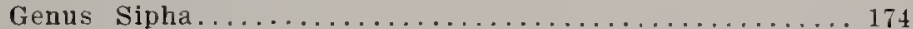

Supertribe Aphiea (with Key to Genera) .............. 175

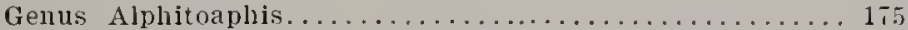

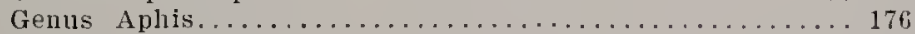

Genus Asiphonaphis........................... 225

Genus Brachycolus.......................... 228

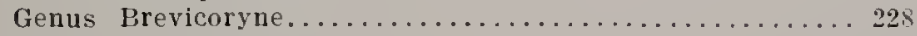

Genus Cavariella............................... 229

Genus Cerosipha.............................. 229

Genus Hyalopterus.......................... 231

Genus Hysteroneura........................... 232

Genus Rhopalosiphum........................ 224

Genus Toxoptera........................... 241

Supertribe Callipterea (with Key to Genera).............. 242

Genus Calaphis.............................. 243

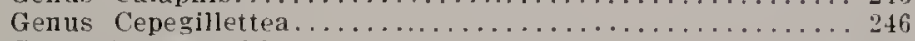

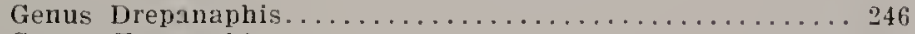

Genus Euceraphis............................... 249

Genus Iziphya............................. . . 250

Genus Velanocallis................................... 25 


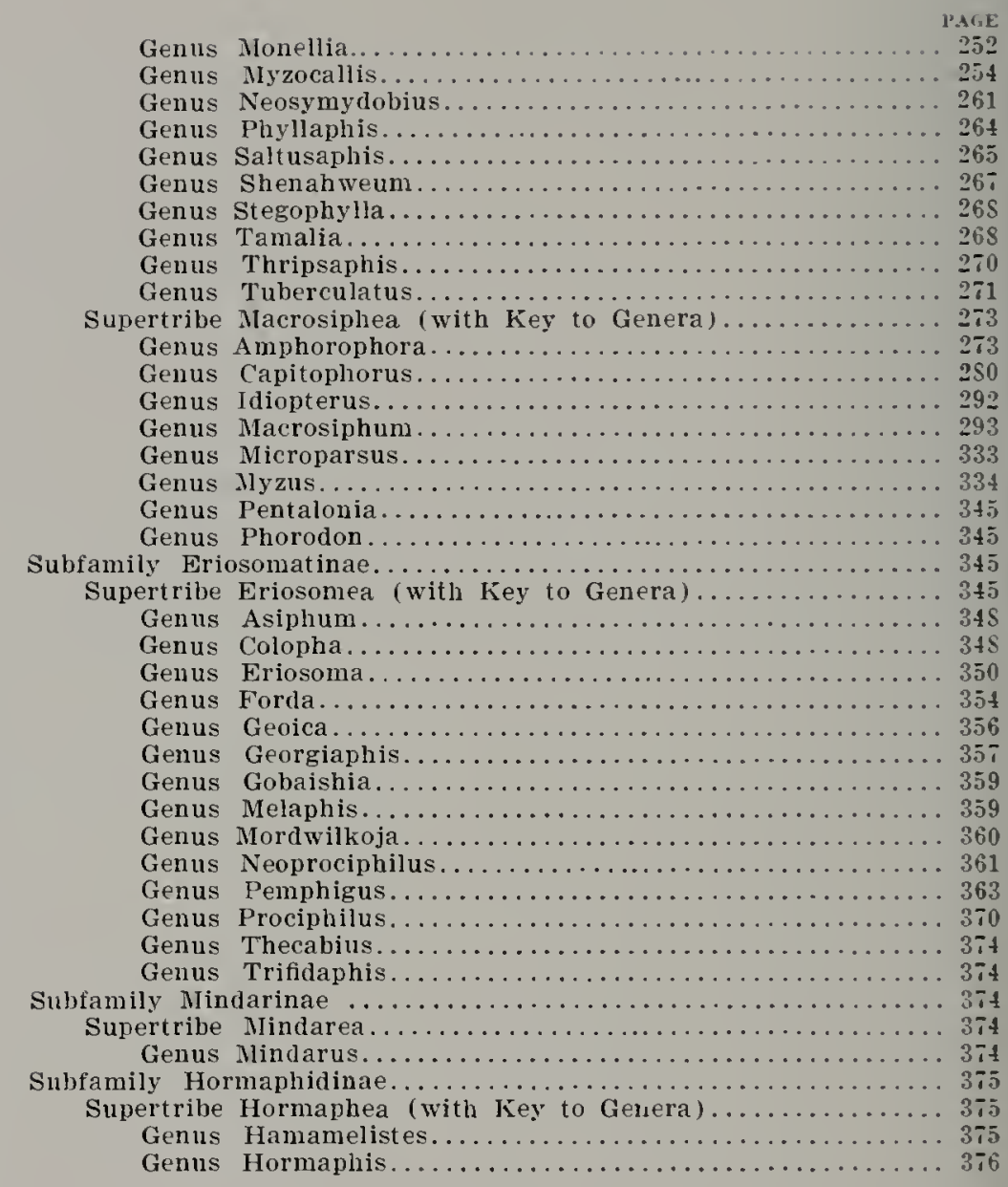

\section{PART III}

Keys to Species of Plant Lice Grouped with Reference to Host Plants:

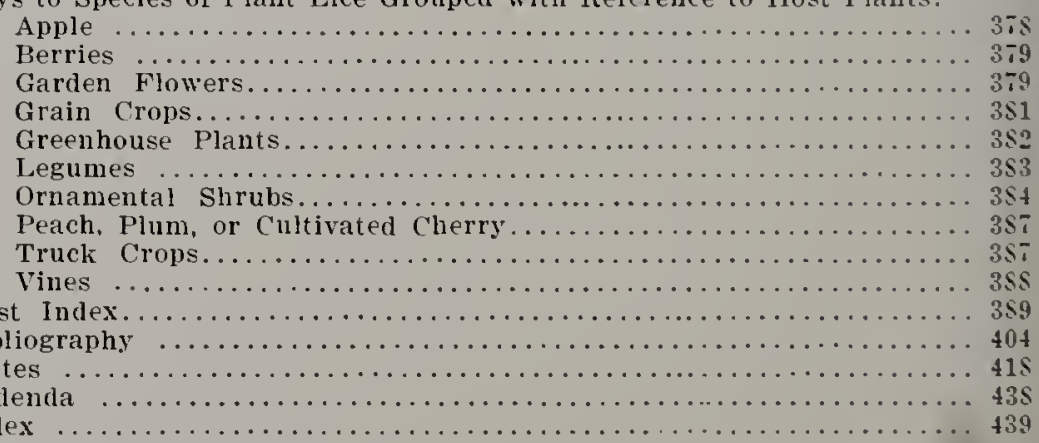




\title{
'THE PLANT LICE. OR APHIIDAE. OF' ILIANOIS
}

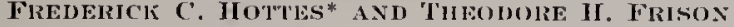

\section{PART I \\ INTRODUCTION}

A cursory examination of the literature relating to any phase of the study of the plant lice, or Aphiidae, is sufficient to show that Illinois has contributed much to our present knowledge of these small but nevertheless often destructive and biologically most interesting insects. In fact, all of the four State Entomologists of Illinois, Walsh, LeBaron. Thomas, and Forbes, have given them considerable attention and published much of a varied nature concerning them.

Benjamin Dann Walsh, the first official entomologist of Illinois $(186 \%-1869)$, besides writing about the life histories and control of plant lice, described ten species which he thought to be new to science. IVillian LeBaron, State Entomologist for five years (18it)-18.5), published the least concerning plant lice of any of the State Entomologists of Illinois, but even he went so far as to describe one plant louse which he thought to be new. The publications on plant lice of Cyrus Thomas, the third State Entomologist of Illinois (18.5-18.5:), are without doubt the most important contributions to an unclerstanding of the classification and bionomics of the plant lice of North America published prior to 1880. Succeeding Thomas came Stephen Alfred Forbes as State Entomologist from 1882 to $191 \%$; and he, like his predecessors, recognized the importance of studies of plant lice. Besides the naming of several forms supposed to be new, he published much concerning the biology of the species attacking corn and strawberries, his studies of the species attacking corn being particularly noteworthy.

Apparently the study of plant lice has been so long and so inherently a page in the history of entomology in Illinois, that many others at one time or another connected with entomological investigations in the state have been drawn to the study of these insects. The numerous and valuable papers of Davis, Hart, and lleed are proof of this; the first mentioned, in fact, being one of the two greatest contributors to our knowledge of the plant lice of Illinois. Others, tno, such as Shimer within the state, and Monell working close to out borders. without official connections with the work in Illinois, have helperl to swell our knowledge of the plant lice. As a result of all of these studies, Illinois may well be thought of as one of the chief centers of aphidology in North America until within recent years.

In view of all of this previous work on plant lice in Illinois it may seen a bit paradoxical, then, to state that the present paper addi approximately one hundred species to our list of potential encmies. of

* Head of Tepaltment of [3iology, James Millikin Conjversity, Teealur, 1llinois, and Assistant Entonologist, llinois stite Nitural Histry" survey, sume mers of $1928-1930$. 
which thirty-six species are new to science. The reason ior thus situation lies not in the fact that the plant lice of Illinois have been ncglected in comparison with other political or geographical areas, but lecause of the wonderful and varied assortment of these insects within our boundaries, and the exceptional facilities and opportmnities uresented during the last three years for their intensive study.

Begining in May, 1928, the Natural History Survey started a famistic study of the plant lice occurring in Illinois. with the purpose of providing information concerning the number of kinds found in the state, their characteristics, distribution, host relationships, sensonal adjustments, importance as potential enemies, and a general concept of their life histories. To accomplish this program it was necessary at the very outset to plan a systematic inventory of the plant lice fama of the state. Accordingly, a study was made of all published Illinois records of these insects, and the possibilities of extending this list, based upon a knowledge of the flora of Illinois and of plant lice recorded elsewhere, were considered.

Although many species had been recorded from the state. the Survey collection of these insects was very poor and. except for a few slide mounts, consisted of old material in poor condition preserved in vials and representing but a few species. Previons to extensive field work, this old material was remounted and as much of it salvaged as possible. Based upon a knowledge of zoo- and phytogeographical ditferences in the state, certain lucalities in diverse sections were selected as offering exceptional opportunities for enriching the Survey collection and increasing our general biological knowledge of the plant lice.

Field investigations were made during three summers, $1903-1930$, beginning in May of eacl year. Collecting was first carried on in the southern part of the state. then the central part. and finally the northern part. This order was followed in spring and smmmer lecause of the seasonal differences exhibited between sonthern and northern Illinois, vernal conditions appearing in the latter section ahout two weeks later than in the former. In fall, these localities were wsually visiter in the reverse order. Each of these sections of the state wias visited two or threc times a ycar in order that varions forms of the same species might be taken and no species overlooked becat1se of different seasonal adjustments. Special attention was given to certain widely varied local habitats, such as the sand areas associated with Lake Michigan and the glacial drainage courses, the swamps and bogs in the northeastern counties, the cypress swamps in the extreme southern counties, and the widely distributcd biotas of deciduous forest and the prairic or oak-grove savanna. Over 12.000 milcs were traversed by antomohile in our field work, the general routes idlowed leing shown in lig. 1.

To avoid munecessary duplication in our collecting over a period of three summers, lists were prepared in advance of field trips giving the names of species previously taken in the locality abont to he revisited. A somewhat similar scheme of preparing lists was used in checking up on the work in a restricted area over a perind of a few days. After a certain number of species had heen taken in a given area it was usually found expedient to shift to a new locality. 


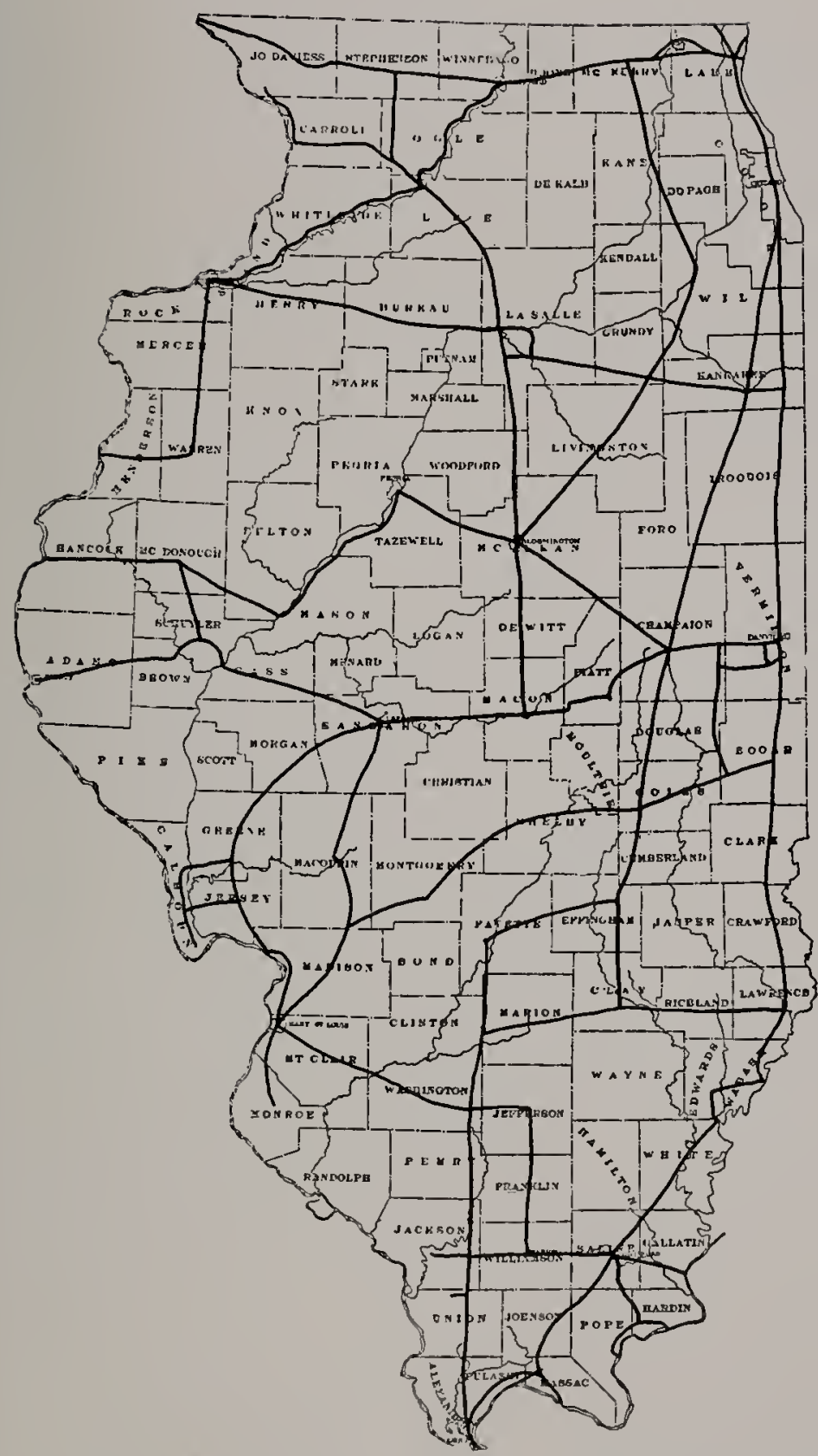

Fig. 1. Map of Illinois showing routes followed in making collections of plant lice in the state, May, 1928, to October, 1930. Many of the routes were traversed several times at different seasons of the same and different years. 


\section{Limitations}

This paper is purely a faunistic or synoptic study of the plant lice of Illinois and is not to be considered as revisional or monographic in scope. Therefore, only those references are cited in the text which refer to the original description of the species, or which are aecessary because of the introduction of new synonymy. or which provide an understanding of the specific names adopted in this paper. A revisional paper should summarize the literature of each species to date and pass upon the correctness of previous determinations recorded in the literature. This we have not attempted to do. As a result, some references in literature dealing with species by the same names as those used by us may refer to different aphids because of misidentifications upon our part or by others. We have tried, however, by careful studies of descriptions, comparisons with types in the Survey collection and elsewhere, and the submission of doubtful determinations to various specialists, to make our determinations as correct as possible.

The lack of comprehensive revisional papers in this group of insects has been a great handicap to such a study as the present hecause many nomenclatorial and taxonomic problems have had to be investigated and decisions made which are really within the field of the revisional paper. The voluminous and scattered literature, too, although providing an enormous fund of useful and indispensable information of varierl extent, has presented some problems which previons revisional work would have simplified.

No attempt has been made to cite in the text all references regarding the species reported or to summarize all information in the literature. We have tried briefly to call attention to previous records from Illinois, and by the incorporation of a few statements or citations to give the general reader some insight into the interesting features in the life histories, classification, or problems of the various species discussed.

The keys have been prepared almost entirely on the lusis of the alate viviparous females, since these forms are the ones usually taken in the field and since they usually present a better combingtion of characters for recognition than do the other forms. The iteal revisional paper would present keys to all forms. The keys given here are not devised to show phylogenetic relationships, even though at times they may do so: but they are intended primarily to make identifications as easy and simple as possible. If these keys are not all that might he desired, the difficulty of defining cortain species and groups must be considered in addition to our own shortcomings. Again. it nust be remembered that these keys are intended for the letermination of plant lice found in Illinois, and for several obvions reasons they may prove misleading if used blindly in other parts of the country.

The problem of generic concepts has been a difficult one. In some cases it has seemed to us that certain proposed genera are more comparable to the subgenera, or unnamed groups and complexes. of other families or orders of insects than they ate to geners. This was particularly forced upon our attention in the preparation of heys, and we have solved this problem to our own immediate satistaction ly re- 
ducing to subgeneric status certain groups which were formerly considered as genera but which we could not sharply differentiate in our keys. For instance, although the genotype of Illinoia may be separated from some other not closely related Macrosiphmm by a certain character, no real dividing place can be definitely established when a large number of species of Macrosiphum are compared. Therefore we have considered such complexes as true synonyms or subgenera.

Although a great deal of effort has been spent in making this paper as complete as possible, a few species have undoubtedly escaped our notice. The presence of some of these in lllinois may be predicted because of their known geographical range and the presence of their host plants in the state. The suggested outlines of the distribution in Itlinois of many of the species listed, based npon our field work, are far from complete, but with a reasonable understanding of the range of the host plants and habits of the species, a fair idea of their zoogeographical distribution in the state can be obtained by an analysis of the data presented.

The aphid specialist will soon discover that the larger classificatory units used in this paper do not agree in every respect with the groupings used by others. In some cases this is due to differences of opinion in regard to the relationship of certain genera and, hence, their inclusion in larger groups where they previously have not been placed. lin most comprehensive classifications the aphids are keyed first to subfamilies, then to tribes, then to subtribes, and finally to genera. Such an arrangement has much in its favor, particularly to the special student of aphids interested in their phylogeny. but in this famistic paper. where the ready and simple determination of species is one of the chiet aims. we lave felt that the inclusion of supertribal groupings only. between the subfamilies and genera, lias been an advantage.

Frequent citations are given in the keys to figures which have been incorporated to aid in identification. In many cases the figures cited refer to the identical genus or species mentioned in the key. In other instances, as a measure of expediency. we have cited figures which are not the identical genus or species referred to in the key. In other words, then, the figures cited in the keys refer to a condition rather than always to the identical species. The illustrations cited in descriptions and the general text, however, are based upon actual specimens of the species under consideration. It should be stated that the illustrations are not all drawn to the same scale, and different illustrations are, therefore, comparable only in regard to structural characteristics.

\section{ACKNOWLEDGMENTS}

The writers wish to express their apjoreciation of the voluminous published contributions by past and present writers to our knowledge of the biology and classification of the plant lice. Without this background it would have been impossible to complete a fainistic study of the plant lice of Illinois in the short time allotted to this project. For the loan of material and assistance in a variety of was we are greatly indelsted to the following: Dr. C. R. Cutright, Olin Agricultural Ex- 
periment Station, Viooster, Ohio: Professor I. I. Daris, Purluc Lniversity, Lafayette, Indiana: Professor E. O. Essig. University of California, Berkeley, California; Professor C. P. Gillette. Cclorado State Agricultural College, Fort Collins, Colorado; Dr. A. A. Granovsky, University of Minnesota, University Farm, St. Paul. Minnesota; Dr. T. L. Gnyton, Department of Agriculture. Harrisburg, Pennsylvania; Mr. G. F. Knowlton, Agricultural Experiment Station. Logan, UtaI, Dr. P. IV. Mason, Bureau of Entomologg: Washington. D. C.; Mr. A. C. Maxson, Great Western Sugar Company, Longmont. Colorado: Dr. O. WV. Oestlund, University of Mimesota, Mlinneapolis, Ninnesota; Professor M. A. Palmer, Colorado State Agricultural College, Fort Collins, Colorado; Dr. Edith M. Patch, Maine Agricultural Experiment Station, Orono, Maine; Dr. F. V. Theobald, South-Eastern Agricultural College, Wye, Kent, England: Professor Emeritus $17^{\circ}$. Trelease, Department of Potany. Lniversity of Illinois, Litbana. Illinois; and Professor H. F. Wilson. University of Wisconsin, Marlison. Wisconsin.

In addition we are inclebted to the following members of the stati of the Illinois State Natural History Survey or temporary assistants: Mr. W. P. Flint, for the preparation of the statement regarding control measures; Mr. C. O. Mohr and Mrs. K. H. Paul, for the prefaration of drawings; Mr. L. R. Tehon, for assistance with the names of plants: Mr. O. E. Tauler, for miscellaneous services: Mliss Alberta Dukes, for stenographic assistance; Mr. A. R. Park. Jr. for much assistance with the preparation of slide mounts. with field work, and a variety of services: and lastly we are under special obligation to $\mathrm{Mr}$. H. H. Ross, who has assisted with every detail and phase of the laboratory and field work necessary for the progress of the investigation and the completion of this paper.

\section{STRLCTLRE}

This is not the place for the presentation of a detailed description of the various features of the morphology of plant lice. It seens desirable, however, to inclucle for the benefit of the general student a hypothetical figure of an aphicl (Fig. :) , with the various parts labeled to correspond to the terminology used in the liess and descriptions, and a few drawings (Figs. 3 and $f$ ). snggesting the possihilities of variation of color markings or patterns. It has been inpossible in this paper to include color illustrations of the rarious species baseil upon live material, though the value of such illustrations camnot le clenied (see Gillette and P'almer, 1!94). The color descriptions, houever, of most of the new species described in this paper have been made from live material.

For comprehensive discussions of the morphological characters presented by aphids, the reader is reterred to papers by Baker (1915. 191id, 1920), Jackson (190i). Patch (190)!a). Sanforn (19)(1). Swain (1919), Theobald (1926). Thomas (18:9). Vickery (1908). and others. It is highly probalik that systematic studies in the tuture will make more use of certain obscure characters which are now almost entirely neglected in systennatic writings. 
In preparing our descriptions we have uniformly omitled the word millineter, or its customary abbreviation, num, when stating measurements regarding length of body, comparative lengths of antennae, width of head across eyes, and so on. We have found it advantageous to use both a compound binocular microscope with high magnifications and a wide-field binocular nicroscope with low magnifications. While the former brings out clearly the more minute characters, the latter is more useful in preparing color descriptions and in suggesting comparative and grosser differences which may be checked with higher magnifications.

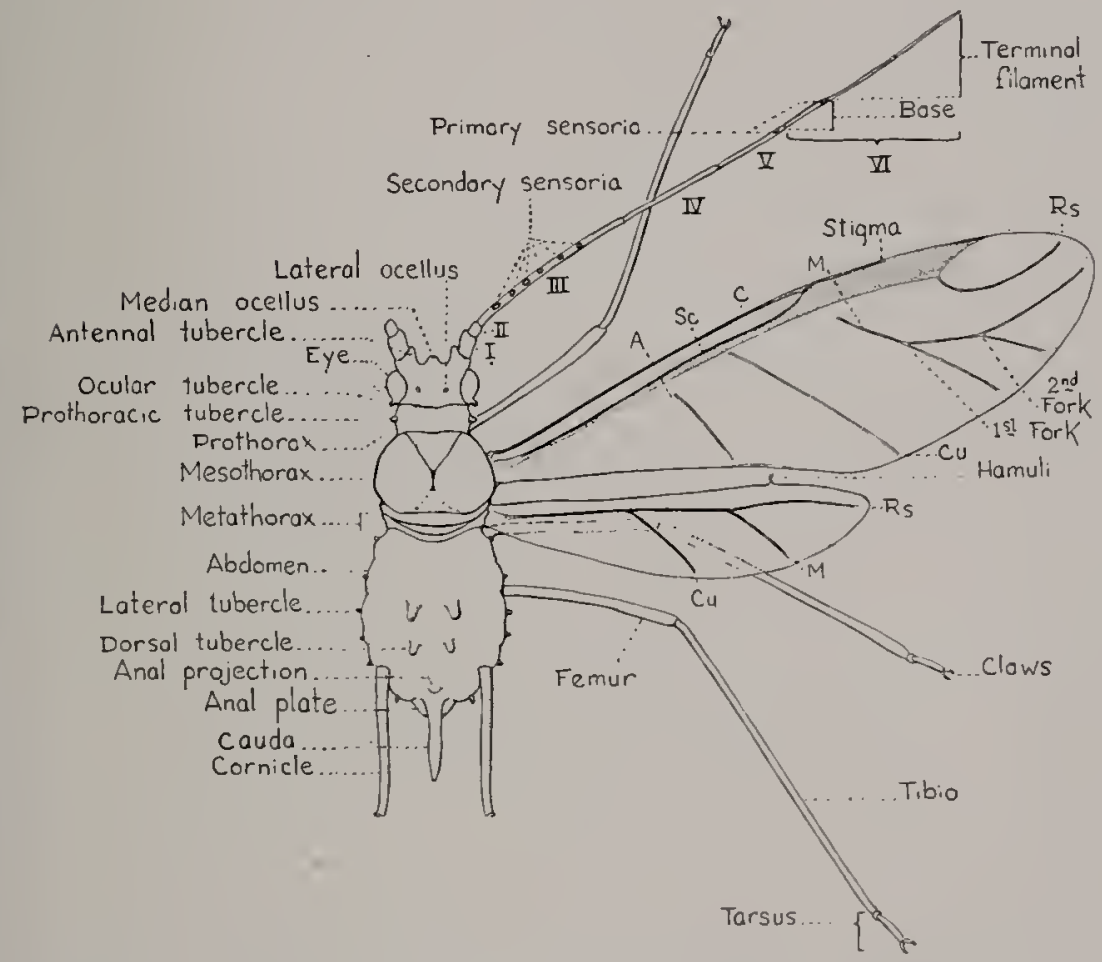

Fig. 2. Outline drawing of an imaginary plant louse. labeled to show anatomical structures used in describing and keying the various species.

In the fore wings of some aphids there is a kind of accessory thickening resembling a vein which runs somewhat parallel to the longitudinal radial vein. Since this structure has not heen named in any of the previous works consulted and since it is often worthy of note in preparing descriptions, we have proposed for it the tem of cccessory radial thickening. 


\section{Life Histories}

Aphids have so many and varied llays of existence that no one generalized account can cover all of their interesting and ofien complicated life histories. Information about the lite history of a species all too often begins and ends on a given host. leaving us in complete ignorance of the events transpiring between the time in the spring or early summer when the species leaves the host upon which it overwinters and the time when it returns to the same host again in the tall after a summer's sojourn upon some unknown host. Thus in the past. and even now perhaps, it has happened that a species of plant louse was known by one name when taken on its winter (primary) host and by another name when taken on its summer (secondary) host. This has been particularly true of those migratory species in which structural differences exist between the various forms of the same species. and it
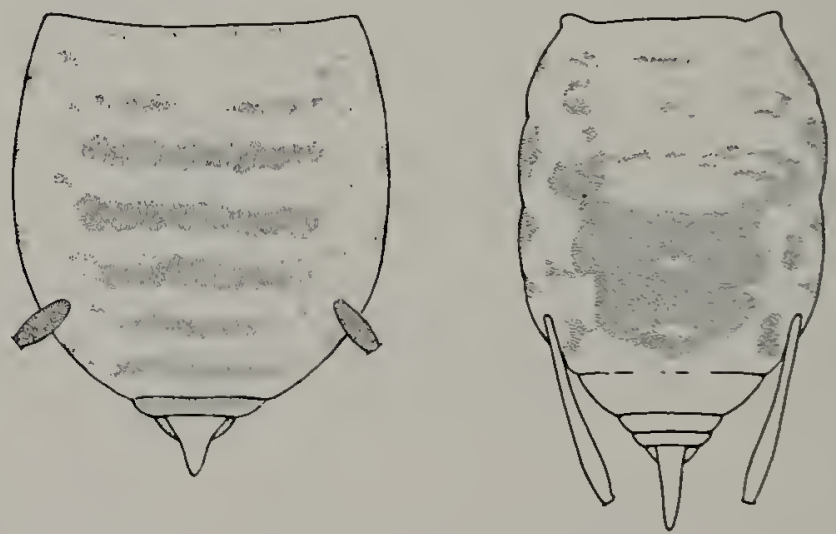

Fig. 3. (Left) Dorsal view of abdomen of the cabbage aphid, Brevicoryne brassicre (Linnaeus), showing pattern of lark marlings.

Fig. 4. (Right) Dorsal view of abdomen of Capitophorus gillettei Theobald, showing pattern of dark markings.

is especially in such cases as these that biological studies are inclispensable to a thorough and accurate picture of the relationships or classitication of these insects. Dr. Edith M. Patch (19:0) has a(mirably stated the difficulty: "To attempt to epitomize the life cycle of the aphid is like trying to draw an orderly slietch of (haos. But after all, the confusion may be more sceming than real and certain rules, beset though they may be with exceptions. govern the life of even the aphid."

An aphidls behavior is governed very largely by its fool preferences. A species that passes its entire life history on one host is said to be monophagous. If. however, a species requires two or more linds of food, it may change its diet in early smmmer by migrating from the host on which it over-winters to a new host. called the smmmer or 
secondary host, and such a species is said to be polyphagous. Some aphids, such as My'us persicac (Sulzer), are practically omnivorous in that they accept as a secondary host almost any plant which offers sufficient nourishment and succulence for their ever-increasing numbers. Strangely enough, this ability to live on many different secondary hosts does not carry over to the sexual forms, for at the approach of cold weather in temperate and northern climates such plant lice return to their specific primary hosts like so many tourists returning to their hones from vacations spent in foreign places.

\section{Gencralized Life Cycles}

In Illinois most aphids under natural conditions spend the winter in the egg stage. Is a rule, the primary host upon which the eggs are laid is a tree or shrub (Figs. 8 and 9 ), the woody twigs and branches of which offer a greater degree of permanence for the preservation of the eggs than the more fragile, pithy stems of anmul and herbaceous plants, which are often broken off at the ground and carried away by various agencies. The eggs, which are small, ovoid, and ustally black, are laid either upon the twigs near the dormant buds, or upon the bark of the limbs, or in some cases even on the trunk. The hatching of the eggs in spring is usually correlated with the opening of the buds of the host.

If the species is a leaf-feeding form, the newly hatched aphids, which are called stem nothers, wander about on the twigs and branches until they reach the opening buds. Once they find these, they settle down and begin to feed. This feeding continnes for about two weeks (the exact time depending largely on the temperature and species), and during this period the young aphids find it necessary to molt or shed their skins four times in order to provide for their rapidly increasing size. At the end of the fourtl molt these first aphids to appear become full grown.

The stem mother is almost invariably apterous (wingless) and gives birth to living young parthenogenetically (without fertilization, there being no males at this time of the year). The production of living young is known as viviparous reproduction. I stem mother normally lives for about thirty days and gives birth to numerous young during this time. These progeny, when they become mature, closely resemble the stem mother and also give birth to living young parthenogenetically.

The thircl and fourth generations may or nay not be apterous. Usually, however, especially if the species is migratory (polyphigous), a large proportion of the aphids are winged (alate) and are called spring migrants. If the species is not migratory, continuous generations of agamic fenales, either alate or apterous, are produced until the appearance of the sexual forms. The time of appearance of the sexual forms varies in accordance with the seasonal arljustments of the various species, but usually they are protuced in the fall of the year.

If the species is migratory, the spring migrants fly to the sconclary host of the species and there establish themselves and their progeny for the summer. Usually a migrating species entirely deserts its primary host for the smmmer. but occasionally the spirit of the wanderlust fails to revelop in all individuals. so that some of them remain upon the 
prinary host throughout the year. On the secondary host several generations of alate and apterous females are produced luring the remaining portion of the summer, each generation passing through the various stages of nymphal life before becoming mature. Summer generations usually require less time to mature than the stem nothers, and some individuals may become adults on the sixth or seventh day

LIEE CYCLE OF A MIGRATORY APHID

\begin{tabular}{|c|c|c|}
\hline SEASON & $\begin{array}{c}\text { FORMS ON } \\
\text { PRIMARY HOST } \\
\end{array}$ & $\begin{array}{l}\text { FOFUS ON } \\
\text { SECONDARY HOST }\end{array}$ \\
\hline WIN TER & Egg & None \\
\hline $\begin{array}{l}\text { EARLY } \\
\text { SPRING }\end{array}$ & $\begin{array}{c}\text { Stem Mother } \\
\text { Apterous viviparous } \\
\text { females }\end{array}$ & None \\
\hline $\begin{array}{l}\text { LATE } \\
\text { SPRING }\end{array}$ & $\begin{array}{c}\vee \\
\text { Alate viviparous } \\
\text { females }\end{array}$ & pring Migrants \\
\hline SUMMER & A few strays & $\begin{array}{l}\qquad \\
\text { Alate and apterous } \\
\text { viviparous females }\end{array}$ \\
\hline $\begin{array}{l}\text { EARLY } \\
\text { FALL }\end{array}$ & Ca11 Nignan & $\begin{array}{c}\downarrow \\
\text { Alate viviparous } \\
\text { females } \\
\text { sometimes alate } \\
\text { males }\end{array}$ \\
\hline $\begin{array}{l}\text { LATE } \\
\text { FALL }\end{array}$ & $\begin{array}{l}\text { Sexual forms: } \\
\text { males and } \\
\text { oviparous females }\end{array}$ & $\begin{array}{l}\text { Sometimes a few } \\
\text { strays }\end{array}$ \\
\hline WIN TER & $\begin{array}{r}\vee \\
\text { Egg }\end{array}$ & None \\
\hline
\end{tabular}

Fig. 5. Chart showing main sequence of crents in the life cycle of a migratory aphia. 
after birth. Each of then may produce from 60 to 100 progeny before dying at an age of 20 to 30 days. In the fall of the year alate females linown as fall migrants, and occasionally alate males, are produced on the summer host. These alate females return to the primary host and there give birth to oviparous females (egg-laying females) and males in case the latter are not produced on the secondary host. The oviparous females, after mating. lay fertilized eggs as described above, and in this stage the species usually over-winter.

The short time that it takes these insects to mature, associated with their tremendous reproductive capacity (there may be ten or more generations a year even out of doors in temperate clinates) led Huxley to calculate that the progeny of a single stem mother would in the fall of the year equal in weight the total weight of the population of China. This, fortunately, is purely hypothetical and never happens because cnormous numbers of aphids are destroyed by other insects e?ependent upon them for food, by unfavorable weather conditions, and by many other means.

The cabbage aphid, Brevicoryne brassicae (Linn.), may be cited as a good example of a common and econonic species with a rather generalized or orthodox life history. In Illinois this plant louse passes its entire life history, that is, from stem mothers in spring to sexual forms and eggs in autumn. on cabbage or related plants. There is no true or rhythmic nigration from, or desertion of, the spring food plant, but simply a dispersion of individuals from time to time to other cruciferous plants.

Many other aphicls, such as the various species of Cinaru that feerl on pine and certain species inhabiting oaks and birches, do not nigrate from their primary food plants to secondary ones, but spend the entire life cycle upon a single host or at least upon very closely allied hosts. The alate foms of these monophagous aphids serve only to distribute the slecies, and not to satisfy a desire for a change in diet as do those of polyphagous species. Certain species, such as Myzus cssigi Gillette and Painer, living on columbine, and Aphis rociadac Cockerell, living on larkspur. find their hosts becoming unsuited for them ver! early in the summer, but instear of developing a migratory luabit to nore suitable hosts they meet this adversity hy producing sexual form, and laying eggs, at an early date.

A step further, lut still a more or less generalized life cycle, is prescnted by the rusty plum aphid, II ystcroncura sctariac (Thomas), shown in Fig. 30. This plant louse, which over-winters upon plum, migrates in early summer to varions grasses upon which it spends the remainder of the summer. In fall certain alate viviparous fonales, the fall migrants, again return to plum in order that the life cycle may be completed on the primary host. Other examples of species with secondary hosts but still with more or less generalized life histories are: Rhopalosiphum prunifoliae (Fitch), which migrates letween apple and cercal crops (lig. 31) ; Iy yoloptcris pruni (Geoffroy), which migrates between plum and certain grasses; and Aphis illinonsensis Shimer, which migrates letween viburnums and grape (loig. "?.). 


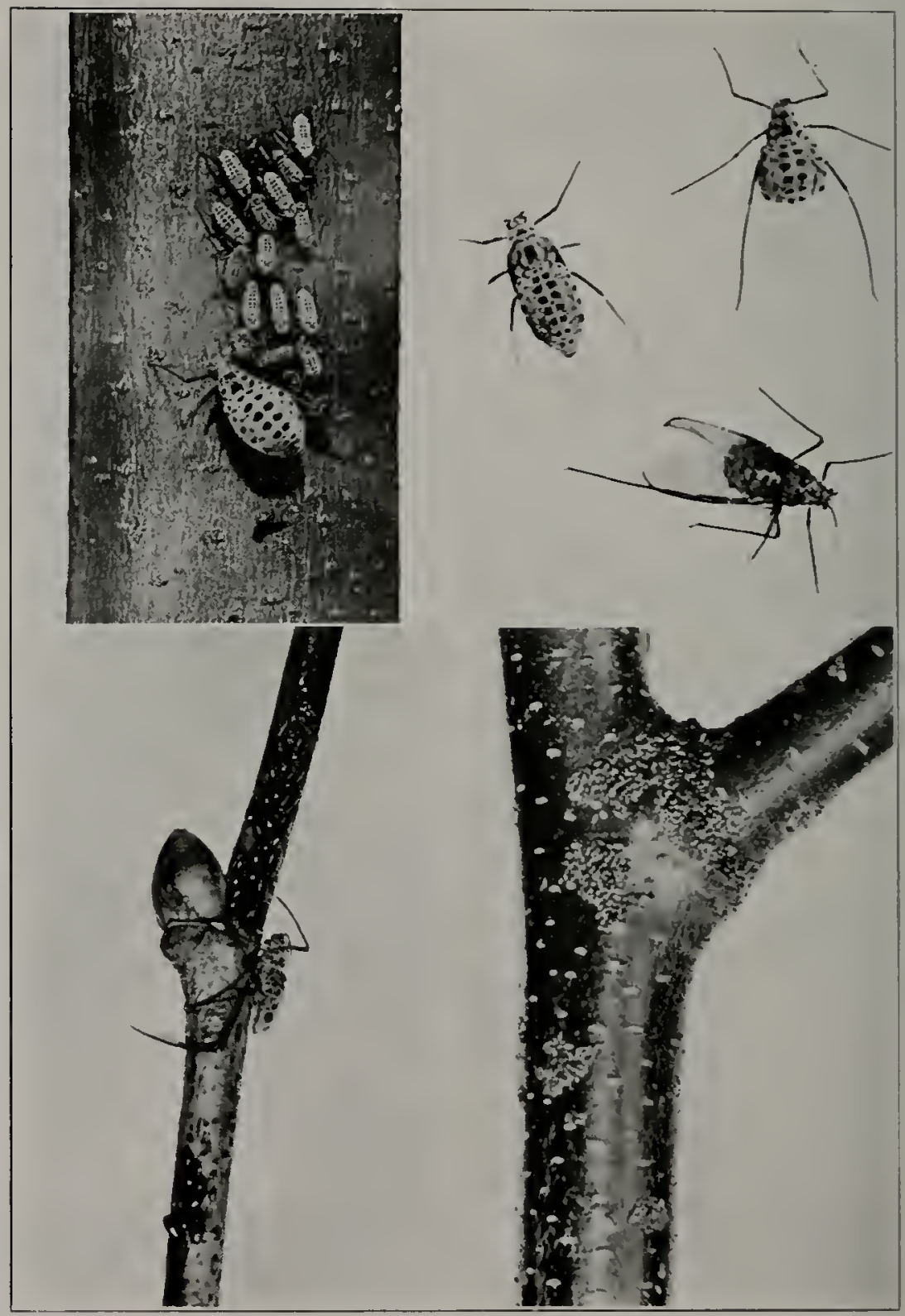

Fig. 6. (Lmper lefi) Apterous viviparous female and young uymplis of Longistigma caryap (Harris) on the sycamore, Plafanus occidenfolis: Lrbana. Oet. 14, 1929.

Fig. 7. ( ( of Longistioma caryar (Harris): Urbana. Oct. 9. 1929.

Fig. 8. (Lower left) Oviparous female and eggs of Longistigme caryut (Ilarris) on the basswood (Tilia Americana): Urbana. Oct. 15. 1929.

Fig. 9. (J.ouer rioht) Egg masses of Calaphis betulacolens (Fitch) on low branches of the canoe birele (Bctula alba var. paplrifera): Erbana. Oct. 15,1929 . 


\section{Specialized Life Cycles}

Many plant lice have gone so far, in the development of generations living under difficult conditions, that the forms freguenting the secondary host have changed structurally and are markedly different from those produced on the primary host. For example, most of the plant lice producing true galls on the primary host plant (Figs. 10, 41 , $\pm \therefore, 49)$ have very complicated life histories. Some of the common species producing galls in spring and early summer on poplars (Pcmpligus populi-transicrsus Riley and P. populicaulis Fitch) migrate to the roots of various grasses for at least part of the summer. The alate females which return to the poplars in late fall or early spring are called sexuparae and give birth to odd-appearing sexual forms.

Very complicated life histories are exhibited also by several species in Illinois which migrate between very distantly related plants. Anong these may be named Hamamclistes spinosus Shimer, Hormaphis hamamelidis (Fitch), and Prociphilus tessellatu (Fitch), which is one of the few aphids known to hibernate in temperate clinates as nymins.

Hamanclistes spinosus Shimer hibernates on white birc!n in the form of greatly modified individuals (Fig. 40), resembling coccids more than they do aphids: descendants of these hibernating coccid-like aphids fly in early spring to witch-hazel, upon which the sexual forms are produced. The eggs are soon laisl but do not hatch until May or Jume of the following year. Descendants of the individuals hatching from the over-wintering eggs on witch-hazel migrate to birch, where other generations soon modify themselves into the coccidlike individuals mentioned above. Thus this species spends the winter on both of its hosts but in two different ways.

Prociphilus tesscllatu (Fitch) migrates between maples and alders. The sexual forms are produced on maples by migrants leaving the alclers in fall. The over-wintering eggs produce stem mothers in spring, which produce generations (accrifolii Riley) destined to return in summer to alders. Although interrupted on its probable origina! host, the maple, the life cycle may continue on alders until the colony is clestroyed by accident, disease, death of the host plant, or attack by enemies.

In warm climates, and uncler greenhonse conditions in coller climates, the life histories of aphicls may be so noclified that they may go on indefinitely reproducing viviparously for years. Certain subterranean species, too. like Geoica squamosa Hart, have beconie modified to an entirely subterranean type of life, so that the aerial forms have dropped out of existence, at least in certain geographical areas.

\section{DISTRIBUTION}

In many ways the plant lice offer much material for the stuctent of zoogeographical distribution in temperate climates. They are large enough as a fannily to give 115 a sroup of closely related organisms surpassing in the number of species within the confines of our state such familiar, larger. and varied taxomomic groups as the trees, fishes, birds, or mammals. Two easily recognized factors, together with many others less tangible and apparent, have conspired to make the plant louse 
fauna of Illinois an extensive one; namely: the fact that aphid: as a group are preeminently at home in temperate climates and that the flora of Illinois upon which they directly depend for sustenance is a large and varied one. comprising components characteristic of the cypress swamp: of the south, the tamarack swamps of the north, the prairie. the deciduous forests, and local biota of diverse composition.

It seems clear at the present time in Illinois that the zoogeographical distribution of our plant louse fauna is governed primarily by the distribution of their plant hosts, all other factors being secondary and
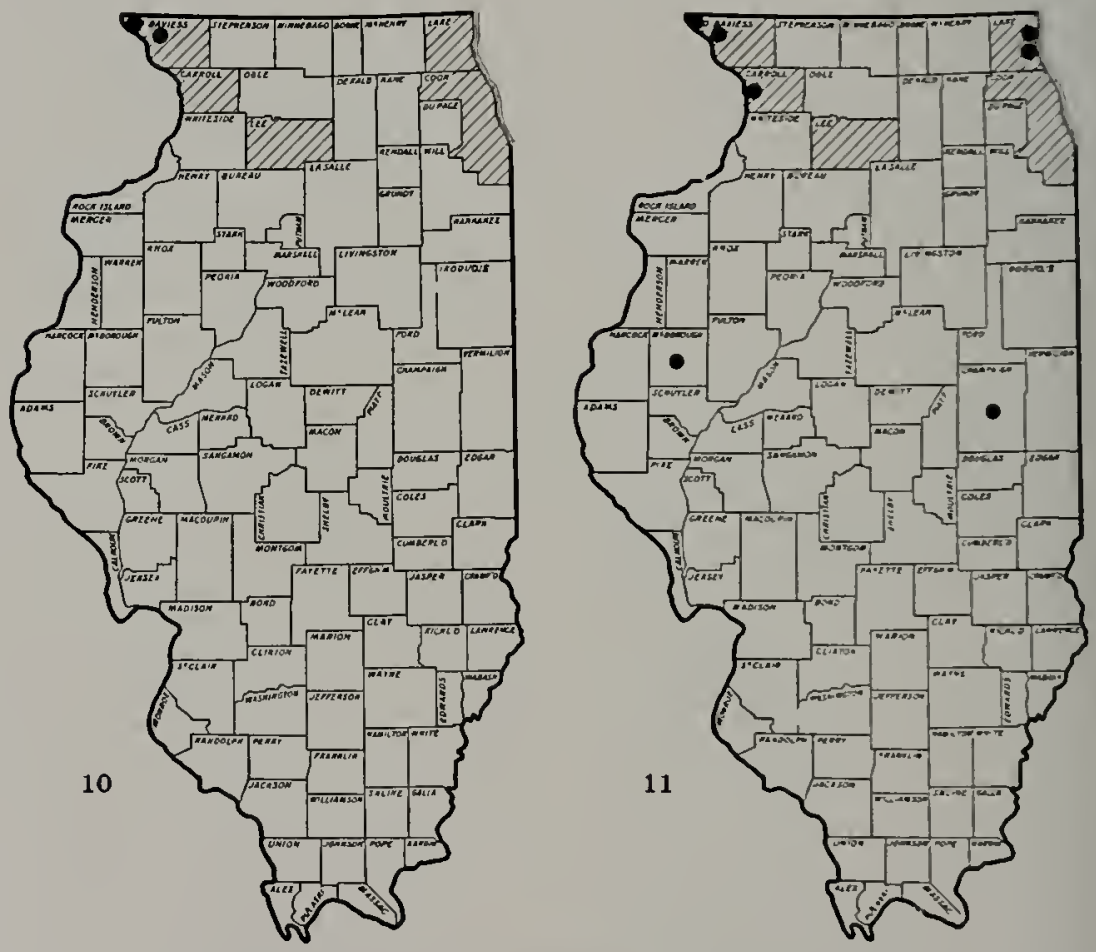

Fig. 10. (Left) Distribution of Euceraphis betulae (Foch) and its host. the canoe birch, Betula alba var. pamyrifera.

Fig. 11. (Kight) Distribution of Calaphis bctulaccolens (Fitch) and its host, the canoe birch, Bctula alba var. pamyrifera. Dots in the central portion of the state indicate occurrence on planted trees.

often of a fluctuating character. This generalization, obvious to the student of the aphids, is readily illustrated by the maps in our file showing the known distribution in our state of all species of aphirls known to occur in Illinois with the distribution of their hest plants. A few of these maps are reprofluced here (Figs. 10-1i). On each map the dot: indicate licalities in which the species has been collected and the crosshatching inclicates the counties in which its host has been recorded as nitive. 
Of course, the physiological nature of the various species plays an important part in their distribution and abundance. It must not be forgotten, however, that the plant lice have developed after the plants and have had to fit into a floral pattern probably previously and certainly independently determined. The tamarack of our northern bogs: would continue to live, conditions being favorable for its existence, withont its aphid. Cinura laricis (Hartig) (Fig. 1?), but since the aphid has become restricted to this one host it could not survive without the tamarack. Where the physiological make-up of a species of aphid in
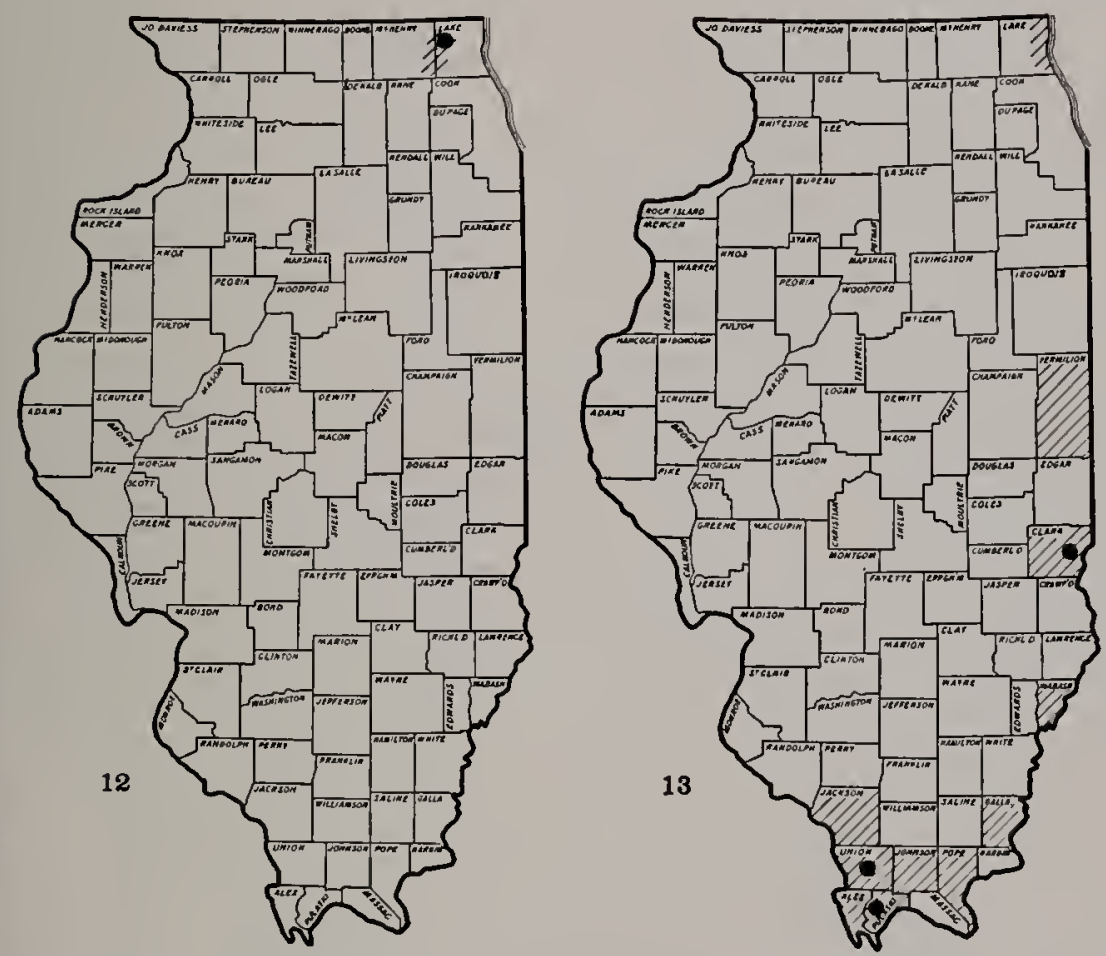

Fig. 12. (Left) Distribution of Cinura laricis (Hartig) and its host, the tamarack, Larix laricina.

Fig. 13. (light) Distribution of Phyllaphis fagi (L.) and its host, the beech, Fagus grandifolia.

Illinois has tightly tied it up with a single species of host plant, or several very closely related host plants, that aphirl obviously cxists only where its host is present. Many examples of the primary factor of host distribution governing the distribution of monophagous plant lice in Illinois could be cited (Figs. 10-13).

There is ample cvirlence to slow that the physiological constitution of an aphid has limits. secondary to the presence of host plant or host plants. which regulate the outlines of a full and complete picture of 
the distribution of any given species of aphid over North. America or the world as a whole. The aphid, Euccraphis betulac (Koch). naturally occurs in Illinois only where the canoe or paper birch (Fig.10) is native, but its physiological construction is such that it can live on specimen trees in various parts of the state. It would be a mistake to think of the present natural distribution of this plant louse as we find it in Iilinois as being strictly in conformity with certain optima of temperatures. humidities, and other meteorological factors. The maximum extent of its distribution certainly can be linited or influenced by such factors,
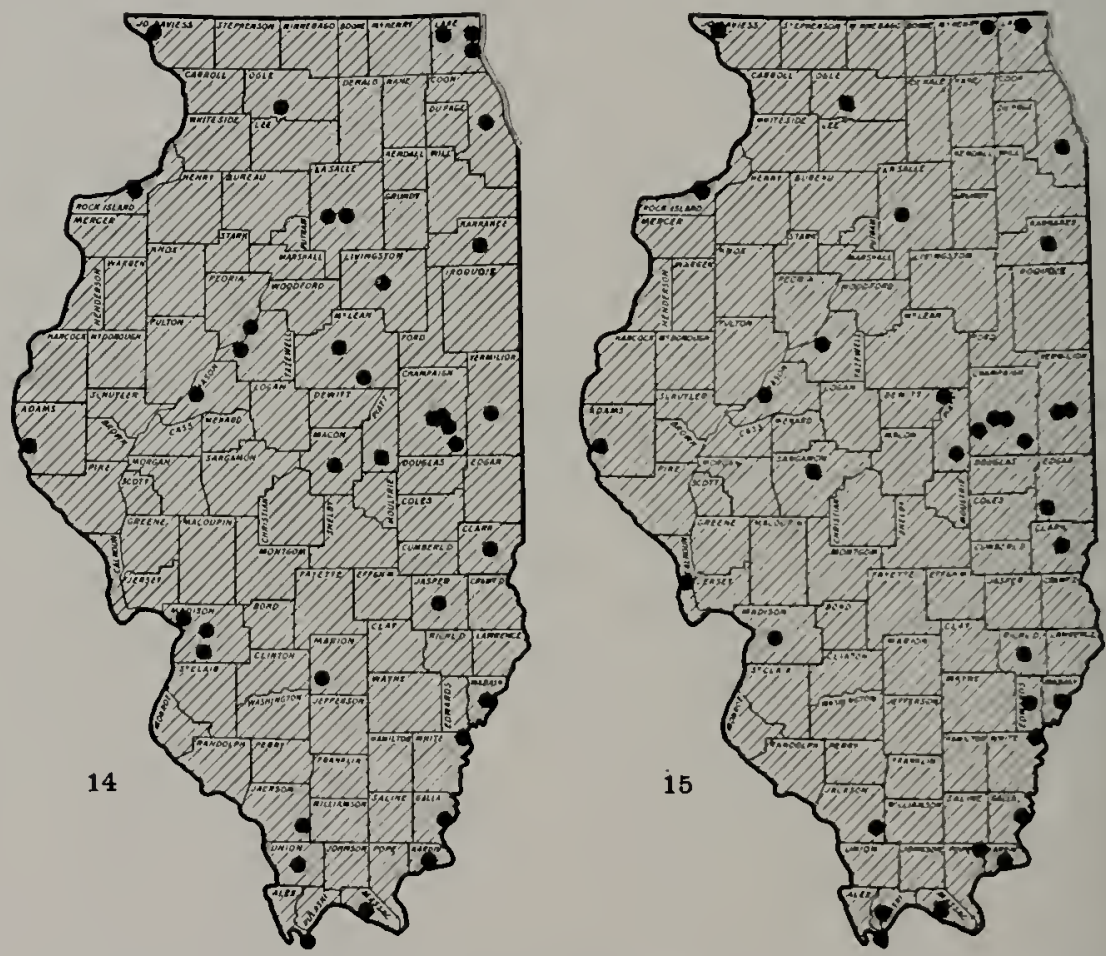

Fig. 14. (Left) Distribution of Aphis pomi DeGeer and one of its many hosts, the cultivated apple, Pymus Malus.

Fig. 15. (Right) Distribution of Macrosiphum pisi (Faltenbach) and one of its losts, the red clover, Trifolium pratense.

but these limits cannot be deternined solely by a glance at a clistribution may of this aphich as we see it in Illinois where the natural range of its host is alone sufficient to be the decisive and the liniting factor.

There are, no doubt, species of plant lice in lllinois which, in spite of having a suitable host or combination of hosts in all parts of the state, exhibit a tendency of "sontherness" or "northernes" of chistrilution because of liniting factors of a plysiological nature. Our survey of the plant lice fauma, however, has not been thoroush enough. 
or quantitative enongh, in all parts of the state, to bring such cases into bold relief. Aphis teminea Hottes is a conspicuons reddish brown and black species with a gregarious habit known only to occur on the wild black cherry so common in all parts of lllinois. WVe have taken it only once, in spite of diligent searching in apparently similar situations in many places throughout the state. (Fig. 1\%). Why have we not found it elsewhere? Perhaps it is a migratory form and the host combination essential for its existence rarely occurs; perhaps it is a recent or accidental introduction (only recorded in literature from
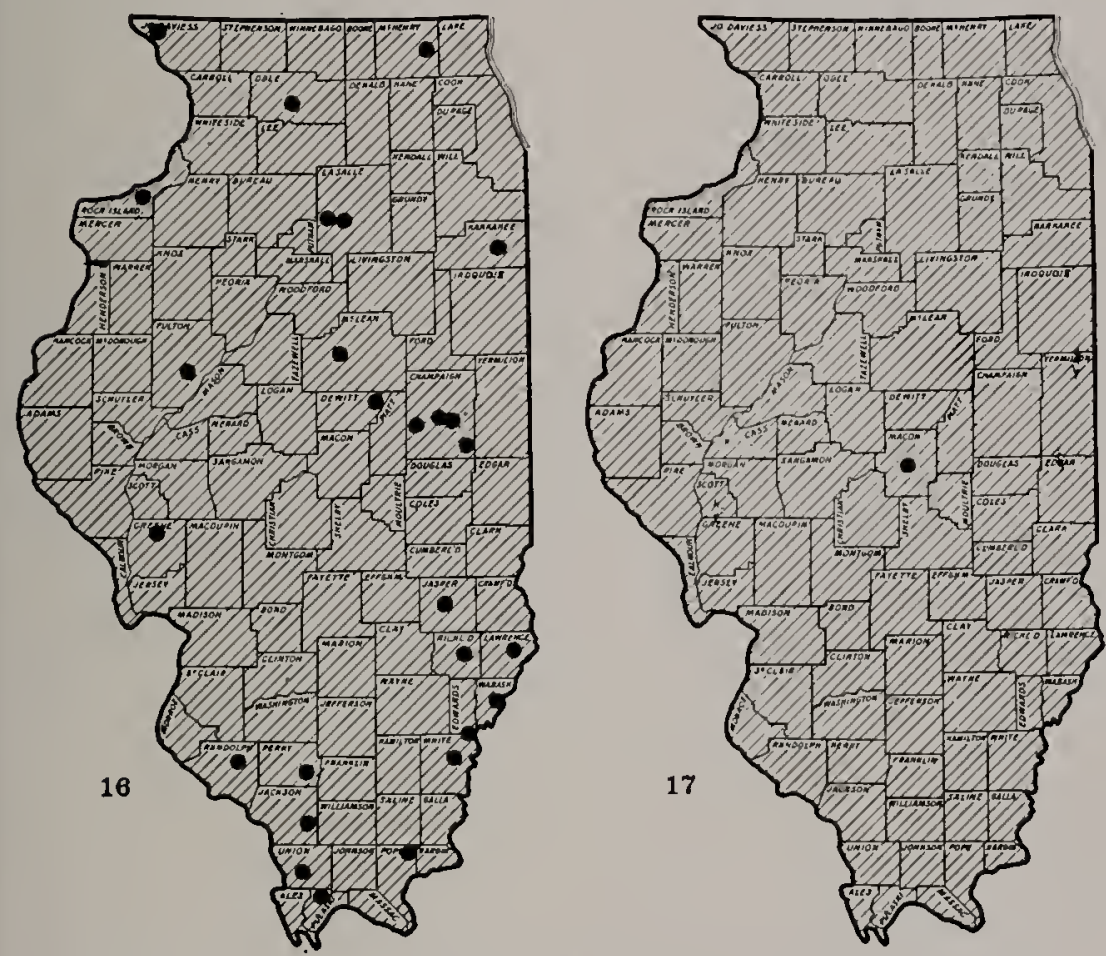

Fig. 16. (Left) Distribution of Macrosiphum granarium (Kirby) and its usuat host, oats, Avena sativa.

Fig. 17. (Right) Distribution of Aphis feminea Hottes and its host, the wild black cherry, Prunus serotina.

Maine): perhaps it is such a rarity where it does occur that it is selclom seen; lut perhaps the limiting factor is a physjological make-up which denands a certain combination of environmental factors which its host does not require. Phyllaphis fagi (Limnacus) and Prociphilus imbricator (Fitch), both founcl as yet only on beech, are at present known only in Illinois from certain localities in the extrene sonthern part of the state (Fig. 1:3) where beech trees are closely associated and numerous. We have looked for these species in other parts of 
Illinois (Fig. 13) where beech is native, but scarce, without finding them. This may be due to the physiological nature of these aphid species which ties up their distribution with large stands of beecha tree of the climax forest in Illinois. The absence of records of $P$. fagi and $P$. imbricator from certain places in Illinois, however. may be due to the lack of a stritable combination of hosts, if these species have alternate hosts, or to error in collecting. Even though definite lllinois species of aphids are difficult to select as exhibiting examples of distribution linited by the physiological constitution of the aphid, there is ample evidence from a study of the world-wide distribution of plant lice, and from experinental studies, to show conclusively that physiological constitution is an important factor, however secondary in a small geographical area as Illinois, it nay now be to a present association with host due to close evolutionary development of aphids with certain plants.

If one wishes to study the influences of tenuperature, relative humidity, and other factors as determinants in the distribution of Illinois species of plant lice, the omnivorous species afford the best prospects. As stated elsewhere, however, our Illinois field work was not thorough or quantitative enough to bring into bold relief examples illustrating this correlation. Illinois appears to us to be located in the center of the aphid current-a group of insects ideally adjusted to temperate climates.

\section{Crrus Tuonas Collection}

Davis (1913), in an earlier article of the present bulletin series. reported upon the Aphiidae in the Cyrus Thonlas collection. !elonging to the Survey, which at that time could be associated with data or recognized as types. In that article the types, or probable types, of twelve species were reported as recovered and notes given regarding their systematic status, insofar as their identification was possible by labels or bits of information associated with certain vials or slides.

At the tine of the writing of the paper by Davis, it was $110 t$ possible to report mpon much of the original Thomas material becanse many vials or slicles were associated only with a number, the key to which had been lost. In 1926 , a letter written to Professor S. A. Forbes in April 21, 1884, by Mrs. Nettie Reattie (Miss Nettie Micldleton). at one time an assistant of Thomats, was found by Frison in an old letter file while searching for data regarding the dates of publication of certain reports of the state entomologists of Illinois. This letter contained a list of numbers from 1 to $F S$ and gave data to be associated with certain numbloced vials or slides of specinnens in the Thomas collection. The fortunate finding of this letter las resulted in the recovery of the types of thirteen more of the Thomas species clescribed in $18.8-$ 1869 and the confirmation of the true "type" status of almost all 111aterial previonsly reported as heing "probable" types by Davis. It so happens that the real Thomas types previously found by Davis with one exception, were species described in the $18 i$ ) article and the types recently identificd were described in the $1 s i s$ paper. The types of all but four of the cighteen species described as new in lsis have now heen found. 
Notes concerning these recently recovered types are scattered thronghout the text under the specific names of the species to which the various types must be referred. The finding of these types ends definitely the uncertainty in regard to the specific status of some of the species originally described by Thomas. For their better preservation, all of the specinens in the Thonlas collection of plant lice in the Survey collection have been mounted on slicles. For the convenience of workers located elsewhere, the following list of the species described by Thomas is given together with notes concerning their present placement, the slide numbers assigned to them, etc.

\section{DESIGNATION OF TY'PES}

In the description of new species of aphids the anthors have departed from past customs in definitely selecting, wherever possible, a slide mount of an alate viviparous female as the holotype and a complement of mounts designated as allotypes, morphotypes, and paratypes. 'The term allotype is applied to a slide mount of a specimen of the opposite sex from the type, either when included in the paratypic series of a new species or when described for the first time in this paper. It happens that all allotypes in this paper are males. The oviparous and apterous viviparous females have been designated as morphotypes, whether included in the paratypic series of a new species or described for the first time in this paper, except where a new species has been described from the apterous viviparous female on account of the lack of alate specimens. The employment of this terminology is in line with present procerlure in other groups of insects, and it leads indirectly to the better preservation of the specinens upon which first descriptions are based-a boon to future students and revisional writers. It also directs attention to the descriptions of forms which should and will receive more study in the future.

Oftentimes but one specimen has been monnted on a slide with the encl in view of making such a mount a holotypic, allotypic, or morplotypic slide. IThere this was not possible. from lack of recognition of forms as new to science in proper time, certain specimens have been indicated by the well-known method of "ringing" then on the slide. Wherever possible, the sexual forms have been described from mating pairs or from sexual forms taken on the same host and at the same time and place.

In a few cases loctotyic slicles have been designated to stand as holotypes from a series of cotypic slides. This has been done to help eliminate nomenclatorial problems restlting fron the mixing of two species in a series of cotypic slides. Such selections are clearly noted in the text under the names of the species concerned. Certain slides in the Survey collection previously have leen designated as lectotypes, or their typic status reported upon, by Frison (19?i). 


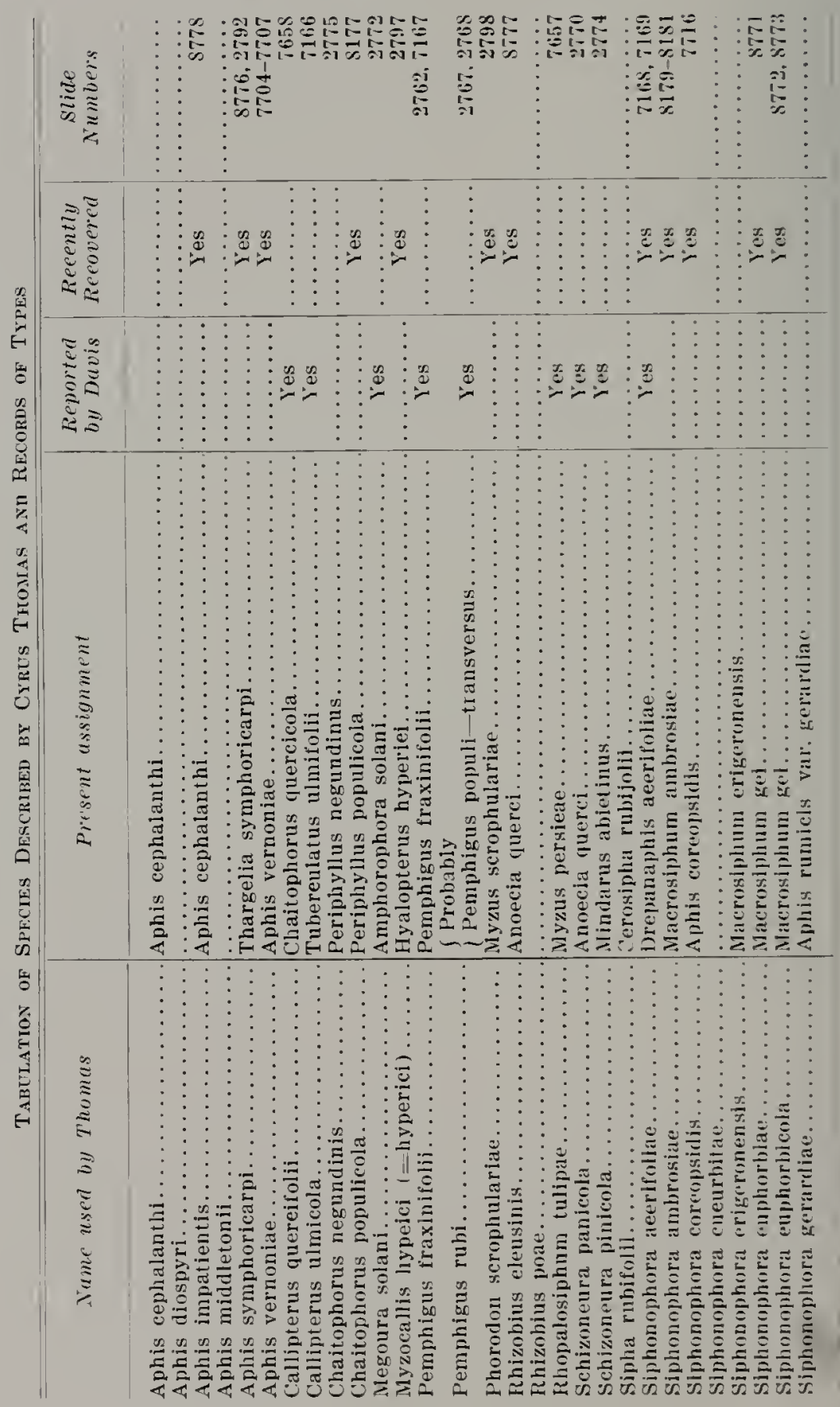




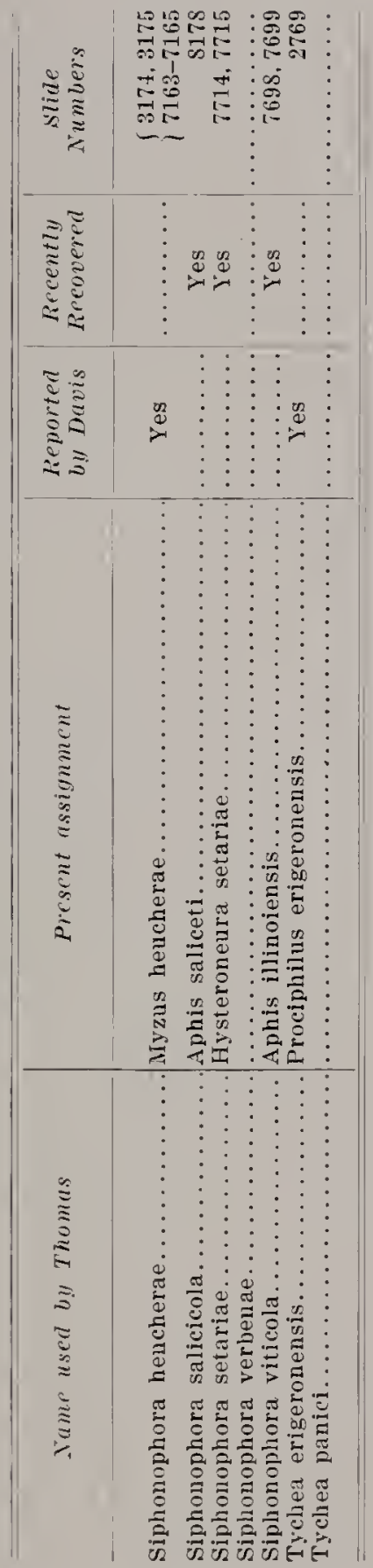




\section{Collection aNi Preservation of Miterial}

Aphid material in the field was collected by lorushing the plant lice off the host into a metal-capped vial partly filled with tissue paper to absorly moisture or by breaking off a small portion of the iniested plant and placing it, together with the plant lice, in a similar vial. Specimens collected in this manner were usually mounted the sane day or the next day, by the methods mentioned in following paragraphs. Almost all of the material collected on field trips was monnted on slides. and to do this it was necessary to carry a rather complete equipment with us in the field. The slide monuts thus made from live material, however, more than justified the carrying of the extra equipment and the spending of many hours at night making slides. It was found that three persons constituted an icleal aphid-collecting party. two doing the field work during the day while one made slide preparations, and all assisting with slide mounts at night. Without automobile facilities for rapidly transferring the field party and equipment. such intensive work on a group of insects within such a short time would not be possible.

Since plant lice are small, soft-bodied, delicate insects. they must be preserved in fluids in vials or mounted on slides. From the standpoint of maintaining a reference or study collection, and the ordinary determination of specimens, we are very partial to the preservation of all material on slide mounts. For certain morphological studies. however, plant lice may be best preserved in fluids, and an $80 \% \mathrm{c}$ alcolool solution has proved very satisfactory.

Aphids preserved in alcohol can be mounted rery easily in "Euparal," a prepared mounting flud. They are simply taken from the alcohol and mounted directly in "Enparal" on the slide. The! clear in a day or two, depending upon their size. and the mediun forms a yellowish, hard monnt. This method of dealing with alcoliolic material, especially when it is of considerable age, is more satisfactory than that of running the material through alcohol and xylol and mounting in balsan: for the treatment with the higher concentrations of alcohol, and especially with xylol, makes the legs and antennae of aphids so brittle that they break off when the cover glass is put over the insects on the slide.

For killing aphids and mounting them immediately. we have nsed the following method, which, besides being relatively fast, ustally gives very good results. With a camel's hair brush the aphids are remored from their host to a beaker ( $j 0 \mathrm{cc}$ ), where they are killed by pouring hot water over them. The water is immediately drained off and replaced with hot $95 \%$ alcohol. The contents of the beaker are then poured into a Syracuse watch glass, in which the aphicls can he handled more easily. Large or shrivelled aphids are punctured with a needle. to allow the infiltration of xylol and consequent clearing. Small. thinskimned forms do not repuire puncturing. After standing until cool, the alcolol is drained from the aphicls and xylol carefully poured over then. They are left in this until clear and then monnted in Damar balsam on "xl" glass slicles, using as thin a cover-glass as can be handled with efficiency. This method of momting gives particularly beautiful results with some of the light and highly-colored Macrosiphea. 
preserving in a measure the natural colors which are enhanced by transparency.

Certain species of aphids are hard to clear, particularly some of the large, apterous, root-feeding forms. If they do not clear after being in xylol for fifteen or twenty minutes, drain off the xylol and add a little alcohol; then draw off this alcohol after a minute or two, and add a second lot of xylol. This will usually hasten the clearing. but the entire procedure may have to be repeated several times in order to give the desired transparency. This process, however, makes the aphids very brittle and should be avoided whenever possible. We believe that Damar balsam is very much superior to Canada balsam as a mounting medium, because it forms an almost unstained medium and harclens a little faster when the slides are first prepared.

Full data concerning lyost plant, time of year, etc., should be kept associated with all collections of plant lice, regardless of the method used in their preservation. Since the natural colors of aphids are liable to be lost by any method of preservation, it is highly desirable to keep detailed color notes made from living specimens.

\section{Applied Control*}

Being soft-bodied, sucking insects, aphids are best controlled by the use of contact insecticides. The susceptibility to insecticides, however, varies greatly among different species of aphids. Many species can be killed by very mild preparations which will not affect other species. The most common materials now in use for combating aphids are soap solutions, oils, nicotine, pyrethrum, and derris. Only the more susceptible species may be killed with the soap solntions. These insecticides are applied in the form of dusts or sprays. In many cases spraying is more efficient and reliable than dusting. Because of their tremenclous powers of reproduction, it is generally considered that any control measures used against aphids must kill at least $98 \%$ of them in order to be commercially successful.

The insecticides must be applied in such a way as to come into actual contact with the bodies of the aphids. Spraying or dusting the tops of leaves where aphids are working on the underside of the leaf is of no value. The problem of satisfactory control is made more difficult by the fact that many species of aphids cause curling of the foliage on which they are feeding. It is uswally necessary to apply the dust or spray with considerable force in orcler to reach the aphids in curled foliage.

\section{Dusts}

Of the dust insecticiles, nicotine is by far the most effective. Where the fumes from nicotine dust can be partly confined around the bodies of the aphids, a very good kill may be obtained. Nicotine dusts may be purchased ready to use or may be mixed at home by several methorls. The adrantages of home nixing, or "rolling your own," are a saving of nearly one-half of the cost of the prepared chust, a better guarantec of fresh material which is of a higher killing power.

* This section was prepared by W. 1'. Flint. 
and immediate availability when needed without waiting for shipment from a distance. Good homemade nicotine dust can be prepared as follows:

For Mixing Small Quantitics of Dust.--Place o pounds of hydrated lime, talc, dusting sulphur, or other dust to be used as a rliluent. in a can, bucket, or small keg. which has a tight-fitting lid. Pour j onnces of $40 \%$ nicotine sulphate, or $10 \%$ free nicotine, over the dust in the container; add 10 to 15 small stones about the size of walnuts. close the lid tightly, and roll the container back and forth for ten minutes. Do not roll rapidly, as the dust will mix better at about 30 to $t 0$ revolutions per minute. After the mixing lias been completed and the stones removed, the dust should be allowed to stand for $2 t$ hours in a closed container before being used. If it is to be stored, it should be placed in a tight container and kept in a dry, cool place.

For Miring Larger Quantitics of Dust.--Use a j0-gallon tight barrel, or large lieg. Cut a door in the side of the barrel to make a 6 " $\mathrm{x}^{\prime \prime}$ opening. Attach the door so that it will fit tiglitly into the barrel, padding the edge with cloth or felt to prevent leakage of the dust. and fastening it on the outside so that it will be held tightly in place. Place the hydrated lime, dusting sulphur, or other dust in this container. Pour the desired amount of nicotine over the dust (see table of anounts), and add about .0 small stones from the size of a walnut to that of an egg. Close the door and roll the barrel back and forth over the ground for ten minutes. Remove the dust by pouring through a wire screen with meshes of $1 / 4$ or $1 / 2$ inch to catch the stones. Store in tight containers.

Table Showing Ayorvits of Misterials to be Lsed ix Mixisci Nicotise Dists

\begin{tabular}{|c|c|c|}
\hline $\begin{array}{l}\text { Percentage } \\
\text { desired }\end{array}$ & $\begin{array}{c}\text { Pounds of } 10 \% \text { free nicotine or } \\
\text { nicutine sulphate to be used }\end{array}$ & $\begin{array}{l}\text { Pounds of hydrated lime } \\
\text { or other dust to be used }\end{array}$ \\
\hline 1 & $11 / 4$ & 49 \\
\hline 2 & $21 / 2$ & $4 S$ \\
\hline 3 & $31 / 4$ & 45 \\
\hline 4 & 5 & $4 \overline{5}$ \\
\hline
\end{tabular}

As the materials for making the dust will keep much better than the prepared dust, it is advisable to mix only what is needed at one time rather than larger quantities to be stored for the scason. The nicotine sulphate has a more lasting cffect than the tree nicotinc, but does not give quite as high a lill of resistant insects for the same percentage of nicotine in the mixtmre.

Talie care to avoid brcathing the fumes when mixing nicoinc dust. Especially avoid holding the head too close to the mixer when pouring out the dust, as the nicotine will be strong enough to canse headache or nausea if a sufficient ymuntity is breatled.

$$
\text { Sproys }
$$

A spray that is very effective against aphicls can be macle at home very easily aud quickly by mixing one part of fo\% nicotine sulpluate with eight-hundred parts of water and four parts of "Penetrol," which is a commercial product recently developed as an activitor for micotinc. 
The "Penetrol" increases the killing power of the nicotine so that the spray can be relied upon to be $100 \%$ effective against all classes of plant lice if applied to their bodies.

A spray of nearly as high killing power may be made by using soap instead of Penetrol. In this case soft water should bc used. The following formula will make an excellent aphid spray:

$$
\begin{aligned}
& \text { Nicotine sulphate ....... } 1 \text { part } \\
& \text { Water ..................... } 800 \text { parts } \\
& \text { Soap } \ldots \ldots \ldots \ldots \ldots \ldots \ldots \text { I/2 ounce to } 1 \text { gallon of water }
\end{aligned}
$$

A number of commercial preparations for the control of aphicls are now on the market. Where these are used, they must be applied at strengths and under conditions recommended by the manufacturers.

\section{Natural Control and Interrelations}

Plant lice are often so completely held in check by natural control factors, such as parasitic and predaceous insects, fungus diseases, and unfavorable weather conditions, that applied or artificial control is not necessary. The writings on this subject would fill several volumes and it wonld be inadvisable in this paper to attempt to give a detailed account of them. The reader is referred, rather, to the numerous publications listed in the bibliography, many of which contain much information about this phase of the subject.

The clief insect enemies are the common lady bird beetles (Coccinellidae), the syrphicl flies (Syrphidae), the lace wing flies (Chrysopidae), and certain minute wasp-like insects (Braconidae and Chalcidiclae). The first three of these groups of insects are predaceous. and only the last group are internal parasites. The chiei fungus enemies belong mainly to the genus Empusa. Nany birds, also, eat plant lice and their eggs and thus aid in their control.

The interrelations between ants and aphids have attracted the attention of scientists and others from the earliest to the present times. and again volumes have been written upon the subject. It suffices here simply to state that ants frequently care for aphids in returis for a secretion commonly known as "honey-dew." ln some cases this care on the part of the ants for the aphicls is of a temporary nature, but in other cases the interrelationship has proceeded so far that certain species of plant lice are said to be absolutely depenclent upon ans. The corn root aphid (Aphis maidi-radicis Forbes) is a good example of a plant louse relying to a great extent upon ants. Forbes (188t) has shown that the eggs of this aphid are cared for by the ants during the winter. For a complete review of the interrelations between ants and aphids the reader is referred to a recent and excellent paper by Jones (1929). 


\section{PART II}

\section{FAMILY APHIIDAE}

By the incorporation of information regarding the biology and phylogeny of aphicks, along with certain structural characters. it is possible by the use of a few couplets to key the aphids into two. three. or four subfamilies, depending upon the classification adopted. In preparing a purely artificial key for the determination of the aphids for the use of persons not having esoteric information, it is impossible to key the subfanilies without resorting to the use of numerous conplets or expanding a few couplets to include numerous exceptions. In line with our policy of making keys to begin with an unknown and end with a known, without the injection of information concerning phylogeny or biology, we have been forced to use numerous couplets. This is rather indicative of the fact that the aphids can not be divided easily: concisely, or sharply into two, three, or four subfamilies comparable to the subfamilies of some other families of insects. It indicates, also. that the present classification has many points in it which are purely arbitrary and hence may be changed in the future.

It must also be kept in mind that this paper is not a revisional study in its broadest sense. and that the keys are prepared solely for the recognition of our Illinois fauna. Species not included in this paper may or may not key out correctly.

\section{KEY TO SUBFAMILIES \\ (Based on alate viviparous females)}

1. Antennae with pronounced annular or band-like sensoria almost completely encircling segment (Fig. 224$) \ldots \ldots \ldots \ldots \ldots \ldots \ldots \ldots$

- Antennae with circular (Fig. 2S3), transverse (Fig. 226) or elongate-oval (Fig. 227) sensoria, not almost completely en.

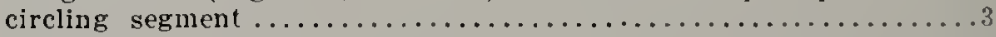

2. Anal plate indented, cauda knobbed (Fig. 222), both distinct: antennae of alate forms either three- or five-segmented. aleurodiform or coccidiform generations (Fig. 332) developed, aerial

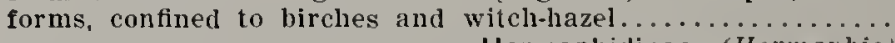

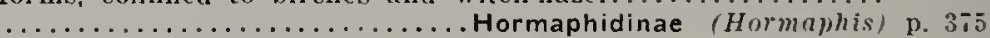

-. Anal plate and cauda rounded, indistinct (Fig. 221); antennae of alate forms six-segmented [except Mclaphis minutus Baker which is five-segmented-not known from Illinoisl: aleurodiform or coccidiform generations not developed; aerial generiltions on various plants, especially elms and poplars, and subterranean generations on roots of various plants...........

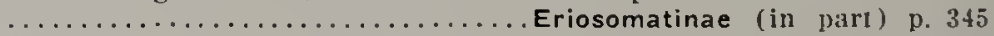

3. Radial vein of fore wing arising near base of stigma or where stigmal shading begins (Fig. 51) ........Mindarinae (Mindarus) p. $3 i t$

-. Radial vein of fore wing arising from body of stigma (Fig. 56) or at its apex (Fig. 67), always beyond base of stigma or where stigmal shading begins...................................... 
4. Terminal filament of sixth antennal segment longer than basal

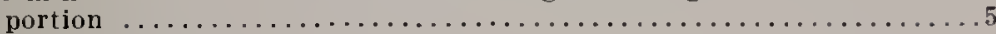

- Terminal filament of sixth antennal segment not longer than

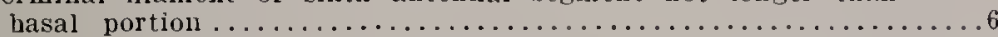

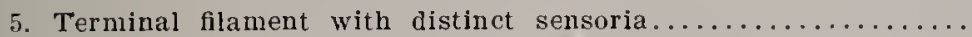
............... Eriosomatinae (Mordwoilkoja, fundatrigenia) p. 345

- Terminal filament without distinct sensoria...............

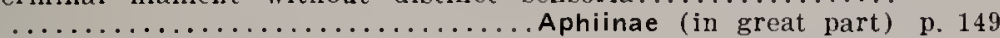

6. Terminal filament a mere stub (Fig. 241), in length abont equal

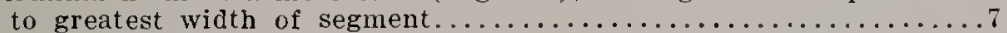

- Terminal filament distinct (Fig. 266), at least twice as long as greatest width of segment...............Aphinae (ill part) p. 149

7. Costa of lind wing nearly straight, branches not originating at same point and more or less parallel (Fig. 87 ) ..............

- Costa of hind wing curving upwards near point of articulation with branches originating at or about the same point, therefore forming a somewhat three-fingered fork (Fig. 94)....... . Eriosomatinae (in part)

8. Cornicles conspicuous, cone-like or on prominent elevations (Fig. $130) \ldots \ldots \ldots \ldots \ldots \ldots \ldots \ldots \ldots \ldots \ldots \ldots \ldots \ldots \ldots \ldots \ldots$ Aphinae (in part) p. 149

- Cornicles lacking, or indistinct and mere rings, not on prominerit

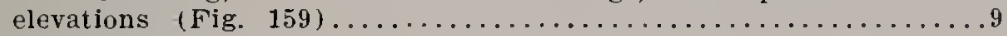

9. Anteunae five-segmented......Eriosomatinae (Forda and Geoica) p. 345

- Antennae six-segmented............................

10. Fore wings with medial veins not branched (Fig. 64) ....... ............... Eriosomatinae (Prociphilus and Trifidaphis) p. 345

- Fore wings with medial veins branched (Fig. 69) .............11

11. Sensoria narrow, transverse, many encircling at least half of segment...................Eriosomatinae (Georgiaphis) p. 345

一. Sensoria circular or transverse-oval................. ...Aphiinae (Tamalia, Phyllaphis. Eulachnus and stegophylla) p. 149

\section{SUBFAMILY APHINALE}

\section{KEY TO SCPERTRIBES}

1. T srminal filament of sixth antennal segment shorter than base

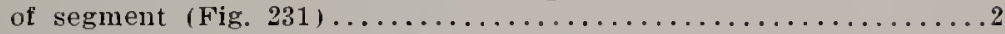

- Terminal filament of sixth antennal segnent equal to (Fig. 234), or longer than (Fig. 248), base of segment.................

2 Stigma of fore wings linear, very long and narrow (Figs. 52, 59, 67); epicranial suture on head distinct (Fig. 75) .......... Lachnea (Cinura, Eulachnus, Longistigma. and Tubrolachnüs) p. 150

- Stigma of tore wings short, usually more bulbous in shape (Figs. $54,56,62,66$ ); head without epicranial suture (Fig. 79) . . . . . . . 3

3. Antennae with numerous, long, hair-like setae (Fig. 231) .......

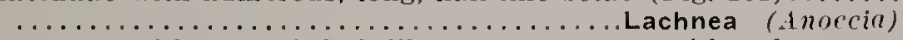
Antennae without such hair-like setae, at most with a few, scattered sholt setae (Fig. 235) .............. Callipterea (in part) p. 242

4. Body or appendages (exclusive of tibiae and tarsi), or both, with numerous, long, hair-like setae (Figs. 230, 32t), the setae never enlarged or modified at tip............ Chaitophorea (in part)

- Body and appendages (exclusive of tibiae and tarsi) without long, hair-like setae, either with a few short, scattered setae (Fig. 2s5), or with setae enlarged at the tip and modified

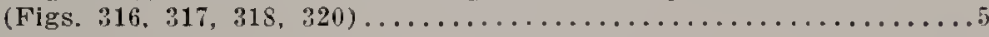


5. Anal plate either distinctly indented (Fig. 220) or bilobed (Figs. 16S, 219) except in Euceraphis: cauda knob-like (Figs. 178. 219 ), with a constriction near the middle, the apical portion circular or transverse-oval; cornicles, if apparent, trapezoidal (Fig. 155), never long and cylindrical; secondary sensoria often elongate-oval (Fig. 236) ...........Callipterea (in part)

-. Anal plate always with apex rounded (Fig. 214), never indented; cauda clavate (Fig. 187) or tapering (Figs. 185, 199), never knob-like; cornicles, if apparent, usually cylindrical (Fig. 135), often long (Fig. 120) or swollen (Figs. 145. 14S, 149. 160), never trapezoidal; secondary sensoria round (Figs. 26S, 27t,

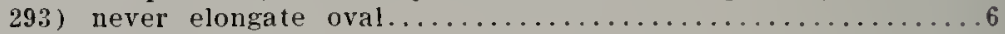

6. Comicles either absent or much shorter than hind tarsi exclus-

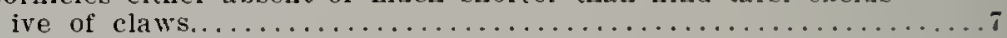

-. Cornicles subequal to, or longer than, length of hind tarsi ex-

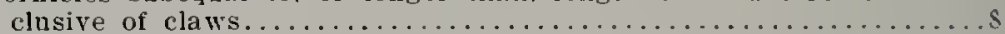

7. Anal plate widle $\Gamma$-shaped (Fig. 209), cauda subequal to anal plate in length. ronnded: third antennal segment very long, almost twice width of head across eyes.Chaitophorea (in part)

-. Anal plate semi-circular (Fig. 210), cauda tapering to more or less of a point, usually much longer than anal plate; third antennal segment (except in Brevicoryme) subequal to width of head across eyes.............................. (in part)

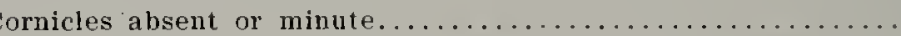

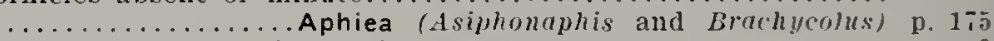

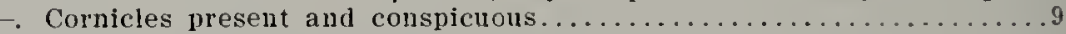

9. Hind wings with one oblique vein (cubitus) lacking (Fig. 89) or only partially developed, or with both oblique veins (cubitus and media) lacking (Fig. 96) ..........................

-. Hind wings with both oblique veins (cubitus and media) present

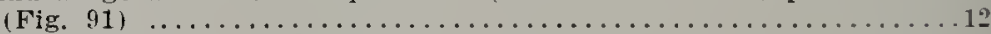

10. Radial sector of fore wing deeply curverl downward and either uniting with media to form a closed cell beneath stigma (Fig. 74 ) or almost uniting with media (Figs 58,66$) \ldots \ldots \ldots \ldots$. .................Macrosiphea (Idiopterus and Pentalonia) p. $2-3$

-. Radial sector of fore wing not deeply curved downward, no

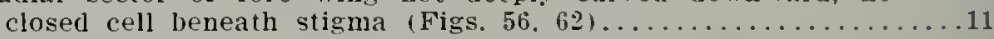

11. Hind wings without oblique reins (cnbitus and media) (Fig. 96)

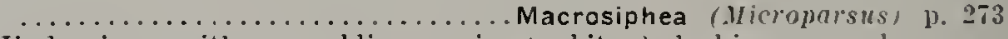

- Hind wings with one oblique vein (cubitus) lacking or only partially developed... Aphiea (.1lphitoaphis and Hysteroncura) p. 175

12. Nledia of fore wings normally branched once (Fig. 70$) \ldots \ldots$.

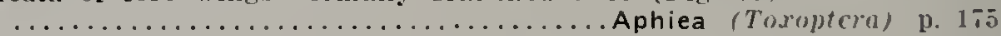

-. Media of fore wings normally branched twice (Fig. 62) ...........13

13. Inner margins of antennal sockets considerably produced nuter. iorly (Figs. $\$ 2 . \$ 6) \ldots \ldots \ldots \ldots \ldots \ldots$ Macrosiphea (in part) p. 273

-. Inner margins of antennal sockets not produced anteriorly or only very slightly so (Fig. 80 )..............Aphiea (in part) p. 175

\section{SUPERTRIBE L.ACHNE.A}

\section{KEY TO GEXERA}

1. Fore wings (Fig. 59) with dark suftusion of stigmal region extending as a distinct band beyond stigma to tip of wings....

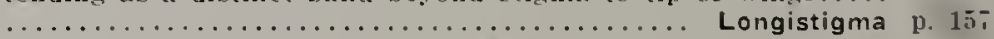

- Fore wings (Figs. 60,67) with stigmal suffusion not extending as

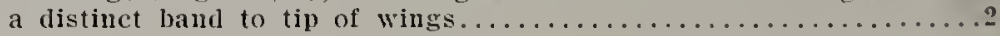


2. Radial sector (Fig. 6S) of fore wings bowed, arising from boty

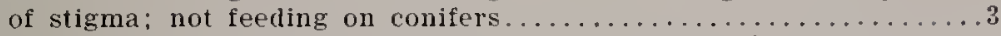

- Radial sector (Figs. 60,67 ) of fore wings straight, arising from lower distal angle of stigma; feeding on conifers..............

3. Dark stigmal suffusion of fore wings bulbous in shape (Fig. 68); hind tibiae little if any longer than antennae; without large tubercle on dorsum of abdomen; small species...... Anoecia

- Dark stigmal suffusion of fore wings elongate and more linear (Fig. 52); hind tibiae about twice as long as antennae; with large tubercle on middle of dorsum of abdomen (difficult to see on flat-mounted specimens on slicles but conspicuous in live material); very large species........... Tuberolachnus

4. Cornicles on conspicuous cone-shaped areas (Fig. 153); ocular tubercles present but small; comparatively large robust forms: feeding on bark of stems and branches................... 153

- Cornicles pore-like, not on cone-shaped areas (Fig. 158); ocular tubercles absent; medium-sized elongate forms; feeders on needles ......................... Eulachnus

\section{Gents ANOECl 1 Koch}

\section{Key to spccics of the Genus Anoceia*}

1. Third antennal segment with about seven secondary sensoria, fourth and fifth antenual segments each with one or two secondary sensoria; dark forms...............querci (Fitch) p. 152 - Third, fourth, and fifth antennal segments rarely with secondary

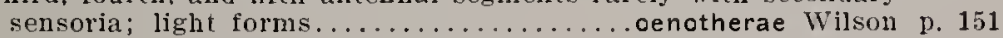

\section{ANOECIA OENOTHERAE WIISOX}

Anoceia oenotherae Wilson, Canadian Entomologist, Vol. XLlII, No. 2, February, 1911, p. 63.

This subterranean aphid is recorded from Illinois for the first time. It is retained tentatively as a good species, but further investigations may reveal it to be a summer form of Anoccia querci (Fitch) as Baker (1!16) has suggested. When Wilson described this plant louse he stated that the third segment has "three or four widely-separated sensoria, which are not as prominent as those in other species of Anoccia." Onr alate viviparous females rarely have secondary" sensoria on the third segment, and $\mathrm{Miss} \mathrm{M}$. 1. Palmer reports that a cotypic slicle of ocnotherue Wilson examined by her "contains two alate viviparae, one shows no sensoria on antennal joint fII and the oflerexample shows only one or two."

A. sctariac Gilletle and Palmer $(1 ! 9+1)$ is very similar and, as statcel in a letter from Miss Palmer. "may be identical." liological investigations are neerled to settle the 'juestion definitely.

Data associated with our specimens, collected on roots of ormothera, are as follows: Nuncie ( May 5) and Oakwood (July 8), 1928; Oakwood (July 22), Oregon (July 11), Rock Island (July 7), Seymour (July 20), and Starved Rock State Park (July 6), 1929.

* The alate viviparous females kegud here as separate spucies maj" represont a summer (of nolherac) form and soring and fall (querei) forms of a single variable species. 


\section{A.NOECIA QL'ERCI (FITCH)}

$F_{1 i,}, 6 S$

Eriosoma qurrei Fitch, Fifth Report of the Noxious and other Insects of the State of New York. Transactions of the New Jork Stale Agricultural Society. Vol. XYJII. 1858 (printed 1S59), ๒. S04.

What was presumably this species was first recorded irom Jllinois (near Ruck Island) 1, Walsh (1s6;3) as "Eriosomu?" comicole "1. .p." It was again reported from Illinois by Thomas ( lisis) under the new. specific nane of "Schizoncura panicola." Davis (1!)101) wan the fir-t to report this species from the state (northern Il!inuss) uncler the specific name of tuerci Fitch.

Baker (1916ic) has given the best accomnt of the habit- and characters of this species. In addition to placing Rhizohius clensinis Thomaand Schizoncura panicola Thomas as stmonyms of this specien (Cstorn harl previonsly placed the latter as a sinonym of cormi in sense of previons anthors). Baker sugesests that Anoccia ocnothere $11 \mathrm{ilson} \mathrm{is} \mathrm{"mly}$ another of the root-feeding forms of qucrci. which in this 1:articular case was feeding npon Ocnothera." Forbes and Hart (1s!is) have presented under the name of Silizoncura panicola Thomas much information regarding what are no doubt the summer or root forms of this species. Althougl they frepuently found this form on roots of corn. they considered it as having little econmmic significance.

Both clcusinis Thomas and panicold Thomas, as shown by the cotypic material, belong to the genus Anocio. laker's (1!1lic) position in sinking clcusinis Thomas as a synonym, based upon rearings of Pergande, seems tenable to us, especially since the apterous cotypic naterial can not $x_{x}$ separated from apterous ioms of yucri (Fisch). The cotypic slide of pamionla is in such poor condition. and our tresent hnowledge of the genus is so limited, that a specific determination is opinionative. Maxson lass stated in a letter to ns that it "is different than any species of this genus (Anocia) with which 1 an acpnainted." We believe that Raker is probably correct in considering panicola Thomas as a synomym of ylucrit.

Since this species spencls part of its life cycle as a smmer form on the roots of grasses, etc., and has Cormus as its over-wintering hoot. the specific name of yuerci appears to be a mismomer. "D) rilis" of quere Fitch from Cormus are freepuently tound on plants other than their hosts, as are many other species of migratory plant lice

Data associnted with our specimens collected on varions species of Cornus are as follows: lrbana (May 17), 1S94: Catlin (Sept. 27). Danville (Sept. 1S). Herod (Dec. 12), 1928: Decatur (Oct. 5). Fapla (Sep1.9. 22. Oct. 3), 1929; Humboldt (Nov. 12), 1930 . Specimens of "drifts" or migrating specimens were collected as follows: Lrbana (June 25). 15s9: Lrhana fOet. 19). 192S; Homer l'ark (Oct. 23), Seymour (Oct. 30), 1929; I'rbana (Sept. 2S-Oet. 30), 1930. Dita associated with apterous forms on roots of sefarin. Zru, Erigeron and undetermined grasses are as follows: Champaign (July 31), Polo (July t5), tS83: (roana (.llay 20), 1SST; Crhina (Oct. 10), 1Sgn; Champaign (Oct. 17), Is94; Urbana (Sept. 27). 1930. Cotypic slide of Rhiablus ('leusinis Thomas (Slide No. STTT) is from carbondale, Illinois, on roots of Eleusin" indirn. September 3, 1STT. and the cotypic slide of schizonfum manicolit Thomas (Slide No. 27T0) is from St. Louls, Missouri. November. on roots of Punicum glubrum, collected by H. Pergande. 


\section{GiNuS CINARA CURTIS}

The life histories of the species in this genus are so minformly similar that conments concerning them are not given miner each plecies, as is the case in some of the more complex and migratory forms in other genera. Along wilh other closely related forms, the genus Cinara is considered to be anong the most prinitive of the living aphicls.

The various species show strict firlelity to the pine family, or P'inaceae, upon which the entire non-migratory life cycle is spent. The aphids orer-winter in the egg stage. The stem molhers produce apterour viviparous fenales, which in turn give rise to other apterouts viviparous fenales, alate viviparous females, and finally alate or apterous males and oviparous females.

\section{hey to species of the fienus cimure}

1. First tarsal segment about one-fifth the length of the second segment exclusive of claws..........pinicola (Kaltenbach) p. 156

First tarsal segment from about one-third to one-half the length

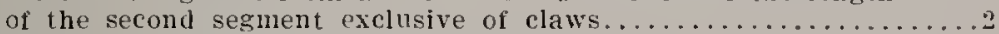

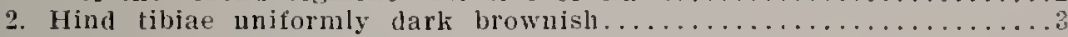
Hind tibiae with basal and apical portions dark brownish, area between yellowish brown, the two colors distinctly contrasting.....t

3. Third antennal segment approximately twice as long as hind tarsus exclusive of claws.......................... 157

- Third antemal segment but slightly longer than hind tarsus exclusive of claws.................... difficilis n. sp. $\mathrm{p}, 153$

4. Hairs on antennae very slort and spine-like, little if any longer than width of the antennal segments........laricis (Hartig) p. 155

Hairs on antennae longer, many of them at least twice the width

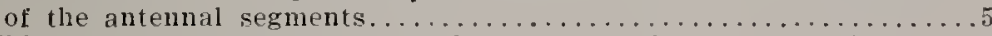

5. Tibiae of fore legs almost unitormly dark brownish; hair on hind tibiae not numerous, stout, rather spine-like, many erect particularly on basal half..................pini (Linnaeus) p. 156

Tibiae of fore legs with basal and apjeal portions dark brownish. area between yellowish brown, the two colors distinctly con trasting: hairs on hind tibia numerous, rather fine and mostly

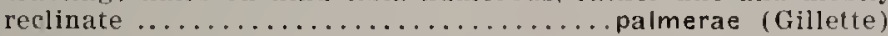

\section{CINARA DIFFICILIS new species}

FIt: 231

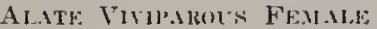

Sizc aml yencral color.-Length from vertex to tip of anal plate, 2.60.* Entire body dull with a fine waxy hloon easily seen under a microscope. Head and thorax dusky brown, the head with a conspicuous darker median line, the thorax with the tegulae, paraptera, and notal membranes reddish brown. Abromen cinnamon brown with a slight pinkish cast; cornicles and the cone-shaped areas at the base of the cornicles, cauda, anal plate, and a transverse patch immediately anterior to the caula are dark brown. There are four rows of small brownish spots longitudinally arranged on the dorsum of the abdomen. The first two antennal segments are concolorons with the liead; the base of the third antennal segment is much lighter in color than the remaining portion of this segment which is a light cliestnut brown: fourth, fifth, and sixth antennal segments uniformly light chestnut brown. ('oxae and trochanters of all legs blackish brown; femora of all legs uniformly dark chestnut brown, except that the femora of the hind legs are

* All measurements in this palper ale in millimelers. 
slightly lighter at or near their base; tibiae dark chestnut brown with a sight tendency to he a shade or so lighter near the center of the segment. except for the tibiae of the hind legs which are uniformly urownish: tarsi dark chestnut brown. The last three apical segments of the beak are dark chestnut brown, the remaining segments are considerably lighter in color than the apical segments, and the apical portion of the long second sezment is more or less spotted with dark brown areas from which arise hairs with a light colored base. Costal margin of wings deeply suffused with brown.

Heal and appendayes.-Average width of head across eyes, .69. Antennal segments with comparative lengths as follows: IIl-.29 to .39, average .35; $1 \mathrm{~V}-.10$ to .16 , average $.14 ; \mathrm{V}-.14$ to .21 , average $.17 ; \mathrm{VI}-.14$ to .14 . average .14 plus .03 to .04 , average .03 . The secondary sensoria are distributed as follows (Fig. 231): third antenual segment with six to nine sensoria, and with the exception of a single sensorium arranged in a straight row. the first sensorium heing located about one-fifth of the length of the segment from the base; the fourth and fifth segments have a single, more or less centrally located. secondary sensorium in addition to the large primary sensorinm. The ocular tubercles are present but are poorly developed. The beak alcuost reaches to the cornicles.

Thorax and uppendages.-Fore wings with a prominent dark brownish suffusion along the costal margin; subcostal vein large and dark brown, interrupted or broken near stigmal area, therefore a clearly definerl stisnial area lacking; median vein only once forked and feebly developed; radial sector, cubitus, and first anal veins strongly outlined; hind margin cf wing slightly thickened at point of articulation with first anal and cubital veins Tibiae of metathoracic legs slightly inwardly curved a short distance beyond the middle. Tarsi of metathoracic legs about one-fifth shorier than the length of the thirt antennal segment.

Abdomen.-The cornicles are situated on comparatively shallow cone. shaped areas which have their outer margin very irregular. The maximum dimensions of the cornicles plus the cone-shaped area are as follows: height, .16; width, .36. The cauda is one-third wider at the base than it is long; its sides are not rounded but arise to form an angle of slightly more than ninety degrees.

Hnir.-Hair, wherever found, fine and not spine-like; on antennae almost $t$ wice as long as width of segment and quite erect for about one-half their length; on basal portion of hind tibiae quite erect and about one-fifth longer than wioth of segment, and on apical portion somewhat longer and more recumbent than those on the basal portion; on anal plate and cauda nuch longer than any other found on the body.

\section{AlTEROLS VIVHPliots FEMIILE}

Size and general color.-Averaze length from vertex to tip of anal plate, 2.71. Color, except for legs and a slight grayish-brown on the abdomen, ictentical with color cluacters as given for the alate viviparous fenale. The legs of this form are a dark chestnut brown except that one-half to onethird of the tibiae near their basal portions are light yellowish brown as are also the hases of the femora. Antenuae colored as in the alate except in some specimens they are lighter in color as a whole.

Hrarl and apprulancs.-Average width of head across eyes. .74. Antennal segments with comparative lengths as follows: $111-.24$ to 41 . average 31 ; $1 V-.10$ to .16 , average $.13 ; V-.14$ to .19 , average .17 ; Vi-. 10 to .14, average .12 plus .03 to .06 , average .04 . The secondary sensoria are confinet wholly to the fiftl antennal segment and range in number from one to two (two in only one case). The head is divided by a median line. the position of which is further emphasized by a mediun furrow which in some individuals makes the head appear bilobed or indented at its anterior margin. The beak is colored as in the alate viviparous female. The hind tibiae are shaped as the hind tibiae of the alate female: the hind tarsi cxclusive of chaws are subrqual in length to the third antemal segment. 
Ablomen.-Ablomen and structures similar to those described for the alate viviparous female. The cornicles vary from .31 to .43 and average .35 . The cauda is broadly rounded.

Hair.-The hairs are similar to those described for the alate viviparous female except that those on the apical portions of the hind tibiae are slightly more upright.

Holotype-Alate viviparous female; Herod. Illinois, June 2S, 1931, on Juniperus virginiona. (Frison and Ross). The wings of the holotype are broken off a slort distance from articulation with the thorax, a condition probably caused by the manipulation of attendant ants. On slide with two nymphs and one pupa. Slide No. 1059S. Norphotype.-Apterous viviparous female; Herorl, Illinois, June 16, 1930, on Juniperus virginiana, (Frison aud Ross). Slide No. 10599. Puratypes. Forty-two slides of alate viviparous females, apterous viviparous females, pupae and nymphs; all collected in Illinois ou Juniperus virginiana by T. H. Frison, F. C. Hottes, and H. H. Ross. The localities and dates are as follows: Herod (June 21 and September 27), Anna (June 24), and Galena (June 10), 1929; Herod (June 16), 1930. Slides Nos. 10600-I0625 and others unnumbered.

This species was discovered by investigating a covered rmuvay in which an ant (Crematogaster lincolata Say) was seen to enter; the rumway was located on a small woody branch of red cedar. In this protected situation a single alate viviparous female with niutilated wings was found. Examination of other and similar ant structures on the trunk and branches of the host tree revealed additional specinens. The specimens were ustally in two's or three's but nearly onc-lnindred specimens were removed from one place where a branch had split away from the main trunk of the tree and then partially healed, the open and exposed crevice being walled over by the ants with mud and shreds of bark until it was effectively concealed. Specimens found at ali three localities were associated with the same species of ant and cleverly concealed by the ant structures. The mutilated condition of the wings of all but one alate viviparous female may be due to the ants chewing off the wings.

The characters of the body of this species strongly suggest Cinara rubicunda (Wilson) described from Jumiperus commmis in Oregon. It nay be separated from that species, however, by the venation. In this new species the median vein is but once-forked, whereas in rubicundus it is stated and illustrated as twice-forked. This species also comes close to $C$. junipcri DeGeer of Europe, but apparently may be separated from it on the basis of the longer beak.

Specimens of this species were stibmitted to Professor H. F. Wilson who kindly examined them and reported that these specimens "do not agree with any that I have." Other specimens were sulumitted to Xiss M. A. Palmer, who reported that she did not linow this form.

\section{CINARA LARICIS (HARTIS)}

Figs. 12, 75, 153, 213, 216

Lachnus hricis Hartig. Jahresberichte ijber die Fortschritte der Forstwissenschaft und forstlichen Naturkunde im Jalne 1836 and 1837 . Berlin, 1839 , p. 645 .

t phis laricis Walker. The Annals and Magazine of Natural History, Vol. II, second series, 1S1S, 1). 102. IIomonym und synonym. 
This European ats well as American species has not been previously recorded from Illinois. Although its host, the tamarack. Lurialaricinu. occurs as a specimen tree in numerous localities throughout the state. ontr material was taken only in the locality where the tamaratk ciccurs as a native tree. Our determination of this species has been clecked by Professor H. F. Wilson. Theobald (1!1:!) and Wilson (1!1:3) give goorl descriptions of the varions forms except the oviparous iemale. which is described lyy Schouteden (1906). Patch (1:11?a) has presented descriptions and drawings, under the name of Lachums laricife.: Fitch. based upon specimens collected in Maine.

The placement of laricis Hartig (1593) in the genus Lachnis and its association with the larch (Lari.r) are sufficient to make this name valid according to Article s:sa of the International Rules of 7 oological Nomenclatıre.

Data associated with our viviparous specimens are as follows: Antioch, June 16,1928 .

\section{CINARA PAlmerae (GHllette)}

Lachnus patmerac Gillette. Annals of the Entomolngical Society of America. Vol. X, No. 2, June, 1917 , p. 135.

This species is here recorded from lllinois for the first time. Our specimens were determined by Professor H. F. Wilson and at his suggestion sent to Professor C. P. Gillette and Miss .1. A. Palmer for comparison with cotypic material. Such a comparison was made by Miss Palmer who found that our specimens cheched with the types. The host of this species is spruce (Picca sp.). Gillette has described all forms of this species in detail.

Data associated with our specimens are as follows: Gatena. July. 10. 1929.

\section{C'INARA PINI (LIXXAEs)}

Aphis pini Linnaeus, Systema Naturae, Editio Decima, 175s, p. 453.

A widely distributed species not previously recorded from the state. It is a large species and feeds on the hark of pine (Pinus sp.). Theobald (1!9!9) and Vilson (1923) give good descriptions and notes regarcling this plant lonse.

Data associated with our lllinois specimens are as follows: Decatur (Nov. 4), Havana (June 21), 192S; Chicago (June S). 1930.

\section{CINARA PINICOLA (KNITENBBICH)}

Lachmus pinicolı Kaltenbach. Monographie der Familien der Pflanzenläuse. Aachen, 1843. p. 154.

This species, occurring in Europe as well as America. has not been previonsly recorded from llinois. (iood descriptions and motes regarding this plant louse are given ly Theobald (1!9!9) and Wilson (1!9:3). IIe are inclebted to Professor it. F. II ilson for checking our determination of this species. 
Data associated with our specimens, all taken on Picen sp., are as follows: Champaign (June 7), 1886; Carbondale (June 4), Champaign (.luly 1S), Galena (June 26), Herod (May 31), Kankakee (June 29), Oregon (June 27), Urbana (June 19), 192S; Galena (July 10), 1929.

\section{CINARA STROBI (FiTel)}

Fil: 67

Eriosoma strobi Fitch. Fourth Annual Report of the Regents of the University on the Condition of the State Cabinet of Natural History, State of New York, January 14, 1S51, p. 69 .

Our report of this species is the first actual record of its uccurrence in Inlinois. See Wilson (1923) for descriptions and notes regarling this aphid attacking white pines.

Data associated with our specimens, all taken on Pinus strobus, are as follows: Urbana (Nov. 1-5), 1928; Flora (June 18), Jerseyville (June 25), 1929.

\section{Genes EUL. JCHNUS Del Guercio}

\section{EULACHNUS RILEYI (WITIANS)}

FIG. 60

Lachnus rileyi Williams, University Studies, University of Nebraska, Vol. X. No. 2, March, 1911, p. 24.

This species has been reported from Chicago, Moryan Park, and Urbana, by Davis (1!) ta). Following 1 illians and Davis we are considering it distinct from the European Euluchnus agilis (Kalt.), although the two forms are unquestionably very closely allied. The difference between rilcyi and agilis is expressed by the presence in the latter of secondary sensoria on the third and sometimes fourth antennal segments and their lack, or rarity, in the former. Onr records indicate that this elongate and active species, which spends its entire life upon pines, is widely distributed through the state. Good descriptions of all forms are given by Davis (191t).

Data associated with our specimens, all collected on Pinus sylecstris. Pinus echinatu, Pinus strobus, or Pinus sp., are as follows: Urbana (Oct. 11, 12), 1889; (rrbana (May 7), 1925; Antioch (Jume 15). Galena (June 26), Nietropolis (June 1), Pekin (June 20), Quiney (June fi), Urbana (May 23, Sept. 26, Oct. 19), 1928; Macomb ( May 4), Rock Island (July 7), 1929. Sexual forms taken at Urbana on October 19,1928 .

\section{GENIS LONGISTIGMA WILSON \\ LONGISTIGIA (ARYAE (HABMIS)}

Flus. 6, 7, S, 18, 59

Aphis conyul Harris, A Report on the Insects of llassachusetts Injurious in Vegetation, ('ambridge, 1841, p. 190.

This complicuous and well-marlied species is the langest aplicl occurring in the Linited states. It wats probalbly first secorded from 


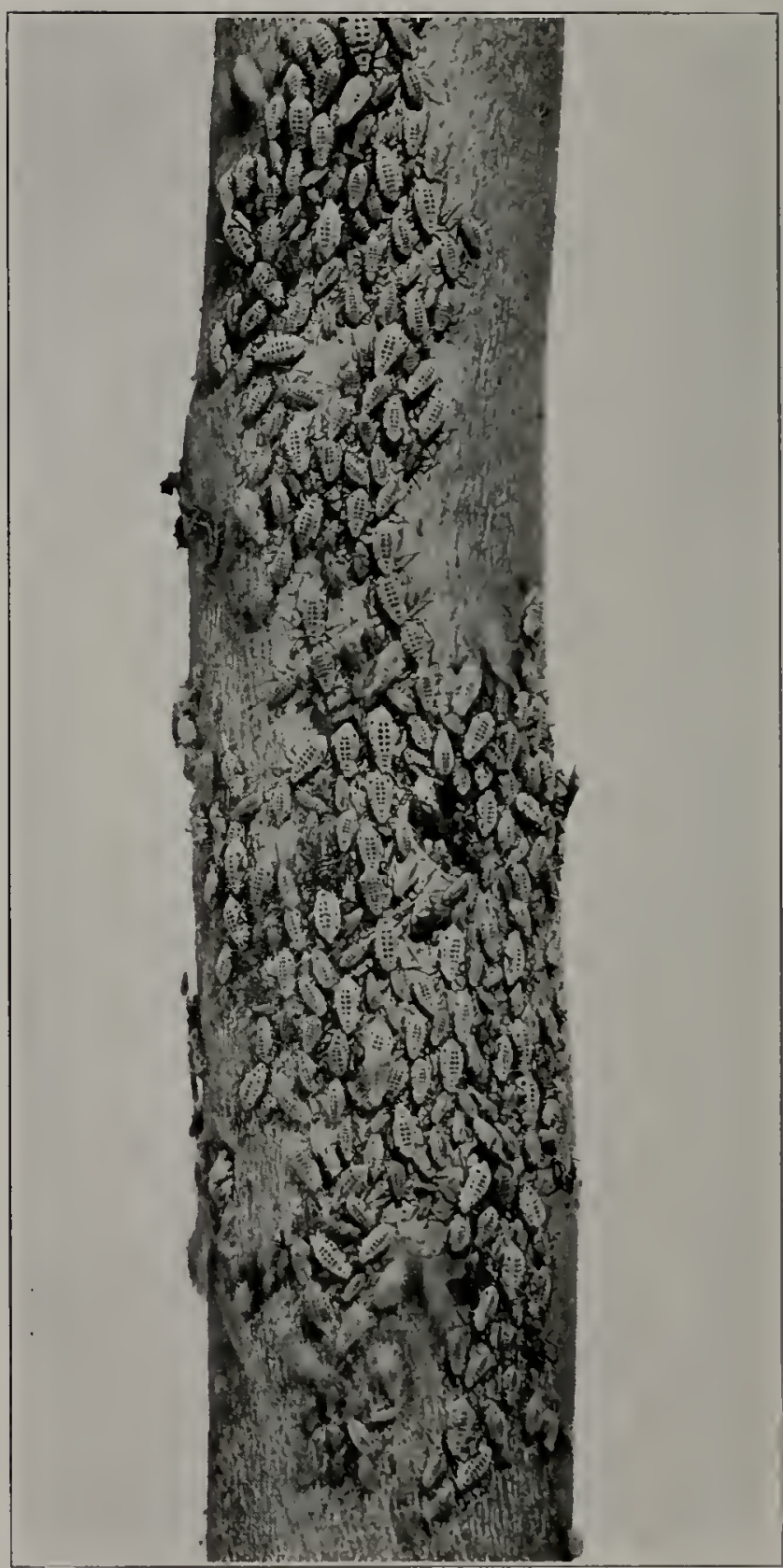

Fig. 1S. A colony of apterous viviparous females and nymphs of Lomgistigma carmar (Harris) on the sycamore. Platanus orevilentalis: Erbana, oct. 14, 1929. 
Illinois by Thomas (1879), who reported it as clustered on the underside of the limbs of the pig-nut hickory (Carya porcina) in summer. It is likely, too. that the specimens of this species studied and described by Walsh $(1862)$ were from Illinois. Davis $(1910)$ listed it as common throughout the state, and said that the sexual forms occurred (hring October in northern Illinois. Descriptions of the various forms, together with a short note on the biology of the species, were given by Tieed (1891).

It various times this species occurs in such large numbers upon the boulevard trees (Fig. 18) in some cities that it becomes a considerable pest because of the clropping of honey-dew upon the sidewalls beneath. During the last few years in Illinois, however, we have never found it extremely abundant: in fact. have never been able to find it except in autumn. We have records of this species from sycamore (Platanus occidentulis), pecan (Carga illinoensis), and basswoorl (Tiliu (americana).

Data associated with our viviparous forms are as follows: Champaign (Sept. 6), 1S\$6; Makanda (June 4), 1919; Urbana (Oct. 26), 1924; Marion (Dec. 5), 1927; Herod (Nov, 30), Homer Park (Oct. 23), Urbana (Oct. 5, 19. Nov. 6). 1928; Alton (Oct. 15), Urbana (Oct. 14), Woodstock (Aug. 6), 1929. Sexual forms have been taken at Decatur (Nov. 4), Herod (Nov. 29), Urbana (Oct. 19), 1928, Granite City (Nov.), and Urbana (Oct. 14), 1929.

\section{Genus TUBEROLACHNUS MORUVLKO}

\section{TUBEROLACHNUS SALIGNA (GMFLIX)}

Fig. 52

Aphis saligna Gmelin, Caroli a Linné. Systema Naturae, 13th Ed., Lipsiae. Tom. 1, Pars. 1V, 1790, p. 2209, No. 62.

1.eBaron ( $18 i_{1}$ ) in the "Second Report on the Insects of Illinois" descriled this species as Lachmus dentatus, probably from Illinois specimens. It was reported uncler this latter name by Davis (1910d) as being a conmon species in northern Illinois, beconing very abundant in the fall, and a considerable nuisance on ornamental willows. This aphich is easily recognized because of its large size and prominent dorsal abdominal tubercle. It is restricted to willow (Sali.t sp.).

We are following Theolald (192!!) in considering saligna as having priority over the specific name of punctatus (Burmeister) now in use in this country.

Data associated with our specimens are as follows: Decatur (Sept. 25), 1S87; Elizabethtown (Oct. 12), Herod (Nov. 30), 1928; Edwardsville (Sept. 11), Urbana (Oct. 13, 14). 1929; Urbana (Aug. 26), Watson ( Nov. 13), 1930. 


\title{
SEPLRTRIBE CHAITOPHOREA
}

\section{IEEY TO GENERA}

1. Cornicles always present, varying from minute to large............2

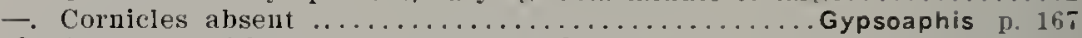

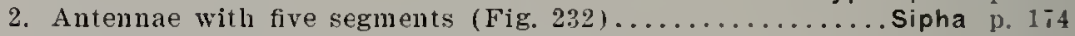

-. Antennae with four segments (Fig. 230) ......Paducia new genus p. 167

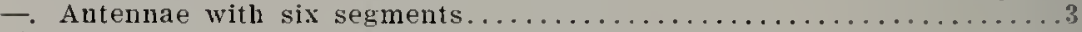

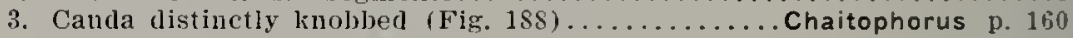

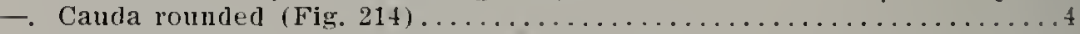

4. Cornicles witl apical portion swollen (Figs. 145, 146, 162) and

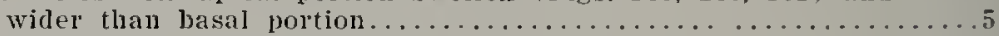

- Cornicles either cylindrical or with basal portion wider than

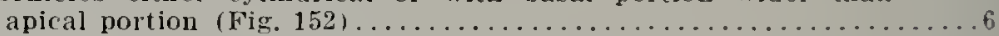

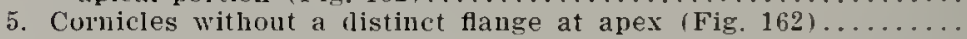

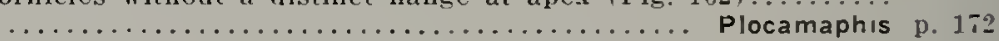

- Cornicles with a distinct flange at apex (Fig. 145)....Clavigerus p. 155

6. Cornicles cylindrical; third antennal segment long. twice or more as long as width of head through eyes... Amphicercidus p. 160

- Cornicles witl basal portion wider than apical portion, hence trapezoidal in shape (Fig. 152); third antennal segment snorer, much less than twice as long as width of head through eyes

Periphylius p. 170

\section{Genus AMPHICERCJDUS Oestllad}

\section{AMPHICERCIDUS PULVERLLENS (GILtFTE)}

\author{
Figs, 144,248
}

Aphis pulverulens Gillette, Journal of Economic Entomologr. Vol. 4. No. 3. June, 1911, p. 324 .

This species, miginally described from Colorado, has not been previonsly recorded from Illinois. Our records indicate that it is a common species in the southern portion of the state. We have no records indicating its presence in the northern purtion of the state, but since it occurs in Minnesota it should be present wherever it: host occurs in lllinois. It shows a decided preference in lllinois for coral-berry growing in moist, sumewhat shaded situations. This species produces a white flucculent secretion, is a bark iecder. and is never far removed from the gromul. The sexual forms have been described by Gillette (1911).

Data associated with on apterous and alate viviparous female sperimens, all collected on sumphoricarpos orbiculatus. are as follows: Elizalietli. town (May 29). Golconda (May 31). Herod (May 29). Mattoon (Jume 10). Metropolis (May 31, June 1), Mt. Carmel (May 26), Quincy (June 6). Shawneetown (May 27), 1928: Flora (June 18), Hardin (June 25), Monticelln (May $241,1929$.

\section{GENLS CH.1ITORHORUS KOOA}

The forms comstituting this group of plant lice have presented us with one of our most hafting problems. and it is evident from

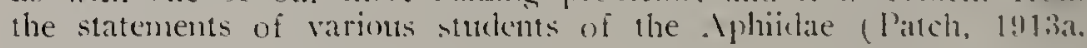


and Davis, 1!10d) that others have faced the same unsatisfactory situation. With the exception of one species (quorcirolu), which is readily separated in the alate forms because of its conspicuously marked wings and in apterous forms because of its spiny condition, no good differential structural characters have been found. Comparative lengths of antennal segments, number of sensoria, etc. are quite variable $i_{11}$ a series of apparently the same species. In all parts of lllinois onr captures are readily separated on the basis of habitus and host plants into the following five forms: the clistinct qucricolu with markerl wings on waks, a medium-sized green or blackish form on willows such as Sali.r nigra, a minute whitish pellucid form on Sali.r amy gdaloides, and two light-colored forms cone large and une small) on rariuns species of Populus. Biological studies including numerous transfer tests of forms from one host to another are badly needed to thruw light npon our present dilemma. Meanwhile it seems the best policy to keep separate the forms involved, however weak nay be onr key for their differentiation.

\section{Key to speries of the Genus Chatophorus}

1. Veins of wings malgined with fuscous (Fig. 62); stout dark spines on dorsum of ablomen in apterous forms............ $\ldots \ldots \ldots \ldots \ldots \ldots \ldots \ldots \ldots \ldots \ldots \ldots \ldots \ldots \ldots \ldots \ldots$ quercicola Monell p. 164

- Veins of wings not margined with tuscous (Fig. 70), no stont dark spines on dorsum of abdomen in apterous forms...........2

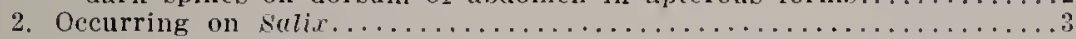

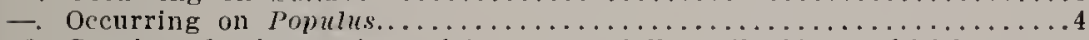

3. Species of minnte size; abdomen partially pellucid or whitish; on sutix amygrlatoidrs................... pusillus 11. sp. p. 163

Larger species; abdomen partially greenish or blackish; on var-

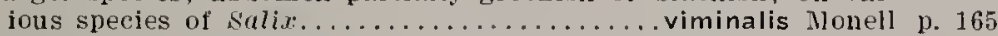

4. Secondary sensoria on third antennal segment forming an irregular row (Fig. 250); transverse dark patches on dorsum of middle abdominal segments broad and rectangular in shape

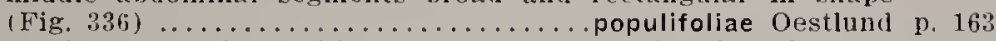

- Secondary sensoria on third antennal segment forming almost a straight row (Fig. 253): transverse dark patches on dorsum of middle abdoninal segments narrower with lateral ends tapering and clear intersegmental areas more prominent (Fig. 335)

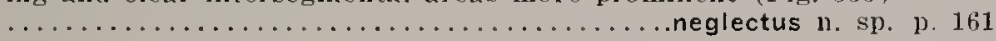

\section{CHAITOPHORUS NEGLECTUS new species}

Figs. 253, 835

AIATE VIVIPAROI'S FHMAIL:

Size and goneral rolm:-Average length from vertex to tip of anal plate, 1.27. Head and thorax dusky brown. Abdomen (Fig. 335) light greenish. yellow, the dorsum marked with dusky-brown bars and spots, as follows: each segment anterior to cornicles typically with a transverse, elongate, diamond-shaped bar often extending almost the entire width of the segment, with a large lateral subquadrate spot, and with several small, variously shapped spots extending transversely hetween the lateral spots and forming a chain between the large transverse bands. Segments posterior to cornicles with dorsum, except for intersegmental areas, a solid dusky brown. Cornicles, caucla, and anal plate light dusky. First and scemd antennal segments concolorous with head, thirl antennal segment light brownish, usually 
somewhat lighter at or near the base, remaining segments brownish with thoir apical portions darker. Femora usually yellowish basally and apically, middle portion light brownish, some specimens with the hind femora con. siderably darker than the others; tibiae uniformly yellowish; tarsi light brownish. Beak yellowish with apex brownish. Stigma and veins brown; posterior margin of wing in vicinity of anal vein brownish.

Head and appendages,-Average width of head across eyes, .39. Antennal segments with comparative lengths as follows: III-.30 to .39, arerage .3.; $\mathrm{IV}-.14$ to .21 , average $.17 ; \mathrm{V}-$.I1 to .16 , average $.14 ; \mathrm{VI}-.09$ to .10 , average .10 plus .27 to .40, average .34. Secondary sensoria (Fig. 253) usually confined to the third antennal segment, numbering from $i$ to 13 and areraging 9. arranged in a straight row, sometimes fourth segment with a single sensorium. For a chaitophorus. this species is remarkably constant in regard to numbers and arrangement of secondary sensoria. Primary sensorium on sixth antennal segment with a group of about 5 marginal sensoria at one side. Front of head with about six long hairs. Beak reaching abont midway between first and second coxae.

Thorar and appendages.-Stigma of fore wings somewhat arehed anteriorly, wing beyond apex of stigma distinctly narrower than at stigma. Second fork of media variable in position but always nearer to margin of wing than to the first fork or midway between them. All reins falling to reach the margin of the wing. Hairs on legs fine, long, and only slightly drooping.

Ablomen.-Comicles about .06 long with closed reticulations at the apex. very little wider at base than at apex. Cauda .os long, distinctly knobbed. Anal plate roumder.

\section{APTERol's VIVTPRot's FEMALE}

Size and gencral color.-Average length from vertex to tip of anal plate. 1.52. Head yellowish-brown, darkest on dorsum. Thorax brownisl on dorsum with yellowish-green towards the lateral portions. Abdomen yellowish-green with two broad, longitudinal bands of brown on dorsum. bands confluent anteriorly with browu on thorax and on the segment posterior to the cornicles with each other. Brown marks on dorsum of entire body fashioned into a somewhat fork-shaped effect, outlined by the surrounding yellowish color of the body. Cornicles yellowisb-green. Cauda and anal plate very light dusky brown. First two anteunal segments concolorous with head, third antennal segment and basal half of fourth antennal segment yellowish, remaining portion of antennae brown. Legs and beak as in alate viviparous fentale.

Head and appendages.-Average width of head across eyes, 37 . Antennal segments with the following proportions: III -.27 to 29 , average $.2 S$; IV.14 to .17 , average $.16 ; \mathrm{V}-.13$ to .14 , average $.14 ; \mathrm{V}-.09$ to .11 , average .10 plus .16 to .37 , average .30 . There are no secondary sensoria; primary scusorium on sixth antennal segment with ahout six marginal sensoria to one sicle. All antennal segments lightly imbricated. Beak reaching just to or but slightly beyond mesothoracic coxae.

Thorax and abdomen.-Similar to thorax and abdomen of alate viviparous female except that the anal plate has a very slight indentation near the center of the posterior margin.

Holotlypr.-Alate viviparous female: Starved Rock State Park. Illinois. Angust 14, 1929, on Populus deltoides. (Frison and Hottes). On slide witl paratypic apterous viviparous females and nymphs. Slide No. $1003 \%$. Morphotype.-Apterous viviparous female; some data as holotype. On slide witl paratypic alate and apterous viviparous females and nymphs. Slide No. 10038. Puratypes.--Funteen slides containing alate and apterous viviparoms females, pupae, and nymphs, all collected in 1929 on Pojulus delloides and $P$. grundiucntuta by T. H. Frison and F. C. Hottes as follows: Beach (August 29, and Starved Rock State Park (Angust 14). Slides Nos. 10039. lo0t9 and others unnumbered. 
This species is extrennely close to $C$. cssigi (iillette \& Palmer and $C$. populclla Gillette \& Palner, from which it differs in having a larger numulser of sensoria on the third antennal segment and in having distinct bands on the dorsum. Specimens tentatively cleternined as Chaitoplorus populclla G. \& P. were submitted to Miss I'almer who pointed out the differences already mentioned and suggested that if the forms run constant it would be the safest procedure to describe them as new. At the same time she venturert the opinion that they are perliaps connecting links between $C$. populclla and $C$. cssigi, which she says nuay sometime prove to be symonymous.

\title{
CHAITOPHORUS POPLLIFOLIAE OESTIXY
}

\author{
FIris. 250, 336
}

Chaitophorus populifoliar (Fitch) Destlund, Geological and Natural History Survey of Mlinnesota, Bulletin No. 4, 1857, p. 38. Misidentification. Chatophorus populifoliar Oestlund proposed for Chaitophorus populifoliae (Fitch) Oestlund, Davis, Journal of Economic Entomology, Vol. III, No. 6. 1910, p. 489 .

This species (Fig. 336) was redescribed by Davis (1910e), but credit for the specific name was given to Oestlund. Very little is known concerning the biology and distribution of this species.

Data associated with our specinens, all collected on leaves of Populus deltoides or P. grandidentata, are as follows: Cave-in-Rock (Nay 30), Elizabethtown (Oct. 12), Herod (Oct. 12), Starved Rock State Park (June 13), 1928; Elizahethtown (June 20), Farmer City (Sept. 22), Grayville (June 19), Oakwood (July 22), Starved Rock State Park (Jujy 5, Aug 14), 1929 ; Starved Rock State Park (Nay 13), 1930.

\section{CHAITOPHORUS PUSILLU'S new species}

FIgs. 70, 151, 252

Alate Viviparous Feinal:

Nize and yincral color.-Average length from vertex to tip of anal plate. 95. Head and thorax light hrown. Abdomen yellowish, almost whitish, with a large light-brownish or buff spot on the dorsum. Cornicles fuscous; cauda and anal plate yellowisl. Legs variable in color, usually yellowish. with tarsi and sometimes portions of femora distinctly fuscous. Stigma fuscous, veins of wings light brown. Beak yellowish except for extreme tip, which is fuscous.

Head and appenfluges.-Average width of head across eyes, .31. Antennal segments with comparative lengths as follows: Ill-.20 to .29, average .24; IV- .09 to .16 , average $.11 ; \mathrm{V}-.11$ to .14 . average $.13 ; \mathrm{VI}-.07$ to .09 , average .08 plus .20 to .29 , average .26. Secondary sensoria (F'ig. 252) on third antennal segment ranging in numbers from 4 to 7 and averaging six; fourth and fifth segments with sometimes one or two sensoria each; sensoria usually arranged in a straight row. Primary sensoria on sixth antennal segment with a gromp of marginal sensoria at one side. Hair on antennae sparse, but very long and fine, being two to three times as long as the width of the segment. Beak reaching midway between the pro-and mesothoracic coxae.

Thorar and appenlages.-Costal margin of wing in vicinity of stigma very much curved, stigma comparatively narrow, short, and bluntly pointed; second fork of media variable in posiljon, usually midway between first fork and margin of wing.

Abdomen.-Cornicles (Fig. 151) typical for genus in shape; averaging .95 in Jength. imbricated very faintly and reticulated at apex. Cauda typical for genus, rarely extending beyond tip of anal plate which is rounderl and not indenter. 


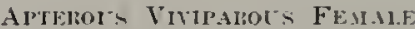

Size and general color.-Average length from vertex to tip of anal platt. 1.09. Head, thorax, abdomen, cornicles, cauda and anal plate a pellucid yellowish-white. Apical portion of fifth antennal segment, base of sixth and apical portion of termiual filament are fuscous. Eyes reddish-brown. Legs concolorus with body except that tarsi are often somewhat iuscous.

Hoad and upprndu!pes.-Average width of head across eyes. .33. Antennal segments with comparative lengths as follows: $111-.16$ to .24 , average .19; $\mathrm{IV}-.07$ to .11 , average $.10 ; \mathrm{V}-.09$ to .11 , average $.10 ; \mathrm{V}-.07$ to .09 , average .09 plus .17 to .29 , average .25 . There are no secondary sensoria. The beak reaches to the end of the mesothoracic coxae.

Abromen.-The cornicles and cauda have the same average length as similar structures in the alate viviparous female. The body is sparsely covered with fine but unusually long hair, the hairs average .14 in length.

Holotypt.- Alate viviparous female; Starved Rock State Park, 1llinois, Juiy 6. 1929, on salix tmygringirl's. (Frison and Hottes). Slide No. 10650 Morphotype.-Apterous viviparous female; same data as for hololy]". On slide with numerous apterous viviparous females and nymphs. Slide No. 10681. Paratypes.-Thirty slides of alate and apterous viviparous females and nymphs, all collected on stlix amygdnloirles in Illinois, by T. H. Frison. F C. Hottes, and H. H. Ross, with localjties and data as follows: Galena (July 10), Oakwood (Juiy 22), Rock Island (July 7), and Starred Rock State Park (July 6-August 14, and September 10). 1929; Oakwood (1195 9), and Starved Rock State Park (May 13), 1930. Slides Nos. 1068:-10704 and others unnumbered.

This species shows a preference for the terminal leaves of Sulir amygdaloides and occurs on lonth the dorsal and rentral leat suriaces. Its minute size, pellucicl appearance, ancl host are a combination of characters which distinguish it from other describerl species of Clemilophorus. The lack of acod structural characters for the sepraration of the forms now considered as species lias already becil mentioned in our remarks concerning the genns as a whole.

\section{CHAITOPHORUS QUERCICOLA (MIONEI.1.)}

$$
\text { Fili. } 62
$$

Calliptras? quereicola Monell, Bulletin of the Inited States Geological and Geographical Survey of the Territories, Yol. V. No. 1. January 22, 1579. Art. 1, p. 31. (Alate form described).

(hatophorus qucreicola Monell, ibid., p. 32. (description of apterous formu).

This species was originally described by 11 onell (1si!) from specimens sent to him from Peoria. Illinos. Both Davis (1!101) and Baker (191:b) have placed $C$. spinosus Oestlund as a srmonim of quercicola, and this placement seems to us to be correct. spinosus heing clescribed from aplerous oviparous females. Daris (1!lukl) haalso placed Collipterus uncrifolii Themas (1si!) as a stmonrm of quercicola (Alonell). The cotypic slick of Callipterus quercitalii

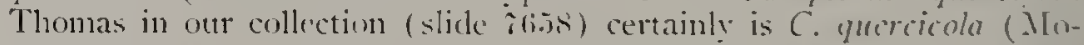
nell) as Davis has stated (19101 and 19133). This slide contains alate and apterous fentess in poor condition from Sauk City. Wisconsin. collected in June by Buncly on red oak leaves.

Data associated with our alate and apterous viviparous females, all collected on Qurreus mucrocurpu. are as follows: Antioch (June 16). Kan. kakee (June 29). Oregon (.1une 28), 1928. Davis reports the oviparous females from kankakee. Oct. 13. 190s, and viviparous fomales from Heyworth. April 10, 1908 . 


\title{
CHAITOPHORUS VIMINALIS MoNiL,
}

\author{
Fici, $1 S S$
}

Chatophorus viminulis Monell, Bulletin of the United States Geological and Geoglaphical Survey of the Territories, Vol. V, No. 1, January 22, 1\$79, Art. 1, p. 31.

The material in our collection strongly inclicates that $\vec{C}$. ziminalis Monell and $C$. nigras Oesthund are the same species, the latter leeing a clark phase of the former. Baker $(1 ! 1 \% 1)$ helrl that siminalis and nigrac were distinct. mainly upon the reticulated condition of the shin of the apterous forms. We are not able to separate our series of slides upon this basis. Conparative lengths of antennal segments and distribution of secondary sensoria intergrale, too, in specimens which on the basis of color might be regarded as two species. In all parts of Illinois we have found the dark and light forms closely associated and intermixerl on the same leaves and stems. This is rather unusual if they are different species.

Data associated with our specimens, all collected on various species of Salix, are as follows: Antioch (June 16), Carbondale (June 4), Elizahethtown (Oct. 12), Galena (June 26), Havana (June 21), Kankakee (June 29), Mattoon (June 10), Mletropolis (June 1), Muncie (May 12). Quincy (June 6). Starved Rock State Park (June 13). Urbana (July 10), 192S; Beach (July 13, Aug. 29), Cairo (June 22), Chebanse (Apr. 24), Elizabetlitown (June 20), Galena (July 10), Hardin (June 25), Muncie (April 17), Oakwood (Oct. 13), Olney (June 1S), Oregon (July 11), Rock Island (July 7), Starved Rock State Park (Aug. 14), 1929; Robinson (April 14), Snyder (April 14), 1930. Slide No. 3784 in the Survey collection was compared with a slide mount of cotypic specimens " $/ 8 / 86 \mathrm{Mlpiis} 26$ " in the collection of Dr. Oestlund.

\section{GENES CL. IVTGERUS SZEPLIGETI}

kipy to thr species of the Gomus Clavigrrus

1. Cornicles about $t$ wice as long as their greatest diameter (Fig. $145) \ldots \ldots \ldots \ldots \ldots \ldots \ldots \ldots \ldots \ldots \ldots \ldots \ldots \ldots \ldots$ smithiae (Monell) p. 166 - Cornicles three times or more as long as their greatest diameter (Fig. 146 .......................... populifoliae (Fitch)

\section{CLATIGERUS POPULIFOLIAE (FITCII)}

\author{
F11: $77,146,147$
}

Aphis populifoline Fitch. Fourth Annual Report of the Regents of the Uni. versity on the Condition of the State Cabinet of Natural History, State of New York, January 14, 1851, p. 60 .

This species is here reported for the first tinle from Illinois. Davis, in 19loe, used the speeific name assignerl to this species by Fitch in connection with another species for which l'atch (1!1i) has proposed the nance of 1 . dazisi. All of our material has leen collected on Salis. Descrijtions of two heretofore undescribed forms are presenterl. 
Data associated with our specimens are as follows: Elizabethiown (May 29, Oct. 12), Harrisburg (May 2S), Oakwood (May 12. 23), Shawneetown (May 27), 1928; Elizabetlitown (June 20), Galena (July 10), Oakwood (Nov. T, Oct. 17), 1929; Calvin (April 15), Cobden (April 19), Oak (Jnne 1), 1930.

\section{ALATE MIALE}

Average length, 2.96. Color essentially similar to that of alate vivip. arous fenale. Average width of head across eyes, 64 . Comparative lengths of antennal segments as follows: IIJ -.59 to .61 , average $.60 ; 1 \mathrm{I}-.39$ to .43 , average $.40 ; \mathrm{V}-.36 ; \mathrm{VI}-.17 \mathrm{plns} .26$. Secondary sensoria on third, fourth, and fifth antennal segments, averaging as follows: III-35, IV-14, V-11, ilregularly arranged, but confined to one side of the segment. Beak reaching to mesothoracic coxae. Prothorax with a large lateral tubercle. Cornicles .24 long, cauda .10 , both structures similar in shape to those of alate viriparous female. Genitalia very dark hrown.

\section{Apterots Oriphot's FeMile}

Average length, 3.26. Color essentially similar to apterous viviparous female. Average width of head across eyes, .71. Comparative lengths of antennal segments as follows: III -.54 to .60 , average .58 : IV-.33 10.39 . average $.36 ; \mathrm{V}-.30$ to .36 , average $.34 ; \mathrm{VI}-.16$ to .17 , average .17 plus .21 . There are no secondary sensoria. Prothorax with lateral tubercles. Lateral tnhercles on abdomen not constant but sometimes present. Cornicles .36 long, cauda .1s long, both similar in shape to those of apterons viviparous female. Sensoria on hind tibiae numbering between three and four hundred.

Allotype.-Alate male; Slide No. 8295, Oakwood, Illinois, October 7. 1929. on Salix sp., (T. H. Frison). On slide with male. Jorphotypr.Apterous oviparous female; Slide No. $\$ 294$, same data as allotype. On slide witb oviparous female.

\section{CI.AVIGERTS SMITHIAE (MONELI.)}

F1G. 145

Chatophorus smithine Monell, Bulletin of the I"nited States Geological and Geographical Survey of the Territories, Vol. V. No, 1, January ?2. 1879 , Art. 1, p. 32.

Specincens from I'eoria, Illinois, formed the cotypic material from which this species was described. This large aphid with its bright orange cornicles is quite common on Salis. Specinnens have been collected, also, on Populus grandidontas and Acor saccharimm. Descriptions of the previously molescribed sexual forms are presented here.

Data associated with our specimens are as follows: Normal (Aug. 31 , Sept. 24), 1S\$3; Chicago (Oct. 9), 1S97; Mansfield (Sept. 22). 1921: Champaign (Sept. 26), Decatur (Sept. 1S. Oct. 4), Fisher (Nor. 11). Homer Park (Oct. 23), Kankakee (June 29), Nahomet (Oct. 2), I'rlana (Sept. 26), 1928; Duncan Mlils (May 4), Oakwood (Oct. 13, 17), (rona (Oct, 21). 1929: Fox Lake (May 14), Joliet (April 23), 1930. Mating pairs were collected November 11,1928 .

\section{Al.ATE Ml.1.F}

Average length from vertex to tip of anal plate, 2.32. Color essentially similar to alate viviparous fenale. Average widtl of head across eyes, .66 . Comparative lengtlis of antennal segments as follows: III- .53 to .64 , arerage .58 ; IV - .33 to .51, average $.41: V-.31$ to .34 , average .32; VI-.16 to .19. average .17 plus .19 to .21 , average .20. Secondary sensoria present on tlird. fourth, and fifth antemul segments, irregularly arranged on all segments. 
apparently on all sides of the thild segment but confined largely to one side of the fourth and fith segments; average distribution as follows: III-95. IV-63, V-12. l'rothorax with lateral tubercles. Four abdominal segments anterior to cornicles as well as the segment posterior to cornicles with lateral tubercles. Beali reaching middle of metathoracic coxae. Cornicles .19 long, callta 08 long, otherwise similar to those of alate viviparous female.

\section{Alterol's Orip.lious Frilate}

Average length from vertex to tip of anal plate, 3.39. Color essentially that of apterous viviparous female. Average width of head across eyes, .69. Comparative lengtlis of antennal segments as follows: IIJ-.46 to .54, average $.50 ; \mathrm{IV}-.30$ to .31 , average .31 ; V-.23 to .29 , average .26 ; VI-.1I to .16, average .I3 plus .20. There are no secondary sensoria. Beak reaching to base of metathoracic coxae. Cornicles .29 long, cauda .14 , both similar to those of the apterous viviparous fenale. Hind tibiae slightly swollen, with about 90 sensoria.

Hllotype.-Alate male; Slide No. 70S6. Homer Park, Jllinois, October 23, 1928, on sirlix sp., (Frison and Park). On slide with male, oviparous female. and nymph. Jorplowtype.-Apterous oviparous female; Slide No. 7019, Fisher, llinois, November 11, 1928, on Acer sucohtrinum. (T. H. Frison).

\section{Genes GipsOAI'HIS OEstLexin}

\section{GYPSOAPHIS OESTI,UNDI HOTTEN}

$$
\text { Fins. 209, } 314
$$

Aphis lonicirac Monell, Bulletin of the United States Geological and Geographical Survey of the Territories, Vol. V. No. 1, January 22, 1879, Art. J, p. 26. Numi meoceupird.

Gypsorphis afstlunat Hottes, Proceedings of the Biological Society of Washington, Vol. 43, October 7, 1930, p. 181. Niw name.

This species was first recorcled from Illinois by Davis (1910e) by the name given it in the orisinal description. It is peculiar anong the supertribe Chaitophorea of lllinois in that the cornickes are lacking This plant lonse is partial to the leaves and nuore terminal shoots of the red honeysuckle (Lonicera sp).)

Data associated with our records of this species are as follows: Antioch (Jume 15). Galena (June 26), Mt. Carroll (June 25), Oregon (Jume 2S), Rock Islanel (June 24), 1928; Decatur (May 12), Lrbana (May 26), 1929.

\section{I'.1DLC'1.1 new genus}

Antenuac fonr-sennented (Fig. :330) and nuch shorter than the body. Antennile, lesis, and body cosered with numerome longr latirs as in Lachnus. llead (Fig. ifi) very broal and without antemal tubercles. Meelia of fore wings (Fig. in) once-forlied, hind wings with both meclia and culditus present. Cornicles (Figr. 119) long and sreatly swollen, consiricted ncar basc and lefore flange al apex. Caltula

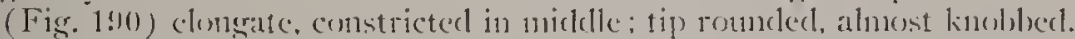

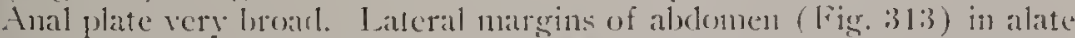

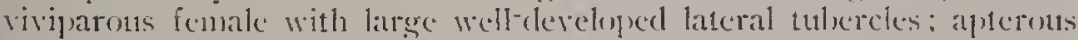
oviparons fenales with lateral glands on the abdonen pouty developed. 
Genotype, Melanoxantlecrimm antemnatum Patch, ly original and present designation.

This gents has heen placed in the sulvertribe Chaitophorea and probably is most closely related to the tribe Pteroconmini, but it might be considered as representing a new tribe because of its four-segnented antennac and elongate constricted canda.

\section{PADECIA ANTENNATA (PATCII)}

Melunoxantherium antennatum Patch, Maine Agricultural Experinent station, Bulletin 213, June, I913, p. si.

This unique and curious plant louse has not as vet been definitely associated with its lost. Onr first specimen, ain alate viviparons fencle, was found resting on a fern leat, and the oviparous ienales were first noticed on the surlace of a small strean fluwing into the Salt Fork River near Oakwoul. Illinuis. Subseruently a iew sprecimens were found clinbing orer rocks protruding from the stream. The restriction of these oviparons females to ai area of stream $13 n t$ exceeding forty feet in length and two to four feet $i_{11}$ width is significant and indicates the host plant was somemhere in the inmediate neighborhood. Although a thorough search failed to locate the host. sonne evidence was obtained to indicate that this aphid occurred on plant roots exposed hy the erosive action of the stream. The typic specimens described by Patch were cullected "on and in a pump which stands beneath an old willow." indicating that willow is probably the host.

We are assuciating the alate and oviparons iemales on the hasis of similar cornicles and numerous other peculiarities.

This species and the new genus to which it las been assigned have no near relatives and may be sharply and distinctly separated from all other Aphiidae. The cornicles. cauda, and anal plate strongly stgegent similar structures of Amiphorophore solami Thonns. but the lack of antemial tulxercles, the once-forked media, the lateral siands, and, most significant of all, the four-segnnented antenuace at once sever all attempts to assuciate the two specien. Tentatively. We have considered this new form as most closely related to the trilie l'terocomminit.

since the alate viviparons iente has not heen previously described. and the oviparous fentale lut briefly: we are presenting detailed descriptions of these two forms.

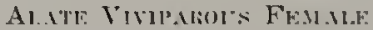

Nize um genernl color.-Length from vertex to tip of anal plate. $1 .: 6$. Head and thorax dark brown, boundaries of thoracic sclerites particularly darkly outlined. Abdomen mostly brown, lighter yellowish-brown areas on buth sides and posterior to large. median. brownisli spot. With lateral tuber. cles arising Irom brownish areas; cauda and anal plate dark brown: cor. nicles dark brown, darkest near base and posterior to widest purtion of cormicles. First and second antennal segments brownish but lighter in color than heal. second segment a little more yellow than first segment. third antennal segment dark blown except for extreme tip of segment which is yellowish, fourth segment essentially brownish becoming more yellowishbrown near base. legs brown: femora lightel at base than elsewhere: tibiae almost uniformly brown, darkest at apices; tarsale somewhat lighter in color 
than tibiae. Veins of fore wings brown; base of radius, cubitus, and anal veins more cistinctly margined with brown than other veins. Beak brownish. Body and appendages with numerous long hairs.

Hord and appendages.-Average width of head across eyes, .4. Antennal segments with comparative length as follows: I- .10; 11- .10; I1I- .55; 1V. .11 plus .41. Third autennal segment (Fig. 230) with nineteen to twentythree secondary sensoria which are irregularly arranged but mostly confined to one side of the segment The beak extends to the base of the coxae of the metathoracic pair of legs.

Thork and appendayes.-Prothorax with three pairs of lateral glands or tubercles. Stiguna of fore wings (Fig. 55) narrow, distinctly pointed, and with a well-developed brownish accessory vein; media once-forked, hind wings with both medius and cubitus present.

Abromen.-Four pairs of tubercles (Fig. 313) on lateral portion of ab. domen anterior to cornicles, and a single pair of tubercles posterior to the cornicles. some of the tubercles appear to arise from low volcano shaped areas. The cornicles (Fig. 149) are about four times the length of the cauda and ale weakly imbricated just before their apex. Cauda (Fig. 190) somewhat narrowed at base and distinctly constricted beyond middle, with two pairs of hairs on lateral margins. Anal plate witle and distinctly rounded.

\section{Al'TEliol:s OVIPAliot's FFullF}

Nize aml aneral color.-Average length from vertex to tip of anal plate. 2.02. Body and aptsendages clothed with numerous long hairs as in alate viviparous female. Head, thorax, and abdomen essentially dark chocolate brown shading to almost black in some tlaces; area at base of cornicles more noticeably yellowish and contrasting with the cornicles, which are dark brown to almost black; cauda and anal plate clark brown to blackish. First, seconi, and third antennal segments mostly concolorous with head: fonrth :egment at base about concolorous with other segments but lighter beyond sensoria. l.egs essentially concolorous with the body, somewhat larker at apices than at Lases; tarsi lighter in color than the other segments. Beak brownish, with terminal segments darker.

Ifral anl apprmilues.-Average width of heat across eyes, .49. Antennal cegments with comparative lengtl as follows: III- :37 to .5T, aver. age $.45: t \mathrm{x}^{*} .10$ to .14 , average .12 plus .31 to .39 , average .35 . There are nn secondary sensoria. Head sometimes with two glands on dorsum but occasionally with only one or lone. The beak reaches about to the metathoracic pair of legs and sometimes beyond.

Thome and mmenda!ges.-Prothorax with three pair of lateral glands as in the alate viviparous female. Mesothorax on dorsum separated from metathorax by an almost continuous row of glandular structures. All femora with large oval sensoria. Hind tibiae with from eight to twenty exceedingly small sensoria, which are extremely difficult to distinguish from the light colored bases of the hairs.

Ablumsn.-Four double rows of glandular structures on the lateral and mid-lateral suriaces anterior to the cornicles; lateral portion of ablomen bosteriol to cornicles always with two pairs of glandular structures and occusionally three pairs (possibly three is the normal number but the third and nore dorsal pair is smaller than the others and more difficult to dis tinguish). The cornicles are shaped as in the alate viviparous female and are faintly imbricated at the constricted area near the apex; in some specimens these imbrications are indenter all over the surface of the cornicle but are extremely faint. The tip of the abdomen always extents beyond tloc anal blate. aud may even extend beyond the constriction of the caucla so that only the extrene tip of the canda may be seen unobstructed. The iip of the culudil is very "buslyy," the hairs, which are difficult to count, average about six pairs on a side The ablomen of the oviparous female nsually contains only two very large eggs.

Vorphotypr.-Alate viviparous female; Starverl Jark State l'ark. 1lli. nois. July fi, 1929 (Frison and Hottes). Host unknown. 
Out material, in adclition to the single. previously unknown alate vivijarous female, consists of oviparous females. collected at Chaworyt. Illinois, on Nosember $i$ and 10,1929 (T. H. Frison) and November ?. 1929 (H. H. Ross). One of the specimens taken on November $;$ is aberrant in that the cornicies are not as swollen as in typical specimens. Host in all cases unknown. Our oviparous females have been compared with a cotypic slicle of this species kindly furnished by Dr. Patcls.

\section{Genl's PERIPHYLlL'S Yax der Hoetex}

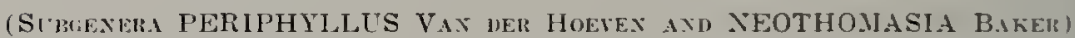

\section{They to the species of the Genus Periphyllus}

1. Veins of fore wings conspicuously margined with dark fnscons (Fig. 54) ........................... populicola 1Thomas) p. 1i2

-. Veins of fore wings not margined with fuscous..................

2. Secondary sensoria of thirc antennal segment numerous, varying in number from fourteen to over twenty; dorsum of abdo. men with brownish markings; sixtl antennal segment with terminal filament at least three times as long as basal portion $\ldots \ldots \ldots \ldots \ldots \ldots \ldots \ldots \ldots \ldots \ldots$. . . . . . . $\ldots \ldots$.

-. Secondary sensolia of third antennal segment few. varying in number from six to ten; dorsum of abdomen without brownish marlings; sixth antennal segment witl terminal filament less than three times as long as basal portion................ $\ldots \ldots \ldots \ldots \ldots \ldots \ldots \ldots \ldots \ldots \ldots \ldots$ negundinis 1 Thomas) p. 170

\section{PERIPHYLLIS LYROPICTLS (KESNIER)}

(Thatophorus lyropictus Kessler. Nova acta Academie Caesareae LeopoldinoCarolinae Germanicae Naturae Curiosorum. Band LI. No. 2, 1856. p. 171.

This larec species, which inhalits the under writace of the leaves of majples, has lieen previnusly reported from Chicago and the near vicinity ly Gillette (1!0!(d) and Davis (1910d) moler the name of Chatofhorus aceris Lim. The entire life history is spent upon its host. No dimorples, as in P. nogudinis, have thus far leen observed.

All of our specimens have been collected on hard maple. Acer sacharum. lata associated wilh our specimens are as follows: Decatur $10 \mathrm{ct}$. 2. Nov. 22), 192s: Decatur (Oct. 21), Urbaua (Oct 29), Waukegan (July 13, Aug. 29), 1929: Urbana (May 20), 1930. Our earliest record for the alate and apterous viviparous fenales at Urbana is May 20. Males and oviparous females are found in Illinois in September and October. A mating pair was observed at Urbana on October 29, 1929.

\section{PERIPHYLITS NEGUNDINIS (TUOM.K)}

F1(is. 152, 331

Chuitomborus mennumis Thomas. Bulletin Illinois State Laboratory of Nalural History, Vol. I, Xio. 2, June, 187\&, p. 10.

This species is of special interest lecatuse of the production of the so-called "dimmolls." which are readily recosnized by peculiar leatlike fabedlac potruding from the sirles of the abdemen and head (Fis. 331). Onr best information concerning these dimorplus is given in two 
papers by Davis (190,8b and 1910a). In the locality of Lrbana, the dimorphs apyear in June. Later in the season they are replaced by the normal forms. A related Enropean species, P. tesludinatus Thorntom, has similar dimorphs.

At times this plant louse becomes so abunclant on box elcler in Illinois that it is exceedingly obnoxions, for the honey dew covers the

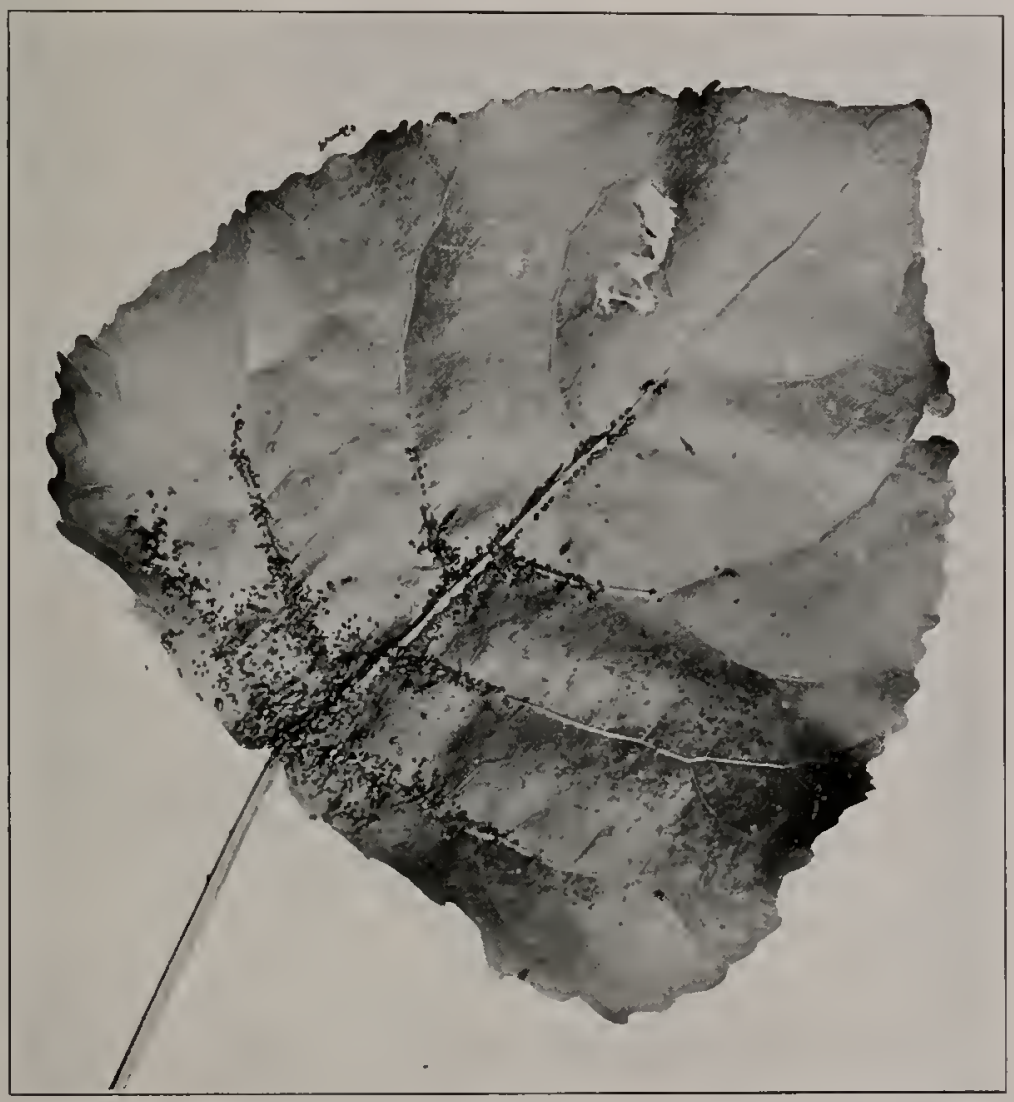

Fig. 13. Characteristic grouping of a colony of periplnyllus populicola (Thomas) on upper side of a leat of the cottonwood, l'opulus drfloirles: Champaign. Sept. 9, 1929.

sidewalks bencath infested trees. On1r records inclicate it is commente and widely distributerl in all parts of the state. The lest general acconnt regarding it is griven by llobser (191\%).

The cotypic specimens from which the original description was made are mounted on Slide 2775 of the Survey collection. Data associaterl will this slide mount of alate and apterous viviparous females are as follows: Peoria, Illinois, Jume, collected by Miss Smitli, on drer Nirymmo. 
Data associated with our specimens, all collected on Acer Jegunro are as follows: Normal (Sept. 24), 1883; Normal (Mlay 12, 14), 1854; Antioch (June 15), Carbondale (June 4), Champaign (.lay 17, 21), Galena (June 26), Havana (June 21), Kankakee (June 29), LeRoy (June 20), Mattoon (June 10), Metropolis (May 31), MIt. Carmel (May 26), Mt. Carroll (June 25), Oregon (June 27), Pekin (June 20), Quincy (June 6), Shawneetown (May 27), Starved Rock State Park (June 12, 13). Lrbana (.llay 24. June 7. Oct. 1), 1928; Collinsville (Sept. 11), Effingham (June 18), Macomb (Ma: 4), Rantoul (April 24), Rock Island (July T), Springfield (May 2), 1929.

\title{
PERIPHYLLIS POPLLICOLA (TIOMAS)
}

\author{
Flis. 19, 54
}

Chatophorus populicola Thomas, Bulletin Illinois State Laboratory of Natural History, Vol. 1, No. 2, June, 1s7s, p. 10.

This clark-colored aphid (Fig. 19), with wing veins bordered with fuscous (Fig. 54), is one of the most common aplids on poplar in Illinois. Dimorphic forms, such as are produced in summer by $P$. negundimis (Thomas), are not prodticed by this species. It is partial to water-sprouts or new and succulent growth. Since the description ly. Thomas, based on [llinois material, it has been recorded from the state by Davis (1910d). Wilson (1910b) made this species the type of a new genus called Thomasia. Finding that Thomasia 11 ilson had been used previously for another genus of insects, Baker (19:0) projosed the generic name of Nothomasia for the same insect. $1 V^{*} \mathrm{e}$ are considering Neothomasia as a subgeneric complex.

Cotypic specimens of this species were found among the receutly discovered Thomas types in our collection. These cotypic alate and apterous specimens, in poor condition but easily recognizable as this species, are mounted in damar balsam on Slide No. \$17\%. They were collected at Carboudale, I!linois, July 19 , $187 \%$, on sprouts of Populus.

Data associated with our alate and apterous specimens, all collected on Populus sp., are as follows: Pekin (Aug. S), 1S52: Champaign tJuly 1\%. 27), Danville (Sept. 18), Elizabethtown (Oct. 12), GaJena (June 25). Ha. vana (June 20), Metropolis (June J), Morton (July 22). Muncie (Ang. \$). Oakwook (July 18), Oregon (June 27, 28), Pekin (July 22), Quincy (Jume 6). T'rbana (July 27), 192S: Cairo (June 22). East St. Louis June 2fl. Edwardsville (Aug. 11), Eldorado (June 9). Elizabethtown (June 20). Galena (July 10), Grayville (June 19), Hillsboro (Sept, 10). Kansas I Jume 17), Oakwood (Oct. 13, 17. Nov. 10), Richmond (July 12). Fock Island July 7), Starved Rock State Park (July 5), 1829: Oakwood (Oct. 22). Starved Rock State Park (May 13), 19:0. We have taken the sexual forms at Oakwood, Illinois, on October 10, 1T, ant November 10, 1929, and October $22,19: 30$.

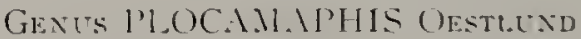

\author{
Ley lo spreies of the Genus Plocomalnis
}

1. Body flocculent in living specimens, cornicles distinctly swollen and well developed $(\mathrm{Fig}$. 162), secondary sensoria on thind antennal segment averaging about twenty....flocculosa (Weed)

- Body not focculent in living specimens, cornicles not distinctly swollen and weakly developed (Fig. 161), secondary sensoria on thirl antennal segment averaging about thirteen.......... 


\section{PLOCANIAPHIS FLOCCULOSA (WEED)}

Helanoxanthus flocculosum Weed, Insect Life, Vol. III, No. 6, March, 1891, p. 291 .

This species has not previonsly been reported from Illinois. It is a bark feeder. Because of its body being very flocculent it is quite conspicuous on the bare and leafless branches of its host. The sexual forms have been described by IVeed.

Data associated with our specimens, all taken on salix sp., are as follows: Elizabethtown (Oct. 12), Herod (Nov. 30), 1928; Kankakee (July 25), Mounds (June 21), Oakwood (Oct. 17, Nov, 10), Oregon (July 11), 1929. We have taken the oviparous females in October and November. Eggs were being deposited on willows at Herod, lllinois, on November 30 , 1928.

\section{PLOCANIAPHIS TERRICOLA new species}

Fisis. 161, 214, 256

\section{Al.tTE VINIPAROIS FEMIILE}

sizc and general color.-Length from vertex to tip of allal plate, 2.46 . Head and thorax dusky cinnamon brown; abdomen light cimmamon brown with darker brown on outer margin of cauda; anal plate slightly darker than the ablomen and reddish tinge less in evidence. First antennal segment concolorous with the head, second segment and basal portion of third segment light brown, remainder of antemnae a dusky brown. Coxae, trochanters, and basal portion of femora light brown; remainder of femora, tibiae, and tarsi dark brown, particularly apical ends of tibiae and tarsi. The beak is mostly light hrownish slıading to dark hrown at its apex. Wings with the stigma and the base of wings slightly suffused, the veins are well definerl and light brown in color.

Head and appendages.-Average width of head across eyes, .66. Antennal segments with comparative lengths as tollows: III-.46 to .50, average $.49 ; \mathrm{IV}-.36$ to .36 , average $.36 ; \mathrm{V}-.31$ to .36 , average .33 ; VI- .17 to .20 , average .18 plus .31 to .43 , average .39 The secondary sensoria are limited to the third antenual segment (Fig 256) and with the exception of one or two are arranged in a straight row; in number they average about 13; the terminal filament is more blunt than usual; liairs on antennae fine and fairly numerous, those on the third antennal segment from subequal to one and onehalf times as long as width of segment. The beak is musually long, always extending to the tip of the anal plate and often beyond.

Thorax and appenduges.-Fore wings with the second fork of niedia variable in relation to the first fork and margin of the wing, either closer to first fork or midway between first fork and margin of the wing; and in one specimen MI. is entirely lacking. The second segment of the bind tarsi, exclusive of claws, is about as long as the cornicles but in several examples it is slightly longer. The prothorax has a pair of large, well-developed lateral tubercles.

Abdomen.-At least three abdominal segments with well-developed lateral tubercles anterior to the cornicles. The cornicles (Fig. 161) are feebly developed and without a flange, are but slightly swollen and difficult to locate because of being lighter in color than the ahdomen and not protruding beyond it: their length varies from .13 to. IT and averages. 15 . The cancla (Fig. 214) is much shorter than the anal plate and varies in length from . I0 to .15 and averages .13. The anal plate (Fig. 214) is unusually well developeil, often having its sirles almost parallel and its posterior mar. gin only slightly rounded. 


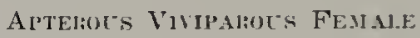

Size and fentrul color.-Average length from rertex to tip of anal plate. 3.05. General color about as describer for the alate viviparous female: differs in that the antennae and legs are darker in color. The dorsum and lateral portions of thorax and certain small areas in the abdomen are dis. tinetly dusky bown.

Heal and apprniluges.-Average width of head across eyes, .73. A11. tennal segments with average comparative length as follows: III- $.40: 10^{\circ}$. $.30 ; \mathrm{V}$. .30; VI- .17 plus .36. The secondary sensoria are restricted to the third antennal segment and vary in number from one to four. The beak is similar to that of the alate riviparous female but usually extends only to the base of the cornicles.

Abdomen.-Iateral tubercles, caula, anal plate. and cornicles as in the alate viviparous female.

Holofype.- Alate viviparous female: Beach, lllinois, July 13, 1929, on snlis sp. (Frison and Hottes). Slide No. 10659. Morphotype.-Apterous viviparous female; Beach, 1llinois, July 13. 1929, on Niatis sil.. (Frison and Hottes). Slide No. 10b60. Paratypes.-Thirty-four sides of alate and apterous viviparous females, pupae and nymphs: all collected at Beach. lllinois, July 13, and August 29. 1929, on siltiv sp., (Frison and Hotles). Slides Nos, 10661-10679 and others unnumbered.

This species was found on the roots and near the crown of a species of Sali.1 growing in the sand not far from the shore line of Lake Michigan. It may be separaterl from Plocumaphis flocoulosmm (IVeed) by mot being fieculent and terrestrial as well as hy morphological charaters. the most noticeable of which is the fact that the cornicles are nuch shorter and distinctly less swolleis. In spite of the fact that the median vein has two forks instead of one. this species is perluaps most closely allicel to I'loramaphis loraggi Gillete and Palmer. In addition to venational chacaters it may he separated from this latter species by its larger cornicles and differtnce iil comparafive lengths of antennal seuments.

\section{Gents Sil'Hil Passeriat \\ SIPHA FLAVA (Fomis. )}

Chaitophorus flurus Forbes, Thirteenth Report of the State Eutomoiogist of the State of Illinois, Mlay 31, 1854. p. 42.

Althugh the sorghum aphis was described irom lllings by forle: in 1 sst, its life history Wats mainly unknown until the studies of Davis (190!a ) were published. The gencral details of the life history are similar to most other non-migratory species. except that some eviclence was obtained ly Davis to lead him to helieve that the stem motherare winged. The sorghum aphis is sometimes abundant chomgh en catre seriots dimage to brom corn and sorghum in Illinois. In Porto Rico it has frequently been a serious pest of young sugar cane.

Data associated with material iu our collection are as follows: Heyworth (Aug. 11), 1883: Champaign (Mily 7), 18s6; Yrbana (Sept. 11), 1sss: Havana (June 26), 1907; Carboudale (June 4), Decatur (Nor, 4), Mtt. Carmel (May 26), 1928: Nlitchell (June 25), 1929.

Lectotypic slide, io. 3152 , selected by Frison (1927), contains an alate viviparous female collected at (Chanmaigu. Inlnois. Iuly 25. 1S53. on sorghum by S. A. Forles. Paratypic slides, Nos. 3151. 3153-3156, are associated with the same data as the lectotype slide. 


\title{
SUPERTRIBE APHIEA
}

\section{IEY TO GEXER.L}

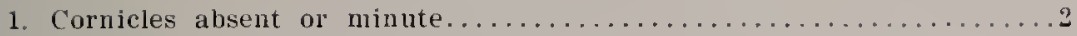

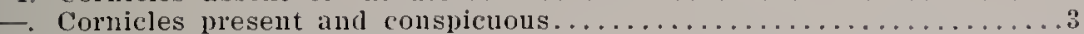

2. Abdomen with lateral tubercles (Fig. 312); cormicles absent; borly not elongate; basal portion of sixth antennal segment much shorter than fiftl segment............. Asiphonaphis

- Abdomen without lateral tubercles; cornicles present but minute; body elongate; fifth and basal portion of sixth antenual

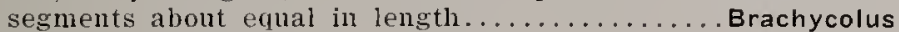

3. With a caudal projection (supra-anal process) situated above

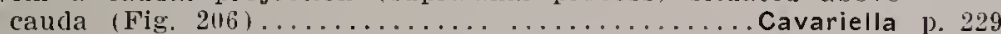

- Without a caudal projection above cauda . . . . . . . . . . . . . . .

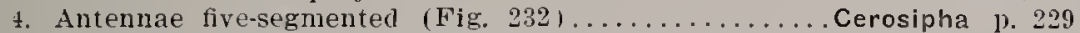

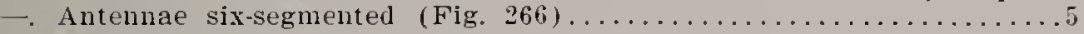

5. Media of fore wings normally brancied once (Fig. 70)...... $\ldots \ldots \ldots \ldots \ldots \ldots \ldots \ldots \ldots$ Toxoptera p. 241

- Media of fore wings normally branched twice (Fig. 57) ..........6

6. Hind wings with cubitus lacking (Fig. 89) or only partially de-

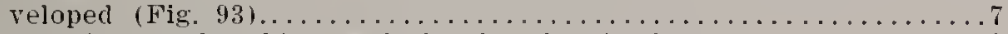

- Hind wings with cubitus well developed (Fig. 91) ..............s

7. Cornicles witlout a flange (Fig. 136); secondary sensoria num. erous on third, fourth and fifth segments; hind tibiae between four and five times as long as cornjcles........... Alphitoaphis

- Colnicles with thange (Fig. 135); secondary sensoria few or lacking on fourth and fifth segments; hind tibiae about three times as long as cornicles.............................................. 232

s. Cornicles cylindrical or tapering (Fig. 131)............Aphis p. 176

- Cornicles more or less swollen (Fig. 160) with distinct constric-

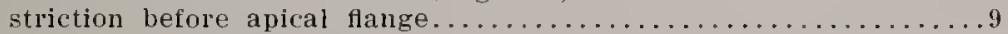

9. Cornicles about as long as basal portion of sixth antennal seg-

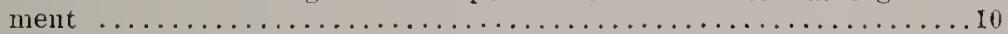

- Cornicles much longer than basal portion of sixth antennal segment .......................... Rhopalosiphum p. 234

10. Cauda short, width at base about equal to length (Fig. 204).... $\ldots \ldots \ldots \ldots \ldots \ldots \ldots \ldots \ldots \ldots$ Brevicoryne p. 228

- Cauda elongate, much longer than width at base (Fig. 199)...

Hyalopterus p. 281

\section{GENIS ALPHITOAPHIS HotTES}

\section{ALPHITOAPHIS LONICERICOLA (WIIAMS)}

\author{
Ficis. 79, 93, 136
}

1 phis lonicericola Williams, University Studies, University of Nebraska, Vol. X, No. 2, March, 1911 , p. 45 .

This comparatively rare aphicl is here recorded for the first time from Illinois. It causce the terminal leaves of its host, the red honeysuckle. to curl. A complete accumnt of the life history of this nonmigratory species, giving descriptions of all the various forms, has never been pullisherl.

Data associated with our specimens, all collected on Lonicrer sp., are as follows: Antioch (Jume I5), Galena (Jume 26), Mt. Carroll (Jume 25), Oregon (June 28), 192s; Oakwood (June 1), 1929. 


\section{GENTS APHIS LINNAEL'S}

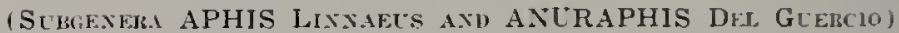

\section{Key to the species of the Genus Aphis}

1. Dorsum of abdomen with a large dark patch or saddle-like area

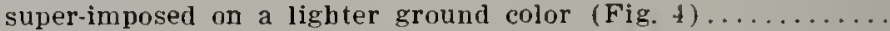

- Dorsum of abdomen of a uniform light or dark color, or at the most with lateral dark spots, narrow median, entire or inter. rupted, transverse bars, or dark areas around or posterior to the bases of the cornicles (Fig. 23 ) .....................

2. Cauda or anal plate or both brown, decidedly darker than renter of abdomen; cornicles dark brown or blackish, sometimes

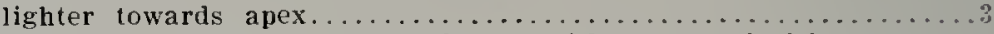

- Cauda and anal plate red, concolorous with venter of abdomen (both appearing yellow in cleared specimens). cornicles pale, sometimes slightly dusky near apex........ rociadae Cockerell

3. Cornicles either without imbrications, or with them only indistinctly developed, the sicles of the cornicles appearing prac.

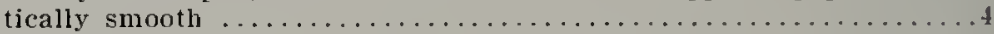

- Cornicles with distinct, fine, close imbrications, giving the sides of the cornicles a minutely serrate appearance ...............

4. Cornicles less than twice length of cauda: cornicles practically

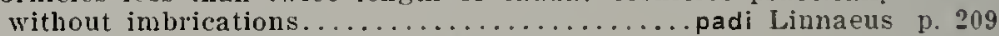

- Cornicles distinctly longer than twice length of cauda; cornicles with feeble imbrications. . . . . . . . . . . . . . . . . . .

5. Fourth antennal segment with more than 15 sensoria; on apple. $\ldots \ldots \ldots \ldots \ldots \ldots \ldots \ldots \ldots \ldots$. . . . . . . . . . . . . . . . . .

- Fourth antennal segment with less than 10 sensoria: on thistle $\ldots \ldots \ldots \ldots \ldots \ldots \ldots \ldots \ldots \ldots \ldots \ldots \ldots \ldots \ldots \ldots \ldots \ldots \ldots \ldots \ldots$ cardui Linnaeus

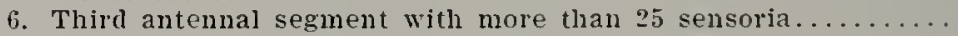
$\ldots \ldots \ldots \ldots \ldots \ldots \ldots \ldots$ tulipae Fonscolombe

- Third antennal segment with less than 25 sensoria...............

7. Cormicles and cauda subequal in length; migrating between apple and clover........................................... Cowen

- Cornicles two or three times length of cauda: mahing a leaf-cur] on Viburnum (Fig. 28)................viburnicola Gillette p. 223

S. Abdomen bright yellow with a very large black spot at the base

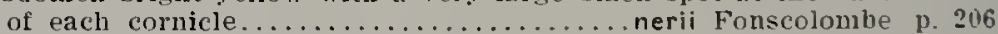

- Abdomen either not a bright yellow or without such a rery large

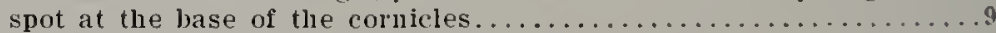

9. Cornicles subequal to only one-half length of cauda.............

- Cornicles subequal to. or greater than. eutire length of cauda.......11

10. Fourth antennal segment with secondary sensoria $(4-5)$ : third antenual segment with more than 10 sensoria............. $\ldots \ldots \ldots \ldots \ldots \ldots \ldots \ldots$ debilicornis Gillette and Palmer

- Fourtl antennal segment normally without sensoria. rarely with one or two; third antenlul segment with less than 10 sensoria $\ldots \ldots \ldots \ldots \ldots \ldots \ldots \ldots \ldots \ldots \ldots . \ldots \ldots$ spiraephila Patch

11. Cornicles smooth, entirely withont imbications: species forming a tight leaf-fold on solicla!no (Fig. 27)

1 The preparation of a kes for the recosuition of the llimois species of plant lice belonsing to the genus iphis his proved to he a dillicult and highly unsatisfactory undertaking. This key is sulmitted with the realizatinn that it is inperfect and that it demands a partial kmowledge of the colors of livims anhiels as well as the structures revealed hy slide promilrations. The lify hils heph made liy il study of many imbividuals of each shociss and an effort has heen mate in talie into consideration reasonable vintation. The inabilits to ensily

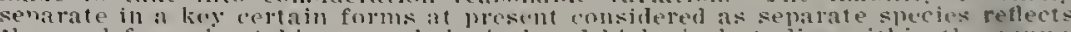
the need for pains-laking morphologir:al and liblogionl sindies within the genus. studies of a cliaricter not possible for us in carry in completion at this time.

"We have mot examined alate vivipamls females of this snecies but have

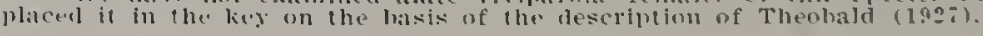


- Cornicles with imbrications, usually distinct, especially on basal portion, but only weakly developed in the case of persicar-niger . . .12

12. Antennae with numerous conspicuous setae as long as, or longer than, the width of the segments of the antennae; on Populus..

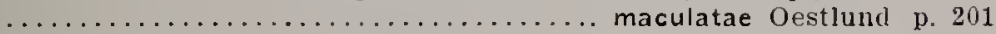

- Antennae with only inconspicuous, translucent setae, usually

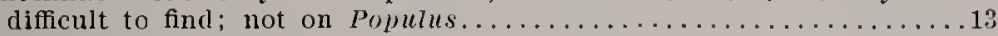

13. Sensoria on third antennal segment arranged in a more or less

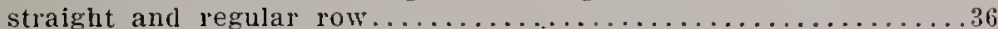

- Sensoria on third antennal segment not arranged in a straight row, being scattered more incliscriminately over the surface of

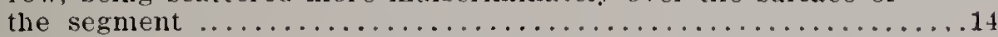

14. Cauda elongate, constricter near the middle (Fig. 197), always

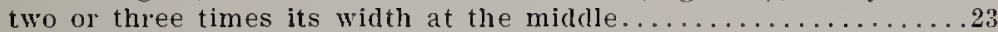

- Cauda shorter, conical (Fig. 194), spatulate (Fig. 193), or broadly

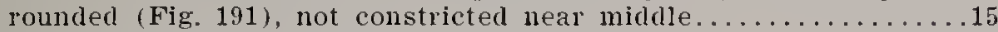

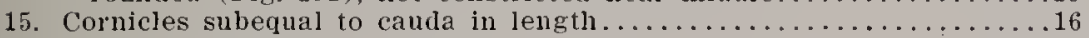

- Cornicles longer than cauda ........................

16. Fourth antennal segment with more than 10 sensoria; on Physocarpus....................... neilliae Oestlund p. 205

- Fourth antennal segment normally lacking sensoria; on Cornus ........................................... 182

17. Terminal filament of sixth antennal segment less than twice

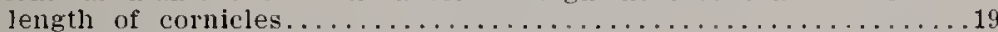

- Terminal filament of sixth antennal segment twice or more than

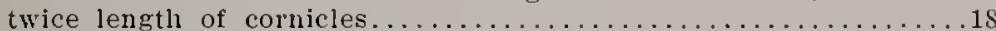

1S. Cornicles subequal to or only slightly greater than length of base of sixth antennal segment................ crataegifoliae Fitch p. 190

- Cornicles at least twice as long as base of sixtl antennal seg. ment..................... persicae-niger Smith

19 Ablomen a very dark green, appearing almost bluish or black; hind tibiae usually pallid with the apex darker; on sumbucus $\ldots \ldots \ldots \ldots \ldots \ldots \ldots \ldots \ldots \ldots$ sambucifoliae Fitch

- Abdomen red or yellow with darker lateral or caudal patches; hind tibiae entirely black or blackish brown, sometimes with a

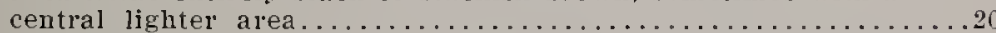

20. Abdomen with four pairs of large lateral tubercles anterior to cornicles....................... feminea Hottes p. 193

- Abdomen with only one or two pairs of large lateral tubercles

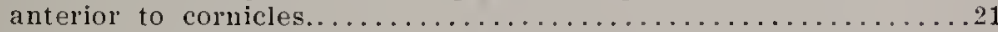

21. Sixth antennal segment with terminal filament not more than twice the length of the base; a subterranean or semi-subterranean species on the roots and crowns of dandelion (Tarar cum sp.)...................knowltoni Hottes and Frison p. 199

- Sixtl antenual segment with terminal filament more than twice length of base, often three times or more; not subterranean,

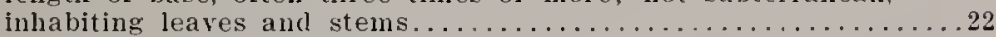

22. Color of abdomen distinctly reddish brown; distance from second fork of media to closest edge of wing four-fifths or more times the distance from second fork to first fork of media; fourth antennal segment with 2 to 4 sensoria.....viburniphila Patch p. 224

- Color of abdomen yellow; distance from second fork of media to closest edge of wing less than two-thirds of the distance between frst and second forks of media: fourth antennal segment with 7 to 13 sensoria.......... luridis Hottes and Frison p. 200

23. Abdomen black, brown, or reddish, not green or yellow ..........24

- Abdomen green or yellow or some shade of these two colors.........

24. Terminal filament subequal to length of thirc antennal segment, always much longer than one-half of the third segment ........25 Terminal filament subequal to one-half length of third antennal

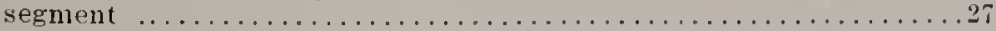


25. Cornicles almost equal to, or longer than, twice length of hind tarsi exclusive of claws: color bluish or black or greenisly black

- Colnicles shorter, at most scarcely more, than one and one-half times lengtl of hind tarsi exclusive of claws: color of abdomen

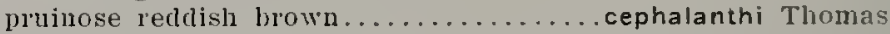

26. Fourth antennal segment with 3 to 16 sensoria; on ficrardia... ....................... rumicis var. gerardiae (Thomas)

- Fourth antennal segment with less than $S$ sensoria. usually 1 to 3: on a great variety of plants............ rumicis I.innaeus p. 213

27. Third antenual segment with 20 or more sensoria...............

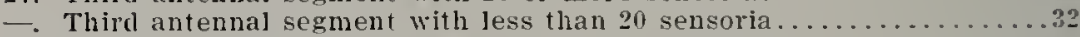

28. Fonrth antenmal segment with more than 5 sensoria..............?

- Fourth antennal segment with less than $f$ sensoria...............

29. Terminal filament of sixth antennal segment about twice as long as fifth antennal segment, ground color of abdomen golden yellow......................

- Terminal filament of sixth antennal segment only slightly longer than fifth antennal segment. ground color of ablomen vellow

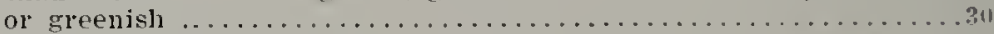

30. Secondary sensoria conspicuously large, those on fourth antennal segment mostly larger than prinary sensorium on fifth: abdomen essentially dark brown or almost black: on senecio..... econdary sensoria mostly small, those on fourth usually dis tinctly smaller than primary sensorium of fiftl: abdomen Essentially dark green; on $7 i z i(t$ and other umbelliferous

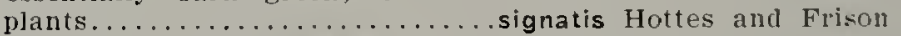

31. On Asclepias and Apmcymmm sp.; abdomen yellow with lateral and caudal black spots; third antennal segment with 111-211 sensoria, fouth without sensoria; cornicles not more than 11 ; times length of cauda and subequal to, or longer than. fourth antenual segment; sixtl antennal segment with terminal filament 2 or 3 times length of base............ asclepiadis Fitcl n circium: abdomen essentially mollerately dark green; with lateral and candal hlackish spots: third antennal segment with 15-25 sensoria, fourth witlout: cornicles subequal to, or consiclerably more than, 11/2 times cauda, and slightly longer than fourth antennal segment; sixth antennal segment with term. inal filament about twice length of base...... carduella Walsh

- On Pastinucu: abdomen yellow with large lateral blackish patches: third antennal segment with $35-50$ sensoria, fourth usually without sensoria but occasionally with one or two: cornicles always ristinctly longer than i ín times length of cauda, and always longer than fourtl antennal segment; sixth antennal segment with terminal filament about thee times base.................... decepta Hottes and Frison

- On Cormus or Ihlianthils: abdomen dark green with dark brown lateral and candal patches: third antenmal segment with 25-35 sensoria, fourtl normally without sensoria, rarely with one or two: cornicles subequal to, or longer than. 11/2 times length of cauda and much longer than fourth antemal segment: sixul antennal segment with terminal flament about twice length

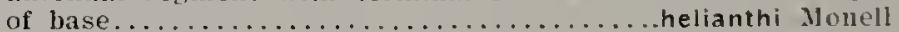

32. Hind tarsi entirely dark brown or black: on corn... maidis Fitch

- Hind tarsi pallid or yellow with the apices dark brown and contrasting with the basal portion; not on corn.................3

33. Fourth antemal segment usually with three or more sensoria. rare specimens without sensoria ou fourth................

- Fourth antennal segment normally without sensoria. rarely with

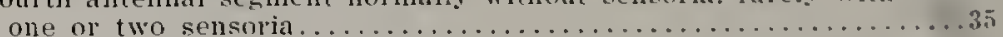

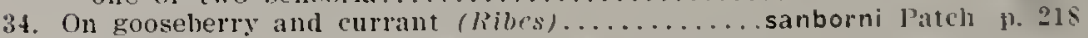

- On lihommus and a large variety of summer hosts........... $\ldots \ldots \ldots \ldots \ldots \ldots \ldots \ldots \ldots \ldots$ rhamni Fonscolombe. 1. 214 
35. Abdomen yellowish green; on dsctrpias and Apocymum sp.... $\ldots \ldots \ldots \ldots \ldots \ldots \ldots \ldots \ldots \ldots \ldots \ldots \ldots \ldots \ldots \ldots \ldots \ldots \ldots \ldots$ asclepiadis Fitch p. 181

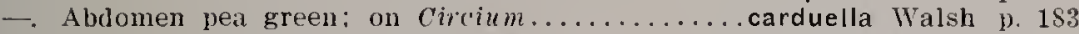

36. Hind tibiae pallid or yellowisin with apex brown. contrasting with

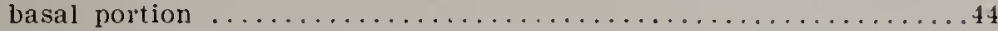

- Hind tibiae entirely black or blackish brown, or with the basal half and the apex dark brown and the middle portion lighter.....37

37. Ground color of abdomen yellow or greell...................

-. Ground color of abdomen red, purplish, or reddish brown .........40

3S. Teminal filament of sixth antennal segment four or more times the length of basal portion of segment.....

ageratoidis Oestlund p. 181 and

coreopsidis (Thomas) p. $1 S S$

- Terminal filament much less than three times the length of basal portion of segment, usually about twice as long. . . . . . . . . . . 39

39. Cauda short and conical (Fig. 201), not constricted near midule: on roots and crowns of corn and other plants.............. auda ionger (Fig. 197), constricted near midlle: on leaves and

- Canda longer (Fig. 197), constricted near midcle: on leaves and stalks of corn and other plants............maidis Fitch p. 205

40. Cauda short, not constuicted near middle (Figs. 192, 201) .........41

- Cauda longer, distinctly constricted near midlie (Fig. 197) ..........43

41. Abdomen with four pairs of large prominent lateral tubercles anterior to cornicles: fourth and fifth antennal segments with secondary sensoria, usually 3 to 5 on each....feminea Hottes

Abdomen at the most with only one or two pairs of large laterai tuhercles anterior to cornicles; fourth and fifth antennal seg-

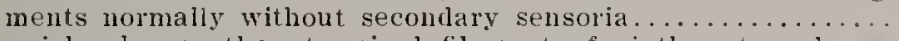

42. Cornicles longer than terminal filanent of sixth antennal segment; on Prunus.............chetansapa Hottes and Frison

- Cornicles very much shorter than terminal filament of sixth an tenual segment, subequal to half its length; on Psetert...... $\ldots \ldots \ldots \ldots \ldots \ldots \ldots \ldots \ldots$ folsomii Davis

43. Cornicles subequal in length to terminal filament of sixth antennal segment: on grape................ illinoisensis Shimer

Cornicles very much shorter than terminal filament of sixth antennal segment, subequal to half it:; lengtli; on Cephatanthus

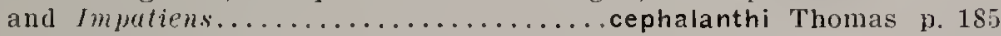

44. Abdomen blue, blackish, brown or reddish-brown............45

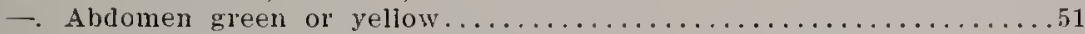

45. Cornicles very much shorter than third antennal segment.........46

- Cornicles subequal to, or longer than, thisd antennal segment....... 49

46. Cauda short, broad, and rounded (Fig. 202), not constricted near middle; on cornus.............................

- Cauda longer and more slender iFig. 200), slightly constricted

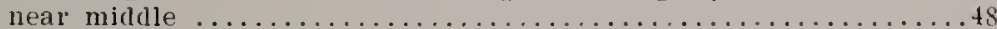

47. Cornicles slightly shorter than cauda: abcomen with the single pair's and one double pair of large lateral tubercles anterior to cornicles (Fig. 309).............caliginasa Hottes and Frison

- Cornicles longer than cauda; ablomen with less than five pairs of lateral tubercles anterior to cornicles......cornifoliae Fitch p. 189

45. Fourth antemnal segment usually with one to four sensoria; a pruinose reddish-brown species an crphulanthus or Imputiens.

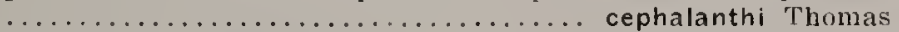

- Fourth antennal segnent without sensoria: a pulverulent bluishgreen species on Euphorbia......pulchella Hottes aud Frison p. 212

49. Distance between first and second iork of media less than twice distance between second fork and edge of wing measured

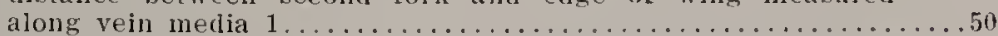

Distance between first and second fork of media more than twice distance between second fork and edge of wing measured along voin media $1 \ldots \ldots \ldots \ldots \ldots$............ farbesi Weed 
50. Sixth antennal segment (base plus filament) longer than cor. nicles: species on Liatris.........funesta Hottes and Frison

- Sixth antennal segment subequal to cornicles; species on Labur$n u m$ and other legumes............... laburni Kaltenbach

51. Base of sixth antennal segment shorter than fifth, and also

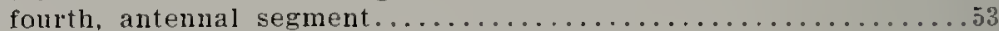

- Base of sixth antemnal segment subequal to, or slightiy longer than, fitth, and usually also fourth, antennal segment........... 2

52. Cornicle nearly twice or more than twice, length of cauda; species on leaves and stems of Eupatorium and allied Compositae $\ldots \ldots \ldots \ldots \ldots \ldots \ldots \ldots$ vernoniae Thomas $p .222$

- Cornicle distinctly less than twice as long as canda; species on

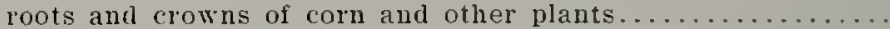

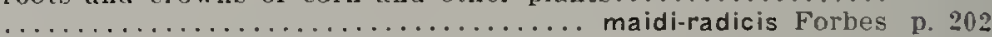

52. Cornjeles longer than cauda..............

-. Cornicles equal to or slightly shorter than canda...............

54. Fourth antenual segment with secondary sensoria, usually num-

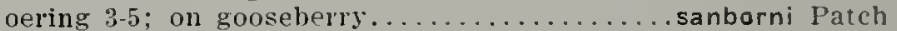

- Fourth antennal segment lacking secondary sensoria: on Lintris .........................................

55. Cornicle subequal to, or greater than, twice length of fourth an-

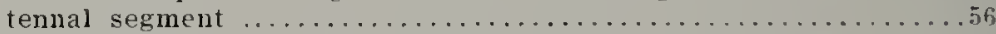

- Cornicle distinctly shorter than twice length of fourth antennal

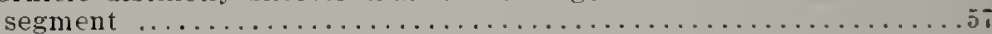

56. Cauda (Fig. 19⿺) triangular in ontline, not markedy constricted near mitlle; small species with a bright yellowish green abdomen; on Eupatorium and Ternonia.........vernoniae Thomas Cauda (Fig. 197) markedly constricted near middle: species with

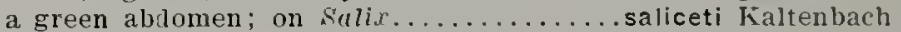

57. Fourth antennal segment usually with sensoria numbering from one to six, occasionally without, in which case the third segment usually has $s$ or more sensoria.................

- Fourth antennal segment normally without sensoria, a rare specimen with one or two: third antennal segment usually with less

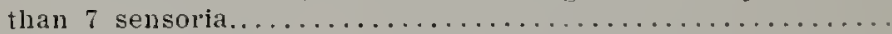

5S. On gooseherry and currant (Ribes): cornicles shorter tban third antennal segmeut; third antenmal segment with 6-10 sensoria. often not in a straight row: fomrth with 2-6 sensoria. either in a row or grouped..................................... Patch

- On Monarin: cornicles shorter than third antenual segment: third antennal segment with $4-6$ sensoria. always in a row: fourth with 1.3, usually 2: cauda with portion beyond constriction relatively short and broad (Fig. 190)..monardae Oestlund p. 20,3

- Gn hosts other than hile's or Monarda.....................

59. Cornicles usually as long as third antennal segment, only rarely distinctly shorter: third antennal segment with $6-10$ sensoria.

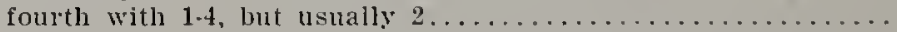

- Cormicles always shorter than third antennal segment; third antennal segment with $6-16$ sensoria, fourth with $0-s$, fith with $0-4$; overwintering on Rhammus and migrating to many and varied summer luosts................ rhamni Fonscolombe

60. On apple and related species (Pyrus or (rofacous): hind tibiae of oviparous females slencer, with few sensoria: males apterous. ................................ pomi DeGeer

- On spiraca and many other summer hosts: hind tibiae of oviparous females swollen. thickly studled with semsoria: males

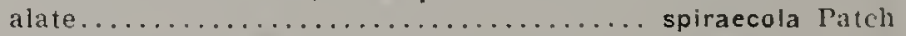

61. Cauda spatulate (Fig. 193 ) or triangular in outine (Fig. 194), not

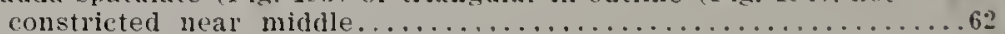

- Cauda constricted near middle (Fig. 197 ).................. 
62. Cauda spatulate (Fig. 193), apex rounded; third antennal segment subequal in length to telminal filament, small species curling leaves of blackberry............ rubicola Oestlund

- Cauda triangular (Fig. 194), apex pointed; third antennal segment distinctly shorter than terninal fitament, a medium-sized

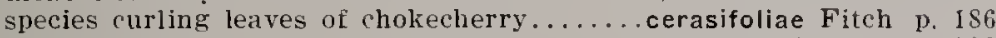

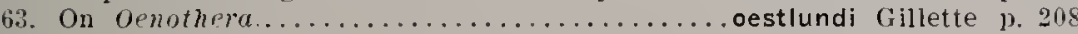
-. On cotton, cucurbits, and many other plants.....gossypii Glover p. 195

\section{APHIS AGERATOIDIS OEsTLENH}

Alhis ageratoidis Oestlund, Fourteenth Annual Report of the State Geologist of Minnesota, March, I\$ $\$ 6$, p. 38 .

This species is recorded now from Illinois for the first time. When Oestlund described this species he commented on its being very closely allied to. Afhis fromdosac Oestlund. The latter has since been made a synonym of atphis corcopsidis (Thomas). Although recognizing the difficulty of separating Afhis agcratoidis from $A$. corcopsidis, we prefer for the present to recognize the two forms is distinct. The sexual forms have not been describerl.

Data assoriated with our viviparous specimens placed as this species are as follows: Catlin (Sept. 27, Oct. 6), East Dubuque (June 26), Havana (June 21), Herod (May 29). Mt. Carroll (June 25), Oakwood (Sept. 17), Oregon (June 2S), Crbana (May 16, July 10). 1928: Liappa (Sept. 9). Oakwood (Oct. 17), 1929; Oakwood (Oct. 22), 1930. Collected on Blephilin hirsuta, Brickrllia sp., Eupatorium urticuefolium, Euputorium sp, Yepetu cutritu, and Teinoniu sp.

\section{APHIS ASCLEPIADIS FiTCI}

1 phis asclrpirdis Fitch, Fourth Annual Report of the Regents of the University on the Condition of the State Cabinet of Natural History, State of New York, January 14, 1851, p. 65.

The species which we are considering under the above name has been previously reported from Jllinois by Gillette (1910) and by Daris (1!)(ia). The Aphis aposynii Koch listed by Thomas (18:!) from Wisconsin, as shown ly a slicie (?:65), of Thomas, is undoubtedly this species. It is quite generally distriluted in Illinois on nuilkweerl.

Data associated with our alate and apterous viviparous specimens, all collected. on Asclinirts sp. or Aporymum sp., are as follows: Galena (June 25), Kankakee (June 29), 1928; Beach (July 13), Bloomington (July 5), Edwardsville (Sept. II), Jerseyville (June 25), Rock Island (July 7), Seymour (June 13), 1929.

\section{APHIS BAKERI COWEN}

F11. 99

Aphis bukeri Cowen, Agricultural Experiment Station of Coloraclo State Agricultural College, Bulletin No. 31, Technical Series No. I, May, 1895, p. IIS.

The short-beaked clover aphid was first reported as occurring in Illinois ly Davis ( $19($ )ice) who reported it as a commom species throughout the state on ret clover. This species hats heen shown by Gillette 
and Taylor (1908) to spend the winter in the egs stage chiefly upon apple. pear. Cralacyus, etc., and the summer upon clover. Gillette (1!Msb) has given detailed descriptions of all the varions forms. In Colorado 4 l. bakeri is sometimes a pest on apples.

Data associated with our alate and apterous viviparous specimens, all collected on Trifolium protense, are as follows: Normal (May 14), 18s4: Champaign (Nov.), 1885: Bement (Jnne 17), Cairo (June 2). East Penria (July 22), Galena (June 25), LeRoy (Jnue 20), Morgan County 1 June 19 ). Muncie (Oct. 6), Oakwood (Jnly 1S), Oregon (June 2S). St. Anne (July 15). 1928; Cairo (June 22), Edwardsville (Sept. 11), 1929.

\section{APHIS CALIGINOSA new species}

Figs, 140, 202, 2\$4, 309

Al.ATE VIVIPAocs FeMALE

size anl general color.-Average length from vertex to tip of anal plate. 1.60. Head, thorax, and cornicles black. Abdomen with base and apex blackish, intermediate area somewhat light brown. First and second antennal segments concolorons with head; apex of fifth and all of sixuls segments blackish: remainder of antennae light brownish. Eyes black. Coxae and trochanters concolorous with venter of body: fore femora yellowish brown. middle and hind femora blackish except for extreme brownish bases; tibiae of all legs essentially yellowish brown with apices black for a distance about equal to length of tarsi; tarsi of all legs black. Beak brown, with extreme tip blackish. ('ostal margin of front wing yellowish brown near base; remainder of veins dark brown.

Head and appendages.-Average width of head across eves. 39. Antennal segments with comparative lengths as follows: $111-.20$ to .29 . average .25: $1 \mathrm{~V}-.13$ to .16 , average $.15 ; \mathrm{V}-.11$ to .16 , average .13 ; V $1-.07$ to .11 , a rerage .09 plus .14 to .23 , average .1S. Secondary sensoria (Fig. 2st) limited in the third segment, numbering from 5 to 9, averaging 6 , arranged in a more or less straight row, ol in two sub-parallel rows. Sensoria usually eloser together towards apex of segment, leaving the basal thirl of the segment free from sensoria. Primary sensorium of the sixth antennal segment subeqnal to that of fifth, with a group of marginal sensoria. All antennal segments beyond second distinctly imbricated. Beak varying in length, reaching either not quite to, or a little beyond, the mesothoracic coxae.

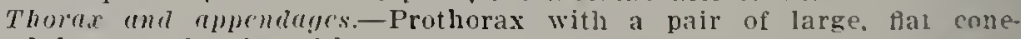
shaper, lateral tubercles with unusually large bases. Fore wings with stisma rather bluntly pointel at apex. Cell $R_{1}$ shallow, not much, if any, witler than stigma. Second fork of media closer to margin of the wing than to the first fork, although not constant in position: in some cases entirely absent. Niddle and hind femora with from three to four sensoria near their base. Hairs on tibiae fine and abott as long as the width of the segment.

Abdomrn.-Abdomen (Fig. 309) with five pairs of lateral tuhercles anterior to the cornicles, the first segment apparently bearing two pairs. The posterior three pairs are small, usually difficult to finc. Segment posterior to cornicles with a pair of unusually large lateral tubercles. which are approximately the same size and shape as those on prothorax. Cornicles (Fig. 140 ) averaging .10 in length, shorter than caudil, straiglut. Without an apical flange, imbricated througlout, and very slightly colsstricted at, or just before, apex. Caudal (Fig. 202) averaging 12 in length. nol constricted. larger than cornicles, with from $i$ to 8 pairs of laternl hairs. in addition in a dense covering of small spinc-like setae. Anal plate well developed. a little longer than nsual. and elothed with short spine-like setae in addition to fringe of numerous long hairs.

\section{Prist}

Cojor-Head and thorax more greenish than alate form: dorsum of abdomen with two longitudinal pruinose areas and a transverse pruinose patch posterior to cornicles. 


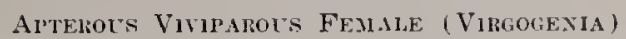

size and general color.-Average length from vertex to tip of anal plate, 1.27. Color as in alate viviparous female, except that abdomen is nuottled, due to green embryos showing through integument, and the fore legs are darker in color.

Head and appendages.-Average width of liead across eyes, .39. Antennal segments with comparative lengths as follows: III-.17 to .19, average .18; $1 \mathrm{~T}-.09$ to .11 , average $.10 ; \mathrm{V}-.09$ to 11 , average $.10 ; \mathrm{V} 1-.09$ to .10, average .09 plus .10 to .17 , average .14. Secondary sensoria absent. Antennae imbricated and with scattered, short, fine hairs. Beak extending to, or slightly heyond, metathoracic coxae.

Thorax and appendages.-Surface of thorax reticulate. Prothorax with large lateral tubercles.

Abdomen.-Surface of abdomen imbricated or imperfectly reticulate. Lateral tubercles similar in number and position to those of alate viviparous female, but smaller, the anterior pair on the first segment being small and pointed, much smaller than those of the second, third, and four segments. Tubercles on segment posterior to cornicles, the same shape and size as those of alate viviparous female. Cornicles .10 in length, in shape similar to those of the alate viviparons female. Cauda .12 in length, similar to that of the alate viviparous female.

\section{Alterous Viviparous Female (Fuxdatrix)}

Similar in size, color and structure to virgogenia, but differing in the following details. Average width of head across eyes, .39. Antennae fivesegmented, the comparative lengths being as follows: I1I-.21 to .26, average .24 ; IV - .10 to .11, average .10; V-.09 to .10, average .09 plus .09 to .I1, average .10. Lateral tuhercles of prothorax and abdomen slightly smaller, those of second, third, and fourth abdominal segments being especially small and flat.

Holotype.-Alate viviparous female; Starved Rock State Park, Illinois, June 13, 1928, on Cornus sp., (Frison and Hottes). On slide with paratypic specimens of alate and apterous viviparous females, pupae and nymphs. Slide No. 3966. Morphotype-Apterous viviparous female (virgogenia); same data as holotype. Slide No. 3968. Morphotype.-Apterous viviparous female (fundatrix); Starved Rock State Park, Illinois, May 13, 1930, on Cornus sp., (Frison and Ross). Slide No. 10481. Paratyprs.-Seventy-one slides, containing alate and apterous viviparous females, pupae and nymphs. collected in Illinois on spccies of Cornus, by T. H. Frison, F. C. Hottes, H. H. Ross and Marten. The dates and localities are as follows: Urhana (May 1. 12 and 15) (Acc. Nos. 19944, 19945, and 19946), 1894; Herod (May 29) and Starved Rock State Park (June 13), 1928; Hardin (June 25). Herod (June 21) and Macomb (May 4), 1929: and Starved Rock State Park (May 13), 1930. Slides Nos. 3964-3965, 3967, 3969-3970, 3984-3986, 10482-10524 and others unnumbered.

This species may be collected on the more terminal branches of its host. In at least one case it was attended by the ant. Crematogaster lineolata Say, which had constructed an aphid shed over the aphids. This species is closely allied to Aplis maidi-radicis Forbes from which it may be separated by its brownish color, and the much more strongly developed lateral tubercles posterior to the cornicles.

\section{APHIS CARDUELLA WALSI}

Figs. 132, 195, 279

Aphis cardurlla Walsh, Proceedings of the Entomological Society of Philadielphia, Vol. 1. December, 1862, p. 300.

Althongh this species seems to be common in Illinois on Cirsium lanceolatum, Oestlund (188\%) is the only writer known to wh who has 
noted its occurrence anywhere since the origrinal description was published. Our specimens agree well with the meagre original description except for minor details and statement regarding color. $11 \mathrm{e}$ are of the opinion that in this last mentioned respect 11 alsh was misled by dead material. We are informed by Oestlund that his description of this species is based upon a male. thus accounting for the difficulty at first encountered in connecting our material with his description and our interpretation of the species described by Walsh. Specimens identified as carduclla by Oestlund are sinilar to those we are considering as this species. The oviparous female has not been describer.

Since the original description is very meagre and the types are lost, Slick No. $9+61$ in the Survey collection has been selected as the neotypic slirle and redescrijtions are given of the alate and apterous viviparous fentales.

Data associated with this neotypic slide are as follows: Alate ripiparous female; Sparta, Illinois, June 24, 1929, on Cirsium luncenlatum. (Frison and Hottes). On slide with alate viviparous female.

All of our Illinois material has been collected on Cirsium lancrolatum. Our data are as follows: Bloomington (July 5). Farmer City (July 5), Mitchell (June 25), Nameoki (June 25), Rock Island (July $\div$ ). St. Clair County (Jnne 24). St. Joseph (June 29), Sparta (June 24). Crbana (August 27 ), and Woodford (July 5), 1929.

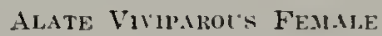

Size and general color:-Average length from rertex to tip of anal plate. 1.31. Head and thorax dark greenish browu. Abdomen green with five lateral brown spots, those posterior to the cornicles being the largest. Cornicles, cauda, and anal plate dark brown. Antennae concolorous with. or slightly lighter than, head. Legs with coxae dark brown. trochanters luteous; femora luteous at base with apical two-thirds brown, middle and lind fenora dark brown; tibiae luteous with enlarged apica] portion dark brown; tarsi dark brown. Forewings with stigna brownish, reins light brown, posterior margin of wing in vicinity of anal vein brownish. Beak brownish, its apical portion darkest.

Head and appendagc's.--Average width of head across eyes, .38. Antennal segments with comparative lengths as follows: III-.IT to .29. average .24; IV-.I1 to .16 , average $.14: V-.10$ to .14 , average .12: VI-.07 to .10, a Terage .09 plus .17 to .23, average .18. Secondary sensoria (Fig. 279) typically limited to third antennal segment, numbering from is to 25 , areraging 20 . mostly confined to one side of segment. very irregularly arranged and varying greatly in size; some specimens differ in having from 1 to 4 secondary sensoria on fourth antennal segment. Primary sensorium on sixth antenual segment with a group of snall marginal sensoria to one side of it. Antennae imbricated and with a few short hairs. Beak extending to middle of metathoracic coxac.

Thorar and appendages.-Prothorax with a pair of small lateral tubercles. Second fork of media closer to margin of wing than to first fork. Stigma rather bluntly pointed.

Abdomen.-First abdominal segment and segment posterior to cornicles witlı a pair of small lateral tubereles. Cornicles (Fig. 132) straight. averaging .19 in length, without a distinct flange at apex, and imbricated. Canda (Fig. 195) averaging .12 in length, constricted at middle, with trom five to six pairs of lateral hairs, the terminal pairs incurved.

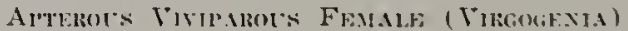

Nise and yencral color.-Average length from vertex to tip of anal plate. 1.35. Body (head, Ihorax, and abdomen) with anterior part brownish green shading posteriorly to dark green. Cornicles, cauda, anal plate, and patehes 
posterior to cornicles, brown. Basal half of antemnae concolorous with head, extreme apex of third segment, apical third of fourth and fifth, and sixth almost entirely, brown or hrownish infuscate. Legs patterned as in alate viviparous female, but lighter in color. Beak as in alate viviparous female.

Head and appendages.-Average widtl of head across eyes, .40. Antennal segments with comparative lengths as follows: Ill-.21 to .29. average .25; $1 \mathrm{~V}-.09$ to .16 , a verage $.13 ; \mathrm{V}-.09$ to .14 , average $.11 ; \mathrm{V} 1-.06$ to .09 , average .07 plus .16 to .21 , average .1S. Secondary sensoria absent, antennae imbricated, and bearing a few fine hairs. Beak extending to middle of metathoracic coxae.

Thorax and appendages.-Prothorax with a pair of lateral tubercles.

tbdomen.-First abdominal segment and segment posterior to cornicles with a pair of lateral tubercles. Cornicles averaging .20 in length, shaped as in the alate viviparous female. Cauda averaging .15 in length, con. stricted near the middle, and with from five to six pairs of lateral hairs.

Morphotype.-Apterous viviparous female; Urbana, Illinois, August 27, 1929, on Cirsium lanccolatum, (H. H. Ross). Slide No. 9462.

This species differs from Aphis rumicis Limn. by its color and by the distribution of secondary sensoria. Two other species of this crenus. rumicis Linn. and cardui Linn., have so far been found on Cirsium in Illinois in addition to this species. For other distinguishing characters see the key to species belonging to this gentis.

\section{APHIS CARDU1 LINTIES:}

Aphis cardui Linnaeus, Systema Naturae, Editio Decima, 1758, p. 452

This species has not been recorded from Illinois under this name, but probably the record of $A$. prunifoliae Fitch from Niles Center, Illinois, by Davis (1910) and the indefinite record of A. pruni Koch ly Thonas (18i?) refer to this species. Thistles attacked by this species in summer are usually heavily infested, but according to our experiences infested plants are scarce. Patch $(1 ! 1+1)$ ) calls attention to the fact that in Europe this species migrates between plum and thistle.

Data associated with onr viviparous specimens, all collected on cirsium sp., are as follows: Galena (June 25), Morton (July 22), Rossville (July 15), 1928; Oakwood (Nov. 9), Oregon (July 9), 1929.

\section{APHIS CEPHALANTHI TIIOMAS}

Aphis cephalanthi Thomas, Bulletin lliwois State Laboratory of Natural History, Vol. I, No. 2, June, 1878, p. 11.

Aphis imprtientis Thonas, Bulletin Illinois State laboratory of Natural History, Vol. 1, No. 2, June, 1878, p. 12. New synonymy.

This species was described as new from specinens collected at Cantondale, Illinois, and was again reported from the state ly Davis (1!)10e). Nithongh the typic specimens of $A$. ceplahantli have not been recovererl, there is no doubt regarding the aphid that Thomas described under this name. A. impaticntis Thomas was described at the same time as coplablunthi. Wut the latter has page priority. "Typic specimens of impaliculis prove that this species is a synonym of cephalanthi. Our field collecting show's that this species has the luttonbush ats its overwintering host and the touch-me-not as its summer lost. On lutton- 
bush this species is found on the terminal twigs and leaves and on touch-me-not on the under sicles of the leaves.

Data associated with our viviparous specimens, all collected on Cephalanthus occirlentalis or Impatiens sp., are as follows: Herod (Oct. 12), 1928; Cairo (June 21), Collinsville (Sept. 11), Herod (Sept. 2T), Mahomet (Aug. 17), Starved Rock State Park (Aug. 14), 1929: Homer Park (June 17), 1930 .

Neotypic slide.-Since this species was originally described from Carbondale, lllinois, by Thomas, and the types are lost, a slide in the Survey collection is selected as the neotype. The data associated with the neotypic slide are as follows: Cairo, lllinois, June 21, 1929, on Cephalanthus sp.. collected by T. H. Frison and F. C. Hottes. Slicle 6373 .

Data associated with the cotypic slide (87i8) of Aphis impaticntis Thomas are as follows: Carbondale, Illinois, August, on Impatiens fulra.

\section{APHIS CERASIFOLIAE FITCI}

Aphis cerasifoliae Fitch, Transactions of the New York State Agricultural Society, Vol. XIV, 1854 (printed 1855), p. 835.

The choke cherry aphid was first reported from Illinois by Davis (1911) . This species curts the leaves of the choke cherry, and certain other species of Prumus used in landscaping, so badly that it often disfigures them. We have no record of this species occurring south of the central portion of the state. The alate and apterous forms have been described in full by Parch (1914b) and Swain (1919). The sexual forms have apparently not been described.

Our viviparous specinjens in the Survey collection, all collected on Prunus virginiana or Prunus sp., bear the following data: Normal (May 27), 1886; Galena (July 10), Nacomb (May 3, 4), Richmond (July 12), Waukegan (July 13), 1929.

\section{APHIS CHETANSAPA new species}

Figs. 142, 193, 2S0

Alate Vuviparous Female

Size and general color.-Average length from vertex to tip of anal plate. 1.10. Head and thorax dark blackish brown; abdomen purple-lake with six pairs of lateral black patches anterior to cornicles, with large black patches near base of, and between, cornicles. Which in many specimens connect and form a transverse black band: and posterior to this band, with two other transverse bands in some specimens, successively narrower, making a total of three. Cauda and anal plate black, cornicles dark hrown. Eyes reddish-brown. Antennae concolorous with the head or only slightly lighter. Legs black, except front femora which are yellowish-brown, slightly darker at apex. Beak at hase concolorous with head, apex black, intermediate portion yellowish. Wings hyaline, with the following parts greyish-brown: stigma, costa, apical half of subcosta, veins, and the posterior margin of the wing in the vicinity of the anal vein; veins with a suggestion of a border.

Head and appendages-Average width of head acrozs eyes, .37. Antennal segments with the following comparative lengths: III-.23 to .29 , arerage $.25 ; \mathrm{IV}-.14$ to .17 , average $.16 ; \mathrm{V}-.13$ to $.1 \%$, average $.14: \mathrm{V}-.10$ to .13 , average 11 plus .16 to .19 , average .1T. Secondary sensoria (Fig. 2sio) confined to the third antennal segment, arranged in a straight row, num. bering from $\&$ to $\delta$, averaging 6 . Primary sensorium of sixth antennal seg. ment small, slightly smaller than that on fifth, the marginal sensoria groupecl to one side of it. All segments of flagellim distinctly imbricated. 
Beak variable in lengtl, usually extending only to mesothoracic coxae, but sometimes extending past the metathoracic coxae.

Thorax and appeniages.-Prothorax with a large lateral tubercle on each side. Second fork of media usually present and very close to margin of wing, in one or two cases entirely lacking. Femora with moderately numerous, erect, fine hairs. Tibiae clothed with long, declinate hairs, increasing in length and numbers from base to apex, thickest on hind tarsi; bases of hairs transparent yellow, giving the tarsi a mimute speckled appearance.

Ablomen.-Cornicles (Fig. 142), straight, without flange, imbricated, length averaging 22 . First segment with a pair of small, tooth-like, lateral tubercles. Segment posterior to cornicles with a pair of large lateral tubercles. Canda (Fig. 193), averaging .08 in length, with about five hairs on each side, the terminal hairs strongly incurved. Anal plate normal in shape.

Aitemols Viviparots Feidale (Virgogexia)

Size and general color.-Average length from vertex to tip of anal plate, 1.22. Head yellowish-brown to reddish-brown, thorax and abdomen lighter, yellowish-brown to yellowish-red. Antennae with the two basal segments concolorous with head, base of flagellum much lighter but gradually becoming darker towards apex. Prothorax, lateraI pleural areas of thorax, coxae, legs except front femora and base of middle and hind femora, small patehes on dorsum posterior to cornicle, anal plate, and cauda, light or dark reddish brown; front femora sometimes concolorous with rest of legs, sometimes light yellowish-hrown; middle and hind femora with hase yellowish-brown. Cornicles blackish-brown. Beak as in alate viviparous female.

Head and appendages.-Average width of head across eyes, .34. Antennal segments with comparative lengths as follows: 1 II -.24 to .43, average .32; $1 \mathrm{~V}-.10$ to .26 , average $.17 ; \mathrm{V}-.14$ to .17 , average $.16 ; \mathrm{VI}-.09$ to .13 , average .11 plus .14 to .20, average .16. Secondary sensoria absent; antennae imbricated. Primary sensorium present on fifth and sixth antennal segments, that on sixth small, with six marginal sensoria grouped to one side of it.

Thorax and appendayes.-Prothorax with a large, tooth-like, lateral tubercle on each side. Legs similar to legs of alate viviparous female in structure.

Auromen.-First segment and segment posterior to the cornicles each with a pair of lateral tubercles subequal to or smaller than those on prothorax. Cornicles similar to those of alate viviparous female, $.31^{\circ}$ long. Cauda not constricted, .11 long, with 4 or 5 pairs of lateral hairs.

\section{Alpelot's Viviparous Fediale (Fundatrix)}

size and gcneral eolor.--Length from vertex to tip of anal plate, 1.34 . Head, thorax, antennae, legs, cornicles, and canda, black. Abdomen and posterior portion of thorax pinkish brown.

Hear and appendages.-Average width of head across eyes, .43. Antennae five segmented, comparative lengths as follows: $11 \mathrm{I}-.36$ to .40 , average .38; IV-.11 to .13 , average $.12 ; \mathrm{V}-.11$ to .13 , average .11 plus .09 to .11, average .10 .

Otherwise similar to virgogenia.

Holotylle.-Alate viviparons female; Oregon, Illinois, June 28, 1928, on Purus sp., (Frison, Hottes, and Ross). On slide with alate viviparous fenale, apterous viviparous females and nymphs. Slide No. 10530. Iorphr)lippr.-Apterous viviparous female (virgogenia); same data as holotype. On slide with alate and apterous viviparous females and nymphs. Slide No. 10531. Worphotypr.-Apterous viviparous female (fundatrix); Oregon, Illinois. May 15, 1930, on Prunus sp., (Frison and Ross). Slide No. 10532. Paralypes. - Eighty-five slides of alate and apterous viviparous females, pupae and nymphs, collected in Illinois by T. H. Frison, F. C. Hottes, and H. H. Ross on Pyrus and Prunus sp. The localities and dates are: Galena (June 26), and Oregon (June 28), 1928; Oregon (July 11) and Oakwood (July 22), 1929; and Oregon (May 15), 1930. Slides Nos. 10533-10569, 10579-10597 and others nmmumbed. 
This species causes the terminal leaves of the host to curl very tightly. In life it does not suggest in habit or form any other Aphis. Mounted specimens resemble Aphis fominca in color. but the alate viviparous females differ from feminea in having no sensoria on the fourth and fifth antennal segunents and in having iewer sensoria on the third antennal segment.

\section{APHIS COREOPSIDIS (THOMAS)}

Siphonophore corcopsintis Thomas, Bulletin Illinois State Laboratory of Natural History, Vol. 1, No. 2, June, 1878, p. 4, 5 figures.

This species is quite generally distributed orer Illinois and has been recorded from the state by Davis (1910) in addition to being described on the basis of Illinois naterial. The discovery of the sexual forms in fall on black gum indicates that this may be the over-wintering host of this species in southem Illinois. From its prinary host it migrates in early summer to Eupatorium and Bidcns. On black gum it shows a decided preference for the stems and leaves of new shoots. often conpletely encircling the apical portions of the stems for several inches. It occurs on the unclersides of the leaves and the flower stalks of its summer liosts. Descriptions of the previonsly undescribed sexual forms are here presented.

Cotypes of this species were found preserved in vials of the Thomas Collection. These have been mounted in damar balsan on Slide 70.776 . Data associated with this slide are: St. Louis. Missouri. October on Corropsis aristosa. collected by T. Pergande. Dr. Oestlund has determined slides of this species as A. frondoste Oestlund, and Davis (1910) has definitely placed this name in the synonymy of coreopsidis.

Data associated will our viviparons specinens are as follows: Carbondale (June 4), Elizabethtown (Oct. 12), Herod (May 29), Metropolis (Jlay 31. June 31), Muncie (Oct. 6), 192S; Decatur (Sept. 21), Fern Cliff (Sept. 27), Grayville (June 19), Herod (Sept. 27). Tappa (Sept. 22), Oakwood (Oct. 13, 17). Waulegan (Aug. 29), 1929; Fairmount (Sept. 2S), 1930. Collected on Eupatorium urticacfolium. Bidens vulgata. and Xyssa sylrutica. Sexual forms taken only on the latter host at Feru Cliff on September 27. 1929.

\section{Amate MaLE}

Length, 1.00. Head and thorax dark greenish brown, abdomen dark green; cornicles and cauda brownish, antenuae brown. Legs greenish brown with apical portions of femora and tibiae darker: fore legs lightest in color. Stigma greenish brown. veins brown. Average will of head across eyes, 41 . Comparative lengths of antennal segments as follows: III$.23 ;$ IV-.27; V-.21; V1-.09 plus .46. Secondary sensoria on third and fourth antenual segments scattered. on fith arranged in an irregular row: numbering as follows: $1 \mathrm{II}-1 \mathrm{~s}$ : $1 \mathrm{~V}-1 \mathrm{~s}$; $\mathrm{V}-6$. Beak reaching beyoud mesothoracic coxae. Second fork of media distinctly closer to nargin of wing than to first fork. Cornicles .21 long, straiglit, entire surface im. bricated. Cauda .11 long, with about 5 hairs on a side.

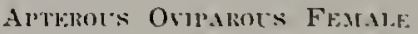

Length, 1.16. Color yellowish or yellowish green, with flagellum of antennae except hase brown: apices of cornicles and more or less of tibiae and tarsi, infuscate with brown. Average widh of head across eyes, .29. Comparative lengths of antenual segments as follows: 1]1-.26; 11-.24: $V-.26$; VI-.10 plus .50. All segments imbricated. Cornicles . 30 long. Cauda about 10 long with ahout 5 lateral hairs. Hind tibiac decidedly swollen, with about 95 sensoria. 
Allotype.-Alate male; Slide No. 8325, Fern Cliff, lllinois. September 27, 1929, on Nyssa sylvatica. (Frison and Hottes). On slide with alate viviparous female. Horphotypr.-Apterous oviparous female; Slide No. 8324 , same data as allotype. On slide witl alate viviparous females.

\section{APHIS CORNIFOLIAE FITCH}

Figs. 133, 271

Aphis cornifoliae Fitch, Fourth Annual Report of the Regents of the University on the Condition of the State Cabinet of Natural History. January 14,1851, p. 65.

Slicles of our specimens have been compared with two slicles of 4. cornifoliac, which are undoubtedly the types, kindly loaned to us by the U. S. National Museum. According to Mason, these slides are associated with notes No. 846 and 9020 of Pergande which indicate the specimens were originally mounted by Fitch on card points and then remonnted on slides. The number assigned to this species in the original description is 8.46 . Since this species has never been arlequately described, or even authentically recorded, since the brief original description of the apterous females, a more detailed description of the apterous form is given here as well as a description of the previously undescribed alate viviparous female.

Aplis comifoliac Fitch has been mentioned twice in literature by Oestlund (18si, 1885), and the name again appears in an article lyy Daris $(1 ! 110 \mathrm{e})$, who does not, however, record it from Illinois but refers certain references to hclianthi Monell. In 1910, also, Gillette records this species, figures it, and gives notes on its life history. All of these records refer to the true helianthi of Monell. Oestlund's description was based upon a male.

\section{Aitelots VIVImaRous FeMATE}

Sizc and general color.-Average length from vertex to tip of anal plate, 1.02. Color throughout almost identical wjth color of alate viviparous female, except that sometimes the thorax may be greenisli, and the legs and antennae may be lighter.

Head and appentages.-Average width of head across eyes, .36. Antennal segments with the following comparative lengths: $111-.24$ to .33 , average .27 ; IV-.13 to .17 . average $.15 ; \mathrm{V}-.10$ to .16 , average $.13 ; \mathrm{VI}-.09$ to .11, average .10 plus .23 to .31 , average 28 . Antennae without secondary sensoria or hair, flagellum imbricated.

Thorax and abdomen.-Dorsal surface of thorax and ahdomen imbricated or reticulated. Lateral tubercles as in alate vivinarous fenale. Cornicles averaging .21 in length, similar to, but more strongly outwardly curved than, the cornicles of the alate viviparous form. Cauda and anal plate as in the alate viviparous female.

The abdomens of the apterous viviparous females appear to be free from embryos, and this, together with the extremely small size of these specimens, suggests that they may be dimorphic forms.

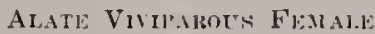

Sizr and grneral color.- Average length from vertex to tip of anal plate, 1.08. Head. thorax and abdomen uniform dark brown or brownish-black. Cornicles, cauda, and anal plate dark brown. extrene hase of cauda lighter. First and second antennal segments concolorous with head, remaining segments brownish, sometimes slightly darker towards apex. Femora Irown except for yellowish-brown areas near the base, the posterior pair darkest; 
tibia light yellowish-brown, darker at the apex; tarsi brown. Stigma and veins dusky brown, posterior margin and wing in vicinity of anal vein dusky. Beak dark brown.

Head and appendages.--Average width of head across eyes .36. Antennal segments with comparative lengths as follows: III-.24 to .29. aver. age $.28 ; \mathrm{IV}-.14$ to .17 , average $.16 ; \mathrm{V}-.13$ to .14 , average $.14 ; \mathrm{V}$-. 09 to .11 , average .10 plus .23 to .34 , average .29 . Secondary sensoria (Fig. 271) confined to third and fourth antennal segments, sensoria on the third arranged in an irregular row, uswally numhering from five to eight, average seven, one apparently aherrant specimen with fifteen sensoria; fourth segment with from 0 to three sensoria, usually two: sensoria very difficult to distinguish, due to dark color of antennae. Beak barely reaching to mesothoracic coxae. Primary sensorium on sixtl antennal segment small, marginal sensoria grouped to one side of it.

Thorar and appendayes.-Prothorax with a pair of lateral tubercles. Stigma of fore wings comparatively narrow, and sharply pointed at apex; radial sector little bowed; second fork of media closer to margin of wing than to the first fork.

Abdomen.-A pair of lateral tuhercles on first abdominal segment, and on segment posterior to cornicles. Cornicles (Fig. 133) longer than cauda. length .16; imbricated, with narrow flange at the apex, of almost $11 n i f o r m$ width throughout, except sometimes very slightly swollen near apex and somewhat outwardly curved. Cauda not constricted, length .11, bluntly rounded at apex, with four pairs of lateral hairs. Anal plate normal in shape. Body sparsely covered with fine hairs.

Morphotype.-Alate viviparous female; Pekin. Illinois, June 20, 1925, on Cornus sp., (Frison, Hottes, and Ross). On Slide 9750 with alate viriparous females and nymphs.

Data with our other slides, containing alate and apterous riviparous females and nymphs, collected on Cornus stolonifera and Cornus sp., are as follows: East Peoria (July 22), Oregon (June 2S) and Pekin (June 20). 1928; Lyle (July 14), 1929.

This species differs from the other members of the genus by characters given in the key. It is most closely allied to caliginosa $\mathrm{n}$. sp.. another dark-brown species occurring on Cormus in Illinois. Aphis cornifoliac is found on both the lower and upper sur faces of the leaves. whereas the other species recorded from Cormus in Illinos ocem only on the lower surfaces of leaves and on the stems.

\section{APHIS CRATAEGIFOLIAE FiTu}

Fr: 90

Aphis cratuegifoliae Fitch, Fourth Anuual Report of the Regents of the University, on the Condition of the State Cabinet of Natural History. State of New York, January 14, 1851, p. 66.

This species was first reported from lllinois by Thomas (1s:?) and it was again recorded from this state by Davis (1!10e) muler the name of Aphis lureis Sanderson. Onr records show it to be common and quite generally distributed orer Illinois. It over-winters on apple and hawthorn, from the leaves of which it migrates in summer to the stems and crowns of red clover and ertain other plants (Sandersom. 19(1), and P'atch, 191:ia).

Data associated with our specimens, all collected on hawthorn (Cratac* gus) or red clover (Trifolium bratens'), are as follows: Cormal (June 21). 1883; Decatur (Sept. 29), Galena (June 26). Metropolis (June 1). Oakwood (Sept. 17), Urbana (May 19, 21. Sept. 26, Oct. 1, Dec. 19), 1925; Gdwards- 
ville (Sept. 11), Muncie (Sept. 22), Urbana (Oct. 11), 1929; Urbana (Oct. 20). 1930. Sexual forms were taken on Crutuegus at Urbana on October 11,1929 .

\section{APHIS DEBILICORNIS (GILIETTE \& PALAER)}

Fici, 20

Anuraphis debilicornis Gillette and Palmer, Annals of the Entomological Society of America, Vol. XX11, No. 1. March, 1929, p. 10.

Aphis helianthi Oestlund (not Monell), Geological and Natural History Survey of Miunesota, Bulletin No. 4, 1857, p. 52 o. New synonymy.

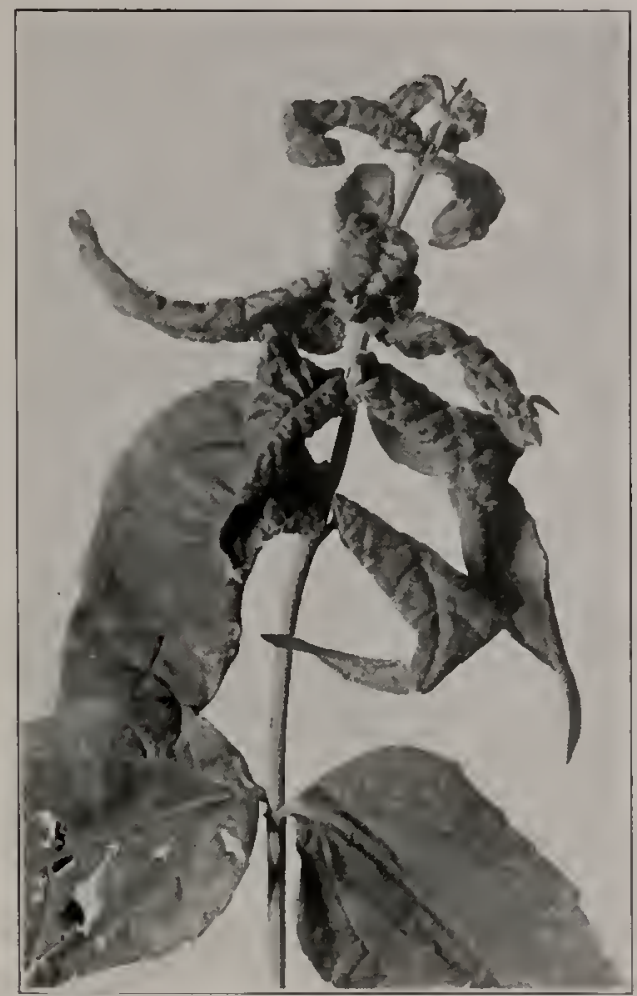

Fig. 20. Curling of leaves of wild sunflower, Helianthus sp., caused by Aphis rebilicornis (Gillette and Palmer); Oakwood, July 22, 1929.

This species is here recorded from Illinos for the first time. Our records show that it is quite generally distriluted throughout the state. The terminal leaves of its host curl tightly and twist (Fig. 20) when attacked ly this aphid. It differs markedly from iphis helianthi Monell, with which it has been confuser!. Descriptions of all forms are given by Gillette and Palmer (19:9). No mention is made by these writers that it causes the leaves of its host to curl, but in answer 
to our query I'rofessor Pahmer writes that "wc are of the impression that they do curl leaves but can find no written record as to this point." "We have taken this species every month from May to Octoher. except August, on its host, Helianthus sp. and believe it is not a true nigratory form.

Professor I'almer has checked slicles of our material with typic specimens of dcbilicormis and rejorts that they agree.

Data associated with our specimens are as follows: Antioch (July 15). East Peoria (July 22), Mluncie (Oct. 6). Oakwood (July ls). Shawneetown (Nay 27), 1928: Batchtown (June 25), Edwardsville (Sept. 11), Jonesboro (June 23), Oakwood (June 29), Urbana (July 19, Oct. T), 1929; Oakwood (June 1), 1930. Sexual forms have heen taken at lluncie (Oct. 6). 1925. and Urbana (Oct. 7), 1929.

\section{APHIS DECEPTA new species}

$$
\text { FIcis. 130, } 281
$$

\section{Alate Vivirinots Fralle}

Size and general color.-Average length from vertex to tip of anal plate, 1.45. Head and thorax dark chestnut brown. Abdomen deep golden yellow with a tinge of brown, except as follows: lateral portions of abdomen with large segmentally arranged brownish patches, these becoming confluent in the vicinity of the cornicles, so that abdomen posterior to cornicles, and a small connected patch near the anterior base of cornicles, as well as cornicles, cauda, and anal plate, are distinctly brownish. Antennae very uniform in color and essentially concolorous with the head. Femora chiefly brownish, fore legs usually lightest and hind legs dark, basal portion usually yellowish-brown; tibiae of all legs yellowish, except apices which are brownish for a distance equal to the length of the tarsi: tarsi brown. Beak brownish, somewhat darker towards apex. Stigma of fore wings only very faintly duskv; veins fine, fuscous, hind margin of wing near junction with anal vein distinctly fuscous.

Hearl and appendages.-Average width of head across eyes, .46. Antennal segments with comparative lengths as follows: III-.34 to .49, average .42: IV -.23 to .24 , average $.24: V-.19$ to .21 , average $.20: V I-.10$ to .13 , arerage .11 plus .36 to 40 , average .38. Secondary sensoria (Fig. 281) essentially confined to the third antennal segment, but some specimens have a few sensoria on the fourth segment; usually large. with wide rims, completcly covering the surface of the third segment and giving it a very tuberculate appearance; ranging from 37 to $4 S$ on the third segment and none to four on the fourth segment, strongly imbricated. Beak reaching to coxae of the metathoracic pair of legs.

Thorex and appendages.-The prothorax has a pair of large, welldeveloped lateral tubercles. Fore wing with the second fork of the media usually much closer to the margin of the wing than it is to the first fork.

Abromen.-First abdominal segment and the segment posterior to the cornicles each with a pair of large lateral tubercles. Tlie cornicles (Fig. 130) slightly tapering from base to apex, strongly imbricated and with a flange at the apex; about twice the length of the canda or one and one-half times the length of the fifth antennal segment, varying from .24 to .31 and averaging .28. Cauda with from five to seven hairs on a side. all of which are strongly bent inwardly; distinctly constricted at the middle. Anal plate reaching to middle of the cauda.

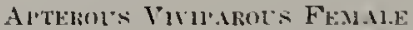

Size and goncral color.-Average length from vertex to tip of anal plate, 1.57. Color yellow except as follows: a slight brownish cast on head; lateral portions of thorax in some specineus and small patches on abeomen immediately posterior to the cornicles rlark brown; cauda and anal plate 
brownish but not as dark as the cornicles. Legs essentially yellowish except dark brown apices of tibiae and all of tarsi. Basal segments of antennae usually concolorous with head, sometimes lighter, gradually shading to brownish about the middle of the fifth antennal segment and continuing this color to apex. Beak yellowish, except for brownish apex.

Head and appendages.-Average width of liead across eyes, .47. Antennal segments with comparative lengths as follows: $111-.39$ to .43 , average .41 ; IV-.21 to .24 , average $.23 ; \mathrm{V}-.17$ to .20 , average $.19 ; \mathrm{V}-.10$ to .11 , average .11 plus .29 to .36 , average .32 . Antennae without secondary sensoria, faintly imbricated. Beak reaching to the coxae of the metatloracic pair of legs.

Thorax and appendages.-The prothorax with a pair of large lateral tubercles.

Abdomen.-First and the segment posterior to the cornicles each with a pair of lateral tubercles. Cornicles similar to those of the alate viviparous female; about twice the length of the fifth antennal segment, averaging about .37. Canda a little shorter than fifth antennal segment, with from six to seven hairs on a side and bent inwardly at apex.

Holotype.-Alate viviparous female; Urbana, llinois, July 10, 192S, on Pastinaca sativa, (Frison and Hottes). On slide with morphotype (No. 4374). Worphotype.-Apterous viviparous female; same date as for holotype. On slide with lolotype (No. 4374). Paratyprs.-Twenty-nine slides of alate and apterous viviparous females, pupae and nymphs; Same data as for holotype. Slides Nos. 4372-4373, 10441-10458 and otliers unnumbered.

This species structurally stgggests a close relationship with Aphis luridis new species, described in this paper, but may be separated from it by the fact that the fifth antennal segment never has secondary seinsoria and the fourth segment has few, if any. This species occurs on the lower sides of the leaves.

\section{APHIS FEMINEA HoTTES}

Fid. 17

Aphis tuberculata Patch, Maine Agricultural Experiment Station, Bulletin 233. November, 1914, p. 261. Name preceupier.

Aphis feminca Hottes, Proceedings of the Biological Society of Washington, Vol. 43 , October 7,1930, p. 183 . New nume.

This is the first time that this aphid has been recorded from Illinois. The red and black cherry aphid, as it has been styled by Patch. is a beatifully colored species. It completely incrusts the twigs and sulall branches of the black cherry and occasionally is found on leaves acljacent to a bark infestation. The sexual forms have not been described. Dr. Patch has kindly checked our determination of this species by comparison with typic specinens. This species was diligently searched for all over Illinois but was never located outside of Decatur, and we do not believe it has been reported previously except from Maine.

All our alate and apterons viviparous females were collected on prunus serofina at Decatur. Nay 12, June 12 and $27,1929$.

\section{APHIS FOLSOMII DAYis}

Fli. 201

Aphis folsomii Davis, Entomological News, Vol. XIX, No. 4, April, 1908, p. $145, \mathrm{pl}$. VII.

This species, originally describer from Urbana, Illinois, by Davis, is wirlely distributed throughout the state. It is never abundant conough, 
however, to be conspicuous and is not likely to become of economic importance. It occurs along the stems oi the new growth and tendrils of Virginia creeper and Boston ivy. Davis has described the sexual as well as the viviparous forms.

Data associaled with our viviparous specimens, all collected on Parthenocissus tricuspidata or Parthenocissus sp., are as follows: Muncie (Oct. 6), Oregon (June 27). Pekin (June 20), Urbana (June 7), 192s; Batchtown (June 25), Carbondale (June 21), Elizabethtown (June 20), Galena (July 10), Grayville (June 19), Olney (June 18), Cllin (June 21), Crbana (May 31, June 3), 1929.

\section{APHIS FORBESI WEED}

Aphis forbesi Weed, Bulletin of the Ohio Agricultural Experiment Station, Vol. 11, No. 6 (Second Series, No, 13). September, 18s9, p. 14 S.

This species, named in honor of the late Professor S. A. Forbes, was first reported as occurring in Illinois by him. Davis (1910e) reports it as common throughout the state. It is a small dark bluishgreen aphid normally occurring on the undersicles of the leaves and stems, especially near the crown, of strawberry. It is also found trequently on the roots, to which it is carried by ants from the leares and stems. It is a troublesome pest of strawherries, particularly of plants growing in sandy or light soils. The apterous sexual forms liave been briefly described by Sanderson (1900).

Data associaled with our viviparous specimens, all collected on Fragaria. are as follows: Kankakee (June 29), Oregon (June 28), 1928; Bement (. Iay: 24), Seymour ( Mlay 24), Urbana (May 22), 1929; Woodyard (April 14), 1930.

\section{APHIS FUNESTA new species}

FlG. 131, 203, 282

\section{Alate Viniparots Female}

Size and general eolor.-Length from vertex to tip of anal plate, 1.2S. Head, thorax, and abdomen dark brown, shining. Lateral aud posterior regions of abdomen sometimes mottled with lighter brown. Cornicles, canda. and anal plate dark brown. Antennae with first and second segments concolorous with head; either flagellum entirely dark brownish or third and fourth antennal segments and basal half of fifth segment light rellowish brown, with remaining portion of fiftl segment aud all of sixtb dusky brown. Femora mostly dark brown, yellowish near base, metathoracic femora darkest, prothoracic femora lightest; tibiae conspicuously light yellowish with apical band equal to length of tarsi, dark brown, tarsi dark brown. Beak dark brown. Stigma of fore wings light yellowish brown, darker posteriorly, veins brown, posterior margin of wing in vicinity of anal veiu brownish.

Head and appendages.-Average width of hend across eves, .39. Comparative lengths of antennal segments as follows: III-.20 to .26. average .23 ; IV-.19 to .24, average .21: V-.14 to .21. average .19; VI .09 to .13. average .11 plus .20 to .27 , average .24 . Secondary sensoria (Fig. 2S2) confined to third antemnal segment, usually arranged in a straight row, numbering from 4 to 7 and averaging 5 . Primary sensorium on sixth anteunal segment with a group of exceedingly small marginal sensoria at one side. All antennal segnents imbricated. Beak reaching just beyond the middle of the mesothoracic coxae.

Thorax and appendages.-Prothorax with a pair of small peg-like lateral tubercles. Stigma of fore wings more or less shallow and sharply pointed. Second fork of media closer to margin of wing than to first fork. 
Abdomen.-Cornicles (Fig. 131) .26 long, straight, imbricated throughout their length, and with the flange at apex very poorly developed. Cauda .15 in length (Fig. 203), distinctly constricted heyond middle, with the portion beyond constriction thin and more or less sharply pointed; with two or three hairs ou each side, all strongly inwardly curved, besides numerous sliort spine-like setae. First aud third ahdominal segments and segment posterior to cornicles with small lateral tubercles. Anal plate nornal.

\section{Apterous Viriparous Fearale, (Vimogexia)}

Sizc and gencral color.-Average length trom vertex to tip of anal plate, 1.43. Color essentially the same as in the alate viviparous female, except that the third, fourth, fifth, and base of sixth antennal segments are light yellowish, and the femora are a lighter shade of brown.

Head and apprndages.-Average width of head across eyes, .43 . Comparative lengths of antennal segments as follows: $1 I I-.24$ to 36 , average $.29 ; 1 \mathrm{~V}-.17$ to .24 , average $.20 ; \mathrm{V}-.14$ to .23 , average $.19 ; \mathrm{VI}-.09$ to .13 , average .10 plus .14 to .23 , average .20 . Secondary sensoria absent. All antennal segments finely imbricated. Primary sensorium on sixth segment with a group of very small marginal sensoria at one side. Beak similar in length to that of alate viviparous female.

Thorax and appendages.-Prothorax with a pair of lateral tuhercles.

Abdomen.-Cornicles about .36 long, otherwise similar to those of alate viviparous female. Cauda about .17 long, considerably more robust than the cauda of the alate viviparous female, constricted, and with two or three hairs on each side in addition to a dense covering of short spine-like setae. Anal plate normal. Lateral tubercles as in alate viviparous female.

Holotype.-Alate viviparous female; Beach, 1llinois, August 29, 1929, on Liatris sp., (Frison and Hottes). On slide with paratypic apterous viviparous female and pupae. Slide No. 10386. Morphotype.-Apterous viviparous female; same data as holotype. On slide with paratypic alate and apterous viviparous female and nymph. Slide No. 10387. Paratypes.-Ten slides, containing alate and apterous viviparous females and pupae; same data as holotype. Slides Nos. 10388-10395 and others unnumbered.

This species was collected on the flowering stems of blazing star (Liatris sp.). Nounted material most resembles . A. laburni Kalt.. but differs in having the sixth antennal segment much longer than the cornicles. In life the difference is very marked, A. labumi being black and A. funcsta mahogany red.

\section{APHIS GOSSYPII Grover}

Aphis gossypii Glover, Report of the Commissioner of Agriculture of the Operations of the Department for the year 1876, (Government Printing Office, Washington, 1877), p. 36 .

The cotton, or melon, aphid was first reported from Illinois by Forbes (1883) as a new species under the name of Aphis cucumcris. It is widely distributed throughout the world. In choice of food plants it is more cosmopolitan than most species of aphids and has been taken in Illinois on a large variety of plants including cotton-the host from which it was originally described. It is a serions pest of melons and cucumbers. In greenhouses it is apt to beconne a serious pest on a large variety of plants. Economic literature is full of articles dealing with the destruction caused by this plant louse, its bionomics, methods for control, and so on. In spite of all the attention paid to this insect by entomologists and others, nothing was known concerning the overwintering host, or hosts, of this species until the appearance of the 
paper by Patch $(19.5)$ in which orpine, or live-forever. was shown to be a primary food plant in Maine. The sexmal forms. both apterous. have been briefly described by Patch.

Data associated with our viviparous specimens are as follows: Cormal (July 19, 1882; Chicago (June 14), Herod (Nay 29, Oct. 29), Rock Istand (June 24). Urbana (Mlay 9, Aug. 6, Oct. 5, 8, 18), 1928: Cairo (June 21, 22), Collinsville (Sept. 11), Oakwood (Oct. 13), Urbana (July 24. Aug. 19, 31, Oct. 6, 8, 9, 15, 16), 1929; Cerro Gordo (Oct. 15). Starved Rock State Park (Mlay 13), Urbana (Oct. 20), 1930. Sexual forms and mating pairs were collected on Oenothera at Oakwood on October 22, 1930.

We have taken this species in Illinois on the following plants: Achillea Millefolium. Anchusa myosotillifiora. Apium sp., Arabis Drummonli. Capsicum dulce, Coccoloba flendanu. Coccoloba laurifolia. Crocus sp., Cucumis melo. Cucumis sativus, Cucurbita masima, Diervilla sp., Gassypium sp., Helenium sp., Lagenaria vulgaris, Mulva sp., Portulaca oleracea sp., Saxifragn splendens, sedum rettexum. spinacia olerucea.

The typic stide of Aphis cucumeris Forbes is No. 1557 in the Surver collection.

\section{APHIS HELIANTHI MONELL}

Fig. 21

Aphis helianthi Monell, Bulletin of the Uuited States Geological and Geographical Survey of the Territories, Vol. V, No. 1, January 22, 18:9, Art. 1, p. 26.

This species was first reported from Illinois, and the sexual iorms described, by IVeed (1888) under the name of Aphis connifoliac Fitch. a species with which it has been often contused. Since then it has been again reported from Illinois under its right nane by Daris (1!11/e).

Aphis helianthi over-winters in the egg stage on dogwood. and in the spring it often canses very serions damage to ornamental plantings by twisting and curling the leaves (Fig. :1). In early summer it migrates to smufower upon which host it mav he collected all summer. Gillette (1910) has given a brief accotnt of the biology of this species and the work of Bragg in denonstrating migratory habits of this species between ilogwood and sunflower.

There has been much confusion in literature regarding the names used in connection with species of Aphis attacking Cornus and HoliunIhus. Accorting to our collecting in Illinois, we have four species of Aphis on clogwool: the true holianthi, alternating between Cormus and Helianthus: culiginosus new species and ionifoliue Fitch, both of which thus far have been found only on Cormus; and spiracolu. which occurs on a large variety of plants, inclucling Cornus. Ife have three species of Aphis attacking smnflower: helimthi. alternating between Cormus and Hclianthus as alrearly mentioned: dobilicormis, which bally twists the terminal leaves (Fig. 30 ) and produces all forms on this host: and occasionally the omnivorous 1 . mmicis.

Our use of the name hclianthi Nomell is based upon a clecking of a cotypic slicle of this species linelly loaned by Professor I. I. Daris. Our use of the nume cormifoliae Fitch is based npon an examination of typic specimens kindly loaned hy Mr. I'. MS. Mason of the $L$. S. National Musemu. It should be mentioned that we are intormed by Pro- 
fessor Oestlund that his description of helianthi Monell (188i) is based mon a male and accordingly is not to be compared with descriptions based upon alate viviparous fennales: and judging from his statenents about the curling of leaves and subsequent collections of material, his reference is to what we are ealling dcbilicomis.

Data associated with our viviparous specimens, all collected on Cornus stoloniferu, Cormus mas. Cornus sp., or Helianthus sp., are as follows: Danville (Sept. 18), Herod (Oct. 12), Urbana (May 16), 1928; Beach (Aug. 29), East St. Louis (.lune 25), Galena (July 10), Maconb (May 3), Riverside (July 14), Rock lsland (July 9). Springfield (May 2), Urbana (April 17, 22, 26, May 1, June 17, Aug. 16, 19), 1929.

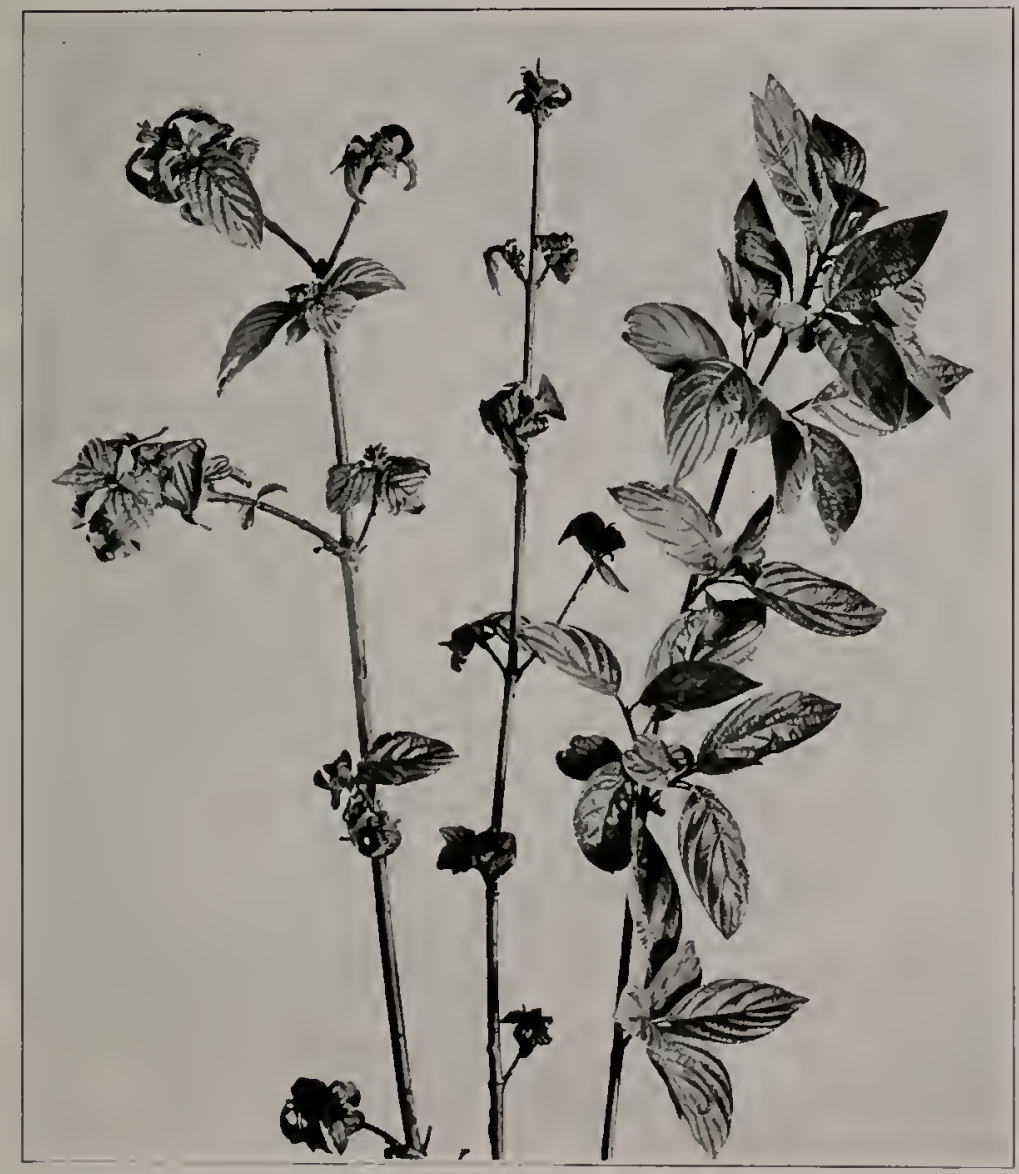

Fig. 21. Curling of leaves of the dogwood, Cornus mas. caused by $\mathrm{t}$ phis hrliamthi Monell; Urbana, June 22, 1929. Nornal loliage on right and infested foliage on left. 


\section{APHIS ILLINOISE.NSIS SHIIER}

Fic: 198

Aphis illinoisensis Shimer, Prairie Farmer, Vol. 18, No. 20, November 17. 1866 , p. 316.

The grapevine aldhid has been shown by Baker (1!1:ic) to overwinter on libumm and to migrate to wild and cultivated grapes in spring. Detailed descriptions of all torms are given by the same writer. This aphid is often destructive to cultivated varieties and is rarely absent from sone of the succulent stems. leares. tendrils. and

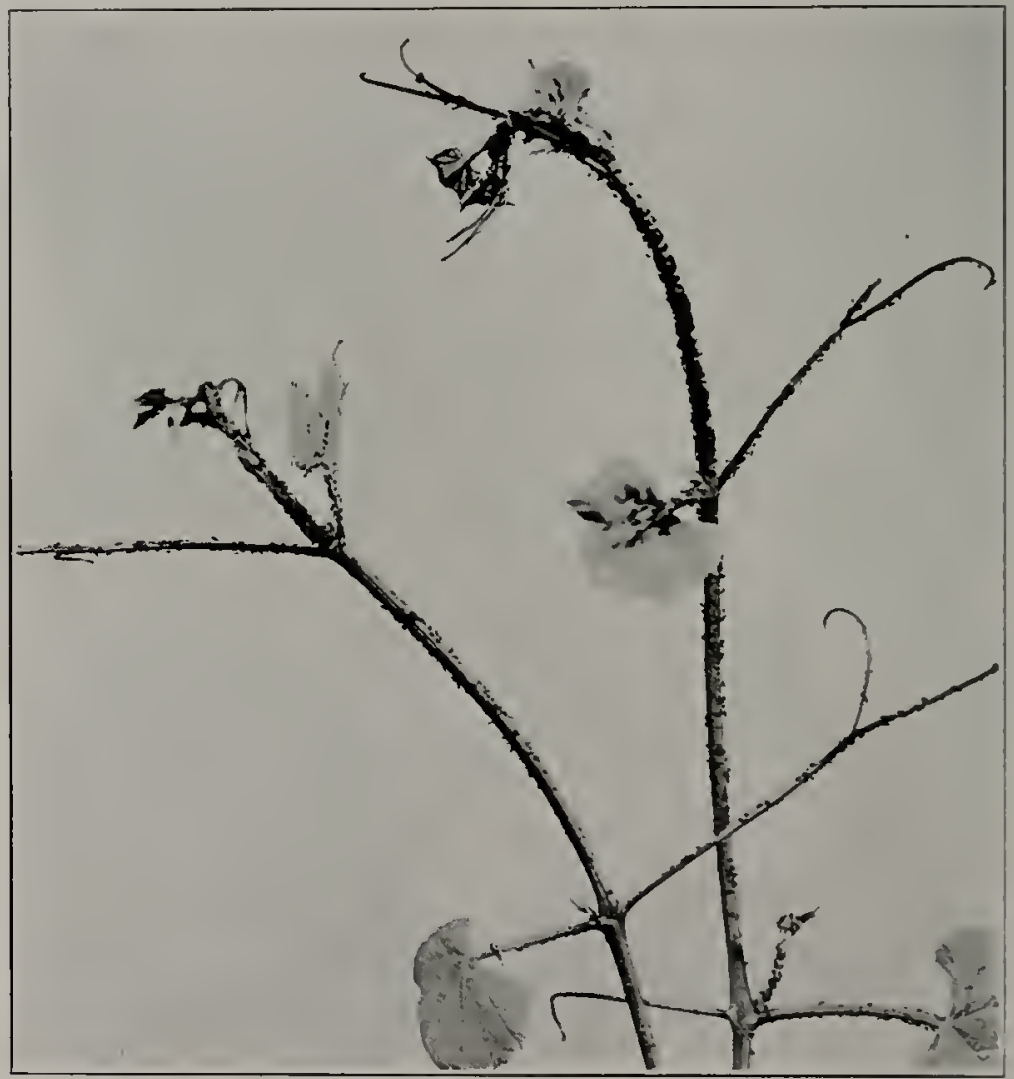

Fig. 22. Tendrils and leaves of the grape, Titis labrtusca, covered with the grape-vine aphid, Aphis intinoisensis Shimer.

leaf petioles (Fig. :2:) of such plantings. We have taken this species in twenty-three localities in all parts of Illinois, and it is sate to asstme that it occurs in every county in the state.

Among the recently recovered types of plant lice described from Illinois hy Thomas (1sis) are those of Siphonophora iviticola. These specimens agree witl the species now going by the name of illinoisensis 
Shimer, and hence riticoli Thomas can be definitely placed as a synonym of it as Davis (1911) thought. Undoubtedly the Illinois records of "A. inlis? Scopoli" of Walsh (1Sti2) refer to this species. The cotrpes of aiticold Thomas have been mounted in damar balsan on two slicles. Slicle No. atogs has been clesignated as the lectotypic slicle and Slide No. ifi!! as a paratypic slide. Both contain specimens of alate and apterous viviparous females and nymphs. The original vial containing these typic specimens was assigned the number 33 by Thomas. The data associated with the typic slicles are as follows: Irvington, Illinois. June $\bullet !), 18 \%$, on grape.

Neotypic slide.-Since this species was originally described from lllinois by Dr. Shimer and there is no record of a type having been preserved, a slide (4098) in the Survey collection is selected as the neotype. The data associated with the neotypic slide are as follows: Oakwood, Illinois, on grape, July 18, 1928 (Coll. Frison and Hottes).

our records for viviparous specimens of this species are as follows: Morris (July) and Villa Ridge (July 11), 18s3; Cairo (June 2), Champaign (June 10-19), Havana (June 21), Jacksonville (June 18), LeRoy (June 20), Hattoon (June 10), Metropolis (June 1), Neoga (June I0), Oakwood (July S-18), Pekin (June 20), Quincy (June 6), St. Josepb (June 17), Urbana (July 7-10), 1928; Beach (July 13), Cairo (June 22), Champaign (June 10), Effingham (June 1S), Elizabethtown (June 20), Galena (July 10), Homer (June 29), Kansas (June 17), Oregon (July 12), Starved Rock State Park (July 6), 1929. Found on the young stems, leaves, tendrils, and leaf petioles of both cultivated and wild grapes (Vitis).

\section{APHIS KNOWLTONI new name}

Chaitophoroides mildletonii (Thomas) Knowlton, Pan-Pacific Entomologist, Vol. V1, No. 1, July, 1929 , p. 34.

In working over material belonging to the maidi-radicis or middlctonii complex. we have sturlied specimens upon which the records and descriptions of Chaitophoroides middletonii of Knowlton (19291) were based. The species he is calling middlctonii Thomas does not come within the concept of maidi-radicis Forbes or middletonii Thonas as used by other writers, and since it represents an aplarently new species we are proposing the new nane of linoaltoni for it. Knowlton has described and figured in detail the alate and apterous viviparous females and the apterous oriparous fomale, and his slides should be considered as the cotypic material. The two cotypic slirles we studied of Knowlton's material bear the following data: Logan, Ltah Sept. $t-\hat{\imath}, 1920$, on roots and crown of clandelion. collected by G. K. Knowlton. By courtesy of Mr. Knowlton these two slides have been assigned the mumlers 89.5\% and 10865 and deposited in the Survey collection.

We have collected apterous viviparous specimens of this species at Irhana on two occasions, September 22, 1928, and Nay 22, 1929, each time on the roots of Taracieum officinale.

\section{APHIS LABURN] KiLTENBACI}

Aphis laburni Kaltenbach, Monographie der Familien der I'tlanzenläuse, Aachen, 1843, p. 85.

This species was first reporterl from Chicago, Illinois. Wy 1)avis (1910e) wnder the name of Aphis modicaginis Koch. Thomas (18ia) 
mentions both laburni, as a synonym of Aplis rumicis L.. and midicaginis. He did not. however, claim to know the species, and his references are not to be construed as Illinois records. Davis reports it as an important enemy of the black locust in the Chicago parks. We ourselves have taken this species only once, on the tender terminal shoots of young black loctsst.

Our viviparous specimens were collected on Robinin Psfullo-Acacin at Union Grove, Illinois, September S, 192S, by Mr. C. C. Compton, and at McCusky, Illinois, June 26, 1981, by Frison and Ross.

\section{APHIS LURIDIS new species}

FIG. 268

Alate Viniparots Feisale

Size and general color.-Average length from vertex to tip of anal plate. 1.79. Head and thorax dark chestnut-brown. Dorsum and venter of abdomen golden yellow, with brownish, segmentally arranged, lateral patches which tend to become confluent a short distance posterior to the base of the cornicles; cornicles, cauda, and anal plate dark brown. Antennae essentially concolorous with head except extreme base of third segment, which is lighter. Legs brownish, fore pair lightest and hind pair darkest. femora usually paler near base, tibiae usually darker at apical portion; tarsi concolorous with apices of tibiae. Fore wings with stigma smoky, veins light brown and only moderately well developed, posterior margin of wing brownish near junction with and vein. Beak almost uniformly brownish.

Head and appendages.-Average width of head across eyes, .43. Antennal segments with comparative lengths as follows: III-.37 to .49, average 44 ; IV-. I6 to .21, average $.19 ; \mathrm{V}-.14$ to .17 , average $.16 ; \mathrm{V} I-.10$ to .11 , average .11 plus .26 to .31 , average .28 . Secondary sensoria (Fig. 269 ) are found on the third, fourth and fifth segments and are distributed as follows: III-2S to 40 , average $35 ; \mathrm{IV}-7$ to 13 , average $10 ; \mathrm{V}-2$ to 7 , average 5 . Secondary sensoria well developed, with wide rims, and very tuberculate: on the third antennal segment they appear to be quite equaly distributed over its en. tire surface, except for a short free area near the base which is less in length than second segment and a tendency in some specimens towards a concentration near apex; on fourth and fifth segments confined mostly to one side of the segment; those on fourth segment scattered and those ou fiftl segment in a more regular row. All segments of the antennae, except where sensoria interfere, strongly imbricated. The beak is quite variable in length, in some specimens not quite reaching the coxae of the mesothoracic pair of legs and in others reaching the coxae of the metathoracic pair.

Thorux and appendiges.-Prothorax with a pair of large, unusually well developed, lateral tubercles; mesothorax with a pair of wax glands on the ventro-lateral surface which are rather difficult to distinguish. Fore wing with second fork of the media variable in relation to margin of wing and first fork. Second joint of the tarsus, exclusive of claws. subequal to the base of sixth antennal segment.

Abdomen.-First abdoninal segment and segment posterior io cornicles each with a pair of large, well-developed, lateral tubercles. Cornicles but slightly tapering from base to apex, a little less than twice the length of the fifth antennal segment. or abont twice the length of the canda, and averaging about .25 in length, strongly imbricated througliout and with a poorly developed flange at the tip. Cauda distinctly narrowed beyond middle. with from four to five hairs on a side, the four termimal hairs strongly: bent inwardly, averaging about .15 in length. Anal plate rather deep and rounded.

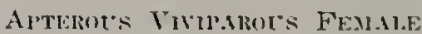

Size and gencral color.- Average length from vertex to tip of anal nlate. 1.52. Head yellowish brown: thorax and abdomen golden yellow, exept for a small hrownish patch near posterior base of each corniclo. Cornicles 
dark brown. Cauda and anal plate considerably lighter in color than similar structures of the alate viviparous female but still somewhat browish or dusky. First and second antennal segments concolorous with the hearl; remaining segments almost uniformly dark brown, except basal half of third segment which is lighter in color than the apical half. Fenora varying in color from almost uniform brown to basal half yellowish and apical half brownish, fore temora usually lightest; tibiae yellowish-brown with the exception of apical portions, which are darker brown; tarsi brownish. Beak brownish.

Head and appendages.-Average width of head across eyes, .4I. Antennal segments with comparative lengths as tollows: III-.33 to .37, average .36: $\mathrm{IV}-.16$ to .19 , average $.17 ; \mathrm{V}-.13$ to .14 , average $.14 ; \mathrm{V} 1-.09$ to .11 , average .10 plus .17 to .21 , average .20 . Secondary sensoria nsually present on third. fourth and fifth antennal segments; not very constant and varying considerably in size; on the thind antemal segment they are confined to the apical one-third of the segment and they number trom one to nine; scattered on the fourth and fifth antennal segments, on fourth segment varying in number from five to seven and on fifth segment from two to three; all segments strongly imbricated. The beak usnaily extends to the midcle of the coxae of the metathoracic pair of legs.

Thortx and appendages.-Prothorax with a pair of large, well-developed, lateral tubercles.

Abromen.-First abdominal segment and the segment posterior to the cornicles each provided with a pair of large, well-cleveloped, lateral tubercles. Cornicles about three times the length of the base of the sixtl antennal segment and averaging about. 28 in length, tapering a trifle towaris the apex. strongly imbricated, the flange poorly developed. Cauda about one-half the length of the cornicles, averaging about .16 in length; in shape it is similar to that of the alate viviparous female; with from five to six pairs of lateral hairs, the two terminal pairs strongly bend inwardly. Anal plate similar to that of the alate viviparous female.

Holotype.-Alate viviparous female; Carbondale, Illinois, June 4, 1928. on Zizia sp., (Frison and Hottes). Slide No. 10459. Morphotype.-Apterous viviparous female; Channel Lake, Antioch, Illinois, June 15, 192S, on Zizia aurea, (Frison and Hottes). On slide with alate viviparous female. Slide No. 10460. Paratypes.-Twenty-five slides of alate and apterous viviparous females, pupae and nymphs; all collected in Illinois by T. H. Frison, F. C. Hottes, and H. H. Ross from Zizia aurea or Zizia sp. The localities and dates are as follows: Beach (July 13, 1929); Carbondale (June 4, 192S); Channel Lake, Antioch (Jnne 15, 192S); Mletropolis (Mlay 3I, I92S); and Starved Rock State Park (June 13, 1928). Slides Nos. 10461-10480 and others unnumbered.

This species is very closely allied to. Aphis signatis, a new species described in this paper. It may be distinguished by its color, the longer cornicles, and the fact that the apterous viviparous female has secondary sensoria on the third, fourth, and fifth antennal segments. It may be separated from both A. nyctalis and A. signatis by characters given in the key.

Specinens of this new species are found both in folded leaves and along the main flower stalks, particularly the latter.

\section{APHIS MACULATAE OESTIENI}

Alhis marulathe Oestlund, Geological and Natural History Survey of Minnesota, Bulletin No. 4, I8s7, p. 61 .

tphis dritisi Patcl, Jonrnal of Economic Entomology, Vol. 10, No. 4, August 1917, р. 419. New s?monymy.

This specias was first reported by Davis (1910e) from northern Illinois. -1. maculalae Oestlund has lecen considerect a synonyen of 
populifoliac Fitch, but Baker (1916a) has shown that the typic specimens of the latter belong to the genus Clavigons, and hence maculatac is the first name available for this species. The original description of $A$. populifoliac Fitch is very unsatistactory and there are some points upon which the description better fits this species than that of the species with which the name is associated on the basis of the existence of typic specimens.

Davis (1910e) and Patch (1!)13a) have referred to this species as A. populifoliac Fitch. Later, as a restult of Baker's (1:116a) work. showing populifoliac helongs in a different genus. Patch (1!1i) proposed the name darisi. Oestlund's (1s8i) matulatac. however. refers to this same species and hence las priority over the name proposed by Patch.

Patch (1!13a) and Knowlton (1!):!b-under name of populif clues Fitch-luve given good descriptions of the viviparous forms and the male. As far as know'm, the entire life cycle of this largre. handsome species is spent upon the poplar or aspen. It occurs on the undersides of leares and on succulent shoots.

Some recent writers have placed this species in the genus Chuitophoroides Mordvilko (1909), but we have not seen fit here to recognize this genus.

We have taken this specjes only once, upon Populus tremuloides at Oregon, Illinois, June 27, 1928.

\section{APHIS MAIDI-RADICIS FORIE:}

$$
\text { FI(is, 23, } 24
$$

Aphis maidi-radicis Forbes, Seventeenth Report of the State Entomologist on the Noxions and Beneficial Insects of the State of Illinois. Sixth Report of S. A. Forbes for the years 1589 and 1590,1891, p. 64.

The corn root lunse (Figs. :3. 24) was first reported from Illinois by Walsh ( $18(\%)$ ) under the nane of "Aphis maidis." Fitch." Since then, hecause of its ecomomic importance, it has attracter the attention of many workers, so that the literature referring to it is very extensive. Forbes has published numerons papers concerning this insect, anong which his articles of $18 ! 11$ and 1895 are most inportant. In the 1891 paper, a new specific name was propused, based upon experinents demonstrating that the aerial aphicl on corn was not the same as the stibterrancan aphid on corn: both formerly groing under the mance of maidis Fitch.

The life history of this root louse in Illinois may he brietly summarized as follows: the egess are careel for by common field ants during the winter: in spring the first young nympls are placed hy ants upon the rootlets of varions plants such as sumartweed: later the plant lice are transfered to certain plants including corn where the sexual forms are produced in late fall. The corn root aphid is one of the few aphicls that secm to be alnust. if not entirely, elepenclent upon ants. I more cletailed but still comparatively short account of the corn root louse and suggested methods for control is siren ly: Davis (1!)1i). 
Previons to the separation of maidi-radicis from maidis Fitch, Thomas (18,9) named an Aflis fotmd in Illinois on the roots of various plants, as middlctonii. The close, if not co-specific, relationship of the latter to madi-radicis appears never to have been suspected by Forbes. Now, however, there exists considerable doubt whether there are two or lut one species involved; if the latter ever becomes clemonstrated, the nante of Thomas will have priority.

After a careful study of a large series of slides belonging to the Survey collection. and an equally large number kindly loaned to us by various individuals from Maine to California, we are still in a quanclary whether we are dealing with one variable or two species in this state, though inclined to the riew that only one species is involverl. Since the name of maidi-radicis Forbes is so well estal-
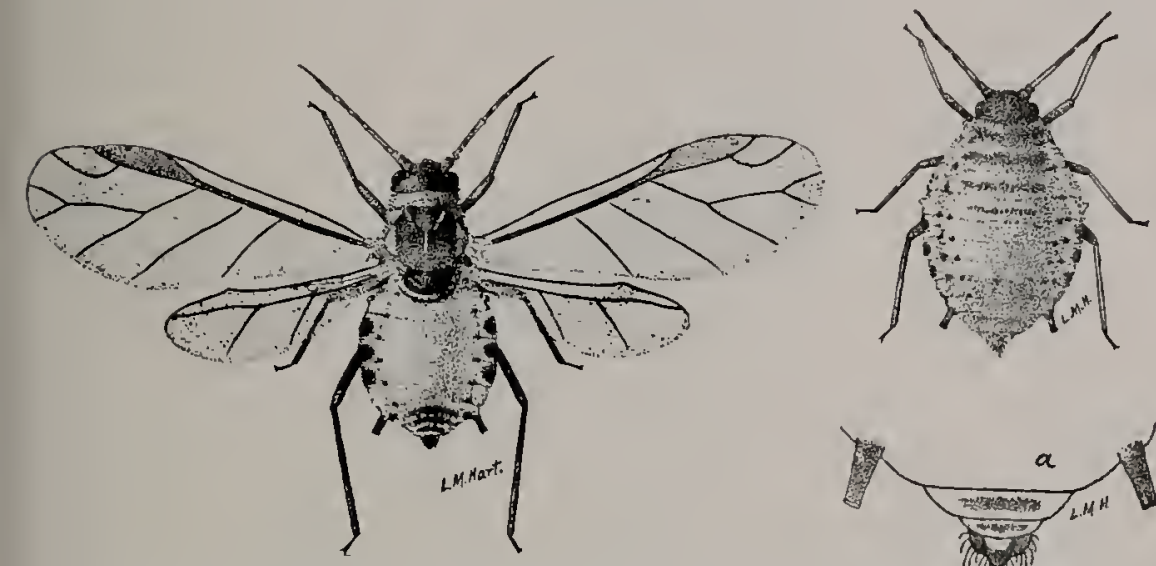

Fig. 23. Alate and apterous viviparous females of the corn root aphid. A phis maili-ralicis Forbes. (Atter Forbes: Ill. Ent. Rep. 18.)

lished in economic literature, we are not definitely considering it as a synonym of middletonii Thomas. The name maidi-radicis is associated by some students of aplijds mostly with material collected on roots of corn, and the name of middtelonii applied to a very similar appearing root louse found on such plants as Erigeron. Solidago, and Aster. The former is considered, too. as having on the average fewer seconclary sensoria than the latter. We lelicve that only careful biologrical investigations can solve the problem of whether we are dealing with one, two, or perhaps three species. Such an investigation should study variation in color patterns shown by different generations on the same ancl different hosts, as well as variation in antennal structures, and should inclucle transfer tests.

We are recording under one name (madi-radicis) almost all of our Illinois material of this complex. because of general uniformity in structural and color characters. A few slicles of viviparous specimens which approach most clesely the present concept (Vickery. 1!10) of middletonii, are left as undetermined. 
Data associated with our specimens are as follows: Champaign (July 31). Normal (July 27), 18s3; Freeport (July 16), 18s4; Cbampaign ( May 14. July 2, 5), Urbana (May 21, Aug. 7), 1886; Champaign (May 26, Oct. 18). Urbana (June 9), 1887; Urbana (June 19), 1888; Urbana (Oct. 3. 14),

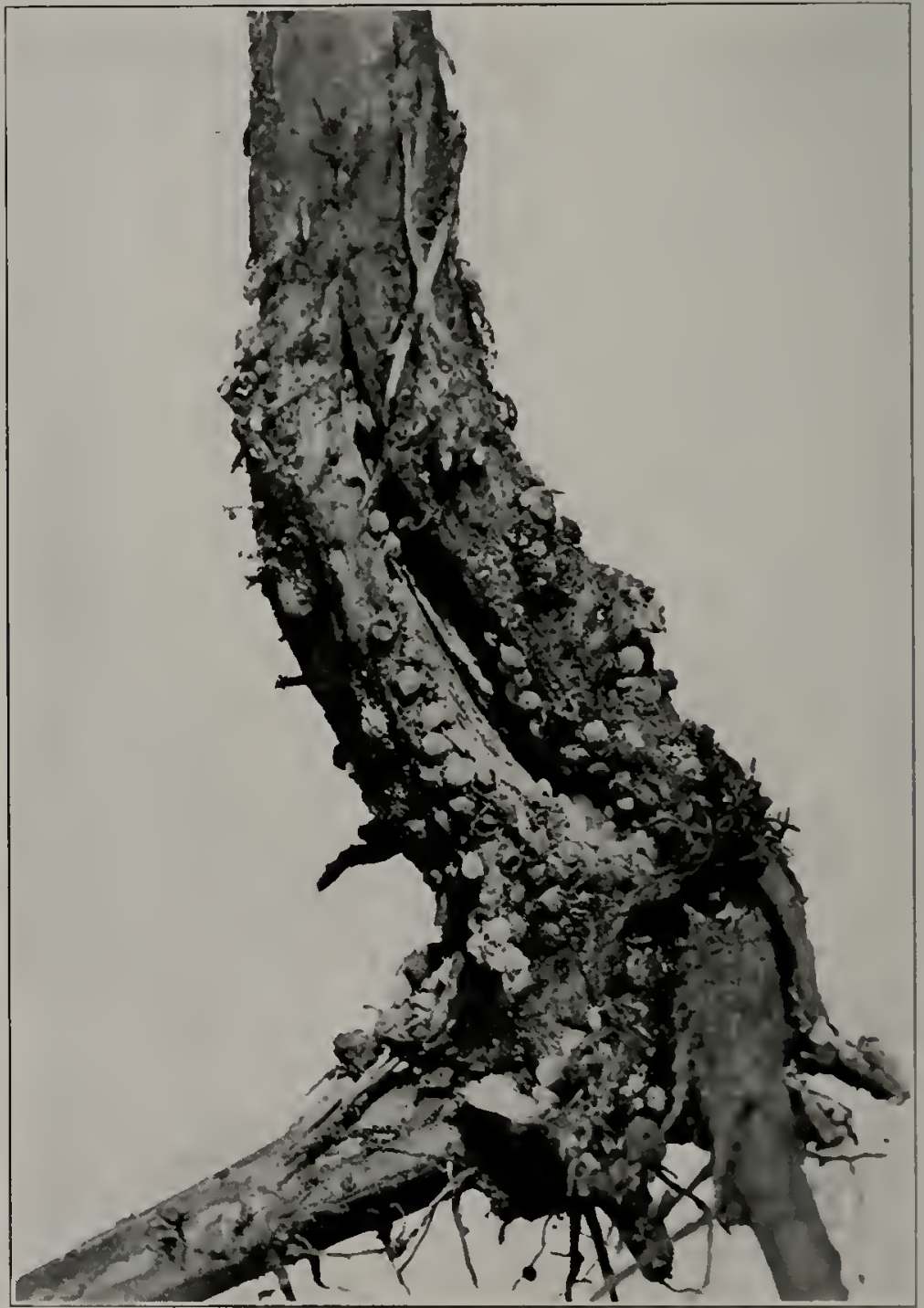

Fig. 24. Aphis maili-radicis Forbes on roots of Erigcron philadclphicus: Seymour, July 19, 1929.

1S\$9; Urbana (June 26, 29. Oct. 6), 1891: Urbana (Aug. 5), 1\$93; Champaign (Oct. 17), Urbana (May 21), 1894; 13uda (May 29). Bureau (May 30 ), Knoxville (Nay 25), 1901; Arnold (Jume 19). Irrbana (June 14), 192s: Allerton (June 17), Clayton (June 21), Edwardsville (Sept. 11), Oakwood 
(June 29), Seymour (July 19, Aug. 6) Starved Rock State Park (July 5), 1929; Beardstown (Nov. 7), Fairmount (Sept. 28), Humboldt (Nov. 12), Oakwood (Oct. 22), Vandalia (Nov. 14), 1930. Sexual forms taken in 1930 in October and November at Beardstown, Humboldt, Oakwood, and Vandalia. Nating pair taken at Oakwood on October 22 on corn roots.

Host plants are as follows: Avena sativa, Erigeron. Plantago, Polygonum sp., Portulaca oleracea, and Zca Mays.

\section{APHIS MAIDIS FITCH}

Aphis maidis Fitch, Transactions of the New York State Agricultural Society, Vol. XV, 1855 (Printed 1856), p. 550.

Walsh reported Aphis maidis Fitch as questionably occurring in Illinois. As he was dealing with a root-feeding form, the species referred to by him was unquestionably Aphis maidi-radicis Forbes and not the corn leaf aphid. The record of Thomas for maidis in Illinois undoubtedly covers both this species and maidi-radicis. The complete life history of this species, at least in the north-central states, is not known. It appears in corn fields in Illinois about midsummer and remains there until late fall, rarely becoming of serious importance as a pest. The sexual forms are unknown, and the late appearance of maidis in Illinois is suggestive either that the corn leaf aphid has an alternate host or that it uigrates each season from the south, where it is present during the winter months. Davis (1909a) gives a good account of the known biology and descriptions of this species.

Data associated with our viviparous specimens are as follows: Cedar Lake (Oct. 17), Normal (Oct. 25), Pekin (Aug. S), Waterman (Aug. 25-26), 18s2; Champaign (July 31), Heyworth (Aug. 11), 1883; Anna (Sept. 5), Cbampaign (Aug. 2-4), Normal (Aug. 11, Oct. 30, Nov. 8), 1884; Champaign (Sept. 1-14), Urbana (Sept. 3, Oct. 27), 1885; Centratia (Sept. 23), Champaign (Aug. 10, 21-23), Urbana (July 31, Aug. 1-9. Sept. 1), 18s6; Urbana (July 31), 18ss; Urbana (Sept. 2-23, Oct. 3-5), 18s9; Champaign (July 23-31, Aug. 3), Farina (Sept. 19), Havana (June 13), 1894; Urbana (July 9-17), 1897; Aetna (July 11), 1905; Decatur (Nov. 4), 1928; Káppa (Aug. 14, Sept. 9), Mattoon (Sept. 10), Seymour (Oct. 30), Urbana (Sept. 8), 1929. Taken on corn, sorghum, broom corn, and grass.

\section{APHIS MONARDAE OESTLUNI}

Aphis monardac Oestlund, Geological and Natural History Survey of Mlinnesota, Bulletin No. 4, 1887 , p. 58 .

Aphis monardac is here recorded from Illinois for the first time. It may be collected on the molersides of the leaves of horse ninint, whicl it causes to curl.

Data associated with our viviparous specimens, collected on Monarda sp., are as follows: Carbondale (June 4), Champaign (July 15), Galena (June 26), Herod (May 29), Kankakee (June 29), Marshail (May 25), Oakwood (May 21, July 18), 1928; Flora (June 18), Urbana (June 1), 1929.

APHIS NEILLIAE OEsTLIXNI

th this neilliae Oestlund, Geological and Natural History Survey of Min. nesota, Builetin No. 4, 1887, p. 59.

This species was first reported from Oak Park, Illinois, by Davis (1!10e) who mentions appearance of apterous sexual forms in Octolser. 
Our observations at Lrbana indicate that this species is at times extremely alntundant on the undersides of the leares and terminal portions of the new growth of nine-bark used in ornamental plantings.

Data associated with our viviparous specimens, all collected on Physocurpus opulifolius, are as follows: Galena IJune 26). Crbana (July 26), 1928; Macomb (May 4), Urbana (April 13), 1929; Urbana (June 20. $30), 1930$.

\section{APHIS NERII Fosscolomir}

Aphis nerii Fonscolombe, Annales de la Société entomologique de France. Tome X, 1841, 1. 179.

Aphis lutescrns Monell, Bulletin of the United States Geological and Geograplical Survey of the Territories, Yol. V, No. 1. January 22, 1579, Article 1, p. 23. Niru synonymy.

This species was first reported. prestumably from Illinois, by Thomas (18i!) as "Aphis ncrii? Fonscol." It was later reprorted from the vicinity of Chicago, Illinois, by Davis (1!lue) at Aftris lutesccus Monell. The loright golden yellow abdonen and the blach head. antennac, cornicles, and canda niake this one of the mont comspicuons of Illinois aphids. Good descriptions and illustrations of the viviparous forms are given by Essig $(1911 \mathrm{a}, \mathrm{b})$.

An examination of cotypic slides loaned to $11 \mathrm{~s}$ by Professor Daris convinces us thal lutescens Alonell is the same as this norii.

Data associated with our viviparous specimens are as follows: Elizabethtown (Oct. 12). Pekin (June 20), 1928; Cairo (June 22). Carbondale (Sept. 2S), Centralia (Sept. 2S), Collinsville (Sept. 11). Elizabethtown (Sept. 27), Forsyth (Oct. 27), Jonesboro (Sept. 28), Netropolis (Sept. 27), Oakwood (Oct. 13), Urbana (Oct. 3, 29, Nov. 10), 1929. Up to the present time we have taken this form only on its sunmel hosts: Gomololus laris. Asclepias curassavica, and convolvulus scpium.

\section{APHIS NYCTALIS new species}

FIGs. 137. 197, 266. 267

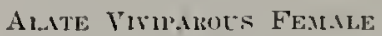

Size und genernl color.-Average length from vertex to tip of anal plate. 1.94. Head, thorax, and abdomen in live specimens essentially dark brown o! almost black. In mounted specimens the colors are as follows: Head and thorax mainly dark dusky brown. Abdomen yellowish to dark brown, the lighter areas with a distinct greenish tinge; lateral portions of ablomen witl segmentally arranged fuscous spots which vary in size. shape, and intensity of color: lateral patches in the vicinity of the base of the cornicles extend only around the posterior side of the cornicles; a large bloteh of tbe same color as the latcral spots just anterior to the anal plate. Cornicles black; cauda black except for mid-dorsal region anterior 10 constriction: anal plate concolorous with abdomen at base, darker towards outer margin The antennae are but slightly lighter in color than the head and are practic. ally uniformly colored throlighout, except that often extreme base of third antemnal segment is lighter in color than the remaining portion of segment. The femora of the prothoracic pair of legs are vellowish at their base and ventrally for almost onc-half their length, remaining portions dark brown: meso- and metathoracic legs rellowish at extreme base. and remainder dark brown: tibiae uniformly dark brown: tarsi dark brown but sometimes lighter in color than tiblae. Stigma of fore wings brownish: the reins, and posterior margin of wing where it meets anal vein. light brown: the anal vein lightly hordered with brown. The beak with basal half yellowish. apical half dusky brown. 
Head and appendages.-Average width of head across eyes, .46. Antennal segments with comparative lengths as follows: III-.34 to .46, average 40 ; $1 \mathrm{~V}-.23$ to .31 , average $.29 ; \mathrm{V}-.17$ to .23 , average $.20 ; \mathrm{VI}-.07$ to .14 , average .11 plus .14 to .29 , average .22. Secondary sensoria (Fig. 266) found on third, fourth and fifth antennal segments; sensoria on third segment appear to be about equally distributed over the entire surface of the segment, vary. ing in number from 25 to 37 and averaging 32 ; fourth segment with sensoria about equally distributed throughout length but in some specimens there is a slight tendency for a grouping on one side of the segment varying in number from 12 to 20 and averaging 16; sensoria on fifth segment in a straight row, varying in number from 1 to 3 ; sensoria on third and fourth segments varying in size, the larger ones being unusually large; all sensoria have wide rims. The beak extending about to the coxae of the metathoracic pair of legs.

Thorax and appendages.-Prothorax with a pair of well developed lateral tubercles. Stigma of fore wings sharply pointed at apex. Position of second fork of media somewhat variable, but always nearer to the apex of the wing than to the first fork. Hind tarsi, exclusive of claws, about onehalf the length of the cornicles.

Abdomen.-The first segment of the abdomen and the segment posterior to the cornicles have latera! tubercles, which may be easily over-looked hecause they are not well developed. Cornicles (Fig. 137) with straight, sicles, tapering but slightly towards apex, flange at apex poorly cleveloped, strongly imbricated throughout their length, in length either equal to or subequal to the length of the fourth antennal segment and averaging about 27. Cauda (Fig. 197) about equal to the length of the filth antennal segnent and averaging about 19 , constricted in the middle; with four to five hairs on a side, the two terminal pairs being very strongly inwardly bent.

\section{Alteliots Vivilarol's Fean.ue}

size and gencral color.-Average length from vertex to tip of anal plate, 1.87. Head and thorax mainly dark dusky brown. Abdomen yellowishbrown witb a greenisl tinge, particularly greenish on lateral portions. Ab. domen free from lateral patches anterior to cornicles, but there is a small brownish patch directly posterior to the cornicles; posterior extremity of the abdomen, cornicles, cauda (posterior to constriction), and patch directly anterior to anal plate are dark brownish, almost black. First and second antennal segments concolorous witb head; basal half of third antennal segment lighter in color than remaining balf. which is brown; remaining antennal segments miformly brownish. Legs similar in color to those of the alate viviparous female.

Head and appendages.-Average width of head across eyes, .47. Antennal segments with comparative lengths as follows: III-.29 to .41, average .35; $1 V-.23$ to 33 , average $.27 ; V-.13$ to .23 , average $.19 ; V I-.11$ to .14 , average .12 plus .19 to .29 , average .23 . The secondary sensoria of this species present an interesting study in variation: two specimens, apparently normal in every other way, liave no secondary sensoria; many other specimens, also apparently normal apterous females, not presenting the appearance of alate individuals in which the revelopment of the wings has been arrested, have secondary sensoria on the third, fourth, and fifth antennal segments (Fig. 267). Other evidence that these female specimens having secondary sensoria are not potentially alate viviparous females is provided by the peculiar arrangement of the sensoria, which is entirely unlike that of the alate viviparous female and utterly unlike that of any Ajlis species now known to the writers. The sensoria, when present, are flistributed on the segments as follows: thirl segment 2-9, average 5; fourth segment $8-17$, average 10 ; fifth segment 1-2, generally 1. The sensoria on the third segment, althougl scattered. are limited to the apical one-third of the segment-a very unusual occurrence outside of the genus Cinum: on the fourth segment they cover a little more than one side of the segment but extend from end to end; and on the fifth segment the sensoria appear to have no fixed position. 
Thorax and abdomen.-Similar to alate viviparous female.

Holotype.-Alate viviparous female; Cairo, Illinois, June 2, 1928, on Senecio glabellus. (Frison and Hottes). Slide No. 10338. Jorphotype.-

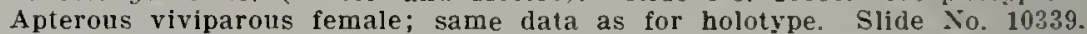
Paratypes.-Twenty-four slides of alate and apterous viviparous females, pupae and nymphs; all collected at Cairo, Illinois, on Senecio glabellus. June 2, 1928, and June 22, 1929, (Frison and Hottes). Slides Nos. 10340. 10357 and others unnumbered.

Superficially this new species is suggestive of Aphis rmmicis L. It differs, however, as follows: the apterous viviparous female normally has secondary sensoria on the third and fourth antennal segments: in alate viviparous females the secondary sensoria are nore numerous on the third and fourth antennal segments and are invariably present on the fifth antennal segment: and there is no pulverulent matter on the dorsum of live specimens. It differs from Aphis scuccionis Williams, a closely related species, of which cotypic slides were kindly loaned by the U. S. National Museum. in having a longer fonrth antennal segment and in the larger number of sensoria on the third, fourth, and fifth antennal segments. It may be separated from $A$. luridis and $A$. signatis by characters given in the key.

This aphid congregates on the main flower stalks, particularly near the flower heads. It is easy to detect because its color contrasts with that of its host plant.

\section{APHIS OESTIUNDI GILIFTTE}

Aphis oestlundi Gillette, Annals of the Entomological Society of America, Vol. XX, No. 3, September, 1927, p. 345 .

This species was probably first reported from the state by Davis (1910) as Aphis ocnotherac Oesthund. A. ocstlundi is almost impossible to separate from A. gossypii on the basis of mor phological or color characters, but appears to be clistinct biologically, having the evening primrose (Ocnothera bicmnis) as its primary host. We have tried without success to transfer spring migrants from Ocnothcro to squash plants in the insectary so that in spite of a lack of risible differences. it seems necessary to consider the species on Ocnothera distinct from A gossypii.

In Illinois we have found in October the sexual forms of ocstlundi on the mulersides of leaves of Ocnothcra located near the ground. Since they have never been described. the following descriptions are given. Both sexes are apterous and resemble closely the briei descriptions of the sexual forms of gossypii given by l'atch.

\section{ATtEBOLS MALE}

Length from vertex to tip of anal plate, .7. Color of head. including antennae, brown; thorax yellowish gleen with pleurae and lateral and anterior areas of dorsum brownish: abdomen yellowish green with the corni. cles and external genitalia brown. Legs. with coxae, most of femora, apices of tibiae, and tarsi. brown; trochanters. bases of femora, and most of tibiae, luteous. Winth of head across eyes $2 \%$. Antenmae imbricated, comparative lengths as follows: III-.19, IV--13, V-.14, VI-.07 pliss .21. Secondary sensoria distributed at random over segments as iollows: III-13 to 13 . average 17 ; $I V-i$ to 10 , average $s ; V-3$ to $s$, average 6 . Third and fourth segments often fused. Cornicles and cauda as in other forms, respectively. .13 and .09 in length. 


\section{Apteliots Oniphrots Female}

Length from vertex to tip of anal plate, 1.10. Color deep bright green, with the head, antennae, cornicles, anal plate, apices of tibiae, and tarsi, brownish. Width of head across eyes .29. Antennae only five-segmented, imbricated, the comparative lengths as follows: III-.20, IV-.10, V-.0? plus .21. Secondary sensoria lacking, fourth segment with a small circular primary seusorium near apex, fifth with one at base of terminal flament. Cornicles and cauda as in other forms, respectively .17 and .09 in length. Hind tibiae .43 in length, rohust, slightly swollen and tuberculate, with distinct setae; sensoria, if present, small and very inconspicuous.

Allotype.-Apterous male; Slide No. 9712, Oakwood, Illinois, October 22, 1930, on Oenothera. (Frison and Ross). On slide with two apterous males.

Morphotype.-Apterous oviparous female; Slide No. 9716, same data as allotype. On slide with two oviparous females.

Data associated with our viviparous specimens, which were all taken on oenothera biennis, are as follows: Carbondale (June 4), Galena (June 26), Havana (June 21), Herod (May 31), Marshall (May 25), Pekin (June 20), Quincy (June 6), Shawneetown (May 27), Starved Rock State Park (Jume 12), 1928; Columbia (Sept. 11), Monticello (May 24), Peoria (May 4), Springfield (May 2), Urbana (Aug. 13), 1929; Garden Prairie (May 15), Oakwood (Oct. 22), 1930. Sexual forms and mating pairs, also on Oenothera, at Muncie on October 22, 1930.

\section{APHIS PADI Liviaei's}

Fx. 25, 210

Aphis padi Linaeus, 1758, Systema Naturae, Editio Decima, p. 451.

This species is here recorded from Illinois for the first time. Our observations indicate that it has possibilities of doing serious injury to peach and plum trees, the leaves of which it causes to curl (Fig. 25), and it has been recorded by Smith (19:21) as the most important plant louse affecting plum trees in Idaho. According to Theobald (19:\%), who presents a good account of the habits and structural characters of this species, it over-winters on plum and migrates to numerous plants during the summer months. Our records from Illinois indicate that the life cycle is about the same in Illinois as in Europe. This species has heretofore been known under the name of Aphis helichrysi; we follow Theobald in considering it a synonym of radi.

Our data associated with our viviparous specimens are as follows: Bondville (Sept. 26), Evanston (Feb. 19), Urbana (Sept. 3. Oct 7, 9), 1929; Evanston (March 12), 1930. Oviparous females were found at Bondville on September 26, 1929. Our material was collected in fall from Prunus and in winter in greenlouses on Scnecio cruentus and Myosotis.

\section{APHIS PERSICAE-NIGER SMITH}

thlis persicte-niger Smith, Entomologica Americana, Vol. VI, No. 6, Brooklyn, June, 1890, p. 101.

The black peach aphicl has been previously reported as a common pest of peach in Illinois by Davis (1!10e). Accorling to variouts writers, it over-winters on the roots of peach and migrates to the leaves and tender shoots in spring. The alate and apterous viviparous 
females have been described and figured by Smith (1sion) and Gillette $(1008 b)$. The sexual forms are unknown.

We have records of this species only from Carbondale (May 14) and Herod (Mlay 31), 1928, both times upon Prumus Persicn.

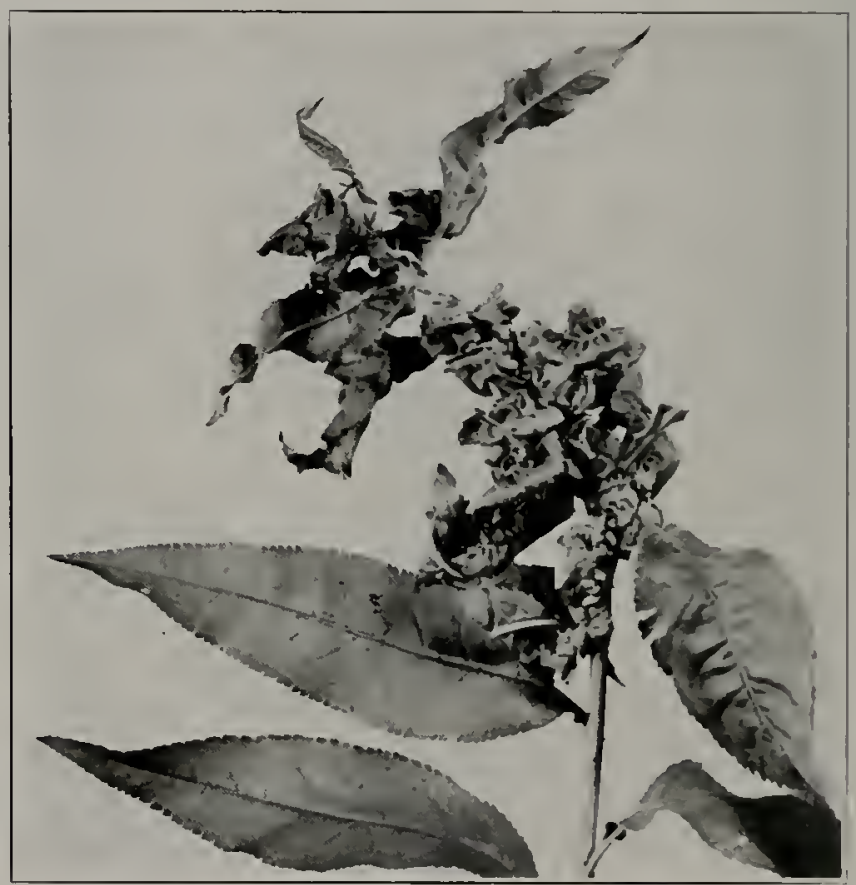

Fig. 25. Curling of leaves of peach. Prunus Persicu. caused by thhis padi Linnaeus: Urbana. Oct. T. 1929.

\section{APHIS POMII DEGEF:}

Fli. 14

Inhis pomi DeGeer, Mémoires pour servir á l'histoire des Insectes. Tome IIl, 1773 , p. 53. Pl. 3 , fig. 20.

Becanse the green apple aphicl is wickely distributed throughout the wothl and is often a serions pest of apples, it has heen the subject of many extensive investigations. Lntil rather recent years, it was known as 4 . mali Fabricius, but at the present time the prior name of pomi is in use. The recognized presence of pomi in Illinois certainly (lates back to Thomas (1si!)). and it is possible that some of the Illinots material recorded by fitch (1sin) belonged to this species. Davis (1!1/le) recorded it from lllimois as "common and often destructive pest of the apple." 
The most complete account of the structural features and biology of this aphid is that by Baker and Turner (1916), and their summary of it is here reproduced:

"The life history of tphis pomi may be briefly outlined as follows: The egg is laid upon the tender twigs of the apple, though occasionally it is laid upon the bark of the older twigs. It is light yellow when laid, but later changes to shining black. Development for a few days is very rapid, after which the egg rests tor the winter. When the revolution of the embryo is completed in the spring, an increase in temperature will cause the egg to hatch. Before this revolution a high temperature only tends to destroy it. Early in April the egg hatches by a uniform splitting over the insect's head.

"The stem mother is wingless and becomes mature in about 10 days. She produces summer forms, hoth winged and wingless, with the winged ones predominating. There are 9 to 17 generations of the summer forms at Vienna, Va. After the second generation the wingless forms always outnumber the others, but winged forms may occur in every generation. They become rare toward the end of the season. On the other hand, a wingless line may be carried from the stem mother to the egg. A third form, the intermediate, may occur throughout the summer.

"The wingless sexes begin to appear about the 1st of September. They occur in all generations, from the eleventh to the nineteenth, inclusive, and probably also in the ninth and tenth.

"The summer wingless forms and the oviparous females, which live longer than the males, remain on the trees at Vienna, Va., until the leaves drop, usnally about the middle to the last of November.

"Mating commences toward the close of September, one male usually serving more than one female. Both sexes feed. The oviparous female may lay infertile eggs if not reached by a male. and these eggs do not hecome black. The fertile egg develops to the resting stage before the first lieavy frosts; otherwise it may be winterkilled and will not hatch to a stem mother the following spring."

The bulletins of Gillette and Taylor (1908), Matheson (1919), Hodgkiss (1919), and Patch (1923a) contain much additional data of interest to the general student of aphids. Coutrol measures are fully dealt with in numcrous experiment station publications and general entonological texts (Metcalf and Flint, 1928).

Within recent years the opinion has heen advanced that $\mathcal{A}$. pomi DeGeer and $A$. spiraccola Patch (= spiracella of American authors) were the same species. Patch (1923a and 192!) has conchuded that the two forms are very closely related and "originated from a conmon ancestor and that the diverging forms have not yet gone far on their separate ways," and has shown that Spiraco is the over-wintering host in Maine for a form (spiraccola) whose summer generations frequent a great variety of plants. Likewise, the other form (pomi) finds apple an "all year host," althongh it may have summer generations on other plants and can be colonized on Spiraca. In this paper we have considered the two as separate species becatse of the following: (1) the presence in the sonth of an aphid attacking citrus which is of much economic importance and clearly of the spiraccola race: ( $(2)$ the fact that the tiliae of the oviparous females of spiraccola are swollen and thickly studded with sensoria, whereas in pomi on apple they are comparatively slender and with lut few sensoria; (3) the males of spiraccols, as far as known, are winged and the males of pomi apterous. 
Data associated with our specimens are as follows: Normal (Aug. 24), 18S3; Anna (Aug. 13), 1\$84; Normal (Aug. 7), 1885; Urbana (July 13), 1897; Antioch (June 15), Bement (July 17), Carbondale (June 4), Centralia (Aug. 6), Cliampaign (June 21), East Peoria (July 22). Elizabethtown (.lay 29, 31), Galena (June 26), Kankakee (June 29), LeRoy (June 20), Jetropolis (May 31, June 1), Mt. Carmel (Nay 26), Oregon (June 2S). Rock Island (June 24), Shawneetown (May 27), St. Joseph (June 17), Union County (June 4), Urbana (Nay 22-24, June 6, 11, 14, 23), 1928; Beach (June 13), Decatur (Jume 12). Homer (June 17). Nitchell (June 25). Newton (June 17), Rock Island (July 7), Waukegan (July 13), 1929; Fffingham (Nor. 13), 1930. Naterial collected on Crataegus sp., Prunus domestica. Prunus japonica. Prunus virginiana, Pyrus americana, Pyrus communis, and Pyrus Malus.

\section{APHIS PULCHELIA new species}

$$
\text { Fis: 141, 276 }
$$

\section{ALATE VIVPABOT: FEMaLE}

Size and general color.-Average length from vertex to tip of anal plate. 1.36. Head, thorax, and abdomen, including cornicles, cauda, and anal plate. dark brown in mounted specimens. In life the body of this species is distinctly bluish-green and somewhat pulverulent. First and second antennal segments concolorous with head or lighter: flagellum entirely yellowish brown. Front and middle femora hrown, paler at base; hind femora with extreme base light yellowish, remainder dark brown; tibiae light yellowish, with dark brown band at apex equal to length of tarsi; tarsi dark brown. Beak yellowish brown, extreme tip blackish. Stigma and veins light yellowish brown. posterior margin of tront wings in vicinity of anal vein light brown.

Heul and appendages.-Average width of head across eyes. 43 . Antennal segments with the following comparative lengths: III-.24 to .36. average $.32 ; I V-.23$ to .30 , average $.26 ; V-23$ to .30 , average $.27 ; V t-.09$ to .14 , average .13 plus .16 to .30. average .26. Secondary sensoria (Fig. 276) limited to third antennal segment, arranged in a straight row and numbering from 5 to 7 , averaging 6 . Antennae with very sparse, short, fine hair; all segments imbricated. Primary sensoria of fifth and sixth segments sub. equal. Beak extending to, or a little beyond, the mesothoracic coxae.

Thorax and apprndages.-Prothorax with a pair of peg-like lateral tubercles, which are only slightly larger than the ocular tubercles. Second fork of media closer to margin of wing than to first fork. Hair on tibiae short, abont half the width of tibiae, spine-like and comparatively sparse.

Abdomen.-First abdominal segment and segment posterior to cornicles with small, lateral tubercles. Cornicles (Fig. 141) averaging .17 in length. straight, neither constricted nor with a distinct flange at apex, the apical third smooth, the remaining portion imbricated. Cauda . 6 iu length, constricted just anterior to tip of anal plate, with from $t$ to $\overline{5}$ pairs of lateral hairs, the apical pair strongly incurved. Anal plate normal.

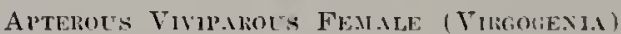

Sizn and gen'rnl color.-Average length from vertex to tip of anal plate, 1.63. General color as in alate viviparous female, differing in having the appendages a slightly deeper shade of brown.

Heal and apprindates. - Average width of head across eyes, .43. Antennal segments with conparative lengths as follows: IIl-2i to 27 , average $.30:$ IV - .11 to .29. average .21: V-.13 to .24, arerage .21: TI-.10 to 13, average .11 plus .16 to .27 , average .22. Secondary sensoria absent. Primary sensorium on sixtli antennal segment with a group of much smaller marginal sensoria on one side. Antennae imbricated. Witl comparatively: few, fine, short hairs. Beak extending slightly beyoud mesothoracjc coxae.

Thorar and appendagcs.--Prothorax with a pair of lateral tubereles

tbiomen.-First ablominal segment and segment posterior to cornicles with small lateral tubcreles. Cornicles averaging .19 in length, in shape 
similar to those of alate viviparous female. Cauda averaging .19 in length. slightly constricted beyond the anal plate, and with 6 to 7 pairs of lateral hairs, the terminal ones incurved.

AI.ATE M.ILE

Size and gcneral color.-Average tength from vertex to tip of anal plate. 1.17. Color essentially as for atate viviparous female except as foltows: antennae being darker; first three segments almost concolorous with head, the remainder of antennal segments decreasing in intensity towards apex. the extreme bases of alt segments of flagellum tuteous. Genital organs dark brown

Head and appcnalages.-Average width of head across eyes. .43. Antennal segments with the following comparative lengths: III- 26 to .89, average $.33 ; \mathrm{IV}-.24$ to .33 , average $.28 ; \mathrm{V}-.23$ to .29 , average $25 ; \mathrm{VI}-.10$ to .13 , average .12 plus .27 to .33 , average .29 . Secondary sensoria numerous on third, fourth, and fifth segments, very much crowded on one side (hence difficult to count), distributed as follows: III-22 to 33 , average 29 ; IV17 to 22 , average $20 ; \mathrm{V}-10$ to 14 , average 11 . Primary sensorium of sixth antenual segment with a group of small marginal sensoria on one side. Beak reaches to, or just beyond, the mesothoracic coxae.

Thorax and appendagcs.-Prothorax with a pair of lateral tubercles. Venation of wings as in atate viviparous female.

4 bdomen.-Cornicles averaging .11 in length, slightly imbricated with the flange very poorly developed. Cauda averaging. 14 in length, indis. tinctly constricted near base, and with from 4 to 5 hairs on each side.

\section{Apterous Ovipalots Female}

Size and general color.-Average length from vertex to tip of anal plate, 1.52. Head, thorax, and abdomen, including cornicles, cauda, and anal plate, reddish brown. Antennae entirely yellowish-brown. Beak yellowish-brown. tipped with darker brown. Femora reddish-brown; tibiae slight!y lighter except their apices which are tipped with dusky-brown; tarsi dusky-brown.

Head and appendages.-Average width of head across eyes, .43. Antennal segments with the following comparative lengths: IJI-.2I to .24, average .2:; IV - .17 to .26 , average $.2 \mathrm{I} ; \mathrm{V}-.21$ to .24 , average $.22 ; \mathrm{VI}-.11$ to .13 , average .12 plus .21 to .27 , average .25 . Antennae without secondary sensoria; primary sensorium on sixth segment with a group of several marginal sensoria; alf antennal segments imbricated. Beak reaching to metathoracic coxae. Hind tibiae considerably swolten except for apical portion; with numerous sensoria, one tibia with approxinately 90. bercles.

Thorax and appcndages.-Prothorax with a pair of small lateral tu-

Abdomfn.-First abdominal segment and segment posterior to cornicles with smatl tateral tubercles. Cornicles about. I6 long, distinctly imbricated at base, less distinctly at apex, with very poorly developed flange. Cauda about .20 long, only slightly constricted, and with 6 to 7 pairs of laterat hairs, the terminal ones incurved. Anal plate normal.

Hololypr.-Alate viviparous female: Beach. Illinois, July 13, 1929, on Euphorbia sp., (Frison and Hottes). On slide with alate viviparous female and nymphs. Slide No. I0404. Alotype.-Atate mate; Centratia, Itlinois, September 26, 1929, on Euphorbia sp., (Frison and Hottes). On slide with apterous viviparous females and apterous oviparous lemate. Stide No. 1040:. Morphotypr.-Apterous viviparous femate; same data as for holotype. On slide with alate viviparous femates, apterous viviparous female, and pupa. Stide No. I0406. Horphotype.-Apterous oviparous female; same data as altotype. On slide with male, apterous oviparous fenale, and apterous viviparous females. Slide No. 10407. Paratyprs.-Fifty-one slides, containing atate and apterous viviparous femates. alate males, apterous oviparous females, pupae, and nymphs, alt with same data as holotype or allotype: and five slides, Kankakee, 11., September 19, 1980, on Eumhorbia. Stides Nos. 1040\$-10440 and others unnumbered. 


\section{APHIS RHAMNI Foxs OLONBF.}

Aphis rhamni Fonscotombe, Annales de la Sociêtẻ Entomologique de France.

Tome X, $18+1$, p. $17 \%$.

This aphid is here reported from Illinois for the first time. It has been studied very thoroughly by Patch (19.2t) under the name oi A. abbrcitata l'atch, with especial reference to its seasonal migration. Theobald $(1 ! * i)$, also. describes the forms of this species and gives its synonymy. The winter and spring host is buckthorn (Rhammus), from which the spring migrants disperse to a large number of smmmer hosts. The sexual forms mate on the buckthorn in fall. and the over-wintering eggs are depositerl on this host.

Data associated with our viviparous specimens are as follows: Galena (June 26), Quincy (June 6), Havana (June 21), 1928: Homer (June 29). Kappa (Sept. 9-22, Oct. 1-3), Starved Rock State Park (Aug. 14), 1929; Kappa (May 7), 1930. Males and oviparous females taken at Kappa (Oct. $3), 1929$, on Rhamnus lanceoluta. Viviparous specimens taken on Amsonia Tabernaemontana, Hibiseus sp., Tepeta cataria, and Rhammus lanccolata.

\section{APHIS ROCIADAE COClíklied.].}

F1G. 191

Alphis rociadac Cockerell, Transactions of the American Entomological Society, Vol. XXIX, 1903, p. 115.

Aphis rociadac is here recorded from Illinois for the first time. When abundant on its host, larkspur. it causes screre leaf curlingr and encrusts the flower stalls. The sexes are produced in Illinois in May. so that the larger part of the year is passed in the egg stage. This seems to be an arlaptation to the short period of growth of its host. The hairs of this species are sontewhat enlarged apically-a rather peculiar characteristic for a species belonging to this genus. Davis (1919) hats descrilued all forms.

Data associated with our viviparous specimens are as follows: Eranston (July 15), 1929; Decatur (May 12), Elk Grove (June 7), Kappa (. Hay $7,13)$, 1930. Oviparous females collected at Kappa. Ilay 13, 1930. Ail specimens collected on Dclphinium tricorne.

\section{APHIS ROSEA (B.IKER)}

F16. 139

Anuraphis roseus Baker, Canadian Entomologist, Vol. LII. No. 4. Aprit. 192 I, p. 95.

The rosy apple aphid in many sections of the conntry is one of the most injurions plant lice feeding upon the leaves of apple. It times, when the infestation is particularly heary. the fruit is attacked and characteristic deformed "aphid apples" produced. Outhreaks of this aphid are fortumately scarce in Illinois.

This species has heen previously reported from Illinois hy Davis $1910 \mathrm{e})$ under the name of $A$. sorbi Kaltenlach as a "rather" uncommon species, which I lave taken only in southern Inlinois." Baker and Turner (1!16), uncler the name of $\alpha$ molifoliac Fitch, have 
given a complete account of its general biology and descriptions of its varions forms. Their studies show that it migrates between apple and plantain, the latter plant serving as the summer host.

Data associated with our viviparous specimens, all collected on Pyrus Malus or Plantago sp., are as follows: Marshall (May 25), Murphysboro (Jime 22), Shawneetown (May 27), Union County (June 5), and Urbana ( Ilay 23, 28, June 6), 1928; Oakwood (Oct. 22), 1930.

\section{APHIS RUBICOLA OESTLE:Tll}

Aphis rubicola Oestlund, Geological and Natural History Survey of Minnesota, Bulletin No. $4,188 T$, p. 60 .

This species is now recorded from Illinois for the first time, and our observations indicate that it is not common. The name of $A$. rubicola Oestlund (188i) was thought by Hottes (1930a) to be preoccupied by rubicola Haldeman (18t1). Haldeman's specific name referring to a different, red-colored species, however. was spelled rubccula in the original description, as photostat copy shows, and hence the name of rubicola Oestlund is still available. The best account of the life history of this rasploerry aphid is that by Winters $(1929 b)$, whose studies have shown that $A$. mbiphila Patch is a synonym of rubicola Oesthmd.

Data associated with our specimens, all taken on raspberry (Rubus sp.), are as follows: Kansas (June 17), Macomb (May 4), 1929.

\section{APHIS RUMICIS LINXAET'S}

Figs. 26, 2S, 80

Aphis rumicis Linnaeus, Systema Naturae, Edito Decima, 1758, p. 451.

This species (Fig. 20 ) is the most common dark-colored aphid found in Illinois. Its polyphagous habits make it of special importance as a pest in home gardens and greenhouses. It may be that this plant louse, supposed to be a native of Eurasia. was found in Illinois by Thomas (18:9) but he gives no definite data regarding its occurrence. There are, however, specinens in the Survey collection proving its existence in the state at least as early as 1884 . Gillette (1:10) was apparently the first to record it from Illinois. The biology of this insect has been studied from various angles by many investigators. These studies have shown it to be a somewhat variable species, attacking over two hundred plants, and over-wintering on Chcuopodium, Ezonymus, Rumcr, and Tiburmum. Good teclunical descriptions of all its forms and nuch other summarized information concerning its biology can be found in the papers of Davidson (1921). Horsfall (19:5), and Theobald (19.2\%).

Data associated with our viviparous specimens are as follows: Normal (May 9. June 2), 1884: Normal (May 24). Urbana (April 28), 1887; Albion (May 26). Antioch (June 15), Bement (July 7), Cairo (June 2), Carbondale (June 4), Champaign (Nay 19), East Peoria (July 22), Elizabethtown (May 29). Galena (July 27), Golconda (Oct. 13), llavana (June 21), Kankakee (June 29), LeRoy (June 20), Mattoon (June 10). Metropolis (June 1). Muncie (Oct. 6), Oregon (June 2T), Pekin (June 20), Quincy (June 


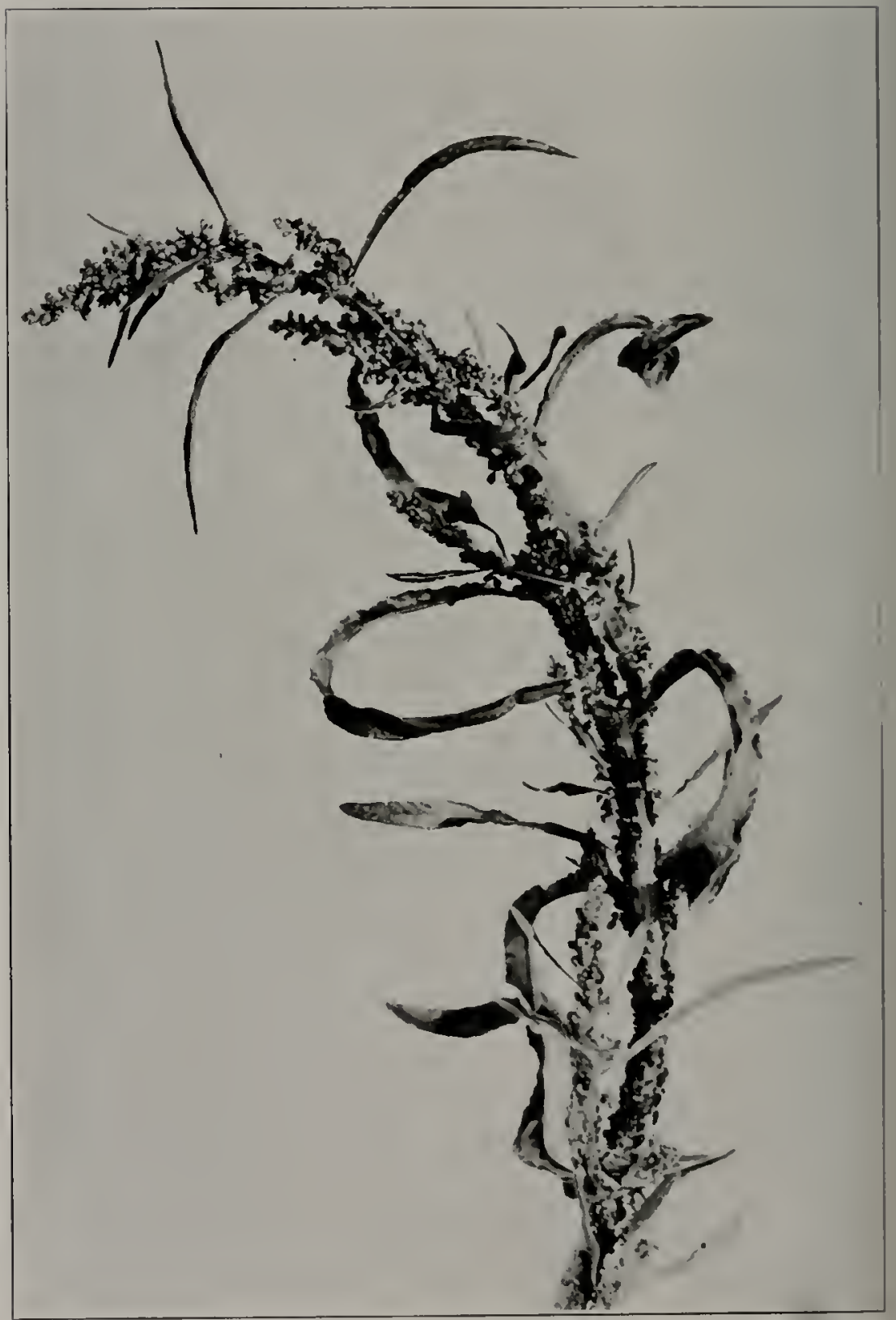

Fig. 26. One of the most common aphids in Inimois. Aphis rumicis Linnieus, on dock, humer crispus; I'rbana, June 10. 1929. 
6), Rock lsland (June 23), Shawueetown (May 27), Urbana (May 14, 17, $22,23,28$, June 6-7, July 7,23 , Sept. 26, Oct. 19, Dec. 5), 1928; Arlington Heights (July 3), Beach (July 13), Decatur (June 12), DesPlaines (July 10), Elizabethtown (June 20), Grayville (June 19), Herod (June 21), Homer (June 17), Kankakee (July 14), Lewistown (May 4), Macomb (May 4), Melrose Park (July 12), Oakwood (May 17, Sept. 22), Oregon (July 9), Putnam (May 5), Springfield (May 2), Starved Rock State Park (July 5, 6. Urbana (April 18, May 1, June 28), Waukegan (July 13), Woodford (July 5), 1929; Effingham (Nov. 13), Urbana (Oct. 20, 24), 1930. Sexual forms taken at Effingham (Nov. 13), and Urbana (Oct. 20-24). 1930, on Viburnum sp. Mating pair taken at Urbana (Oct. 20), 1930. What are apparently sten mothers were collected in early May on Evonymus, Ligustrum, Rumex, and Tiburnum. We have not given a complete list of food plants upon which we have found this aphid, since it attacks alnost any plant.

\section{APHIS RUMICIS VAl. GERARDIAE (TIIUMAS)}

Niphonophora gerarliae Thomas, Eighth Report of the State Entomologist on the Noxious and Beneficial Insects of the State of Illinois, 1879. p. 65 .

Colonies of blackish aphids which agree rery well with Thomas original description of Siphonophora gerardiac have been collected on Gerardia pediculariu at Tremont. Indiana, and at Kankakee and Oakwood, Illinois, in September and October. Thomas' material was collected on "Gcrardia temuifolia" at Carbondale. Illinois, during the latter part of Septenber. This species has not been reported since the time of its original description. Although our material is closely related to 4 . rmmicis L., agreeing well in color and general proporlions, we have preserved the name of gerardiac as a varietal nane. This is because the cornicles average longer and the secondary sensoria are much more numerous on the fourth ( $(i-16)$ and fiftl antennal segments than in rumicis and its rariations as defined loy Daridson $(19 \% 1)$, Horsfall $(19 \% 5)$, and Theobald $(19 \div \%)$.

Possibly future investigations will prove that the material reported 11pon here is entitled to specific recognition. If not, the concept of rumicis must he broadened. That we are here dealing with the form named as gerardiac by Thomas seems certain to us.

Data associated with our viviparous specimens from Jllinois are as follows: liankakee (Sept. 19) and Oakwood (Oct. 5), 1930. All material collected on fierardia perlicularia.

\section{APHIS SALICETI KIITTEXIACH}

Aphis saliceti Kaltenbach, Monographie der Familien der Pflanzenläuse, I Theil, Aacben, 1843, p. 103.

This species was redescribed by Thomas (1869) as new by the nance of Siplonophoru sulicicola from specimens sent to hin from Peoria, Illinuis. Although we have not collected it in soutlern Illinois, we believe it will eventually be found to be distributed throughout the state. Davis (1!10e) reports it as common in Illinois. For descriptions of all forms and further information, the reader is referred to the paipers by Gillette and lisagg (1918) and Theobald $(1928)$. This aphicl is peculiar in that the sexual forms are producerl during spring or early summer, as is the case with 4 rociulue 
Cockerell. According to all who have studied this species. it does not have an alternate host.

Specimens of $S$. salicicola Thomas (Vial $6 i$-Thomas) were included among the cotypic material recenty recovered and have been mounted in damar balsam. This slide (\$1is) contains portions of alate viviparous females. The data associated with this cotypic sicle are as follows: Peoria, Illinois, June $28.15 i ;$, on Salir. collected by A. E. Snith.

Data associated with our viviparous specimens are as follows: Champaign (May 16, 23), Kankakee (June 29), Oregon (June 27). Slarred Rock State Park (June 12), 1928; Springfield (May 2), Starved Rock State Park (July 6), 1929; Urbana (Mlay 6), 1930. All material collecied on salis sp.

\section{APHIS SAMBUCIFOLIAE FitCIT}

Aphis sumbucifoliae Fitch, Fourth Annual Report of the Regents of the Cniversity, on the Condition of the State Cabinet of Natural History. State of New York, January 14, 1851, p. 66.

This species was first reported from Illinois by Thomas (18:9) as Afhis sambuci Linn. Thomas questionably considered A fhis sambucifoliac Fitch as a synonym of $A$. sambuci. It was again reported by Davis $(1910 \mathrm{e})$ as common on "ornamental elder in the Chicago parks." Theoluald (192\%) has recently considered this species a synonym of 4 . sambuci, but we are holding sambucifoliac as distinct. largely on the lasis of additional secondary sensoria on the fourth and fifth antemal segments. Sanborn (190t) has given tairly complete descriptions of the viviparous forms. Davis mentions the sexual forms on elder in September and October in northern Illinois.

We have never taken this species on elder growing in the open: it seemingly show's a decided preference for hosts growing in shaded situations.

Data associated with onr viviparous specimens are as follows: Trbana (June 13, July 23, Oct. 18), 1928; Grayville (June 19). Jonesboro (June 23 ). Rock Island (July 9). Starved Rock State Park (July 5). L'rbana (April 8, Sept. 23), 1929; Effingham (Nov. 13). Urbana (Oct. 13, 20 and 241 . Vandalia (Nov. 14), 1930. Oviparous females liave been taken as follows: Effingham (Nov. 13), Urbana (Oct. 13-24), and Vaudalia (.Yov. 14), 1930. All specimens from Sambucus canalensis.

\section{APHIS SANBORNI P.ITII}

Aphis sanbarni Patch, Maine Agricultural Experiment Station, Bullerin 225. February, 1914, p. 52, figs. $8,9,10,11,29.35$.

The crreen gooselerry aphicl. now recorded from Illinois for the first time, is a fairly common species on gooseberry in the northcentral portion of the state. We have never found it doing conspicuous injury to its host since it nsually attacks only the terminal leaves or a feil shoots on a bush. Our determination of this species has been verified by Dr. Patch, who has described the species and further reported on its liology $(192:)$. stating that it alternates between Rilics and E Eilobium.

Data associated with our viviparous specimens are as follows: Galena (June 26) Oakwood (July 18), Starved Rock State Park (June 12, 13). 192S; El Paso (July 5), Kansas (June 17), 1929: Rock Island (June 3). 1930. All specimens collected on Ribes Grossularia and l'ibe's nigrum. 


\section{APHIS SIGNATIS new species}

FIG. 265

\section{Alate Viviparous Feniale}

size and general color.-Average length from vertex to tip of anal plate, 1.5i. Head and thorax dark brown; abdomen dark green except for some dark brown, lateral, segmentally arranged patches. Cauda, anal plate, and cornjcles greenish-brown to dark brown. Dark lateral patches at base of cornicles more or less confluent posteriorly. Antennae with two basal segments concolorous with liead, flagellum a uniform, slightly lighter brown. Front femora with base and ventral nargin yellow, apical and dorsal portions light brown; middle and hind femora yellowish at extreme base, the remainder dark brown. Tibiae yellowish to light brown, slightly darker at hase, and with a distinct dark brown band at apex, not quite as wide as twice length of tarsi. Tarsi brown. Stigma, costa, veins, and hind margin of wing at apex of anal vein, brown. Beak yellowish-brown, its extreme apex dark brown.

Head and appendages.-Average width of head across eyes, .46. Antennal segments with the following comparative lengths: IJI- .39 to .47, average .43; $1 \mathrm{~V}-.19$ to .24 , average $.21 ; \mathrm{V}-.17$ to .21 , average $.19 ; \mathrm{VI}-.09$ to .10 , average .09 plis .16 to .29 , average .22 . Secondary sensoria (Fig. 265) present on third, fourth, and fiftl segments, distributed as follows: 1II-3S to 43, average $41 ; \mathrm{IV}-7$ to 15 , average $11 ; \mathrm{V}-1$ to 8 , average 4 . Third segment, except extreme base, thickly dotted with sensoria, tuberculate in appearance; fourth and fifth segments with scattered sensoria, those on the fith usually confined to one side; sensoria with rather wide rims. Beak extending to middle of mesothoracic coxae.

Thorax and appendages.-Prothorax with a pair of well-developed, peglike, lateral tnbercles. Second segment of hind tarsus subequal to one-half the length of the cornicles. Second fork of media closer to margin of wing than to first fork, distance from first to second fork nsually twice the distance from second fork to margin of wing.

Ablomen.-First segment and segment posterior to cornicles with lateral tubercles, the tubercles posterior to cornicles small and difficult to locate. Cornicles subequal to three times the length of the base of sixth antennal segment, middle portion usnally slightly narrowed, otherwise of almost uniform thickness throughout, strongly imbricated, flange present but poorly developed. Anal plate broadly rounded. Cauda subequal to three-quarters length of cornicle, constricted in the middle, with four to five hairs on each sicle, the terminal hairs strongly incurved.

Apterous Viviparous Fevale

Size and general color.-Average length from vertex to tip of anal plate. 1.79. Head, including two basal segments of antenuae, prothorax, anterior portion of mesothorax, and pleurae of meso- and metathorax, chocolate brown; remainder of thorax and ahdomen, except brown patch at base of cornicles, dark green. Cornicles, cauda, and anal plate brown to dark greenish-brown. Flagellum of antennae varying in color; yonnger specimens usnally with the third and most of the fourth antennal segment yellowisli, the apical portion shading to dark brown; older specimens sometimes with only the basal half of the third antennal segment yellowish, tlie remainder dark brown. Legs and beak essentially as in the alate viviparous female.

Head and appentages.-Average width of head across eyes, .44. Antennal segments with comparative lengths as follows: IIJ-.33 to .43, average .39; IV-.I7 to $.2 \mathrm{I}$, average $.18 ; \mathrm{V}-.16$ to .20 . average $.19 ; \mathrm{V}-.09$ to .11 , average .11 plus .21 to .29 , average .25 . Secondary sensoria absent. Beak extending to metathoracic coxae.

Thorar and Ablomen.-Prothorax with a pair of well-developed lateral tubercles. Tarsi, exclusive of claws, equal to half length of cornicles. First scgment of ablomen and segment posterior to cornicles with a pair of lateral 
tuhercles. Cornicles subequal in length to the terminal process of the sixth antennal segment, usually straight, sometimes slightly constricted as in the alate viviparous female. Cauda more than half as long as the cornicles. Holotypc.-A Aate viviparous female; Urhana, Jllinois. May 22, 1929, on $Z$ izia sp., probahly $Z$. aurea. (Frison and Ross). On slide with alate viviparous female, apterous viviparous females, and pupae. Slide خo. 10396. Morphotype.-Apterous viviparous female; same data as holotype. On slide with alate viviparous female, pupae, and nymphs. Slide .io. 1039\%. Paratypes.-Thirty-three slides containing alate and apterous viviparous females, pupae, nymphs, collected in lllinois, by T. H. Frison, F. C. Hottes. H. H. Ross, and C. O. Mohr, on Zizia aurea, Zizia sp. Angelica sp., and Sanicula sp. The localities and dates are as follows: Channel Lake, Antioch (June 15), Herod (May 29), 1925; and Urbana (May 22). 1929; Charleston (May 31), and Homer (May 29), 1931. Slides Nos. 10398-10403 and 10S\$1-10\$9\$, and seven others unnumbered.

This species resembles somewhat in color and structure Afhis sambucifoliac Fitch. from which it differs in having shorter. ieebly constricted comicles, fewer tubercles on the ablomen, and a peg-like prothoracic tubercle. It may be separated from $A$. luridis and $A$. nyctalis by characters given in the key.

\section{APHIS SOLIDAGINIFOLIAE WILLAMS}

FIG. 27

t this solidaginifoliae Williams, University Studies, University of Nebraska, Vol. X, No. 2, March, 1911, p. 5 s.

This species has not been previously recorded irom Illinois. Although we have collected it at only four localities, it is probably more widely distributed than our records indicate. It is peculiar among most memhers of the genus ffhis in that it canses the leaves of goldenrod (Solidago sp.) to fold longitudinally and become podlike (Fig. :?). Since these folded leaves still retain their nomal green color, infesterl plants are apt to he overlooked. The body of this species has long. somewhat knobberl hairs. The viviparous iemales have been described by Daris $(1911 \mathrm{c})$. The oviparous temales formed the basis for the original description.

Data associated with our viviparous specimens are as follows: Danville (Aug. 4), Muncie (Oct. 6), 192S; Rock lsland (Julỵ †), Lrbana 1Aug. 21), 1929. Oviparous females were collected at Muncie, October 6. 192S.

\section{APHIS SPIRAECOLA PATU}

Aphis spiruerlln Schouteden. Gillette, Journal of Economic Entomology: Vol. 3 , No. 5, October, 1910 , p. 404. Misidentification.

Aphis spiruccoln Patch. Maine Agricultural Experiment Station. Bulletin 233. November, 1914, p. 270.

This species is rery closely related to $A$. pomi and has heen considered by some writers as identical. Our reasons for holding it as distinct have alrcaly been given (see pomi). The articles by" Patch (19:3a and $19 \cdot 2 ! 9)$. jercrionsly cited, show that spiracold over-winters on Spiraca in Naince and has a large number of stmmer hosts.

This aphicl is referred to in the soththern states as the "citrus aphid" and is of considerable economic importance. It is a pest on 
Spiraca used in ornamental plantings in all parts of Illinois. Davis (1!)10e) records it from Illinois by the name of "spiracella Schout.??" and doubts its iclentity with the European species. He also describes the viviparons fema?es and mentions the swollen tibiae bearing numerous sensoria.

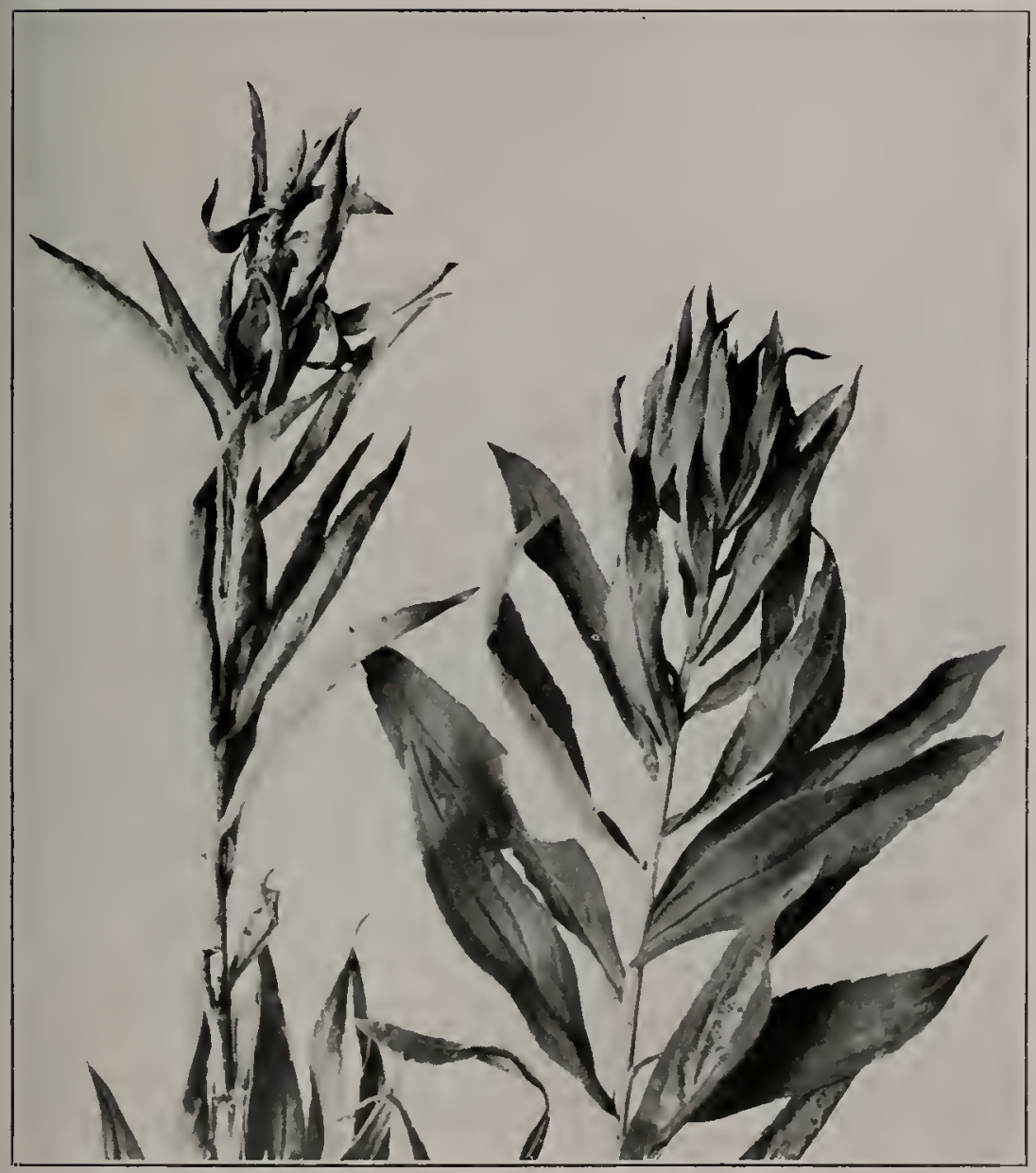

Fig. 27. Pseudo-galls on leaves of golden rod (Nolilago), caused by Alhis solirlaginifoliae Williams. Normal foliage on right and infected foliage on left; Seymour. Aug. 22, 1929.

Data associated with our viviparous specimens are as follows: Berwyn (June 14), Cairo (June 3), Carbonclale (June 4), Centralia (Aug. 6), Champaign (May 21), Elizabethtown (May 29, 31), Galena (June 26). Havana (June 22), Kankakee (June 29), LeRoy (June 20). Marshall (May 25), Metropolis (May 31. Jume 1), Mt. Carmel (May 26), Muncie (Oet. 6), Oregon (June 27, 28), Ottawa (June 14), Pekin (June 20, July 22), Quincy (June 6), Rock 1sland (June 22), Shawneetown (Nay 27). St. Joseph (dune 17), 
Urbana (May 22, 29, June 7. July 10, 26), 1928; Alton (June 25). Decatur (June 12), Edwardsville (Sept. I1), Grayville (June 19), Jerseyville (June 25). Pontiac (Aug. 12), Starved Rock State Park (July 6). Ĺrbana (May 15, June 10), 1929; Des Plaines (June 16), Crbana (Sept. 2S). 1930 . Col. lected on lecr Nryundo. Apocynum sp., Aquilegia canadensis, Asclepias sp., Catalpa speciosa. Celustrus scandens. Convolvulus sp.. Cornus stricta. Cucumis sativus. Helichrysum bracteatum. Hydrangea sp., Liatris squarrosa. Pastinaca sativa, Polygonum sp.. Rumex crispus, Ternonia sp.. T"iburnum sp. Titis sp.

\section{APHIS SPIRAEPHILA PATCII}

F1G. $20 \mathrm{~s}$

Aphis spirarphila Patch, Maine Agricultural Experiment Station, Bulletin 233, November, 1914, p. 270.

This aphid, previously unrecorded Irom Illinois, frequents the terminal shoots of native meadow-sweet. Spiraca salicifolia. According to Patch, it apparently spends its whole life cycle on this one host. Through the kindness of Dr. Patch our specimens were compared with cotypic naterial of this species. The original description relers to the apterous viviparous form as being "huckleberry black with a slight white bloon of wax powcler." Our Illinois material was more pinkish than black.

Data associated will our viviparous specimens are as follows: Harana (June 22), 192S; Beach (July 13), Rock lsland (July 9). Erbana (July I). 1929; Rock Island (June 3), I930.

\section{APHIS TULIPAE FoxsCoLOMBE}

Aphis tulipae Fonscolonbe, Annales de la Société Entomologique de France. Vol. $\mathrm{X}, 1841,13.167$.

This more or less cosmopolitan species is recorded iron lllinois: for the first time here. It has been recorded in Europe ieeding upon various liliaceous plants, including Gladiolus and Tulipa, and upon carrot and parsley roots. According to Theobald (192:). Felt (19(0!)) redescribed it under the nance th his gladioli irom gladioli in . Anerica. prestumably New lork. I little information concerning this species is given by Theobalk (192:).

The siugle lllinois collection was made at Lrbana. October 19. 1930, on roots of carrot (Daruens carota).

\section{APHIS VERNONIAE THOM.LS}

Aphis vernoniuc Thomas, Bulletin llinois State Laboratory of Natural History, Vol. 1, No. 2, June, ISis, 1) I0.

This species, descriled from Illinois by Thomas in 1s: been recorded fron the state since then. Our records inclicate that it is yuite generally distributed thromghont Illinois. It accurs an the flower stems of jto hosts. Supplementary descriptims have heen given by Sanboril (1!10.t).

Cotypes of this species were included among the typic material of Thomas recently recovered. They lave heen monuted in damar balsam on 
four slides: Slide No. 7704 has been designated as the lectotypic slide, and Slides Nos, 7705-7707 as paratypic slides. Data associated with the lectotypic and paratypic slides, alate and apterous viviparous females, are as follows: Carbondale, Illinois, June 20, 1877, collected by Thomas on Vernonia fusciculata.

Data associated witl our viviparous specimens are as follows: Carbon. clale (June 4), Morton (July 22), Urbana (July 23), 1928; Cairo (June 22), Elizabethtown (June 20), Hardin (June 25), Newton (June 17), Olney (June 18), Rock Island (July 7), Urbana (August 21), 1929. Collected on Eupatorium purpureum var. maculatum, Helenium autumnale, and Fernonia fasciculata.

\section{APHIS VIBURNICOLA GILLETTE}

\section{Fig. 28}

Aphis viburnicolu Gillette, Entomological News, Vol. Xx, No. 6, June, 1909 , p. 280 .

Aphis riburmicola Gillette was first reported from Illinois by Davis (1910e). Our records indicate that it is very widely distributed in lllinois. This species over-winters on snowball ( $/$ iburnum) and in

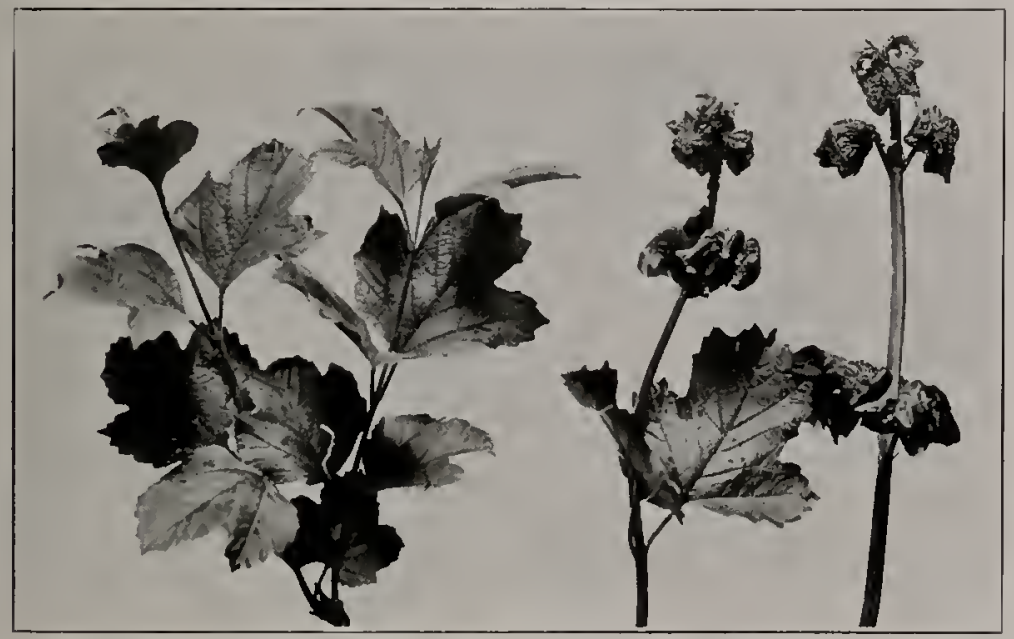

Fig. 28. Pseuclo-galls on the snowball, riburnum opulus var. Americana, started by Aphis viburnicola Gillette, later occupied by Aphis rumiris Linnaens and Aphis viturniphill Patch; Urbana, June 10, 1929. Normal foliage on left and infested foliage on right.

early spring causes the leaves to curl and form pseudo-galls (Fig. es. ). After a short time the species leaves its primary host for an mnknown one and then returns again in autumn. Gillette (1!n!) has given detailed descriptions of all the forms fotmel on the winter host.

Data associated with our viviparous specimens are as follows: Antioch (June 15). Decatur (Oct. 20). Lrbana (May 17), 1928; lewistown (May 4), Macomb (May 4), Rantoul (April 24), Springfield (May 2), Urbana (April 16), 1929; Carbondale (April 17), Effingliam (Nov. 13), Lawrenceville (April 14), Metropolis (April 17), Crbana (Oct. 20, Dec. 20), 1930. Sexual forms have heen taken at Effingham (Nov. 13) and Urbana (Dec. 20), 1930. A mating pair was collecter at Effingham. All specimens rollected on Viburnum opulus var. americanum or Viburmum sp. 


\section{APHIS VIBLRNIPHILA PATUH}

FIG. 28

Aphis viburniphila Patch, Journal of Economic Entomology, Vol. I0, \$o. 4. August, 1917, p. 416.

This species is probably the aphid reported by Thomas ( $18: 01)$ from Carbondale, Illinois, under the name of Aflis ziburni Scop. Specimens of this species are often found mixed with colonies of Aphis rumicis Linn. The alate and apterous viviparous iemales and the apterous oviparous females have been described by Patch (1!1i). who states that the species is present all year on Tiburmum.

Data associated with our viviparous specimens of this species are as follows: Galena (June 26), Havana (June 21), Kankakee (June 29), LeRoy (June 20), Metropolis (June 1), Oregon (June 2\%, 2S), Pekin (June 20). 1928; Catlin (Nay 17), Rantoul (April 24). Springfield (May 2), Urbana (April 16), 1929; Urbana (June 23), 1930. All material collected on Viburnum sp.

\section{APHIS ZILORA new species}

Figs. 143, 194, 278

\section{Alate Viviparovs Fedale}

Size and general color.-Length from vertex to tip of anal plate, 1.11 . Head and thorax dark dusky brown, lateral portions of prothorax and posterior portion of head somewhat yellowish. Abdomen green. Cornicles greenish, slightly dusky apically. Cauda yellowish hrown, anal plate brown. Antennae uniformly brown. Femora light yellowish brown, more yellowish near base; basal portions of tibiae yellowisl, or liglt yellowish brown with apical portions darker brown; tarsi brown. Beak yellowish brown at base shading to light dusky brown at apex. Stigma of fore wings light dusky brown, brownish subcostal infusion present; vains and posterior margin of wings in vicinity of anal veins concolorous with stigma.

Head and appentages.-Average width of head across eyes, .33. Compparative length of antennal segments as follows: 1I1-.14 to .16. average.14; $1 \mathrm{~V}-.10$ to .13 , average $12 ; V-.10$ to .13 , average $.11 ; Y I-.0$; 10.09 , average $.0 \mathrm{~S}$ plus .14 to .19, average .1\%. Secondary sensoria (Fig. 2is) confined to third antennal segment, arranged in a straight row, numbering from 3 to 5 . usually 3, in most cases confined to apical portion of segment. Primary. sensorium on sixth segment with marginal sensoria apparently absent. All antennal segments imbricated. Beak reaching to metathoracic coxae except in one specimen in which it just fails to reach the mesothoracic coxae.

Thorar and apnenlages.-Prothorax with a pair of lateral tubercles. anterior lateral malgin of mesothorax also with lateral tubercles. Stigma of fore wings quite shallow and bluntly pointed. Radial sector ouly slightly curved. Second fork of media lacking in one specimen, in others extremely. variable in regard to first fork and margin of wing. usually closer to the latter. Ventral portion of mesopleuron with a wax-pore plate.

Abdomen.-Cornicles (Fig. 143) .09 long, straight, faintly imbricated. without flange at apex, subequal to base of sixth antennal segment, and either equal to or shorter than the cauda. Cauda (Fig. 194) .10 long. not constricted, with four inwardly curved hairs on each side, apex sharply pointed. First abdominal segment and segement posterior to cornicles with a pair of lateral tubercles.

\section{Al'Throl's Vwiparots Framal}

Sizc und uenerul color.-Average length from vertex to tip of anal plate. 1.09. Color of head, thorax, and abdomen light green. Cornicles yellowish with the apical portion lusky. Cauda and anal plate brownish. Antennac yellowish, except for apical segments, which are light dusky. Beak rellowisls 
with the apical portion brown. Femora yellowish with apical portions dusky; tibiae yellowish with the apical portions brownish; tarsi brown.

Head and appendages.-Average width of head across eyes, .30. Comparative lengths of antennal segments for specimens with six-segmented antenuae as follows: IIJ- 09 to .13 , average .11; IV - .09 to .10, average .09; $\mathrm{V}-.09 ; \mathrm{VI}-.07$ to .09 , average $.08 \mathrm{plus} .14$ to .16 , average .15 . Comparative length of antennal segments for specimens with five-segmented antennae (which are the most common) as follows: III-.17 to .21, average .19; IV.09 to .11 , average $.09 ; \mathrm{V}-.07 \mathrm{plus} .14$ to .19, average .15 . Secondary sensoria absent. Primary sensorium on last antennal segment with a group of five marginal sensoria. All segments of antennae imbricated. Beak reaching to metathoracic coxae.

Thorax.-Prothorax with a pair of lateral tubercles, anterior portion of mesothorax also with lateral tubercle.

Abdomen.-Abdomen with a pair of lateral tubercles near anterior portion and a pair posterior to the cornicles. Cornicles .10 long, cauda .09 long, cornicles, cauda and anal plate similar to those of alate viviparous female.

Holotype.-Alate viviparous female; Beach, Illinois, August 29, 1929, on Liatris elegans, (Frison and Hottes). On slide with paratypic alate and apterous viviparous females. Slide No. 10525. Morphotype.-Apterous viviparous female; same data as holotype. Slide No. 10526. Parutypes.-Four slides of alate and apterous viviparous females and nymphs. Same data as holotype. Slides Nos. 10527-10529 and one other unnumbered.

This species belongs to the maidi-radicis group, and may he separated from closely allied forms by the characters given in the key to the genus Aphis.

\section{Genus ASIPHONAPHIS WiLson ANI DAvis}

\section{Kry to the spceies of the renus Asiphonaphis}

1. Antennae with very few hairs; lateral tubercles on abdomen slender, much longer than width at hase (Fig. 315); pulver-

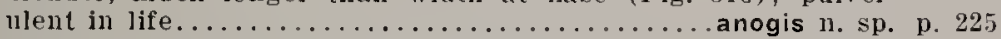

Antennae with numerous hairs about as long as width of antennal segments; lateral tubercles on abdomen stout, about as long as width at base (Fig. 312 ); not pulverulent in life......

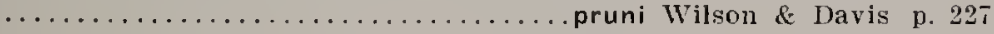

\section{ASIPHONAPHIS ANOGIS new species}

Flas. 205, 270, 315

\section{Alate VIVIP.IROUS Fl:UAle}

Size and general color.-Average length from vertex to tip of anal plate, 1.68. Body in live specimens covered with a dense coat of whitish down, more abundant posteriorly than anteriorly. In mounted specimens the head is dark dusky brown, becoming almost black at the vertex, but usually a lighter color in the vicinity of the eyes and posterior to them. The prothorax on the dorsum is concolorous with the head; laterally it has a greenish tinge and is considerably lighter in color; the meso- and metathoracic segments are dark dusky brown, certain portions being almost black. The abdomen is yellowish brown, the cauda and anal plate dusky brown. All antennal segments essentially concolorous with lighter portions of the head. Basal portion of anterior femora slightly lighter in color than remaining femora, femora essentially dusky brown or dusky yellowish brown near the base, shading gradually to a more intense dusky brown at the ape $\bar{x}$; tibiae almost uniformly dusky brown; tarsi dusky brown. Stigma fuscus: veins fine, dark brown, very faintly bordered with brown, allal vein darkest and 
most heavily bordered, posterior margin of wing near articulation with anal vein thickened and brownish. Beak yellowish-brown with the apical segments darker than others.

Head and appeninges.-Average width of head across eyes, .44. Antennal segments with comparative lengths as follows: IIl-.33 to 46 . arerage .41: IV - .21 to .31 , average $.27 ; V-.14$ to .26 , average $.21 ; V 1-.09$ to $.1 \%$. average .14 plus .14 to .26 , average .20 . Numerous secondary sensoria on third and fourth antennal segments (Fig. 270), sometimes one or $t$ wo secondary sensoria are found on the fifth segment; in structure they are large and have wide rims; sensoria on the third antennal segment number from 9-16 with an average of 12 and are arranged in an irregular row; sensoria on fourth antennal segment arranged in a regular row and number from 3 to 7 with an average of 5 . The primary sensorium on segment six is small; in fact, the only way that it can be distinguished from the marginal sensoria is by the fringe of hair which is around its outer circumference. The beak is exceedingly variable in length: in some specimens perhaps failing to reach beyond the midway point between the coxae of the pro- and mesothoracic segments, whereas in others it may extend as far as the coxae of the metathorax.

Thorar and appeniages.-Prothorax with a pair of tooth-like lateral tubercles. The tarsal segments are quite long, about equaling in length the first and second antennal segments combined. Normally the media of the fore wings is twice-branched, the second branch occurring much closer to the margin of the wing than it is to the first branch; abnormal renation is common, the media of both wings being only once-branched. or one wing with the media once-brancherl and the other wing with the media tricebranched, or with the media twice-branched on one wing and thrice-branched on the other.

Abdomen.-Abdomen entirely covered with wax glands similar to those found in dmphicercillus pulverulens (Gillette) or Gypsoaphis oestrundi (Hottes), and with seven pairs of tooth-like lateral tubercles (Fig. 312). Cauda (Fig. 205) not quite as long as the hind tarsae exclusive of claws, not constricted, and distinctly tapered toward apex, with from three to fire pairs of lateral hairs, the terminal hairs usually strongly incurred; length varies from .13 to .14. Anal plate narrow, scarcely wider than the cauda at the base and ahout one-half as long.

Apterots Vhiparots Female.

Size and general color.-Average length from vertex to tip of anal plate, 1.63. Body in live specimens entirely covered with a dense coat of whitish down. In mounted specimens the head, thorax, and abdomen are dark brown, and the cauta and cornicles as in the alate viviparous female. First and second antennal segments light brown, lighter in color than the head, sometimes slightly dusky on the anterior margin: basal half of third antennal segment concolorous with second segment, apical half more fuscous; fourth, fifth, and sixth segments uniformly light hrown. All legs of about the same intensity of color, similar to the legs of the alate form except that the apical portions of the tibiae are considerably darker than the remaining portions. Beak colored as in alate viviparous female.

Head and appendages. - Average widt h of head across eyes, .3t. Antennal segments with comparative lengths as follows: III- 30 to .40 . average $.36 ; 1 V-.17$ to .24 , average $.21 ; V-.17$ to .24 , average .21 : VI-.13 to .14 , average .14 plus .19 to .21 , average .20 . Normally there are no secondary sensoria. Hairs on antennae twice as long as width of segment and fine. The beak usually extends to the coxile of the metathoracic pair of legs

Thorax and appenduges.-Prothorax with lateral tubercles. Hairs on legs fairly ahundant. fine. and rery long, ahout twice widtl of segments.

.1 blomen.-Entire surface covered with wax glands and with seven pairs of tooth-like lateral tubercles (Fig. 315). Cauda about equal to the length of the hind tarsi exclusive of claws, measuring from .11 to .14 and averag. ing .13, usualiy with four pairs of lateral hairs on a side, the terminal hairs strongly incurved. Anal plate about twice as wicle as the cauda at the hase ancl about half as long. 
Alate MaLe

Size and general color.-Average Iength from vertex to tip of anal plate, 1.5t. General color practically the same as in alate viviparous female.

Head and appendages.-Average width of head across eyes, .44. Antennal segments with the following proportions: $11 \mathrm{I}-.37$ to .43 , average .40 ; $1 \mathrm{~V}-.26$ to .29 , average $.27 ; \mathrm{V}-.23$ to .24 , average $.23 ; \mathrm{V} 1-.11$ to .14 , average .12 plus .13 to .24 , average .21 Secondary sensoria present on the third, fourth, and fifth antennal segments; although scattered, confined largely to one side of the segment; distributed throughout the length of the third and fourth antennal segments; confined to the basal two-thirds of fifth segment; varying in size, the Iargest usually being on the third segment and the smallest on the fifth segment; varying in number, third segment with from 18 to 25 and average of 24 , fourth segment with from 13 to 21 and an average of 15 , fifth segment with from 5 to 10 sensoria and an average of 7 . The marginal sensoria are almost as large as the primary sensorium on the sixth antennal segnient. The beak reaches to or beyond the coxae of the metathoracic pair of legs.

Thorax and appendages.-Same as in the alate viviparous female.

Abdomen.-Similar in all respects to abdomen of alate viviparous female except that the cauda does not taper off to the apex so quickIy and is more blunt at the tip. MaIe genitalia dark dusky-brown.

Superficially the structure of the male is so nearly Iike that of the alate viviparons female that a hasty examination might lead to confusing the two. The male genitalia are often rather obscured, thus leaving the presence of the more numerous secondary sensoria on the fourth and fifth antennal segments as the hest means of differentiation between the two sexes.

Holotype.-Alate viviparous female; Decatur, 11Iinois, Octoher 19, 1929, on Pilea pumila, (Hottes and Tauber). Slide No. 10747. Allotype.-Alate male; Decatur, 1Ilinois, October 13, 1929, on Pilea pumila, (Hottes and Tauber). Slide No. 10748. Morphotype.-Apterous viviparous female; Decatur, 1llinois, October 20, 1929, on Pilca pumila, (Hottes and Tauber). Slide No. 10749. Paratypes.-Thirty-five slides of alate viviparous and apterous females. pupae and nymphs, collected at Decatur, Illinois, Octoher 13-20, 1929, on Pilea pumila, (Hottes and Tauber). Slides Nos. 10750-10772 and others unnumbered.

This species feeds along the main stem near the top of the plant and along the main stalk of the flower stem. When seen on their host plant they do not suggest aphids at all, because they are so closely clustered along the stem and often obscured by their downy flocculence. This new species can be separated from A. pruni Wilson and Davis, the only other species in the genus, by the following characters: the entire surface of the body is covered with wax glanrls, the lateral tubercles are considerably less developed and thimner, and there are no hairs on the antennae.

\section{ASIPHONAPHIS PRUNI WIISOX AXID DANIS}

$$
\text { FIG. } 312
$$

Asiphonaphis pruni Wilson and Davis, Entomological News, Vol. Xxx, No. 2, February, 1919, p. 39.

This species is here reported from Illinois for the first time. We have found it only in the extreme northern portion of this state. V'ery little information is available concerning its range in North Inerica. The typic material was collected in Wisconsin. Accorcling to our observations, pruni causes a severe curling of the leaves of its host. 
Descriptions of the viviparous females and male are given by Wilson and Davis (1919).

Data associated with our viviparous specimens are as follows: Chicago (June 13), 1928; Beach (July 13), Galena (July 10), 1929. All collected on Prunus virginiana.

\section{GENLS BRACHYCOLLS BLCKTON}

\section{BRACHYCOLUS TRITICI GILIETTE}

Brachycolus tritici Gillette, Entomological News, Vol. XXIl, No. 10, December, 1911, p. 441.

Davis $(1910 \mathrm{~d})$ first reported this species from lllinois. It has not been taken since. Parker (1916) refers to this aphid as the "Western wheat aphis" and states that at times it is a serious pest of winter wheat in Montana and that it also attacks barley. According to Parker this plant lonse over-winters in the egg stage on wheat. All forms have been described by Gillette (1911c).

Data associated with our viviparous specimens are as follows: Anrora (Sept. 24), 1908, collected from grass by J. J. Davis.

\section{GENIS BREVICORYNE VAN DER GOOT}

\section{BREVICORINE BRASSICAE LIXAET:}

Flus. 3, 160, 204

Aphis brassicae Linneus, Systema Naturae, Editio Decima, 175s, p. 452.

The cabbage aphid is cliscussed at some length by Thomas (1+io). and it is rery probable that his remarks can be construed as indicating the presence of this louse in Illinois in 1si! although no definite 1 llinois locality is mentioned. Davis (1!)1/c) reports it from Illinois as "our most generally clestructive aplis of the regetable gardens." A1though our records for the cabbage aphid are confined to the central and northern parts of the state, it no dould occurs everywhere within our territory. It is a pest in linrope as well as in this country. Herrick and Hungate (1:11) have published a detailed account of this species and show that the entire life cycle is spent upon cabbage or closely related plauts.

Data associated with our viviparous specimens are as follows: Clampaign (Oct. 1, 2), Normal (Sept. 10). Rose Hill (Sept. 26), 1SS3: Decatur (Nov. 11), 1928; Kansas (June 17), 1929; Arlington Heights (Sept. 29). 1930. Males are in the collection from Cliampaign. October I-2, 1s\$3. All collected on Brassica oleracer. 


\title{
Gexus CAVARIELLA Del Guekcto
}

\section{CAVARIELLA AEGOPODI) (SCOPOL)}

\author{
Fit: 206
}

thhis aegopodii Scopoli, Entomologica Carniolica, 1763, p. 399.

Hyadaphis pastinucue Davis, Journal of Economic Entomology, Vol. 3, No. 6. December, 1910, p. 493. In part misidentification.

An examination of nuaterial belonging to I'rofessor J. J. Davis proves that some specinens of this species were included in his records of Hyadaphis pastinacac from Illinois in 1!10. These slides are as follows: Chicago, lllinois, Oct. 1, 190s, on Ziziu aurea, and Oak Park, Illinois, August $4,190 !)$, on willow. No lllinois records, however, have been previously reported under this specific name. Dr. Theobald has kindly determined specimens of this species subnitted to him. Although we have collected this species only on Sulir it is known to migrate to Acgopodium and other plants, as the records of Davis (1910) and others demonstrate.

Data associated with our Illinois specinens, all collected on Sa7ir, are as follows: Elizabethtown (June 30), Grayville (June 19), Starved Rock State Park (July 6), 1929; Seymour (June 20), 1930.

\section{Genus CEROSIPHA Del Guercio}

\section{CEROSIPHA RUBIFOLII (THOMA.S)}

\section{Figs. 29, 138, 192, 275}

Sipha rubifolii Thomas, Eighth Report of the State Entomologist on the Noxious and Beneficial Insects of the State of Illinois, 1S79, p. 121.

This is a minute yellowish-green aphid with five-segmented antennae. Our records indicate it is widely distributed in Illinois. Although small and usually not very abundant, its habit of twisting and curling the leaves (Fig. $2 ! 1)$ of blackberry (Rubus sp.) makes it conspicuous. It is likely that Thomas clescribed this species from material collected in Illinois. Davis (1!)10e) was the first to definitely record the species from lllinois stating it "is very common in lllinois, curling and injuring the foliage of the cultivated and wild blackberry." Winter (1!)!?b) has summarized most of the literature relating to this species.

Data associated with our slides of viviparous specimens of this species are as follows: Albion (May 26), Carbondale (June 4), Champaign (Aug. 9), East Peoria (Juty 22), Herod (May 29), Metropolis (May 31, June 1), IIt. Carmel (May 26), Oakwood (May I2, 20, July I8, Sept. 17), Oregon (June 28), 1928; Elizabethtown (June 21), Hardin (June 25), liansas (June 17), Lisle (July 14), Maryville (Sept, 11), Oakwood (June 1), Olney (June 18), Rock Island (July 7), Starved Rock State Park (July 6), Urbana (Oct. 21,28 ), 1929. Oviparous females taken at ITrbana, October 21-28, 1929. Male at Oakwood on October 14, 1929.

In view of the linitations of the original description, a few descriptive details of the alate viviparous female are given, together with a description of the heretofore unrecordect apterous oviparous female. 


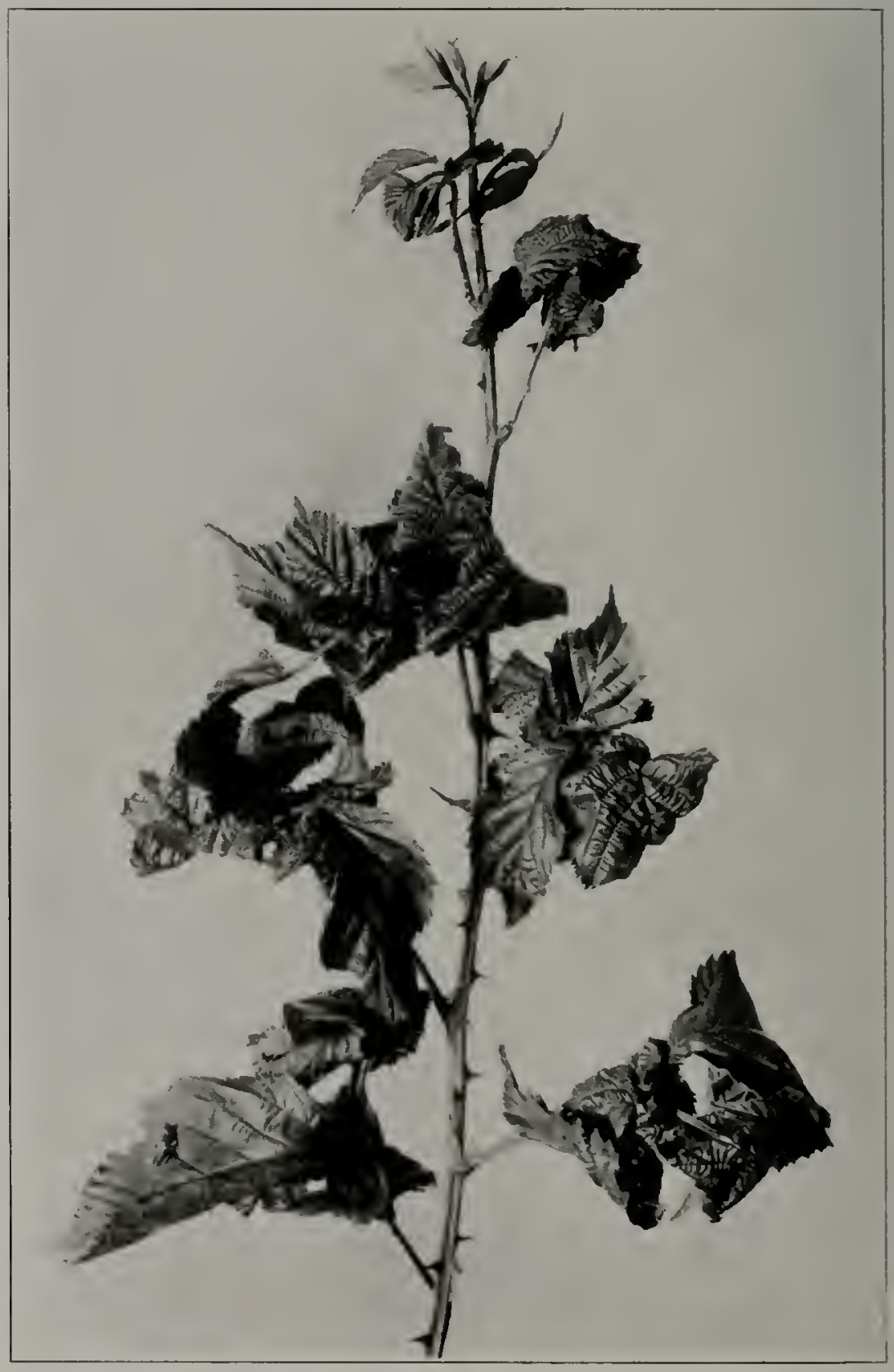

Fig. 29. Curling leaves of blackberry, Rubus. caused by corosipha rubifolii (Thomas): Oakwood, July 24, 1929. 


\section{AIATE VIIPALOUS FEMALE}

Thomas' orjginal description may be emended as follows: J.ength, 1.12 . Average width of head across eyes. 37 . Comparative lengths of antennal segments as follows: III- .27, IV-.15. V-.11 plus .26. Secondary sensoria (Fig. 275) confined to third antennal segment, numbering from 22 to 7 , averaging 4, rarely as few as 2 or as many as 7 . Cornicles (Fig. 13S). I6 long, straight. Canda (Fig. 192) .08 long, not constricted, with about four hairs on a side. Second fork of media variable in position.

\section{Arrekot's Orminous FEMALE}

Average length from vertex to tip of anal plate, 1.14. General color throughout essentially similar to apterous viviparous female Average width of head across eyes, .29. Comparative lengths of antennal segments as follows: III-.17 to .23 , avejage .21: IV-. I1 to .13, average $.12 ; \mathrm{V}-.09$ to .10 , average .09 plus .16 to .21 , average .20 . Antennal segments without secondary sensoria. Beak reaching to mesothoracic coxae. Cornicles. It long, straight, imbricated. rim at apex poorly developed. Cauda .11 long, constricted near middle, with three hairs on a sille. Hind tibiae only slight. ly swollen, with about 20 to 30 sensorja.

Neotype.-Alate viviparous female; Slide No. 4425, Albion. Illinois, May $26,192 \mathrm{~S}$, on blackberry, (Frison and Hottes). On slide with alate and apterous viviparous females, pupae, and nymphs. Since this species was originally described from Illinois and the types are lost, a slide in the Survey collection has been selected as the neotype. Morphotype.-Apterous oviparous female: Slirle No. 8424, Urbana, Illinois, October 28, 1929, on blackberry. (T. H. Frison). On slide with oviparous fenales and nymplis.

\section{GFNES HJALOPTERUS Kocu}

\section{Fey to the species of the Genus Hyulouterls}

1. Secondary sensoria present on fourth antennal segment (4-9) ......2 Secondary sensoria absent on fourth antennal segnent, numbering from $S$ to 14 on third................

2. Secondary sensoria present on fifth antemal segnent (3-5). third segment with abont 10-15, less than 20..hyperici (Monell) p. 232

- Secondary sensoria absent on fifth antennal segment, third segment with 20 to $40 \ldots \ldots \ldots \ldots \ldots \ldots \ldots \ldots$. pruni (Geoffroy) p. 232

\section{HYALOPTERI'S ATRIPLICIS (LIXXAEISI)}

Aphis atriplicis linnaeus, Fauna Svecica. Editio Altera, Anctior, Stockholm. 1761, p. 262.

This cosmopolitan species was first recorded from Carbondale, Illinois, by Monell (18:9), who examined specimens sent to him lw Thomas' assistant, Miss Middleton. Also previously reported from Illinois by Forbes (1900) and Davis (191(1)). It causes a severe leaf curling or podlike folding of the leaves of gonsefoot, or lamb's quarters. Hayhurst (190!) has given detailed descriptions of all the various forms and a general account of its biology.

Our records of viviparous specimens of this species are as follows: Antiocl (June 15), Cajro (June 2). Carboulale (June 4), Danville (July 15), Elizabethtown (Oct. 12), El Paso (July 5), Galena (June 25), Havana (June 2I), Kankakee (June 29), LeRoy (June 20), Oregon (June 27), Quincy (June 6), Rock Island (June 24), Shawneetown (May 27), Starved Rock State Park (Jume 13), 1928; Homer (June 17), Sparta (June 24), Urbana (May 26), 1929. All collected on Chenominglium album. 


\section{HYALOPTERC'S HYPERICI (MNXELI.)}

Aphis hyperici Monell, Bulletin of the United States Geotogical and Geo. graphical Survey of the Territories, Vol. V. No. 1, 1879, Art. 1, p. 25. Ifyzocallis hypeiri Thomas, Eighth Report of the State Entomologist on the Noxious and Beneficial Insects of the State of Illinois, $15 \% 4$, p. $10 \mathrm{~S}$. New Symonymy.

The types of Myrocallis hypcici Thomas (index indicates spelling of specific name was intended for hyperici) have recently been discovered, on Slides No. 2i96 and 2is in the Survey collection. Slide No. 2isi has been designated the lectotvpe and Slide No. 2391\% the paratypc. These have been compared with slices of $H$. hyperici (Monell) kindly loaned by Professor J. I. Davis. The species apparently belongs to the genus Hyalopterus. It has not been recorded irom Illinois except by Thomas, the data with bis specimens being: Carbondale, Illinois, in April, on Hyporicum prolificum.

\section{HYALOPTERT'S PRINI (GFOFFIROY)}

FIG. 199

Aphis pruni Geoffroy, Histoire abrégée des Insectes qui se trouvent aux environs de Paris, dans laquelle ces animaux sont rangés suivant un ordre méthodique. Paris, Durand, 1762, 2 Vols., p. 497. Published anonymously but known to be work of Geoffroy.

The proper specific name to use for this species, commonly referred to as the mealy plum aphid, is prumi Geoffroy $(1 ; 6 \%)$. Fabricius (1755) listed this species under two nanes, armudivis and pruni; the former having page priority and lence causing its use by recent writers. Pruni, however, should be used and credited to Gcoftrov $(1 ; 6 \%)$ because Geoffroy first proposed it as a binomial name. Attention has been called to Geoffroy's use of pruni as a binomial by Hottes (1930a).

This enemy of phums and related fruits has been previonsly recorded from northern Illinois by Davis (1910e) nuder the name of $H$. armaninis Fabricius. A good account of its life history and thabits is given by Davidson (1919). It is known to migrate, having spring and fall generations on plum, the leaves of which it causes to curl, and summer generations on Plragmitcs, Typha, and Arundo: or at times in certain localities to spend the entire year on plum. Jike many other aphids of economic importance, it is reported from many parts of the world.

Data associated with viviparous specimens in the Survey collection are as follows: Antiocl (Aug. 13), 1906, on Phragmites: Rock Island (July $;$ ), and LTbana (Jume 25), 1929, both on Prunus domcstica.

\section{GENUS HYSTERONELRA DAMS}

\section{HYSTERONEIRA SETARIAE (THOMAS) \\ Futis. 30, 89, 135, 2S3}

Siphonophora setariac Thomas, Bulletin of the lllinois State Laboratory of Natural History, Vol. I, No. 2 , June, $18 i s$, p. 5.

This brown plum aphid was described hy Thomas from specimens collected at Carlondale, lllinois. Onr recorts indicate that it is very 


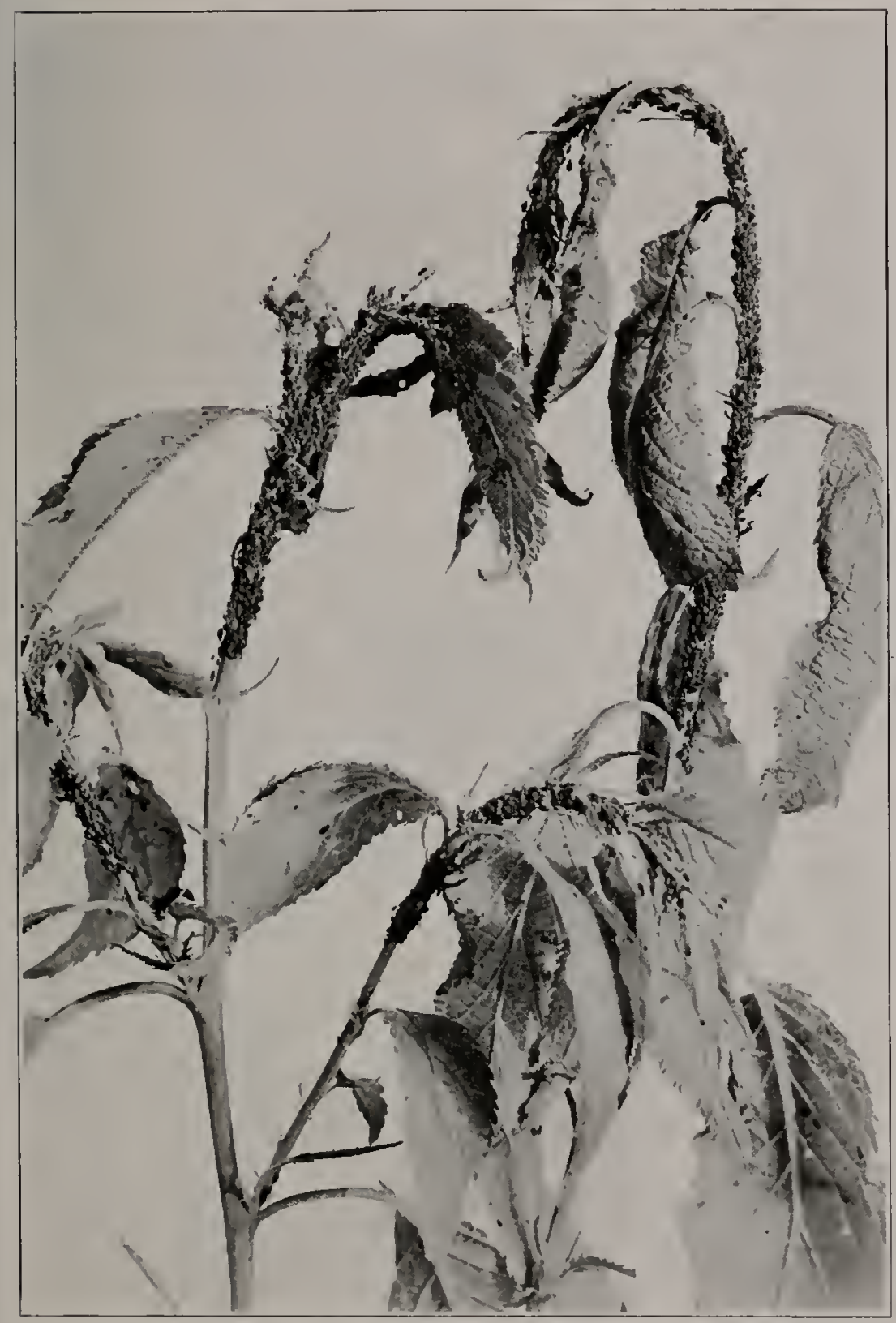

Fig. 30. Infestation of the rusty plun aplid, Hysteroneura sefariae (Thomas), on the ornamental plum, Prumus triloba: [Trbana, June 3, 1929. 
widely distributed in the state. It over-winters on plum and in spring is often very abundant on the stems and leaves of the new growh (Fig. 30). Later it migrates to grasses and other plant- upon which it spends the summer.

The cotypes of this species (Vial 40 of the Thomas collection) have recently been recovered and mounted on two slides in gum daruar. Slide No. 7714 has been designated as the lectotypie slide and Slide .0 .7715 as the paratypic slide. Both slides contain specimens of alate and apterous viviparous females. Data associated with these slides are as follows: on Sctarin glauca, Carbondale, Illinois, August 16, 157\%.

Data associated with our viviparous specimens are as follows: Normal Aug. 7), 18\$3; Duquoin (June 7), 1884; Odin (May 7), 1895: U'rbana (October 29), 1901; Rockport (May 21), 1906; Lincoln (Nay 6), 1925; Albion (May 26). Carbondale (Jay 17, June 4-14), Centralia (Oct. 12). Elizabethtown (May 29-31), Herod (May 31), LeRoy (June 20), Metropolis (June 1), Mt. Carmel (Nay 26). Nuncie (Oct. 6), Shawneetown (May 27), Urbana (Nay 23-24), 1928: Bondville (Sept. 26), Galena (July 10), Nacomb (Nay 3), Olney (June 18), Oregon (July 11), Rock Island (July $T$ ), Springfield ( Lay 2), Urbana (June 1-17, July 24), 1929: Effingham (Nox. 13). Flora (Nov. 13), Metropolis (April 17) and Starved Rock State Park (Mlay 13), 1930. Sexual forms and mating pairs were collected at Flora. November 13, 1930. Host recoris are as follows: Melilotus alba. Prunus aritm. Prunus domestica. Prunns persica, Prunus triloba, Prunus virginiana, Prunus sp.. Setaria glauca, and setaria viridis.

\section{GENUS RHOPALOSIPHLM KOCH}

\section{(SUPGEXEA RHOL'ALOSIPHUM KocH, HYADAPHIS KIRKAIDY. AND LIOSOMAPHIS WALKER)}

\section{Fell to the species of the Genus Rhopalosiphum}

1. Cornicles with apical portion much swolleu aud contrasting with

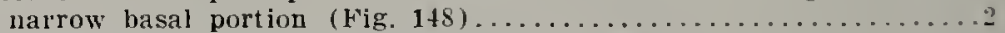

- Cornicles approximately cylindrical (Fig. 134 ) ................

2. Terminal filament of sixth antennal segment about as long as

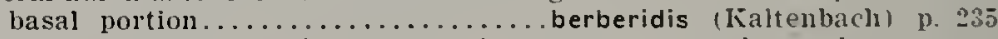

- Terminal filament of sixtl antennal segment over twice as long

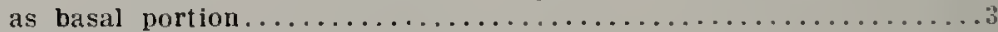

3. Third antennal segment with more than $\mathbf{2 5}$ sensoria; fourth antennal segment with at least 5 sensoria..melliferum (Hottes) p. 23S

- Third antenual segment with less than 25, usually about 15 sen. soria; fourth antennal segment usually without sensoria. some-

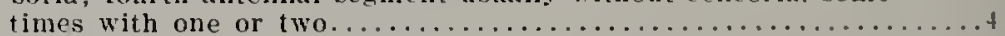

4. Hind tihiae about three times as long as width of liead through the eyes; third antennal segment rarely with as many as ten secondary seusoria: cauda stout.............. rhois Monell p. 240

- Hind tibiae about twice as long as width of liead through the eyes; third antemal segment with more than ten secondary sensolia; cauda somewhat elongate... nymphaeae (Limnaeus) p. 238

5. Terminal filament of sixth antennal segment less or not more than twice as long as hasal portion: basal portion about equal in length to the fiftl antenual segment................. .......................... rufomaculatum (Wilson)

- Telminal filament of sixtl antenual segment over twice as long as basal portion; hasal portion not as long as fifth antenual segmeut 
6. Terminal filament of sixth antennal segment less than three times as long as basal portion; cornicles and hind tibiae usually of about the same thickness .pseudobrassicae (Davis)

- Terminal filament of sixth antennal segment about four or nore

times as long as basal portion; cornicles usually wider than

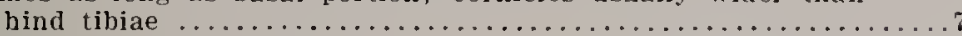

7. Abdomen essentially greenish..........prunifoliae (Fitch) p. 239

-. Abdomen essentially brown.................enigmae n. sp. p. 235

\section{RHOPALOSIPHUMI BERBERIDIS (KALTFNACII)}

Fig. 148

Aphis berberidis Kaltenbach, Monographie der Familien der Pflanzenläuse, Aachen, 1843, p. 95.

The barberry plant louse was first recorded from lllinois by Davis in 1908 ' and again in 1910 as "a common and often abundant species. occasionally in such numbers as to injure the barberry." It is a small yellowish form with the apterous forms predominating. According to our observations and those of others, it spends its entire life cycle on barberry. Detailed descriptions of all forms are given by Daris $(1908 \mathrm{c})$.

Data associated with our viviparous specimens are as follows: Antioch (June 15), Berwyn (June I4), Galena (June 25), Marshall ( May 25), Mt. Carroll (June 25), Oregon (June 27), Urbana (Sept. 26, Oct. 19), 1928; Alton (June 25), Catlin (May I7). Effingham (June I8), El Paso (July 5), Starved Rock State Park (July 6), Urhana (May 8. Oct. 24), 1929. Males and oviparous females were collected at Urbana, October 24, 1929. All material taken on Berberis Thunbergii minor.

\section{RHOPALOSIPHUM ENIGMAE new species}

Flgs. 134, 200, 207. 262, 263

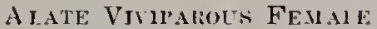

Size and general color.-Average length from vertex to tip of anal plate, 2.1s. Head and thorax dark dusky brown. Abdomen varying in color from yellowish brown to dark reddish brown with slight jndications of darker brown spots on the lateral margins. Cornicles, cauda, and anal plate lark dusky brown. Antennae dark dusky brown except extreme base of third segment and terminal filament of sixth, which are yellowish brown. Femora of all legs dark brown except for basal portions, which are yellowish or yellowish brown. Tibiae yellowish brown with a dark brown band at apex equal to length of tarsi; tarsi dark brown. Stigna of fore wings yellowish brown, veins of wings dusky, posterior margin of wings in vicinity of anal vein brown. Beak hrown.

Hear and appentages.-Vertex of head prominently pointed. Average width of head across eyes, .46. Antennal segments with the following com. parative lengths: III-.33 to .36 , average $34 ;$ IV $-.19 ; \mathrm{V}-.17$; VI-.09 plus .50 to .57 , average .5:. Secondary sensoria (Fig. 262) confined to third and fourth antennal segments. Third segment with sensoria numbering from 7 to 11 , averaging 9, arranged in an irregular row. Fourtl segnent usually witl one or two secondary sensoria. Primary sensoria on sixtl segnent with a group of very small marginal sensoria. All segments of antenmae imbricated. Beak comparatively short, failing to reach middle coxae by a considerable distance.

Thores and appentages.-Prothorax with a pair of small finger-like lateral tubercles. Mesothorax with a pair of small wax glands on the 
anterior ventro-lateral region. Stigma of fore wings rather sharply pointed; second fork of media extremely close to margin of wing when present; all veins ending in brownish suffusions.

Ablomen.-First abdominal segment and the segment posterior to cornicles with small lateral tubercles. Cornicles (Fig. 134) about .29 in length, only very slightly swollen, the swelling accentuated by the pronounced constriction just before the well-developed flange; entire surface distinctly imbricated. Cauda (Fig. 200) poorly developed, 12 in length, distinctly con. stricted near middle, with two hairs on each side. Anal plate about three times as wide at the base as the cauda, and with only a few hairs.

\section{Apterols Viriparous Feutale}

Size and general color.-Average length from vertex to tip of anal plate, 2.26. Head, thorax, and abdomen concolorous, varying from dark reddish brown to greenish brown. Cauda, anal plate, cornicles, and beak dark brown. Antenuae similar in color to those of alate viviparous female. Femora dark brown, paler at base; tibiae greenish yellow, their apices and the tarsi infuscated with brown.

Head and appendages.-Average width of head across eyes, 47. Antennal seguents with the following comparative lengths: $111-.27$ to .33 , average .31 ; IV -.17 to .23 , average $.20 ; V-.17$ to .23 , average $.20 ; V 1-.09$ to .10 , average .10 plus .46 to .57 , average .50 . All segments without secondary sensoria, distinctly imbricated, and with sparse hairs. Beak reaching just beyond mesothoracic coxae.

Thorax.-Prothorax with a pair of small lateral tubercles.

Ablomen.- Surface of abdomen reticulated and with a very few long. fine hairs. First segment and segment posterior to cornicles with minute lateral tubercles, similar tubercles occasionally seen on other segments. Cornicles similar in shape to those of alate viviparons female, averaging .45 in length. Cauda about $.17 \mathrm{long}$, and little stouter than that of the alate viviparous female, with two bairs on each side, one side occasionally with three hairs. Anal plate normal.

\section{AlTERot's ONIPAROL'S FEATAL:}

Size and general color.-Average length from vertex to tip of anal plate, 1.90. Color essentially similar to that of apterous viviparous female.

Head and appendages.-Average width of head across eyes, .44. Antenua] segments with the following comparative lengths: $111-.19 ; 11-.11$ to .13 . average $.12 ; \mathrm{V}-.13 ; \mathrm{VI}-.07$ plus .29 to .46 , average .37 . Secondary seusoria absent. Third and fourth antennal segments with a decided tendency to remain united or to separate incompletely, and in many cases the antennae are but five-segmented. All segments of antennae imbricated. Beak reaching midway between pro- and mesothoracic coxae.

Thorax and alnchlages.-Prothorax with a large, well-developed pair of lateral tubercles. Hind tibiae with the basal half rery slightly siollen, sensoria very pale and difficult to count.

Abdomen.-Six segments of the abdomen with very minute lateral tubercles. Cornicles about .2S long, otherwise similar to those of alate viviparous female. Cauda .11 in length (Fig. 207), with hairs on each side, very thick, and not constricted, in this respect unlike that of viviparous females. Aual plate normal.

\section{ALATE MALE}

size and general color.-Length from vertex to tip of aual plate. 1.20. Color essentially similar to that of alate viviparous female.

Hearl and appendages.- Antennal segments with the following com. parative lengths: $11 \mathrm{I}-.33$; I $\mathrm{Y}-.23$ : V-.21; Vl-.09 plus .54. Secoudary sensoria (Fig. 263) distributed as follows: 111-17: $1 V-14$ : V-10: irregularly arranged and scattered over entire surface of segment. Primary sensorium of sixth antennal segment with a group of about five small marginal sensoria at one side. Antenuae imbricated and with a few short hairs. Beak reaching to the mesothoricic coxae. 
Thorax and appendages.-Prothorax with a pair of lateral tubercles. Wiugs and wing veins similar to those of alate viviparous female.

Abdomen.-Cornicles .24 long, otherwise similar to those of alate viviparous female.

\section{NYMPII}

Nymplis of apterous and oviparous females usually with five-segmented antennae.

Holoty/pe.-Alate viviparous female; Eldorado, lllinois, June 19, 1929 , on Typha latifolia, (Frison and Hottes). On slide with four paratypic nymphs. Slide No. 10719. Allotype.-Alate male; Danville, Illinois, November 4. 192S, on Typha latifolia, (T. H. Frison). On slide with paratypic nymphs. Slide No. 10720. Morphotype.-Apterous viviparous female; Catlin, Illinois, May 17, 1929, on Typha latifolia. (Frison and Ross). On slide with paratypic apterous viviparous female and nymplis. Slide No. 10721. lorphotype.-Apterous oviparous female; same data as allotype. On slide with paratypic oviparous females and nymphs. Slide No. 10722. Paratypes.Thirty-seven slides, containing alate and apterous viviparous females, oviparous females, a male, and nymplis, all collected in lllinois on cat-tail (Typlua latifolia) by T. H. Frison, F. C. Hottes, and H. H. Ross, except one slide collected at Thompson's Lake, Havana, Illinois, August 11, 1896, on sparganium, (Hart and Adams). The dates and localities are as follows: Carbondale (June 4), Centralia (Oct. 12), Danville (Nov. 4), Herod (May 31). Metropolis (June 1), and Quincy (June 6), 1928; Allerton (June 17), Catlin (May 17), Eldorado (Jume 19), Elizahethtown (June 20), Hardin (June 25), Maryville (Sept. 11), Oakwood (Oct. 17), and Seymour (June 12), 1929. Slides Nos. 4516-4521, 4524, 4535, 10723-10746 and others un. numbered.

This species is structurally very similar to $R$. prunifoliae (Fitch), from which it differs in color, being a deep reddish brown instead of green or greenish yellow. The few alate specimens of $R$. cnicmac in our possession differ from the usual condition found in prunifoliac in having only one or two sensoria on the fourth antennal segment. Prunifoliac, however, varies so greatly in respect to this character that it is not of practical use. This species was sent to Dr. Edith M. Patch for determination, and she considered it to be $R$. nymphacac (L.). but it differs from the form we are considering as $R$. nymplacae in a number of characters, especially in the length and shape of the connicles. It should be noted that we have taken all forms on cat-tail and that specimens have been taken on this host in the spring before any migratory species in the same vicinity, so far as known, had left their overwintering hosts.

\section{RHOPALOSIPHUM ENIGMAE VAR. PARVAE new variety}

This variety is essentially like $R$. enigmae new species, except that the antennae are only five-segmented, the cornicles shorter, and the lateral tubercles better developed. The average width of head across the eyes is .41 . The comparative antennal measurements are as follows: III-.I9 to .26, average $.22 ; 1 \mathrm{~V}-.08$ to .10 , average $.09 ; \mathrm{V}-.07$ plus .21 to .27 , average .24 . The cornicles average .15 in length.

Holotype.-Apterous viviparous female, Danville, Illinois, July 22, 1930, on Carex, collected by F. C. Hottes and O. E. Tauher. Slide No. 10642. Paratypes.-Twenty-one slides with same data as for holotype. Slides Nos. 10643-10656 and others unnumbered.

In view of the shorter cornicles and certain other slight differences, it has seemed inatvisable to group these specimens with 
cnigmac. Future collecting may prove chimmae to be a very varialule species and that this new variety can be relegated to synomy On one other hand there is the possibility that the variety paral may prove to be an entirely clistinct species.

\section{RHOPALOSIPHUM MELLIFERLM ( HoTIE-)}

Aphis xylostei Schrank, Fauna Boica, Durchgedachte der in Baiern ein. heimischen und zahmen Thiere, $2 \mathrm{Bd} ., 1 \mathrm{Abt.}$ Ingolstadt, 1801, p. 10. A homonym.

Hyadaphis mellifera Hottes, Proceedings of the Biological Society of Wash. ington, Vol. 43, October 7,1930 , p. 184 .

This cosmopolitan species migrates from honessuckle, npon which it over-winters, to parsnip and a number of other summer hosts. Good descriptions of the vivifarous forms ate given by Theobald (1!?:) and some data regarding its biology by Gillette (19111). IVe have seen two of the slicles recorderl as "Hyadaplis pastinacas Limn. "? from Illinois by Davis (19)10e) and find them to be the species Carariclla aegopodii (Scopoli) and not this species. which is the pustinucar ui some American authors.

Data associated with our viviparous specimens are as follows: Mt. Carmel (June). Normal (Aug. 18), 18\$4; Urbana (July 2i). 1912 (Davis): Albion (May 25-26), Antioch (June 15), Cave-in-Rock (Alay 29-30), Champaign (May 17. July 26), Decatur (Nov. 4), Metropolis (May 30-31, June 1). Quincy (June 6), Starved Rock State Park (June 12), Lrbana 1.May 23-2S, June 7, Sept. 26, Oct. 1), 1928; Allerton (June 17), Alton (June 25), Catlin (May 17), Galena (June 10), Morriston (July 9), Oakwood (Oct. 14), Oregon (July 11), Rock 1sland (July 7), Seymour (Oct. 16), Starved Rock State Park (July 6), Urbana (May 26, Juue 3, July 2, Aug. 22), 1929. We have taken males at Seymour, October 16, and at Oakwood, October 14, 1929. Collected on Carex sp.. Conioselimum chinense. Cryptotarnin canadensis. Lonicera flava, Lonicera simpervirens. Lonicera sp., and Pastinaca satira.

\section{RHOPALOSIPHUM NYMPHAEAE (LIXIETS)}

Aphis nymphaece Linnaeus, Fauna Svecica, Editio Altera, Auctior. Stockholm, 1761, p. 260.

This cosmopolitan aphid is of more than ordinary interest because it attacks aquatic plants and at times leads almost a semi-aquatic existence. Patch (1915b) has clemonstrated that the species is migratory, plum serving as the over-wintering host and apuatic plants as the summer host. The same type of iife cycle is to.lowed also in California, according to Davidson (1913). It occasionally spoils the appearance of acpatic plants in greenhouses and may injure the fruit of plums.

Davis (l!1lle) first recorded it from Illinois and proved that aquaticus Jackson (1!)(1) was a synonym of uymplatide. Jackson (1908), P'atch (1912a). and Theobald (192i) have given good descriptions of the viviparous forms and male. Davidsun $(191$ il $)$ lorictly mentions the oviparous females which are produced in autumm on pluni. Our material agrees well with the description of the Furopean form except that the secondary sensoria on the fourth antemal segnems of alate forms consistently average fewer. 
Data associated with our viviparous specimens are as follows: Havana (Sept. 14), 1894; Havana (July 21), 1897; Ottawa (July 20), 1901; Decatur (Oct. 20), (rrbana (May 23), 1928; Cobden (June 21), Mt. Vernon (Sept. 26), Oakwood (Oct. 17), 1929; Evanston (Mlarch 12), 1930. Collected on Nymphaca costaleifora, Nymphaea sp.. Lemna trisulca, Potamogeton natans, Galium sp.. Eichhornia sp.

\section{RHOPALOSIPHUM PRUNIFOL1AE (FIT'ג)}

FIGS. 31,196

Aphis prunifoline Fitch, Transactions of the New York State Agricultural Society, Vol. XIV, 1854 (printed 1855), p. 826.

The apple-grain aphid was first reported from lllinois by Thomas in the Praric Farmer for 1 slit as Aphis atenac Fabricius. Because of its cornicles-somewhat intermediate between an aplis and a typical

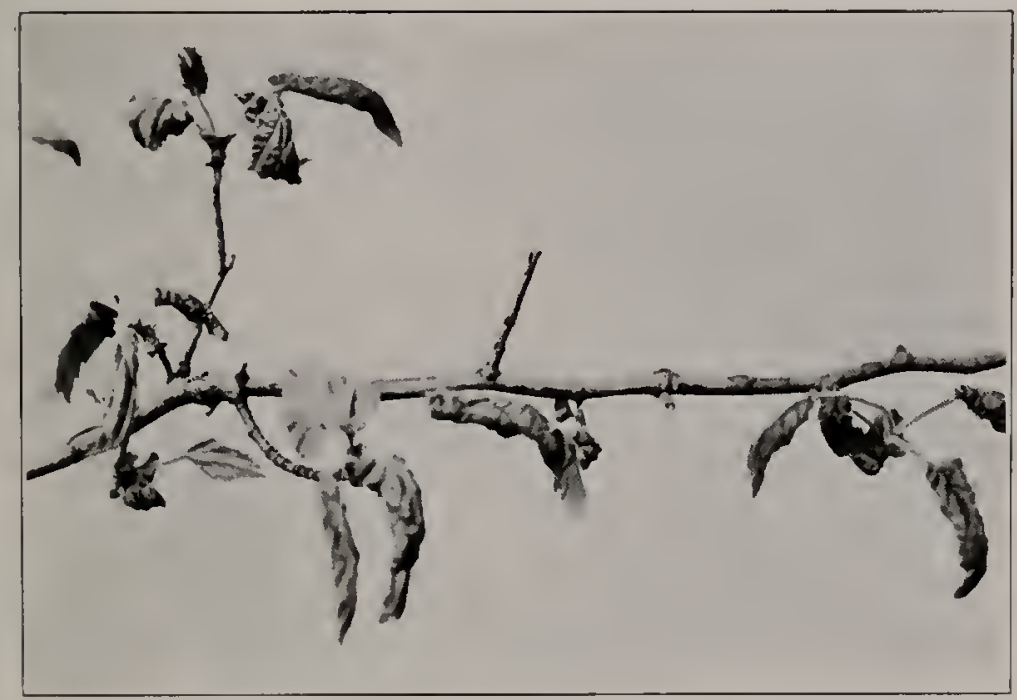

Fig. 31. Leaves on hawthorn, Cratuegis, curled by spring generations of the apple grain aphid. Rhopalosiphum prunifoliae (Fitch); Urbana, April 20, 1929.

Rhopalosiphum-this species is difficult to place generically. We are placing it in the genus Rhopulosifhum in accordance with present usage, althongh it has no more in common with species in this genus than with certain species of Aplis, the genus in which it was placed for many years. It is exceedingly abundant in lllinois in the spring of the year on Cratacgus (Fig. 31) and on apple, from which it soon migrates to grasses and smatl grains to spend the summer months. The fact that this species leaves the apple early in the season lessens its importance ats an apple pest.

Data associated with our viviparous specimens are as follows: Normal (June 21), 1883; Urbaua (May 23, Aug. 9), 1885; Urbana (Oct. 27), 18s6; Tonti (Oct. 14), 18s7; Urluana (June 25), 1889; Normal (Nov. 16), 1894; Havana (Aug. 11), 1S96; Peoria (Nov. 7), 1906; Beecll Ridge (May 22). 
1907; Carbondale (Oct. 13), 1926; Antioch (June 15), Carbondale (May 17. June 4), Decatur (Sept. 20. 29, Nov. 4), Herod (May 31), Marshall (May 25), Metropolis (June 1), Muncie (Oct. 6), Nelson (June 8), Quincy (June 6), Urbana (May 21, Oct. 9, 18, 19, Nov. 14), 1928; Lewistown (May 4), Macomb (May 3), Malnomet (April 3), Olney (June 18), Rantoul (ApriI 24), Seymour (Oct. 30), Springfield (May 2), St. Joseph (April 12), Urbana (April 16, 17, 22, 24, May 9), Woodriver (May 20), 1929; Effingham 1. Nov. 13), Urbana (Nov. 19), 1930. Collected on Avena sativa. Carer sp., Crataegus sp.. Prunus joponica. Pyrus Malus. Pyrus sp., and undertermined grasses.

\section{RHOPALOSIPHLM PSELDOBRASSICAE (D.MS)}

Aphis pseudobrassicae Davis, Canadian Entomologist, Vol. XLVI. July. 1914, p. 231, Figs. 21, 22.

Probably many of the previously published records of Breitrorync brassicac Lim. from Illinois have rejerence to this species since it has been our experience that pscudobrassicac is by far the more comlmon and destructive species attacking cabbage and cruciferous plants in the state. Only the viviparous forms have been described. and? there is some question as to how the species over-winters in Illinois. In the original description Davis suggests that the viviparons females overwinter. Paddock (1!)15), who has studied this species in considerable detail in Texas, reports that in Texas it is not found on cultivaterl host plants from Mlay until September, thus suggesting it has an alternate jost during the hot summer months. It occurs throughout the state and often is a serious pest in spring and fall on cruciferous garden crops.

Data associated with our viviparous specimens are as follows: Cairo (June 3), Carbondale (June 4), Champaign (June 19), Decatur (Sept. 1S). DesPlaines (July 6), Elizabethtown (May 29), Galena (June 25). Golconda (Oct. J3), Harrisburg (May 28). Havana (June 21). Herod (May 31). Kaukakee (June 29). Metropolis (May 31, June 1). Mt. Carroll (June 25). Oregon (June 27), Quincy (June 6). Urbana (Aug. 6), 1928: Cairo (June 21). Homer (June 17), liansas (June 17), Oakwood (June 29\}, Starred Rock State Park (July 5. 6), 1929; Allendale (October \$), 1930. All our material has been collected on Brassicu olcracca. Brassica rapa, Kaphanus sativus, and Lepidium virginicum.

\section{RHOPALOSIPHUM RHOIS IIONELL.}

Rhopalosiphum rhois Monell, Bulletin of the United States Geological and Geographical Survey of the Territories, Vol. V, .io. I, January 2?, 1879, Art. 1, p 27.

This large brown aphid is often very conspicuons lecause of its superabundance on the unclersides of the leares of sumach. In the early summer this species is reported to migrate to various grasses (Gillette, 1915) upon which it spends the remaining portion of the summer. We have collected it only on sumach (Rluws glabra). The smmmer generations of this aphid were described as a new species ly Wilson (1911) muder the name of Amphorophort hourdrii. Later Davis (1914a) redescribed in cletail the viviparous forms and the male produced on wild and cultivated gratsien. The latter author states. "Although careful searcl was malle. We were malle to ind oviparcus iemales [produced un grasses |." Further he states, "It appears . . that 
the winged males and winged viviparous females migrate [from grasses] to an unknown host in the fall of the year, where the oviparous females are produced." We have found the oviparous female on sumach in fall. A description of the heretofore undescribed apterous oviparous female is presented.

Data associated with our viviparous specinens of this species are as follows: Dixon (July 29, 30), 1S83; Clıampaign (July 18), 18S4; Champaign (June 26), 1886; Clumpaign (July 31), East Peoria (July 22), Golconda (Oct. 13), Marshall (May 25), Metropolis (May 31), Mit. Carmel (May 26). Starved Rock State Park (June 13), Urbana (July 10, Aug. 2), 1928; Collinsville (Sept. 11), Elizabethtown (June 20), El Paso (July 5), Galena (July 10), Hardin (June 25), ISappa (July 5), Mounds (June 21), Mt. Carroll (July 9), Oregon (July 11), Richmond (July 12), Rock Island (July 7), 1929.

\section{Aptenoty Oripinou's Fenale}

Average length from vertex to tip of anal plate, 1.34. General color essentially similar to apterous viviparous female. Average width of head across eyes, .34. Comparative lengths of antennal segments as follows: III-.30; IV - .16 to .17, average .I7; V-.14; VI-.10 plus .30 to .36, average .34. Secondary sensoria absent. Primary sensorium on sixth antenal segment with about 5 marginal sensoria. Cornicles .36 loug. Cauda .18 long, with about three strongly incurved hairs on a side. Hind tibiae considerably swollen, with about 130 sensoria.

Iforphotype.-Apterous oviparous female; Slide No. 8125, Collinsville, Illinois, September 11, 1929, on Rhus glabra, (Frison and Ross). On slide with alate viviparous female and apterous oviparous females.

\section{RHOPALOSIPHUMI RUFOMACULATUM (W1Lsox)}

Aphis rufomaculata Wilson, Entomological News, Vol. XIX, No. 6, June, 1908 , p. 261.

This species was first reported from Illinois by Davis. Our records indicate that it is of considerable economic importance as a pest of chrysanthemums growing in greenhouses. None of our specimens were taken on chrysanthemum growing out of doors. This species is the genotype of Coloradoa Wilson which has been placed as a synonym of Rhopalosiphum by Baker (1920). There is some evidence, however, for retaining Coloradoa as a subgeneric name. Only the viviparous forms have apparently been described.

Data associated with our viviparous specimens are as follows: Carbondale (June 4), Chicago (June 14). Des Plaines (Dec. 18), Hutsonville (Nov. 28), Lawrenceville (Nov. 28), Urbana ( Mlay 23, June 6), 1928; Quincy (Nov. 6), 1930. Collected only on Chrysanthemum sp.

\section{GENUS TOYOPTERA KocH}

\section{TONOPTERA GRAMINUMI (RONMAXI)}

Aphis graminum. Rondani, Nuovi annali delle scienze naturali. Bologna, Ser. 3, Vol. VI, 1852, p. 10.

The green bug, as it is referred to in the literature of economic entomology, has at times caused serious and wiclespread clamage to wheat and oats in Illinois and many other states. It is of particular in- 
terest to entomologists because of the marked epiclemic character of its depredations, the epidenics depending mostly upon weather conditions. In normal years the excessive abundance of the green bug is held down by parasites. During long periods of cool. wet weather. lowever, when the temperature remains below $6.5^{\circ} \mathrm{F}$, the rate of reproduction of the parasites is retarded whereas the green bug continues its normal rate of reproduction under temperatures rumuing almost as low as $40^{\circ} \mathrm{F}$. Sexual forms are produced in Illinois, but in the southern states the green bug breeds viviparously throughout the year.

There are numerous references to this species in literature, amoner which those by Hunter and Glem (1909), Nebster and Phillips (1912), and Theobald (192\%) contain good descriptions of the varions forms as well as giving much information regarding its biology.

Data associated with our viviparous specimens are as follows: Ilt. Carmel (June 101, 1890; Beech Ridge (Mlay 22), 1907: Homer (June 1\%), Rock Island (July 7), Seymour (June 13), 1929. Collected on drena sativa. Carex sp., and Triticum sp.

\section{SUPERTRIBE CALLIPTEREA}

\section{KEY TO GENERA}

1. Eyes without ocular tubercles (Fig. 321 ) ..................

- Eyes with ocular tubercles (Fig. 83 ) ....................

2. Hind wing with longitudiual vein rarely forked more than once (Fig. S8); cauda constricted near middle and knob-like (Fig. 17S): terminal filament much longer than greatest width of

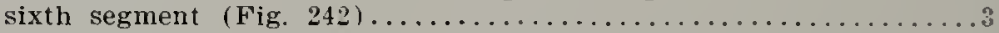

- Hind wing with longitudinal vein forked twice (Fig. 91); cauda not constricted but rounded (Fig. 216); terminal filament scarcely, if any, longer than greatest width of sixth segment

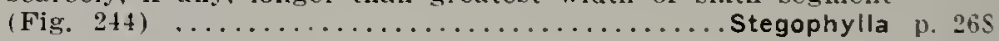

3. Body with peculiar modified setae (Fig. 316) ................

- Body with nolmal type of spine-like setae (Fig. 324 ). Thripsaphis p. 270

4. Modified setae on margins of abdomen long and conspicuous: third antennal segment and hind tibiae about equal iu length; veins of wings conspictously outlined with fuscous...lziphya p. 250

- Modified setae on margins of abdomen small and inconspicuous; third anteunal segment much shorter than hind tibia: reins of wings not conspicuously outlined with fuscous.... Saltusaphis p. 265

5. Terminal filament scarcely, if any. longer than greatest width of

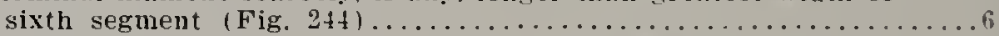

-. Terminal filament much longer than greatest width of sixth seg-

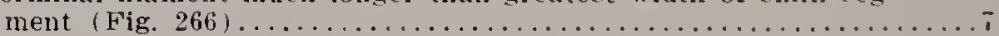

6. Cauda rounded (Fig. 216): third antennal segment with ten or more narrow and transverse secondary sensoria, fourth segment with a few sensoria................... Tamalia p. 26 s

- Cauda knobbed (Fig. 211): third antenual segment with less than ten secondary sensoria which are almost circular in shape, foulth segment without sensoria........... Phyllaphis p. 264

7. Conspicuous tubercles on dorsum of anterior abclominal seg-

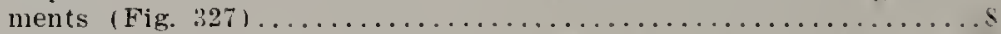

- Tubercles on dorsum of anterior abdominal segments wanting or

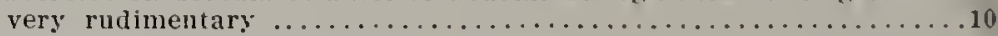


8. Terminal filament of sixth antennal segnent at least three or four times as long as basal portion of same segment (Fig. 243); cornicles moderately long and prominent (Fig. 154): anal plate slightly indented (Fig. 217).......... Drepanaphis

Terminal filament of sixth antennal segment at most twice as long as basal portion of same segment (Fig. 247); cornicles short and somewhat trapezoidal (Fig. 156); anal plate deeply

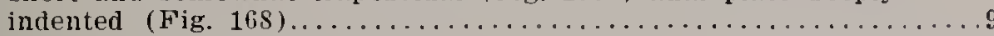

9. Abdomen with well-developed lateral tubercles (Fig. 310) in

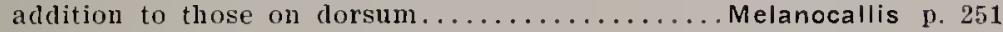

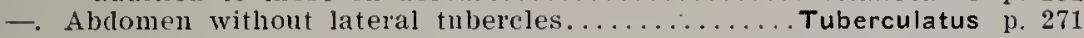

10. Cauda elongate and spatulate-shaped beyond constriction (Fig.

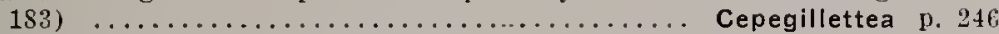

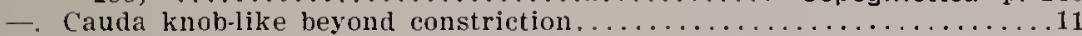

11. Fore femora with a projection or tubercle near distal end (Fig 325) $\ldots \ldots \ldots \ldots \ldots \ldots \ldots \ldots \ldots \ldots$ Shenahweum n. gen. p. 267

- Fore femora without a projection or tubercle near distal end

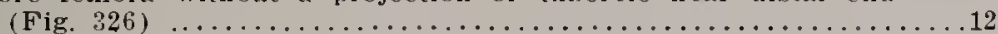

12. Cornjcles very short, not produced, almost ring-like (Fig. 155)...

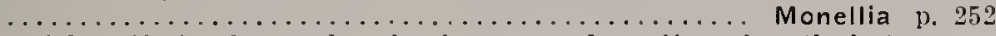

- Cornicles distinctly produced, short or of medium length but never almost ring-like (Fig. 150 ) .......................

13. Mesal apex of antennal tubercle protruding much beyond vertex (Fig. is) $\ldots \ldots \ldots \ldots \ldots \ldots \ldots \ldots \ldots \ldots \ldots \ldots \ldots \ldots \ldots \ldots \ldots \ldots \ldots$ n.

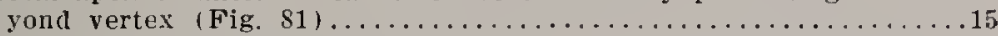

14. Radial sector well-developed (Fig. 72); anal and cubital veins of fore wings not margined with fuscous (Fig. 72); anal plate

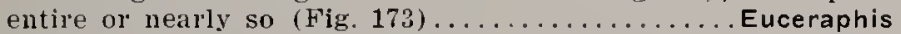

- Radial sector lacking (Fig. 65) or partly developed (Fig. 57). except that in some specimens of $C$. castanear it is entirely but weakly developed; anal and cuhital veins of fore wings distinctly margined with fuscous (Fig. 57); anal plate somewhat

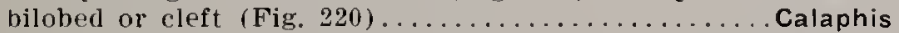
anda lengthened, constricted and with apex knob-like (Fig. $178) \ldots \ldots \ldots \ldots \ldots \ldots \ldots \ldots \ldots \ldots \ldots \ldots \ldots \ldots \ldots \ldots$ Myzocallis

- Cauda not distinctly constricted and more rounded (Fig. 211) ...

Neosymydobius p. 261

\title{
GENLS CAIAPHIS WALSH
}

\author{
Fry to the species of the Genus Calaphis
}

1. Dorsum of thorax with one median and two lateral dark stripes $\ldots \ldots \ldots \ldots \ldots \ldots \ldots \ldots \ldots \ldots \ldots \ldots \ldots \ldots \ldots \ldots \ldots \ldots \ldots \ldots$ betulella Walsh p. 244

-. Dorsum of thorax without dark stripes.......................

2. Fourth and fifth antennal segments uniformly dark-colored, third antenual segments with about eight round sensoria (Fig.

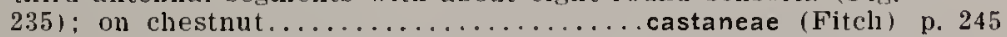

- Fourtli and fith antennal segments with basal portions light and apical portions dark, third antennal segment with about twelve to eighteen oval sensoria (Fig. 236); on birch........

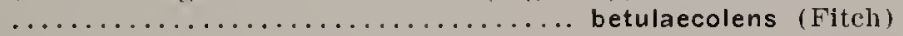




\section{CALAPHIS BETULAECOLENS (FITC'I)}

Ficis. 9, 11, 236

Aphis betulafcolens Fitch, Fourth Annual Report of the Regents of the Iniversity on the Condition of the State Cabinet of Natural History, State of New York, January 14, 1851, p. 66.

Davis (19091) first reported the taking of this species in Illinois. saying "it doulttless occurs [in Illinois] wherever the birch is found." Our collecting indicates it is conmon in the northern part of the state. where the white birch, its host, is native, and that it is likely to be found wherever there are trees of this species. All of the various forms have been previously described in detail, particularly by Davis (1909b) and Baker (1916d). At times this species is abundant at Urbana and the eggs form regular masses (Fig. 9) on the low branches and watersprouts of its host. The lack of apterous viviparous females. or at least their rarity, is a feature in the life history of this species. and that of the next two following species. which differs from that of certain other closely related genera.

Data associated with our alate viviparous specimens, pupae, and nymphs are as follows: East Dubuque (June 25), Galena (June 25), Urbana (July 10), 1925: Beach (Aug. 29). Macomb (May 3), Savanna (July 9). Erbana (Aug. 20), Waukegan (July 13), 1929. Mlales and oviparous females have been taken at Decatur (Oct. 7) and Urbana (Oct. 15), 1929. All specimens collected on white or canoe birch, Betula alba var. paply-ifera.

\section{CALAPHIS BETULELLA W.AL:II}

Figis. 65, 78, 220

Calaphis betulella Walsh, Proceedings of the Entomological Society of Philadelphia, Vol. I, December, 1862 , p. 301.

This large and handsome species of plant louse was originally. described by Walsh from specimens taken in August on Botula nigria at Rock Island. Illinois. Since then it has not been recorded from the state, but our survey has shown that it is common from May to September in all parts of Illinois on the red or river birch (Botula nigra). This agile species preferably frequents the undersides of the succulent leaves. Baker (1:16d) gives further details of the structural characters of the alate viviparous females.

Our collection records for alate viviparous females. pupae, and nymphs of this species are as follows: Cairo (June 2), Carbondale (June 4 ). East Dubuque (June 25), Harrisburg (May 28), Herod (Mlay 29), Kankakee (June 29), Metropolis (Mlay 31), Quincy (June 6), Rock island (June 24), Urbana (Sept. 22), 1928; Hardin (June 25), Macomb (Mlay 4 ), Pincknevville (Jume 25), 1929; Urbana (Sept. 2S), 1930. Betula nigra is the preferred host, but at times specimens were taken on other species of trees of this same genus.

Nicotypic Slide.-Since this species was originally described from Rock Island, Illinois, by Walsh and the types are lost, a slide in the Survey Collection is selected as the neotype. The data associated with this slide are as follows: Slide No. fi5T, Rock Island, Illinois, June 24. 192s, on Bctula nigra, collected by T. H. Frison and F. C. Hottes. 
CALAPHIS CASTANEAE (FITH)

F1G. 57, 235

Callipterus castanene Fitch, Transactions of the New York State Agricu!. tural Society, Vol. XVI, 1856, p. 471. [Third Report on the Noxious and Other Insects of the State of New York, 1856, p. 471].

Not previously recorded from Illinois. Found by the writers on specimen trees of Castunca dentata in southern and central Inlinois. Baker (1916d) has presented information regarding the typic specimens of Fitch and further details concerning characters of alate viviparous females. Descriptions are presented of the heretofore undescribed sexual forms.

Data associated with our specimeus of alate viviparous females, pupae. and nymphs of this species are as follows Decatur (Oct. 20), Urbana (July 1), 1928; Carbondale (June 21), Grayville (June 19), 1929. Oviparous females taken at Decatur (Oct. 20), 192S, and males and oviparous females taken at Urbana (Oct. 14), 1929. All taken on the under sides of leaves of host.

\section{AIATE M.ILE}

Size and general color.-Average length from vertex to tip of anal plate, 1.50. Head dusky brown; prothorax dusky brown on dorso-meson, remain. ing portion yellowish: meso- and metatborax dusky brown on dorsum, ye]lowish laterally; abdomen uniform pale yellowish, including cornicles, cauda, and anal plate; genitalia brownish. Femora yellowish except for slightly brownish areas on dorsum near apex; tibiae and tarsi uniformly dark brownisb black. First and second antennal segments and extreme base of third antennal segment concolorous with head, remaining segments brown. Stigna with posterior margin brown, remaining portion smoke-color, extreme basal portion with a much darker brownish spot. Anal and cubital veins mucl darker than media, with brownish borders. Beak yellowish witl terminal portion brownish.

Structure.-Average width of head across eyes, .46. Comparative length of antennal segments as follows: III-.86 to .93 , a verage .89 : IV-.56 to .57 , average $.56 ; \mathrm{V}-.40$ to .46 , average $.43 ; \mathrm{VI}-.17$ to .23 , average .19 plus .36 to .43 , average .40 . Secondary sensoria present on third, fourth, fifth, and sixth antennal segments; on the third and fourth segments widely scattered, covering the entire segment; on the fifth and sixth more frequently confinerl to an irregular row. Beak scarcely reaching midway between hirst and second pair of coxae. Second fork of media considerably closer to first fork than to margin of wing. Radial sector absent for part of its length. Cornicles .07 long. Cauda .08 long, with a well-developed knob-like structure at the tip.

\section{AlTERot's Oviparot's FeuAl.E}

Size and general color.-Average length, 2.10. Head reddish brown; pro- and mesothorax dusky greenish brown; metathorax and abdomen yellowish green. dorsum anterior to cornicles with segmentally arranged transverse greenish brown strips and subquadrate lateral spots, all of which merge for three or four segments to forn a brown patch immediately in front of cornicles. Segments posterior to the cornicles yellowish green. Cornicles and cauda dusky. Legs and antennae same color as in alate male.

struclure.-Average width of head across eyes, .41. Comparative average lengtlis of antennal segments as follows: $1 \mathrm{II}-.82 ; \mathrm{IV}-.46 ; \mathrm{V}-.40 ; \mathrm{VI}-$ base .21, with no measurements for the terminal filament. Antennae usually without secondary sensoria, rarely third segment witl one. Cornicles as in alate male, 10 long. Hind tibiae much swollen and with from 30 to 90 sensoria. usually more than 60. Distance between tip of ovipositor and cornicles, .46.

Allotype.-Alate male; Slide No. $83 \$ 6$, Urbana, lllinois, October 14. 1929. on Castanea dentata, (Frison and Park). Morphotype.-Apterous oviparous female; Slide No. S3S3. same data as allotype. 
GENLS CEPEGILLETTEA GRANONSKY

\section{CEPEGILLETTEA BETULAEFOLIAE GR:NorsKY}

Figs. 1S3, 326

Celegillettea betulaefoliae Granovsky, Proceedings of the Entomological Suciety of Washington. Vol. 30, No. 7, October, 192S, p. 115.

This recently described species was collected in Illinois and recognized as rlistinct previous to its description by Granowsky. It is highly. probable that it is restricted in distribution in Illinois to the extreme northeastern part of the state. Although it is recorded from Bctulc albo var. papyrifora by its describer, we have found it only on a dwari birch. Bctula fumila. Granovsky gives excellent descriptions of all form. of this species. His material was from Misconsin and British Culumbia.

Our specimens were collected at Antioch, June 15, 192S, and at Beacb, Aug. 29, 1929.

\section{Gexes DREPANAPHIS Del Giercio}

The treatment of this genus was prepared with the collaboration of Dr. A. A. Granovsky. His description of a new species is included without change. His measurements of antenmal segments are expressed in comparative terms, not in millimeters.

\section{Ley to the Species of the Genus Drepanaphis}

1. Species with more than one pair of prominent finger-like tubercles on dorsum of anterior abdominal segments (Fig. 327).... $\ldots \ldots \ldots \ldots \ldots \ldots \ldots \ldots \ldots \ldots \ldots \ldots \ldots$ acerifoliae (Thomas) p. 246

- Species with only one pair of prominent tubercles on dorsum of anterior soblominal segments and these united at the base

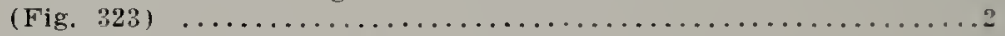

2. Wing veins broadly borlered with fuscons; only a single pair of prominent tubercles on dorsum of anterior abdominal seg-

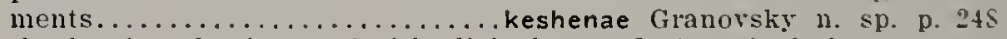

- Only the tips of veins marked by light brown flecks; single large or promineut pair of tubercles and occasionally two additional pairs of mimnte on dorsum of anterior abdominal segments.... $\ldots \ldots \ldots \ldots \ldots \ldots \ldots \ldots \ldots \ldots \ldots \ldots \ldots$ monelli (Davis) p. 249

\section{DREPANAPHIS ACERIFOLIAE (THOM.S)}

\section{Ficis. 154, 21T, 243, 327}

siphonophort aefifoliae Thomas, Bulletin lllinois State Laboratory of Nalural History, Vol. I, No. 2, June, 18is, p. 4.

This species spends the entire year on its host. It appears carly. in spring and produces the sexual forms in the autumn. The corss are laid in almost any protected place on the limbs and trmo. We are not aware of the production of apterous viviparons females. Daris (1!)10d) reports the species as "common thromghout the state on solt maple and uccasionally on hard and Norway maple but selelom in such numbers as 
to be injurious." At Urbana in late summer or fall this species sometimes becomes a nuisance, the walks beneath iniested trees heing kept damp by the falling of honeydew. The alate viviparous females have been described and figured by several (Sanborn, 19(1)4, and Patch, 1 (!)33). Descriptions of the apterous oviparous female and male have apparently not appeared in literature and hence are given here.

Cotypes of this common species, which inhabits the undersides of the leaves of maple trees. were included among the recently discovered typic specimens of Thomas in the Survey collection. These cotypes have been nounted in damar balsan on two slides. Slide No. 7168 has been designated as the lectotypic stide and Slide No. 7169 as a paratypic slide. Both slides contain alate viviparous females and pupae in poor condition. The original vial containing these specimens was given the number 59 by Thomas. The data associated with the typic slides are as follows: Ft. Dodge, Iowa; Dubuque, Iowa; and Peoria, Ithinois; September 1, 1877.

\section{Apterou's OVIPAliot's FEMALE}

Length from vertex to tip of anal plate, 2.18. General color yellowish suffused with light dusky hrown. Antennae dusky brown, terminal filament and base of third segment lighter in color. Femora yellowish brown, tibiae either uniform brownish or with the basal portion darker than the apical portion; tarsi light dusky. Average width of head across eyes, .57. Antennae with the following comparative lengths: III-.57 to .69 , average $.61 ; \mathrm{IV}-.36$ to .46 . average $.42 ; \mathrm{V}-.43$ to .53 , average .47 : VI -.10 to .14 , average .13 plus .43 to .53 , average .48 . Secondary sensoria absent. Beak reaches to mesothoracic coxae. Dorsum of ahdomen without tubercles. Cornicles .18 long, with just a suggestion of a swelling at one side near the bace. Posterior extremity of abdomen with a very elongate ovipositor. Anal plate and cauda rounded. Cauda .08 long, not longer than it is wide at base. Hairs on body enlarged at the tip. Hind tibiae very slightly swollen, with about 50 sensoria, mostly on one side, of the basal threefourths of the segment.

IIorphotype.-Apterous oviparous female: Slide No. $842 \%$, Urbana, Illinois, October 9, 1929. on Acer succharinum. (T. H. Frison). On slide with other oviparous temales.

\section{Al.1TE MAI.E}

Length from vertex to tip of anal plate, 1.09. Width of head across eyes, .54. Color essentially as in alate viviparous female. Wings with veins, except bases, distinctly bordered with fuscous Abdomen with a lateral row of quadrate brown spots and a median, dorsal brown stripe separating into small spots towards apex. Venter of abdomen with a median brown stripe terminating in the gonapophyses, which are also brown.

Average comparative antennal lengths as follows: III - .89. IV - .59, V--.56, VI-. It plus 1.00 . Secondary sensoria present on all antennal segments, numbering as follows: III- 1 to 98 , average 83 ; IV -24 to 55 , average $4: 3-15$ to 29 , average 20 ; VI- 0 to 2 , average 1 . Dorsal tubercles of abdomen prominent, much as in alate viviparous female (Fig. 32T), but with the first two small pairs reduced or absent. Cornicles 28 in length, mesal margin more or less straight, outer margin often greatly flared out at base, base wide. Cauda and anal plate as in alate viviparous female.

Allotypr.-Alate male: Slide No. 8414, Metropolis, Illinois, September 28,1929 , on Acr saccharinum, (Frison and Hottes). On slide with nynph.

A series of specimens in which the veins of the front wings are not margined with fuscous except at the extreme apices, differ from the above description only in having the cornicles shorter, averaging .20 in length, and les; swollen at the base.

Data associated with our Illinois specinens are as follows: Normal (Alay 10-15), 1884; Springfield (July 1), 1855; Lrbana (June 24), 1887; Tonti (May 10), 185s; Urbana (Oct. 28, 1897; Albion (May 26). Cairo (June 2). Carbondate (June 4), Catlin (Sept. 27), Danville (Sept 18), 
Elizabethtown (May 29), Golconda (Oct. 13), Havana (June 21), Kankakee (June 29), Leroy (June 20), Mlarshall (May 25), Matioon (June 10), Mletropolis (May 31), Mt. Carmel (May 26), Mt. Carroll (Jnne 25), Oregon (June 27), Pekin (June 20), Quincy (June 6), Shawneetown (Ilay 27), Starved Rock State Park (June 12), Urbana 1.May 16, Jnne 6-7, Oct. 251 , 1928; Alton (June 25), Edwardsville (Sept. 11). Elizabethtown (June 201. Grayville (June 19), Herod (Sept. 27), Macomb (May 3), Metropolis (Sept. 28 , Oct. 7 ). Newton (June 17), Rock Island (July 7), Springfield (May 2). Urbana (Oct. 7-9), 1929. Collected on Acer saccharinum and Acer sarcharum. Sexual forms and mating pairs collected at Lrbana in October.

\section{DREPANAPHIS KESHENAE GRITotsKY new species}

Ainte Viviparots Female

Length of boly from frons to the tip of cauda about 2.054. General color is light brown or tan with yellowish undertone. The entire body is somewhat heavily covered with the white, waxy, flocculent secretion. This secretion is especially heavy along the dorso-median line of the prothorax. thorax and abdomen. The first two anterior abdominal segments and the transverse area just back of the cornicles, as well as the lateral abdominal tubercles, are also covered with heavy wax. The dorsal tubercles and the areas around the cornicles are free from waxy threads, and only slightly dusted with a gray powder of waxy secretion. Head dusky brown with black circles around ocelli: posterior margin of the head witb a distinct narrow black line, extending from eye to eye. Frons provided with a few fine hairs. Eyes large, carmine. Antennae placed on prominent diverging tubercles. Length of antenna-434. Comparative average lengths of antennal segments as follows: - I- $7.50 ; \mathrm{II}-3.00 ; \mathrm{II}-.56 .78 ; \mathrm{IV}-40.64: \mathrm{V}-39.83$; VI- 9.25 plus umguis 91.00. Antennal segment I dusky brown; segment II yellowish orange: segments 111 to VI orange to light brown with very nar. row black annulations at distal ends. Base of the segment VI short, dusk! brown. Unguis long. dusky. Antennae distally imbricated and provided witll a few short, fine setae. The basal three-fifths or two-thirds of antennal segment IJI carries from 12 to 15 rather large, circular, secondary sensoria. The primary circular sensorium at the end of the segment $Y$ and the long oval sensorium at the base of the unguis are fringed with long sensilia in a form of crown; the latter sensorinm is surrounded with a crowded row of auxiliary sensoria and two additional circular sensoria, each placed singly some distance from its poles of longitudinal axis. Rostrum not quite reaching to the second pair of coxae.

Thorax dark brown; thoracic lobes prominent, occasionally almost black. Legs pale yellow, clothed with fine hairs. Fore femora dark brown to dusky black: hind femora slightly dusky with dark brown to black bands at distal ends; middle femora the ligbtest in color, without such bands. All tibiae dusky brown at proximal ends and to a lesser extent distally. the middle tibiae being the lightest. All tarsi slightly dusky. Wings hya. line. Costa and subcosta of the fore wings yellow with brown or dusky areas near anal veins. Stigma heavily bordered with dusky brown, leaving the yellow oblong cell in the niddle, which louches the outer margin of the stigma. Radial sector deeply curved. Media twice-branched. All veins. with the exception of costi and subcosta, are broadly banded with dusky brown, especially toward the tip of each vein, while bases of the media and cubitus are lighter and almost free from dusky borders. Hind wings witl nedia and cubitus present, although latter only fainty indicated: media, clistal end of costa, and areas near hamuli bordered with dusky brown.

Abdomen yellowish olive green to light brown, sparsely clothed with fine hairs. Lateral tubercles small, each bearing a single hair and usually: dusky, especially on third, fourth, and fifth abdominal segments. The dorsum of the third abdominal segment is provided with a pair of black fingerlike tubercles, united from the upper third to the base. The average length of the entire tubercle is 0.37 ; the widh of the base 0.27 : the height of the 
united base 0.24 ; and the leugth of the finger-like processes 012 . Cornicles dark dusky brown, almost black, having bowling-pin shape, paler and somewhat constricted at the base, and with a narrow pale flange at the distal ends. The average length of the cornicle 0.23 ; the width at the base 0.09 : the width of the narrow neck 0.05 . The abdominal area between the dorsal tubercles and the cornicles often with four rows of small dusky tubercular spots; these are often inconspicuous and faint. Cauda yellow, slort, globular on a conical base with several long hairs. Anal plate yellow, slightly dented, hairy.

Host plant and fecling habits. Hard maple (Acer saccharmm), feeding singly on lower side of the young leaves. Adults are quite active and often leap when foliage is only slightly disturbed.

Described from 7 alate viviparous females collected by A. A. Granovsky, September 14, 1927, at Keshena, Wisconsin, in virgin torest, and 9 specimens taken by T. H. Frison and F. C. Hottes, June 20, 1929, at Elizabethtown, lllinois.

Type localily. Keshena, Wisconsin, and Elizabethtown, Illinois.

Cotypes in the collections of the U. S. National Museum, Illinois State Natural History Survey (Slide Nos. 7616-7617), and in the private collection of A. A. Granovsky.

\section{DREPANAPHIS MONELLI (DNIS)}

FIG. 323

Phymatosiphnm monelli Davis, Annals of the Entomological Society of America, Vol. II, No. 3, Sept., 1909, p. 197.

This species is here recorded from Illinois for the first time. Our specimens were collected from the undersides of the leaves of hard maple and buckeye. The sexual forms have not been described.

A lectotypic slide (3119) was selected from cotypic slides of this species by Frison (1927).

Data associated with our viviparous specimens, all collected on Acer saccharum and Aesculus glabra, are as follows: Havana (June 21), Kankakee (June 29), Nit. Carroll (June 25), Oakwood (July 8), Urbana ( May 16, June 7), 192s; Rock Island (July 9), 1929; and Urbana (July 23), 1930.

\section{GENLS ELCERAPHIS WALKER}

\section{ELCERAPHIS BETULAE (LIXX.AET'N)}

Figs. $10,72,173$

Aphis betulae Linnaeus, Systema Naturae, Editio Decima, 1758, p. 452.

This is the first record of the occurrence of this species in Illinois. It was collected on native white, or canoe, birch (Bctula alba var. papyrifera in the northwestern part of the state. Records in literature, ranging in North America from Connecticut to California and Europe, indicate that betulac is likely to be found wherever its host grows as a native tree. Good descriptions of the alate viviparous female and sexual forms have been given by Theobald $(192 \mathrm{i})$. Baker (1!1ils) has shown that cerasicolens (Fitch) is a synonym of botulue and has presented a key for the recognition of nust of the American species leslonging to this genus.

Data associated with our specimens of this species are as follows: East Dubucue (June 25) and Galena (June 25), I1928. 


\section{GENES IZIPHY: NevSKY}

\section{IZIPHYA FLABELLAA (S.YพMOH:N)}

F1G. 316

Chaitophorus fubellus Sanborn, Kansas Lniversity Science Bulletin, Vol. III, No. I, July, 1904, p. 37.

This species has not previonsly been reported from Illinois. It is nost easily taken by sweeping Carcr, the host genus to which, according to published records and our collecting, it is confined. Originally described from Kansas and reported since from Colorado. Gillette (1909b) has given good descriptions and illustrations of the alate and apterous viviparous females.

Data associated with our specimens are as follows: Beach (Aug. 30), Carbondale (June 21), Grayville (June 19), Seymour (June 26, July $20), 1929$.

\section{GenUS MELANOCALLIS OESTLMD}

\section{MELANOCALLIS FUMIPENXEELLA (FıTCII)}

Aphis fumipennclla Fitch, Transactions of the New York State Agricultural Society, Vol. XIV, 1854 (printed 1S55), p. 570.

Davis $(1910 \mathrm{~b})$ described this species as new from material collected at Lake Forest. Jllinois, under the name Callipterus caryctoliat. Balier (1:1:b), on the basis of a study of Fitclis type. declared the species described by Davis a synonym of Mclanocallis fumipomella (Fitch). Fitch's original description, however, fails to agree in some respectwith specinens we are calling this species. This minute and rery active black aphid was collected on the under surface of leaves of Ciry sp. One of the cotypic slides of caryacfoliae Davis was designated as the lectotypic slicle, No. 1838, by Frison (192?). Descriptions of the sexual forms, heretofore undescribed, are presented.

Data associated with our specimens are as follows: Mt. Carmel (May 27), 1SS4; Lake Forest (June 24), 1909: Dauville (Sept. 1S). Havana (June 21), Marshall (May 25), Metropolis (June 1), Mt. Carmel (May 26), Mt. Carroll (June 25), Shawneetown (May 2

\section{Al.ITE MII.E}

Length from vertex to tip of anal plate, 1.16. Color essentialiy that of alate viviparous female. Average width of head across eyes, .50 . Comparative lengths of antennal segments as follom: III-.49, IV-.26, V-.24, VI-.It plus .10. Secondary sensoria (Fig. 234) distributed as follows: III-60, IV-24, V-I7, VI-7, irregularly arranged and scattered over eutire surface of segments. Wings, legs, cornicles, cauda, anal plate, and tubercles similar to those found on alate viviparous female.

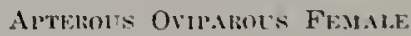

Length from vertex to tip of anal plate, 1.43. Head dusky brownish. tborax and abdomen light brownisl with dark brown spots on dorsum and lateral portions, spots on middle of dorsum of abdomen often confluent and forming stripes. Cornicles and area around their base brown; no brownish 
marking posterior to cornicles. Average width of head across eyes, .39. Comparative lengths of antennae as follows: III-.36; IV-.16; V-..17; VI-.11 plus .10. Secondary sensoria absent. Ovipositor elongate. Hind tibiae scarcely swollen, with about 35 sensoria. Dorsum and lateral portions of abdomen without tubercles. Hairs on body very elongate and with enlarged tips.

Allotype.-Alate male; Seven Hills, Alabama, October 24, 1928, on Carya illiocnsis, (L. L. English). Slide No. 10570. Morphotype-Apterous oviparous female; on same slide as allotype, together with another male and two alate viviparous females.

\section{Genus MONEllia Oestlund}

The key to the species belonging to this genus and the description of a new species were prepared by Dr. A. A. Granovsky, and the identification of all Illinois material has been checked by him. His measurements of antennal segments are expressed in comparative terms, not in millimeters.

\section{Liey to the Species of the Genus Monellia}

1. Costal margin of wing with broad black band intercepted before stigma............................... costalis (Fitch) p. 252

- Costal margin clear or yellowish witliout black band.............

2. Abdomen without brown or black maculation; terminal filament about equal to or only very slightly shorter than the basal portion of the sixth antennal segment; anal veins narrow and delicate; wings at rest held in flat position...caryella (Fitch)

- Abdomen usnally with brown or black maculation with the exception of early summer forms, which have abdomen without such maculations, but then antennae and wings typical of the species; anal veins prominent, somewhat dusky; wings at

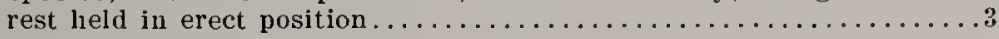

3. Abdomen usually with four rows of large brown or black spots most conspicuons on anterior segments; spring forms without such spots; terminal filament usually longer than, or seldom equal to, the basal portion of the sixtl antennal segment....

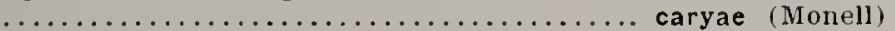
bdomen usually with two very prominent black spots near the cornicles; spring forms without such spots: fall forms with six or eight rows of small spots over the dorsum; terminal filament usually shorter than and seldom equal to the basal por-

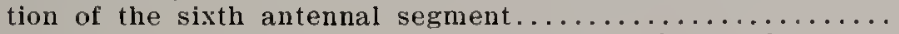
$\ldots \ldots \ldots \ldots \ldots \ldots \ldots \ldots$ nigropunctata Granovsky n. sp. p. 252

\section{MONELLIA CARYAE (MONELL)}

Callipterus caryae Monell, Bulletin of the United States Geological and Geographical Survey of the Territories, Vol. V, No. 1, Jannary 22, 1879, Art. 1, p. 31.

Davis (1910d) has previously recorded the American walnut aphid as "occurring everywhere throughout the state on hickory and walnut." It frequcnts the lower surfaces of the leaves and holds the wings erect while resting. Davidson $(191 \mathrm{Hh}$ ) has given detailed descriptions of all forms and presented much information concerning the life history of this species as he found it in California on walnut. Davidson 
failed to find, during eighteen months of study, any trace of wingless viviparous females.

Data associater with our viviparous specimens are as follows: Mt. Carmel (Mlay 27), 1884; Danville (Sept. 18), Kankakee (June 29, July 15), MIt. Carmel (Nlay 26), St. Joseph (Aug. 5), 1928; Blooningt on (July 5), Edwardsville (Sept. 11), Galena (July 10). Hardin (June 25), Kansas (June 17), Rock Island (July 7), 1929. An oviparous female was collected at Edwardsville, Sept. 11, 1929. All specimens taken on Carya sp., Juglans nigra, Juglans sp., and Quereus sp.

\section{MONELLIA CARYELLA (FITCH)}

FIG. 157

Aphis ceryellu Fitch. Transactions of the New York State Agricultural Society, Vol XIV, $1 \$ 54$ (printed 1\$55), p. $\$ 6 \overline{7}$.

The little hickory aphid was first recorded irom Illinois by Davis (1!)1(1). who states, "I have collected this species but once. namely, on hichory at Centralia, I1l., August 13. 190\%." In the field it may be separated from $M$. curye and $M$. nigropunctata by the lact that the wings are held when at rest in a flat position orer the body. Davidson (1!) 1 b) has publisher much information concerning the biolngy of this species and given technical descriptions of all the forms. He reports that the viviparous forms, so far as observed, all develop wings.

Data associated with our viviparous specimens from Illinois, all collected on Carya ovata. Curya sp., or Juglans sp.. are as follows: Antioch (June 15). Mt. Carroll (June 25), Shawneetown (May 27), 192s; Columbia (Sept. 11). Elizabethtown (June 20), Grayville (June 19), 1929.

\section{MONELLIA COSTALIS (FITCH)}

F1G. 155, 251

A phis carlyella var. costalis Fitch. Transactions of the lew lork State Agricultural Society, Vol. XIV, 1854 (printed $1 \$ 55$ ), p. $\$ 69$.

This species has not been previonsly recorded trom lllinois. It is easily recognized because of the dark hand on the costal margin of the fore wing. Baker (1!1ib) las redescribed the alate viviparous female but the sexual forms are apparenty unkmown or at least not clescriberl.

Data associated with our viviparous specimens are as follows: Mt. Carroll (June 25), Oregon (June 28), 192s: Cairo (June 22), Elizabethtown (June 20), Grayville (June 19), 1929. All specimens collected on Carya oratu. Curya sp.. and Juglans nigra.

\section{MONELLIA NIGROPINCTATA GRINOMKY new species}

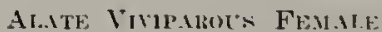

length of body from frons to the tip of cauda about 1.i1. General hody color from pale lemon ycllow to orange or deep butter yellow with greenish tinge. Head concolorous with the body; frontal lobes may be slightly dusky about ocelli with a few singly placed bristles. Eyes bright red. Antemnae on very small frontal tubercles, each of which is marked with a thin black line on lower edge of the antennal socket, nearly as long 
as the width of the first antennal segment, slightly thicker at the outer end. Length of antenna 1.19. Comparative average lengths of antennal segments as follows: I- 3.2; II - 3.0; III- $22.10 ; \mathrm{IV}-12.78 ; \mathrm{V}-12.43$; VI -8.04 plus unguis 6.77. Inguis dusky, usually shorter than the base of the sixth segment. Autennae pale to pale yellow with dark brown to black annulations at distal ends of segments II to Vl, inclusive; irregular slightly dusky shading over the sensorated area of segment III usually present. The entire antemnae, with the exception of segments 1 and $I I$, finely inbricated, more conspicuously distad of each segment. Antennae almost naked or with a few extremely minute setae. The tip of the unguis carries a few capitate hairs. The basal three fifths or more of segment III with a row of from 4 to $S$, usually 5 to 7 , rather large, oval, secondary sensoria. Only rarely some individuals have more and as many as 11 sensoria, covering alnost the entire segment III. Segment $V$ with a circular primary sensorium, and the usual primary oval sensorium with a few auxiliary ones at the base of the unguis. Both primary sensoria provided with fine friuges of short sensory hairs, especially at the base of each sensorium. Rostrum with its dusky tip barely reaches beyond the first pair of coxae.

Thorax deep orange, occasionally with dusky tinge. Each lateral margin of prothorax is marked with a dark brown or black line, extending from the head margin to half or two-thirds of the length of the prothorax, fading caudad. Legs pale yellow, sparsely clothed with short fine hairs. Distal ends of pro- and meta-femora on inner side narked with black conspicuous patches. Meso-femora without such patches. All femora and tibiae very slightly dusky distad. All tarsi dusky. Wings hyaline. Fore wings with costa and subcosta pale yellow; stigma deeper yellow with brownish margins, especially along the radial vein, and with a conspicuous dusky pateh at the base. Radial sector short, nearly obsolete or very faintly indicated distally. Media twice-branclied, brown at the base, color fadiug to the tips of the branches. Cubitus dark brown at the base, intensity of the color diminishing distally. Anal vein lark brown with diffused shading. Cubitus and anal veins conspicuously curved at their bases. Hind wings with media and cubitus present. Wings when at rest are held in upright position.

Abdomen from pale yellow to orange yellow normally with an oval, black or dark brown blotch, placed on each side, somewhat in front of the middle of the fifth abdominal segment, each with a clear hair tubercle in the middle. These blotches from dorsal and ventral sides may appear as heavy lines. They are often lacking on early spring forms, or they may be only faintly indicated. Late summer and fall forms almost without exception have dorsum of the abdomen speckled with from six to eight rows of small dark brown or dusky tubercles, each bearing very small fine hair. Lateral tubercles small and usually without maculations. Cormicles reducer to pore-like chitinized rings, back of the black ablominal blotches. Cauda yellow, short, globular, with five long bristle-like and several smaller hairs. Anal plate yellow, deeply bilobed, and provided witl a few long. stout hairs supplemented with several sliorter ones.

Inmature forms are pale yellow to orange, with from six to eight rows of very prominent dusky tubercles, each bearing stiff, long, capitate hairs.

Descrihed from over two hundred specimens collected at various places in Wisconsin, lllinois, Pennsylvania. Minnesota, New York, Georgia, South Carolina, Mississippi aud other states.

Host plants. Black walnut (Juglans nigra), butternut (Juglans (ineren). shagbark hickory ('arya ovata). bitteruut ('arya cordiformis). and pecan (Carya illinornsis). Names of the trees given after Gray.

Hobit of fofling. This species feeds singly or in small scattered colonies, usually near the mid-rib or lateral veins on lower side of the leaves.

bistribution. It is evidentiy distributed throughout the eastern half of the Inited States and Southern Canafla, wherever host plants are available. It has not been collected in the area of the Great Plains and in the Western states.

Typr locality. It is advisable to limit the type locality to two states, namely, Illinois and Wisconsin. 
Cotypes in the collections of the U. S. National Museum, Illinois State Natural History Survey, and in the private collection of A. A. Granorsky, are listed in the following tabulation:

\begin{tabular}{|c|c|c|c|c|c|c|c|c|}
\hline \multicolumn{2}{|c|}{ Jate } & I,ocality & Collector & \multirow[t]{2}{*}{ Hosts } & \multirow{2}{*}{$\begin{array}{c}\text { Sumber } \\
\text { of } \\
\text { slides }\end{array}$} & \multirow{2}{*}{$\begin{array}{c}\begin{array}{c}\text { dlate } \\
\text { vivip- } \\
\text { parous } \\
\text { females }\end{array} \\
3\end{array}$} & \multirow{2}{*}{ Iynohs } & \multirow[t]{2}{*}{ Dexes } \\
\hline July: & 24,1925 & legg Harlor, Wis.. & A. A. G. & & & & & \\
\hline Aug. & 12,1925 & Egg Harbor, Wis.. & 1. A. $1:$ & Butternut.... & 2 & 2 & 3 & \\
\hline Aug. & 17. 1925 & Sun Prairie, Wis... & A. A. 1 . & Hicliory...... & 3 & 3 & 6 & \\
\hline July & 8. 1927 & Viroqua, Wis........ & A. A. 1:. & Black waltut & 2 & 5 & I & $\ldots \ldots \ldots \ldots \ldots$ \\
\hline Aug. & 7,1927 & Egg Harbor, Wis... & A. A. G. & $\begin{array}{l}\text { Black walnut } \\
\text { shagbirk }\end{array}$ & 2 & 15 & & \\
\hline Aug. & 9. 1927 & Green Bay, Win.... & A. A. 1:. & lickory..... & 3 & 7 & 13 & \\
\hline Augr. & 28,1927 & Egg Harbor, Wis... & 1. A. (i. & Bitternut.... & 5 & 10 & & \\
\hline Sept. & 2,1927 & Green Bay, Wis... & A. A. 1: & 11ickory...... & 6 & 4 & Is & \& $A 119$ Q \\
\hline June & 2I. $192 S$ & Ilavana, $111 . . . . . .$. & $F \& 11$. & Hickory..... & 3 & 4 & 2 & ................ \\
\hline June & 19,1929 & Grayville, I1l....... & F. \& 11 & Wa]nut..... & 5 & 12 & 1 & .............. \\
\hline Jume & 20,1929 & Elizabethtown, 111 . & F. \& H1. & Hickory...... & 3 & 6 & . & ............. \\
\hline Iune & 20.1929 & Elizabethtown, Ill. . & F. \& 11 . & Black ialnut & 1 & 4 & $\ldots \ldots \ldots$ & ............. \\
\hline June & 22,1929 & Cairo, $111 . . . \ldots \ldots$. & F. \& $H$. & Hickort...... & 2 & 4 & $\ldots \ldots \ldots$ & .............. \\
\hline
\end{tabular}

In addition to the cotypic material listed above we bave the following lllinois records: Kankakee (July 29), Metropolis (June 1), IIt. Carroll (June 25), Urbana (July 10), 1928; and Columbia (Sept. 11), 1929. All taken on Carya illinocusis. Carya ovata, or Carya sp.

\section{GFAT'S MYZOCALLIS PASSERINI}

\section{(SuRuexeli MYZOCALLIS PAsserixi Axi THERIOAPHIS W.aker)}

\section{Hey to the Spccies of the Genus Myzocallis}

1. Wings between veins conspicuously mottled with brownish or blackisl patches (Fig. 61): markings not restricted to border-

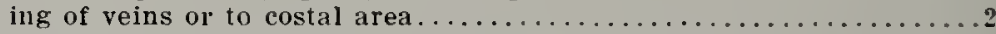

- Wings between veins not conspicuously mottled (Fig. 63): dark markings restricted either to the apices and bordering of veins

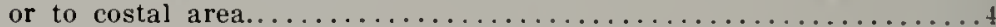

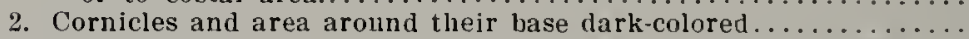
$\ldots \ldots \ldots \ldots \ldots \ldots \ldots \ldots \ldots \ldots \ldots$ discolor (Monell) p. $25 s$

- Cornicles and area around their base not dark but light ............

3. Species found on milkweed (Asclepias)..... asclepiadis (Monell) p. 256

- Species found on oak (Quercus)............alhambra Davidson p. 255

4. Cornicles almost or at least with apical portion dark-colored..........

- Cornicles entirely light-colored........................

5. Dorsum of abdomen with numerous dark patches or spots; third antennal segment with about eight secondary sensoria...... $\ldots \ldots \ldots \ldots \ldots \ldots \ldots \ldots \ldots$ ononidis (lialtenbaclı) p. $25 s$

- Dorsum of abdomen without dark patches or spots; third antennal segment usually with less than six secondary sensoria.......6

6. Basal third of third antennal segment with two to four secondary sensoria............................ IDeGeer) p. 256

- Basal portion of third antennal segment witlout secondary sensoria. sensoria numbering from three to eight and located upon swollen middle area of segment (Fig. 249).......... $\ldots \ldots \ldots \ldots \ldots \ldots \ldots \ldots \ldots \ldots \ldots \ldots$ alnifoliae (Fitch) p. 256

7. Basal portion of third antennal segment dark-colored and with more or less oval or transverse oval sensolia............. ........................ tiliae (Limaeus) p. 259

- Basal portion of third antennal segment light-colored and wirl

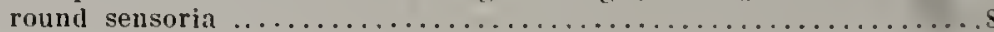


8. Fore wings with tips of all or almost all veins ending in fuscous

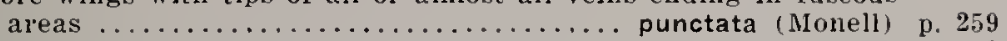

- Fore wings with tips of few or no veins ending in fuscous areas.......

9. Fore wings immaculate except for small dark spot in stigmal area; forms small: on hazel (Corylus)...........coryli (Goeze) p. 257

- Fore wings not entirely immaculate, usually a distinct dark band extending along costal margin to tip of wing (Fig. 63): on

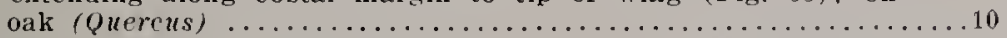

10. Femora of fore legs mostly dark.............. bella (Walsh) p. 257

-. Femora of fore legs mostly pale.............walshii (Monell) p. 259

\section{MYZOCALLIS ALHAMBRA Danusox}

FI1;, 334

Myzocallis alhambra Davidson, Canadian Entomologist, Vol. LII, No. 6, August, 1920 , p. 176.

This species has been determined for us by Dr. Granovsky and is here recorded from Illinois for the first time. It is so closely related to M. asclcpiadis (Monell) that we have been unable to separate it from the latter except upon the basis of host plants. Davidson described this species from California. Our material has been collected on Quercus macrocarpa, Qucreus alba, and Quercus bicolor. Since the sexual forms have not been described, brief descriptions of them are presented here.

Data associated with our specimens are as follows: Carbondale (June 4), Catlin (Sept. 27), Havana (June 20), 1928; El Paso (July 5), Urbana (Oct. 11, 15), 1929; Urbana (Oct. 20, 24), 1930. Sexual forms were taken at Urbana on various dates in October, 1929 and 1930. A mating pair was taken on October 24, 1930.

\section{Alate: Ml.L:}

Size and general color.-Length from vertex to tip of anal plate, 1.35. Width of head across eyes, .45 . Head and thorax dark brown, thorax with lighter areas. Dorsun and venter of abdomen with segmentally arranged, wide, oblong dark brown areas occupying most of the two aspects; lateral margins of abdomen with quadrate dark spots; area between these spots yellowish green, sometimes interspersed with small round brownish areas; gonapophyses brown. Antennal flagellum brown, bases of segments lighter. Legs and wings as in alate viviparous female. Cornicles dusky, but with a clear area surrounding the base.

slructure.-Average comparative antennal lengtbs as follows: III$.51, \mathrm{IV}-.36, \mathrm{~V}-.30$, VI- .14 plus. 20 . Secondary sensoria present on all segments of flagellum, numbering as follows: III- 22, IV $-21, V-7$, $\mathrm{VI}$ - 3. Otherwise as in alate viviparous female.

\section{Alterotis Oripalot's Fendale}

Length from vertex to tip of abdomen, 2.04. Width of head across eyes, .43. Venter of body and general ground color of other portions yellow. Antennae yellowish with apical portions of flagellar segments and all of sixtl except base, dusky. Dorsum of body with dark brown markings and clothed with capitate setae arising from distinct tubercles. Pattern of color markings and setae as in Fig. 334. Legs mostly concolorous with body, but with tarsi and extreme apices of tibiae blackish.

Comparative antential lengths as follows: III- .42, IV - .26, V- .21, VI- .11 plus .17. Secondary sensoria absent. Hind tibiae swollen, with about 60 sensoria. Cornicle and cauda as in alate viviparous female.

Allotype.-Alate male; Slide No. 9654, Urbana, Illinois, October 24, 1930, on Quercus macrocarpa. (Frison and Ross). On slide with males. J/orphotype.-Apterous oviparous female: Slide No. 9350, Urbana, Illinois, October 11, 1929, on Quereus marrocarpa, (Frison and Ross). 


\section{MYZOCALLIS ALNI (DEGEE:)}

Aphis alni DeGeer, Memoirs pour servir à l'histoire des Insectes. Tome 3. 1773, p. 47.

This species was first reporterl from the Lnited States by Daris (1910d) from specimens collected in parks at Chicago. Illinois. on the undersides of alder leaves (Almus sp.). He stated that it was rather common at time of collection, October 1,4 , and $: 0$. 1!)!!. It has not been reported from this state since then. Davis described the alate vivijarous females and sexual forms. All forms have been reclescribed in detail and figured by Granorsky (1!9:-b). Davis (1!1!1) referred his determination of this species in 1910 to alnifoliae (Fitch). but Granovsky has shown that the original determination of Davis was correct. According to Granovsky it is known in North America wnly from Illinois. Oregon, and British Columbia. It is a common species in Europe (Theobald. 1!2i).

\section{MYOCALLIS ALNIFOLIAE (FIT'H)}

FIri, 249

Lachnus alnifoliar Fitch, Fourth Annual Report of the Regents of the Inni. versity on the Coudition of the State Cabinet of Natural History State of New York, January 14, 1851, p. 6 -

This species is here recorded for the first time from Illinois. since the record of Davis (1!19) refers to $M$. alni (DeGeer). It was tound to be exceedingly abundant on the undersides of the leares of alder (Aluts sp.) in the Ozarkian region of southem Illinois. Ciranowsky (1928b) has given detailed descriptions and illustrations of all forms, as well as a summary of its present known distribution.

Data associated with our specimens are as follows: Herod (June 21) 1929 and (April 16) 1930.

\section{MYZOCALLIS ASCLEPIADIS (MoxEII.)}

FiG. 311

Callipterus asclepiadis Monell, Bulletin of the [njted States Geological and Geographical Survey of the Territories, Vol. V, No. 1, January 22. 1879. Art. 1, p. 29.

Gillette (1910) was the first to report this species from lllinois. and later Davis (19101) reported it as common throughout the state. As already mentioned elsewhere, this species is closely related to $. / / y-$ zocallis alhambra Davidson, and we have been able to separate the two only on the basis of host plants: allambra occurring on Quteris and asclcpiadis on Asclcpias. Dr. Granowsly writes us that the two are distinct. It is very common in all parts of lllinois and feeds on the undersides of the leaves. A description of the previously molescriled oviparous female is given bere.

Data associated with our specimens are as follows: Chaupaign (July 27), Danville (July 15), llavana (June 21). Kankakee (July 15), Oakwood (Sept. 17), St. Joseph (Aug. 5), Crbana (July 23). 192א: Beacli (Aug. 29 ). 
Cairo (June 22), Edwardsville (Sept. 11), Eldorado (June 19), Galena (July 10), Grayville (June 19), Jerseyville (June 25), liansas (June 17), Richmond (July 12), Rock Island (July 7), Seymour (Oct. 16), Starved Rock State Park (July 5, 6), 1929: Cerro Gordo (Oct. 15), 1930. Oviparous te. males have been taken at Seymour (Oet. 16) and at Urbana (Oet. 14), 1929.

\section{APTELOLS ONIPAROL'S FEMALE}

Length from vertex to tip of body, 1.97. Width of head across eyes, .39. Body coloring as in oviparous female of $M$. allambra (Fig. 334 ) with very similar markings and setal distribution. Average comparative antennal lengths as follows: $1 \mathrm{II}-.34, \mathrm{IV}-.21, \mathrm{~V}-.21, \mathrm{VI}-.10$ plus .20. Sec. ondary sensoria absent. Very similar to the oviparous fenale of $1 \%$. alhambra and perhaps iuseparable from it.

Morphotype.-Apterous oviparous female; Slide No. 8978, Urbana, Illinois, October 14, 1929, on milkweed (Asclepiess sp.), by T. H. Frison. On slide with oviparous female.

\section{MYYOCALIIS BELLA (WALSII)}

F16. 68

A phis bella Walsh, Proceedings of the Entomological Society of Philadelphia, Decenber, 1862, p. 299.

This species, originally described from near Rock Island, Illinois, by Malsh, was reported as being very common in the state by Davis (1911)d). It may be collected on the indersides of the leaves of black wak, where it is often associated with the somewhat similarly colored, but smaller, species Myrocallis a alshii (Monell). The latter has often been considered a symonym of $M$. bclla (Walsh). Our determination of this species has been verified by Dr. Granovsly.

Data associated with our specimens, collected on Quercus velutina and Quereus sp., are as follows: Decatur (Sept. I8), Oregon (June 28), 1928; Decatur (Sept. 20, Oct. 12), Starved Rock State Park (Aug. 14), 1929; Starved Rock State Park (May 13), 1930. It is very likely that the sexual forms of this species are represented in a collection from Decatur (Oct. 12), but due to lack of mating pairs and mixing with material of $M$. wulshii (Monell) they have not been definitely segregated and therefore are not described or recorded as such.

\section{NYYZOCALIJIS CORYLI (GOEZE)}

Aphis coryli Goeze, Entomologische Beyträge zu des Ritter Linné zwölften ausgabe des Natursystems, Theil 11, Leipsig, bey Weidmanns Erben und Reich, $17 \%$, p. 311.

This species was first reported from the vicinity of (hicago, Illinois, ly Davis (19101). who published descriptions and illustrations of the sexual forms and alate viviparous female. Its small size, pale color. and more or less solitary habit make this species rather difficult to collect. It frepuents the under surface of leaves of hazelnut (Corylus

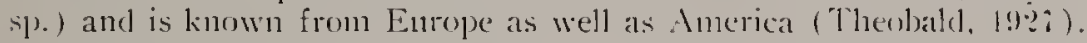

Data associated with our specimens are as follows: Antioch (June 15), Catlin (Sept. 27), Galena (June 25, 27), Kankakee (July 15), Oregon (June 28), Urbana (July 10), 1928; Beach (Aug. 29), 1929. 
MYZOCALLIS DISCOLOR (MOXELL)

Figis, 61, 168, 178

Callipterus discolor Monell, Bulletin of the Lnited States Geological and Geographical Survey of the Territories, Vol. V, No. 1, January 22, 1879 , Art. 1 , p. 30.

This species was first reported from Illinois by Daris (1910d). who stated it was connum in Illinois. It is a dark-colored aphid with brown or blackish spotted wings and occurs as solitary specimens on the under surface of the leaves of oak and hichory. The sexual forms have been described by Weed (1sss) and by Knowlton (1929b). Dr. Granovsky has checked our determination of this species.

Data associated with our specimens are as follows: Mlt. Carmel ( Mlay 27, 28), 1884; Carbondale (June 4), Danville (Sept. 18), Decatur (Oct. 23), Herod (May 29), Mt. Carmel (May 26), Oakwood (Nor. 4), 192\$; Cairo (June 21), Starved Rock State Park (Aug. 14), Urbana (Oct. 11), 1929: Starved Rock State Park (Mlay 13), 1930. We have taken the sexual forms at Quincy (Nov. 6) and Urbana (Oct. 20), 1930.

\section{MYZOCALLIS ONONIDIS (KALTEXBICI)}

\section{F1c. 32}

Aphis ononidis Kaltenbach, Entomologische Zeitung. Herausgegeben ron dem entomologischen Vereine zu Stettin, Vol. VII, 1846, p. 173.

Most remarks and descriptions in literature relating to the yellow. clover aphid (Fig. 3:) have been recorded under the name of Callip-

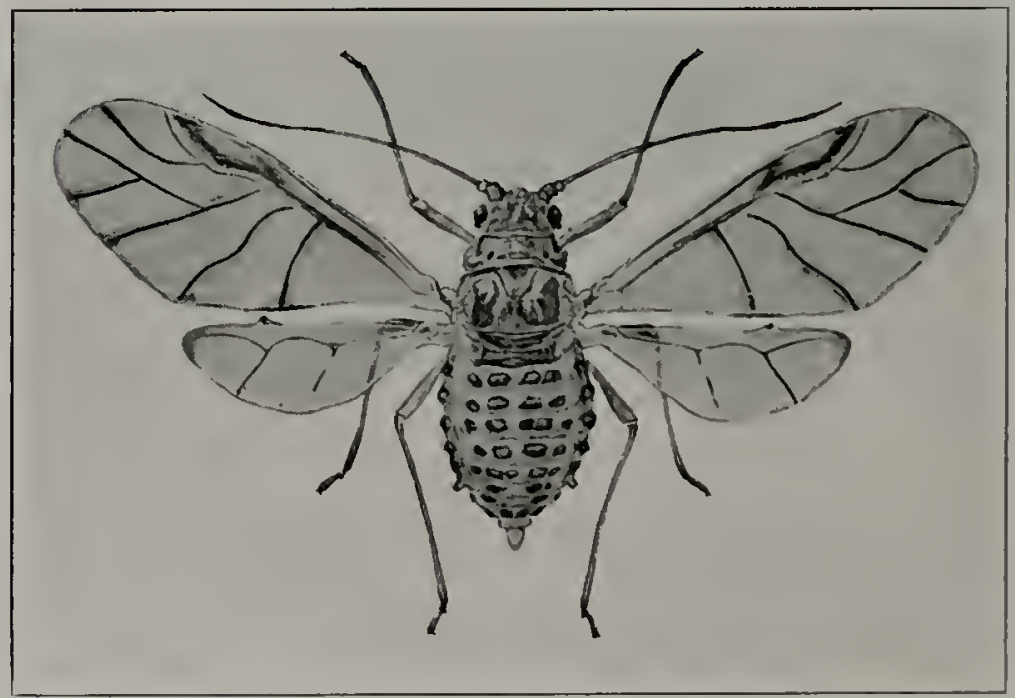

Fig. 32. Alate viviparous female of Mysocallis anonidis (lialtenbach). (After Folsom: Ill. Ent. Rep. 25.)

terus trifolii Monell which is now considered to be a swonym of .M. ononidis (Kaltenbach). This species was first recorded from lllinois 
by Daris (1908c) as a "common species on clover, but of little cconomic significance." The accounts by Folsom (1909) and Davis (1908c, $191+b)$ give a very complete picture of the biology, characteristics, and structural details of all forms of this species. All writers seem to agree. and this also is our own opinion, that althongh the yellow clover aphid is common in clover fields every year, it does not rank with . Macrosiphum pisi (Kaltenbach) as a serious clover pest. It is found in Eurasia and Africa as well as North Anerica.

Data associated with our specimens, all collected on Trifolium pratense and T. procumbens, are as follows: Mascoutah (July 17), 1906; Carbondale (June 4), Herod (Oct. 12), Marshall (Mlay 2S), St. Aune (July 15), 1928; Edwardsville (Aug. 11), Elizabethtown (June 20), Farmer City (July i). Homer (June 17), Olney (June 1S), Orleans (ApriI 15, June 15), 1929.

\section{MYZOCALLIS PUNCTATA (MONEI.L)}

\section{Fig, 71}

Callipterus punctatu Monell, Bulletin of the United States Geological and Geographical Survey of the Territories, Vol. V, No. 1, January 22, 1879 , Art. 1 , p. 30 .

Mrocallis punctatus (Nonell) was reported by Davis (1910d) as "not unconmon in Illinois." Very little is given in literature regarding this species, and the sexual forms have apparently not been described. Our determination of this species has been checked by Dr. Granorsky.

Data associated with our specimens, all collected on various species of Quercus and Aselcpias, are as follows: Antioch (June 15), Havana (June 21), Herod (May 29), Iiankakee (June 29), Mt. Carmel (Mlay 26), Sliawneetown (May 27), Urbana (May 2S, 31, June 6), 192S; Bluff Springs (May 2). 1929 .

\section{YZOCALLIS TILIAE (LIXXAEUS)}

Aphis tiliae Limnaeus, Systema Naturae, Editio Decima, 1758, p. 452.

This species was first reported in Illinois from Chicago and vicinity by Davis (1!)(1)b) under the name of Callipterus tiliuc. It lives on the undersides of the leaves of basswood (Tilia americana). It is easily determined by its clouded wings. It is another one of the species of this supertribe which are widely distributed in North Imericá and Europe. 1 ll forms have been described and figured in detail by Davis.

Data associated with our alate and apterous viviparous specimens are as follows: Antioch (.Iune 16), Starved Rock State Park (June 1:3), Urbana (July 6. 7. Aug. 6, 11, Sept. 26), 1925; Chicago (July 13). Urbana (Oct. 16), Waukegan (July 13), 1929. Sexual forms were taken at Urbana on Oct. $16,1929$.

\section{MY"ZOCALLIS WALSHII (MONEL1)}

F11:. 393

Colliptrous walshii Monell, Bulletin of the United States Geological and Geographical Survey of the Territories. Vol. V, No. 1, January 22, 1879 , Art. 1, 1). 2!.

This species has nut leen previously recorded from Illinois. Onr collections indicate that it is quite widcly distributed in the state. We 
are considering it a distinct species from . M. bellu (Walsh). from which it differs in having much lightuter-colored legs. particularly the prothoracic legs, and lighter-colored wings and lateral stripes. Our determinations of certain of our slides of this species liave been checkerl ly. Dr. Granovsliy. Specinnens have been collected on the undersides of leaves of various oaks and hichories (Qucrens alba, Q. iclutinu, Q. imbricuria. Qucrus sp., and Carya sp.).

Data associated with our specimens are as follows: Danville (Sept. 18). Golconda (Oct. 13). Havana (June 20, 21 , Marshall (May 25), Mt. Carmel (May 26, 28), Oregon (June 28), Shawneetown (May 27), Lrbana (June 6, July 10, 26, Ang. 23, 25, Sept. 26), 1928; Beach (July 13). Cairo (June 22), Decatur (Oct. 12), Metropolis (Sept. 28), Starved Rock State Park (July 6). Crbana (Oct. 14), 1929: Trbana 1Oct 14), 1930. Sexual formis and mating pairs have been taken on Oct. 14, 1929, and 1930, at Lrbana.

We have a series of slides collected on Jume 1, 1!rs, at Metropolis. Illinois, which may represent spring forms of this species or. . punctata Monell, or again may represent a new species. We have preferred to consider them for the present as undetermined.

Descriptions of the undescribed sexual forms are presented here:

\section{ALATE MALE}

Size and goneral color.-Length from vertex to tip of anal plate, 1.37. Width of head across eyes, .40. Head and thorax dark browll except the metathorax and a longitudinal dorsal area on each side of meson of prothorax, which are luteous, and the scutellum, which is conspicuously brownish black; abdomen pale greenish yellow, with the gonapophyses brown. with from two to several pale-brown lateral tubercles, and witl seven segmentally arranged, oblong, blackish-brown areas on the dorsum forming a mesal band running the length of the abdomen. Antennae grayish brown. with basal lialf of third segnent and extreme bases of fourth and fifth segments paler. Legs as in alate viviparous female, bnt with the femora infuscate with grayish brown. Wings as in alate viviparous female.

Structure.-Average comparative antennal lengths as follows: $111-$ $.47,1 \mathrm{~V}-.31, \mathrm{~V}-.29$. VI -.15 plus .28. Secondary sensoria present on all segments of flagellum, averaging in number as follows: $111-26,15-13$. V- 10, VI- 4. Abdomen with small lateral tubercles as mentioned in color description. Dark patches of abdomen bearing one or two lateral setae. Remaining structure, except gonapophyses, as in alate viriparous female

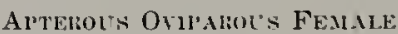

Length from vertex to tip of abdomen, 1.S6. Width of head across eyes, .38. Venter of entire body and ground color of dorsum greenish yellow. Antennae greenish white with the apical portion of the third, fourin and fifth segments and sixth except base, blackish. Dorsum of body with brownish black areas, these areas bearing tubercles upon each of which is a capitate seta. Arrangement of color pattern and setae as in Fig. 333. Cornicles dusky. Legs mostly concolorons with body, but with tarsi and extreme apices of tibiae blackish

Average comparative antennal lengths as follows: IIl- .34. IV- .2., V- .22, VI- .16 plus .29. Secondary sensoria absent on antennae. Hind tibiae swollen, with abont 70 sensoria. Cornicle and caluda as in alate rivi. parous female.

Allotype.-Alate male; Slide No 9699. Urbana, Illinois. October 14. 1930. on Quercus alba. (T. H. Frison). On slide with other males. Morphotupe. -Apterous oviparous female; Slide No. 9703, same data as allotye. Cn slide with oviparous fenule. 


\title{
GENUS NEOSYMIYDOBIUS IBAKER
}

\author{
Iicy to the species of the cienus Neosymyrobius
}

1. Sixth antennal segment with the terminal filament shorter than the base (Fig. 245)......................

- Sixth antennal segment with the terminal filament as long or

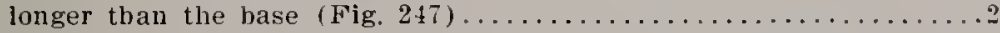

2. Secondary sensoria of third antenual segment extending from near base to about two-thirds the length of segment (Fig. 254)

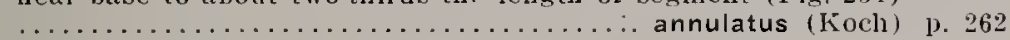

- Sccondary sensoria of third antennal segment extending from near base almost to apex of segment (Fig. 255 )...............

3. Secondary sensoria on third antennal segment averaging about nine; head and thorax brown, abdomen dorsally essentially lemon yellow; on oak................memorialis n. sp. p. 262

- Secondary sensoria on third antennal segment averaging over twenty; color essentially brown; on birch.americanus (Baker) p. 261

\section{NEOSYMIDOBIUS ALBASIPHUS (DAMS)}

F1G. 245

symylobius albasiphus Davis, Canadian Entomologist, Vol. XLVI, No. 7, July, 1914 , p. 226 .

Daris described this species from specimens among others collected at Elgin, Illinois. Since then it has not been reported in literature. In Illinois we fund that this species has no preference between the npper and lower surfaces of the leaves of certain oaks, and that it is ustially, if not always, attended by ants. All forms of this plant louse were described and illustrated by Davis. The gronjps of sensorialike structures on the lateral portions of the thorax and abdomen have not been mentioned in the descriptions. Our determination of this species has been verified by Dr. Granovsky.

Data associated with our specimens, all collected on Quercus macrocarpa or Qurreus stellata, are as follows: Catlin (Sept. 27, Oct. 6), Cave-in-Rock (Oct. 12), Elizabethtown (May 29, 31, June 31), 1928; Elizabethtown (June $20), 1929$. Sexual forms have been collected at Catlin and Cave-in-Rock on dates already mentioned.

\section{NEOSYMYDOBIUS AMERICANUS (BALER)}

symydobius americanus Baker, Canadian Entomologist, Vol. L, No. 9, September, 1918 , p. 319.

This species has not previously been reported from Illinois. It was collected only once, in extrence northwestern Illinois, where the white, or canoe, birch (Bctula alba var. papyrifera) is abmolant and native. The specimens were found feeding on the young growth near base of trees.

All forms except the male have been described by Baker in the original description. According to this same author, the records of Patch (1:10b) of $S$. oblongus Heyden from Maine refer to this species.

Our material consists only of apterous specimens collected at Galena, July $10,1929$. 


\section{NEOSYMYDOBILS ANNLLATUS (KnCH)}

Fik. 254

Chaitophorus annulatus Koch, Die Pflanzenläuse, Aphiden, Nürnherg, Heft. I, 1854, p. i.

This species, widely distribtted in North America and Etrope. has not previotsly been reported from Illinois. We have fotnnl it quite generally distributed in the state on the undersides of the leaves of cut-leaf birch (Bctula pondulu). Generically there is so little rlifference between this species, formerly placed in an assortment of scinera. and species already placed in the genus . Nosymydobius that we have placed it in the latter genus. The fact that apterous viviparous forms are common throughout the year indicates that it does not belones in the gents (alapliis in a narrow sense as most recently placed. Ian der Goot (1!)1.j) and Davidson (191ia) have descriled the sexual forms as well as viviparous forms.

Data associated with our viviparous specimens are as follows: Oregon (June 28), Quincy (June 1), 192S; Carlinville (Sept. 12). Champaign 1Oct. 7. 9), Decatur (Oct. 3, 7), Galena (July 10), 1929. Sexual forms have heen taken at Decatur and Champaign in company with viviparous forms on dates already given. A mating pair was taken at Champaign on October 9. 1424.

\section{NEOSYMYDOBIUS MEMORIALIS new species}

FIGS. $81,150,211,247,255$

Al.ATF. VIVIPAliot's Fr.uli.k.

Size and general color.-Average length from vertex to tip of anal plate. 1.32. Head and thorax essentially chestnut-brown with darker markings: some specimens have the prothorax and head slightly lighter in color than the renaining thoracic segments. Abdomen lemon yellow on dorsum and posterior regions, with seven pairs of lateral dusky patches on the sides; cornicles arising from lateral patches but slightly lighter in color than the area around their base; anal plate concolorous with abdomen, but the cauda is a shade less yellow than the abdonen and slows some indications of being dusky, particularly along its outer margin. The first two antennal segments are concolorous witl the head, the third segment is lighter in color than first and second segments except that apical one-fifth again becomes concolorous with these segments; fourth and fifth seguents whitish except for apical brownisl bands equal to about one-third the length of the segments: the base of the sixth segment is approximately half white and half brown. whereas the terminal process gradually sliades from almost white to larker towards the apex and is never more than a dark dusky color. Femora of pro- and mesothoracic legs usually considerably lighter in color than the metathoracic femora, being yellowish-brown. with the dorsal regions somewhat darker; metathoracic fenora brown except for extreme bases, which are yellowish; tibiae of all legs yellowish, usually slightly dusky at base and before apex: tarsi light brown. Stigma of fore wings light fuscous; veins brownish, anal and cubital velus darkest. all veins bordered with a light tuscous suffusion: surface of wings covered with brownish scale-like structures. Beak yellowish except extreme tip, which is browish.

Henl and uppendages.-Average width of head across eyes, .40. Antenual segments with comparative lengths as follows: 11 I- .31 to .43, average .36: IV -.20 to .26 , average $.23 ; V-.14$ to .23 , average $.20 ; V 1-.10$ to .14: average .12 plus. 16 to .21 , averige 20 . Secondary sensoria (Fig. 255 ) limited to third antemal segnent; varving in number from eight to ten. nine being the more common number; arringed in a straight row the length 
oi segment and unusually large. The beak extends to the coxae of the mesothoracic pair of legs.

Thorax and appcndages.-The prothorax is quite prominent and extended laterally; upon this lateral extended area, particularly the posterior half, are grouped from six to eight sensoria-like structures. The fore wing witl an accessory radial thickening (Fig. 55) and with media twice-forked; the second fork of the media is not always constant in position, but it is usually midway between the first fork of the media and the margin of the wing; an interesting feature of the venation of the wings is that none of the veins reach the margin of the wing. The tibiae of all legs are quite liairy, the longest hairs exceeding the width of the segment; hind tarsi are about equal in length to the base of the sixth antennal segment.

Ablomen.- The lateral dusky patches on the margins of the abdomen. except the patch surrounding the cornicles, contain sensoria-like structures similar to those found on the prothorax, they are very difficult to Jocate and count, but appear to number three or four to a patch. The cornicles (Fig. 150) are short and ahout as long as the anal plate, with sides slightly incurved and the valve considerably sunken. The cauda (Fig. 211) is distinetly bilobed and covered with long hairs.

\section{Al'terol's Viviparol's Female}

size and general color.-Average Jength from vertex to tip of anal plate, 1.58. Head jale yellowish, thorax light dusky brown except for a few pale irregular patches, abdomen yellowish and without lateral markings. First antennal segment essentially concolorous with the head, except for a brownish tinge on the anterior margin of the segment; second segment whitislı; third, fourth, and fifth segments whitish except for narrow dusky brownish bands at their apical ends which increase in intensity and length respectively; sixtl segment whitish at base, then with a dark brownish area extending from about the middle of the basal portion of the segment to just beyond the primary sensorium; this band, in turn, is followed by a light area, which is followed by a dusky terminal area. The cornicles, cauda, and anal plate are concolorous with the abdomen. Legs mainly whitish-yellow, each with a dusky-brownish spot on the dorsum of the apical region of the femora (darkest on the femora of the metathoracic pair of legs); tarsi with apical halves dusky. The beak concolorous with body except extreme tip, which is dusky.

Hear and apluendagrs.-Average width of head across eyes, .40. Antennal segments with comparative lengths as follows: $11 \mathrm{I}-.39$ to .44, average .41; $1 \mathrm{~V}-.24$ to .26 , average $.25 ; \mathrm{V}-.17$ to .23 , average $.20 ; \mathrm{VI}-.10$ to .14 , average .1: plus .13 to .21 , average .17. Secondary sensoria few or lacking; when present, only on third antennal segment; distribution irregular (one specimen luas four secondary sensoria on one antenna and one on the other); situated near the apex or middle area of the segment. The beak reaches hetween coxae of the meso- and metathoracic legs.

Thorud and allyendages.-The prothorax with sensoria-like structures on posterio-lateral margins similar to those of the alate viviparous female. The tibiae have long decumbent hairs; the tarsi are slightly over half as long as the filth segment of the antennae.

$A b r o m r n$. - The lateral margins of the abdomen have segmentally arranged sensoria-like structures similar to the alate viviparous lemales but the light color of the abdomen makes their differentiation exceeding difficult. The abdomen of this form is otherwise similar to the abdomen of the alate viviparous female.

\section{Apremots Onimous Frinak}

Size and genroul color.-Average length from vertex to tip of anal plate, 1.28. Head nainly yellowish with a tinge of fuscous, thorax mainly dusky brown; abdomen yellowish on dorsum and witl fuscous lateral patches. First and second antennal segments essentially concolorous with head, remaining segments as in apterous viviparous female. Femora light dusky yellow, dorsal regions darkest, posterior femora considerably darker than 
anterior pair; tibiae of pro- and mesothorax nniformly light dusky, posterjor tibiae darker than tibiae of anterior pairs of legs; all tarsi light dusks:

Head and apprndages.-Average width of head across eyes, 41 . Antennal segments with comparative lengths as follows: III- .36 to .37, average .35; IV - .21 to .26, average .23; $Y-.19$ to .20 , average .19; VI- .14 to 14 . average .14 plus .20 to .21 , average .20 . No secondary sensoria on antennae. The beak extends to the coxae of the metathoracic pair of legs.

Thorax and appentages.-Prothorax similar to prothorax of apterous viviparols female. Hind tibiae swollen and thickly studded with sensoria. which extend from base to about two-thirds length of the segment; as many as 60 sensoria lave been counted on a tibia. but this is scarcely more than an estimate because they are very difficult to count accurately.

Abdomen.-Lateral portions of abdonen similar to alate viriparous female except that there appear to be fewer sensoria-like structures. Cornicles similar to cornicles of alate viviparous fenale. Cauda not discernib!e or distinctive characters not evident. Ovipositor elongate and typical for genus.

Hololype.-Alate viviparous female; Elizabethtown, Illinois, May 31. 1928, on Quereus strllatu. (Frison and Hottes). Slide No. 10103. Morpholype. -Apterous viviparous female; Elizabethtown, Illinois, June 20, 1929. on Quercus stellata, (Frison and Hottes). On slide with two nymphs. Slide No. 10104. Morpholype.-Apterous oviparcus female; Elizabethtown, 11linois, October 12, 1928, on Quercus slellata. (Frison and Hottes). On slide witl apterous viviparous and oviparous female and nymphs. Slide No. 10105. Paratypes.-Eighteen slides of alate and apterous viviparous females. oviparous females, pupae and nymphs: all collected at Elizabethtown. Illinois, on Quercus stellatu, by T. H. Frison and F. C. Hottes, on May 29-31 and October 12, 1928 , and June 20, 1929. Slides Nos. 10106-10120 and other unumbered.

This species is probably most closely allied to Acosymydobius albasiphus (Davis), from which it may be separated at once iy it: color and by the fact that the terminal process of the sixth antennal segment is much longer than its base. This species occurs in natnre on the same leaves with Ncosymylobius albasiphus (Davis) and is found an both the clorsal and ventral surfaces of the leaf. It seems to preier the regions close to the mid-rib and principle reins. Specinens were sent to Dr. Granovsliy for examination, who confirmed our belief that it was undescribed.

Since this species was first collected on Nemorial Day, in 1!1!? the sprecific name of momorialis has been assigned to it.

\section{GEN'S PHYLLAPHIS Kocu}

\section{PHYLLAPHIS FAGI (LINAETS)}

FIGs. 13, 159

Aphis fugi Linnaeus, Systema Naturae, Addition 12. 1767, p. 735.

This widely distribnted species has not provously leen reported from Illinois. It occurs in floceulent masses on the undersicles of the leaves of beach (Fagus grandifolica). which occurs as a native tree in extreme southern 11 linois and in a few ofher comties in the state. Thus far we have taken this species only in southern fllinois in woods where the beach was abundant and never on specimen trees in other parts oi the state. Future collecting may reveal its presence in lemilion Comnty, Jllinois, where some small stancls of native beach still exist. 
Good accounts of the habits of this plant lonse and descriptions of all the forms are given by Swain (1919) and Theobald (192:). The latter author states it often does a great deal of harm to beach trees and hedges in Europe.

Data associated with our apterous viviparous specimens are as follows: Marshall (May 25), 1928; Jonesboro (June 23), Mounds (June 21), 1929.

\section{Genus SALTUSAPHIS Theobald}

\section{Key to the species of the Genus saltusaphis}

1. Alate and apterous viviparous females with posterior margin of abdomen distinctly bilobed (Fig. 215) ........elongata Baker p. 265

- Alate and apterous viviparous females with posterior margin of abdomen not distinctly bilobed, almost truncate (Fig. 219)....

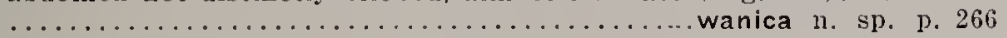

\section{SALTUSAPHIS ELONGATA BAKER}

Figs. $215,233,321$

Saltustphis clongatus Baker, Canadian Entomologist, Vol. XLIX. No. 1, January, 1917, p. 4.

This elongate and vellowish species has not previously been reported from Illinois: in fact we are not aware that it has been reported from other than the typic locality of New Jersey and Madison, Wisconsin. At Seynour, Illinois, in a low prairie habitat, this species is very common, and it has been under observation from June until the last of October. It is most easily taken by sweeping species of Carc.r. Evidently no alate viviparous fenales are produced and the sexual forms are likewise apterous. Our determination of Saltusaphis clongatus has been verified by Dr. Granovsky. Since we know of no description of the male of this species, the description of this form is presenterl.

Data associated with our apterous viviparous females, all taken on Curex sp., are as follows: Beach (Aug. 30), Mineral (July 8), Seymour (June 13, 26, July 20, Aug. 6, Oct. 7, 16,30), Silvis (July 9), Villa Ridge (Aug. 30), 1929. Sexual forms were first observed at Seymour on Oct. 16, 1929, and were very numerous on Oct. 30,1929 , when mating pairs were collected.

\section{Aptizots MaLE}

Size and ycumal color.-Average length from vertex to tip of cauda. 1.90. Body pale yellow, with anterior portion of head, extreme lateral margin of abdomen, and cornicles pale yellowish brown; dorsum of thorax and abdomen with small brownisb spots between segments, some spots confluent. Genitalia dark brown. Femora pale yellow, tibiae and tarsi slightly dusky. Antennae with first two segments and base of third concolorous with vertex, remainder of flagellum uniformly dark brown except that terminal filament is sometimes as light as the base. Beak yellowisl except for extreme tip which is brownish.

structurr.-Average width of head across eyes, .40. Comparative lengths of antemmal segments as follows: $111-.79$ to .97 , average $.87 ; 1 V-.49$ to .51 . average $.50 ; \mathrm{V}-.43$ to .47 , average $.46 ; \mathrm{V} J-.20$ to .21 , average .21 plus .36 to .39 , average .37 . Secondary sensoria (Fig. 233) located on the third, 
fourth, and fifth antennal segments, all arranged in a very recular row and very minute, average distribution as follows: III -20 , IV- $10, V-12$, greatest variation from average being 2 . All segments very finely imbricated. Posterior extremity of body much like that of apterous oviparous female except that the posterior notch is less deep.

tllotype.-Apterons male; Slide No. 8244, Seymour, Illinois, on carex sp., October 30,1929 , (T. H. Frison). On slide with oviparous female; mating pair.

\section{SALTUSAPHIS WANICA new species}

$$
\text { FIı:s. 219, 23т, } 242
$$

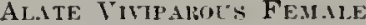

Size and gencral color.-Length from vertex to tip of anal plate, 2.19. General color of body light yellowish with dusky brown lateral patches. Head light yellowish on dorsum with light dusky brown patches laterally and anteriorly. Prothorax with mesal third of dorsum yellowish and with lateral portions light dusky brown; mesothorax with dorsal lobes light brown and lateral portions yellowish; metathorax yellowish with small dusky patches at sides. Abdomen light yellowish with lateral spots on first seven segments; cornicles, cauda, anal plate, and an irregular oblong patch in center of dorsum, a dusky brown; posterior to dorsal patch are five or six small dusky spots; lateral to large spot on dorsum, and following this. are several groups of from 2 to 3 minute dusky spots. Cornicles situated in, and concolorous with, the lateral dusky spots. First and second anteunal segments yellowisl dusky; third segment, with the exception of the extreme base, uniform brown; basal half of fourth and fifth segments yellowish, apical portions brownish; sixth antennal segment with the terminal process somewhat lighter than the base, otherwise concolorous with apical portion of fiftl. Pro- and meso-thoracic femora yellowish with brownish markings towards apex; meta-thoracic femora yellowish at the base and extreme tip, otherwise brownish. All tibiae vellowish except for extreme tips, which are dusky; tal'si dusky. Stigma of fore wings light dusky brown with a brownish suffusion posteriorly; veins light brown, ending in brown. ish suffusion, posterior portion of wing in vicinity of anal vein dusky brown. lieak yellowish with extreme tip light brown.

Head and appendages - Average width of head across eyes, 43 . Antennal segments with the following comparative lengths: III $-.5 \%$; -.40 ; $\mathrm{V}-.33 ; \mathrm{Vt}-.20$ plus .21. Secondary sensora (Fig. 23i) confined to third antennal segment, arranged in a straight row, varying greatly in size and numbering 11 and 12 . Marginal sensora on sixth antenual segment probably lacking. All segments very finely imbricated and sparsely clothed with exceedingly fine hairs. Head with vertex rounded, with ino rather large spine-like hairs on the front and with numerous, scattered, foer hairs. Beak very short, reaching only to posterior margin of prothorax. Ocelli well developed, lateral ocelli close to eyes.

Thorar and ap)endag's.-Prothorax with postero-lateral corners turned outward, the sicles somewhat bell-shaped in contour, thickly set with gland. ular structures on the dorsun; mesal half of mesonotum also glandular. Stigma of fore wings long and narrow, second fork of media considerably (loser to margin of wing than to the first fork. Hind femora with about 1? sensoria on inner surface.

Abromen.-Cornicles mere elevated pores, typical for the genus. Pos. terior extremity of abdomen transverse, at most only a little indented on the meson. Cauda .10 long, distinctly knobbed; canda and posterior extremity with a few spine-like hairs. Anal plate hilohed. Entire surface of abdomen coverel with exceedingly small, delicate imbrications. Surface of thorax and abdomen very sparsely covered with mushroom-like lairs.

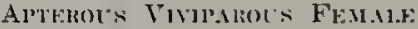

Sizc and frneral colm.-Average length from vertex to tip of anal plate. 2.31. llead, thorax, and ablomen pale yellow; thorax and abdomcn oc- 
casionally with exceedingly faint dusky markings along lateral margins, in rare cases abdomen with narrow, faint, somewhat broken, fuscous, transverse bands on the dorsum. Eyes reddish-brown. First and second antennal segments concolorous with head; third segment very pale yellowish except for extreme apical portion, which is dusky brown; fourth with basal half to two-thirds yellowish, remaining portion dusky brown; fifth with varying amount of the basal portion yellow, and the remaining portion dusky brown; sixth segment dusky, usually with the terminal filament lighter thin base, and extreme base pale. Legs entirely pale yellowish. Beak yellowish with extreme apical jortion light dusky brown.

Head and appenilages.-Average width of head across eyes, .44. Antennal segments with the following comparative lengths: III- 44 to .59, average $.49 ;$ IV -.27 to .36 , average $.32 ; \mathrm{V}-.26$ to .34 , average $.30 ; \mathrm{VI}-.17$ to 23 , average .21 plus .17 to .21 , average .20 . Secondary sensoria absent. Marginal sensoria on sixth antennal segment probably lacking. Beak reach ing just beyond prothoracic coxae. Anterior margin of head considerably arched with tour long hairs near center.

Thorad-Prothorax with posterior margin expanded, but not with postero-lateral portions produced. Mlushroom hairs more abundant than on alate form.

Ablomen.-Cornicles similar in shape to those of the alate viviparous female. losterior portion of abdomen quite variable in shape, sometimes not unlike that of alate viviparous female, at other times considerably indented and somewhat prolonged laterally. Cauda (Fig. 219) .09 iu length; it and anal plate (Fig. 219) similar to those of alate viviparous female Angular portions of abdomen posterior to cornicles, with long spine-like hairs. Abdomen finely imbricated. with short mushroom-like hairs.

Holotype.-Alate viviparous female; Mitchell, Illinois, June 25, 1929 on Carex sy.. (Frison and Hottes). Slide No. 10626. Morphotype.-Apterous viviparous female; Cairo. Illinois, June 22, ]929, on Carex sp., (Frison and Hottes). On slide witl nymphs. Slide No. 10627. Paratypes.-Twentyeight slides containing pupae, apterous viviparous females, and nymphs, all collected in Illinois on Carex sp. by T. H. Frison and F. C. Hottes. The dates and localities are as follows: Beach (August 30), Cairo (June 22), Elizabethtown (June 20), Galena (July 10), Mitchell (June 25), Seymour (June 13, 26, July 20, Oct. 7), Wenona (July 5), Woodford (July 5), 1929. Slides Nos. 5599-5602, 5608-5611, 5629-5630, 10628-10641 and others unnumhered.

This species is closely related to $S$. airginicus Baker, but differs in having ammulated antennae and the terminal filament of the sixth antennal segment subequal to the base. Specimens of this species. questionably determined as $S$. airginicus, were submitted lo Dr. Granorsky for determination, and he very kindly reported after a comparison with types of inginicus that they were likely a new species.

\section{SIENAHWELA new genus}

Cornicles small, cylindrical, tapering to tip, without flange. Cautcla rounded at apex, showing almost no constriction. Anal plite scarcely indented. Antennale with six segments. Dorsum of alolomen without tubercles. Fore wings with media twice-forked. Differs from Drepanaphis in being smaller; in having differently shajeed cornicles. the anal plate less indenterl, and the cauda not knoblued ; and in lacking prominent clorsal tuluercles.

(ienotype, Dropunaplis minutus Davis, by original and present designation. 


\section{SHENAHWEUM MIÑUTTM (DAYS)}

FIG. 325

Drepanaphis.' minutus Davis, Entomological News, Vol. XXI, No. 5, May. 1910 , p. 195.

This species was described lyy Davis from specimens collected at Glencoe, Illinois, September 2. 1909. on Accr saccharum. We failed to find this species during our collecting in various parts of the state during the last three years.

\section{Genus STEGOphyld.t Oestllid}

\section{STEGOPHYLLA QUERCICOLA (BAKEI)}

Phyllaphis quercicola Baker, Entomological Xiews. Vol. Xxill. No. S. October, 1913 , p. 362 .

Until the appearance of Baker's paper (1916b), qucrci Fitch was the name used by American writers for at least two species belonging to widely separated genera, one of which was the species now under discussion. The first definite record of qucrcicola (Baker) from Illinois is the listing of Davis (1911a), under the name of Phyllaphis? querci (Fitch), of specimens collected on oaks at Aurora. Chicaso. Danville. Joliet, Normal, Peoria, and Rockford, Illinois. Baker (1916ib) proposed Plyyllaplis qucrcicola as a new name for the form now uncler discussion.

Davis (1!11a) has given a good account, as well as detailed descriptions of all stages, of this aphid. It lives in small scattered colonies on the upper and lower surfaces of leaves of various species of oaks and produces a rather dense flocculence. Daris states that hoth alate and apterous males are produced. It is interesting that all our males collected in southern Illinois (Herod and Cave-in-Rock) are winged, whereas those from central Illinois (Lrbana) are a"l apterous.

Data associated with our specimens are as follows: Cave-in-Rock roct. 12), Decatur (Oct. 3), Mluncie (Oct. 6), 192S: Columbia (Sept. 11). Herod (Sept. 27), Starved Rock State Park (Aug. 14), I'rbana (Oct. 11). 19:9: Urbana (Oct. 24), 1930. Collections made in late September and October at Cave-in-Rock. Herod, and Trbana, include the sexual forms. No winged viviparous females lave been taken.

\section{GENLS TAMALIA BAKER}

\section{TAMALIA COWENIl (CAKEKHL)}

Ficis. 33, 83, 244

Pemphigus concni Cockerell, Canadian Entomologist. Vol. XXXll. No. 11. November. 1905 , p. 392.

The collection of this gall-making insect in lllinois is interesting in that its host, the bearberry, has a very restricted clistribution in llinois and is sometmes considered as a boreal relic. Because of the 
strict fidelity of $T$. coareni (Ckll.) to the gents to which its host belongs, it is very probably confined to the sandy beach area along Lake Michigan in northeastern Illinois. This plant louse causes the leaves of bearberry to fold over and form a sort of bladder-like wall (Fig. 33) within which the aphicls live well protected from some of their enemies.

Good descriptions and illustrations of all forms are given by Gillette (1909a) and Essig (1915). There has been considerable doulbt concerning the generic relationships of this aphid, and it has been placed

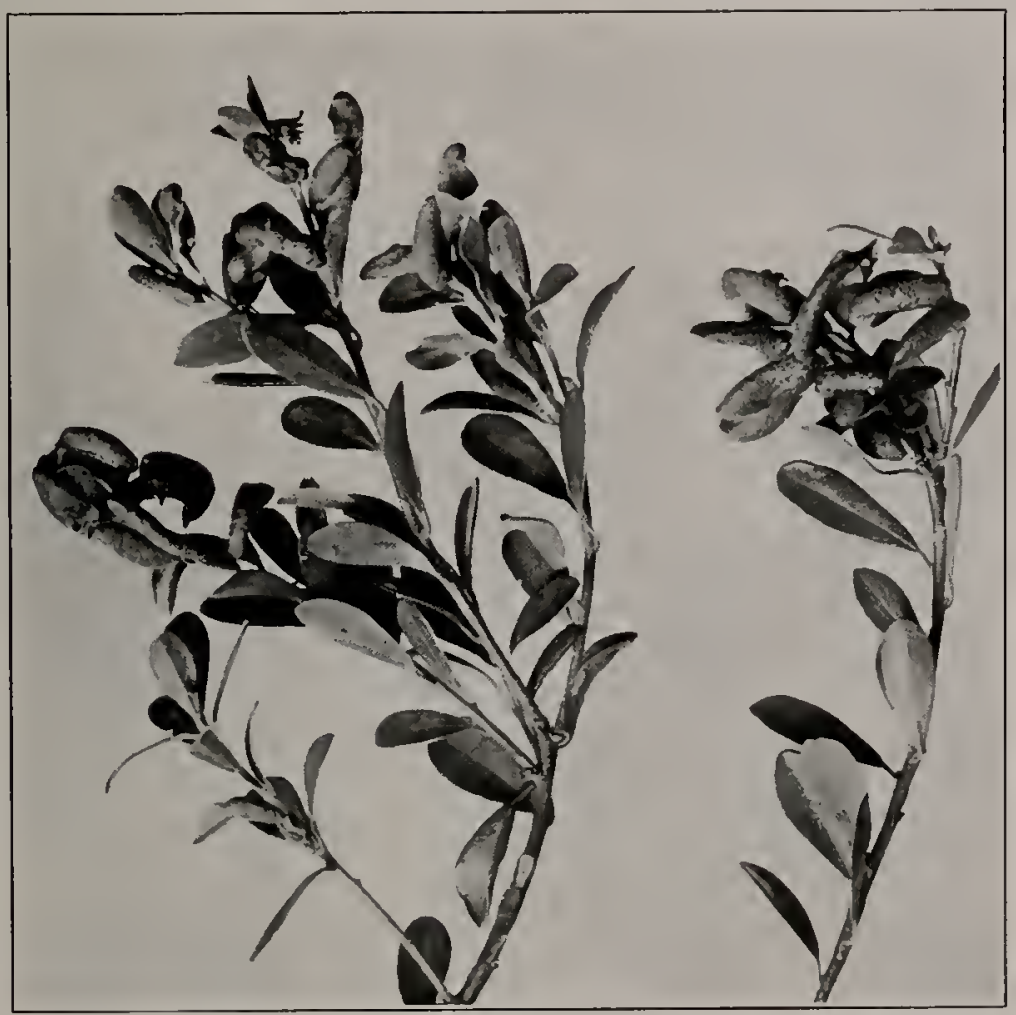

Fig. 33. Bladder-like galls of Tamalia coucni (Cockere]l) on the bearberry, Arctostaphylos Uva-ursi, caused by folding together and swelling of leaves; Beach, July 13, 1929.

in about as many different genera as there are citations to it in literature. We believe that Baker $(1920)$ was correct in making a new genus for this species. Baker $(1920)$ in his original description of the genus states that the media of the fore wing is unce-branched, whereas this should read twice-branched. One feature in the biology of this insect is that the oviparous females are winged.

All of our material has been collected on Arctostaphylos lva-ursi at Beach, Illimois; the alate and apterous viviparous females on July 13 , and the oviparous females on August 29, 1929. 


\section{GENL' THRIPSAPHIS Gillette}

Key to the sipecies of the Genus Thripstphis

(Based upon apterous viviparous forms because alate forms are not common or are undescribed.)

1. Third antennal segment longer than width of head through the eyes ........................ verrucosa Gillette p. 271

- Third antemnal segment not longer than width of head through

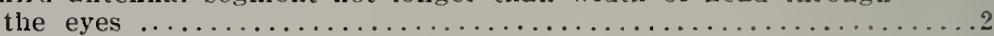

2. Third antennal segment with two or three secondary sensoria; posterior portion of body terminating in a rounded point (Fig. 218), hody never with transverse grey bands..producta Gillette p. 270

- Third antennal segment without secondary sensoria: last transverse segment with its posterior margin of abdomen almost straight and sides broadly rounded (Fig. 212); body always

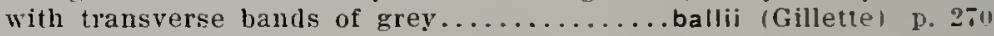

\section{THRIPSAPHIS BALLII (GILLETTE)}

Flis. 212, 324

Brachycolus ballii Gillette. Canadian Entomologist. Vol. XL. .No. 2. February, 1908 , p. 67.

This aphid has not previously been reported from Illinuis: in fact, it has been recorded from only three states. Colorado, New Jersey. and New York. It was transferred to the genus Salusuphis lo Baker (191:a) and later made the genotype of Thripsaphis (iillette (1!1:b). The alate and apterous viviparous females have been described and figured by Gillette (1909) ). Like the other species of this genus, it nay be collected on various species of Carr.r, but sweeping tor it is much less ef fective than a careful examination of the leaves.

Data associated with our alate aud apterous viviparous specimens are as follows: Decatur (Sept. 29), 1928: Allerton (June 17). Decatur (June 12). Hower (June 17), Lawrencevilte (Jnne 1S), Lisle (July 14), Mitchell (June 25), Seymour (June 13, Oct. 7), 1929.

\section{THRIPSAPHIS PRODLCTA GILIFTTE}

Fig. 218

Thripsaphis producta Gillette, Canadian Entomologist. Vot. XIIX. 1917. p. 196.

This is the first record in literature of this species having been talien since it was described by Gillette from material collected in Colorado. It was found at mily one locality in lllinois. (Only the alate and ilpterous viviparous fomales have been described.

Our material consists sotely of the apterous viviparous females and nymplis collected on (rarer st., at t)anville on July 16 and 22, 1930. 


\section{THRIPSAPHIS VERRUCOSA GILLETTE}

Fig. 322

Thripsaphis verrucosa Gillette, Canadian Entomologist, Vol. XLIX, 1917, p. 194.

This aphicl, with the peculiar projection from the vertex, has not previously been reported in literature as having been taken outsile of the typic locality of Colorado. Its host is the same as for the other secies of this genus, namely, Carex. The oviparous female was included through error in the original description of $T$. ballii (Gill.). This mistalie was later corrected by Gillette when the specific name oi a'crrucosa was proposed. Since only the oviparous female has been described, a description of the apterous viviparous female is here presiented.

We have taken only apterous viviparous females, at Danville on July 16 and $22,1930$.

\section{Aptelous Vivilahous Female:}

Length from anterior margin of vertex to tip of abdomen, 2.29. Wilth of head across eyes, .49. Body entirely pale yellow except the eyes and the antennae beyond and iucluding the extreme apex of the third segment, which are black, and the extreme apex of the tarsi, which are dusky.

Average comparative antennal lengths as follows: III -.56, IV -.32 , V- .29, VI - .16 plus .19. Secondary sensoria ahsent. Cauda, anal plate, and terminal segment of abdomen as in Fig. 322. Otherwise, except in secondary sexual characters, as in apterous oviparous female.

Iorphotype.-Apterous viviparous female; Slide No. 9411. Danville, Illinois, August 22, 1930, on Curer sp., (Hottes and Tauber).

\section{GENUS TUBERCULATUS MURdYLKO}

\section{Key to the species of the Genus Tuberculatus}

1. Wings with dark fuscous markings; on oaks..punctatella (Fitch) p. 2i1 Wings clear, without dark fuscous markings; on elm..........

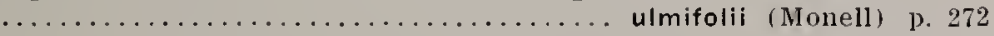

\section{TUBERCILATI'S PUNCTATELLA (FITII)}

\section{FIGS. 56, 319}

th his punctatelle Fitch, Transactions of the New York State Agricultural Society, Vol. XIV, 1854 (printed 1855), p. 869.

This species is here reported from llinois for the first tine. Because of the well-rleveloped tubercles on the dorstmin, it is here considered as belonging to the genus Tuberculatus. It is to be lonked for on the mudersides of oak and hickory leaves. Only the alate viviparous females lave been described (Baker, 1!11 ib).

Data associated with our alate specimens, all collected on Quereus macrocarpa, Quereus alba, Quereus velutinu, Quereus sp., and carya sp., are as follows: Danville (Sept. is), Decatur (Oct. 23), Metropolis (June 1), MIt. Carmel (May 26), Rock Island (June 24), Shawneetown (May 27), 1928; Colliusville (Sept. 11). Malionet (Aug. 17), Starved Rock State Park (Aug. 14, Sept. 10), Urbana (Oct. 11), 192!; Starved Rock State Park (May 13). 1930 . 


\section{TUBERCULATLS LLMIFOLII (MOXELL)}

Callipterus ulmifolii Monell, Bulletin of the United States Geological and Geographical Survey of the Territories, Vol. T, No. 1, January 22, 15i9, Art. 1, p. 29.

Gillette (1910) first reported this species fron Illinois (Chicago). Soon after this it was reported by Davis (1!10d) as being abundant on elms in Illinois, and sometimes "sufficiently common to do injury, causing the foliage to drop prematurely and coating the upper surfaces of the leaves with honey dew." Our records indicate that this yellowish species, which inhabits the undersides of elm leares, is quite generally distributed in our state. It may be collected throughout the year on this host, as it does not migrate. Descriptions of the male and oviparous iemale of this species, which have not previously appeared in the literature, are given here.

Data associated with our alate viviparous females and $n y m p h s$ are as follows: Champaign (June 12, 18), 1886; Cave-in-Rock (Oct. 12), Danville (Sept. 18). Oakwood (Sept. 17), St. Joseph (Aug. 5), Urbana (July 26), 192S; Bloomington (July 5). Cairo (June 21), Edwardsville (Sept. 11), Elizabethtown (June 20), Galena (July 10), Grayville (June 19), Hardin (June 25), Olney (June 18), Rock Island (July 7), Starved Rock State Park (July 6), Urbana (Oct. 9), Waukegan (July 13), 1929. Sexual forms were taken at Urbana on October 9, 1929. Collected on Clmus americana. Llmus alata, and limus fulva.

Alate ilate

Average length, 1.00. General color brownish, tubercles darkest; antennae and legs yellowish, except apical portions of femora and tarsi. Which are light dusky. Genitalia dark brownish-black. Stigma with a large central clear spot, margins brownish, veins brownish with more or less brownish suffusions at their origin. Average width of bead across eyes, .40. Antennae with the following average comparative lengths: III - .45; IV - .24; $\mathrm{V}-.1 \mathrm{~S}$; VI - missing. Secondary sensoria present on the third, fourth, and fifth antennal segments, always arranged in a straight row, numbering as follows: III- $13 ;$ IV - $4 ; \mathrm{V}-3$. Second fork of media closer to margin of wing than to first fork.

\section{Apteroys Oniparol's Female}

Average length from vertex to tip of anal plate, 1.45. General color brownish; candal region of abdomen yellowish; antennae and legs ver: light yellowish, except for apical portions of anteunal segments which are dusky. Average width of head across eyes, .37. Average comparative lengths of antennal segments as follows: III $-.30 ; \mathrm{IV}-.18: \mathrm{V}-.18$; VI -.12 plus 12. Secondary sensoria absent. Hind tibiae much swollen and with numerous sensoria, which, because of the light color of the tibiae, can not be counted. Hairs on boty distinctly enlarged at the tip and situated on tubercle-like bases.

Allolype.-Alate male: Slide No. S6ss, Urbana, Illinois, on $T 7 m u s$ americana, October 9, 1929. (T. H. Frison.) On slide with oviparous female and

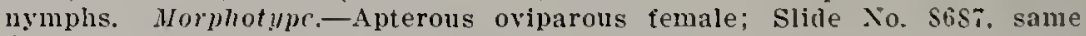
data as allotype. On slide with male and nymplis.

The cotypes of callipterus ulmicoia Thomas, previously recorded by Davis (1913) and placed as synonymous with $T$. ulmifolii (Monell), are mounted on Slide No. 7166 and have the following data associated with them: Sauk City, Wisconsin, June, on elm, collected by Bundy. 


\section{SUPERTRIBE MACROSIPHEA}

\section{Key to Genera}

1. Radial sector of fore wing deeply curved downward and either united with media to form a closed cell beneath stigma (Fig. $74)$ or almost uniting with nedia (Figs, 58,66 ) $\ldots \ldots \ldots \ldots \ldots \ldots 2$

- Radial sector of fore wing not deeply curved downward, no

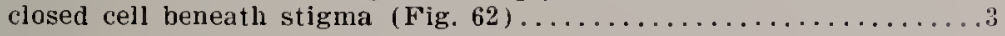

2. Hind wings normally with two oblique veins (Fig. 91), closed cell of fore wings, if present, three-sided (Fig. 5S).......... $\ldots \ldots \ldots \ldots \ldots \ldots \ldots \ldots \ldots \ldots \ldots \ldots \ldots$ Idiopterus

- Hind wings normally with one oblique vein (Fig. 95), closed cell of fore wings always present and at least four-sided (Fig.

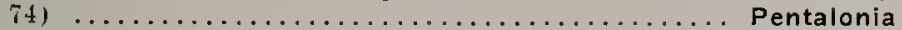

\section{Pentalonia}

3. Hind wing without oblique veins (Fig. 96) .......Microparsus p. 333

- Hind wing with oblique veins (Fig. 91) ...................

4. All veins of fore wings conspicuonsly outlined with wide fus-

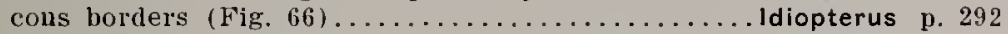

-. Some veins of fore wings not couspicuously outlined with fuscous (Fig. 72), a few species with cubitus and anal veins so

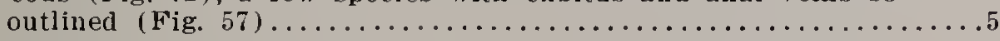

5. Head with antennal tubercles prolonged into finger-like processes

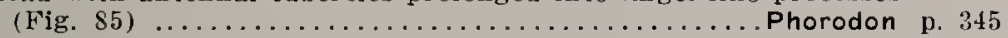

- Head with antennal tubercles not prolonged into finger-like pro-

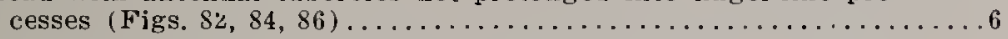

6. Head with antennal tubercles converging (Fig. S6) or projecting forward (Fig. S2); apterous viviparous females with (Fig. 82 ) or without (Fig. S6) conspicuous globate hairs on front of head between antennae..................................... viviparous females without conspicuous globate hairs (Fig. 84)

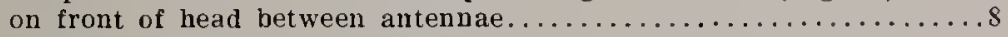

7. Apterous viviparous females always with conspicuous globate hairs (Fig. 320) on front of head between antennae......... $\ldots \ldots \ldots \ldots \ldots \ldots \ldots \ldots \ldots$ Capitophorus Apterons viviparous females without conspicuous globate hairs on front of head between antennae...................... p. 334

8. Cornicles bulging or swollen (Figs. 121, 126, 127), usually conspicuously so and never with sides entirely straight......... $\ldots \ldots \ldots \ldots \ldots \ldots \ldots \ldots \ldots \ldots$ Amphorophora

Cornicles essentially cylindrical or tapering (Figs. 100, 113, 115), not conspicuously swollen; sometimes, however, with apex of cornicles constricted and (in $M$. ribicllum and $M$. (rataegi) cor-

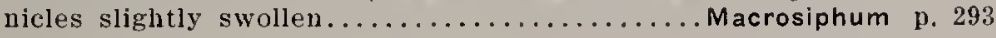

\section{GENUS AMPHOROPHORA BuCKTON}

\section{Key to the species of the Genus Amphorophora}

1. Apex of cornicles distinctly reticnlated (Fig. 126) ..........

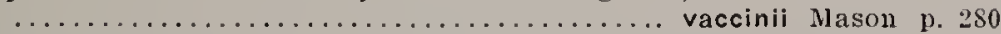
Apex of cornicles not reticulated but sometimes imbricated

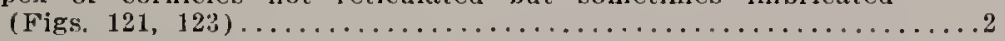

2. Secondary sensoria present on third, fourth, and fifth antennal

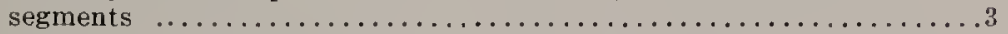

- Secondary sensoria always lacking on fifth $\operatorname{segment} \ldots \ldots \ldots \ldots \ldots \ldots \ldots$ 
3. Cornicles much longer than width of head through eyes; hind

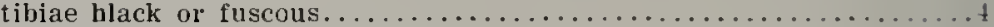

-. Cornicles shorter or not longer than width of head through eyes;

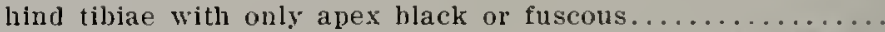

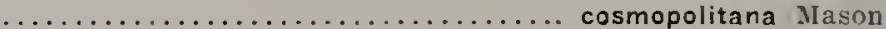

4 Cornicles much shorter than fourth antennal segment and weak-

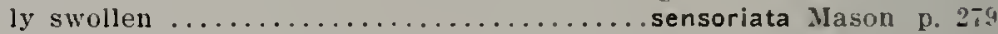

-. Cornicles longer than fourth antennal segment and strongly swollen ........................nabali (Oestlund) p. 275

5. Secondary sensoria numerous on fourth antennal segment.... $\ldots \ldots \ldots \ldots \ldots \ldots \ldots \ldots \ldots \ldots \ldots \ldots \ldots \ldots$ sensoriata Mason p. 279

- Secondary sensoria lacking on fourth antennal segment............6

6. Cornicles scarcely more than three times as long as greatest diameter and entirely black................solani Thomas p. 280

-. Cornicles five or six times as long as greatest diameter and hlack, fuscous, or greenish brown ....................

7. Fourth and fifth antenual segments with basal portion light and apical portion fuscous or black; cornicles entirely dark or black; cubitus and anal veins of fore wings conspicuously outlined with fuscous borders..............nervata (Gillette)

- Fourth and fifth antennal segments uniformly light, fuscous, or black: cornicles ranging from black to greenish-brown: cubitus and anal veins of fore wings rarely conspicuously outlined

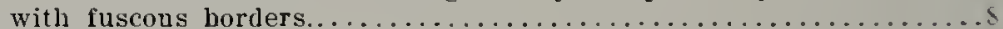

8. Cornicles without a flange (Fig. 122) at apex [alate form unknown but keyed out here on hasis of apterous viviparous

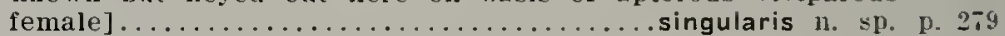

- Cornicles with a distinct flange at apex (Fig. I2:3) ...............

9. Third antennal segment with few secondary sensoria. eight in typic specimen (Fig. 305), arrauged in a straight row......

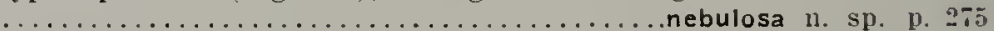

-. Third antennal segment with numerous secondary sensoria. twenty to fifty or more (Fig. $30 \pi$ ), arranged in a very irregular

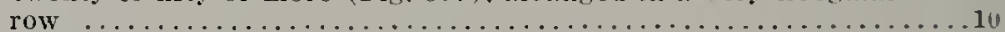

10. Third antennal segment with from 22 to 29 secondary seusoria (Fig. 307); cornicles much longer than width of head through eyes and approximately as long as third antenual segment... $\ldots \ldots \ldots \ldots \ldots \ldots \ldots \ldots \ldots \ldots \ldots \ldots \ldots \ldots$ rossi n. sp. p. 27i

- Third antennal segment with from 38 to 54 secondary sensoria; cornicles slightly longer than width of head through eyes and shorter than third antennal segment...........laingi Mason

p. 275

\section{AMPHOROPHORA COSMOPOLITANA M.ASON}

Amphorophoru cosmopolituna Mason, Proceedings of the Lnited States National Museum, Vol. 67, Art. 20, Sept. 23, 1925, p. 16.

Rhopalosiphum sonchi Davis, Journal of Economic Entomology. Vol. 3. No. 6. December, 1910, p. 495. Misidentification.

This widely distributed species has been recorded previously irom Illinois tuncler the name of Rhopalosiphum sonchi Oestlumel by [Davis (1910). It is widely distributed 1hroughout the state on Lachina and Sonchus. Mason (1!) mation in literature regarding this species and technical descriptions ui all forms. It altermates between various species of Ribes and such plants as Lacluca and Sonchus, occurring on the fomer in spring and late fall and on the latter in summer.

From in study of the actual specincus involved, kindly loaned to us by l'rofessor J. I. Davis. We have found that the Davis" (1910e) record of Rhopalosiphum sonchi "from nurthern Illinoss" refers to 
this species and needs to be added to the bibliography of this species as given by Mason. It is very probable, too, that the record of Siphonophora lactucac Linn. of Thomas refers to a species of Myzus insteat of to cosmopolitana as questiona!bly placed by Mason.

Data associated with our Jllinois viviparous specimens are as follows: Oak Park (Aug. 14), 1909; St. Joseph (Aug. 5). Urbana (Aug. 8, 15, 20. Sept. 26, Dec. 19), 1928; Cairo (June 22), Catlin ( May 17), Edwardsville (Sept. 11), Galena (July 10), Mattoon (Sept. 11), Melrose Park (July 12), Newton (June 17), Oregon (July 11), Riverside (July 14), Rock Island (July 9), Urbana (July 19, Oct. 9, 15, 21), 1929. The specimens taken at Catlin (May 17), 1929 , represent the spring generation and the specimens at Irbana (Oct. 21), 1929, the fall generation on Ribrs. All other specimens taken on Lactura, Sonchus sp., Sonchus oleraceus, and sonchus arvensis.

\section{AMPHOROPHORA LAINGI MANON}

Amphorophora laingi Mason, Proceedings of the United States National Museum, Vol. 67, Art. 20. Sept. 23, 1925, p. 32.

This species is here recorded from llimois for the first time. Mason (19:5) has shown that American specimens previously detemined as .H. ampullata Buckton are distinct from the types of $A$. ampullata Buckton and, accordingly, has renamed the species. He gives (lescriptions of the apterous and alate viviparous females and accepts the descriptions of Van der Goot $((191, j)$ as applying to the male and oviparous female. Very little is known aljout this species except that it attacks various genera of ferns.

We have taken it but once, by sweeping ferns at Starved Rock State Park, July 6, 1929.

\section{AMPHOROPHORA NABALI (OESTLINU)}

Rlonpalosiphum nabali Oestlund, Fourteenth Annual Report of the State Geologist of Minnesota, March, 1886, p. 34.

This species has not been recorded previonsly from Illinois. Although we have taken it in only five scattered loca'ities in the state, it probably occurs wherever its host is common. Slides of our material have leen compared with cotypic material in the collection of Dr. O. 11 . ()esthund. Mason (1925) has described in detail the alate an:l apterous viviparous females. The species tends to congregate on the upper part of the stalk and flower heads of its host.

Data associated with our viviparous specimens, all collected on Pronauthrs alba, are as Iollows: Choat (Sept. 28), Herod (Sept. 27), Makanda (Sept. 28), Oakwood (Oet. 17), Starved Rock State Park (Aug. 14, Sept. 10), 1929.

\section{AMPHOROPHORA NEBTLOSA new species}

FIGs. 127, 164

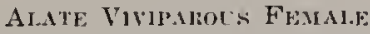

Nize and general color.-Length from vertex to tip of anal plate, 1.56. Head. thorax, and abdomen essentially uniformly brown, with some lighter areas laterally. Cornicles brown with a trace of green; anal plate brown; cauda yellowish. First and secoud antennal segments concolorous with the 
head, gibbous portion of first segment slightly darker than remaining portions; third antennal segment yellowish at base and slightly so near apex, whereas the portion covered by the sensorium is brownish; remaining segments uniformly yellowish. Basal portion of femora yellowish, shading gradually to dusky brown towards apex; tibiae yellowish with apices dusky brown; tarsae dusky brown. Veins of wings rather light in color, cubitus and anal veins slightly margined with fuscous. Beak yellowish, tipped with dark brown.

Hearl and appendages.-Average width of head across eyes, .46. Antennal segments with comparative lengths as follows: III - .50; IV - .t3; V- -36 ; VI- .16 plus .79. The secondary sensoria (Fig. 305) are eight in nnmber, limited to the third antenual segment, and are arranged in a straight row about equally distant from the anterior and posterior ends of the segment. The primary sensorium on the sixth antennal segment is of interest because of the lack of marginal sensoria. The beak reaches just to the coxae of the mesothoracic pair of legs.

Thorax and appendages.-The second fork of media of fore wing is slightly closer to the margin of the wing than it is to the first fork; radial sector strongly bowed; stigma gray, ratber short. The tarsi appear comparatively short, the second segment exclusive of claws being one-third the length of the caucia.

Ablomen.-Cornicles (Fig. 127) rather slender but gradually swollen. faintly imbricated, slightly shorter than third antennal segment, with a distinct flange at their apex; their length is .47. The cauda (Fig. 16t) is abont $t$ wice the length of the base of the sixtl antennal segment, is distinctly constricted, and has two and three hairs on a side; its length is .30 . The anal plate is rounded.

A I'TERUI's VIVIPARot's Fenal.e

Sizf and grucral color,-Average length from vertex to tip of anal plate. 1.13. Head, thorax, and abdomen brown as in alate viviparous female, prothorax with lateral margins and abdomen posterior to the cornicles lighter brown. Femora varying in color from yellowish to light dusky brown; tibiae almost unitormly brown, some perhaps a little darker towards the tip; tarsi brownish. Cornicles, canda, and anal plate as in the alate viviparous female. Beak colored as in alate viviparous female.

Heat and appendagrs.-Average widh of head across eyes. .41. Antennal segments with comparative lengths as follows: $111-.39$ to .43 , average .41; $\mathrm{IV}-.24$ to .24 , average $.24 ; V-.24$ to .24 , average .24 ; VI- .13 to .14. average .13 plus .50 to .54 , average .52 . Antennae without secondary sensoria: hair on the antennae exceedingly fine and short. The beak extends slightly beyond the coxae of the metathoracic pair of legs. Antennal tubercles poorly developed; in fact, nuany species belonging to the genus th $p$ is have the tubercles as well developed.

Thorax and appentulges.-Tibiae of the first two pairs of legs subequal. a little less than five times the length of the base of the sixth antennal segnent: hind tibiae much longer, almost twice as long as the terminal filament of the sixth autennal segment.

Abromrn.-Cornicles shaped as in alate viviparous female and either equal or subequal in length to the third antennal segment; average length. .39. Cauda one-third the length of the terminal filament, with two hairs on a side, but slightly constricted; average length. .17.

Holotype.-Alate viviparous female; Starved Rock State Park. Illinois, August 14, 1929, on $P o u$, (Frison and Hottes). Slide No. 103S2. Morphotype. -Apterous viviparous female; same data as holotype. Slide No. 10383. Partypes.-Two slides of pupie, nympl, and apterous viviparous female: sama data as holotype. Slicles Nos. i 03\$4-10385.

The tyjes of this species were found on a species of aratss ( $P$ ou $)$ growing on the ledges of a small canyon in Starved hock state Park. Illinois. Apparently the closest ally of this new species is A. norata (Gillette) irom which it can be distinguished by its stroner antennal 
tubercles, shorter terminal filament of the sixth antennal segnent, and its wider head in proportion to length of cornicles. This species was submitted to Dr. P. W. Mason who confirmed our supposition that it was new.

\section{AMPHOROPHORA NERVATA (GII.FTTE)}

F1G. 123

Rhopalosiphum nervatum Gillette, Canadian Entomologist, Nol. XL, No. 2. February, 190s, p. 63.

This species is here recorded from Illinois for the first time. The extremely limited distribution of its host plants in the state precludes this aphid from having a wide distribution. Mason (19.25) has reclescribed all the linown forms; he states that in California this plant louse "seens to migrate between rose and Arbutus."

We have taken viviparous specimens of this species only once, at Beach, July 13, 1929, on Arctostaphylos Uva-ursi.

\section{AMPHOROPHORA ROSSI new species}

FIis. 121, 17т, 307

\section{Alate Viviparot's Feidil.e}

Nizp and general color.-Length from vertex to tip of anal plate, 2.14 . Head, first and second and extreme base of third antennal segments, and mesothorax a light hrownish green; protborax, metathorax, coxae, trochanters, abiomen, and anal plate except apical margin a light apple green; abdomen with a medial line and lateral margins a dark green, areas between lighter green, venter uniform dark green. Cornicles with trauslucent brownisl green at base and with swollen area often fuscous; cauda light whitish green. Antennae beyond base of third segment almost black. Femora whitish green at base, shading to light brown at apex; tibiae light brown with a dark brown or black area at apices equal to three times length of tarsi; tarsi lark brown or black. Beak with basal segment whitish green. middle segment light brown, apical segment black. Wings hyaline: stigma, costa, and subcosta a light brown except that bases of latter two are whitish; veins almost of equal width, black. Eyes and base of ocelli brownish black.

Herd and appenduges.-Average width of bead across eyes, .54. Antennal segnients witl comparative lengths as follows: III- .79 to .84, average $.80 ; \mathrm{IV}-.53$ to .64 , average $.60 ; \mathrm{V}-.44$ to .59 , average $.51 ; \mathrm{VI}$ - .13 to .16 , average .14 plus .71 to .83 , average .78. The secondary sensoria (Fig. 30 T) are restricted to the third segment; although not in a straight row, they are confined to one side of segment and extend its full length except for a distance equal to length of the second antennal segment: they numher from 22 to 29 and average 26 . The antennal tubercles are quite well developed. The beak extends slightly beyond the coxae of the second pair of legs.

Thorad and appendarfs.-The second segment of the tarsus, exclusive of claws, is about one-fourth the length of the cauda or as long as the second antenual segment. The second fork of media of tore-wing in relation to the first fork and margin of wings is variable.

.1 blompn. - The cormicles (Fig. 121), .64 in length, slightly longer than the fourth antennal segment, only moderately swollen, the swelling being slightly more pronounced on the inmer margin; apical llange quite well developed: the area immediately anterior to the flange very faintly inbricated. The cauda (Fig. 17T) . .3t long, is twice the length of the base of the sixth antennal segment, with a sliglit indication of a constriction just beyond the middle and four hairs on a side. The anal plate is quite long for its width and rather narrowly rounded at its apex. 


\section{Apterous Vivilarot's Female (Frydatilix)}

Size and general eolor.-Length of single specimen, 2.00. Head, including first two antennal segments, and borders of prothorax a whitish green. Remainder of thorax, anal plate, coxae, trochanters, and basal third of femora apple-green. Abdomen, except for dark green medial longitudinal stripe, a whitish green. Cornicles pale translucent brownish green, with extreme apex dark brown. Third, fourth, and fifth antennal segments greenish brown with the extreme apex dark brown; sixth segment entirely dark brown. Apices of femora and all of tibiae light brown. apices of tibiae darker; tarsi dark brown. Beak as in the alate viviparous female. Eves brownish black.

Heall and appendages.-Average width of head across eyes, .53. Proportional length of antennal segments as follows: III $-.54 ; 1 \mathrm{~T}-.53$; T.29 ; Vl- .12 plus .37. Secondary sensoria absent. Fifth and sixth antennal segments imbricated, others smooth. Primary sensorium on sixth antennal segment with a group of marginal sensoria at one side. Antennal tubercles strongly developed. Hairs on head and antennae knobbed. Beak reaching to midway between meso- and metathoracic coxae.

Thorax and appendages.- Tibiae with hairs on basal half shorter than width, those on apical half subequal to width. Hairs on appendages botls normal and knobbed.

Ablomen.-Cornicles .47 in length, distinctly more swollen on inner than on outer margin, flange at apex poorly developed. Canda 22 in lengtl. stout, broadly rounded at apex, not constricted, with three pairs of inwardly directed hairs on each side. Anal plate normal.

\section{Apterous Viviphots Fratale: (VThgugesia)}

Size and general color.-Average length from vertex to tip of anal plate. 2.30. Differing from stem mother in color only by being a slightly lighter shade of green.

Head and appendages.-Average width of head across eves. .5s. Antennal segments with comparative lengths as follows: III- .79 to .S4, average $.80 ; \mathrm{IV}-.53$ to .64 , a verage $.60 ; \mathrm{V}-.44$ to .59 , average $.5 \mathrm{I}$ : VI- 13 to .I6. average .14 plus .71 to .83 , average .78 . Secondary sensoria limited to the third antenual segment and numbering from one to two. The beak extends to the middle of the coxae of the metathoracic pair of legs.

Thorax and appendages.-Similar to appendages of alate viviparous female, except for lack of wings.

Ablomen.-Cornicles .78 in length, almost always slightly more than twice the length of canda, abont equal to the lengtli of the third antennal segment, with an average length of .72. Cauda and anal plate shaped as in alate viviparous female: cauda with an average length of .32 .

Holotype.-Alate viviparons female; Urbana, Illinois, May 3, 1930, on Geum cunadense. (Frison and Ross). Slide .No. 1035s. Morphotype.-Apterons viviparous female (fundatrix); Same data as for holotype. Slide .ro. 10360. Marphotype.-Apterons viviparous female (virgogenia): Same data as for holotype. On slide with one paratypic apterons riviparous female Slide No. 10359. Paratypes. - Thirtyeight slides of alate and apterous viviparons females, pupae, and nynphs: all collected in Illinois by T. H. Frison, F. C. Hottes, and H. H. Ross from Grum canarlense. Other data are as follows: Muncie (October 6, 192S) and Urbana (May 3, 22 and July 26) Slides Nos. 10361-I03s0 and others nnnumbered.

This species was stbmitted to Dr. P. II. Mason for exanumation because it could not be satisfactorily determined to sjecies in the key published in his revisional paper of this gent1s (1925). Dr. Masoin reported that the species was muknown to him. The alate viviparous female keys to A. nabali (Oestlund) in Dr. Ilason's paper. but differ: from that species by the alsence of secondary sensoria on the fourth and fifth antemal segments. The apterous viviparous females rum in Dr. Matson's key to A. ceransi Theobald which, jotelginge from the non- 
swollen cornicles, is probably not an Amphorophora. A. laingi Mason is apparently another closely allied species from which it differs by the characters given in our key.

\section{AMPHOROPHORA SENSORIATA MASOX}

Amphorophora sensoriata Mason. Proceedings of the Entomological Society of Washington, Vol. 25, No. 9, December, 1923, p. 189.

This species has not previonsly been reported from Illinois. It may be found by examining the stems of new shoots of its host. Our records inclicate that it is generally distributed throughout the state. The species quickly drops from its host when distributed. and it is believed to have no alternate host, although the sexual forms are as ret unkmown. Technical rescriptions of the viviparous forms are given by Mason $(1923$ and 1925$)$.

Data associated with our viviparous specimens, all collected on $R$ ibus sp., are as follows: Bloomington (Aug. 14), Chicago (July 13), Galena (July 10), Jonesboro (Sept. 28), Lisle (July 14), Mlahomet (Aug. 17), Morrison (July 9), Oakwood (July 22), Oregon (July 11), Pana (Sept. 10), Richmond (July 12), Starved Rock State Park (Aug. 14), Urbana (July 22), 1929 .

\section{AMPHOROPHORA SINGULARIS new species}

$$
\text { Fins. 122, } 306
$$

Aptelot:s Vivipakols Frinate

size und general color.-Length from vertex to tip of anal plate 1.47 . Head light brown; thorax and abdomen brownish-yellow (probably badly faded, abdomen witl small clear areas at base of cornicles; cornicles very dark brown; cauda and anal plate light brownish, approximately concolorous with abdomen. First and second antenual segments concolorous with the head, third antennal segment with basal part anterior to sensorium yellowish and remainder of segment dark brown, remaining three apical segments dark brown. The coxae, trochanters and basal three-fourths of femora are yellowish, apical fourtl of femora dark brown: tibiae alternately marked with yellow and brown, yellowish at their base for a distance about equal to the length of the second antennal segment, then dark brown for a distance about equal to one-half of the length of the third antennal seg. ment, then becoming yellowish again for a distance ahout equal to the length of the cornicles, and finally terminating as brownish to the tarsia distance about equal to half the length of the cornicles; tarsi brownish. Beak yellowish, except for the last two segments, which are a light-brown.

Head and appendages.-Average width of head across eyes, 44. Antennal segments witl comparative lengths as follows: III- 54; IV- .51; V-.44; VI- .14 plus .90. The third antennal segment (Fig. 306) lias a single sensorium situated about the length of the first antennal segment from its base at a point where the brown color begins. The beak reaches just beyond the coxae of the mesathoracic pair of legs.

Thoras and ampendages. - The tibiae of the pro- and mesothoracic pairs of legs are about equal to twice the length of the fifth antennal segment; the tarsi comparatively short, without the claws being equal to or slightly longer than the second antennal segment.

Abromen.-Cornicles (Fig. 122 ) .47 in length, approximately sub-equal in length to the third antennal segment, very gently and gradually swollen, ending very abruptly and without a flange, very faintly imbricater. Cauda. .29 in length, two-thircls as long as the cornicles, comparatively narrow, and with one to two hairs on a side. Anal plate roundly pointed. 
Holytulue.-Apterous viviparous female: Golconda, Ilinois, Octoher 13. 1928, on unknown species of grass (Frison and Hottes). Slide No. $103 \$ 1$.

This species is suggestive of our new species Amphorophort ncouluris, from which it may be separated in the apterous vivipasous females by the single sensorium on the third antennal segment. the ditference in the comparative lengths of the antennal segments. the diiferently colored legs, and the shorter beak. In Dr. P. II. Masm : (1925) revision of the genns Amphorophora this species heys to $A$. formosano. Takahashi from Formosa. It differs irom the original description of formosana in that the third, fourth. fifth. and sixth antennal segments are very much shorter and more near?y equal and the cornicles are about uniformly swollen on both sides.

\title{
AMPHOROPHORA SOLANI (THOMAS)
}

Hegoura soluni Thomas, Eighth Report of the State Entomologist on the Noxious and Beneficial lnsects of the State of Illinois, 1879, p. 73.

This species is represented in the surver collection ly a single specimen, the type, taken by Thomas at Carbondale. Illinois. It was collected on tomato in association with other specinens including pupae -an indication that its association with this host was not accidental.

Data associated with this slide (.No. 2772) are as follows: Carbondale (May 26), 1878 , on Tomuto occidentalis (=Lycopersicon csculcutum?) collected by C. Thomas.

\section{AMPHOROPHORA VACCINII IlAsU:}

Fici, 126

Amphorophoru varcinii Mason. Proceedings of the Lnited States National Inseum, Volume 67, Article 20, p. 67.

This species is here reported from Illinois for the first time. Our record is based nom a single collection of viviparons specinens at Grand Detour (May 15-16, 1990, on I'accinium z'acillans. Jason (191-35) has given technical descriptions of the viviparous and oviparons ienales.

\section{GENUS CAPITOPHORLS VAX nFR GOOT}

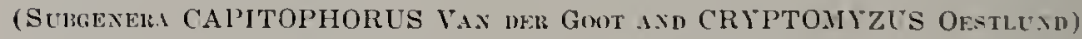

\author{
Key to the species of the renus capitophorus
}

1. Cornicles much shorter than fouth antennal segnent............

- Conicles approximately as long as, or longer than, fourth anten-

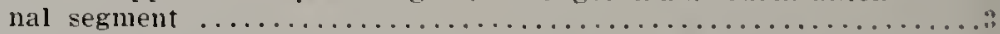

2. Secondary sensoria numerous on fourth antennal secment (about 24), a lew secondary sensoria on fifth antemnal segment: cornicles swollen................poae (Gillette) p. 290

- Secondary sonsolia lacking or few on fourth antennal segment (0 to 5), no secondary sensoria on fifth antennal segment: cornicles not swollen (Fig. 12s)...........patonkus n. sp. p. 25i 
3. Secondary" seusoria restricted to third antennal segment..........t Secondary sensoria at least on third and fourth antennal seg-

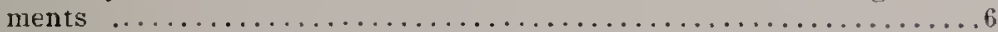

4. Cornicles much longer than fourth antenual segment; hind tibiae almost uniformly dark................... corambus n. sp. p. 281

- Cornicles shorter or approximately the same length as the fourth antennal segment; hind tibiae mostly light colored with apices

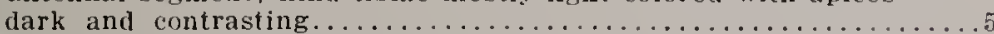

5. Width of head through eyes much wider than length of cornicles; cornieles dark; secondary sensoria on third antemnal

segment averaging over $30 \ldots \ldots \ldots \ldots \ldots$ tetrarhodus (Walker)
Width of head through eyes and cornicles of about equal length; cornicles, except for extreme apices, almost concolorous with abdomen: secondary sensoria on third antennal segment averaging less than $30 \ldots \ldots \ldots \ldots \ldots \ldots \ldots \ldots \ldots$ minor (Forbes) p. 284 6. Cauda blunt or rounded at apex (Figs. 163,167$) \ldots \ldots \ldots \ldots \ldots \ldots \ldots \ldots \ldots \ldots$
. Cauda tapering to point at apex (Fig. 174) $\ldots \ldots \ldots \ldots \ldots \ldots \ldots$

7. Texminal filanient of sixth antennal segment longer than third and fourth antennal segments together; seeondary sensoria on fiftl antennal segment ranging rom 7 to $12 \ldots \ldots \ldots \ldots \ldots$ $\ldots \ldots \ldots \ldots \ldots \ldots \ldots \ldots \ldots \ldots \ldots \ldots \ldots$ ribis (Limnaeus)

Terminal filament of sixth antennal segment shorter than third and fourth antennal segments together; seeondary sensoria on fifth antennal segment ranging from 0 to $2 \ldots$ pakansus 11 . $\mathrm{sp.}$ p. 286

S. Apieal portion of cornicles distinetly swollen.gillettei Theobald. p. 284

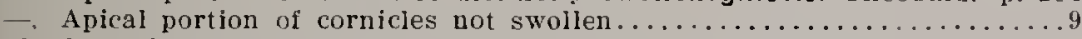

9. Secondary sensoria numerous on forth antemnal segment and ranging from none to many on the fifth; conicles nuch longer than width of head through eyes or length of fourth antemnal segment; on Cirsium or Elatagnus........flaveolus (Walker)

Secondary sensoria few on fourth antennal segment and usually lacking on the fifth; cornicles shorter than or about as long as width of head through eyes or length of fourth antennal seg-

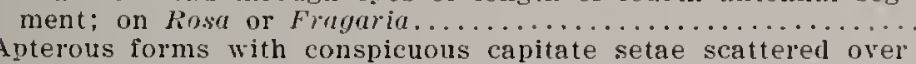
entire body; third antennal segment with secondary sensoria widely scattered and numbering about thirty............... $\ldots \ldots \ldots \ldots \ldots \ldots \ldots \ldots \ldots \ldots \ldots \ldots \ldots \ldots$ fragaefolii i Cockereli) p. 283 Apterous forms with conspicuous capitate setae restricted almost entirely to head and anal regions of abdomen; thircl antennal segment with secondary sensoria less scattered and numbering about twenty...............minor (Forbes)

\section{CAPITOPHORLS CORAMBUS new species}

FIGS, 125, 174, 259, 260

\section{Alate VIVIPAROUS FEMILE:}

Size and general color.-Average length from vertex to tip of anal plate, 1.2:). Head and thorax yellowish brown. Abdomen light yellowish green with brownish narkings around base of cornicles and posterior to them. Cauda and anal plate brownish. Cornicles with basal half yellowish brown, sliading to darker brown towards the apex. Antennae with first two segments concolorous with head and extreme base of flagellum pale yellowish, remainder of flagellum uniform blackish brown. Fenora with about the basal two-thirds yellowish and the remaining portion brown. Tibiae and tarsi usually fairly dark dusky brown, sonetimes apical portions of tibiae darker than the base. Beak light yellowish brown witl the extreme tip lark brown. Stigma of fore wings light dusky brown with the posterior nargin darkest, veins brown, cubital and anal veins darkest, veins failing to reach margin of wing but ending in a brownish sufitusion. that of the anal veins being the largest and darkest. 
Head and appendages.-Average width of head across eyes. .44. Antennal segments with comparative lengths as follows: III- .69 to .73. average .7l; IV - .40 to .43 , average $.42 ; \mathrm{V}-.37$ to .40 , average .39 ; VI -.10 plus.$S 6$. Secondary sensoria (Fig. 260) restricted to third antennal segment, irregularly arranged but distinctly more crowded on one side, in form rather tuberculate and varying in number from 31 to 36 . Primary sensorimm on sixth antemul segment with a group of about 5 marginal sensoria to one side. Hair on third antennal segment slightly knobbed, hair on remaining antennal segments blunt at tlie tip but not distinctly knobhed; base of bairs distinctly lighter in color than remaining portion of antennae and often suggestive of sensoria. Antennal tubercles well developed. Jedian portion of head between antennae with a prominent process from which capitate hairs arise. Beak reaching heyond hase of mesothoracic coxae

Thorax and appendages.- Hairs on tibiae short, rather spine-like, not longer than, if as long as, the width of segment; capitate hairs rare. Stigma of fore wings narrow, radial sector strongly curved. second fork of media distinctly closer to margin of wing than to the first fork.

Abdomen.-Cornicles (Fig. 125) averaging .55 in length, poorly imbricated througbout their length. somewhat constricted in the middle so that they have the appearance of being slightly swollen beyond the middle; the apex with a poorly developed rim. Cauda (Fig. 174) a little less than lialf as long as the cornicles, averaging .23 in length, not constricted or but rery slightly so, with four long non-capitate hairs on each side. Hairs on remaining portion of abdomen scarce but usually somewhat capitate. Anal plate inconspicuous in our specimens but apparently normal.

\section{Apterous VIVIJARots FeIIJLE}

Described from one poorly mounted specimen; hence no general description will be given except for general measurements and a few other rery obvious facts.

Lengtli 1.21. Width of head across eyes, .44. Antennal segments with the following comparative lengths: III $-.64 ; \mathrm{IV}-.36 ; \mathrm{V}-.33 ; \mathrm{VI}-.10$. terminal filament missing. Third antennal segment with niue secondary sellsoria (Fig. 259) on basal half arranged in an irregular row. Cornicles .60 , cauda .29 in length. Cornicles very similar to those of alate viviparous female, but perlaps slightly thicker. Cauda distinctly spatulate. with two hairs on each side. Hairs on body and antennae capitate, remaining hairs spine-like.

Holotype.-Alate viviparous female; Galena, Illinois, July 10, 1929, on Rosa sp., (Frison and Hottes). On slide with nymphs. Slide No. $1065 \%$ Morphotype.-Apterous viviparous female; same data as holotype. On slide with paratypic alate viviparous female. Slide No. 10658 .

This species is probably most closely allied to C. fotramoda (Walker). trom which it may be separated by the more swollen and longer connicles, the differences in comparative lengths of antennal segments, the length of the beak in the alate viviparous iemale, and the presence of secondary sensoria on the thircl antennal segment in the apterous viviparous female.

\section{CAPITOPHORUS FLAVEOLIS (WALKER)}

Apluis flaceole Walker. Appendix to the Zoologist for 1849 . Vol. VlI. p. Ir. Myzus braggii Gillette, Canadian Entomologist, Vol. XL. No. 1. January. 1908, p. 17. N'w symonymy.

This species las not been previotsly recorded from Illinois. IV have placed $M$ laus braggii Gillette as a svinomym of this species because the ielentical material, kindly determined for us as Har'olus by Dr. Theobalcl, has been compared by Mliss l'almer with cotypes of hraggii 
and declared to be the same. All references to $M$. clacaymi Del Guercio and $P$. galcopsidis Kalt. by Davis $(190$ sc, 19111$)$ ) evidently refer to $C$. gillettei Theoball, becanse the cornicles are stated and figured as having the apical portion swolles.

C. Alac'colus over-winters on Russian olive (Elacagnus) and in summer vccurs on thistle (Cirsium). The best general accounts and descriptions of this insect are given by Gillette (191j) and Theobald $(1926)$.

Data associated with our viviparous speciniens are as follows: Catlin (Sept. 27), Champaigu (Oct. 16), Herod (Oct. 12, Nov. 29), Urbana (Sept. 26, Oct. 19), 1928; Choat (Sept. 2S), Edwardsville (Sept. 11), Herod (Sept. 27), Jonesboro (June 23), Lisle (July 14), Macomb (May 5), Oakwood (Aug. 18, Sept. 22), Oregon (July 11), Rock Island (July 7), Urbana (May 9, Oct. 14), 1929. Collected on Cirsium lanceolatum, Cirsium sp., and Elapagnus sp.

\section{CAPITOPHORUS FRAGAEFOLII (COCKERELL)}

Fig. 320

Myzus fragacfolii Cockerell, Canadian Entomologist, Vol. Xxxill, No. 4, April, 1901, p. 101.

My us fraguriue Theobald, Entomologist, Vol. XLV, No. 591, August, 1912, p. 223. New synonymy.

This is the species referred to by most American writers on aphirls, probably including Davis (1910e), as $M$. rosarum Kaltenbach. It is not that species. however, because rosarmm, according to the descriptions of Kaltenbach $(18+3)$ and Theobald $(192(i)$, has slightly swollen cornicles and differs in other respects. As shown under the discussion of C. minor (Forbes), this form is entitled to specific rank, and fragacfolii (Cockerell) seems to be the oldest available name. The viviparous females are well described by Theobald (1926) and the sexual forms by Davidson (1914a).

Although frugacfolii was originally clescribed from material taken on Fragaria, we believe that the same species also occurs on Rosa and Potentilla. At any rate. we have been unable to separate certain material taken in Illinois on these hosts: specimens from all three plants agree with typic specimens of fragacfolii loaned to us by the U. S. National Muscum.

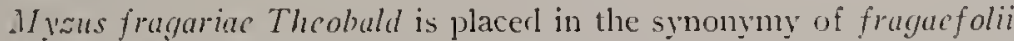
because of determinations of Theobald, who named certain of our slide mounts from Potentilla as fragariac. These specincens seem to us to be iclentical with specimens of fragacfolii.

Data associated with our material are as follows: Antiocl (June 15), Galena (June 26). Havana (June 21), Ogden (July 8), Oregon (June 28), Pekin (June 20), Urbana (May 28, 31, July 10, Sept. 11. Oct. 22. Nov. 11), 1928; Beach (.July 1:3), Edwardsville (Aug. 11), Galena (July 10), Lewistown (May 4), Macomb (May 5), Urbana (April 22), 1929; Oregon (Jay 16), Starved lock State Park (May 13), Trbana (Jay 20, Jume 13, July 12 , Nov, 16. 20, 21), 1930. Collected from Kosa rugrsi, Rosn sp., Potentilla monspeliensis, I'ntentilln sp., and Fragariu sp. Mating sexual fornis were found on November 11 . 


\section{CAPITOPHORLS GILLETTEI THEORALD}

Fig. 4

Capitophorus gillettei Theobald, The Plant Lice or Aphididae of Great Britain, Vol. I, London, 1926, p. 238.

This species (Fig. 4) has heen previonsly recorded from Illinois by Davis (1910b) under the name of Plorodon galcopsidis Kalt. It over-winters on Elacagmus sp., from which it migrates in spring or early summer to Polygomum sp., where it remains until time to remigrate in fall to Elacagmis. All forms except the oviparous temale liave been deseribed by Theobald in the original description.

The data associated with our lllinois viviparous specimens are as follows: Catlin (Sept. 27), Champaign (Oct. 16), Danville (Sept. 1S), Elizabethtown (Oct. 12), Golconda (Oct. 13), Muncie (Oct. 6), 1928; CatIin (.Jay 17), Edwardsville (Sept. 11). Urbana (Oct. 7-14), 1929; Oakwood (Oct. 22), 1930. Collected on Elaeagnus sp., Polygonum hyaropiper. Polygonum sp.. and Luphorbia marginata. The record from Euphorbia represents a capture of alates which were probably there as a result of drifting. The Illinois localities and dates of the Davis (1910) records are as follows: Oak Park (Sept. 11-27 and Oct. 10, 12, 27, 1909), and Urbana (Aug. 11, 1909).

\section{CAPITOPHORU'S MINOR (FURBES)}

Siphonophora minor. Forbes, Thirteenth Report of the State Entomologist on the Noxious and Beneficial Insects of the State of lllinois, 1SS4.p. 101.

In view of the fact that we have found two species of Cupitophorus on strawberry in Illinois, and miscellaneous descriptions of species from this loost in literature, a decision regarding the correct name to use for this species has been leset with difficulty. Through the kindness of Professor Davis and $M r$. Mason, slides with types of M y'ans porosus

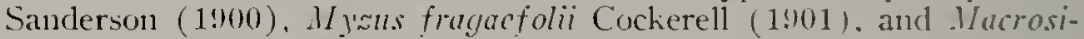
flum fraguriac var. immaculata kiley (1855) were sent to us for examinations. A deternumation of one of our slides as Cupifophorus fragariac Theobald (191:), by Dr. Theobald. has also aided.

Our study of these typic slides shows that the Myis porosus Sanderson belongs in the group for which we are using the generic name of $/ / y z t s$. It is similar to a species which we have taken on rose and which we were considering as new until we saw these ypic slides. Hence, this species, originally describerl from straberry, does not enter into the symonymy of Capitophorus.

The typic slide of $\dot{H}$. fragariac vas. immaculata Riley, also described from strawherry, is in stch poor condition that it is clonlutinl if the species can ever be placed. The frontal projections of the head are sufficient 10 show it is a Macrosiphum, and the cornicles are reticulate. This name, therefore, is also removed from consideration.

Typic slicles of M/ yous fragacfolii Cockerell, with botls alate and apterous specinems, prove this species to be a true Cufifophorus. The apterous forms have the entire body covered with numerous capitate or globate hairs, thus differing from Copitoplorws minor (Forbes). The alates are very sinilar to minor, but apparently differ in secondary sensoria of third antennal segunent. Since we have seen two cotypic slirles of fragacfolii in two collections, one slicle of which is in rery: 
poor condition and not associated with apterous forms, we are designating a slicle in the collection of the Uniterl States National Musemm as the lectotyic slide. Data associated with this slicle are as follows: "Jerome. Arizona, December 1\%. 1900, on strawherry, type of Myzus fragacfolii Cockerell, slide !33i."

A determination of a slicle in our possession as $C$. fragariac Theobald (1912). by Theobald, indicates that fragariac is a symonym of fragacfolii (Cockerell) and not of minor (Forles). This is also indicated by his description of the apterous forms.

The Siphonophora minor Forbes, with capitate hairs restricted to head and anal regions of the apterous forms, remains as a valid species. Slicle No. 315x in the Survey collection is the lectotypic slicle.

Since the male and apterous oviparous female have not previously been described. descriptions of these forms are here presented.

Records associated with our Illinois material are as follows: Nolmal (June 21), 1883; Kankakee (June 29. July 15), Muncie (Nov. 22), Urbana (July 10), 1928; Oakwood (Oct. 17), Savoy (April 18), Urbana (April 17, May 22), 1929; Urbana (April 8, May 20), 1930. All specimens collected on Fragaria sp. Sexual forms taken at Oakwood (Oct. 17). 1929.

\section{ALATE MI.ILE}

Average length from vertex to tip of anal plate, .7I. Head dark brownish; thorax dusky brown with some yellowisls; abdomen yellowish. with brownish spots on dorsum and lateral portions; cornicles, cauda, and anal plate, dusky. Antennae uniform brown. Femora yellowish at tbe base. remaining portion brown; tibiae light brownish, with the apical portions larker. Veins brown, posterior margin of wing in vicinity of anal vein brown. Genitalia dark brown.

Average wiclth of head across eyes, .31. Comparative lengths of antennal segments as follows: III- .44 to .49 , average $.47 ; \mathrm{IV}-.27$ to $.3 \mathrm{I}$, average $.28 ; V-.26$ to .31 , average $.29 ; \mathrm{Vl}-.10$ to .13 , average .11 plus .49 to .60 , average .54. Secondary sensoria present on the third, fourth, and fifth antenual segments. confined largely to one side of segment, those on third more scattered than those on fourth and fifth, distributed as follows: IIII6 to 22 , average 20 ; IV -6 to $\mathrm{S} ; \mathrm{V}-4$ to $\mathrm{S}$, average 7 . Primary sensorium with about four marginal sensoria at the side. Beak reaching to middle of mesothoracic coxae. Second fork of media closer to margin of wing than to hirst fork. Cornicles .19 long, straight, slightly imbricated, but not reticulaterl. Cauda .os long, with about three hairs on a sille.

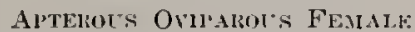

Average length from vertex to tip of anal plate, 1.20. Body yellowish with a slight brownish tinge on the head. Comicles, cauda, anat plate, and legs pale yellowish except tarsi, which are dusky. Antennae brownish except for extreme base of third segment and small ring-like areas at the apical portions of the third, fourth, and fifth segments, which are yellowish. Capitate hairs present on vertex of head, absent or very poorly developed on the second and third antennal segments, numbering about 2 on the first, fairly abundant on posterior regions of abdonen, but rarely found on other parts of the body. Average widtl of head across eyes, .30. Comparative lengths of antennal segments as follows: IIT- .33 to .37, average .35; IV.17 to 24 , average $.2 \mathrm{I} ; \mathrm{V}-.17$ to .26 , average $.22 ; \mathrm{VI}-.10$ to .13 , average .11 plus .49 to .66, average .54. Secondary sensoria absent. Beak reaching to about the midclle of the metathoracic coxae. Cornicles .33 long, in shape similar to those of viviparous female. Cauda .16 long, with about two hairs on a side. Tasal half of tibiae swollen, with about 35 sensoria.

Allotypr.- Alate male; Slide No. S40S, Oakwood, llinois, Octoher 17, 1929 , on Fragaria sp., (Frison and lioss). On slide with oviparous females. .horpholylur.-Apterous oviparons female; Slide No. 8407 , same data as allotype. On slicie with male and oviparous female. 


\title{
CAPITOPHORUS PAKANSUS new species
}

\author{
Figs. 119, 163, 25i, 258
}

Al.ATE VIFIPAHOCS FEMME

Size and general color.-Average length from vertex to tip of anal plate. 1.50. Head and thorax essentially green shading to brown, the brown dominating on dorsum and venter and the green on the lateral portions; abdomen yellowish-green with a median brownish rectangular patch on the dorsum. Cornicles lighter in color than the abdomen for about half their length, remaining portion light fuscous; cauda and anal plate concolorous with the greenish part of the abdomen. First and second antennal segments concolorous with head, third antennal segment light yellowish-green at extreme base, remaining portions of third antennal segment and the two following segments dark brown, sixth antemnal segment brown but much lighter, especially the terminal filament. Coxae somewhat fuscous, trochanters and bases of femora pale greenish, remainder of femora and fourfifths of tibiae pale yellowish-brown, apices of tibiae and tarsi dark brown. Beak greenish except for the extreme tip, which is brownish. Stigma slightly fuscous; veins brownish, the anal vein darkest, posterior margin of wing in the vicinity of the anal vein also brownish.

Head and appendages.-Average width of head across eyes, .37. Antennal segments with comparative lengths as follows: III- 37 to .43 , average $.40 ; 1 \mathrm{~V}-.26$ to .30 . average $.27 ; \mathrm{V}-.11$ to .26 , average $.20 ; \mathrm{VI}-.07$ to .09 , average .08 plus .57 to .60 , average .58 . Secondary sensoria (Fig. 25i) present on the third and fourth antennal segmeuts and sometimes on the fifth. The secondary sensoria distributed as follows: III- 37 to 44 , IV18 to 20 ; V- 0 to 2 . Sensoria widely scattered on the third and fourth antenmal segments, the third segment being somewhat tuherculate in appearance. Hair on the antennae exceedingly scarce, exceptionally short and fine although blunt at the tip. Antennal tubereles very poorly developed, the first antennal segment gibbous on the inner margin but no more so than in the genus Myzus. Beak slender, particularly the terminal segment, extending to the coxae of the metathoracic pair of legs.

Thoral and appendages.-Stigma long, narrow, and sharply pointed: second fork of media closer to the margin of the wing than it is to the first fork. Brownish areas at the apices of the tibiae distinctly swollen: hairs on the legs not capitate but pointed at the tip. increasing in length from the base to the apex of the segment, and declinate.

Ablomen.-Cornicles (Fig. 119) subequal to. or very slightly longer than, the third antennal segment, averaging 43 in length, of almost uni. form thickness throughout their length except that they are slightly thicker at their apices; without a distinct flange. Anal plate normal; cauda (Fig. 163) short, about as long as the base of the sixth antennal segment, wide and blunt but smaller than the cauda of a typical species of the subgenus Anuraphis.

\section{ALATE, MILE}

Size and yencral color.-Average length from vertex to tip of anal plate, 1.68. Head and thorax essentially greenisl shading to brown. the brown dominating on dorsum and venter aud the green on lateral portions. Abdomen, instead of luaving a single median spot on the dorsum, has three oblong transverse spots anterior to the cornicles. Antenuale brownish with the exception of the extreme base of the third antenual segment and the terminal process, which are lighter. Legs and cornicles very similar in color to the same structures of the alate viviparous female. Cauda and anal plate more tuscous than the abdomen. Wings similar to the wings of the alate viviparous female. Opercula dark brown.

Henl and appendage's.-Average width of head across eyes, .37. Anten. nal segments with comparative lengths as follows: III- to to t3; average $.41 ; \quad \mathrm{V}-.27$ to .31 , average $.29: \mathrm{V}-.26$ to .30 , average .27: VI- 107 to .09 , average .os plus .54 to .59 , average .55 . Secondary sensoria (Fig. 258 ) scattered, on third, fourth, and tifth segments; so little variation in 
their numbers that averages are not given: on one specimen distributed as follows: $1 \mathrm{II}-42 ; 1 \mathrm{~V}-23 ; \mathrm{V}-15$. Antenual tubercles, first antennal segments, and the beak similar to the same structures in the alate viviparous female. male.

Thorar and appenages.-Similar to those of the alate viviparous fe-

Ablomen.-Cauda, anal plate, and cornicles essentially similar to the same structures of the alate viviparous fenale; cauda about one-fourth the lengtl of the cornicles, averaging .09 in tengtl, with fine hair on posterior margiu. Opercula with numerous short hairs.

Holotype.-Alate viviparous female; Urbana, Ilinois, October 17, 1929, on Inula royaleana. (Frison and Ross). Slide No. 10843. Allotype.-Alate male; same data as for holotype. Slide No. 10844. Paratypes.-Thirty-one slides of alate viviparous females, males and pupae. Same data as for hololype except some specimens collected on October 15. Slides Nos. 1084510864 and others unnumbered.

This species is extremely closely allied to Capitophorus inulac (Walker) of Europe and may eventually be shown to be the same. It differs from innlac as described in rather meager descriptions in laving comparatively longer antennae, the fourth antennal segment longer than the fifth instead of equal as stated by Van der Goot, and the comparative length of the cauda in relation to the length of the cornicles-the cauda being about one-sixth the length of the cornicles rather than one-fourth the length of the cornicles. It differs from Capitophorus similis Van der Goot, another closely allied species, in the lack of black spots at the bases of the cornicles, the relatively larger number of sensoria. and comparative lengths of fourth and fifth antennal segments.

On one slide there is a specimen of an apterous viviparous female which is apparently immature and in such condition that it is not described.

This species was exceelingly nunerous under the larger leaves of a few specimen plants of Inula royalema in the floricultural gardens of the University of Illinois.

\section{CAPITOPHORUS PATONKUS new species}

Figs. 82, 128, 169, 272, 274

Alate Vinhabots Frusis:

size and yenerul color. Average length from vertex to tip of anal plate. 1.50. Head, thorax, aud abdomen with numerous spatulate hairs. Head yellowish green, with fuscous area about ocelli. First and second anteunal segments concolorous with head; remaining antennal segments fuscous or black except extreme basal portion of third, which is a yellowish green. Thorax, ablomen, cauda, anal plate an apple green: cornicles at base concolorous with abdomen, gradually shading to brown or fuscous at apex. legs concolorous with body except that apices of tibiae, all of tarsi. and dorsal portions of femora are brownish or black. Beak greenish, with ter. minal segment dark brown or black. Wings with costal margin (costal, subcostal, and base of radial veins) slightly greenish, rest of veins distinctly dark brown. liyes black. Adult with hoary appearance in life dlue to capitate hairs.

IIfal and alupenluges.-Average width of head across eyes. .43. Antennal segments with comparative lengths as follows: $111-.57$ to .69 , average .62; IV- .5:" to .60, average .57: V- .50 to .56, average .5:; VI- .14 to $1 \%$, average .15 plus .80 to 1.00 , average .91 . Seconclary sensoria (Fig. 274) confined to the third and fourth antennal segments, sometimes sensoriat 
lacking on fourth segment. numbering from 13 to 18 and averaging 15 on third segment, numbering from 0 to 5 and averaging 2 on fourth segment, arranged in an irregular row. Primary sensorium on sixth segment with a group of small marginal sensoria at one side. Beak sometimes extending as far as coxae of metathoracic legs, but usually less than this distance: terminal segment extremely pointed. Head with antennal tubercles well developed (Fig. 82), with four capitate hairs on the anterior median portion.

Thorar and appendages.-Fore wing with stigma rather short and bluntly pointed; second fork of media closer to margin of wing than to first fork, most veins not reaching margin of wings, posterior margin thichened and dark where anal vein reaches wing.

Abdomen.-Cornicles (Fig. 128) shorter than caucla, averaging .16 in length, sides straight and hut slightly tapering from base to apex, which is without conspicuous flange; imbricated entire length. Cauda (Fig. 169) gradually tapering from hase to rounded apex, averaging 24 in length. with two sharply pointed curved hairs on each side.

\section{Apterot's Vivpanol's Fealdif: (Vhigolifita)}

Size and gcneral color.-Average length from vertex to tip of anal plate. 1.31. Head, thorax, and abdomen with numerous heavy spatulate hairs. Head and first two antennal segments yellowish green: thorax, abdomen. anal plate, and cauda an apple green except that dorsum of abdomen has a darker green medial and a lateral stripe on each side: cornicles essentially concolorous with abdomen except that apex is slightly fuscous. In life the entire body has a loary appearance due to the bulbous pale setae. Third antennal segment yellowish green at extreme base, remaining portion of segment and following segments essentially dusky brown to almost black. Legs yellowisll-green, with the exception that apices of the tihiae. all of tarsi, and sometimes dorsal portions of the femora are dusky brown. Beak yellowish-green, except last two segments, which are dusky or hrownish. Eyes black.

Head and appenda!les.-Average wilth of head across eyes. .4. Antennal segments with comparative lengths as follows: III- .39 to 60 . average $.52 ; \mathrm{IV}-.27$ to .57 , average $40 ; \mathrm{V}-.30$ to .40 , arerage $.35 \% \mathrm{~V}-.09$ to .13 , average .12 plus .36 to .76 average .58 . Secondary sensoria (Fig. 272) two to six, on third antenual segment, never farther removed from the hase of the segment than the length of the second segment of the hind tarsus exclusive of claws. Beak varying in length, in some specimens reaching to the coxae of the metathoracic pair of legs and in others reaching only to mesothoracic coxae. Hair on antenuae not spatulate, exceedingly short, and not equaling the width of the segment.

Ablomicn.-Cornicles exceedingly short for a species of Capitophorus. averaging .10 , about as long as base of sixth antemnal seguemt or one-half the length of the cauda, tapering somewhat to the tip, which is without a flange: indistinctly inbricated. Cauda long, averaging .21, distinctly con. stricted beyond base, with two non-spatulate hairs on a side and a single median hair a little posterior to the base of the last lateral pair. Anat plate rounded, not reaching to constricted portion of the cauda. four non-spatu. late hairs on romderl posterior margin.

\section{Altenot's OrtrikOt's Fram}

Sizr and gencral colol.-Average length (two specimeus) from vertex to tip of anal plate, 1.61. Head, thorax, and abdomen with numerous spatulate hairs. Head, thorax, and most of abdomen colored as in apterous viviparous females. Cornicles, cauda, anal plate, and patch ventral to anal plate, dusky brown. First and second antennal segments dusky brown, darker than the heid, in color, remainder of antennae either miformly dark brown or with the third antennal segment somewhat lighter than the others. legs darlier than in the viviparous female; femora concolorous with body at the base, remaining portions light dusky green, to almost brownish dor. sally; tibiae dusky grcenishyellow, apical portion, and especially portion 
covered by sensoria on hind tibiae, darker and somewhat brownish: tarsi brownish.

Head and apmondages.-Average width of head across eyes, .44. Altennal segments with comparative lengths (two specinens) as follows: III.43 to $.44 ; \mathrm{IV}-.30$ to $.34 ; \mathrm{V}-.31 ; \mathrm{VI}-.10$ plus .53 . Secondary sensoria restricted to an area near the base of third antennal segment equal to the length of the hind tarsi exclusive of claws; from two to three in number, arranged in a stright row. Beak similar to that of the apterous viviparous female.

Thurar and appcunlages.-Posterior tibiae slightly swollen near base for about one-fourth their length. swollen area with from twelve to eighteen sensoria.

Abdomen.-Cornicles essentially shaped as in apterous viviparous female but uniformly dusky, averaging .0s in length; cauda and anal plate also similar to the same structures in apterous viviparous female but dusky througliout length.

\section{AL.STE M.ILE}

Size and yrneral color.- Length of single specinien from vertex to tip of anal plate, 1.21. In color entirely unlike that of apterous viviparous female (may be due to poor preparation), being a very deep brown, darkest on the liead, thorax, and posterior region of the abdomen; cornicles dusky brown, not as dark as rest of body: cauda darker than the cornicles and brownish black. Antenuae uniformly deep brown with the exception of the extreme base of the third segment and apical one-fourth of the terminal filament, which are lighter. Legs brown with the exception of the bases of the feniora, particularly fore femora, which are dusky yellow; apices of tibiae, knees of femora, and tarsi somewhat darker than the rest. Hairs on inner sides of tibiae longer, distinctly more spine-like than remaining hairs on tibiae. Wings dark, but their color is probably somewhat accentuated by the very dark brown veins and the dark stigma.

Heal and appenduges.-Antennal segnents of single specimen with comparative lengths as follows: III- .54; IV- .57; V- .44; VI- .16 plus 1.06. Secondary sensoria present on third, fourth, and fifth segments; small. usually confined to one side of the segment, irregularly arranged except on fifth segnent where they are somewhat more regular; they number as follows: III- 28; IV- 26; V- 17. The dusky brown beak reaches the coxae of the mesothoracic pair of legs, its extrene tip is darker than the rest.

Thorar and appendages. - Stigma of fore wings comparatively narrow and not slarply pointed; second fork of media is closer to the margin of the wing in one wing and closer to the first fork of the media in the other. Posterior margin of fore wing much thickened near point of connection with anal vein.

Ablomen.-Cornicles of uniforn thickness thronghout; feebly though distinctly imbricated, with a poorly developed rin; subequal in length to the base of sixth antemnal segment or the cauda. Canda probably con. stricted near the base, but in the manner in which specimen is mounted on the slide this is merely suggested; with four lateral and two somewhat more dorsal hairs Anal plate indistinct due to mounting of specimen. Cpercula very dark brownisl-black, covered with rather long hook-shaped hairs.

Holotype.-Alate viviparous female; Metropolis, Illinois, April 17, 1930, on thlillu'v Millefolium. (Frison and Ross). Slide No. 10786. Allutype.Alite male; Trbana, Illinois, October 7, 1929, on Achill'a Millefolium. (Frison and Ross). Sijde No. 1075T. Worphot l/pe.-Apterous viviparous female (virgogenia); same data as holotype. Slide No. 1078s. Horphotype.Apterous oviparous female: Urbana. Illinois, November 5. 1929, on Arhillea Uillefolium. (Frison and Ross). Slide No. j0789. Pamtumes.-Wighty-three slides of alate and apterous viviparons females, pupae, and luyplis; all collected in lllinois, on Achillet Ifllefolium, as tollows: Metropolis, April 17. 1930; Starved Rock State 1'ark, May 13, 1930; and Trbana, September 3 . October 6, 7, 15 and 16 , and November 5, 1929. Collectors T. 11. Frison, F. C. IIottes, and II. H. Ross. Slides Nos. 10790.14S.12 and others unnum. bered. 
The combination of structural characters of this new species is such that we know of no very closely allied species within the genus. It is most easily separated from all other described Capitophoris by virtue of its extremely short cornicles. According to our observations. this species is at times abundant locally. but it is difficult to locate because its general color agrees so well with that of its host plant. A plant of Achillea found in Starverl Rock State Park was so heavily infested by this species that many of the leaves were turning brown.

\section{CAPITOPHORUS POAE (GILLETTF)}

Rhopalosiphum poae Gillette, Canadian Entomologist, Vol. X̌L, No. 2, February, 1908, p. 61.

This species has been recorded from Aurora. Illinois. by Davis (1911b) under the name of Rhopalosiphum poae. It was not found by us in our collecting during $19 ? 8$ to 1930 and apparently is not very abundant. Gillette mentions that it is capable of killing blue grass. Only the viviparous females have thus far been described.

Data associated with slides deposited in the Survey collection through the kindness of Professor Davis are as follows: Aurora, Nor. 14, 1910. and Rockford, Nov. 12, 1912. All specimens taken on Pon pratensis.

\section{CAPITOPHORUS RIBIS (LIXXAES)}

Figs. 34,167

Aphis ribis Linnaeus, Systema Naturae, Editio Decima, 1758. p. 451.

The currant aphid, which causes a characteristic distortion or "puffiness" and reddish discoloration of the leaves (Fig. 3t), was first

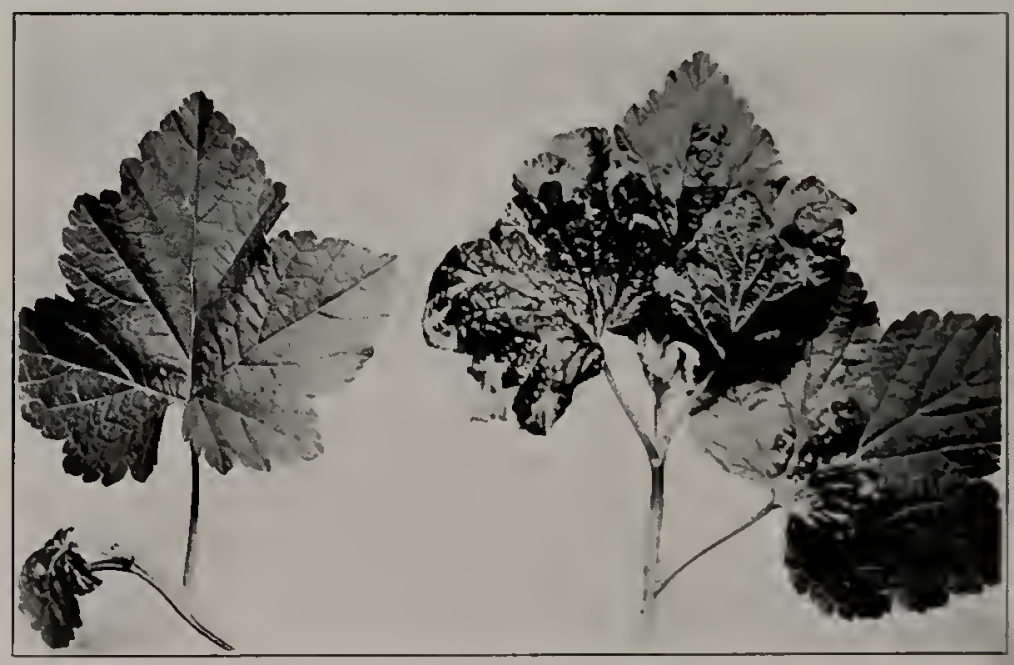

Fig. 34. Malformation of leaves of the red currant. Ribcs rut. gure, caused by the curram aphid. Coutophorus ribis (Limulus); Champaign, Jume 14, 1929. 
definitely recorded from Illinois by Davis (1911) ). The fruit of barlly infested currant bushes often ripens prematurely and is poor in qualit $y^{\circ}$ because of the falling of infested leaves. According to Gillette and Brags (1916), Theobald (19:6), and others, the currant aphid ustually migrates in summer from its over-wintering host to sucl plants as Galcopsis, Stachy's, Polygonum, and Lcommis. All forms have been described by several authors, including Gillette and Brags (191i) and Theobald $(19: 6)$.

Data associated with our viviparous specimens are as follows: Normal (May 29), 1884; Clampaign (May 18), French Grove (June 4-4), 1886; Champaign (June 19), LeRoy (June 19-20), 1928; Arcola (Nlay 10), Champaign (May 22). Galena (July 10), Lawrenceville (June 18), Macomb (May 26). Monticello (May 24), Putnam (May 5), Rock Island (July 9), 1929; Grand Detour (May I6), Rock Island (June 3), 1930. All specimens taken upon Ribes Grossularia, Ribes nigrum. Ribes odoratum, and Ribrs sp.

\section{CAPITOPHORUS TETRARHODUS (WALKER)}

A phis tetrarhora Walker, The Annals and Magazine of Natural History, Vol. IV. Second Series, London, 1849 , p. 42.

This species has not previously been reported from Illinois, unless the records of Davis (1910e) under the name of $M$ yaus rosarum $I$ alker ap)]y to it. Only the viviparons females have been described (Theobald, $1 !(6)$. and very little is known concerning the biology of this plant louse. Specimens taken out of doors at Urbana in Novenber failed to continue to reproduce parthenogenetically in the greenhouse. Two of our specimens are of special interest in that in one a cornicle is entirely lacking and in a second specimen a cornicle is very aberrant. Dr. Theobald has kindly checked our determination of this species. The sexual forms are described here for the first time.

Data associated with our viviparous specimens are as follows: Urbana (June 6), 1928; and Urbana (Nov. 19, 26), 1930. Sexual forms and eggs have been taken Nov. 19-26, 1930. All collected on Rosa sp.

\section{APTERoUs MALE}

Lengll from vertex to tip of anal plate, 1.10. Body dark grayish brown, with greenish bands extending between the segments across the dorsum of the abdomen, and with the venter almost entirely greenish. Antennae, legs except base of fenora, external genitalia, cornicles, cauda, and anal plate, dark brown. Extreme base of third antennal segment, basal fourth of fenora, and area around base of cornicles, pale yellowish. Middle portion of hind tibiae lighter brown than the remainder.

Width of head across eyes, .34. Head with about 16 capitate hairs. Antennae with scattered capitate hairs, the comparalive lengths of the segments as follows: $111-.43$, IV - .19, V- .17, Vl- .09 plus .23. Sec. ondary sensoria present on the third and fifth segnents, and occasionally on the fourth, as follows: III -20 to 26 , average $22 ; 1 \mathrm{~V}-0$ to $\mathrm{I}$ : $\mathrm{V}-$ 4 to 8 , average 6. Body with a row of capitate setae along each lateral margin. Abdomen with four longitudinal dorsal rows of setiferous tubercles arranged segmentally, two on each side of the meson, the two mesal tuber. cles each with two capitate setae on the middle segments, the two lateral tubercles eacl with one seta. This pattern is reduced on the lhorax. Cor. wicles and cauda as in other forms, respectively .19 and .10 in lenglh.

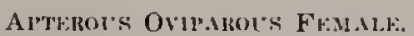

l.ength from vertex to tip of anal plate, 1.37. Body yellowish green; tlagella of antennae, apices of front and middle tibiae, hind tiblae except 
extreme base, tarsi, cornicles, cauda, and anal plate yellowisb brown; eyes black.

Body with numerous capitate hairs, arranged in two lateral and four dorsal series, but not on such distinct tuberculate areas as in the male. Width of head across eyes, .33. Comparative lengths of antennal segments as follows: JIJ- .24, IV- .10, V- .14, VI- .09 plus .19. Secondary sensoria absent. Cornicles and cauda as in other forms, respectively .20 and .13 in length. Hind tibiae .61 in length, swollen before middle, with about 70 distinct sensoria.

Allotype.-Apterous male; Slide No. 9796, Trbana, lllinois, November 24, 1930, on Rosa sp., (T. H. Frison). Norphotype-Apterous oviparous female; Slide No. 9795, Urbana, Illinois, November 19, 19:30, on liosn sp., (T H. Frison). On slide with oviparous females and nymphs

\section{GENL'S IDIOPTERUS DNIS}

\section{Fey to the sipeeies of the Genus Idiopterns}

1. Cornicles cylindrical and tapering towards apex. with basal one. third dark and remainder light in color.... nephrelepidis Daris p. 292 - Cornicles slightly swollen, rather mniformily dark in color..... $\ldots \ldots \ldots \ldots \ldots \ldots \ldots \ldots \ldots \ldots$ violae (Pergande) p. 292

\section{IDIOPTERUS NEPHRELEPIDIS D.M}

FIgs. $5 S, 66$

Idiopterus nephrelepidis Davis, Annals of the Entomological Society of America, Vol. II, No. 3, September, 1909, p. 199.

This species has not been taken in Illinois since it was originally. described by Davis (19)!c) from sword fern growing in a Clicag(i) greenlouse. It is a species with beatifully marked wings and of special interest because of the variation exhibited in the radial and medial veins (Figs. is, (iti) of the fore wings. There is not much doulht that it is a species of tropical origin introduced into greenhouses. Besides the descriptions and illustrations of the viviparous females contanined in the original description, there are articles by Essig (1!1111). Baker $(1919 \mathrm{~b})$. and Theobald $(1926)$, which contain additional information and rescriptive matter.

Data associated witl the lectotypic slide (No. 3117) in the Surrey collection are as follows: Chicago (May 2), 1908, oll Fiphrelepis sp.. coliected by J. J. Davis.

\section{IDIOPTERIS VIOLAE (Priandive)}

Rhopalosiphnm violue Pergande, Canadian Entomologist. Vol. XXXII. No. 2. February, 1900, p. 29.

This species has been taken only once in Hlinois. at Peoria, by Davis (19)1he). who collected it on violets. its only kmown host. Bésicles the original description and a tew records there is almost unthing in literature conceming this species. Baker (1!)!lb) comsiclers that

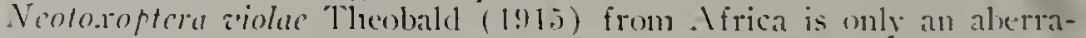
tion of this species. Is in I. Meplerlepidis Davis, the radial and medial veins are variable and the wing veins are prominently outlined with 
fuscous shading. The genera Idiopterus, Microparsus, and Pentalonila have been grouped together by several writers to form the sulutribe Pentalonina.

Data associated with our viviparous specimens are as follows: Peoria (Sept. 24), 1910, on Viola sp., collected by J. J. Davis.

\section{Genus MACROSIPHUM Passerixi}

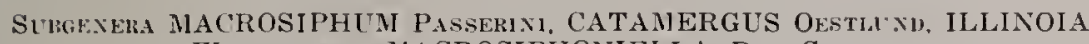
Wilsox, AN1) MACROSIPHONIELLA DE, Guercio

\section{Ir'y to the species of the Genus Macrosiphum.}

1. Apex of cornicles with closed reticulations (Fig. 120) ............ Apex of cornicles smooth or imbricated, never with closed retic-

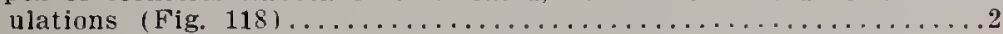

2 Secondary sensoria ou third antennal segment very irregularly arranged, not in a straight row (Fig. 296) ...................

- Secondary sensoria on third antennal segment essentially in a

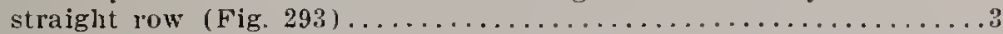

3. Cauda more than one-half length of cornicles..pisi (Kaltenbacli) p. 317

- Cauda about one-third the length of cornicles.schranki Theobald p. 326

4. Fonrth antennal segment with from 8 to 20 secondary sensoria $\ldots \ldots \ldots \ldots \ldots \ldots \ldots \ldots$ purpurascens (Oestlund) p. 318

- Fourth antenul segment never with more than four secondary

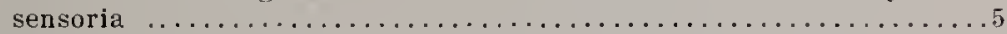

5. Fourth, fifth, and sixth antennal segments black or dark brown ...... 6

- Fourth and fifth antennal segments yellowish at base, dusky at apex ......................... ribiellum Davis p. 319

6. Tibiae almost uniformly brown or black; apical third of cornicles

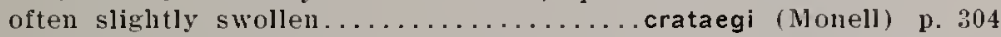

- Tibiae not uniformly brown ol black, apex darker; cornicles never swollen ....................dirhodum (Walkel) p. 304

7. Secondary sensoria on third antennal segment approximately in

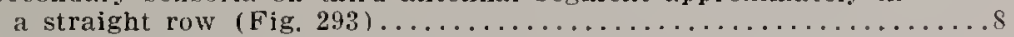

- Secondary sensoria on third antennal segment not approximately

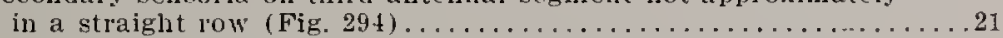

8. Cornicles much shorter than length of third antennal segment........9

- Cornicles approximately equal to, or longer than, length of third

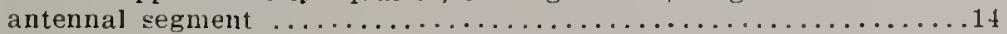

9. Cornicles approximately as long as, or longer than, width of head

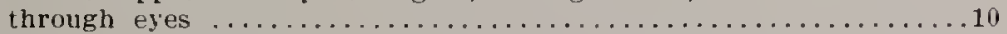

- Cormicles shorter than width of head through eyes........... $\ldots \ldots \ldots \ldots \ldots \ldots \ldots \ldots \ldots \ldots \ldots \ldots \ldots \ldots \ldots$ granarium (Kilby) p. 308

10. Fourth antennal segment almost twice as long as width of head

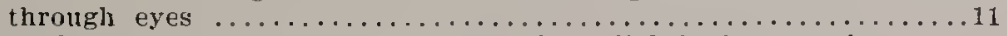

- Foarth antennal segment shorter, or but slightly longer, than

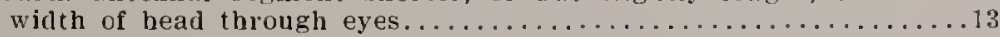

11. Tirird antennal segment distinctly imbricated, anal and cubita] conspicuously outlined with fuscous border.............. $\ldots \ldots \ldots \ldots \ldots \ldots \ldots \ldots \ldots \ldots \ldots \ldots \ldots \ldots \ldots$ carpinicolens Patch p. 301

- Third antennal segment not distinctly imbricated.............. 12

12. Cornicles black except for extreme base; anal and cubital veins of fore wing strongly outlined with fuscous borler: extreme apical reticulated portion of cornicle slightly constricted.... venaefuscae llavis

- Cornicles with basal half pale and apical halt fuscous: anal and cubital veins not ontlined with fuscous borler: extleme apical reticulate.l portion of cornicle not constrictedl...pallens 11. sp p. 315 
13. Secondary sensoria on third antennal segment numbering from 15 to 20 ; femora essentially pale greenish; in life with abdomen pale greenish.................adianthi (Oestlund)

- Secondary sensoria on third antennal segment numbering from 5 to 10 ; femora with apical half dark brown or black; in life with abdomen with brownish markings on a ground color of ruby red or yellow.................... sanguinarium $n$. sp.

14. Anal and cuhital veins of fore wings strongly outlined with a

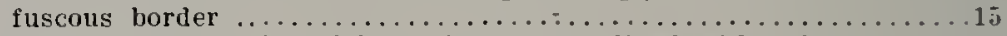

- Anal and cubital veins of fore wings not ontlined with a fuscous

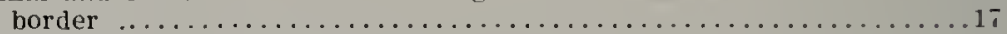

15. Abdomen surrounding base of cornicles greenish; canda approximately half the length of cornicles.....................

-. Abdomen surrounding base of cornicles blackish or brownish: cauda considerably less than one-third the length of cornicles

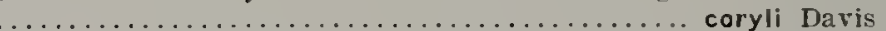

16. Hind tibiae about five times as long as width of head through eyes: on wild geranium.................geranii (Oestlund) p. 30 t

- Hind tibiae about four times as long as width of head through eyes; on basswood, or linden..................tiliae (.Monell) p. 331

17. Length of cornicles at most equal to length of thircl antennal

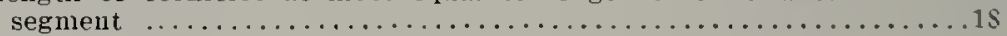

-. Length of cornicles considerably ionger than third antennal segment....................... laevigatae Essig. p. 314

18. Fumth antemnal segment as long as, or longer than, the third.. ................................... tiliae (Moneli) p. 331

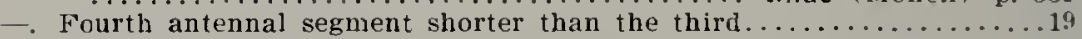

19. Cornicles almost uniformly cylindrical, not bulging before reticnlations at apex (Fig. 111); abclomen in life usually greenish or pink; developing on a great variety of plants but not nat-

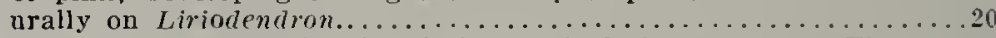

- Cornicles slightly bulging just before reticulations at apex (Fig. 110); abdomen in life usnally yellowish green: developing on Liriodentiron ....................... liriodendri (Monell)

20. Cornicles a deep black. hind tibiae usually uniformly deep black ................................ pseudorosae Patch

- Cornicles pale to dusky, hind tibiae usnally pale to dnsky with apices darker and contrasting..................... gei (Koch) p. 306

21. Cornicles much shorter than width of head throngh the eves.......22

- Cornicles about equal to, or longer than, width of head through

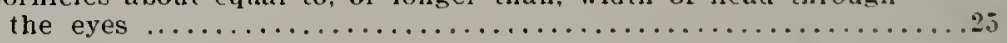

22. Fourth antennal segment with five or more secondary sensoria. body rather uniformly reddish brown in color.sanborni Gillette p. 323

- Fourth antennal segment usually withont any secondary sensoria but sometimes with one or two; body not reddish brown.........23

23. Cauda short, somewhat triangular in shape, about as long as combined length of first and second antennal segnients......

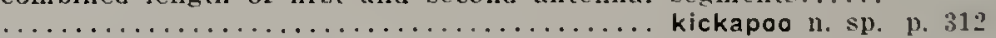

- Cauda more elongate and tapering, much longer than combined length of first and second antenual segments.................

24. Cornicles much shorter than width of head; secondary sensoria on fourth antemal segment rarely exceeding thirty-five in number; fourth antennal segment scarcely Jonger than width of head .......................... frigidicola (G. \& P.) p. $\$ 0 \pi$

- Cornicles but shightly shorter than width of head; secondary sensoria on fourth antemnal segment usually more than forty in number: fourth antennal segment much longer than width of head ........................ ludovicianae (Oestlund)

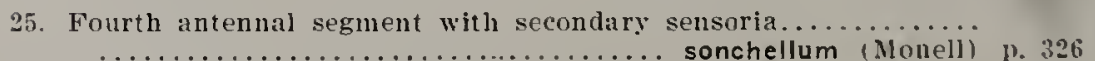

-. Fourth antennal segment without secondary sensoria............. 26 
26. On ferns; general body color green; third antennal segment with about fity secondary sensoria, cauda very short........ $\ldots \ldots \ldots \ldots \ldots \ldots \ldots \ldots \ldots \ldots$ ptericolens Patch

- Not frequenting ferns: general body of various colors iucluding green; thircl antenual segment with various numbers of

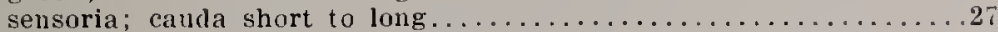

27. Cornicles equal to or longer than third antennal segment...........

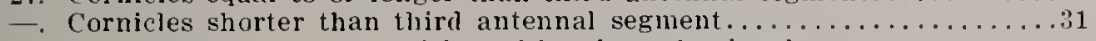

2S. Segment anterior to cornicles with a lateral tubercle..........

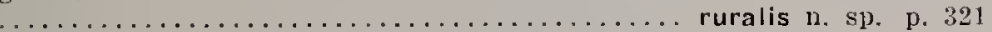

- Segment anterior to cornicles without a lateral tubercle...........29

29. Reticulated area of cornicles about equal to length of basal portion of sixth antenual segment (Fig. 108); base of cornicles surrounded with a blackish or brownish area............. $\ldots \ldots \ldots \ldots \ldots \ldots \ldots \ldots \ldots \ldots$ rosae (Linnaeus)

Reticulated area of cornicles much longer than length of basal portion of sixth antennal segment (Fig. 120); base of cornicles not surrounded with a blackish or brownish area $\ldots \ldots \ldots \ldots \ldots \ldots . . .30$ not surrounded with a blackish or brownis segment with less than forty secondary sensoria: fourth antennal segnent much shorter than third.......... $\ldots \ldots \ldots \ldots \ldots \ldots \ldots \ldots$ erigeronensis (Thomas)

Third antemal segment with more than forty secondary sensoria: fourth and third antenual segments about equal in Jength $\ldots \ldots \ldots \ldots \ldots \ldots \ldots \ldots \ldots \ldots \ldots \ldots \ldots \ldots$ zinzalae n. sp. p. 332

31. Third antenlial segment longer than the metathoracic femora..

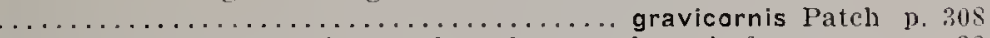

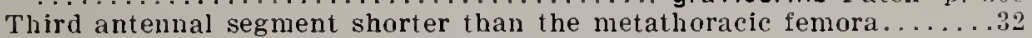

32. Fourtl antennal segment averaging about as long or longer than

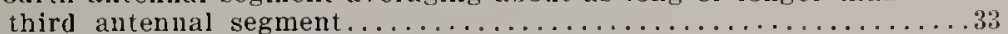

- Fourth antenual segment averaging much shorter than third

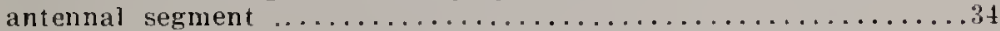

33. Anal and cubital veins distinctly outlined with a border of fuscous; area of cornicles with closed reticulations about one-fifth of total length: cauda light green; cornicles without dark area

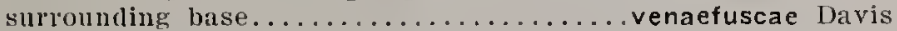

- Anal and cubital veins not outlined with a border of fuscous; area of cornicles with closed reticulations abont one-third of length: cauda dark brown or black; cornicles with dark area

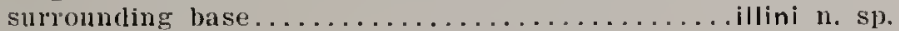

34. Cornicles much shorter than length of fifth antemal segment; abdomen yellowish green or pea green, dark cornicles strongly contrasting with boly, pulverulent in life.............. .......................... ludovicianae (Oestluud)

Cornicles about as long as, or longer than, length of fifth antennal segment: ablomen greenish, brownish or reddish...........35

35. Abdomen dominantly colored some shade of green................ 36

- Abdomen dominantly colored some shade of brown or red.........38

36. Hind tibiae with basal one-fifth light brown, middle three-fifths yellowish or yellowish-green, and apical one-tifth clark brown or black......................... tapuskae n. sp. p. 327

- Hind tibiae almost uniformly dark brown or black, or at least with basil third dark brown or black and midcle third not strongly contrasting with base and apical thirds.................

37. Thirl antenul segment seldom with more than 25 secondary sensoria, these sensoria rather narrowly scattered and not sspecially tuberculate (Fig. 297 ,..........pseudorosae Patch p. $31 \mathrm{~s}$

Thirl antennal segment seldom with less than 35 secondary sensoria, these sensoria widely scattered and very tuberculate

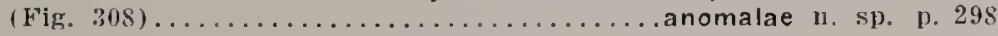

3. Body of species essentially shades of red . . . . . . . . . . . . . 39

- Body of species essentially sharles of brown...................40 
39. Third antenual segment seldom with more than 25 secondary sensoria, these sensoria rather narrowly scattered and not prominently tuberculate (Fig. 297)........ pseudorosae Patch

- Third antennal segment seldom with less than $3 \overline{5}$ secondary scnsoria, these sensoria widely scattered and prominentiy tuberculate (Fig. 308)................. rudbeckiae (Fitch)

40. Hind femora at most with basal one-third light colored and contrasting witl remaining dark portion; hind tibiae uniformis lark colored; antennal segments. legs, head, and body with numerous stout spine-like setae, many of which may be capitate; about crown of dandelion.........taraxaci (Kaitenbach)

-. Hind femora with basal half light colored and contrasting with dark apical lualf, rarely with proportions less: hind tibiae uniformly dark or with dark apical portion contrasting with basal or mesal portions; spine-like setae less numerous and more slcnder, sometimes capitate; on stems and leares of upper

41. Color in life deep blackish red; cauda dark, abont concolorouns with abdomen; species apparently restricted to Helcrium: coefficient $A^{*}$ averaging $4.5 \ldots \ldots \ldots \ldots \ldots \ldots \ldots$ tardae n. sp. p. 329

- Color in life brownish: canda light or yeliowish in color: not restricted to Helenium: coefficient A averaging more than $5.0 \ldots \ldots \ldots+2$

42. Restricted to Impaticns.............. impatiensicolens Patch p. 3 I?

- Common on a large number of plants, particularly Compositae.......43

43. Cornicles averaging shorter in length: coefficient $A$ averaging slightly more than 5: most often taken on Birlens..........

$\ldots \ldots \ldots \ldots \ldots \ldots \ldots \ldots \ldots \ldots \ldots \ldots \ldots$ chrysanthemi (Oestiundi p. 302

- Cornictes averaging tonger than the preceding; coefficient A averaging about 6 ; not yet recorded from Bidens but common

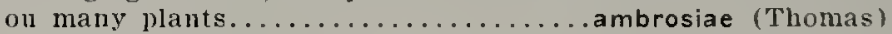

D. $31 \mathrm{~S}$

p. 320

p. 329

p. $29 \mathrm{~s}$

\section{MACROSIPHUM ADIANTI (OEstLxND)}

Siphonophora adianti Oestlund, Geological Survey of Minnesota. Fourteenth Report, 1886, p. 26.

This species. not previously reported from Illinois nor recurded since it was described from Minnesota. was abundant on the undersides of the divisions of the fronds of ferns of the genus. Aspidium on sicie walls of the various canyons in Starved Rock State Park. . late forms seem to be uncommon, and the two specimens secured by us were reared from pupae. Dr. Oestlund has confirmed our identification of this species and agreed that the statement concerning length wi cornicles in the original description was in error.

In view of the fact that many details are mitted in the urivinal description, a redescription is presented of the previously known apterous viviparous female. A description is given, also, of the alate form which had not been previously discovered.

\section{Alate: Vivildiot's Femsik:}

Size and general color.-Average length from vertex to tip of anal plate, 1.41. Color of head light dusky yellow with brownish area around ocelli. color of thorax and abdomen pale yellowish green: cornicles and cauda concolorous with abdomen. First and second antennal segments concolorous with head, third brown with exception of extrene base which is light yellowish, remaining segments lighter in color. Femora pale vellowish green with the extreme apical portions fuscous: tibiae greenish with apical por-

* Coffient. I equals length of hind tibine plus length of cornicle, divided by widu of head. 
tions fuscous; tarsi fuscous. Stigma smoke-colored; veins brown, anal and cubital veins darkest and bordered with brownish suffusions; posterior margin of wing in vicinity of anal vein brownish. Beak greenish yellow with the last two segments brownish.

Hcarl and appendages.-Average width of head across eyes, .49. Antennal segments with the following comparative lengths: Ill- 71 to .74 , average $.72 ; 1 \mathrm{~V}-.39$ to .44 , average $41 ; \mathrm{V}-.43$; VI- .14 plus .91. Secondary sensoria (Fig. 293) with wide margins, confiued to the third antennal scgment, arranged in a straight row and numbering from 15 to 20 , averaging 17. Beak reaching to mesothoracic pair of coxae. Width of head through eyes averaging .48 .

Thorax and appendages.-Stigma of fore wings quite pointed. Second fork of media considerably closer to margin of wing than to the first fork, all veins failing to reach margin of wing.

1udomen.-Cornicles (Fig. 101) .49 long, straight; apical area covered by closed reticulations equal to about one-fifth their length, remaining portion imbricated. Cauda (Fig. 165) .21 long, not constricted, with about four hairs on a side. Anal plate rounded.

Morphotype.--Alate viviparous female; Starved Rock State Park, Illi. uois, May 13, 1930, on fern. (Frison and Ross). Slide No. 10571.

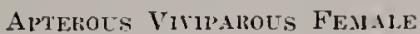

Size and gcneral color.--Average lengtb from vertex to tip of anal plate, 1.45. Entire body light yellowish-green. Anal plate concolorous with abdomen; cauda somewhat ligliter in color than abdomen. Cornicles very light yellowish-green, almost white, at the base but somewhat fuscous at extreme apex. Beak yellowish-brown, the tip brownish. First and second antennal segments essentially concolorous with head, beginning with the third antennal segment and extending to apex of antennae gradually shading from dusky yellow to dark brown, the apices of third and fourth segments darker than rest of segments and contrasting. Coxae, trochanters, and basal portions of femora essentially concolorous with body; apical portion of femora and tibiae light yellowish-green but gradually hecoming more and more brown until at apices of tibiae color is dark brown; tarsi dark brown.

Herd and appendages.--Average width of head across eyes, .46. Antennal segments with comparative lengths as follows: III- .59 to .64, average .61; IV - .30 to .36 , average $.34 ; \mathrm{V}-.36$ to .39 , average $.38 ; \mathrm{V} 1$ - .10 to .11 , average .11 plus .71 to .83 , average .79. Secondary sensoria limited to the third antennal segment, small, arranged in a straight row and limited to the basal half of the segment, number varying from 3 to 7 and averaging 5 . Hair on the antennae exceedingly scarce, fine and short. Beak stout, reaching ahout to the coxae of the metathoracic legs.

Thora.r and appendages.-The hairs on the basal portious of the tibiae are exceedingly fine and short; they increase in length toward the apex, where they are just slightly shorter than the width of the segment.

Abromen.-Cornicles straight, comparatively short for a species of Macrosiphum, averaging about .45 in length; with from 3 to 5 indistinct rows of closed reticulations at the apex; flange at the apex poorly developed; imbrications present but exceedingly faint. The cauda averaging .16 in length, not constricted, stont, conical, with four hairs on a side; like the cornicles, it is short for a species of Macrosiphum. Anal plate as normal tor the genus.

Data associated with our specimens are as follows: Starved Rock State Park (Aug. 14. Sept. 10), 1929, and (Nay 13). 1930.

This species is easily separated from the related 11 . ptericolciss P'atch (also found on ferns in Illinois) by the fact that the cornicles are only slightly fuscous at the apex, whereas in picricolens they ate very clark for most of their length; by the alssence of a constriction of the cornicle before the apex; by its smaller size: and by the reduced number of the secondary sensoria. 


\section{MACROSIPHUM AMBROSIAE (THOMAS)}

Siphonophora ambrosiar Thowas, Bulletin Illinois State Laboratory of Natural History, Vol. I, No. 2, June, 187S, p. 4.

This connmon and widely distributed species in Illinois (Fig. 3.j) was described by Thomas ( $18 \hat{i}$ ) from specimens collected at Sioux City, Iowa, but was not recorded by him from Illinois. The species is not listed by Davis (1911b), but his host records for M. rubeckiac (Fitch) indicate it was included with the latter.

Cotypic specimens of this species were found among the Thomas materia] and mounted on slides. Slide No. 8179 has been selected as the lectotypic slide and Sildes Nos. SISO and S1S1 labeled as paratypic slides. All typic material is in poor condition but recognizable. Data associated with the typic slicles are as follows: Sioux City, lowa. September 3, 1S77 (original description states September 1 ).

Illustrations are given of the cauda (Fig. 1S4), cornicle (Fig. 114), and third antennal segment (Fig. 302) of the alate viviparous female on the lectotypic slide and the third antennal segment (Fig. 301) of the apterous viviparous female on the same slide.

Data associated with our viviparous specimens are as follows: Carbondale (June 4), Champaign (July 9), Danville (June 15), Elizabethtomn (Oct. 12), Havana (June 21), LeRoy (June 20), Mahomet (Oct. 2), Mattoon (June 10). Norton (July 22). Nit. Carroll (June 25), Muncie (Oct. 6), Oakwood (July S, Sept. 17), Oregon (June 27), Quincy (June 6), Rock Island (June 24), Starved Rock State Park (June 12, 13), Lrbana (July 10, Aug. 2. Sept. 10, Oct. 7, 22), 1928; Beach (Aug. 29), Cairo (June 22). Champaign (May 28), Choat (Sept. 28), Edwardsville (Sept. 11), Farmer City (Sept. 22), Grayville (June 19). Homer (June 19), Jonesboro (June 23), ilahomet (Aug. 17). Nitchell (June 25). Oakwood isept. 22. Oct. 13). Starved Rock State Park (Sept. 10), (Trbana (Sept. 17, Oct. 2S), 1929: Starved Rock State Park (May 13), 1930. Collected on Achillea Millefolium. Actinomeris sp.. Amurosia trifida, Ambrosia sp., Aster sp., Cirsium sp., Eupatorium urficap. folium. Helianthus sp., Lactuca sp.. Denothera biennis. Pronanthes alba. Prenanthes sp., Runbeckia hirta. Solidago sp., Ennchus sp. Turaxaeum officinale, and Funthium candense. Sexual forms collected at Elizabethtown (Oct. 12), 1928, on Kunthium eanatense and at L'rbana (Oct. 2S), 1929. on Cirsium sp.

\section{MACROSIPIIUM ANOMALAE new species}

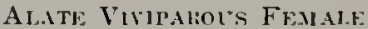

size and gencral color.-Average length from vertex to tip of anal plate. 1.66. Head, with exception of areas around simple eves which are brownish. light green; thorax and abdomen light green. Cauda concolorous with abdomen: cornicles concolorous with abdomell at base for a distance about equal to the length of the first antennal segment, remaining portion fuscous or often almost black. First and secoud antennal segments dusky brown; remaining segments dark brown except that the base of the third segment is yellowish for a distance equal to the length of the second segment, and that the apical half of the terminal filament is yellowish-white or at least lighter than the basal portion. Coxae, trochanters, and basal halves of femora es. sentially concolorous with body, remaining portion brownish, the brown most extensive on the dorsal portions; tihiae yellowish at extreme base, remaining portion almost if not entirely uniformily brown; tarsi brown. Stigma of fore wings only slightly clouded with fuscous, reins light brown in color and thin. Beak concolorous with body, except for the two terminal segments. which are brownish.

Heul and apprndugrs.-Average width of head across eyes, .49. Antenual segments with comparative lengtlis as follows: IlI- 60 10 .91, average .75 ; 


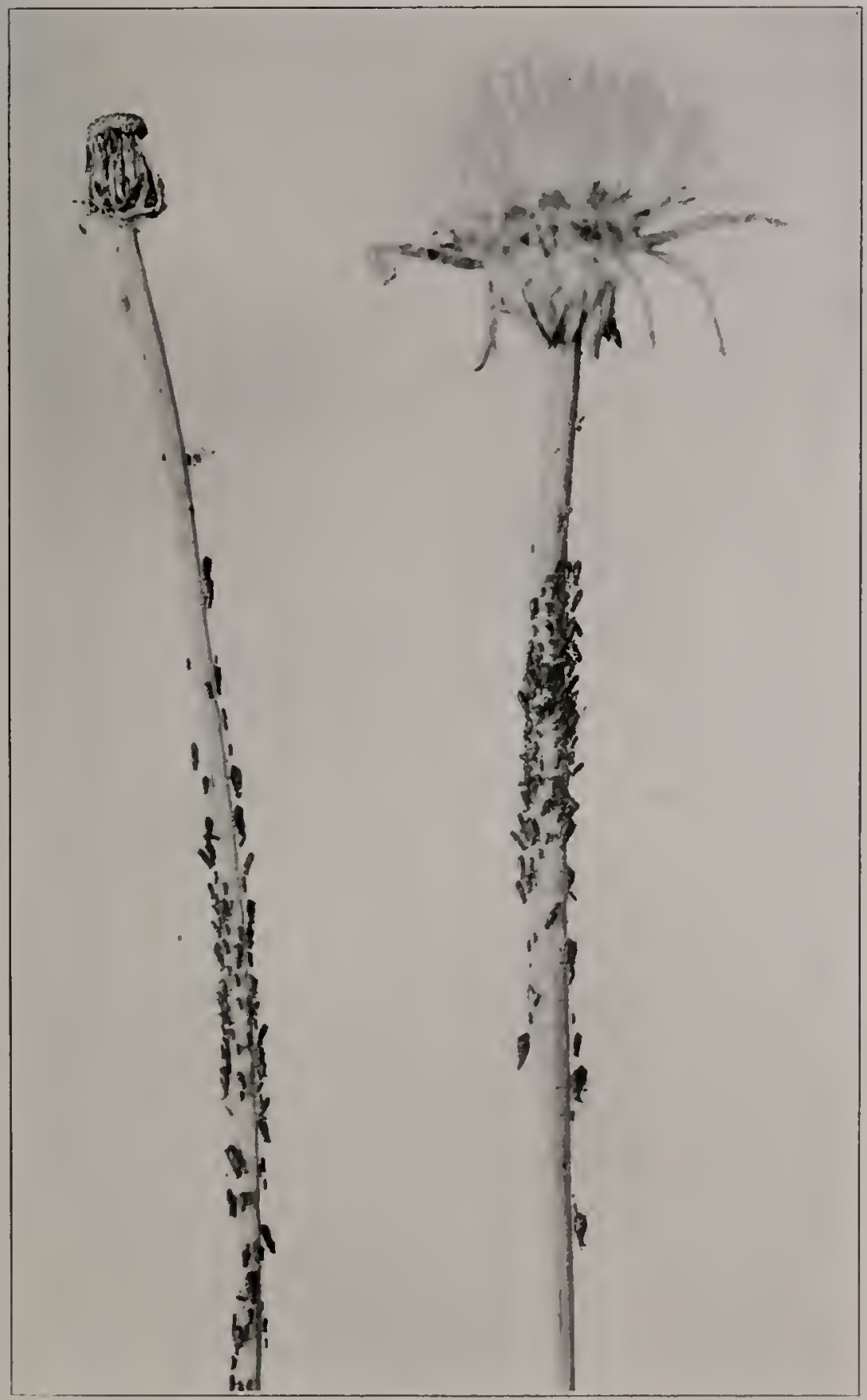

Fig. :35. Vurrosimhum ambrosine (Thomas) on flower stems of the

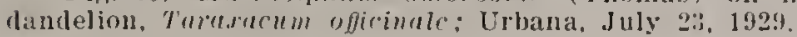


IV- .34 to .57 , average $.48 ; \mathrm{V}-.31$ to .59 , average $.45 ; \mathrm{VI}-.11$ to .17 , average .14 plus .41 to .86 , average .55 . Secondary sensoria (Fig. 308 ) limited to the third antennal segment, varying from thirty-five to fifty-one, large, witb wide veins, and althongh scattered are nevertheless most numerous on one side of the segment. Beak extends to the coxae of the third pair of legs or slightly beyond.

Thorax and appendages.-Stigma narrow and pointed at tip; second fork of media usually closer to the margin of the wing than it is to first fork. Hairs on the tibiae distinctly spine-like, numerous and lighter in color than the tibiae.

ibdomen.-Cornicles (Fig. 116) about four times the length of the base of the sixth antennal segment, averaging about .49, being about subequal to the fourth antennal segment, tapering sligbtly to the tip, with a very poorly developed flange, area covered with closed reticulations about equal to one-fifth the length of the colnicles. Cauda (Fig. 180) Jong in comparison to the length of the cornicles, extending approximately as far as the tips of the cornicles, slender, sharply pointed, and only moderately constricted. usually four hairs on a side.

\section{Apterots Viviparot's FeMale}

Size and general color.-Average length from vertex to tip of anal plate. 1.92. Head, thorax, and abdomen light green. First and second antennal segments concolorous with head, except that gibbous portion of first segment is often dusky brown; third segment concolorous with second up to where the secondary sensoria begin, then gradually blending to dusky brown at the apex; fourth and fiftl segments varying from entirely brown to a condition witl basal half yellowish and apical half brownish, sixtl segment brownish witl terminal filament lighter than basal portion. Femora as in the alate viviparous female with the exception that the brown is less extensive; tibiae as in the alate viviparous female or light yellowish at the base, quickly replaced by brown which in turn is replaced by yellowish beyond the niddle and then by brown at the apex; tarsi brown. Beak, cauda, and cornicles colored as in the alate viviparous female.

Head and appendages.-Average width of head across eyes, 47 . Antennal segments with comparative lengths as follows: III- .71 to .\$9, average .\$1; IV - .39 to .59 , average $.48 ; \mathrm{V}-.34$ to .54 , average $.44 ; \mathrm{VI}-.11$ to .19 , average .14 plus .44 to .64 , average .53 . Secondary sensoria similar in structure and position to those of the alate viviparous female, numbering from $2 S$ to 41 and averaging 35 . Beak reaches to, or slightly beyond, the coxae of the third pair of legs.

Thorax and appendages.-Except for the lack of wings, similar to the alate viviparous female.

Abdomcn.-Cornicles and cauda similar in shape to those of the alate viviparous female except that they are longer, cornicles averaging .5s and cauda .46, although retaining about the same relative proportions.

Holotype.-Alate viviparous female; Urbana. Illinois, August 29, 1929. on Aster novae-angline, (H. H. Ross.) Slide No. 102+2. Morphotupe.Apterous viviparous female; Urbana, llinois, August 22, 1929, on Aster novae-angliae, (H. H. Ross). On slide with three other specimens of apterons viviparous females. Slide No. 10243. Paratypes.-Forty-nine slides of alate and apterous viviparous fenales, pupae and nymplis; all collected in Jllinois by T. H. Frison, F. C. Hottes, H. H. Ross, and A. R. Park, on aster novac-angliae and Astr sp. The localities and dates are as follows: Oregon (June 27), Pekin (June 20), and Trbana (July 30), 1928; Ogdell (Nay 26). and Urbana (July 1. August 18 aud 29), 1929. Slides Nos. 10244-1027 and others unnumbered.

This species is suggestive of Macrosiphum origeronensis (Thomas). from which it may be distinguished by its comparatively shorter cornicle in relation to the third antennal segment, and by the reticulated area of the corniche heing considerably less in exicut than the reticulated area of crigcroncusis. 
This new species congregates near the top of the flower stalks of its host plant in much the same manner as crigcroninsis.

\section{MACROSIPHUM CARPINICOLENS PATCM}

Macrosiphum carpinicolens Patch, Maine Agricultural Experinent Station, Bull. 282, December, 1919, p. 209.

This species has never been reported from Illinois; in fact, we know of no records of its occurrence except from Naine. We have found it to be particularly partial to the young and tender shoots of its host, the blue beach. Our determination of the apterous viviparous female of this species has been verified hy Dr. Patch, who compared our specimens with types.

Data associated with our viviparous specimens are as follows: Starved Rock State Park (July 6), 1929; Golconda (April 15) and Oakwood (Mlay 9), 1930. Sexual forms taken at Oakwood (Oct. 17), 1929. All collected on Carpinus caroliniana.

This species was originally described by Dr. Patch from the apterous viviparous female only. We have included here the descriptions of several forms which to our hnowledge have not before appeared in literature.

\section{Alate Viviparous Feitale}

Size and gencral color.-Length, 1.86. Head light brownish, thorax and abdomen pale greenish. Antennae black except first two segments and base of third, which are concolorous with head. Cornicles with basal one-furth greenish, renuining portion black or dark brown with a greenish cast. Cauda and anal plate concolorous with abdomen. Femora yellowish green with apical portion dark brown; tibiae brown with apical portions almost black; tarsi black or very dark brown. Veins of wings, especially anal and cubital veins, deep brown bordered with brownish.

Head and apprndages.-Average width of head across eyes, .51. Antennal segments with the following comparative lengths: $11 \mathrm{I}-1.04 ; \mathrm{IV}-1.00$; $\mathrm{V}-.86 \mathrm{VI}-.23$ plus 1.36. Secondary sensoria (Fig. 292) confined to third antennal segment, arranged in a straigbt row and numbering from 5 to 10 ; not extending heyond middle of segment. Third antenual segment with characteristic imbrications peculiar to species. Beak extending just beyond mesothoracic coxae.

Thorux and appendages.-Stigma and fore wings quite sharply pointed. Second fork of media variable in position, in one case lacking. All veins ending in brownish suffusions.

Aldomen. - Abdomen with a pair of small lateral tubercles just anterior to cornicles. Cornicles .\$6 long (Fig. 102), straight, a little more than apical sixtl reticnlated; remaining portions of cornicles imbricated. Apex of cornicle witl a poorly developerl flange. Cauda (Fig. 170) only slightly constricted and about .37 long, with three hairs on a sicle.

\section{Al_tTE MALE}

size and gencrul eolur.-Average lengtl, 1.35. Color essentially the same as tluat of alate viviparous female. Genitalia brownish.

frod and rlprnduges.-Average width of head across eyes, .49. Antennal segnents with the following proportions: $11 \mathrm{I}-.90$ to .97 , average .93 ; $1 \mathrm{~V}-.92$ to .96 , average $.95 ; \mathrm{V}-.7 \mathrm{I}$ to .86 , avelage $78 ; \mathrm{V}-.17$ to .21 , average .18 plus .64 to 1.36 , average 1.10 . Secondary sensoria usually confined to third and fifth antenual segments, one specimen with two sensoria on fourth. The absence of sensoria on the fourth antennal segment together with their presence on the fifth is very unusual but apparently constant. Sensoria on third antennal segment irregularly arranged althougl nore abundant on 
one sille, numbering from 38 to 47, averaging about 40 ; sensoria on fifth segment numbering from 17 to 21, averaging about 19; all segments imbricated. Primary sensorium on sixth antennal segment with a group of about 6 marginal sensoria at one side. Wings similar to those of alate viviparous female. Cornicles averaging .47 in length, otlierwise as in the alate viviparous female. Cauda averaging .17 long, not constricted, with about four hairs on a side.

\section{Apterol's ONIPAROT'S FEMILE.}

Average length 1.97. Essentially the color as described for alate viviparous female. Average width of heacl across eyes, .43. Comparative lengths of antennal segments as follows: III - .67 to .80 , average .75 ; IT -.60 to .79 , average $.70 ; \mathrm{V}-.57$ to .66 , average $.63 ; \mathrm{VI}-.19$ to .21 , average .20 plus .79 to 1.00 , average .90 . Third antennal segment with a single secondary sensorium near base. All segments imbricated. Cornicles .56 long. Cauda .21 long. Hind femora very much swollen and with about 300 sensoria.

\section{Ap'terots Viviparots Female (Friditrix)}

Average length, 2.50. Color essentially as in alate viviparous female, except in life a mucl darker reddish green. Average width of head across eyes, .54 Antennal segments with the following comparative lengths: IIl.69 to .81 , average .75 ; IV -.57 to .59 , average $.5 \mathrm{~S} ; \mathrm{V}-.50$ to $.5 \%$, average $.53 ; \mathrm{VI}-.2 \mathrm{I}$ to .23 , average .22 plus .64 . Third antennal segment with a single sensorium near base, less imbricated than that of other forms. Beak reaching to middle of mesothoracic coxae. Prothorax with lateral tubercles, differing in this respect from the other forms. Cornicles .56 long; cauda (Fig. 166) .21 long. Otherwise as in alate viviparous female.

Morphotypc.-Alate viviparous female; Slicle No. 8900 , Oakwood, lllinois, May 9, 1930, on corpinus crroliniana, collected by T. H. Frison. On slide with nymphs. Allotypr.-Alate male; Slide No. $\$ 470$. Oakwood, Illinois, October 17, 1929, on Curpinus caroliniana, collected by Frison and Ross. Morphotylye.-Apterous oviparous female; Slide No. \$474. same data as allotype. On slide with oviparous females. Iorphofypc.-Apterous viviparous female (fundatrix): Slide No. S\$99, Golconda, Illinois. April 15. 1930, on Carpinus curolinianu, collected by Frison and Ross.

\section{MACROSIPHCM CHRYSANTHEMII (OETLINII)}

Siphonomhova chrysanthrmi Oestlund, Fourteenth Annual Report of the Geological and Natural History Survey of Minnesota, 1S\$6, p. 22.

This species has not heen reported previously from Illinois. Our determination of it has been verified by Dr. Oestlund. Solman (19:3) has given technical clescriptions of the viviparous forms. It is very closely allied to .K. ambrosiac (Thomas), and future biological studies may prove them to be forms or varieties of the same species. The sextal forms consiclered by us as this species. however, appear to difier from sexual forms of ambrosice in having fewer secondary sensoria. Deseriptions of the alate male and the apterous oriparous female of this species are given here since they have not been described elsewhere.

Data associated with our viviparous specimens are as follows: Elizabethtown (Oct. 12), 192S; Decatur (Sept. 21, Oct. 19), Jonesboro (Sept. 2S), Kappa (Sept. 9), Mahomet (Sept. 4). Mt. Vernom (Sept. 27), Oakwoor (Oct. 13). 1929. Sexual forms lave been collected as follows: Elizabethtown (Oct. 12), Mahomet (Oct. 6), 1928; Decatur (Oct. 19). Oakwood (Oct. 13), and Urbana (Oct. 24). 1929. Both viviparous and sexual forms collected on

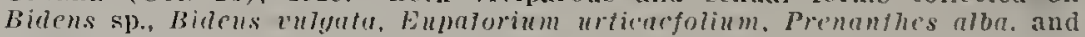
Solirlago sp. 
Al. ITE NALE

Sizc and grneral color.-Average length, 1.91. Head and thorax rather dark lusky brown, thorax with a greenish cast. Abdomen greenish with lateral brownish spots on dorsum and similar spots posterior to the cornicles. Cornicles dark brownish black, cauda varying from greenish to dusky. Antennae liglit brownish green to dark brownish black. Genitalia dark blackisl brown. Coxae, trochanters, and base of femora light yellowisli; remainder of legs uniformly dark brown. Beak dusky brown with yellowish markings between segments. Stigma smoke-colored; veins light brown.

Structure.-Average width of head across eyes, .56. Comparative lengths of antennal segments as follows: III - .79 to 1.00, average .86; $\mathrm{IV}-.64$ to .94 , average $.77 ; \mathrm{V}-.53$ to .77 , average $.67 ; \mathrm{V}$ - -.11 to .17 , average .15 plus .66 to 1.31 , average 1.03 . Secondary sensoria present on third, fourth, and fiftl antennal segments, irregularly arranged on the third and in a more or less regular row on the fourth and fith; average numbers as follows: III- 45; IV - 9; V- 10. Primary sensorium on sixth antennal segment with about six marginal sensoria at one side. Beak reaching to base of metathoracic coxae. Cornicles .49 long, straight; apical one-third with closed reticulations. Cauda .25 long, only slightly if at all constricted, with from 5 to 7 hairs on a side.

\section{Apterous Oriparous Flem.lie}

Average length from vertex to tip of anal plate, 2.22. Color of head, thorax, and abdomen greenish or yellowish brown. Cornicles dark brown; cauda yellowisl green to light brownish. Antennae brownish except for yellowish base of third segment. Legs yellowish except for apical portions of femora, tibiae, and tarsi, which are dark brown. Average width of head across eyes, .53. Comparative lengths of antenual segments as follows: I! $1-.64$ to .74 , average $.69 ;$ IV- .41 to .54 , average $.49 ; \mathrm{V}-.41$ to .50 , average $.46 ; \mathrm{VI}-.09$ to .17 , average .13 plus .61 to .86 , average .75 . Secondary sensoria confined to third antennal segment, irregularly arranged. restricted to one sicle of segment, usually not extending beyond basal half of segnent, varying in number from 7 to 13 and averaging 10 . Beak reaching to mesothoracic coxae. Cornicles .56 long, with slightly less tlian one-third of the apical portion reticulated. Cauda .33 long, not constricted, witl from 6 to 7 hairs on a side. Hind tibrae very much swollell, with about 100 sensoria.

Allotype.-Alate male; Slide No. 8575. Oakwood, Illinois, October 13, 1929, on Birlens sp.. ('T. H. Frison). On slide with alate viviparous female. Horphotype.-Apterous oviparous female; Slide No. 7719, Elizabethtown, Illinois, October 12, 1928, on Bidens sp., (Frison and Hottes). On slide with apterous oviparous females.

\section{MACROSIPHEM C'ORYLI LAWIS}

Macrosiphum. coryli Davis, Canadian Entomologist, Vol. XllVI, February, 1914, p. 48 .

Specimens from Chicago. Illinois, formed part of the naterial from which this species was originally describer. This species, aceording to our observations, is partial to the more tencler teminal leares and sluonts of hazelnut growing in somewhat sharled situations. It is rather solitary in habit and is not as sregarious as many species of the genus. Technical clescriptions of the viviparous forms only are given by l)avis.

Data associated with viviparous specimens in our collection are as follows: Carbondale (June + ), Havalla (June 20), Morton (July 22), I'r. bana (July 10), 1928; El l’aso (July 5), Hardin (June 25). Herod lone 21), Kappa (Aug. 1t), Rock lsland (July 7), Starved Rock State Park (Sept. I0), 1929. All collected on Corylus umeriomu. 


\section{MACROSIPHUM CRATAEGI (MOXFLL)}

Siphonophora crataegi Monell, Bulletin of the United States Geological and Geographical Survey of the Territories, Vol. V. No. 1, January 22. 1879, Art. 1, p. 20.

This comparatively rare species, often somewhat difficult to place generically because of slightly swollen cornicles suggestive of Amphorophora, was first recorded from Illinois by Davis (1911b). It feeds in small numbers upon the undersides of the leaves of Cralacgus and apparently is never abumlant enough to cause damage and attract attention. Davis (1911b) has recorded it from Chicago and figured the antenua of the wingless viriparous female. Patch $(191 \mathrm{tb})$ has described the alate viviparous female. A description of the apterous oviparous iemale is appended because this sexual form has not been recorded or clescribed previously.

Data associated with our series of viviparous specimens are as follows: Bloomington (Ang 12), 1884; Oakwood (Sept. 1T), Urbana (July 10), 192S; Highland Park (July 13), 1929. An oviparous female mas taken at Urbana, Oct. 11, 1929. All collected on Cralaegus sp.

Arterots Orirakot's FeMALE

Length from vertex to tip of anal plate, 1.86. Color essentially similar to that of apterous viviparous female. Average width of head across eyes, .43. Comparative lengths of antennal segments as follows: III-.60, IV$.50, \mathrm{~V}-.46, \mathrm{Vl}-.13$ plus .59 . Secondary sensoria absent, segments feebly imbricated Beak reaching to about mesothoracic coxae. Width of head through eyes, .43 . Cornicles .57 long, with the apical half slightly swollen; flange at apex present. Cauda .21 long, not constricted, with two hairs on a side. Posterior tibiae with basal lalves very much swollen and with about 150 sensoria, which extend beyond the swollen portion of the tibiae. Morphotype.-Apterous oviparous female: Slide No. \$517, Ürbana, Illi. nois, October 11, 1929, on Cratacgus sp. (Frison and Ross).

\section{NIACROSIPHUM DIRHODIM (WAKER)}

Aphis dirhodum Walker, Annals and Magazine of Natural History, Vol. III. 1849 , p. 42.

This species has not heen reported previously from Illinois. Our specimens agree well with the description as published by Theobald (1926). All forms have been described. It over-winters on rose and migrates to wheat, oats, and various other grasses for the summer montlus.

Alate viviparons specimens taken at Urbana (Oct. 21, Nor. 5). 1929, and males at Urbana (Nov. 5), 1929. All collected on cultivated Rosa sp.

\section{MACROSIPHUM ERIGERONENSIS (THOMAS)}

siphonophora erigeronensis Thomas, Bulletin Illinois State laboratory of Natural History, Vol. I. No. 2, Jume, $18 \mathrm{TS}$. p. T.

Specimens from Carbondale. lllinois. provided the material from which this species wis describerl. It is ynute common in the state and is found on the flower stalks and upper parts of the stems of its hosts. The descriptions of the alate male aud the apterous oviparous female, botl previously undescribed, are given here. 
Slide No. 5157 in the Survey collection has been selected as the neotypic slide since the types of this species have not been recovered. Data associated with this slide are as follows: Carbondale, Illinois, June 4, 1928, on Erigeron sp., collected by Frison and Hottes.

Data associated with our viviparous specimens are as follows: Cairo (June 3), Carbondale (June 4), Champaign (July IS), Elizabethtown (May 29), Herod ( May 29), Marshall (May 25), Metropolis (June I), Mt. Carmel (May 26), Muncie (Oct. 6), Oregon (June 28), Starved Rock State Park (June 12), St. Josepli (Aug. 5), Urhana (Aug. 27), 1928; Decatur (June 12), Granite City (June 25), Kankakee (July 14), Kansas (June 17). Mahomet (Aug. I7), Oregon (July 11), Rock Island (July 7), Starved Rock State Park (July 5, 6, Aug. 14, Sept. 10), Urbana (Oct. 14), 1929; Urbana (May 19), 1930. Nales and oviparous females were collected at Urbana (Oct. 14), 1929. All collected on Aster sp., Erigeron annuus. Erigeron canadensis, Erigeron philadelphicus, Erigeron sp., Solidago canadensis, and solialago sp.

\section{Al.ate Male}

Size and general color.-Average length from vertex to tip of anal plate, 1.27. Head and thorax very dark greenish brown; abdomen green with cornicles, cauda, anal plate, and genitalia dark brown. Antennae dark brown with the first and second segments and extreme base of third segment light greenish brown. Femora with basal third yellowish green, remaining portion dark brown; tibiae brown and darkest at apices; tarsi the same. Stigma brownish with posterior margin darkest. Veins brown bordered with very light brownish suffusions. Beak dusky green with two apical segments brownish.

Structure.-Average width of head across eyes, .41. Antennal segments with the following proportional lengths: III- .57 to .74 , average .64 ; IV.40 to .57 , average $.47 ; \mathrm{V}-.37$ to .50 , average $.44 ; \mathrm{VI}-.11$ to .16 , average .14 plus .59 to .71 , average .65 . Secondary sensoria present on third, fourth, and fifth antennal segments, irregularly arranged, on fifth segment inclined to be present on apical half of segment, distributed as follows: III- 3 I to 45 , average 41 , IV- 8 to $3 \mathrm{~S}$, average $21, \mathrm{~V}-12$ to 13 . Primary sensorium on sixth antennal segment with about six marginal sensoria. Cornicles .32 long, apical one-third covered with closed reticulations, remaining portion imbricated, flange at apex poorly developed. Cauda .2I long.

\section{Airtelots Oril'alious FeMale}

Length from vertex to tip of anal plate, 2.14. Color essentially as in apterous viviparous female. Average width of head across eyes, 46 . Contparative lengths of antennal segments as follows: III- .69 to .74, average $.71 ; 1 \mathrm{~V}-.40$ to .43 , average $.42 ; V-.37$ to .41 , average .39 ; VI- .I3 to .14, average .I4 plus .57. Secondary sensoria (Fig. 296) confined to third antennal segment and rarely extending beyond basal half of segment; irregularly arranged but confined largely to one side of the segment, averaging 13, gleatest variation from average being 4. Beak reaching metathoracic coxae. Cornicles $\$ \$$ long, apex covered with closed reticulations for a little more than one-fourth the length of the cornicles, remaining portion faintly imbricated. Cauda .36 long, scarcely constricted, with about five hairs oll a side. Hind tibiae swollen above apical half, with about 60 sensoria.

llotype.-Alate male; Slide No. S488, Urbana, Illinois, October 14, 1929. on Erigeron sp., (Frison and Park). On slide with males. Morphotyle.Apterous oviparous female; Slide No. 8493, same data as allotype. On slide with oviparous females.

\section{MAC'ROSIPHUAI FRIGIDICOLA (GH,LTTE AND l'A.MLI:)}

Uacrosiphoniclla frigilicoln Gillette and l'alner, Annals of the lintomological Society of America, Vol. XXI, No. I, Marcli, I928, p. 3.

This is the first published recorel of this species since it was reseriberl, and the first record of it outsicle of Coloralo. Becanse of its 
protective coloration it is very difficult to locate on its hosts. All forms of this species were included in the original description. Specintens of our material have been compared with paratypic material ly Professor Palmer and found to be identical.

Data associated with our viviparous specimens are as follows: Lrbaua (Aug. 20, 25, Oct. 6, 7), 1929. All collected on Achillea Hillefolium, Artemisia abrotanum, and Artemisia perlemontana.

\section{MACROSIPHUM GEI ( KК H)}

Siphonophora gei Koch, Die Pflanzenlause Aphiden, 185\%, p. 1T1, no. 16. Siphonophora euphorbiae Thomas, Bulletin Illinois State Laboratory of Xat. ural History, Vol. I, No. 2, June, 1S78, p. 6. Xi s symmymy.

siphonophora euphorbicolu Thomas, Bulletin Illinois State Laboratory of Naturat History, Vol. I, No. 2, June, 1878, p. 6. Vex synonymy.

Hundreds of bulletins and short articles have been written concerning this cosmopolitan plant louse because of its economic importance as an enemy of the potato and spinach crops and the role it plass in the transmission of plant diseases. It las attracted the attention of the greneticists because of the existence of hoth pink and green forms or varieties. Patch (191.ic) and Shull (19.25) have shown that parthenogenetic females of each variety produce offspring which remain in color true to the stock from which they cance. This extensive literature. most of which has been associated with the nane of $M$. solunifolii (Ashmeacl), can not he reviewed here. First definitely recorded from Illinois by Davis (1!)11b) the name of $1 \%$. asclepiadis Cowen. We do not believe that curcubitac (Thomas), the tyjes of which are lost, is a valicl species. It jrobably is a synonym of 11 . gci.

The rose is evidently the tavorite winter or prinary hosi of this species, but it is known to over-winter on a few oflher plants. Smmmer generations are found on a large number of hosts. Good descriptions of all forms are given by Patch (1911a and 1!1:x). Smith (1!11!), and Theobald $(1926)$.

Cotypes of Siphonophora euphorbiae Thomas and siphonophora cuphorbicnla Thomas have been recovered. Atthough this cotypic material is in very poor condition, there is no doubt that the specimens involved are identical with $M$. gci. Slide No. 8771 is a cotypic slide of empluarbine Thomas and Slides Nos. $8772-5773$ are cotypic slides of cuphorbicola: all in the Survey collection.

Data associated with our viviparous specimens are as follows: Car. bondale (June 4), Catlin (Sept. 27), Elizabethtown (.lay 31, Oct. I2, 22), Galena (June 25, 27), Havana (June 20, 22), Nahomet (Oct. (i), Metropolis (June 1), Mounds (June 2), Mt. Carmel (May 26), Oakwood (Sept. 17). Oregon (June 28), Paris (Nov. 28), Quincy (June 6), Shawneetown (Ma: 27). St Joseph (Aug. 5), I'rbana ( May 26, 28, 3I, June 6, Juty I0, Aug. bi. 1928; Cairo (June 22), Calbondale (Sept. 2S), Centralia (Sept. 26, 2S). Collinsville (Sept. 11), Decatur (June 12), Edwardsville (Sept. 11), Evanston (Oct. 3), Jerseyville (June 25). Mahomet (Sept. 26). Makanda (Sept. 28 ). Monticello (Oct. 1), Mt. Vernon (Sept. 2S), Cormal (Aug. 14), Oakwood (Oct. 17). Rock Island (July 7, 9), Seymour (Jume 13), Urbana (Sept. 25, Oct. 7, 9, 15, 17), 1929: Golconda (Aprif 15). Metropolis (April 17), Olive Branch (April 19), Irbana (Aug. 18), 1930. Specimens collected on Amaranthus paniculatus. Amaranthus retrofterus. Amaranthus sp., Anthe. mis cotulu, Apium sp., .1porynum sp. Artemisia sp., Asclepias sp.. Calen-

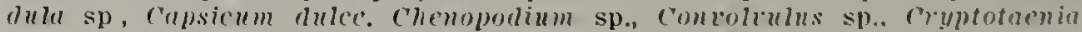


canadensis, Cucurbita marima, Eupatorium urticarfolium. Euphorbia marginata. Euphorbir sp., Hclianthus sp.. Ipomoea Batatas, Lactuea sp., Lagenaria muluaris. Lathyrus sp., Ligustrum vulgare, Ligustrum sp.. Lycopersicon esculentum. Pastinaca sativa. Pentstemon sp.. Pisum sativum. Poly!nuatum sp., Potygonum . Iuhtenbergii. Polygonum sp., Polymnia sp.. Rosa sp., Rumex sp. Sarifraga splendens. Scrophularia leporella. Senecio vulgaris, Solanum metongena, solanum tuberosum. Spinacea olivacea. Trifolium repens. and Tlmus fulva. Sexual forms taken in 1929 at Urbana (Oct. 17), on Iris sp., and at Oakwood (Oct. 17), on S(rophularia sp.

\section{MACROSIPHUM GERANII (OESTLINU)}

Nectrophora geranii Destlund. Geological and Natural History Survey of Minnesota, Bulletin No. 4, 1887, p. 80 .

This species has not been reported previously from Illinois. It occurs on the stems and undersides of the leaves of wild geranitun. Specimens of un material were compared by I'rofessor Oestlund with specimens considered by him as this species (the actual types are lost). The sexual forms are inknown. 1t is closely related to il. gei (Koch) lout may be readly separated because of the heavily shaded anal and cubital veins of the fore wings. The descriptions of the alate viviparous female and the stem mother, never having leen published, are added here.

Data associated with our viviparous specimens are as follows: Starved Rock State Park (June 13), 1928; Golconda (April 15), 1930. All collected on Geranium maculatum, or Geranium sp.

\section{Alate Viviparuls Frulle}

Average length from vertex to tip of anal plate, 2.23. Head and extreme base of third antennal segment yellowish green: mesothorax yellowish, shaded lightly with brown; prothorax, metathorax, abdomen, anal plate, and basal half of cauda apple green; apical half of cauda yellowish green. First and second antennal segments yellowish brown; flagellum except extreme base dark brown. Cornicles black. Coxae and troclianters greenish white; femora greenish wbite, with apical fifth dark brown; tibiae and tarsi dark brown. Beak concolorous with head, tip brown Wings hyaline, stigna and costa whitish yellow, veins black, cubital and anal veins nargined with fuscous. Eyes brownish.

IVirlth of head across eyes, .56. Comparative antennal lengths as folIows: $11 \mathrm{I}-.79$ to .89 , average .54 : IV -.71 to .79 , average $74 ; \mathrm{V}-.67$ to .74 . average .71 ; VI- .16 to .20 , average .18 plus .93 to 1.11 , average 1.01 . Secondary sensoria restricted to third antennai segment, numbering 5 to 8 , average 6 , arranged in a straight row and confined to basal half of segnent. Flagellum beyond sensoria distinctly imbricated, entire antennae with scattered, weak setae. Cornicles.$\$ 5$ in length. slightly sinuate, with a distinct flange at apex, the apical fifth with large, closed reticulations, the remainder moderately inbricate. Cauda .37 in length, constricted at middle, basal lialf subconical, apex portion narrow, but with extreme tip rounded.

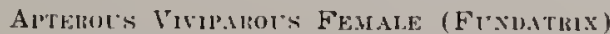

Length from vertex to tip of anal plate, 2.81. Ilead, thorax and abdomen a uniform shing green (pea-green). Cauda and anal plate concolorous with abdomen. lyes black. Cornicles at immediate base greenish, remainder black. ('oxae, trochanters, and most of femora grecnisli; femora near apices stightly brownish: tibiae pale brownish green with black at apices for a distance about equal the tarsi; tarsi black. First and second antennal segments concolorous with head, third antenual segment light brownisl but approaching black at tip; remaincler of flagellum dark brownish or black. Beak concolorous with head at base, gradually becoming darker, and tip lslackish. 
Nymphs.-About as stem mothers except not a shiny green, but a soft, more pruinose green.

Width of head across eyes, .56. Average antennal lengths as follows: $11 \mathrm{I}-.9 \mathrm{I} ; \mathrm{IV}-.62 ; \mathrm{V}-.60 ; \mathrm{VI}-. \mathrm{Is}$ plus .83 . Secondary sensoria usually absent, sometimes one present near base of third antennal segment. Third segment smooth, not imbricated, remainder of flagellum imbricated. Cornicles and canda as in alate viviparous female, respectively .95 and .42 in length, the cauda less inclined to he constricted near middle.

Morphotype.-Alate viviparous female; Slide No. 9014. Golconda. Illinois, April 15, 1930, on Geranium maculatum. (Frison and Ross). Morphotype.-Apterous viviparous female (fundatrix); Slide No.9019, same data as above. On slide witl nymphs.

\section{MACROSIPHUM GRANARIUM (KIRIY)}

Aphis granaria Kirby. Transactions of the Linnean Society of London, 179s, Vol. IV, p. $23 \mathrm{~S}$.

The English grain aphid is a widely distributed and common plant lotse in Illinois (Fig. 16) and sometimes becomes a serious pest of cereals. It was first reported from the state by Thomas who mentions that it did considerable damage in 1860 . In Illinois this aphid orerwinters both in the egrg stage and as viviparous females on grasses and autumn-sown cereals. Both green and pink forms are iound, the pink ones being mainly responsible for the prodiction of the sexual forms.

The litcrature of economic entomology contains many articles concerning the habits of this plant louse. Good technical descriptions of all forms may be found in the publications of Phillips (1!16) and Theolald (1926). Records of ccralis (Kaltenbach) trom Illinois hy l'ergande $(1904)$ refer to this species.

Data associated with our viviparous specimens are as follows: DuQuoiu (Sept. 7), Normal (June 15), 18s3; Carmi (Mlay 30), MlcHenry (July 31). Urbana (June 19). 1884: Urbana (May 21), 1S85; Urbana (June 25), 18s9; Roodhouse (July 16), 1S91; Champaign (July 21), 1894: Beech Ridge (May 22). Lewistown (June 26, 28), 1907; Bloomington (July 5), Carbondale (June 21), Farmer City (July 5), Galena (July 10), Grayrille (June 19). Herod (June 2I). Homer (June 1 7 ), Joneshoro (June 23), liankakee (July 14), LaSalle (July 5), Lawrenceville (June 1S), Newton (June 1T), Olney (June I8, 19), Oregon (July 11), Rock Island (July 7 ), Seymour (June 13). Sparta (June 24), Starved Lock State Park (July 6), Ullin (June 21). 1929; Gray's Lake (June 2I), 1930. All collected on d vena sativa, Trifolium matense. Triticum aestivum, and Ke'd Mays.

\section{MACROSIPHUM GRAVICORNIS PATCM}

Macrosiphum graniornis Patch. Maine Agricultural Experiment Station, Bulletin 2S2, December, 1919, p. 213.

This species bas not previnusly been reported from Illinois. It lins similar habits and hosts to the allied species M. crigerononsis (Thomns). from which it is easily separated becatse of differences in comparative antennal lengths. Di. Patch, who described the viviparous and oxiparous females, kindly checled the determinations of some of our specimens. A clescription of the previously unknown male is presented here.

Data associated with our viviparous specimens are as follows: Galena (June 25, 27), Havana (Jume 21), Herod (May 29), Kankakee (Jume 29). Metropolis (May 31), Mt. Carroll (June 25), Oakwood (Sept. 17), Oregon 
(June 27, 25), Pekin (June 20), Quincy (June 6), Rock lsland (June 24), Starved Rock State Park (June 12), 1928; Beach (Aug. 29). Edwardsville (Sept. 11), Elizabethtown (June 20), Urbana (May 22), 1929. Specimens collected on Aster sp., Erigcron philadelphicus, Erigeron sp.. Lactuca, sp., solidago canadonsis. and Solidago sp. Sexual forms taken on solidago sp. at Oakwood, Oct. 17, 1929 .

\section{Alate M.he}

Averige length from vertex to tip of anal plate, 1.20, General color as in alate viviparous female. Genilatia dark brown. Average width of head across eyes, .43. Comparative lengths of antennal segments as follows: I1I- .64 to .83 , average $.72 ; \mathrm{IV}-.36$ to .50 , average $.45 ; \mathrm{V}-.36$ to .50 , average .43 ; VI- .11 to .14 , average .12 plus .67 to .90 , average .77 . Secondary sensoria distributed as follows: III- 56 to 59 , average $57 ; \mathrm{IV}-9$ to 15. average 11: $\mathrm{V}-4$ to 12 , average $\tau$; sensoria on third segment somewhat tuberculate, covering most of segment, those on fourth and fifth segments usually in a nore or less regular row, those of fifth segment usually nearer apical portion of segment. Beak reaching to, or sometimes beyond. middle of mesothoracic coxae. Cornicles .3T long, with about the apical third reticulated, remaining portion slighlly imbricated. Cauda .20 long, constricted near midd!e, and with about $\&$ hairs on a side.

Allotype.-Alate male; Oakwood, Illinois, October 17, 1929, on Soliflago sp, (Frison and Ross). On Slide No. 8733 with another nule.

\section{MACROSIPHUM ILLINI new species}

\section{Alate Vivipaliol's Fendale}

Sizc und general color.-Average length from verlex to tip of anal plate, 2.27. Head and thorax chestnut brown blending to yellowish-brown at lateral margins. Abdonen lemon-yellow on dorsum with brownish patches on lateral margins; cauda and cornicles dark brown to almost black; area immediately around base of cornicles yellowish. but this area is surrounded by a brownish area much larger than palches on sides of abdomen anterior to cornicles. First antennal segment concolorous with the head, second segment somewlat lighter than the first, third segment concolorous with second for aboul length of second segment al base and then becoming dark brown or black, remaining segments mostly shades of brown with basal portions of segments liglitest, particularly basal portion of fourth segment. Basal portions of femora light yellowish and the apical portion dark brown; tibiae mostly yellowish except for trace of brown near ariculation with femora and a brown area at apex about three times the length of the tarsi; tarsi dark brown. Wings with veins light yellowish brown, the stigma of fore wings dark brown. Beak with basal portion concolorous with head and apical half dark brown.

Hearl and appenduges.-Average width of liead across eyes, 54. Antennal segments with comparative lengths as folfows: $111-.93$ to 1.03, aver age $.99 ; I V-.87$ to 1.04 , average $.98 ; V-.84$ to 1.00 , average $.93 ; V 1-17$ to .24 , average .21 plus 1.29 to 186 , average 1.71 . Secondary sensoria limited to the third antennal segment (Fig. 300 ); while scattered, they are confined largely to the basal half and one side of this segnent; in number they range from 24 to :32. The beak extends to the coxae of the third pair of legs.

Thorur and appendagrs.-Stigma of fore wings sharply pointed; second fork of media of fore wing is closer to the margin of wing than to first fork; veins delicite.

Ablomen.-Four pairs of poorly developed lateral tubercles situated in center of Iateral Jrownish areas, no lateral tubercles posterior to the cornicles. The cornicles (Fig. 103) are a little more than wo times the Jength of the cauda and are reticulated at apex for one-third of their length; cornicles neither swollen or constricted; the Iength varies from .31 to .43 and averages .36. The cauda (Fig. 171) is comparatively sloort for the size of this aphid and about three times the Jength of the second segment of the hind tarsus; its sides are straight, withoul any constriction, and with five to six luairs on a side; their length varies from .75 to .93 and averages .82 . Anal plate but little wider than the base of caula 
Aptekot's Virilakut's Female

Size and general color.-Average length from vertex to tip of anal plate 2.70. Pure lemon-yellow in color except the following which are brownish or blackish: apices of femora and tibiae, tarsi, tip of beak, area on third segment where secondary sensoria are concentrated, remainder of antennae beginning near middle of fourth segment, cornicles, area on abdomen surrounding and near base of cornicles, and cauda.

Head and alpuendages.-Average width of head across eyes, .55. Antennal segments with comparative lengths as follows: III- 97 to 1.42, average $1.05 ; 1 \mathrm{~V}-.86$ to 1.04 , average $.96 ; \mathrm{V}-.86$ to .97 , average $.93 ; \mathrm{V} \mathrm{I}-.20$ to .24 , average .21 plus 1.79 to 1.00 , average 1.47 . The small secondary sensoria (Fig. 27T) are restricted to the third segment and are concentratet in a small area removed from the base of the segment by a distance which is much less than one-half the length of the segment: the area free from sensoria occupies approximately the apical half of the segnient. The beak extends to the coxae of the third pair of legs.

Abdomen-Apparently without lateral tubercles and lateral brownish patches lacking except for large ones around base of cornicles. Cornicles. canda and anal plate as in the alate viviparous female.

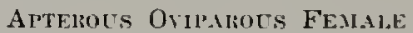

Size and general color.-Average length from vertex to tip of anal plate, 3.00. General color characters of the body similar to those of the apterous viviparons female.

Hearl and appendages.-Average width of head across eyes. 5.. Antennal segments with comparative lengths as follows: $111-.94$ to I 00 . average .97 ; IV- .83 to .83 , average $.83 ; \mathrm{V}-.84$ to .86 , average $.85 ; \mathrm{VI}-.15$ to .15 , average .15 plus 1.43 Secondary sensoria on third antennal segment as in the apterous viviparous female.

Thorax and appendages.-Sinilar to apterons viviparous female except that hind tibiae, partly basal half, are considerably swollen and thickly. covered with sensoria (Fig. 303 ).

Abdomen.- Abdomen and structures found on abdomen as in apterous viviparous female.

\section{Alate: MALE:}

Size and general color.-Average length from vertex to tip of anal plate, 1.43. Head, thorax, abdomen, cornicles, cauda, and legs colored as in the alate viviparous female. The antennae differ in that they are almost en. tirely dark excepting base of third segment, which is somewbat yellowisl for a distance equal to the width of the second segment at its base.

Head and alprndages.-Average width of head across eyes, .44. Antennal segments with comparative lengths as follows: $111-.87$ to .93 , average .89 ; $1 \mathrm{~V}-. \$ 9$ to .93 , average $.91 ; \mathrm{V}-.81$ to .91 , average .87 ; $\mathrm{VI}-.16$ to .17 , average .17 plus .96 to 1.64 , average 1.33 . The secondary sensoria (Fig. 285 ) are arranged as follows: $11 \mathrm{I}-28$ to 43 , average $35 ; 15-$ IS to 29 . average $23 ; \mathrm{V}-10$ to 19 , average 14 . The secondary sensoria are quite widely scattered over the surface of the third segment; on the fourth they are not confined to a row but are more numerous on one side of the segmeut than the other and show a slight tendency to favor the apical two-thirds of the segment; on the fifth segnent they are arranged in a slightly irregular row. The beak reaches almost to the coxae of the metathoracic pair of legs.

Thorar and appendages.-Thorax and appendages similar to those of the alate viviparous female.

Ibdomen.-Abdomen with lateral tubercles as in the alate viviparous female. Comicles twice the length of canda and about one-half the length of third antennal segment, closed reticulations covering a distance equal to about onethird of the length of the cornicle. Cauda dusky brown.

Holotylur.-Alate viviparons female; Jonesboro, Illinois, June 23. 1929, on Helianthus sp.. (Frison and Hottes). Slide No. 10121. tllotupe.-Alate male, Decatur, lllimois, October 5, 192!, on Helianthus s]), (Hottes). Slide No. 10122. Morphotypr-Apterous viviparous female; Urbana, Illinois, August 25, 1929, on Heliamthus sl., (Frison and Hottes). Slide No. 10123. 
Morphotype-Apterous oviparous female; Herod, 1llilois, October 12, 1929, on Heliunthus sp., (Frison and Hottes). Slide No. 10124. Paratypes.-One hundred and two slides of males, oviparous females, apterous and alate viviparous females, pupae and nymphs; all collected in Illinois by $T$. $H$. Frison, F. C. Hottes, and H. H. Ross from species of wild or cultivated Helianthus. The localities aud dates are as follows: Herod (October 12), 1925; Decatur (September 21 and October 5), Edwardsville (September 11), Hardin (Junc 25). Herod (June 29), Jonesboro (June 23), Metropolis (September 2S), Nameoki (June 25). Oakwood (July 22 and October 13), Oregon (July 11), Rock Island (July 7), Savanna (July 9), Starved Rock State Park (July 6), St. Joseph (August 27), Urbana (October 7 and 9), 1929. Slides Nos. 10125-10193 and others unnumbered. Also two paratypic slides from Washington, D. C., on Heliunthus tuberosn, and Lafayette, Indiana. Sept. 19, 1915, on sunflower, (J. J. Davis).

This handsonely colored species was first found at Herod, Illinois, on October 12, 19:5. It was again found there the following year and subsequent collecting has shown it to occur in all parts of the state on wild Hclianthus sp. It is evident from our experience with this species that it almost always frequents the undersides of the lowermost and larger leaves of its host, this habit perhaps being responsible for its escaping the notice of previous investigators. Although individuals of this species are not solitary in habit, we have never found them forming colonies of individuals as large as those formed by the closely related species of $M$. ambrosiac (Thomas) and $M$. mdibckiac (Fitch). Our collecting is sufficient, too, to demonstrate that this new species in Illinois does not have such cosmopolitan tastes as ambrosiae and rudbecliac, and as far as we have been able to discover, it is restricted to wild or cultivated species of Helianthus. The difference in the color of the canda will separate illini from ambrosiac and rulbcckiac; in illini the caucla is clark brown or black, whereas in ambrosiac and rudbeckiac it is yellowish or pale and never dark or black.

The general outlines of the life history of this species conform to those of other species of the genus Macrosiplum in Illinois. The alate and apterous viviparous females, nymphs, and pupae were collected during June, July, August, September, and Octolser. The sexual forms, males and oviparous females, have been found in October only and mating pairs were collected at Oakwood on October 13, 19:9.

This species is named in honor of the past and present students of the University of Illinois, collectively referred to as the "Illini." The name itself comes from a tribe of valiant Indians who once inhabited the territory that is now Illinois.

\section{MACROSIPHUM ILLINI VAR. CRUDAE new variety}

\section{Alate ANi Apterols Vivilarot's Fendies}

Structurally illentical with the typical form of illini. Differs in having the basic color bright green instead of yellow.

Holotype-CAlate viviparous female; Decatur, llinois, October 21, 1929, ou Helianthus sp., (F. C. Hottes). Slide No. 10200. Morphotype.-Apterous viviparous female; same data as holotype. Slide No. I020I. I'aratypes.Six slides, containing alate and apterous females; same clata as holotype. Slides Nos. 4786, 10202-10205, 10718. 


\section{MACROSIPHUM ILLINI rAR. SANGAMONENSIS new variety}

Atate axd Apterocs Vivipakots Females

Structurally identical with the typical form of illini. but differing in having the basic color bright red instead of yellow.

Holotype.-Alate viviparous female; Decatur, lllinois, October 21. 1929, on Helianthus sp., (F. C. Hottes). Slide No. 10194. Jorphotype.-Apterous viviparous female; same data as holotype. Slide No. 10195. Paratypes.Four slides, containing alate and apterous viviparous females and nymphs; same data as holotype. Slides Nos. 10196-10199.

\section{MACROSIPHUM IMPATIENSICOLENS P.TTH}

Macrosiphum impatiensicolens Patch, Maine Agricultural Experiment Station, Bulletin 282, December, 1919, p. 210.

This species has never been previously reported from Illinois. IVe lave had considerable difficulty in separating this plant louse from species belonging to the ambrosiac complex, and in our key have heen forced to key it out on the basis of host plant. We have held it as a distinct species because specimens of our material have been determined as impaticnsicolcns by Dr. Patcl. According to the original description and some of our material, the secondary sensoria on the third antennal segment average fewer in number than in ambrosiac. Possibly future biological studies will prove that the Illinois material we are recording as impaticnsicolens is the same species as ambrosiac.

Data associated with our viviparous specimens are as follows: MIt. Carroll (June 25), Rock Island (June 24), Starved Rock State Park (June 12, 13), 192s; Jonesboro (June 23). Starved Rock State Park 1 Aug. 14, Sept. 10), 1929. Specimens collected on Impaticns sp.

\section{MACROSIPHUM KICKAPOO new species}

\section{Alate Viviparots Fesille}

size and acneral color.-Average length from vertex to tip of anal plate, 1.91. Head and thorax chiefly light greenish brown; anterior margin of head, areas around ocelli, and dorsum of meso- and metathorax darkest; ventral areas of head and prothorax lightest, translucent greyish. Dorsum of abdomen pellucid green, with three or four lateral light dusky brown patches anterior to cornicles; base of cornicles surrounded by a narrow whitish ring which in turn is surrounded by a dusky brown area, the two areas connected posteriorly by a transverse dusky band; posterior to this are two trausverse dusky bands, the anterior band broad, the posterior band narrow and shorter. Cornicles pellucid greenish brown; cauda and anal plate light yellowish brown. First and second antennal seginents concolorous with head; remaining antennal segments uniformly dusky brown except extreme base of third segment, which is lighter in color. Eyes reddish black. Coxae coucolorous with thorax; trochanters and basal halves of fore femora yellowish. remainder of fore femora shading gradually to blackish brown; femora of middle and hind legs with only their extreme basal portions yellowish, remaining portions blackish brown: tibiae darkest at the knees, theu gradually shading to dusky yellowish at about the middle and continuing this color to within a distance from the apex equal to the length of the tarsi, this short apical portion dark brownish; tarsi dark brown, first segment lighter than second. Fore wing with stigma light yellowish: veins of wings dark brown, anal and cuhital veins much the stoutest and darkest and lightly bordered with brownish: posterior margin of wing where it meets anal vein suffused with brownisl. Beak luteous witl the exception of the extreme (ip) of the last segment which is dark brown. 
Herd and appendages.-Average width of head across eyes, .50. Antennal segments with comparative lengths as follows: $1 \mathrm{II}-.66$ to .73 , average .70 ; IV - .50 to .60 , average $.56 ; \mathrm{V}-.53$ to .64 ; average $.58 ; \mathrm{VI}-.16$ to .19 , average .17 plus .97 to 1.00 , average .99 . The secondary sensoria (Fig. 294) are entirely or almost all restricted to the third antennal segment, distributed ahout in a straight row and almost the entire length of the segment beginning at a distance from the base about equal to the length of the second antennal segment and ending very near the end of the segment; occasionally a secondary sensorium on the fourth segment; sensoria large, numbering from 16 to 20 and with an average of 18 . The beak is short. failing to reach the coxae of the mesothoracic pair of legs.

Thorax and uppendages.-Stigma of fore wing quite narrow and sharply pointed; second fork of media usually closer to the margin of the wing than it is to the first fork, but in a few specimens the reverse is true. The hind tarsi. exclusive of claws, are not quite equal to the length of the cauda.

Abromen.-Cornicles (Fig. 109) with sides straight and tapering but slightly to the apex which is without a rim; apical one-fourth covered with closed reticulation, remaining portion strongly imbricated; in length they are a little more than twice the length of the hind tarsi exclusive of claws and average about .29. Canda (Fig. 172) short, stout, non-constricted, about equal to the base of the sixth antennal segment in length or an average length of . Is with four pairs of hairs on a side.

\section{Apterous Vivipakous Feinale}

Size and gencral color.-Average length from vertex to tip of anal plate, 1.90. Entire body and appendages pellucid whitish green except the following parts: sixth antennal segment, tarsi, extreme tip of heak and reticulated apical portion of cornicles, all dusky brown; eyes dark reddish-black.

Head and appendages.-Average width of head across eyes, .47. Antennal segments with comparative lengths as follows: III - .64 to .79, average .72; $\mathrm{IV}-.39$ to .50 , average $.44 ; \mathrm{V}-.4 \mathrm{I}$ to .51 , average .48 ; VI- .14 to .16 , average .14 plus .81 to 1.00 , average .88 . Secondary sensoria limited to the third antennal segment, never farther removed from the base of the segment than one-half the lengtl of the cornicles; numbering from one to three, two being the more common number. The beak may reach as far as the coxae of the metathoracic pair of legs but generally extends just to the mesothoracic pair of coxae or slightly heyond.

Thorax and appendages. - The hind tarsi are a little shorter than onehalf the length of the cornicles, or subequal to the length of the base of the sixth antennal segment.

Ablomen.-Canda similar to that of alate viviparous female except it has three hairs on a side. Cornicles and anal plate similar to the same structures of the alate viviparous female.

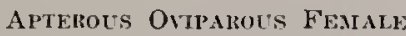

size and gencral color.-Average length from vertex to tip of anal plate, 2.1 I. This form in color and markings is practically identical with the apterous viviparous female.

Hral and appendages.-Average width of head across eyes, .46. Antennal segments with the following proportions: III - .6I to .66, average .64; IV.41 to .51 , average $.46 ; \mathrm{V}-.44$ to .50 , average $.47 ; \mathrm{Vl}-.13$ to .14 , average .14 plus .77 to .90 , average .83 . Other characters as in apterous viviparous ftinales.

Thorax and appendagrs.-Posterior tibiae but slightly swollen with numerous sensoria on basal half which are difficult to count owing to clearness of legs. Otherwise as in apterous viviparous female.

tbdomen.-Similar to the apterous viviparous female, with the exception of apical modifications and cauda which is much shorter and stouter.

\section{ALATE, NIME}

Size and general color.-Average width of head across eyes, .49. Average length from vertex to $t i p$ of anal plate, 1.35. Color and markings almost 
identical with the alate viviparous female, differing only in that the lateral spots on the abdomen are more nearly confluent and that there is less brown on the posterior region of the abdomen since the white extends farther back on the dorsum than the base of the cornicles.

Head and appendages.-Antennal segments with the following comparative lengths: III - .43 to .71. average .59; IV - .33 to .50, average .43; V- -36 to .54 , average .45; VI-. II to .14, average .12 plus .69 to 1.01 , average. SS. Secondary sensoria found on third, fourth, and fifth antennal segments; varying greatly in size, those on fourth and fifth segments being uniformly small while those on third segment vary from large to small, the smaller sensoria outnumbering the large ones on third segment. Sensoria are distributed as follows: III- 26 to 35 , generally more than 30 ; IV- - to $\mathrm{II}$; $\mathrm{V}-7$ to 16 , geuerally more than 9 . On the fourth and fifth segments the sensoria are nearly in a straight line; on the third segment they are scattered although confined largely to one side of the segment and often quite crowded and close together.

Thorax and appendages. - Similar to alate viviparous female.

Abdomen.-Essentially as in alate viviparous female. Male genitalia dark dusky brown.

Holotype.-Alate viviparous female; Starved Rock State Park. Illinois, August 14, 1929, on Polygonatum sp., (Frison and Hottes). Slide To. $_{0} 0313$. Allotype.-Alate male; Same data as for holotype. Slide No. 103I4. Morphotype.-Apterous viviparous female; Same data as for holotype. On slide with two otler apterous viviparous females. Slide No. 10315. Horphotypc.Apterous oviparous female; Starved Rock State Park, Illinois, September 10, 1929, on Polygonatum sp., (Frison and Ross). On slide with male and two other oviparous females. Slide No. 10316. Paratypes.-Twenty-eight slides of males, oviparous females, apterous and alate viviparous females, nymphs and pupae; collected on Polygonatum sp. by T. H. Frison, F. C. Hottes, and H. H. Ross, at Starved Rock State Park, Illinois, on August 14 and September 10, 1929, and May 13, 1930, and Seymour, Illinois, June 20, 1930. Slides Nos. 10317-10337 and others unnumbered.

This small Macrosiphum is not closely related to any of the previously described members of this genus. It is. however, closely allied to $M$. sangumarimm described as new in this paper. It differs from the latter species in the color of the abdomen, cornicles, and legs. and the alate viviparous females may be separated by the more numerous secondary sensoria on the third antemnal segment.

The light coloration of this new species makes it easily detected on the lower sides of the green leaves of its host plant.

\section{MACROSIPHUM LAEVIGATAE EsSIG}

Macrosiphum laevigatae Essig, Pomona College Journal of Entomology, Vol. IlI, May, 1911, p. 548 .

This pale yellowish green species, heretofore recorded only from California and Maine, was taken by us on the tender shoots of a species of Sali.r at Starved Rock State Park. July 6, 19:?. Swain (1919) and Soliman (192i) have used the specific name of califormica (Clarke) for this species, but the antennal measurements do not agree with the original description of Clarke (1903). The sexual forms are unkmown.

\section{MACROSIPHUM LIRIODENDRI (MONFL.)}

Siphonophora liriodendri Monell, Bulletin of the Lnited States Geological and Geographical Survey of the Territories, Vol. I, No. I, Art. I. Jannary 22,1879, p. 20. 
Davis $(1909 \mathrm{~b})$ first reported this species from Illinois. It is very abundant on the undersides of the leaves of the tulip tree in all parts of the state. Good technical descriptions of all forms are given by Davis (1909b). The red color pluase of this aphid was named rufa by Monell.

Data associated with our viviparous specimens are as follows: Champaign (June 26), Urbana (June 21, 24), 1886; Urbana (July 2), 1891; Champaign (July 30), 1894; Herod (Oct. 12), Urbana (Oct. 15, 23), 1928; Bloomington (July 5), Cairo (June 22), Decatur (June 12), Elizabethtown (June 20), Grayville (June 19), Jonesboro (Sept. 26), Metropolis (Sept. 28), Richmond (July 12), and Woodriver (June 25), 1929. Sexual forms have been collected as follows: Decatur (Oct. 20), Herod (Oct. 12), Urbana (Oct. 15), 1928; and Urbana (Oct. 9), 1929. All specimens collected on Liriodendron Tulipifera.

\section{MACROSIPHUM LUDOVICIANAE (OESTLUND)}

Siphonophora ludovicianae Oestlund, Fourteenth Annual Report of the State Geologist of Minnesota, March, 1886, p. 23.

This species has not previously been reported from lllinois. We have found it present in almost every patch of wormwood examined. It shows a decided preference for the terminal portions of the plant. The sexual forms are unknown. The viviparous forms are best described by Soliman $(192 \%)$. Specimens of our material have been determined by Professor Oestlund as this species (actual types lost).

Data associated with our viviparous specimens are as follows: Benton (Sept. 26), Champaign (Aug. 13), Erie (July 9), Herod (Sept. 27), LeRoy (Aug. 14), Mattoon (Sept. 10), Rock Island (July 7), Urbana (Aug. 5), Vandalia (Sept. 28), Witt (Sept. 10), 1929; Metropolis (April 17), 1930. All specimens collected on Artemisia sp.

\section{MACROSIPHUM PALLENS new species}

\section{Alate Viviparotes Female}

size and general color.-Length from vertex to tip of anal plate, 1.89. Head, thorax and abdomen a pale yellow-green, except for small brownish areas immediately snrrounding ocelli. Cornicles concolorous with abdomen for a little over one-lialf their length, apical half light fuscous; cauda and anal plate concolorous with abdomen. First antennal segment concolorous with the head except inner apical margin somewhat brownish, second and base of third segment for a distance equal length of second segment pale yellowish, remaiuder of antennae dark brownish. Coxae, trocbanters, and basal half of femora coucolorous witl abdomen; apical portion of femora and remainder of legs brownish, particularly apices of femora, tibiae, and all of tarsi. Beak, except for brownisl tip, concolorous with head. Stigma of fore wings delicately fuscous, veins light brown, posterior margin of wing brownish near junction with anal vein.

Head and appendages.-Average width of head across eyes, .47. Antennal segments with comparative lengths as follows: III $-.90 ; \mathrm{IV}-.87 ; \mathrm{V}-.91$; VI- .23 plus- 1.43. Secondary sensoria (Fig. 289) limited to the third antennal segment, small, arranged in a straight row and extending along the entire length of the segment, numbering from 12 to 15 . Hairs on the antennae exceedingly fine and short, arising from conspicuous translucent areas, and might easily be overlooked were it not for these areas. Primary sensorium on the sixth antennal segment apparently without marginal sensoria. Beak just failing to reach to the coxae of the metathoracic pair of legs. 
Thorax and appendages.-Fore wing with the second fork of media closer to the margin of the wing than to the first fork. Medial and cubital veins failing to reach the margin of the wing.

Abdomen.-Cornicles (Fig. 112) long, tapering very gradually from hase to apex; with three or four rows of closed reticulations at apex followed by faint imbrications; well-developed flange at apex; about one-half as long as terminal filament of sixth antennal segment and twice as long as cauda, measuring .61 in length. Cauda (Fig. 175) distinctly constricted near middle, measuring .29 in length, with three hairs on each side. Anal plate normal for genus.

\section{Apthious Viviparous FeaI ALE}

Size and general color.-Average length from vertex to tip of anal plate. 2.40. Entire body except appendages an immaculate light green. Cornicles. cauda, and aual plate lighter in color than the abdomen; cornicles with the extreme apex faintly fuscous. First and second antennal segments, and base of third segment to point where the sensoria begin. concolorous with the head; remainder of third and following antennal segments yellowish brown, with apical portions of each segment and the portion of the sixth segment around the primary sensorium somewhat darker. Coxae, trochanters. and basal half of femora essentially concolorous with the body, remainder of femora darker towards apex; tibiae light brownish except apices, which are concolorous with the dark hrownish tarsi.

Head and appendages.-Average width of head across eyes, .50. Antennal segments with comparative lengths as follows: III- $\$ 0$ to .99 , arerage .89 ; IV- .80 to .93 , average $.88 ; \mathrm{V}-.64$ to .74 , average .71 : VI- .20 to .26, average .23 plus .93 to 1.39 , average 1.21 . Secondary sensoria small, ar. ranged in a straight row and confined to about the basal one-third of the segment; varying from three to four in number. four being the more common number. Beak similar to that of the alate viviparous female.

Abdomen.-Cornicles similar to those of the alate viviparous female and averaging .73 in length. Cauda less coustricted than in the alate viviparous female, with from three to four hairs on a side, averaging .38 in length.

Holotype.-Alate viviparous female; Galena, Illinois, July 10. 1929. on silphium integrifolium, (Frison and Hottes). Slide No. 10206. Vorphotype. -Apterous viviparous female; Galena, lllinois, July 10, 1929. on silphium integrifolium, (Frison and Hottes). On slide witl two apterous viviparous females and two nymplss. Slide No. 10207. Paratypes.-Four slides of alate and apterous viviparous females, nymphs and pupae. Galena. Illinois, July 10, 1929, on Silphium integrifolium. (Frison and Hottes), and Danville. lllinois. July 15, 1928, on Ambrosia trifila. (Hottes, Ross, and Park). Slides Nos. 1020 s-10211.

Mounted specimens of this species have a smperficial resemblance to a number of green-colored species of Hacrosiphum. This new species is very closely allied to $M$. pclargonii (halt.). but is distinguished by its pale whitish-green color in life. and by having the third. fourth, and fifth antemal segments subequal. It is also allied structurally to M. shranki Theolald. from which it may be distinguished by having fewer secondary sensoria on the third antemul segment. and the sensoria being $i n$ a row. The absence of marginal sensoria on the sixth antennal segment, the absence of marginal spots on the abdomen of the alate viviparoms females, and the more muiformly green hody in general and the brownish tibiac. are further differential characters. This species may he distinguished at once from . M. gci (Koch) and pisi (Kalt.) by the poorly reticulated comicles and the constricted canda.

The specinens were found scattered here and there on the hower sturfaces of the broad leaves of their host plant. 


\title{
MACROSIPHUN PISI (liWTEXBACH)
}

\author{
Figs. $36,37,1 S 1$
}

A Whis pisi Kaltenbach. Monographie der Familien der Pflanzenläuse, Aachen, 1843 , p. 23 .

The cosmopolitan pea aphid (Figs. 36 and $3 \hat{\imath}$ ) is one of the commonest and most widely distributed aphids in Illinois. Since it is often a serious pest of peas, clovers, and other legumes, it has received much attention from economic entomologists. This species was first recorded from Illinois (Carbondale) by Thomas (18:!).
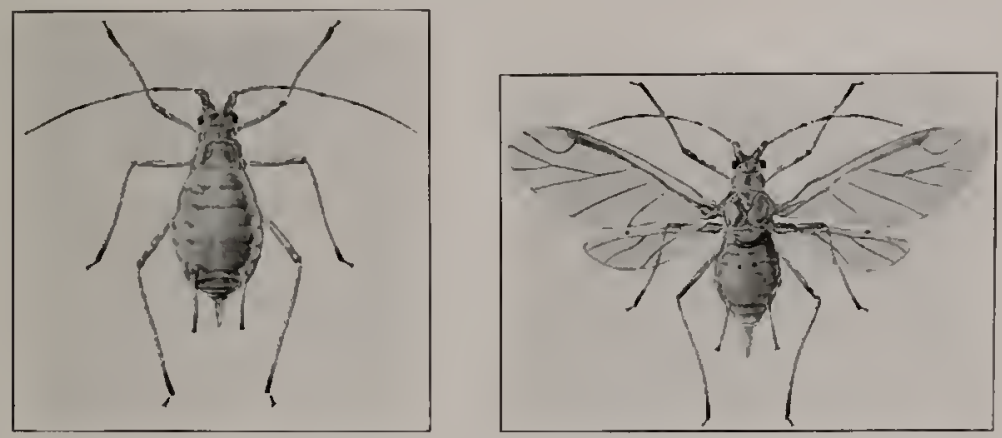

Fig. 36. (Left) Apterous viviparous female of the rea aphid. Iacrosiphum pisi (Kaltenhach). (After Folsom: Jll. Ent. Rep. 25.)

Fig. 37. (Right) Alate viviparous female of the pea aphid, Macrosiphum pisi (Kaltenbach). (After Folsom: 111. Ent. Rep. 25.)

Davis (191.i) and Theobald (192(i) have given very complete descriptions of all forms of this plant louse and much infornation concerning its biology. The article by Folsom (1!)!!) contains data relating to the life history of the pea aphid in Illinois and an especially good discussion of its natural enemies. The following summarized statement of the life history of this species is quoted from Davis:

"The life history of the pea aphis is quite simple, for it loes not have a true alternate host like some species of plant-lice As has been noted, it attacks leguminons plants primarily, some of which are annuals, others perennials. Clovers, particularly rerl and crimson clovers, serve as hosts for this insect the entire year, and it is on these plants that it usually passes the winter, either as eggs or as viviparous females, although during the summer months the migrants also pass to otluer leguminous crops, such as sweet pea, garlen and field peas, and vetches, and on these they multiply very rapidly, oftentimes destroying large acreages. In the latitude of lafayette, Ind., the species winters both as living viviparous females, usually wingless, and as eggs. Farther north it may winter exclusively in the egg stage, although our observations are not complete on this point, while farther south, in the latitude of Tennessee, the sexual forms which lay the overwintering eggs are rare, the insect orlinarily passing the winter as living plant-lice, both wingless and winged forms being able to withstand the lower temperatures in that latitude. Still farther soutl we know only the viviparous females and our observations lead us to believe that the species may reproduce viviparously indefinitely in localities where the winters are quite mild." 
Data associated with our viviparous specimens are as follows: Harvey (Sept. 15), 1907; Albion (May 26), Antioch (June 15), Bement (JuIy 17). Cairo (June 2), Carbondale (June 4), Champaign (July 9). Elizabethtown (May 31), Galena (June 25), Havana (June 21, 22), Herod (May 29), Jacksonville (May 11), Kankakee (June 24), Marshall (May 25), Metropolis (June 1), Mounds (June 2), Mt. Carmel (May 26), Muncie (Oct. 6), Oakwood (May 21), Oregon (June 29), Pekin (June 20), Quincy (June T), Rock Island (June 23), Shawneetown (Nay 27), Starved Rock State Park (June 13), Urhana (May 29), 1928; Cairo (June 22), Edwardsville (Sept. 11). Elizabethtown (June 20), Farmer City (July 5), Galena (July 10), Grayville (June 19), Hardin (June 25), Homer (June 17), Kansas (June 17), Oluey (June 18), Oregon (June 11), Orleans (April 15), Richmond (July: 12), Seymour (June 13), Springfield (May 2), and Urbana (JuIy 22). 1929.

Specimens collected on Carex sp., Cclastrus sp., Lathyrus sp., Medicago sativo, Melilotus alba, lielilotus officinolis, Pisum sativum. Polygonum Muhlenbergii, Solanum dulcamara. Trifolium protense, Trifolium procumbens. Trifolium repens, Trifolium sp., and Ticia sp.

\section{MACROSIPHUM PSEUDOROSAE PATCI}

Macrosiphum pseudorosae Patch, Maine Agricultural Experiment Station, Bulletin 282, December, 1919, p. 206.

Although Macrosiplum pscudorosae has not previously been reported from Illinois, it is widely distributed throughout the state. No doubt it has been confused with the related M. gei (Koch). Nectarophora pallida Oestlund (188:) may be this species, but if so the name is preoccupied by pallida (Walker) and hence is not arailable. Like $M$. gci, this aphid has pink and green forms. The sexual forms have not as yet been described.

Data associated with our viviparous specimens are as follows: Havana (June 21), Herod (May 31), Kankakee (July 15), Starved Rock State Park (June 12), 1928; Decatur (Sept. 21), Herod (Sept. 27), Kappa (Sept. 9), Mahomet (Aug. 7. 17), Oakwood (Aug. 4, Oct. 1\%), Rock Island (July \%), Starved Rock State Park (Sept. 10), 1929; Grand Detour (May 16). Starred Rock State Park (May 13), 1930. Specimens collected on Aruncus sylecster. Gaura biennis, Gaura sp., Gcum canadense. Impaticns. Oenothera bicnnis. Potentilla sp., and Rosa sp.

\section{MACROSIPHUM PTERICOLENS PATCH}

Macrosiphum ptericolens Patch, Maine Agricultural Experiment Station. Bulletiu 282, December, 1919, p. 210.

This species has never been recorded ontside of Maine. Wie have found apterous viviparous fenlales at Galena. Iuly 10. 1!19!!, on the fronds of Asplenimm Filir-femina, which we take to be this species It was originally descrilsed from alate viviparous females. Dr. 1'atch has seen specimens of our material and writes they "are probably this species."

\section{MACROSIPHUM PURPIRASCENS (OESTLLOTO)}

Ncctarophora purpurascens Oestlund. Geological and Natural History Survey of Minnesota, Bulletin No. 4, 1887, p. $\$ 1$.

This sprecies hats not previously been reported from lllinnis. It has the peculiar halit of producing the sexual forms early in the year and later in the seatson it is to be found in the egg stage only. It is a 
leaf feeding species frequenting meadow rue. The ma!e and oviparous forms of this species have never been described, and their descriptions are presented here.

Data associated with our viviparous specimens are as follows: Galena (June 25), Herod (Mlay 29), Oakwood (Mlay 12, 21), Oregon (June 28), Quincy (June 6, 16), Starved Rock State Park (June 13), 1928; Urbana (June 1). 1929; Oakwood (May 9). 1930. Sexual forms were collected at Quincy (June 16), 1928, and at Urbana (June 1), 1929. All specimens collected on Thalictrum sp.

\section{Alate MALE}

Average length from vertex to tip of anal plate, 1.35. Color essentially similar to that of alate viviparous femate. Comparative lengths of anten. nal segments as follows: IlI- .71 to .83 , average $.77 ; 1 \mathrm{~V}-.53$ to .56 , average $.55 ; \mathrm{V}-.43 ; \mathrm{VI}-.14$ plus .83 . Secondary sensoria distributed as follows: IlI- 94, IV- 41, V- 23; sensoria on third and fourth segments covering entire segment, those on fifth segment confined largely to one side of the segment. Cornicles .37 long, cauda. 14 long, both structures similar in shape to those of the alate viviparous female. Genitalia dark brown.

\section{Apterous Ovirarous Fexiale}

Average length from vertex to tip of anal plate, 1.74. General color essentially similar to that of apterous viviparous female. Average width of head across eyes, .50. Comparative lengths of antennal segments as follows: III- .51 to .63 , average $.56 ; \mathrm{IV}-.30$ to .53 , average $.40 ; \mathrm{V}-.29$ to .34 , average . 31 ; V1- .11 to .14, average .12 plus .44 to .50 , average .47. Secondary sensoria confined to third antennal segment, numbering 9 to 16 , averaging 12. Cornicles .58 long, cauda .27, not constricted. Hind tibiae with the basal two-thirds swollen and with about 65 sensoria

Allotype.-Alate male; Shide No. 6542, Urbana, lllinois, June 1, 1929, ou Thalictrum sp., (T. H. Erison). On stide with oviparous females and nymphs. Morphotype.-Apterous oviparous female; Slide No. 5109, Quincy, Illinois, June 16, 1928, on Thalictrum sp., (Frison and Hottes). On slide with alate viviparous female, oviparous females and nymphs.

\section{MACROSIPHUM RIBIELLUM DAVIS}

Macrosiphum riviellum Davis, Canadian Entomologist, Vol. LI, No. 10, Oct., 1919 , p. 231.

The ormamental currant aphid is common and generally distributed throughout Illinois. It was first reported from Illinois (Chicago) by Davis (1909b) ander the name of $M$. cynosbati (Oestlund), which was a misidentification. All forms of this plant louse have been well described by Davis (1909b, 1919). Quaintance and Baker (191i) have briefly chronicled the seasonal history as follows:

"This species usually occurs on the ornamental currants. The eggs hatch in the spring and numerous generations of wingless forms are produced. By August these are present in large numbers on the tender terminal twigs and to a less extent on the undersides of the leaves. Winged forms appear in September or earlier and ants are found attending the insects. Early in October the orange, wingless, egg-laying females may be found mating with the winged males and the eggs are laid shortly afterward."

A cotypic slide (No 4535) of this species has been deposited in the Survey collection through tlie kindness of Professor J. J. Davis.

Data associated with our viviparous specimens are as follows: Urbana (July 26, Aug. 2), I928; Chicago (July 14), El Paso (July 5), Galena (July 10), Lawrenceville (June 18), Macomb (Nay 4), Rock Island (July 9), and Woodriver (June 25), 1929. Sexual forms were taken at Irbana (Nov. 5 ), 1929. All collected on Ribrs odoratum and Ribes sp. 


\section{MACROSIPHLM ROSAE (LIXAEL'S)}

Aphis rosae Linnaeus, Systema Naturae, Editio Decima, 1758, p. 452.

The rose aphid has been doubtedly recorded by Thomas (1si'g) from Illinois and positively so by Davis (1911b). It is common and

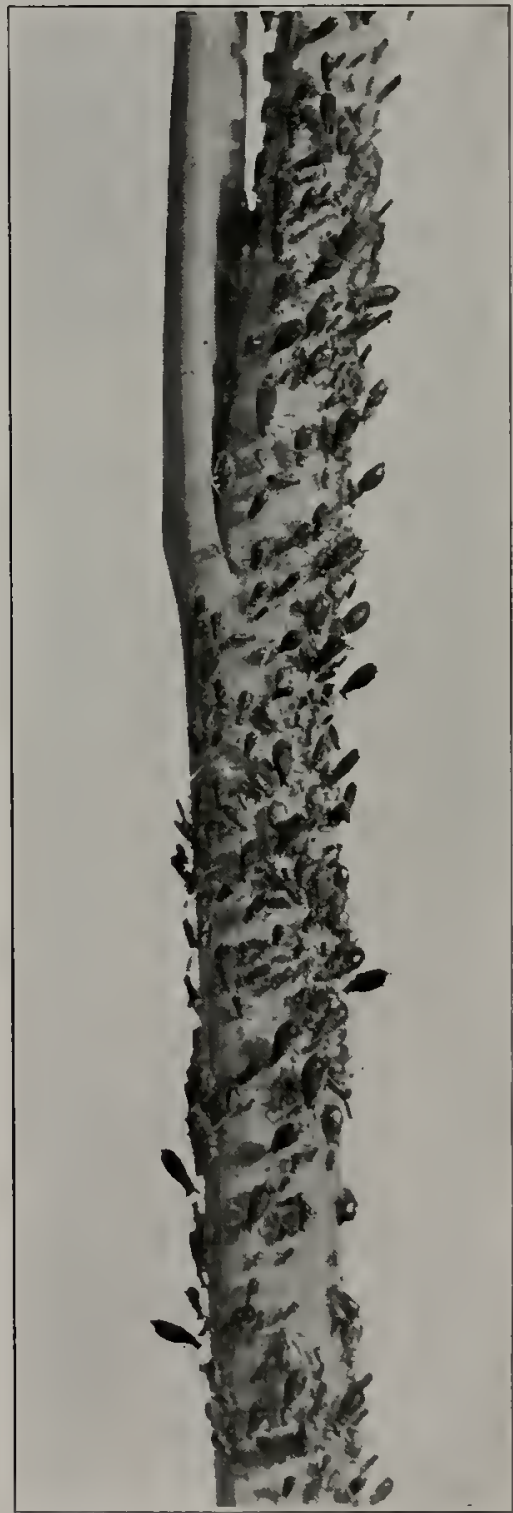

Fig. 38 . A colony of Macrosiphum. rualucelias ( $\mathrm{F}$ it $\mathrm{ch}$ ) ou godden glow. Rudbrekia laciniata var. hortensia: Champaign, June $10,1929$. generally distriluted throughout the state both out of doors and in greenhouses on wild and cultivated roses. Patch (191!) states that it is "not known to migrate and does maintain a continuous resirlence upon the rose." Theobald $(1 \leqslant 26)$. however, lists a few other plants as hosts of this species. This species has pink and green varieties in common with $M$. yci and $M$. pscudorosac. It is partial to the tencler shoots and leaves of the rose.

Good descriptions of all forms are given by Theobald $(1926)$ and of the viviparous forms by Essig (19111) and Soliman $(192 i)$.

Data associated with our viriparous specimens are as follows: Carbondale (June 4 ), Galena (June 2:). Kankakee (June 29). Marshall (May 25), Oregon (June 2S), Pekin (June 20), Quincy (June 6), Rock Island (June 23), St. Joseph (June 1\%), Urbana (May 23, Oct. 1), 1928; Caser (June 17), Chrisman (June 6). Edwardsville (Sept. 11), Granite City (June 25), Houner (June 17), Starred Rock State Park (July 6). [rbana (Nov. 5), Witt (Sept. 10). 1929; Edgebrook, in greenhouse (Feb. 2\$). and Oregon (Nay 16), 1930. Oriparous females were collected at Lrbana (Nov. 5), 1929. All collected on Rose sp.

\section{MACROSIPHLM RLDBECKIAE (Fitcil) \\ Fic:. 3s}

dphis ruriberkiae Fitch. Fourth An. nual Report of the liegents of the Lniversity, on the Condition of the State Cabinet of Natural History, state of New York. January 14. 1\$51. p. S6.

This large vermillion aphid (Fig. 3is) is very common and widespread thronghont Illinois. Very few dmmps of golen glow 
escape being attacked by it, and the stems are frequently covered for much of their length with these aphids standing head downwards. It was first recorded from Illinois by Thomas (18i:9). Onr records indicate that it is not a true migratory species.

The best descriptions of the viviparous forms are those by Essig (1911a) and Soliman (192i). Weed (1888) has described sexual forms under the name of rudbcckiac, but his discussion indicates he may have had two species confused.

Data associated witl our specimens are as follows: Normal (June 22), 1903; Albion (May 26), Cairo (June 2), Carbondale (June 4), Danville (July 15), East Dubuque (June 26), Elizabethtown (May 29), Havana (June 21), Herod (May 29, 31), Homer Park (Oct. 23), Jacksonville (June 18), Kankakee (June 29), LeRoy (June 20), Marshall (May 25), Metropolis (May 31), Mt. Carroll (June 25), Neoga (June 10), Oakwood (May 21, 25), Oregon (June 27), Pekin (June 20), Quincy (June 6), Rock 1sland (June 24), Shawneetown (May 27), Starved Rock State Park (June 13), Urbana (June 14, Oct. 5), 1928: Beach (July 13). Jerseyville (June 25), Kansas (June 17), Monticello (May 24), Newton (June 16), Oakwood (Oct. 17), and Putnam (May 5), 1929. Specimens collected on Ambrosia sp., Eupatorium urticaffolium, Helianthus sp., Hieracium venosum, Rudbeckia laciniata var. hortensia, Silphium perfoliatum. Solidago canadensis, Solidago nemoralis, Solidago sp., and Sonclus sp. Sexual forms taken at Homer Park (Oct. 23), 1928, and Oakwood (Oct. 17), 1929, on Rudbeckia sp.

\section{MACROSIPHUM RURALIS new species}

\section{Alate Viviparol's Feirale:}

Size and general color.-Average length from vertex to tip of anal plate, 2.90. Head, thorax, and abdomen essentially green, but head and particularly the mesothorax often brownish green and abdomen a very dark green. Cornjcles dark brown to black and often with a greenish tinge, particularly near apex; cauda dark brown to black except area covered by anal plate, which is concolorous with abdomen; anal plate concolorous with abdomen. Antennae witl first, second, and very base of third segment almost concolorous with head, except that inner margin of first segment dark brown; remainder of third and following segments dark brown to almost black. Coxae and trochanters light green; basal halves of femora pale whitish green, remainder of femora and following segments dark brown or black. Beak with basal part concolorous with thorax; apical two-thirds dark brown, except for a narrow light-colored band on the long middle segment. Eyes dull reddisll brown. Stigma of fore wings dark brown, veins fine, posterior margin of wing brownish near junction with anal vein.

Hrad and apprndages.-Average width of head across eyes, .60. Antellnal segments with comparative lengths as follows: III- 1.00 to 1.29 , average $1.13 ; \mathrm{IV}-.99$ to 1.16 , average $1.09 ; \mathrm{V}-.91$ to 1.09 , average $1.02 ; \mathrm{VI}$ .23 to 26 , average .24 plus 1.57 to 1.69 , average 1.61 . Secondary sensoria (Fig. 2S6) restricted to the third antennal segment, chiefly confined to one sicle of the basal two-thirds of the segment, irregular in arrangement, numbering from 13 to 27 and averaging about 18 . Beak extending to or slightly beyond the hind coxae.

Thorer and apyendages.-Stigma of fore wings rather narrow and sharply pointed at apex; second fork of media closer to margin of wings than to first fork.

Abdomen.-With four pairs of small lateral tubercles, the pair just anterior to the cornicles being the largest, no lateral tubercles posterior to cornicles. Cornicles (Fig. 115) rather long, base nearly twice as wirle as middle or apex, varying in length from 1.13 to 1.29 and averaging 1.21 ; closed reticulations at apex occupying about one-fourth of length; flange feebly developed. ('auda (Fig. 185) about one-half the length of the cor 
nicles, varying in length from .50 to .66 and averaging .61 ; but slightly constricted near base; with about seven hairs on a side. Anal plate rounded and not much wider than base of cauda.

\section{Apterous Vivtparots Fejiale}

Size and general color.-Average length from rertex to tip of anal plate, 2.93. General color of body and appendages similar to alate viviparous female except as follows: femora mostly light yellowish green, with only apical one-fonth or less dark brown.

Head and appendages.-Average width of head across eyes, .61. Antennal segments with comparative lengths as follows: $11 \mathrm{I}-.97$ to 1.19, average $1.10 ; \mathrm{IV}-.69$ to 1.13 , average $.95 ; \mathrm{V}-.64$ to 1.00 , arerage $.90 ; \mathrm{VI}$ .20 to .24 , average .22 plus .76 to 1.51 , average 1.09 . Secondary sensoria restricted to basal one-third of third antennal segment, beginning about length of second antennal segment from base and continuing irregularly on one side of segment; varying from 5 to 17 in number and averaging about 10. Otlerwise similar to alate viviparous female.

Thorax and abdomen.-Except for lack of wings, similar to alate viviparous female.

\section{Apterous Oviparous Female}

Size and general eolor.-Average length from vertex to tip of anal plate, 2.76. Colored essentially as the apterous viviparous female.

Head and appendages.-Average width of head across eyes, .53. Anten. nal segments with comparative lengths as follows: I1]- S9 to 1.03, average $.95 ; \mathrm{IV}-.69$ to .96 , average $.8 S ; \mathrm{V}-.71$ to .89 . average $.82 ; \mathrm{VI}-.17$ to .23 , average .20 plus .81 to 1.46 , average 1.26 . Secondary sensoria restricted to the third antennal segment, grouped basally on one side of the segment beginning about the length of second antennal segment from base and continning for a distance eqnal to one-half or more of the segment, numbering from 8 to 18 and averaging about 10 . Otherwise as apterous viviparous female.

Thorax and appendages.-Similar to apterous viviparous female except as follows: basal half of tibia swollen and covered with numerous sensoria. one specimen with about 250 sensoria.

Abdomen.-Cornicles, cauda, and anal plate essentially as in apterous viviparous female except average lengths are smaller.

\section{Alate Male}

Size and gcneral color.-Average length from vertex to tip of anal plate, 1.85. Colored essentially as in the alate viviparous female.

Head and appcndages.-Average width of head across eyes, .53. Anten. nal segments with comparative lengths as follows: $11 \mathrm{I}-.80$ to .93 , average $.85 ; \mathrm{IV}-.77$ to .89 , average $.82 ; \mathrm{V}-.69$ to .83 , average $.7 T$; VI- .17 to .20 , average .19 plus 1.29 to 1.43 , average 1.36 . Secondary sensoria present on third, fourtli, and fiftb antennal segments, with average distribution as follows: $111-36 ; 1 \mathrm{~V}-15 ; \mathrm{V}-14$. Sensoria on third segment concentrated chiefly on one side of segment though irregularly arranged: on fourth and fifth segments in a more regular row; scattered along almost entire length of segments, except nore numerous on basal half of third segment. Beak extending to or beyond coxae of hind legs.

Thorax and appendages.-Similar to alate viviparous female.

Abromcn.-Essentially similar to that of alate viviparous female except for presence of dark brown hairy claspers; cornicles and cauda are shorter.

Hololy/pe.-Alate viviparous female; Kappa, Illinois. August 14. 1929. on Aclinomeris allernifolia. (Frison and Hottes). Slide No. 10050. Allopype. - Alate male; Oakwood, Illinois, October 13, 1929, on Actinomeris alternifolia, (Frison). Slide No. 10051. Morpholype-Apterous viviparous fe. male: Same data as for holotype. Slide No. 10052. Morpholypc.-Apter. ous oviparous female; Decatur, lllimois, October 5. 1929, on Actinomeris allernifolia, (Hottes). Slide No. 10053. Paralypes.-Eighty-eight slides of alate and apterous viviparous females, oviparous females, males, pupae and 
nymplis: all collected in Illinois by T. H. Frison, F. C. Hottes, and H. H. Ross, on Actinomeris alternifolia and once on Helinthus sp. The localities and dates are as follows: Elizabethtown (Mlay 31), Herod (October 12), and Narshall (Mlay 25), 192s; Choat (September 28), Decatur (September 22 and October 5). Herod (September 27), Kappa (August 14 and September 9.22), Oakwood (October 13), and Pana (August 10), 1929; Mounds (Horseshoe Lake-April 4) and Úrbana (May 12), 1930. Slides Nos. 1005410102 and others unnumbered.

This new species is very suggestive of specimens of Macrosiphum ambrosiac (Thomas) which are lighter and greener in color than normal. Mounted specimens, nevertheless, are easily separated from ambrosiae because of the dark cauda and the longer and more slender comicles in addition to other finer characters. It is not altogether impossible that this new form is an off-shoot of ambrosiae which has been modified through host selection. IVith regard to our present paucity of knowledge of the limits of variation within this genus and the effects of host selection. it seems advisable to us to classify this new form as a new species.

All forms of this plant louse are found on the mann stalks of the host plant, particularly near the top of the plant. In the case of plants heavily infested, the mature forms are often found bencath the leaves.

\section{MACROSIPHUM SANBORNI GHLLETE}

Fig. 106

Ifacrosiphum sanborni Gillette, Canadian Entomologist, Vol. XL, No. 2, February, 1908, p. 65.

The chrysanthemum aphid is one of the most common and destructive pests of chrysanthemum out of doors and in greenhouses. It was first recorded from Illinois by Davis (1911). The short, somewhat bottle-shaped cornicles are rather peculiar among the Macrosiphum and the species has been placed in the genus Macrosiphoniella, a conplex which we have for the present considered as a subgenus. The best descriptions of the viviparous forms have been given by Gillette (190s) and Theobald (1926). To our knowledge the sexual forms have not been described.

Data associated with our viviparous specimens are as follows: Urbana (Dec. 3), 1906; Danville (Nov. 4), Decatur (Nov, 4), Elizabethtown (May 29, Oct. 12), Hutsonville (Nov. 29). Lawrenceville (Nov. 28), Neoga (June 10), Pekin (June 20), Quincy (June 5). Shawneetown (May 27), Urbana (Oct. 1), 192S; Cairo (June 22), Carbondale (June 21), Collinsville (Sept. 11). Grayville (June 19), Jonesboro (June 23), Oakwood (Nov. 7), 1929; Flora (Nov, 13), and Vandalia (Nov. 13), 1930. All collected on Chrysnnthemum sp.

\section{MACROSIPHUMI SANGUINARIUMI new species}

Alatr: Viviparocs Female:

Size and general color.-Average length from vertex to tip of anal plate, 1.72. Head anc thorax, except intersegmental areas of thorax, which are ruby-red or yellow, a dark chocolate-brown. Abdomen with five rounded chocolate brown patclies on each side anterior to cornicles; dorsum with transverse, segmentally arranged, chocolate-brown bars which become almost fused beginning with third segment and extending backwards to cauda; 
remainder of body of abdomen ruby-red or yellowish. Cornicles variable, usually dark at base and with apical portions yellowish-white. Cauda rubyred or yellowish. Anal plate brownish. Venter of body variable, either rubyred to almost yellow with the mesosternum a chocolate-brown. Eyes reddishbrown. First and second segments concolorous with head, remainder vellowish-brown becoming almost black at apex and near primary sensoria. Coxae. trochanters, and extreme base of femora yellowish-white; remainder of femora brownish to black at apices: tibiae yellowish-white except the apices. which are black; tarsi black. Wings with stigma yellowish and veins light brown and delicate in structure. Beak concolorous with head at base. remainder yellowish-white except extreme tip is black.

Hcad and appendages.-Average width of head across eyes, 46. Antennal segments with comparative lengths as follows: $111-.51$ to .73 , average .62: IV - .33 to .53 , average .47; $V-.43$ to .56 , average $.50: V I-.17$ to .21 , average .18 plus .71 to 1.03 , average .94 . Secondary sensoria (Fig. 2S7) linited to the third antennal segment, arranged in a straight row, numbering from 5 to 10 . They are not equally distributed throughout the length of the segment, usually failing to leach the end of the segment by a greater distance than the first sensorium is removed from the base of the segment. The hair on the antennae is very short and fine and not even equaling in length onehalf the width of the segment. The beak just reaches the coxae of the mesothoracic pair of legs.

Thorax and appendages. - The fork of the fore wings is always closer to the margin of the wing than it is to the first fork.

Abdoncn.-The cornicles (Fig. 105) taper very gradually from base to apex, they are very delicately reticulated for about one-third of their length. and in length they average a little less than three times the lengtl of the cauda. The canda is scarcely constricted if at all, and has from 3 to 4 hairs on a side. The measurements of the cornicles and cauda are as follows: length of cornicles, .30 to .50 with an average of .43 ; length of canda. .11 to .21 with an average of .17 .

Apterous Vivip.liots Fexille (Fr:xDitrix)

Sizr and general color.-Average length from vertex to tip of anal plate. 1.77. Head with the exception of frontal areas, thorax, abdomen, cauda. and anal plate with exception of apical margin, an orange or ruby-red witl paler patches due to pale embryos showing through body wall. Frontal areas of head, first and second antennal segnents, coxae, and trochanters pale yellowish-orange. Cornicles and apical margin of anal plate a translucent whitish. Femora and tibiae whitish, the apices of the tibiae slightly infuscate: tarsi greyish black. Antennae beyond second segment white, with minute rings at apices of fourth and fifth segments and all of sixth segment black. Beak whitish with extreme apex hlack. Eyes deep purplish-red.

Head and appendages.-Average width of head across eyes, .44. Antennal segments with comparative lengths as follows: III- .50 to .57 , average .5t: $\mathrm{IV}-.19$ to .30 , average $.27 ; \mathrm{V}-.26$ to .36 , average $.32 ; V 1-.14$ to .19 , average .17 plus .46 to .57 , average .51 . Secondary sensoria lacking or if present. confined to a single sensorium on the third antennal segment. Primary: sensorium on sixth segment with a group of about five marginal seusoria on one side. Ail antennal segments faintly imbricated and with sparse setae. Antennal tubercles rather shallow. Beak extending to a point in middie of meso- and metathoracic coxae.

Thorax and ampendages.- Hairs on legs fine and short, those on the tibia considerably shorter than the width of the segment.

Abdom $n$.-Cornicles long. straight, without thange at apex. reticulated at apex for a distance about one-sixth of total length, remainder imbricated. averaging about .46 in length. Cauda nou-constricted, with apical portion rather blunt, usually with three inwardly curved setae on each side, averaging about .21 in length. Anal plate normal.

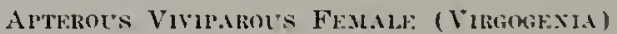

Sizc and general color.-Average length from vertex to tip of anal plate. 1.58. Head pearly-white to light yellowish. In monnted material the thorax 
and portion of abdomen anterior to cornicles and often entire abdomen dusky brown; in life this portion of the body is a briglit, shining ruby-red the color probably being due to the red sap of the host plant; portion of abdomen posterior to cornicles often considerably lighter in color than the portion anterior to the cornicles. Cornicles and cauda uniformly yellowishwhite. Antennae uniformly yellowish-white in most specimens; a few specimens have the apex of the fifth and all of the sixth antennal segments lightbrownish or dusky. Coxae, trochanters, and femora witl yellowish-white at base, the yellow becoming less intense towards the knees but never turning to brown, tibiae yellowish-white with a slightly dusky area at the apex about equal to the length of the tarsus; tarsi brownish. The beak is yellowishbrown tipped with darker brown at apex.

Head and appendages.-Average width of head across eyes, .39. Antennal segments witb comparative lengths as follows: $111-.46$ to .71 , average $.58 ; 1 \mathrm{~V}-.36$ to .50 , average $.41 ; \mathrm{V}-.39$ to .53 , average $.44 ; \mathrm{VI}-.13$ to .19 , average .16 plus .71 to .89 , average $.44 ; \mathrm{VI}-.13$ to .19 , average .16 plus .71 to.$\$ 9$, average .\$1. A single secondary sensorinm is located on the third antennal segment at a distance from the base of the segment about equal to the length of the first antennal segment. The beak reaches about to the middle of the metathoracic pair of legs.

Thorax and abdomen.-Cornicles about three times as long as the tarsi. Cornicles, canda, and anal plate are similar to these structures of the alate viviparous female. Length of cornicles, .39 to .53 with an average of .46 . Length of cauda, .16 to .21 with an average of .1s.

Nymph.-Light yellowish green with eyes reddish. Markedly contrasting in color with adults.

Holotype.-Alate viviparous female; Carbondale, Illinois, June 4, 192S, on Sanguinaria canadensis. (Frison and Hottes). Slide No. 10278. Morphotype.-Apterous viviparous female (fundatrix); Urbana, Illinois, Mlay 3 , 1930, on Sanguinaria eanadensis, (Frison and Ross). Slide No. 10279. Mor:photype.-Apterous viviparous female (virgogenia); Carbondale, Illinois, June 4, 192S, on Sanguinaria canadensis, (Frison and Hottes). Slide No. 10280. Paratypes.-Forty-one slides of alate and apterons viviparous females, pupae, and nymphs collected in lllinois on Sanguinaria canarensis, as follows: Anna, Mlay S, 1925 (Frison); Carbondale, June 4 (Frison and Hottes), Quincy, June 6 (Frison and Hottes), Oakwood, July $S$ (Hottes and Ross). Danville, August 4 (Hottes and Ross), and Urbana, May 3, 12 and 21 (Frison and Ross), I928. Five slides of alate and apterons viviparous females, pupae. and nymplis from St. Panl, Minnesota, on Sanguinaria canadensis, as follows: June 19. June 22, July 26, 1926 (Hottes). Slides Nos. 10281-10312 and others unnumbered.

This distinctive species feeds on the under surface of the leaves of its host, the blood-root. Specimens on the same plant are quite solitary in habit and seem to prefer locations near the larger veins except the small nymplis.

Aside from its generic affinities with Macrosiphlum as a whole, this new species has no near relatives among the described species of this genus known to us. It does, however, show characters suggestive of a close relationship, with a new species $(M$. kickapoo) described in this paper. It may be separated from kickapoo on the basis of the reddish color of the anterior portion of the aldemen, by the lack of dusky cornicles and dusky posterior portion of abdomen, ly differences in color of legs, and by the third antennal segment having considerably fewer secondary sensoria. 


\section{MACROSIPHUM SCHRANKI TIEORALD}

Aphis urticae Schrank, Fauna Boica, 1801, p. 106. Tame preoccupied. Jacrosiphum schranki Theobald, British Aphides, Vol. II, 1927, p. 403. Jew name.

This pale yellowish-green aphich has not previously been reported from Illinois. It was taken on the unclersides of the leares of pigweed. Good descriptions of the viviparous females and the male are griven by Theobalrl (19:6). The oriparous female is mnknown.

Data associated with our viviparous specimens are as follows: Oregon (July 11), and Roch Island (July 7), 1929. Specimens collected on Amaranthus sp.

\section{MACROSIPHUM SONCHELLLMI (MlONELL)}

Siphonophora sonchella Monell, Bulletin of the United States Geological and Geographical Survey of the Territories, Vol. V, No. 1, 1879, Art. 1, p. 21.

This species has not previously heen reported from Illinois: in fact, it has been mentioned only a few tinnes in literature since it was first described by Monell and these records are doubtful. Through the kindness of Professor J. J. Davis we have been permitted to compare alate specimens of our material with typic specinens of sonchella. A description is given of the apterous viviparous female since it never lias been described. Supplementary descriptive notes concerning the alate viviparous female, not covered by the original description, are also presented.

Data associated with our slides of this species are as follows: Nlarshall (May 25), 192S; Nlahomet (Aug. 7), and Urbana (Ang. 21), 1929. Specimens collected on Lactuca sp.

\section{Alate Viviparots Female}

Size and general color.-Average length from vertex to tip of anal plate, 2.07. We have no record as to color. Dark markings essentially as described by Monell in original description except that dark brown to blackish more nearly satisfies the color of the darker markings in place of black.

Head and appendages.-Average width of head across eyes. .53. Comparative lengths of antennal segments as follows: III- I.54; $1 \mathrm{~V}-.46$ to 47 , average $.46 ; \mathrm{V}-.46$ to .47 , average .46 ; VI -.13 -plus .97 to 1.00 , average $.9 s$. Secondary sensoria confined to third and fourth antennal segments. small and very tuherculate, on the third segment numbering from 95 to 108 , averaging 101, dotting the entire segment, on fourth segment numbering from 5 to 7 , arranged in a more or less straight row. Primary sensorium on sixth antennal segment with a group of about 6 marginal sensoria at the side. Hairs on antennae short and spine-like, those on third segment somewhat enlarged at tip. Beak reaching to mesothoracic coxae.

Thorax and abdomen.-Prothorax without lateral tubercles. Cornicles .63 long, straight, with slightly more than the apical one-fourth corered with closed reticulations, remaining portion imbricated. Cauda .43 long, not constricted, with about five hairs on a side. Anal plate rounded.

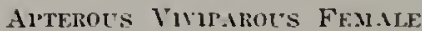

Sinc and general color.-Average length from vertex to tip of anal plate. 2.62. General color of body shining, deep brownish-red. Antennae. except for extreme base of third segment, dark brown. Legs, cornicles, and cauda as in alate viviparous female.

Hrod and appendages.-Average width of head across eves, .54. Auten. nal segments with the following comparative lengths: $111-1.14$ to 1.47 , 
average $1.33 ; 1 \mathrm{~V}-.33$ to .54 , average $.45 ; \mathrm{V}-.37$ to .50 , average $.44 ; \mathrm{VI}-$ .11 to .14 , average .13 plus .59 to 1.07 , average .S6. Secondary sensoria (Fig. 298) confined to third and fourth antennal segments although often absent on the fourth; arranged as in alate viviparous female; numbering fron 71 to $S 0$, averaging 76 , on the third segment and from 0 to 7 on the fourth.

ibdamen.-Cornicles .59 long, with an apical area equal to a little mole than one-fourth their length, covered by closed reticulations, otherwise as in alate viviparous female. Cauda 45 long, with from three to six hairs on a side, otherwise as in alate viviparous female.

Moryhotype.-Apterous viviparous female; Slide No. 737s. Marslall. Illinois, May 25, 192S, on Lactuce sp., (Frison and Hottes). On slirle with alate and apterous viviparous females.

\section{MACROSIPHUM TAPUSKAE new species}

\section{Alate Vivil'arot's FeuAle}

size and yeneral color.-Length from vertex to tip of anal plate, 1.69. Head and most of thorax a greenish brown, prothorax slightly lighter in color. Abdomen and anal plate a light green except for a dark green dorsal band between and around bases of cornicles, which have basal one-fifth light green and remainder dark brown; cauda light yellowish green. First, seconrl, and extreme basal portion of third antennal segments concolorous with head, remainder of segments brownish black. Coxae and trochanters a light green; femora with basal lialves a light green gradually shading to dark brown at apex; tibiae with basal one-fifth light brown, middle three-fifths yellowish, and apical one-fitth dark hrown; tarsi dark brown. Front wings with veins and edges of stigma black and conspicuous; body of stigma. base of costa and subcostal veins pale whitish-green; hind wings with veins delicately traced in brown. Beak with base concolorous with head, apex dark brown. Eyes red.

Herd and appendages.-Average width of head across eyes, .50. Antennal segments with lengths as follows: III- .93; IV- .79; V- .64; VI- .17 plus 1.00. Secondary sensoria (Fig. 204) restrieted to the third antennal segment, irregularly arranged but more abundant on one side than on the other, numbering 36 and $3 \mathrm{~S}$. Fourth, fifth, and sixth antennal segments imbricated, all segnents with a few lairs, not as long as width of segments, which are enlarged at tip. Primary sensoria on fifth and sixth segments, that on sixth segment with about seven small sensoria on one side. Beak reaching to middle of mesothoracic coxae.

Thorax and apprndages.-The second fork of media closer to margin of wing than to first fork in one wing, in other wing media is forked only once; stigua rather narrow and bluntly pointed at extreme tip; veins not reaching margin of wings; posterior margin of fore wing thickened and dark where anal vein reaches margin of wing.

Abromrn.-Cornicles (Fig. 117) .86 in length, grarlually tapering from base to a flangeless but somewhat dilated apex; base about twice the width of apex; closed reticulations at apex equal to about one-fourth total length. remainder of length imbricated. Cauba .39 in length, tapering to a blunt tip, lateral margins with from 2 to 4 hairs on a side. Anal plate normal.

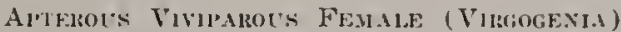

Size and grnerml rolor.-Average length from vertex to tip of anal plate, 2.14. Head, thorax, ablomen, canda, and anal plate apple-green. Cornicles (oncolorous with abdomen except tip. which is black for a distance ahout equal to length of tarsus. First and sefond antennal segments brownish green: third antennal segment concolorous with first and second segments about to first sensorium, which is removed from the base by a distance equal to the length of the second segment of the hind tarsi exclusive of claws; remaining portion of third segment and remaining segments uniformly dark brown or black. Coxae, trochanters, and basal halves of femora concolorous with ablomen and remaining portions slualing to dark brown; in some cases the brown extends further basally on the dorsun of the femora; tibiae 
with basal four-fifths (hind legs) or three-fourths (fore and middle legs) brownish green, remaining apical portion dark brown. Beak essentially concolorous with venter of thorax except its distinctly dark brown terminal segment. Eyes red.

Head and appendages.-Average width of head across eyes, .51. Antennal segment with comparative lengths as follows: 11 I- .87 to 1.00 , average .93 ; IV- .67 to .79 , average $.73 ; \mathrm{V}-.53$ to .57 , average .55 ; VI- .16 to .17 , average .16 plus .81 to .86 , average .83 . Secoudary sensoria (Fig. 299) restricted to the third antennal segnient, small, numbering from $s$ to 13 , located on the basal two thirds of the segment beginning at a distance from the base of the segment about equal to the first antennal segment; arranged almost in a straight row and when seen from the side they are rather tuberculate. The liairs on the antennae are somewhat enlarged and blunt at the tip. The beak reaches to, or just beyond, the coxae of the metathoracic pair of legs.

Thorax and appendages. - The hairs ou the tibiae are Jong (about equal to the width of the tibiae), distinctly spine-like except for tip, which is usually blunt; hind tarsi, exclusive of claws, subequal in length to reticulated portion of cornicles.

Ablomen.-Cornicles widest at base, then gradually tapering towards apex except that apex is flared; apical half with imbrications poorly developed, closed reticulations of apical portion covering a distance equal to the hind tarsi of hind legs: areraging .\$2 in length. Cauda (Fig. 176) heavy, bluntly pointed, almost straight at tbe sides, with four pairs of lateral hairs, over twice as long as the length of the base of the sixth antenual segment or about one-half the length of the cornicles; areraging .38 in length. Anal plate short and wide.

\section{Aptemous Viviphot's Fenlale (FCxDAthix)}

Similar to summer apterous viviparous female except for areraging slightly larger.

\section{Aptenous Oriprocs Feulte}

The oviparous female is essentially an exact counterpart of the apterous viviparous female and therefore no detailed description of this form will be given. Average length from vertex to tip of anal plate, 1.80. Arerage width of head across eyes, .47. Comparative leugths of antennal segments are as follows: $111-.73$ to 1.00 , average .84 ; IV- .57 to .64, average .60 ; $\mathrm{V}-.46$ to .50 , average $.49 ; \mathrm{V}-.11$ to .17 , average .15 plus .57 to .79 , average 70. Secondary sensoria number trom $\delta$ to 11 and average 8.5 . Sensoria on the lind tibiae occupy a little less than two-fiftls of the total length of the tibiae, beginning at a distance from the base equal to the leugth of the lind tarsi; number varying from 15 to 38 ; area occupied by sensoria slighty swollen. Cauda is inclined to have more hairs than the apterous viviparous form.

Holotype.-Alate viviparous female; Metropolis, lllinois, Apri] 17, 1930, on Achilleu Millefolium. (Frison and Ross). Slide No. 10219. Morphotype. -Apterous viviparous female (virgogenia); Urbana, Illinois, October $7,1929$. on Aehillea Millefolium, (Frison and Ross). Slide No. 10220. Morphotypc.Apterous viviparons female (fundatrix); Grayville, Illinois, April 15, 1930. on Achilleu Millefolium, (Frison and Ross). Slide No. 10221. Morphotype.Apterous oviparous female, Urbana, lllinois. October 16. 1929. on tchillea Irillefolium, (Frison and Ross). On slide with two other oviparous fenales. Slide No. 10222. Paratypes.-Twenty-two slides of apterous viviparous females, oviparous temales and nympls: all collected in lllinois, on tehillea Millefolinm, by T. H. Frison and H. H. Ross, as follows: Trbana (October 7. 15 and 16), 1929; Anna (April 19). Grayville (April 15), Harrisburg (April 16). Metropolis (April 17). Starved Rock State Park (May 13), 1930. Slides Nos. 10223-10241 and others umunbered.

This new species stuperticially suggests certain other green species of Macrosiphum which have reticulaterl comicles. It may be distinguished from these forms by the row of minute secondary sensoria on 
the third antennal segment of the apterous viviparous female and the irregularly arranged sensoria of the alate female.

Because of a similarity in the green coloration of both host and insect, and its preference for the leaves close to the ground, this species is difficult to find. Another factor helping to explain why this species has been previously overlooked is its pronounced solitary habit. I good way to collect this species is to jar the leaves of the plant and then collect the aphids on the gromnd directly beneath the lower leaves.

\section{MACROSIPHUI TARAXACJ (KALTEXMAC)}

Aphis taraxaci Kaltenbach, Monographie der Familien der Pflanzenläuse, Aachen, 1843, p. 30.

As far as wc are aware, this dark-colored aplid has not been previously recorded from Illinois. It occurs on the stems and leaves near the crown of its host, the clandelion. The sexual forms are unknown. Theobald (1926) and Soliman (192\%) have given good technical descriptions of the viviparous females.

Data associated with our viviparous specimens of this species are as follows: LeRoy (June 20). Urbana (May 23, June 7), 192s; Champaign (May 2S), Nonticello (May 2t), Starved Rock State Park (July 6), and Urbana (May 22), 1929. All specimens collected on Taraxacum officinale.

\section{MACROSIPHUM TARDAE new species}

Alate Vivipalous Female

size and general color.-Average length from vertex to tip of anal plate, 2.17. Head, thorax, and abdomen uniformly dark hlackish-red. Cornicles almost black. cauda concolorous with abdomen. Antennae brown; basal portion, except base of third segment, darkest. Legs dark reddish-brown shading to black with the exception of coxae and basal third of femora which are more yellowish-brown. Beak essentially concolorous with the head, apex somewhat darker. Fore wings with stigma brownish; veins light yellowishbrown, particularly yellowish near base; posterior margin of wing brownish near junction with anal vein.

Head and appendages.-Average width of head across eyes, .53. Antennal segments with comparative lengths as follows: $111-.71$ to .78, average .75; $1 \mathrm{~V}-.50$ to .59 , average $.54 ; \mathrm{V}$ - .44 to .64 , average .46 ; VI- .14 to .23, average .17 plus .57 to .63 , average .59 . Secondary sensoria (Fig. 288) restricted to the third antennal segment, not uniformly distributed except for grouping on one side of segment, numbering from $2 S$ to 40 and usually with more than 30. The beak extends to the coxae of the metathoracic legs.

Thorax and appendages.-Stigna of fore wings rather narrow and sharply pointed at apex; second fork of media in relation to first fork of media and margin of wings quite variable, but the second fork usually closer to margin of wings than to first fork.

Abdomen.- No lateral tubercles. Cornicles (Fig. 107) rather short and stout in comparison with most species of this genus, about equal to the length of the fourth antennal segment, varying from .47 to .57 and averaging .55 in lengtli; usually reticulated at apex for about one-third of their length; flange slightly developed. Cauda (Fig. 182) about one-half as long as cornicles, varying from .28 to .36 and averaging .32 in length; slightly constricted in middle; with three to five pairs of hairs on a sille. Anal plate rounded, extending almost to middle of cauda.

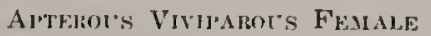

Size and gencral color.-Average length from vertex to tip of anal plate, 2.37. General color of body and appendages as in alate viviparous fenale. 
Hrad and appendages.-Average width of head across eyes, .51. Antennal segments with comparative lengths as follows: $111-.60$ to .80 . arerage .70 ; $1 \mathrm{~V}-.46$ to .54 , average $.50 ; \mathrm{V}-.29$ to .48 , average $.38 ; \mathrm{VI}-.10$ to .17, average .14 plus .47 to .57 , average .55 . Secondary sensoria restricted to the third antennal segment; varying in number from 11 to 20, the most common number being less than 15; sensoria difficult to distinguish because of dark color of segment and large bases of stout setae; beginning to appear about the length of the second antennal segment from base and usually extending little if any beyond middle of segment. Beak extending to coxae of metathoracic legs.

Abdomen.-Cornicles considerably longer than fourth antennal segment. about as long as those of alate viviparous females, varying from .53 to .60 and averaging .57; much wider at base than those of alate viviparous females and bent slightly outwardly where reticulations begin; reticnlated for at least one-third its length from apex; flange weakly developed. Cauda somewhat longer in proportion to cornicles than in the alate viviparous females, constricted near middle, with four to six hairs on a side. Otherwise as in alate viviparous female.

\section{Apterous Oriparous FeM-aleE}

Sizc and generul color:-Average length from vertex to tip of anal plate. 2.14. Head, thorax, and abdomen dark blackish-red; lateral portions sometimes slightly lighter in color, particularly so in the region around the thorax. Mounted specimens show the red replaced hy brown. Cornicles almost black; canda and anal plate dark dusky-brown. First and second antenual segments either concolorous with the head or darker: remainder of antennae dark blackisb-brown, except that the third segment is usually somewhat lighter before first secondary sensorium. Femora with basal half yellowish-brown, abruptly shading to dark dusky-brown at their apex: tibiae dusky-brown, often darker near the base and apex; tarsal segments blackish. Beak fuscous with apical segments darkest.

Hctu and appendages.-Avelage width of head across eyes. .53. Antennal segments with comparative lengtlis as follows: $111-.64$ to $.9 \%$, average .74 ; $1 \mathrm{~V}-.43$ to .57 , average $.50 ; \mathrm{V}-.36$ to .51 , average $.45 ; \mathrm{VI}-.14$ to .17 , average .16 plus .50 to .66 , average .58 . Secondary sensoria confined to the basal three-fourths of third segment, numbering from 13 to 1.9, averaging about 17, scattered along one side of the segment, large and with wide rims. The beak extends beyond the mesothoracic pair of coxae and may reach to or beyond the coxae of the metathorax.

Thorax and appendages.-Hind tarsi, exclusive of claws, subequal to the length of the base of the sixth antennal segment. Hind tibiae with basal two-thirds of segment swollen, this area covered with a variable number of sensoria which are very difficult to count; sensoria may exceed bo in number.

tbdomen.-Coruicles tapering slightly from base to apex, sides nearly straight; reticulated at apex for a little less than one-tlird of their length, the reticulated area being equal to the length of the hind tarsal segments exclusive of claws; flange weakly developed. Cauda about two-tbirds as long as the cornicles, about subequal to the length of the fourth antennal segment, or about three times as long as the base of sixth antemul segment: slightly constricted near middle; with five to eight hairs on a side. Anal plate similar to anal plate of the apterous viviparous female.

\section{ALATE MI.LLE}

Size and yencrul color.-Average lengtl from vertex to tip of anal plate. 1.62. Head, thorax, and abdomen brownish with a greenish tinge. Cornicles dusky green to dark brownish-black; cauda yellowish green: anal plate yellowish brown to dark brown. First and second antennal segments coucolorous witl head, remaining seguents varying in color from light dusky green to dark brown. Femora with slightly less than basal half greenish yellow, remaining portion lark brown to black; tibiae dark brown. sometimes hasal and middle area greenish rellow; tarsi dark. Hairs and bases of hairs on antennae and legs yellowisli, contrasting to ground color of these 
structures. Stigma brownish; veins near base yellowish hrown, otherwise brownish, fine. Beak essentially concolorous with head except terminal segments more brownish.

Heal and appendages.-Average width of head across eyes, .49. Antennal segments with comparative lengths as follows: III- .67 to .71, average .70 ; IV - .49 to .64 , average $.54 ; \mathrm{V}-.43$ to .57 , average $.49 ; \mathrm{VI}-.14$ to .14 , average .14 plus .64 to .71 , average .66. Secondary seusoria present on third, fourth, and fifth antennal segments, witl average distribution as follows: III-4S; IV- $S ; V-S$. Sensoria on third segment quite concentrated on one side of segment though irregularly arranged; on fourth and fifth segments in a more regular row, sensoria varying from small to large, but slightly tuberculate; distributed on third segment for almost its entire length except small area at base and apex, and on fourth and fifth segments starting just before middle and continuing almost to end of segments. Tlie beak extends to the coxae of the metathoracic pair of legs.

Thorar and appcnanges. - Second fork of the media of fore wing much closer to the margin of the wing than it is to the first fork. Otherwise as in alate viviparous female.

Abdomen.-Cornicles tapering slightly from base to apex, with sides almost straight; in length two and one-half times as long as the base of sixth antennal segment, averaging about .36 ; reticulated for about one-fourth of their length, the remaining portion being distinctly imbricated. Cauda about three-fiftlis as long as tlie cornicles, constricted near middle, with from four to six hairs on a side. Anal plate rounded, extending to constricted part of cauda.

Holot!lye.-Alate viviparous female; Beach, Illinois, August 29, 1929, on Helcnium autumnule, (Frison and Hottes). Slide No. 9984. Allotype.Alate male; Seymour, Illinois, October 16,1929 , on Helenium autumnale. (Frison and Ross). Slide No. 9985. Morphotype-Apterous viviparous female; same data as for holotype. Slide No. 9986. Morphotype.-Apterous oviparous female: same data as for allotype. Slide No. 99s7. Paratypes.Seventy-eight slides of alate and apterous viviparous females, oviparous females, males, pupae, and nymphs; all collected in lllinois by $\mathrm{T}$. H. Frison, F. C. Hottes, and H. H. Ross from Helenium autumnale. The localities and dates are as follows: Mahomet (October 2), 192S; Beacli (August 29), Kappa (September 9), Oakwood (October 17), and Seynour (July 20, August 6-2I. September 16. October 7), 1929. Slides Nos. 99S8-10036 and others unnumbered.

This Macrosiphum, because of its dark blackish-red color. superficially suggests in life Macrosiphum samborni Gillette. A closer exanination. however, enaloles one to immediately separate these two species on the basis of differences in comicles and cauda.

All stages of this species are found on the stalks near the flower head and directly under the hearls of the flowers. Often they are so concealed ly the flower heads that their presence is easily overlooked.

\section{MACROSIPHUNI TILIAE (MONHL)}

Siphonophmrn tiliar Monell, Bulletin of the United States Geological and Geographical Survey of the Territories, Vol. V, No. I, Jauluary 22, IS79, Art. 1, p. 20.

This specics, whose host is basswourl, was first reported from Illinois (Chicaso) by Davis (1!111). According to our rocords the species is wiclely distrilnted throughout Illinois. It exhibits a londness for the tender new shemes, particularly those around the lase of the tree. Davis (1914) has griven eroonl descriptions of all fornus.

Data associated witl our viviparous specimens are as follows: Normal (May 29), 1884; Quincy (June 6), I92S; Chicago (July 13), Galena (.July 
10), Lisle (July 14), Rock Island (July 9), Starred Rock State Park (July 5), Urbana (July 2), Waukegan (July 13), 1929; and Carbondale (April 18), 1930. All collected on Tilia americana.

\section{MACROSIPHUM VENAEFUSCAE D.IIS}

Macrosiphum venaefuscae Davis, Canadian Entomologist, Vol. XLTI, No. 2, March, 1914, p. 77.

This species has not previously been recorded from Illinois. Our specinens were taken on common dock and were found on the undersides of the larger leaves close to the ground. According to Davis (1914), this species occurs in summer on Polygonum and the eggs are laid on Rumer. Good descriptions of all forms are given in the original description.

We do not agree with Theobald (1926) in placing this species in the synonymy of $M$. gci (Koch). In habitus this species is very suggestive of $M$. gci (Koch) but it may be separated on the alate viviparous females by the larger number of secondary sensoria on the third antennal segment, their irregular arrangment, and also by the fact that the third antennal segment is shorter than the fourth. In the apterous viviparous forms the third antennal segment is either equal to or shorter than the fourth segment-a condition not found in $\mathrm{M}$. gei (Koch).

We have taken this species, viviparous females, only once at Lrbana on Oct. 1, 1928, on Rumer crispus. A cotypic slide (No. 9466) of this species has been deposited in the Survey collection through the kindness of Pro. fessor J. J. Davis.

\section{MACROSIPHUM ZINZALAE new species}

\section{Alate Vimparocs Female}

Size and general color.-Length from vertex to tip of anal plate, 2.46. Head and thorax dark dusky-green. Abdomen green with large dusky brown spots posterior to base of cornicles, and three pairs of very light and sometimes very small lateral dusky brown spots anterior to cornicles Cornicles greenish black. Cauda yellowish green to yellowish brown, considerably lighter in color than the abdomen. Anal plate concolorous with abdomen. First and second antennal segments concolorous with head, remaining segments greenish brown except base of third which is lighter. Femora with hasal halves pale yellowish green, apical halves greenish brown, darkest apically; tibiae dusky brownisl at base gradually darkening towards apex, which is almost black; tarsi browl. Beak yellowisl with the last segment brown. Stigma of fore wings light dusky brown; veins of wings the same, with just a suggestion of a border; posterior margin of fore wings in vicinity of anal vein brownish.

Head and appendages.-Average width of head across eyes, .60 . Comparative lengths of antennal segments as follows: III- 1.06 to I.I9, average $1.13 ; \mathrm{IV}-1.04$ to $\mathrm{I} 23$, average $1.14 ; \mathrm{V}-.87$ to .99 , average .94 : VI.21 plus 1.21 to 1.29 , average [.24. Secondary sensoria (Fig. 29I) confined to third antennal segment, tuherculate, irregularly arranged and varying greatly in size, numbering from 56 to 62 , averiging 59 . Primary sensorium on sixth antennal segment with a group of six small marginal sensoria ou one side. Beak uuusually long, extending well beyond netathoracic coxae, terninal segment one-tlird longer than base of sixth antennal segment.

Thorax and appendages.-Prothorax without lateral tuhercles. Stigma of fore wings long and comparatively uarrow, rather pointed at apex: second fork of media closer to margin of wing than to the first fork: all veins failing to reach margin of wing. Tibiae of legs with coarse spine-like hair. 
Abdomen.-Cornicles (Fig. 120) 1.14 long, gently tapering from base to apex which is curved outwardly; flange present; apex covered with closed reticulations for from one-third to a little nore than one-quarter the length of the cornicle. Caude (Fig. 186) .53 long, usually not constricted but sometimes slightly so, with eight to ten liairs on a side. Cauda normal.

\section{Aptemous Viviparot's Female (Vimionenia)}

Size and general color.-Average length from vertex to tip of anal plate, 2.71. Color essentially that of the alate viviparous female with these differences: head and thorax more greenish and less dusky; lateral spots on the abdomen lacking; femora yellowish green except for brownish apical portions.

Head and appendages.-Average width of head across eyes, .54. Comparative lengths of antennal segments are as follows: IIJ- 1.07; IV1.03; V- .86; V1- .19 plus 1.14. Secondary sensoria (Fig. 290) restricted to third antennal segment, quite small and for the most part tuberculate; mostly confined to one side of segment: in numbers varying from 30 to 40; area free from sensoria at apical end equal to twice the length of base of sixth antennal segment. Primary sensorium on sixth antennal segment with group of about five marginal sensoria to one side. Beak with apical segment extending beyond metathoracic coxae.

Thorax and appendages.-Prothorax without lateral tubercles.

Abdomen.-Cornicles 1.10 long, in shape similar to those of alate viviparous female, apical two-sevenths covered by closed reticulations, portion of cornicles immediately anterior to reticulated area feebly imbricated, remainder smooth. Cauda .61 long, slightly constricted with about eight hairs on each side.

Holotype.-Alate viviparous female; Urbana, Illinois, May 12, 1930, on Polymnia canadensis, (H. H. Ross). Slide No. 10212. Morphotype.-Aptelous viviparous female; same data as holotype. On slide with nymphs. Slide No. 10213. Paratypes.-Four slides containing alate viviparous females and nymphs, same data as holotype, and two slides containing apterous viviparous females and nymphs, same locality and host, May 3, 1930 (Frison and Ross). Slides Nos. 10214-10218 and one other unnumbered.

The alate form of this species rums in Soliman's key (192\%) to M. madia Swain. from which it may be separated by the mucl longer beak, the more numerous seconclary sensoria on the thircl antennal segment, and the different proportional lengths of the antennal segments. The apterous form keys to $M$. allifrons Essig fron which it differs by the minch longer beak, the coloration of the legs, the alssence of hairs on the legs. and the comparative lengths of the antennal segments. This species feeds on the undersides of the leaves along the nindrib.

\section{GENLS MICROPARSLS PATC1I}

\section{MICROPARSUS VARIABILIS PAT'UI}

$$
\text { FIli. } 96
$$

Microparsus variauitis Patch, Entomological News, Vol. XX, No. 8, October, 1909, p. 338.

This species is here recorcled from lllinoss for the first time. It tightly courls the leaves of Desmodimm and lives on the stoms and unclersides of the leaves of Amphicurpa. According to l'atch (1909) the entire life cycle is pasticed upon Desmodium. Our collecting indi- 
cates that the entire life cycle can also be passed upon Amphicarpa. The wing venation is somewhat variable.

Data associated with our viviparous specimens are as follows: Charleston (Aug. 24), 1910; Oakwood (Sept. 17), 1928; Edwardsville (Sept. 11), Mattoon (Sept. 10), 1929. Sexual forms have been taken at Decatur (Oct. 5). Edwardsville (Sept. 11), and Mattoon (Sept. 10), 1929. All forms collected both on Desmolium sp. and imphicarpa monoica.

\section{Gents MYZUS Passerini}

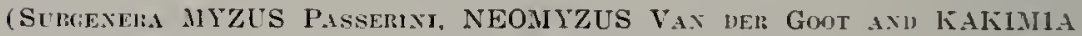
HotTes AxD Frisox)

\section{Key to the Species of the Genus Myzus}

1. Cornicles much longer than width of head througb eyes..............

-. Cornicles in length about equal to, or less than, width of head

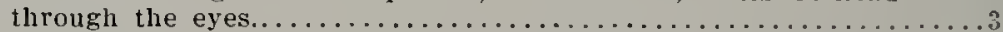

2. Fore wing with second fork of media closer to margin of wing than to first fork; cubitns and anal veins distinctly outlined with a fuscous border; secondary sensoria on fourth autenual segment ranging from 5 to 8 ; alate and apterous forms with dorsum of abdomen uniformly a shade of green............. $\ldots \ldots \ldots \ldots \ldots \ldots \ldots \ldots \ldots$ porosus Sandersou

- Fole wing with second fork of media closer to first fork than to margin of wing or midway between them: cubitus and anal veins not distinctly outlined with fuscous border; secondary sensoria on fourth antennal segment ranging from 0 to 3 ; alate and apterous forms with dorsum of abdomen ofteu with some dark markings, particularly apterous forms........... $\ldots \ldots \ldots \ldots \ldots \ldots \ldots \ldots \ldots \ldots$ circumflexus i Bucktoni p. 335

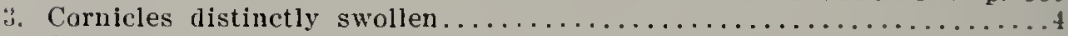

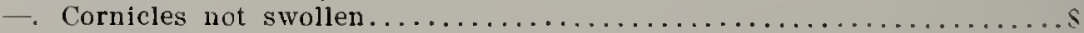

4. Alate viviparous females [alate form of scrophulariae (Thomas)

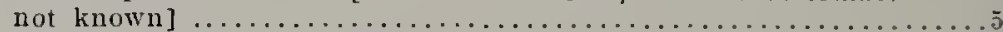

- Apterous viviparous females......................... 6

5. Fore wings with veins distinctly ontlined with a fuscous border: antenual tubercles projecting forward; minute brownish spe-

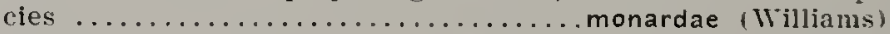

- Fore wings with veins not outlined with a fuscous border: antemul tubercles converging; mediun-size species, usually with dark dorsal abdominal patch on lighter background....

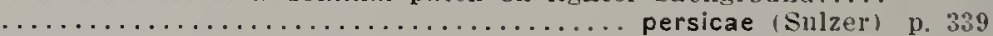

6. Cornicies longer than width of head across eyes; first antemual segment witl mesal margin very little produced. broadly and evenly lonnded; yellowish-green forms......persicae (Sulzer) p. 339

- Cornicles subequal to width of head across eyes; first antenmal segment witl mesal margin considerably produced. somewhat angulate towards apex of segment; brownish forms.............

7. Cornicles with outer margin almost straight and with inner margin convex, the swelling therefore asymmetrical; flagellum of antenuae longer than length of body from rertex to tip of

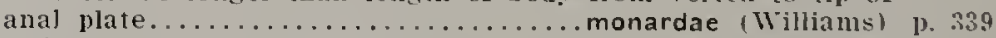

- Cornicles with both malgins convex, producing a symmetrica] swelling: flagellum of antennae slightly slorter thau length of body flom vertex to tip of anal plate..................

scrophulariae (Thomas) p. it

s. Fourth antennal segment without secondary sensoria...............

-. Fourth autenual segment with secondary sensoria............... 
9. Föe wing with at least anal vein distinctly outlined with fus.

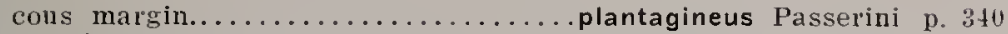

- Fore wings with no veins distinctly ontlined with fuscons margin. . . 10

10. Primary sensorium on basal portion of sixtb antennal segnent about equal in size to one or two of surrounding sensoria; cornicles distinctly imbricated throughout; blackish and

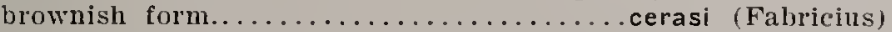

- Primary sensorium on basal portion of sixth antennal segment conspicuously larger than snall surrounding sensoria, which are uniform in size; cornicles not distinctly imbricated throughout; dark dorsal abdominal patch on lighter back.

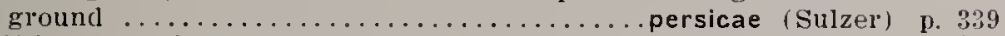

11. Fifth antennal segment with few secondary sensoria $(0$ to 5$) \ldots \ldots \ldots$

- Fifth antennal segment with sensoria more numerous $(7$ to 20$) \ldots \ldots . .14$

12. Cornicles much longer than fifth antennal segment.......... $\ldots \ldots \ldots \ldots \ldots \ldots \ldots \ldots \ldots \ldots$ lactucae (Schrank) p. 338

- Cornicles shorter than fifth antennal segment.............. 13

13. Cornicles and caula of equal Iength......houghtonensis (Troop) p. $33 \mathrm{~S}$

- Cornicles distinctly longer than cauda..essigi Gillette \& PaImer p. 337

14. Fifth antennal segment with more than fifteen secondary sensoria: tibiae uniformly hrown or dark...heucherae (Thomas) p. 337

- Fifth antennal segment with less than fifteen secondary sell. soria: tibiae with extreme apex much darker than remaining

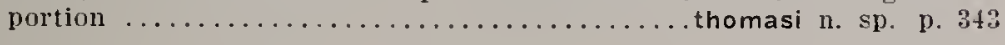

\section{MYZI'S CERASI (FAlBICIL'S)}

F19. 39

Aphis cerasi Fabricius, Systema Entomologiae, 1775, p. 734.

The black cherry aphid, a well-known and cosmopolitan species (Fig. 39), is at times of considerable econonic importance to cherry growers. It is very widely distributed in Illinois and was first reported from the state by Thomas (18:9). Many articles have been written concerning it, but conclusive evidence that it is at least partially migratory has been obtained only recently (Ross, 1!1 i. Wimshurst, 192.5). Galium and Lepidium, in addition to cherry as an all year host, have been found to serve as summer hosts of this species in North America. Technical descriptions of all forms may be found among others in Gillette (1908b) and Theobald (1926).

Data associated with our viviparons specimens are as follows: Normal (Mlay 24), 185:3; Normal ( May 13, July 1S), 1S\$4; Carbondale (June 2), llatioon (June 10), MIt. Carmel (May 26), Oregon (June 28), Quincy (June 6). 192S; Catlin ( Nlay 17), Effingham (June 18), Jerseyville (June 25), liansas (June 17), Monticello (May 24), Oakwood (July 22, Oct. 17), Rock Island (July 9), Starved Rock State Park (July 5, Ang. 14), Urbana (May 14. June 7), 1929. All collected on Prunus avium and Prunus persica except for small specimens taken on Galium sp. at Oakwood (Oct. 17), 1929.

\section{MYZUS CIRCUMFLEXUS (Bi KTON)}

Siphonophora circumflera Buckton, Monograph of the British Aphides, Yol. I. 1876, p. $1: 30$.

This species, first recorded from the state loy Davis (1911), is predominately a greembouse species. The fact that it is 110 overly particular as to the host upon which it feeds malics it a species of con- 
siderable economic importance. According to Theobald (19\%6 6 ). a sexual reproduction may continue in greenhouses for years without the appearance of the sexual forms, which have not as yet been described. If recent synonyny is correct, and it seems to be. Gillette (1908) has reclescribed this species under the name of My rus rincac. The majority of specimens of this species have a horseshoe-shaped brownish area on the dorsum of the abdomen.

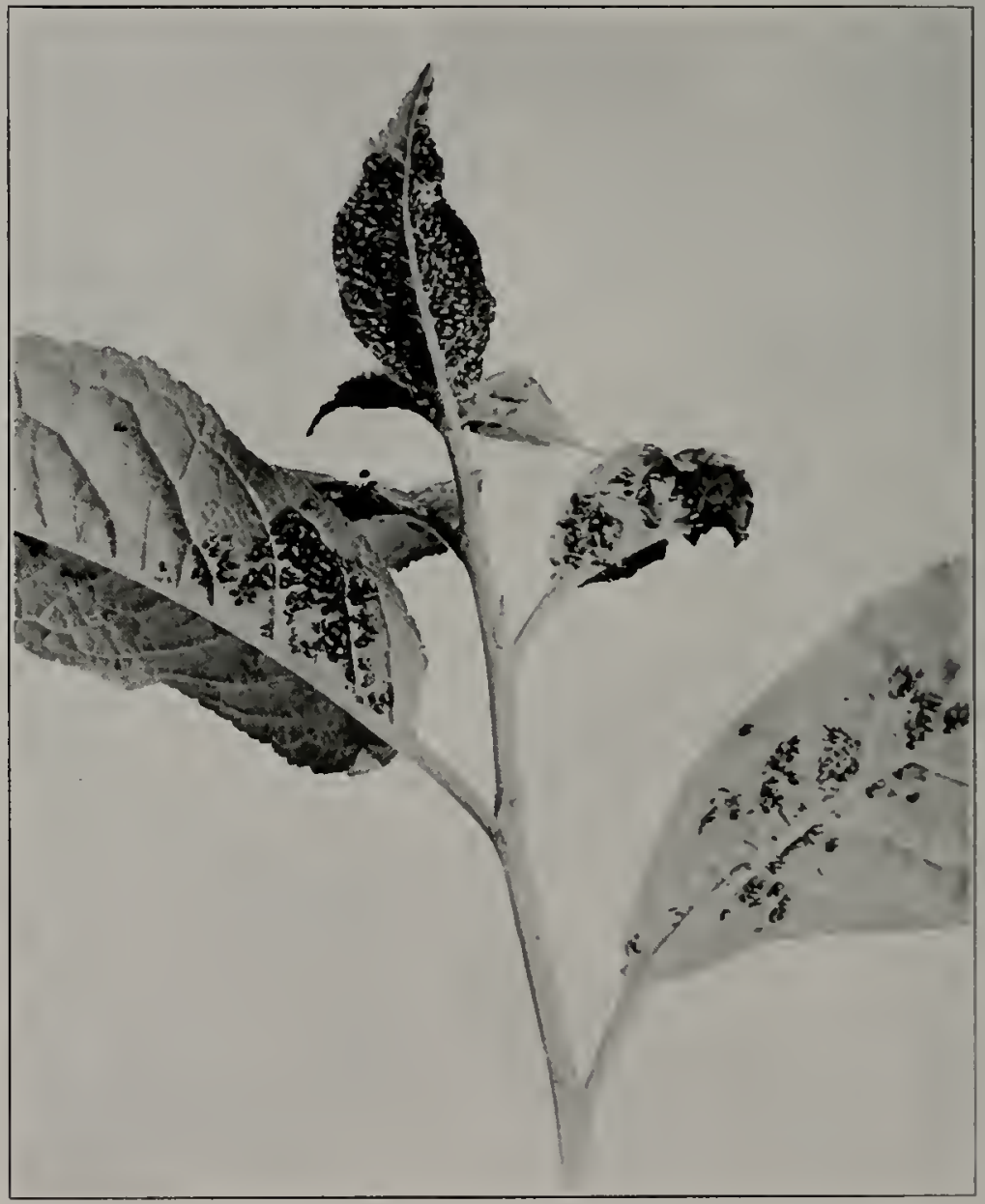

Fig. 39. Characteristic grouping of the black cherry aphid, $M y=u s$ cerasi (Fabricius), on under sides of leaves of new growth on the cherry, Prumus avium: Urbana, June $7,1929$.

Data associated with our viviparous specimens are as follows: Evanston (May 6), 1927: Carbondale (June f), Chicago (June 14), liankakee (June 29), Starved Rock State Park (June 13), 192S; Urbana (Oct. 15), 1929. Collected on Anchusa myosotidiflora. Chrysanthemum. Fuchsia sp., Geranium. sp., Ipomora maxima. Lilium sp., and streprocarpus. 


\section{MyZU's ESSigi Gillette \& Palies.}

Myzus aquilegiae Essig, University of Califoruia Publications in Entomology, Vol. I, No. T, July 20, 1917, p. 314. Name preoccupica.

Myzus cssigi Gillette \& Palmer, Annais of the Entomological Society of America, Vol. XXII, No. 1, Narch, 1929 , p. 30. New name for aquilegiae Essig.

We have found this species to be generally distributed throughou: Illinois both upon Aquilcgia canadensis and cultivated varieties of this genus. Since the sexual forms have not been described to our knowledge, their description is presented here.

Our Illinois records for this species are as follows: Havana (June 21), Herod (Mlay 29), Mt. Carmel (May 26), Mt. Carroll (June 25), Oregon (June 27), Starved Rock State Park (June 12), and Urbana (May 23-24), 1928; Urbana (Oct. 15), 1929; Starved Rock State Park (May 13), 1930. Sexual forms were collected at Urbana on October 15.

\section{Alate Male}

length from vertex to tip of anal plate, 1.24. Head and thorax dark blackish brown, abdomen dark green with lateral brownish spots, spot posterior to the cornicles largest. Cornicles dusky green, cauda concolorous with abdomen, anal plate brownish green. Antennae dark brown. Femora dark brown with base greenish yellow, fore femora lightest; tibiae and tarsi dark brown. Beak brownish. Genitalia dark brown tipped with black. Veins of wings dark brown.

iverage width of head across eyes, .41. Comparative lengths of antennal segments as follows: III - .54, IV- .30. V- .34, VI- .1I plus .63 . Secondary sensoria distributed as follows: III -37 , IV $-15, \mathrm{~V}-7$; scattered over entire third segment, somewhat crowded on one side of fourth segment, arranged in a somewhat irregular row on fifth segment. Beak reaching to mesothoracic coxae. Second fork of media closer to margin of wing than to first fork. Cornicles .23 long, typical for species. Cauda .11 long, very blunt at tip, with two hairs near extreme tip, unlike the cauda of the alate viviparous female.

\section{Apterous ONiparous FeMaLE}

Length from vertex to tip of anal plate, 1.40. Head and thorax light brownish yellow. Abdomen yellow with very minute lateral and dorsal brownish spots. Cornicles yellowish, cauda and anal plate yellowish with some indications of fuscous towards the outer margins. Femora yellowish with some light brown near apex; tibiae yellowish with traces of light fuscous towards apex; tarsi fuscous.

Average width of head across eyes, .39. Comparative lengths of antennal segments as follows: III -.47 , IV -.33 , V- .17, VI - .10, terminal filament incomplete. Secondary sensoria limited to the third antennal segment, numbering about 7 , arranged in a somewhat irregular row. Beak reaching to metathoracic coxae. Cornicles .26 long, cauda .17 long, in shape similar to those of viviparous form.

Allotype.-Alate male; Slide No. 8998, Urbana, lllinois, October 15, 1929, on Aquilegin sp, (Frison and Ross). Morphotype.-Apterous oviparous female; Slide No. $\$ 999$, same data as allotype. On slide with nymphs.

\section{MYZUS HEUCHERAE (THOAIAS)}

Siphonophora heucherae Thonas, Eighth Report of the State Entomologist on the Noxious and Beneficial Insects of the State of Illinois, 1879, p. 66.

Thomas descriled this species from specimens sent to him from Sauk City, IVisconsin, by Professor Buncly. Since that time it has heen 
reported from California by Davidson-apparently the only record of this species based on actual specimens to be published since the original description was nude. This aphid has retained the primitive habit of producing the sexual forms early in the year (May and Iune) and hence spends the greater portion of the year in the egg stage.

All forms have been described in detail by Davidson (1915). Soliman is certainly correct in placing heucheras in the genus Myzus (schs. lat) instead of in Macrosiphum. Five cotypic slides ( Nos. 31 it$3175,8163-8165)$ of this species are in the Survey collection.

Data associated with our viviparous specimens are as follows: Carbondate (June 4), Herod ( May 29), Starved Rock State Park (June 13), 192s. Sexual forms taken at Starred Rock State Park (June 13). 1928. All collected upon Heuchera sp.

\section{MYZUS HOUGHTONE.NS1S (TROOP)}

F1Gs. 124, 157, 273

Aphis houghtonensis Troop, Entomological News. Vol. Xill, No. 2. February. 1906 , p. 59.

The gooseberry witch-broom aphid has been reported from Illinois by Davis (1910), but Baker (1919c) states that this record does not apply to this species. Our material has been compared with cotypic material loaned by the U. S. National Museum. Since other cotypic slicles examined by us show a mixing of species, we have selected one slicle of the U. S. National Museum material as a lectotypic slide. This slicte has associated with it the following data: "9919 houghtoncusis Troop. On gooseberry, LaFayette. Ind., May ?0. 1905. I. Troop."

Good technical descriptions of all forms of this aphid are given by Baker (1919). Del ong and Mathewson (19.35) have studied its development in relation to temperature and humidity and have come to the conclusion that these factors seem to have a definite effect mpon the length of specific generations. According to DeLong and Jones (1:1*2(i). a strain of plant resistant to attack offers the greatest promise as a nethod of control.

Data associated with our viviparous specimens are as foltows: Havana (June 21), Kankakee (June 29), Oregon (June 2i), Pekin (June 20), Rock Islaud (June 23), 1928; Homer (June 29), 1929; Rock Island (June 3), 1930. All collected on Ribes Grossularia and Ribes sp.

\section{MYZUS LACTUCAE (SCHßAK)}

Aphis lactucac Schrank, Fauna Boica, Vol. II, No. 1233, 1801, p. 120.

This species may have been recorded from Carbondale. Illinois. by Thomas (18i9) under the name of "Siphonophore hactucu' Limn. "' but his identifieation is (puestional)le. The Davis record (1910) of Macrosiphum lactucac Sehrank from enltivated lettuce in greenhouses in Iltinois is this species. Through the kindness of l'rofessor Davis. we were permitted to study the material upon which his record was hased and to incorporate a slick motnt in the Survey collection.

Theobald (19?(i) show's that this species migrates from its overwintering host. Ribes. to such plants as lettuce and enclive to spend the 
summer months. Technical descriptions of the adults are given among others by Davis (1!10) and Theobald (19:6).

Data associated with the viviparous specimens collected by J.J. Davis are as follows: Chicago (April 23, May 2), Niles Center (Nov. 2), 190S; Chicago (Dec. 1), 1910. All specimens collected on lettuce (Lactuca) in greenhouses or on celery (Apium sp.) out of doors.

\section{MYZUS MONARDAE (WII.I.LMS)}

F1G. $\$ 6$

Phorodon monardur Wiliams, University Studies, University of Nebraska, Vol. X, No. 2, March, 1911, p. S9.

Rhopalosiphum monardac Williams (Davis), University Studies, University of Nebraska, Vol. XI, No. 3, July, 1911, p. 36.

This specics has not been previously recorded from Illinois. We have followed Davis (1:11c) in giving Williams credit for the species. although Davis was the first to give a technical description of it. It tightly twists and curls the leaves of its host and is often associated with Aplis monardac Oestlund. The sexual forms are mnknown.

Data associated with our viviparous specimens are as follows: Carbondate (June 4), Clampaign (July 15), Fankakee (June 28, July 15), Pekin (June 20), Rock Island (June 23), 1928; Flora (June 1S), Pleasant Plains (May 2), Savanna (July 9). Wayonet (JuIy 6), 1929. Collected on Monarda fistulosa and Monarla sp.

\section{MYZUS PERSICAE (SILZEK)}

Fig. 91

Aphis persicar Sulzer, Abgekürzte Geschichte der Insecten nach dem Linneiscben System. Winterthur, H. Steiner u. Co., II 2, 1776. 1. 105.

The green peach aphid feeds upon a sreat variety of food plants and is widely distributed throughout the workl. It is a potential encmy of considerable econonic importance, attacking truck crops, garden flowers, various plants grown in greenhouses, as well as peach trees. Thomas (18:9) mentions My $/$ us porsicac in such a way that it seems certain his recorrl applies to Illinois specimens, though no definite locality is mentioned. The cotypes of Rhopalosiphum lalipac Thomas (Slide Vo. $\left\{(6)_{i}\right)$, from Sauk (ity. Wisconsin, are this species, as Davis (1910) has stated.

It is not possible to review here the many papers that have been published concerning the control and destructiveness of the green peach aphid. The paper of Weed $(192)$ ) is interesting from biological consirlerations lecause it demonstrates so well the marked responses of aphids to changes in temperature and humiclity. Althougl this species is rlefinitely known to migrate from peach, plum. and other woorly plants (winter hosts) to a great variety of summer losts, it does prodice sexnal forms in greenhouses and on some plants commonly referred to as its summer hosts. Good technical descriptions of all forms are to be found in the pmblications of Gillette $\left(190, b_{3}\right)$ and Theolald $(1926)$. It is a variable species in color and certain structural characters. The 
difference in the cylindrical cornicles of the spring migrant on peach and the somewhat swollen cornicles of the return migrants is rather unusual.

Data associated with our viviparous specimens are as follows: Urhana (Aug. 21), 1885; Urhana (June 20), 1898; Cairo (June 3), Carbondale (May 17. June 4), Champaign (May 23, June 19), Chicago (June 14), Decat ur (Sept. 18), DesPlaines (May 20, Aug. 16, Sept. 19, Dec. 18), Herod (Oct. 12), Kankakee (June 29), Quincy (June 6), Shawneetown (May 2i), Urbana (May 24, June 4, 6, July 10, 18, Sept. 26, Oct. 1, 19, Dec. 5), 1928; Batehtown (June 25), Catlin (May 17), Collinsville (Sept. 11), DesPlaines (Feb. 91, Effingham (June 18), Grayville (June 19), Kansas (June 17), Kappa (Oct. 3), Macomb (May 4), Melrose Park (Oct. 14), Oregon (July 12), Seymour (Oct. 16), Spriugfield (May 2), Urbana (May 11, 14, June 4, 21, July 24, Nov. 11, Oct. 9, 15, 21) 1929; Allendale (Oct. 8), Effingham (Nov. 13), Flora (Nov. 13), Urbana (Oct. 4, 13, 20), 1930. Collected on the following plants: Apium. Aquilegia canadensis, Arctium sp., Aselepias sp., Beta vulgaris. Brassica oleracca, Brassica ropa, Brassica sp., Copsicum dulce, Catalpa speciosa. Convolvulus sp., Cyclamen sp., Dianthus sp., Helianthus sp.. Ipamoca maxima. Ligustrum vulgare, Lycopcrsicon esculentum. Marsilea quadrifolia, Mimulus sp., Myosotis, Philadclplus coronarius, Piqueria trinervia, Portulaca oleracea, Prunus avium, Prunus Persica (L.) Stokes, Prunus serotina, Radicula Armoracia. Raphanus sativus, Ribes aureum, Salvia leucantha. Saxifraga splendcns, Setaria viridis, Solanum melangena. solanum tuberosum. spinacea olivacca, Verbcna sp., and Viola tricolor.

Sexual forms collected as follows: Seymour (Oct. 16), Urbana (Oct. 21), 1929: Effingham (Nov. 13), Flora (Nov. 13), and Urbana (Oet. 13-201, 1930. Collected on Ribes sp., Prunus avium. Prunus domestica. Prunus serotina. and Rosa sp.

\section{MYZUS PLANTAGINEUS PASSERIII}

Myzus plantagineus Passerini, Gli Afidi, 1860, p. 35.

This species was redescribed and first recorded from North America by Davis (1910), who collected it on plantain at Lrbana, LeRoy, and Aurora, Illinois. It has the habit of feeding near the base of the leaves at the crown of the plant and causes the leaves to crinkle and become distorted. Often the colonies are partially covered by "tents" of soil and bits of trash made by ants.

The sexual forms have not been described.

Data associated with our viviparous specimens are as follows: Rock Island (July 7), 1929; Rock Island (June 3), 1930. All collected on Plant. ago sp.

\section{MYZUS POROSUS SAxDMsox}

FIG. 129

Myzus porosus Sanderson, Twelfth Anmual Report of the Delaware College Agricultural Experiment Station. 1901, p. 205.

because this species has been so rarely mentioned in literature since its description from material collected on strawbery, the writers almost made the mistake of describing as a new species the Illinois material from rose listed helow. The fact that our material is My yus porosus Sanderson has been substantiated by a study of cotypic specincus of forosus, kindly loaned to us by the United States National Museun. Since the original deseription of this little known species is rery hrict. detailed descriptions are presented here. 
ITiss Patcl (191t) has figured the antennae of male and oviparous fenale specimens collected on Fragaria which she considers to be this species. It should be noted that her drawing shows a lack of secondary sensoria on the antennae of oviparous forms, whereas they average about four in number in the specimens from rose which we consider as porosus. The original description of the oviparous female, as well as cotypic specimens, reveal a condition similar to that stated in our description. Likewise, the males which we consider to be porosus have more sensoria than those considered as this species by Miss Patch. Variation may be responsible for these discrepancies, or we may be dealing with different forms.

\section{Ainte Viviparous feutal:}

Size and general color.-Average length from vertex to tip of anal plate. 1.73 mm. Prothorax and metathorax pale brownisligreen; head and especially mesothorax brown, polished; ablomen, including anal plate, green. Cornicles translucent whitish-green, cauda chalky whitish-green. Eyes red. dish-brown. Antennae with first two segments and extreme base of third slightly darker than liead, remaining portion black. Coxae, trochanters, and basal two-thirds of femora translucent yellowish green; apical third of fenora black; tibiae light brown, with a band at apex equal to about twice length of tarsi, black; tarsi black. Stigma and costa yellowish hrown; veins and margin of front wing in vicinity of anal vein, black; anal vein and cubitus slightly margined with black. Beak with basal segment concolorous with head. second segment light brown and apex blackish.

Head and appendages.-Average width of head across eyes, .43. Antennal segnents with comparative lengths as follows: III -.53 to .89 , average $.56 ; 1 \mathrm{~V}-.43$ to .54 , average $.48 ; \mathrm{V}-.36$ to .46 , average $.42 ; \mathrm{VI}-.11$ to .17 , average .13 plus .53 to .66 , average .60 . Secondary sensoria usually confined to segments three and four, but occasionally the fifth segment has a sen. sorium; arranged in straight rows; numbering from 14 to 21 and averaging 17 on third segment and from 7 to 8 on fourth segment. Beak extending to the mesothoracic coxae.

Thorar and appenduges.-Stigma of fore wings long, narrow and pointed at apex; second fork of media closer to margin of wing than to first fork.

Abdomen.-Certain specimens show evidences of tubercles, but either these tubercles are not always present or they are so poorly developed that only specimens in certain positions show them. Cornicles (Fig. 129) moderately long, straight; base not greatly wider than apex; with a poorly developed rim; about equal in length to twice the length of cauda, ranging in length trom .43 to .64 and with an average of .56 ; not reticulated but imbricated especially at apices. Cauda slightly constricted a little beyond the tip of anal plate, with from one to three hairs on a side, ranging from .23 to .3.: and averaging .29 in length. Anal plate rounded at a point to the apex.

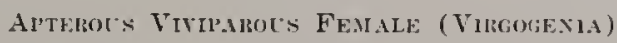

Nise and gencral color.-Average length from vertex to tip of anal plate, $1.84 \mathrm{~mm}$. Head, including first two segments of antennae and base of third, pale greenish brown. Thorax and abdomen green, prothorax shading into the greenish brown of the liead. Antennae with segments three. four, and five yellowish-brown with a narrow black ring at apex; sixth segment entirely black. Eyes, legs, cornicles, and cauda as in alate viviparous female.

ilfarl and alpendages.-Average width of head across eyes, .4t. Antennal segments with comparative lengths as follows: $111-.61$ to .71 , average $.65 ; V-.41$ to .51 , average $.45 ; V-.29$ to .40 , average $.38 ; V 1-.10$ to .13 , average .12 plus .46 to .53 , a verage .51 . Secondary sensoria confinerl to third antennal segment, almost in a straight line, varying in number from $i$ to 10 .

Thoras and ablomen.-Except for lack of wings sinilar to alate viriparous female. Cornicles varying from .54 to .11 and averaging.$t 2$ in length, caucla varying from .29 to .33 and averaging .30 in length. 


\section{Aptrotos Ortparot's Feabale:}

Sizp and grneral color.-Average length from vertex to tip of anal plate, 1.85. Head light yellowish green, remainder of body a slightly deeper shade of green. Cornicles, cauda, and anal plate yellowish green with a slight brownish stain. cornicles particularly dusky toward apices. Basal portion of antennae concolorous with head, remaining portion gradually shading to brown. Coxae, trochanters, and basal halves of femora concolorous with body; dorsal apical portions of femora brown; fore and middle tibiae yellowish green except for brown apices; hind tibiae with swollen portion and apices brown; all tarsi brown. Beak concolorous with head and body except that apex is brown.

Head and appendages.-Average width of head across eyes, .44. Antennal segments with comparative lengths as follows: III- .4 to .54 . average $.51 ; \mathrm{IV}-.34$ to .40 , average $.37 ; \mathrm{V}-.29$ to .31 , average $.30 ; \mathrm{VI}-.10$ to .11 . average .11 plus .43 to .47 , average .35 Secondary sensoria restricted to the basal half of the third antennal segment, ranging in number from 2 to 5 and averaging about 4, arranged in a straight row Beak extending to posterior margins of mesothoracic coxae. Antennal tubercle well dereloped.

Thorax and appentages.-Tibiae of hind legs considerably swollen where sensoria occur, sensoria numerous, 123 counted on one tibia.

Abdomen and appendages.-Cornicles averaging .62 in length. similar to those of alate viviparous female, not distinctly imbricated. Cauda constricted near midrle, with from two to three hairs on a side, averaging .30 in length. Anal plate narrow.

ALATE, M.1LE

Sizr and general color.-Average length from vertex to tip of anal plate. 1.28. Head and thorax dark greenish brown, abdomen green with lateral and posterior brownish markings. Cornicles, cauda, anal plate, and claspers brownish. particularly claspers. Antennae dark brown, extreme base of third segment lightest. Coxae, trochanters, and bases of femora yellowish green; tibiae with basal and apical portions brown, middle area lighter: tarsi brown. Beak concolorous with head at base and with tip brown. Veins dark, anal vein bordered with fuscous, stigma greyish.

Head and appcndages.-Antennal segments witl comparative lengths as follows: III -.60 to .64 , average $.62 ; \mathrm{IV}^{\mathrm{T}}-.40$ to .50 . average $.45 ; \mathrm{T}-.36$ to .39 , average $.34 ; \mathrm{VI}-.11$ plns .59 to .64 , average .62 . Secondary sensoria located on third, fourth, and fifth segments, and in one specimen on sixth segment, distributed as follows: III-26 to 33 , average 27 ; IV- I6 to 20 . average $18 ; \mathrm{V}-12$ to 18 , average 16 ; VI- 0 to 2 . Sensoria on third segment irregularly arranged but confined largely to one side of segment; on fourth and fifth segments they are smaller than on third and confined to one side of segment. Marginal sensoria near primary sensorium on sixth segment apparently lacking. Beak reaching to middle of mesothoracic coxae.

Thorax and appendages.-Stigna of fore wings narrow and comparatively short. Second fork of media closer to margin of wing than first fork.

Ablomcn.-Cornicles straight, imbricated throughout length. with a poorly developed flange at apex, averaging .33 in length. Cauda slightly con. stricted near middle, with from two to three hairs on a side, averaging. Is in length. Claspers dark brown and covered with hairs.

Our specimens, all collected from varions forms of Rosa, have the fol. lowing data associated with them: Cairo (June 2), Carbondale (June 4). Desplaines (in greenhouse, May 20), Kankake (June 29), Metropolis (June 1), Pekin (June 20), Quincy (Jnne 6), Slawneetown (Nay 27), and Irbana (May 23-28, July I0), I928; Cairo (June 22). Collinsville (Sept. 11). Decatur (June 12), Effingham (June Is), Springfield (May 2), and Trbana (Nov. 5), 1929: Decatur (June 10), Effingham (Nov. 13), Maywood (Nov. 3), Metropolis (April 17). Urbana (Nov. 21, Dec. 6, 12), 1930. Sexual forms were collected only on November 5. 1929, at Irbana.

This species, except for antennal tubercles, is sugesestive of Macrosiphmm dirhodum (Walker) which is recorded irom the same host. In 
the alate form it ma be separated from this species by the presence of secondary sensoria on the fourth antennal segment, and from both Macrosifhum rosac (L.) and Macrosiphum pscudorosac Patch by the fact that the cornicles are not reticulated at the apices. The male is distinguished by the comparatively larger number of sensoria on the fourth segment, and the oviparous female by the presence of secondary sensoria on the third antennal segment. This form belongs to the subgenus Vcomyzus Van der Goot and may be the species refered to by Oestlund (19.2.: p. 139). It can he separated from its close ally, circumfic.rus (Buckton), the type of the subgenus Ncomyins, by the characters given in the key.

\section{MYZUS SCROPHULARIAE (THONAS)}

Phorodon scrophulariae Thomas, Eighth Report of the State Entomologist on the Noxious and Beneficial Insects of the State of Illinois, 1879, p. 72 .

This species has remained virtually unknown since its original description, being referred to only twice in literature since then. once when it was recordecl from Berkeley, California, by Clarke (1903) and again when the record of Thomas was mentioned by Davis (1910).

A eotypic slide of scrophulariae has been found in the Survey collection (Slide No. 279S, and Thomas' No. 75). It contains two apterous viviparous female specimens of scrophulariae, one of which is in good condition, and one specimen not this species. The data assoeiated with this slide are: Carbondale. Illinois, April 13, 1878, on Scrophularia norlosa.

The species belongs in the genus Myzlis, and on the basis of the apterous viviparous female, which is the only form known, keys out with persicas and monardac.

\section{MYZUS THOMASI new species}

Figs. 261, 264

\section{Aiate Vivipalots Fenale}

Size and genrral color.-Length from vertex to tip of anal plate. 1.30. Head and thorax essentially light brown, somewhat greenish on lateral plates aud prothorax; abdomen light green. Cornicles, cauda, and anal plate very light dusky brown. Antennae dusky brown, slightly lighter towards the apex and at extreme hase of the third segment. Femora yellowish green at base, shading to dusky brown at apex; tibiae light dusky, with extreme apices brown; tarsi light brown. Stigma, costa, subcosta, veins, and posterior margin of wing in vicinity of anal vein, dusky; cubitus and anal vein darkest. Beak dusky, extreme apex dark.

IIfal and. appendalfes.-Width of head across eyes, .41. Antenual segments with eomparative lengths as follows: III- .60; IV - .4I; V- .36; VI- .II plus 1.03. Secondary sensoria (Fig. 261) located on third, fourtli, and fifth antennal segments, distributed on unique specimen as follows: III- $3 S$ to $4 S$; average $45 ; \mathrm{IV}-22$ to $23 ; \mathrm{V}-7$ to 12 , average 9 . Scnsoria on all segments more thickly distributed on one side of the segment than on the others; sensoria on the fifth segment in an almost straight row. Hair on antennae short and spinc-like, pointing towards apex, not as long as diameter of segment. Beak extending almost to mesothoracic coxae.

thorax and apprnlages.-Stigma long and unusually narrow; second fork of media closer to margin of wing than to first fork; tips of medial veins fulling to reach margin of wings. Femora with scattered setae very similar to those on antennae; tibiae more strongly armed, especially toward apex; spines strong, numerous, and moderately deelinate. 
Abromen.-Cornicles about one-fifth longer than the cauda and one-half as long as third antennal segment; distinctly imbricated throughout; the base distinctly the widest portion, the apex slightly swollen, giving the cornicle a sub-vasiform appearance; the extreme apex slightly constricted and bearing a distinct flange. Cauda with a narrow constriction near the middle, long and comparatively slender, its width only slightly greater than the width of the base of the cornicle, its sides almost parallel, gradually narrowing at apex to a rounded point; apical half with four or five slender scattered hairs. Anal plate normal in shape. Each segment with a pair of small, lateral tubercles. Hairs on body short and sparse.

\section{Apterous Viviparots Finale}

Size and gencral color.-Average length from vertex to tip of anal plate, 1.52. Bolly, except appendages, light green. First and second antennal segments concolorous with head, remaining segments varying from light greenish-yellow to brown, the brown becoming deeper towards apex. Femora greenish-yellow with their apices slightly infuscated with brown; tibiae light yellowish-brown, concolorous with apices of femora, apices of tibiae darker brown; tarsi brown. Cornicles concolorous with abdomen or slightly infuscate; cauda and anal plate concolorous with abdomen. Beak concolorous with head, slightly dusky at apex.

Head and appendages.-Width of head across eyes, .39. Antennal segments with the following comparative lengths: III- .57 to .59, average .5s; IV- .36 to .41 , average $.39 ; V-.34 ; \mathrm{VI}-.11$ plus .69 to .71 , average .70 . Secondary selssoria (Fig. 264) present on third, fourtl, and fifth antennal segments, distributed as follows: III- 23 to 33 , average 27 ; IV - 5 to $\div$. average $6 ; \mathrm{V}-2$. Sensoria on the third segment widely scattered, those on fourth arranged almost in a straight row. Beak extends to coxae of metathoracic legs.

Abdomen.-Cornicle about one-quarter longer than cauda and ahout equal to lengtl of fourth antennal segment, similar in general shape to that of alate viviparous female, but more slender and less distinctly imbricated. Cauda slender, constricted near the middle, with two hairs on each side and one at apex. Anal plate normal.

Holotypr.-Alate viviparous female; Rock Island. Illinois, July 9. 1929. on Ribes sp., (Frison and Hottes). On slide with nymphs, and specimens of Aphis sunborni Patch. Slide No. 10705. Morphotype.-Apterous viviparous female; sime data as holotype. On slide with pupae and specimens of $A p h i s$ sonborni Patch. Slide No. 10706. Paratype--One slide containing an apterous viviparous female and pupae, and specimens of Aphis sanborni Patch. Same data as holotype. Slide No. 10707.

This species may be readily separated from other species of the genus $M$ I'zus by the characters given in the key. The aggregate of characters of this species is such that it seems advisable to erect a new subgents for it, M/ yus houghtonensis (Troop), and $1 /$ yzus houchorac (Thomas), for which we gropose the name of Kukimia. The characterization of this new sulgenus is as follows:

\section{KAKIMIA new subgenus}

Antennal tubercles poorly developed. Antenuae with six segments, with numerous large round sensoria on the third, fourth, and often the fifth segments. Fore wings with media twice-brancled, hind wings with both media and cubitus present. Anal plate rounded. Cornicles with base the widest portion, apex slightly swollen, thus giving cornicles a sub-yasiform appearance; apex with distluct flange. Cauda with narrow constriction near middle, long and comparatively slender, narrowing at apex to a rounded point.

Type of subgenus.-Myzus (Kinkimia) thomasi new species. 


\section{GENTS PENT:ILONIA COQLEREL}

\section{PENTALONIA NIGRONERVOSA COQLEREL}

FIGS. 74, 95

Pentalonia nigronervosa Coquerel, Annales Societë Entomologique de France, Ser. 3, 1859, Vol. V1I, p. 259.

This species is here reported from Illinois for the first time. In this state it is a greenhouse species and undoubtedly an inportation from tropical clinates. Zeck and Eastwood (1929) have shown that this insect not only causes direct danage by sucking sap of the banana, but is a carrier of the virus of "bunchy" top" of Manila henup in the Philippines. Good descriptions of the viviparous forms are given by Theobald $(19: 6)$.

Data associated with our viviparous specimens of this peculiar aphis are as follows: Garfield Park Conservatory, Chicago, June 14, 1928, on Hedychium eoronarium.

\section{Gentes PHORODON I'asserixi}

\section{PHORODON HUMULI (SeHRANK)}

FIG. 85

Aphis humuli Schrank, Fauna Boica, Band 2, 1 Abt., 1S01, p. 110.

The hop aphid was included by Thomas (18ว9) in his Third Annual Rejort. though without definite mention of his having collected it in Illinois. It is not included in the more recent list of Davis (1910). For a long tince it las been known as a serious pest of hops both in Europe and Ancrica. It is easily recognized because of the peculiar sliape of the antennal tubercles (Fig. 85 ).

The winter is passed in the egg stage on plumin. After a few generations on this host the aplids then migrate to hop for numerous summer generations. The sexual forms are produced in fall, the oviparous fentales being produced exclusively on the over-wintering host. The bulletin by Parker (1913) gives a good general account of this aphid in the Pacific Coast Region of North Anerica. Another good general account. together with technical descriptions of all forms, is presented by Theoluald (19:26).

Data associated with our viviparous specimens are as follows: Muncie (July 8). Urbana (July 10), 1928; Gays (Sept. 10), Kappa (Sept. 10, 22. Oct. 1). Rock Island (July T), 1929; Aledo (June 4), 1930. All collected on lop. Humulus Lupulus.

\section{SL'BFAMLLV ERIOSOMATIAHE}

\section{SLIERTRIBE ERIOSOMIE.L}

rey to Genera

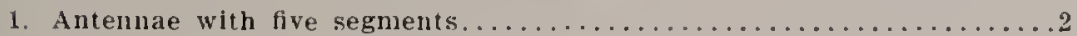

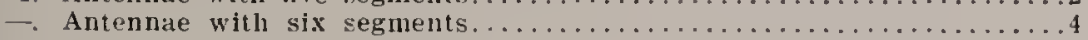


2. Antennae with conspicnous setae; secondary sensoria oral or transverse-oval; stigma of fore wing rounded at apex, posterior margin convex (Fig. 69); wholly subterranean forms, not

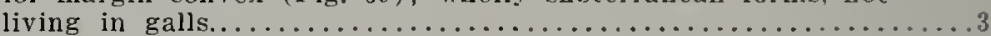

- Antennae withont conspicuons setae; secondary sensoria moze narrow and annular; stigma of fore wings pointed at apex. posterior margin concave (Fig. 73): living in galls on leares

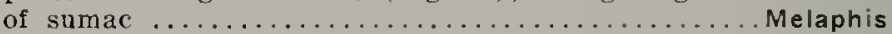

3. Tiird antennal segment with not more than ten secondary sensoria; apterous forms with conspicnaus and peculiarly bent and enlarged setae (Fig. 318 ,....................... pea 356

-. Third antennal segment with twenty or more secondary sensoria; apterons forms withont bent and enlarged setae......... Forda p. 354

4. Third antennal segment with narrow annular. transverse. or ring-like secondary sensoria, giving antennae a corrngated or notched appearance when viewed from the side (Fig. 223$) \ldots \ldots \ldots$.

-. Third antennal segment with oval or oval-transverse secondary sensoria, not annular, giving antennae a more even or cylindrical appearance when viewed from the side (Fig. 238) .........16

5. Fore wings normally with medial vein branched (Fig. 69 ) .........6

-. Fore wings normally with medial vein not branched (Fig. 64$) \ldots \ldots \ldots 9$

6. Fourth antennal segment abont twice as long as greatest width.......

-. Fonrth antennal segment three or four times as long as greatest

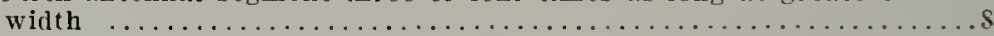

7. Hind wings with only medius present (Fig. 88): annnlar sensoria numbering about ten on third segment. and usnally not more than three each on fourth, fifth, or sixth segments; aerial forms producing cockscomb galls (Fig. 41) on elms... ............................................... 348 Hind wings with both medius and cnbitus present (Fig. 92): annular sensoria numbering abont eighteen on third segment. and usually five or more on fourth, fifth or sixth segments: prodncing bag-like galls (Fig. 46 ) on elms........... Gobaishia p. 359

S. Annular secondary sensoria incomplete or rarely entirely encircling antennal segments, well separated from one another on third segment (Fig. 226); curling leaves of elm (Fig. 45)..

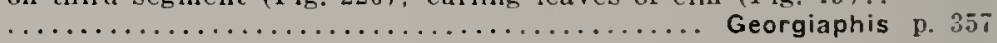

Amnular secondary sensoria of antennae complete, almost or entirely encircling antennal segments: closely paralleling one another on third segment (Fig. 225); stem, bark, root or leaf feeders ................................ Eriosoma p. 350

9. Terminal filament of sixth antennal segment much longer than basal portion (Fig. 239) [Fundatrigenia or spring migrants leaving galls]; producing irregular sponge-like gall (Fig. 4i)

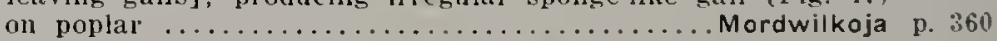

- Terminal filament of sixth antemnal segment not longer than

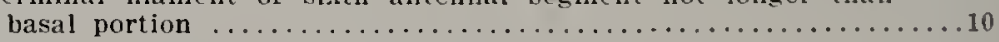

10. Hind wings with only medius present (Fig. ss) ...............

-. Hind wings with both nedius and cubitus present ( $\left.F i g . s_{i}\right) \ldots \ldots \ldots 12$

11. Fourth antennal segment not more than twice as long as greatest width; aerial forms producing cockscomb galls (Fig. 41) on elms .......................... Colopha (Colophella) p. 348

- Fourth antennal segnient about four times as long as greatest willth; curling leaves of elms (Fig. 45)........... Georgiaphis p. 357

12. Longitudinal vein of hind wing not straight, witl radial sector, media, and cubitus arising in a more or less three-pronged fork

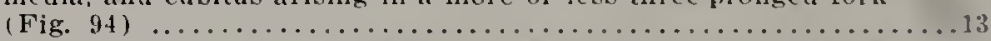

-. Longitudinal vein almost straight, media and cubitus originating far apart and running subparallel to one another (Fig. $\$ 7) \ldots \ldots \ldots 15$ 
13. Dorsum of head between compound eyes with two conspicuous large wax-pore plates [Sexuparae or fall migrants returning to

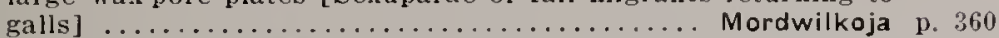

- Dorsum of head hetween compound eyes without conspicuous large wax-pore plates. . . . . . . . . . . . . . . . . . . .

14. Fourtl antennal segment about twice as long as greatest width; antennae of stem mother four-segmented.........Pemphigus p. 363

Fourth antennal segment about four times as long as greatest widtlı: antennae of stem mother five-segmented... Thecabius p. 374

15. Stigma of fore wings pointed at apex, its posterior margin concave (Fig. 73): living in pear-shaped or round galls on leaves

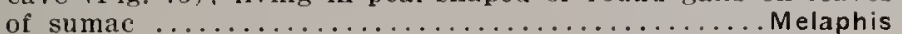

- Stigma of fore wings more rounded at apex, its postero-apical margin convex (Fig. 69); living in bag-like galls (Fig. 46) on

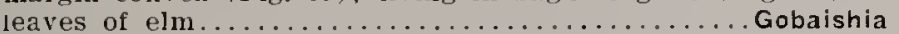

16. Antennae with numerons conspicuous hairs: species strictly subterranean, living continuously as far as known on roots of

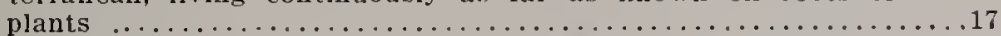

- Antennae without hairs or with only a few minute ones; species not subterranean or hut partially so, living mostly in pseudogalls or in dense colonies on branches and leaves..............

17. Sixth antemnal segment much longer than fifth; apterous forms

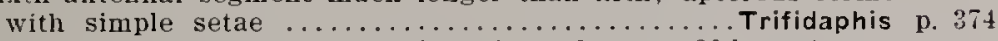

-. Sixth antennal segment approximately as long as fifth; apterous forms witl peculiarly bent and enlarged setae (Fig. 318 ).....

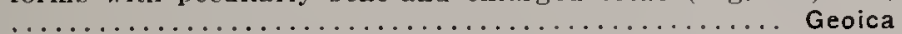

18. Fourth antennal segment comparatively short, ahout one-half (or less) as loug as third, usually shorter than basal portion of sixth antennal segment, its length not exceeding five times its

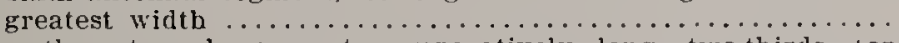

Fourth antennal segment comparatively long, two-thirds for more) as long as third, sometimes about as long as basal portion of sixth antenual segment, its lengtl at least eight times

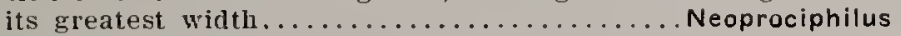

19. Sixth antennal segment (basal portion plus terminal filament) as long as, or longer than, the fifth; never on elms.............20

-. Sixtl antennal segment (basal portion plus terminal filament) shorter than the fifth; living in curled leaves (Fig. 45) on

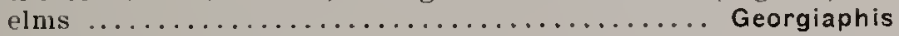

20. Fore tibia but slightly longer than width of head through eyes; media of fore wings usually branched but occasionally simple $\ldots \ldots \ldots \ldots \ldots \ldots \ldots \ldots \ldots \ldots \ldots \ldots \ldots$ Asiphum p. 348 Fore tibia longer, usually much longer than width of head through eyes; media of fore wings simple................ 1

21. Distance between wax-pore plates (Fig. 329) of mesonotum subequal to half the greatest diameter of one of them, except $P$. imbricutor, in which the stigma is narrow, long, and pointed at apex (Fig. 97); stem mother [fundatrix] with five-segmented antennae; species with aerial forms causing pseudo-galls (Fig. 50 ), curling leaves, or living in dense colonies and not

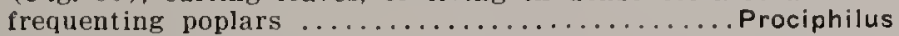

- Wax-pore plates (Fig. 330 ) of mesonotum separated by more than half the greatest diameter of one of them; stigma slort and broad and diagonally truncate at apex (Fig. 98): stem mother [fundatrix] with four segmented antennae; species with aerial forms folming true galls (Fig. 49) and restricted

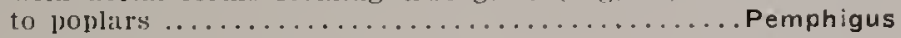

(3. .363 


\title{
GENLS ASIPHU.I KOCH
}

\section{ASIPHUM PSEUDOBIRSA (WALSH)}

Byrsocrypta pscurobyrsa Walsh, Proceedings of the Entomological Society of Philadelplia, December, 1862, p. 306.

This species has not been reported from Illinois since it was first described by Walsh (1862) from material taken near Roch Island. It seems probable that this aphid has an alternate host. because the alate forms leave the poplars in spring or early suminer. Figures showing structural details and general appearance of adults, as well as appearance of infested leaves, have been published by Gillette (191t). who has also given the best descriptions of the known forms and clatat concerning their biology. He states: "The young lice all leave the stem-mother gall, which is a small almond-shaped pocket alout micinav on the miclrib of the leaf, very soon after being born. and locate on the under or ventral surface. The larvae locate along the main beins into which they insert their beaks and their bodies soon become snowy white with a dense covering of short wax threads....... tll of the second generation lice become winged."

According 10 statements in literature the media of the tore wings is branched, but our Illinois material shows that the media may sometimes be simple, or not branched. The determination of our specimens has been checked by Mr. A. C. Maxson.

Data associated with our specimens, all collected on Populus, are as follows: Galena (June 26), Oakwood (July 1S), 1928. There is an alate specimen in the J. J. Davis collection from Chicago, Illinois, August 13. 1908, which is evidently a migrant or drift collected on Pinus.

\section{GENUS COLOPHA MONELL}

\section{(Subgexere COLOPHA Moxel. axp COLOPHELLA Börxek)}

\author{
Key to the species of the Genus Colopha
}

1. Fore wings with medial vein branched (Fig. 69) ..........

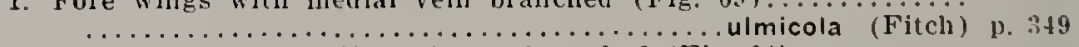

- Fore wings with medial vein not branched (Fig. 64) .........

graminis ( Mlonell) p. 345

\section{COLOPHA GRAMINIS ( MIOXE.L)}

Ficis. 40. 64, SS

Tetraneura maminis Monell, Canadian Entomologist. Vol. XIV. No. I. Janu. ary, 1SS2. p. 16.

Rhizobius spirntus Hart, Fighteenth Report of the State Entomologist on the Noxions and Reneficial Insects of the State of Illinois. (Text by S. A. Forbes, descriptions by C. A. Hart). March, 1\$95. p. 104.

This species and the following one is responsible for the curious cockscomb-like galls so common in spring on the upper surface of leaves of elms (Fig. fo). They migrate between elms and the roots of 
grasses, the latter being the summer host. Rhizobius spicutus Hart (1895) has been placed by Cutright (1925) as the root form of this species, or Colopha ulnicola (Fitch), and we have accepted this synonymy. Certainly, R. spicalus Hart is the root form of some aerial form common in Illinois, and the cotypes agree in general with the illustrations of the root forms of graminis and ulmicola given ly Patch (1910a). The best summary of the characters and habits of this small a)hid is given by Patch (1910a).

Börner (1926) placed this species in the genus Colophclla and later (1930) reduced Colophclla to subgeneric rank. We are considering Colophella as a subgeneric name, pending the solution of the exact relationship between the species under discussion here and Colopha ulmicola (Fitch). As mentioned under the discussion of the latter, we may be dealing with a dimorphic form and hence a single genus. Reducing Colophclia to subgeneric status may be only a temporary shitt. but it will not mislead others into thinking the problem has been solved as the complete abandonment of name Colophella (Trtrancura authors) might do.

Data associated with our specimens, all taken on elns $\left(I^{\prime \prime} l m\right.$ ms fulva and americana). are as follows: Nornal (June 30), 18s4; Mt. Carroll (June 25), Oregon (June 28), 1928; Hardin (June 25), Homer (June 17), Jonesboro (June 23), Newton (June 17), 1929. The data associated with cotypic specimens of $R$. spicatus, all in poor condition, are as follows: Urbana (April 10 and July 20), 1886, on roots of corn, slides 7653 and 7654 ; and Tamaroa (Oct. 5), 1893, on roots of corn, slides 7655 and 7656 .

\section{COLOPHA ULMICOLA (FITCM)}

FItis. 40,69

Byrsocrypta ulmicola Fitch, Transactions of the New York State Agricultural Society, Vol. XVIII, 1858 (printed 1859), p. 843.

Like Colopha (Colophclla) graminis (Monell), this species proruces cochscomb-like galls on the upper surfaces of elm leaves (Fig. fi). These two species can be separated only upon the basis of wing renation, and Patch (1!)10a) has found some evidence that one may be a dimorphic form of the other. Our present information, however, is too incomplete to permit considering them here as the same species. C. ulmicola (Fitch) has been previously recorded from llinois by

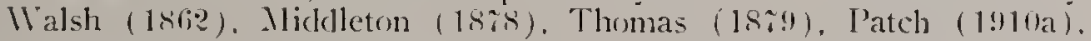
and Davis (1910d). Colopha crayrostidis Middleton (18:s). evidently described from Illinojs material. has been flaced in the synomymy of C. umicolu by several authors, and this is undoubtedly correct.

Data associated with our specimens, all from elns ( $T^{\circ} l m u s$ fulvn and $T^{*}$. (tmericana). are as follows: Anna (April 11), 1884; Antioch (June 15). Cave-in-Rock (May 30), Kankakee (June 29), Oakwood (July 8), Starved Rock State Park (June 13), Irbana (July 10), 1928; Oakwood (June 29), Rock Jsland (July 7), Starved Rock State Park (July 5), Waukegan (July 12), 1924 . 


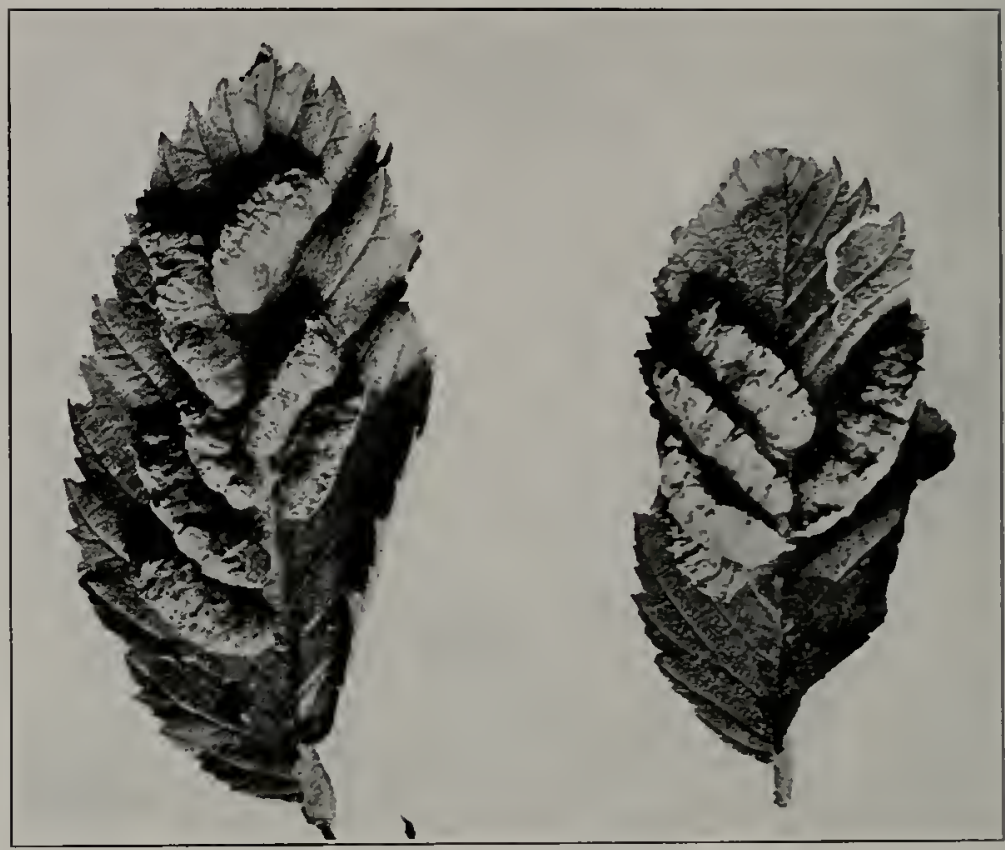

Fig. 40. Cockscomb galls on upper surfaces of leaves of the white elm, Ulmus americana. caused by Colopha ulmicola (Fitch); Oakwood, June 29, 1929. A similar gall is caused by Colopha graminis (Monell).

\section{GENIS ERIOSOMA LEACH}

\section{Ley to the species of the Genus Eriosoma}

1. Fifth antemal segment (Fig. 223) usually without well-developed anmular secondary sensoria: curling leares of elm.....

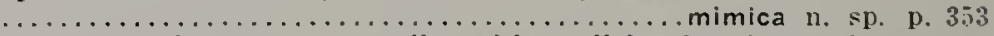

- Fifth antemul segment usually with well-dereloped anmular secondary sensoria: curling leaves of elm or closely clustered on branches (Fig. 42), leaves, or bark (Fig. 43 ) of elm, apple.

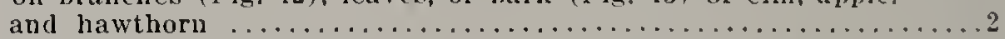

2. Sixth autennal segment usually without amular secondary sen. soria; causing a leaf cluster or rosette on terminal twigs of elms [fundatrigenia]..................lanigera (Hausmann) p. 351

- Sixth antemnal segment usnally with annular secondary sensoria; never causing a leaf cluster: on roots, twigs, or branch-

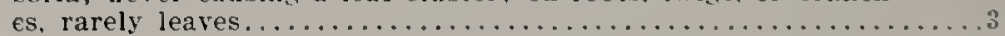

3. Medial vein of fore wing with point of origin of fork much beyoud, or distad of, point of origin of radial sector: forming flocculent colonies on trunk and branches of elms (Fig. 43 )...

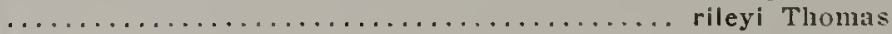

- Medial vein of fore wing with point of origin little, if any, beyoud point of origin of rarlial sector: forming flocculent colonies on trunks, branches, or roots of apple or hawthorn (Fig.

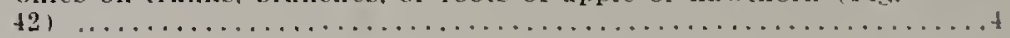


4. Lining lower sides of branches of lawthorn in dense flocculent colonies (Fig. 42); waxy secretion granular; fourth antenual segment with from six to nine annular secondary sensoria: fifth segment with from five to nine annular secondary sensoria

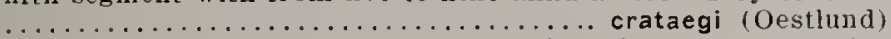

- On bark, roots, branches, and leaves of apple; waxy secretion consisting of long fine wavy whitish flaments; fourth antenual segment with from three to five annular secondary sensoria; fifth segment with from four to six annular secondary sensoria

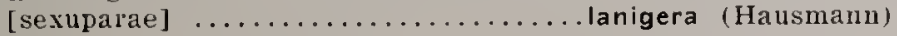

\section{ERIOSOMA CRATAEGI (OESTLUND)}

$$
\text { Filis. 41, } 92
$$

Schizoneura cralaegi Oestlund, Geological and Natural History Survey of Minnesota, Bulletin No. 4, 1887, p. 27.

This species was first reported from Illinois by Davis (1910d), who considered it a "serious pest of hawthorns used in ormamental plantings in Chicago." It has been very abundant on certain Crataegus plantings on the University eampus at Urbana for the last three years. The lower sides of most branches of these shruls were lined with a solid mass of aphids, made particularly conspicuous by the large quantity of white flocculent secretion produced (Fig. 41). The life history is not well known, and the species has at times been thought to be the same as E. lanigcrum (Hausmann) - a view which we think has not been sulsstantiated. The flocculent secretion of $E$. lanigcrum is in long, silken, fluffy threads and often a bluish white, whereas in this species the flocculent secretion is more granular, compact, and chalky white in color.

Records associated with specimens of this species, all taken on Crataegus sp., are as follows: Odin (Aug. 27), 1888; Catlin (Sept. 27), Urbana (Aug. 2, Sept. 26), 1928; Muncie (Sept. 22), Oakwood (July 22), Starved Rock State Park (July 6), 1929; Chicago (Sept. 20).

\section{ERIOSONA LANIGERA (HALSMANX)}

Figs. 158, 221, 225

t $p$ his lanigera Hansmann, Illiger's "Magazin für Insektenkunde," Vol. I, Braunschweig, 1802 , p. 440.

Thomas first reported the woolly apple aphid from Illinois in lsii uncler the generie name of Eriosoma and later (1sial) under Schironcura. It is common in all parts of the state and often is responsible for severe injury to young apple trees. The important discovery that this species migrates to apjle in spring and early summer from leaf elusters or leaf rosettes on elm was first brought to general altention by lattch (1!1:2), whose olservations have since been confirmed by numerous studies lyy others. The paper by Baker (1915) presents at very thorough biological and morpholugical study of this pest.

Data associated with our specinens, all collected from leaf rosettes on elm (Clmus) or bark and twigs of apple (I'yrus), are as follows: Antioch (June 15), Cave-in-Rock (May 30), Danville (July 15), Golconda (May 31), 


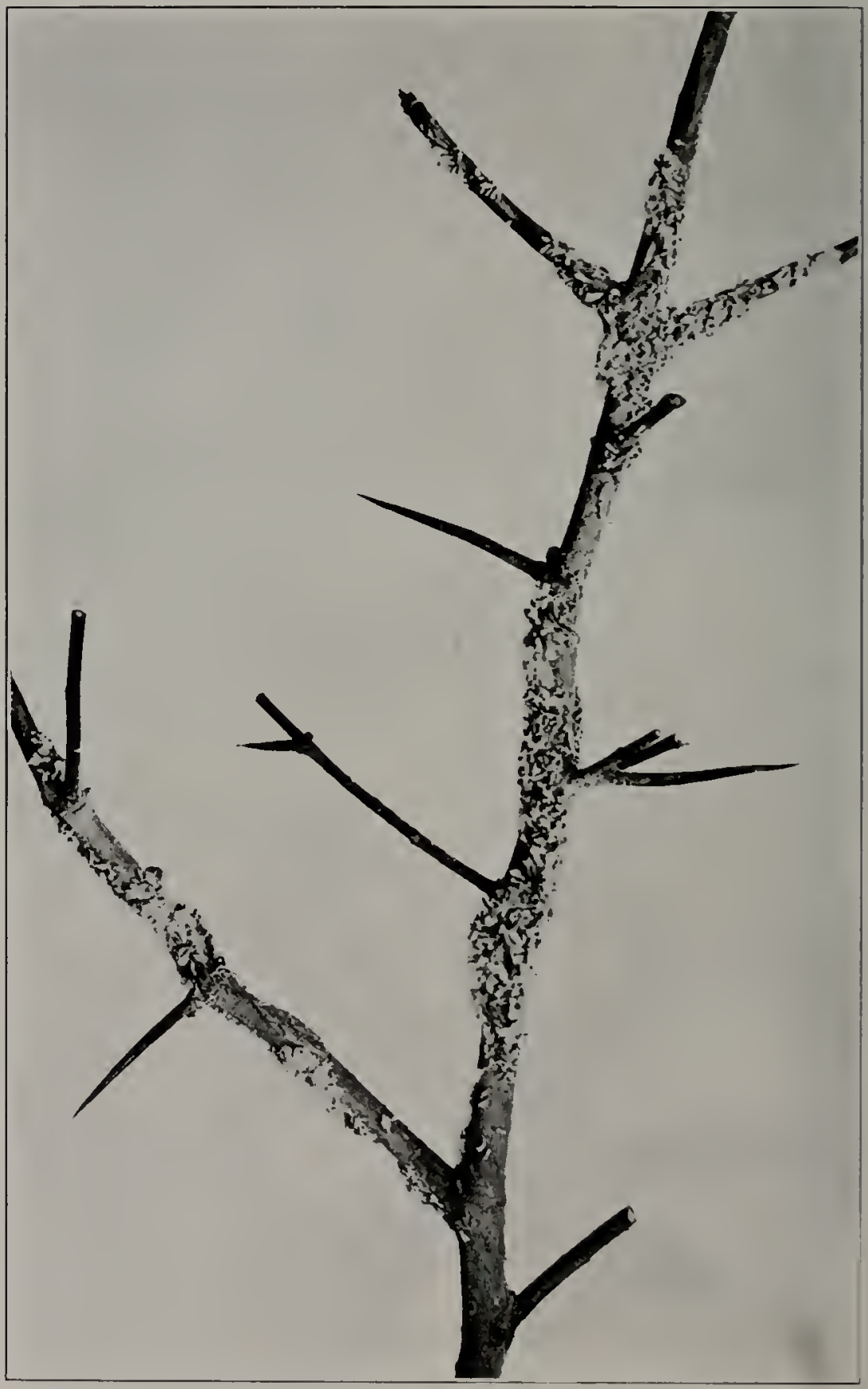

Fig. 41. Characteristic groupings of adults and nymphs of Eriosoma "rataryi (Oestlund) on hawthorn. Cratacous: Irbana, October 2, 1929. l'roduction of large quantities of a white wax secretion makes then very conspicuous 
Metropolis (June 1), Oakwood (May 29), Quincy (June 6), Shawneetown (May 2\%). Starved Rock State Park (June 12), 1928; Decatur (June 12), Elizabethtown (June 20), Hardin (June 25), Newton (June 17), Starved Rock State Park (July 5), 1929; Mletropolis (April 17), 1930.

\section{ERIOSOMA MIMICA new species}

Fig. 223

\section{Alate Viviparols FEMAIE}

Size and general color.-Average length from vertex to tip of cauda, 1.49. Head and thorax dark dusky brown, abdomen yellowish brown. Cornicles dark brown. Antennae, legs, and beak yellowish brown, considerably lighter in color than head. Stigma of fore wings light dusky, veins the same. Head, thorax, and abdomen lightly pulverulent.

Hear and appendages.-Average width of head across eyes, .31. Antennal segments with comparative lengths as follows: III- .23 to .29 , average $.25 ; \mathrm{IV}-.07$ to .10 , average $.09 ; \mathrm{V}-.07$ to .09 , average $.09 ; \mathrm{VI}-.07$ to .09 . average .08. Secondary sensoria (Fig. 223) annular and distributed as follows: III- 17 to 24 , average $19: 1 \mathrm{~V}-4$ to 6 , average $5 ; \mathrm{V}-0$ to one; VI- 0 to 1 . Fifth and sixth antennal segments without secondary sensoria except sometimes at extreme tips of segments. Primary sensorium on fifth antennal segment annular and sometimes cleft; sensorium on sixth segment ovoid, normal. Beak reaching to mesothoracic coxae.

Thorar and appendages.-Mesothorax with a pair of large, oval wax glands on ventral portion of pleurae. Fore wings with stigma comparatively sliort and blunt and with radial sector comparatively straight. Hind tibiae .63 in length.

Abdomen.-Cornicles very shallow, ring-like. Anal plate not much wider than the cauda, which extends harely beyond the tip of the abdomen. Wax-pore plates on the abdomen indistinguisbable in our preparations.

\section{Apterots Vivipalous Female}

Size and general color.-Length from vertex to tip of cauda, 1.72. Head, tborax and abdomen uniformly yellowish brown. Antennae slightly lighter than body with fifth and sixth segment slightly darker. Legs slightly darker than body, with the coxae and femora slightly darker than the tibiae and tarsi. Beak yellowish brown with the extreme tip darkest.

Head and appendages.-Average width of head across eyes, .40. Antennal segments with the following comparative lengths: Ill- .24; $1 \mathrm{~V}-.10$ : V- .09; VI- .09. Apparently both primary and seconclary sensoria are absent. Antennae almost smooth, only slightly wrinkled, with a few scattered, fine hairs.

Thorar and abcomen.-Pro., meso-, and metathoracic segments with large ovate wax-pore plates on the lateral margins. Abdomen with five pairs of wax-pore plates on the lateral margins anterior to cornicles similar to those found on thorax; posterior to cornicles are two very large wax-pore plates which extend across the posterior portion of the abdomen as two transverse bands, one just anterior to base of cauda, the other extending along the extreme posterior portion of the abdomen. Cauda not extending beyond tip of abdomen. Anal plate a little broader than cauda.

Holotypr.-Alate viviparous female: Mt. Carroll, Illinois, June 25, 1928, on Clmus fulva. (Frison and Hottes). On slide with paratypic apterous and alate viviparous females and pupa. Slide No. 55:3s. Morphotypr.-Apterous viviparous female; same data as holotype. Slide No. 5539. Paratypes.Five slicles, containing alate and apterous viviparous females and pupae, collected in Illinois on $T$ lmus fulva, by T. H. Frison and F. C. Hottes, at IIt. Carroll, June 25, and Kankakee, June 29, 1928. Slides . $5 i 342$ and one other unnumbered.

This species resembles E. ulmi (L innaens) in the reduced number, or entire lack, of secondary sensoria on the fifth and sixth antennal segments. It differs from the spring migrants of that species, as figured by 
Patch (1913b) and Theobald (1929), in having much shorter antennae. about one-half as many secondary sensoria on the third antennal segment, and the third antennal segment not conspicuously exceeding the combined length of the fourth, fifth, and sixth segments. This species was declared to be new by Mr. A. C. Maxson to whom it was sent questionably determined as ulmi. We have no exact information as to the gall from which this species came, but we believe it caused a curling of the leat of its host, the red elm (Llmus fulia).

\section{ERIOSOMA RILEYI THONAS}

FiG. 42

Eriosoma ulmi Riley, First Annual Report on the Noxious, Beueficial and other Insects of the State of Missouri, 1869, p. 123. Tame preoccupied. Eriosoma rileyi Thomas, Transactions of the Illinois State Horticultural Society, Vol. X, new series, 1876 (1877), p. 191. Nelc name. spelling of Rilepi a lapsus calami.

This species was originally described by Riley (1869) under the name of Eriosoma ulmi. Thomas $(185 \mathrm{~s})$, recognizing that the specific name for this distinct species was preoccupied by ulmi Limnaeus, gave it the new name of rilcyi. Through a typographical error the mame was first spelled as Rilcpi, but this is an evident lapsus culami because Thomas stated that he "named it after the original describer" and subsequently (185!) spelled the name as rileyi. It is a bark-feeding species (Fig. 42 ) and at times has been considered as a form of E. lanigera (Hausmann). The studies of Patch (1913b) indicate it passes its entire life cycle on elm and is a distinct species. Mordvilko (19:2 states, "All living Eriosomca are inevitably attached to Tlmus. which means that they made their appearance and performed their evolntion together with Ulmus, having originally been monophagous, as for in. stance the living Eriosoma rilcyi Thomas in North America or E. patchiac Börner in the Mediterranean region."

Data associated with our specimens, all collected on the red or slippery elm (Clmus fulva), are as follows: Champaign (June $\$$ ). Urbana (Oct. 22). 1928; Urbana (July 2), 1929.

\section{Gents FORDA HeYdex}

The American forms of this genus are not known to form galls and apparently live a wholly subterranean existence. Mordvilko (1928a) has shown, however, that Forda tricalis in Eurasia may develop in galls on leaves of Pistacia.

\section{he'y to the species of the Genus forda}

1. Antennae of alate female with third segment much longer than length of fourth and fifth segments together, with about thirty secondary sensoria; apterous forms with numerous setae about as long as width of third antemul segment..occidentalis Hart

- Antenuae of alate female with third scalcely longer than length of fourth aud fifth segments together, with about twenty-four or less secondary sensoria: aprerous forms with a few setae much less in length than widtl of third antennal segment... $\ldots \ldots \ldots \ldots \ldots \ldots \ldots \ldots$ olivacea Rohwer p. 356 


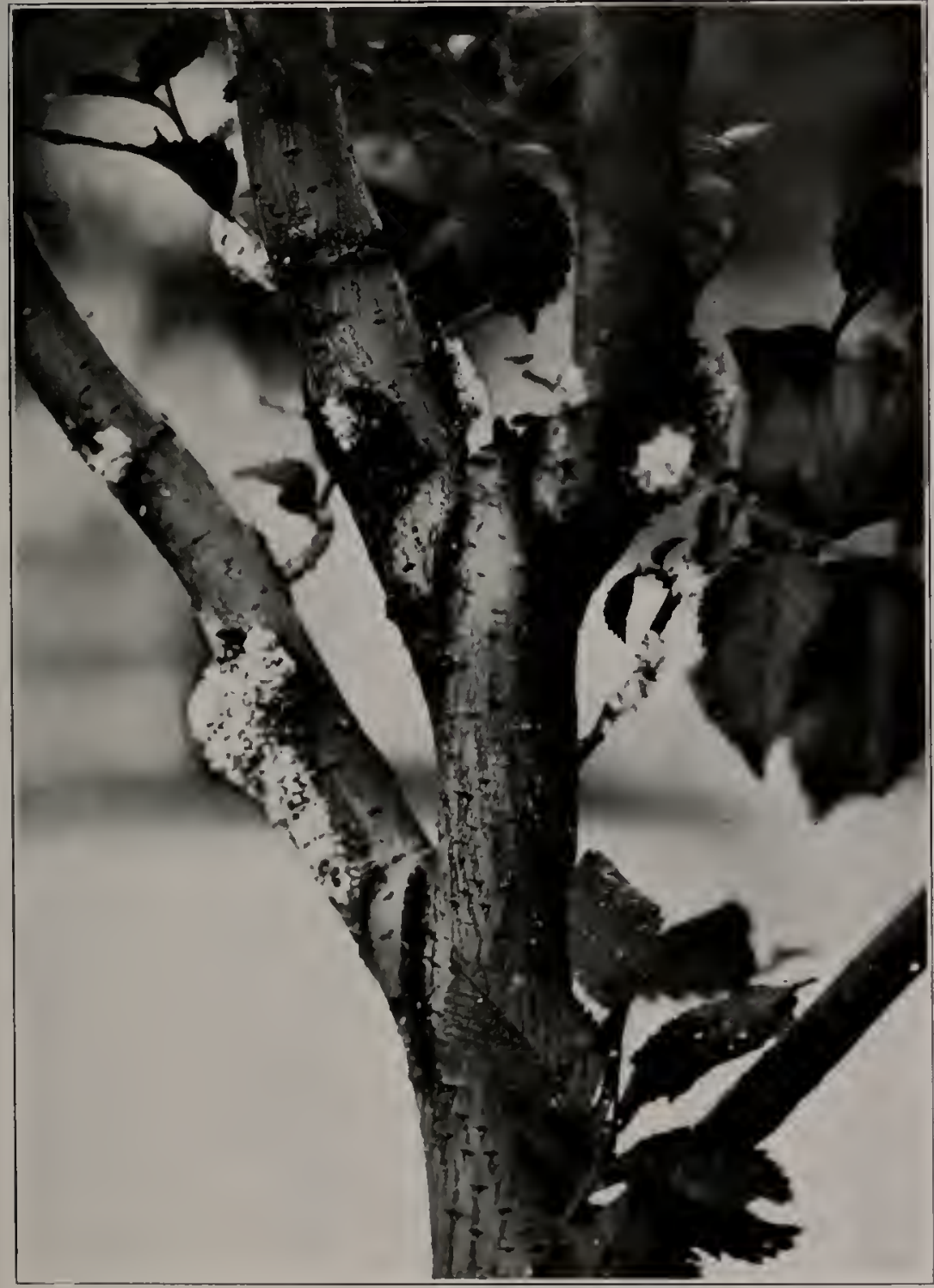

Fig. 42. Adults and nymphs of Eriosoma rilewi Thomas on the slippery elm, Ulmus fulva: Urbana, July 2, 1929. Clusters of the aphids most abuntant at scars where branches were pruned. 


\section{FORDA OCCIDENTALIS HART}

Forda occidentalis Hart, Eighteenth Report of the State Entomologist on the Noxions and Beneficial Insects of the State of lllinois, Springfield, Mlarch 4, 1895, p. 85 .

Hart described this species from specimens collected in Illinois on the roots of shepherd's-purse (Capsella Bursa-pastoris), blue-grass, and corn. Only a few specimens of the original typic material remain and these are in very poor condition but still indicate the generic affinities of the species and show that it has setiferons antennae in the apterous forms. Gillette (1918) has placed this species in the sinonymy of F. formicaria Heyden, but Theobald (19:9) says this is in error. Mlaxson states in a letter to us that this species is unkmown to him and comes nearest to formicaria Heyden. According to the observations of Hart (1895) and Gillette (1918), this species apparently passes its entire life cycle on the roots of grasses and is usually attencled by ants.

Data associated with specimens in the Survey collection are as follows: Champaign (April 28-lertotypic slide, No. T650), L'rbana (April 4 -paratypic slide, No. 7652, and April 10-paratypic slides, Nos. 651 and 3170$)$. 1894 .

\section{FORDA OLIVACEA ROHWER}

Forda olivacea Rohwer, Psyche, Vol. XV, August, 1908, p. 6s.

This species is recorder from Illinois for the first time. Our specimens were determined by Mr. A. C. Maxson. Nost of the intormation that is available concerning the biology of this root-feeding species is contained in the article by Gillette (1918).

Data associated with our specimens are as follows: Danville (Sept. 18), Logan County (May 16), Oakwood (May 16). Urballa (June 10), 192s: Urbana. Brownfield woods (March 25), 1929 . Collected on roots of grass. oats, and wheat.

\section{GENLS GEOICA HART}

\section{GEOICA SQUAHOSA HAIT}

Figs. $43,31 \%, 318$

Gcoica squamosa Hart, Eighteenth Report of the State Entomologist on the Noxious and Beneficial Insects of the State of Illinois, Springfietd, Marelı 4, 1895 , p. I02.

This root-feeding species (Fig. 43), originally described from Illinois material, is readily determined by its peculiar setae, which are bent and enlarged (Figs. 31\%,318). Hart (1895) gives the hest account of its habits. He found it often attended by ants. He reporter it as a minor pest of corn and also recoreled it from the roots of grasses, weeds, and clover. Apparently its entire active life cycle ispent on the roots of its various husts, the egrs being hept by ants during the winter.

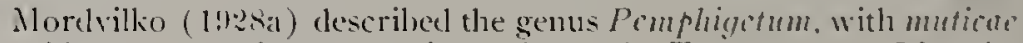
Mordvilko as type, from material collected in Turkestan on Pisfuciu. 
I ater in the same year Mordvillo sunk Pemphigetum as a synonym of Gcoira Hart and stated that squamosa Hart is a symonym of utricularia (l'ass.). In view of the number of species of Geolca recognized by Theobatk (19?!1), and the possibility of squamosa not heing synonymons with utricularia, we are retaining the name of the former. If squamosa and uricularia are synonymous, then the former is certainly anolocyclic jis North Amcrica.

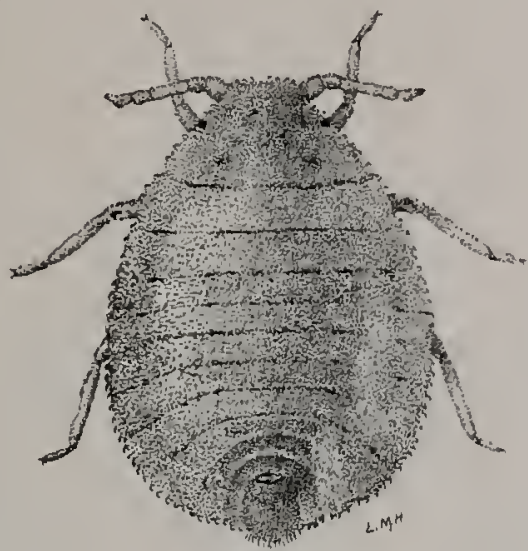

Fig. 43. Apterous viviparous female of a subterranean plant louse, Geoica squamosa Hart. (After Forbes and Hart: 111. Ent. Rep. 18.)

Data associated with our specimens, mostly belonging to the typic series, are as follows: Normal (June 1, 6, Nov. 24), 1883; Normal (April 1. June 13, July 2S, Nov. 19), 1884; Urbana (Mlay 25, July 14, Aug. 11), 18s5; Champaign (Feb. 26, Oct. 28). Normal (Mlay 21), Urbana (May 21. 24, 29, Oct. 28), 1886; Champaign (April 19, Oct. 20), Urbana (Mlay 7, 19, 31. June 1), 1887; Champaign (May 19), Urbana (May 9), 1888: Urbana (. Nov. 24), is90; Urbana (March 26), 1892; Champaign (April 26), Normal (April 1), Urbana (Mlarch 21, 23, April 4, 10, 12, Nlay 12-14), 1894; Urbana (September 16), 1898; Buda (May 28), Oneida (Mlay 27), 1901; Clayton (June 21), 1929; Humboldt (Nov. 12), 1930. The lectotypic slide is number 3164 (Frison. 1927). Paratypic slide numbers are as follows: 3161.3169 , $3172-3173$, and 7661.7675 .

\section{Gents GEORGIAPHIS Maxson AND Hottes}

\section{GEORGIAPHIS ULM (WHLSOX)}

FI(j). 44,226

Gergin ulmi Wilson, Canadian Eutomologist, Vol. XlıII, Xio. 2, February. 1911, p. 64 .

Georgia gilleflei Maxson and Hottes, Entomological News, Vol. XXXVI, No. 5. May, 1926, p. 130 . New synonymy.

This species, not previously recorded from Illinois, has been taken from varions localities over the entire state. It produces a leal-curl (Fig. 4t) on slipuery elm (Ulmus fulda), which is similar to that of Eriosoma amoricana Riley. On certain trees in Libana, Gcorgiaplis 
ulmi produces a very heavy infestation every year, and has in the course of time markedly stunted their growth and sappecl their vitality. At the time of the production of the sexual forms, some of these hearily infested trees produce so many winged lice that large piles of them accumulate under the trees. This species has been taken only on L'mus fulta and Llmus aluta, and our records indicate that the entire life cycle is passed on the one host.

A large series of specimens shows that this species is very variable in regard to certain structural characters which have been used in the past to separate $G$. ulmi and $G$. gillettci. In fact, there is such great variation that we believe that in Illinois there is only one soorl

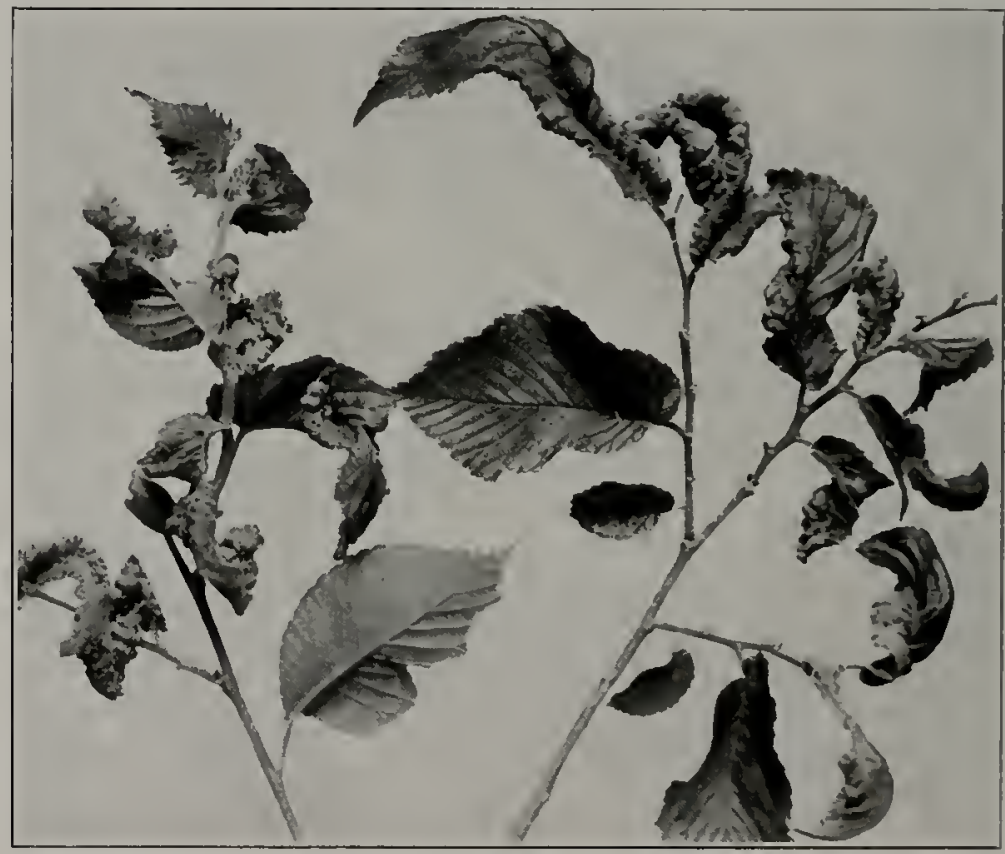

Fig. 44, An elm leaf curl caused by Gcorgiaphis ulmi (Wilson) on the slippery elm, Ulmus fulvu: Urbana, June 10, 1929.

species in the genus, and that gillettci is only a variation of ulmi. Mr. A. C. Maxson has studicel our material and says in correspondence on the matter: "I am beginning to fear that there is but one species of Georgiaplis, in which case gillettci would beconte of symomym of "lmi."

Records of this species in our collection are as follows: [rbana IJume 14), 1885: Berwyn (Juue 15), Carbondale (Jume 4), East Dubuque (June 25), Herod (May 29), Mit. Carmel (May 26), Oakwood (June 17). Oregon (June 27). Pekin (.June 20), Irrbana (May 22, June 11 and 14), 1928; I'rbana (June 4 and 11), 1929. Sexual forms have beeu taken at troana during the first two weeks of June. 


\section{GENIS GOHAISHIL MATEMMRA}

\section{GOBAISHIA ULMI-FUSUS (WALAII AXI RILKY)}

Fli. 45,87

Pemphigus ulmi-fusus Walsh and Riley, American Entomologist, Vol. I,

No. 6, February, 1S69, p. 109.

This species was origrinally described from New York and "South Illinois" in a foot-note by Waish and Riley (186!). Since then it has been recorded again from LeRoy and Utbana, Illinois, by Davis (1910d), and by Gronemann (1930) from the Chicago area (actual

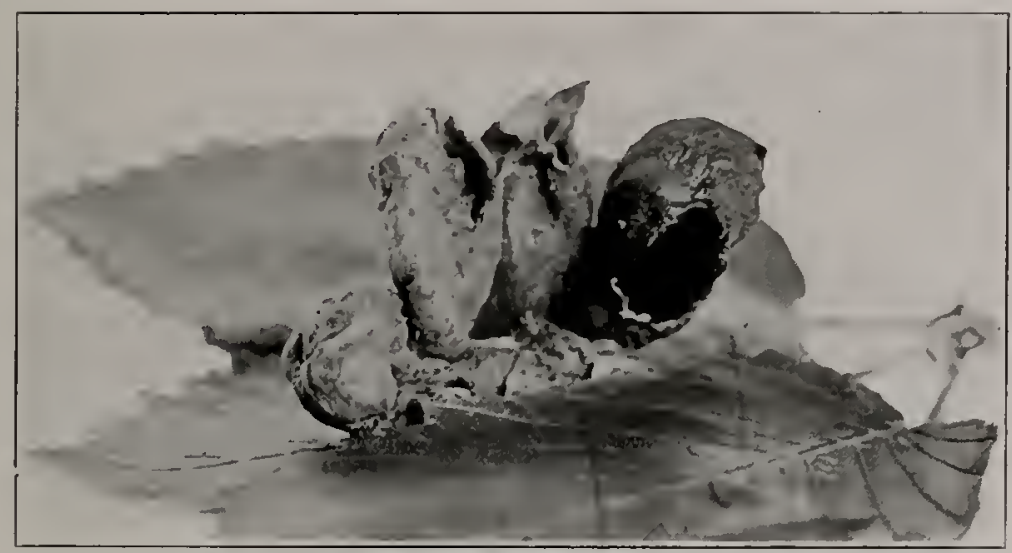

Fig. 45. Pouch-like gall of Gobaisha umi-fusus (Walsh) on upper surfaces of leaves of the slippery elm, tlmus fulva; Jonesboro, June 23. 1929 .

specimens from lilgin). The large conspicuous bag-like gall (Fig. ti) is fommd on the upper side of the leaf of the slippery or red elm. The best account of this insect, together with descrijutions and figures of structural details of adults, is that given by Patch (1910a).

The data associated with our Illinois specimens, all collected on Ulmus fulva. are as lollows: Urbana (June 27), 1887; Tonti (June 12), 1888; Elgin (June 23), 1925; Jonesboro (June 23), 1929.

\section{GENT'S MELAPHIS WALSH}

\section{NELAPHIS RHOIS (FITII)}

FIti, 73

Byrsecrypta rhois Fitch, Journal New Fork Agricultural Society, Vol. XVI, August, 1866. p. 73 .

This species, rare in Illinois, causes a small sac-like gall on the upper surface of the leaves of smach (R/hus spe). It was included anong the species listed by Thomas (18i!) but was not definitely recorded by him from lllinois. Nabsh (1x69) mentions this species 
as occurring both in "Illinois and New York." Baker (191!'a) has described a Mclaphis, called minutus, collected on moss. May j. 1916. at Springfield, Nest Virginia, and suggests that there is a remote possibility of his mimutus being the spring forms of rhois.

This species was not taken by us during our work of the past tliree years, but there are specimens in the Survey collection which were found on sumach (Rhus) at Milan, Illinois, August 16, $18: 5$.

\section{GEXUS MORDMILKOIA DEL GIERCIO \\ MORDWILFOJA VAGABUNDA (W.M.SH) \\ FIG. 46}

Byrsocrypta vagabunda Walsh, Proceedings of the Entomological Society. of Philadelphia, Vol. I, December, 1862, p. 306.

This species was originally described by Walsh from fall migrants collected at Rock Island. Inlinois. The galls caused by this plant louse are large, irregular, blarlder-like growths (Fig. 46 ) on the terminal twigs of poplars. The life history of this migratory aphid is particularly interesting because the sexuparae, or fall migrants. have been

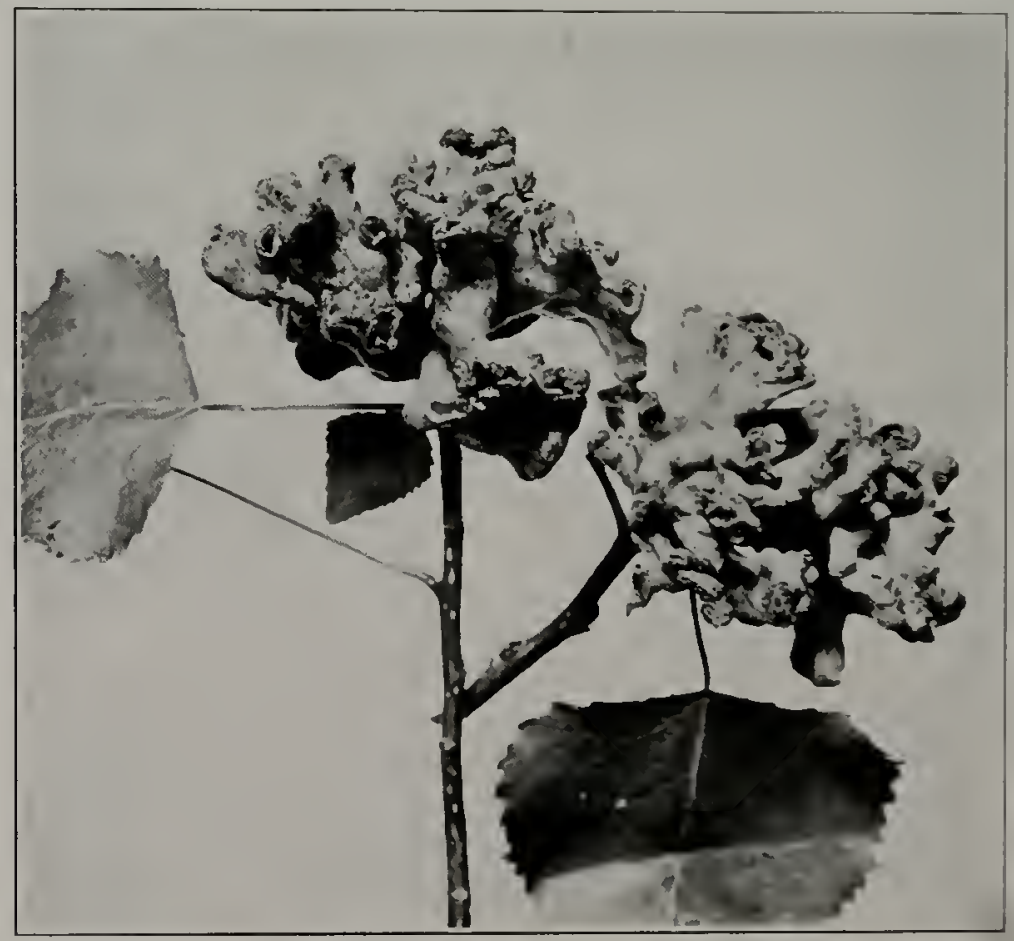

Fig. 46. A curious malformation of buds of the poplar, Populus deltoides. cansed by a plant Inuse, Mordurithoja ragabunda (Walsh); Savanna, July $9,1929$. 
shown by Oestlund and Hottes (19:6) to return from an unknown stmmmer host to the galls formed on poplars by their ancestors in spring or early stmmer, i. c., by forms which preceded them hy three to six gencrations. The finding of the return fall migrants, as well as sexual forms and eggs, in old galls on poplars at Willow Springs. Illinois, on November 5, 1930. shows that in Illinois the life history of this species is identical with that as described by Oestlund and Hottes (19:6) for Minnesota. The summer host is still unknown.

In view of the fact that this species was originally described from fall migrants from Illinois by Walsh, and the types are lost. Slide No. 9744 of fall migrants in the collection of the Illinois State Natural History Survey has been selected as the neotypie slide.

Data associated with our Illinois specimens, all collected on Populus deltoinfs, are as follows: Urbana (July 14), 1855; Shawneetown (June 26), 1909; Beach (June 17-galIs), 192S; Beach (Jnly 13), Savanna (July 9), 1929; Charleston (December It-galls), DesPlaines (July 10-galls), East Peoria (December 3-galls), Palos Park (Feb. 11-galls and eggs), Willow Springs (Nov. 5-galls, sexuparae, sexual forms, and eggs). 1930; Atlanta (Feb. 24). Bondville (Jan. 2s-galls), Decatur (Jan. 2S-galls), Funks Grove (Feb. 24). Harrisburg (ApriI 4), McLean (Feb) 24), Marshall (March 81, Metropolis (April 4), Muncie (Jan. 25-galls), Odell (Feb. 24), Paris (March 8), Pontiac (Feb. 24), Silvis (April 11), West Union (March 8), Williamsville (Feb 24), Wilmington (Feb. 24), 1981. Davis (1910) records this species from Chicago and Fankakee. A conmon species in certain parts of northern lllinois, but uncommon throughout most of central and southern lllinois.

\section{Gexus NeOPROCIPHILUS Patch}

liey to the species of the Genus Neoprociphilus

1. Secondary sensoria present on third, fourth, and fifth antennal segments............ attenuatus (Osborn \& Sirrine)

- Secondary sensoria restricted to third antennal segment......

\section{NEOPROCIPHILL'S ACERIS (MONíl)}

Pemphigus aceris Monell. Canadian Entomologist, Vol. XIV, No. 1, Jannary, 1582, p. 16.

Peoria. Illinois, is the locality from which came the cotypic specimens descrilsed by Monell (1si:e). The species has not again been recorded from the state until now. The information in literature concerning this aphid is meagre. (n the hasis of our observations concerning the biology of $N$. attenututus, the distribution of $N$. attimatus and $N$. accris in Illinois, and their agreenent in certain characters which are not found in other forms, we are inclined to believe that the two represcint the sance specics-a case paralleling that of Prociphilus tesscllate liitch. (See following account of $\mathrm{Y}^{\mathrm{T}}$, attemutus.)

Mr. A. C. Maxion has checked the determination of some of our slirles of this species.

Data associaled with our viviparous specimens are as follows: Herod (May 29), Paris ( Nug. 2), Starverl Rock State Park (June 12), Lrbana (Aug. 8), 1928; Homer (June 29), Rock Island (July 9), 1929. All specimens collected on plants taken on hard maple (Ar"r sacch(r) alate viviparous female on smilar rotumlifolin at Starved lock State Park (June 12). Alates llying at Lrbana (Aug. 8) and at Starverl Rock State Park (June 12). 


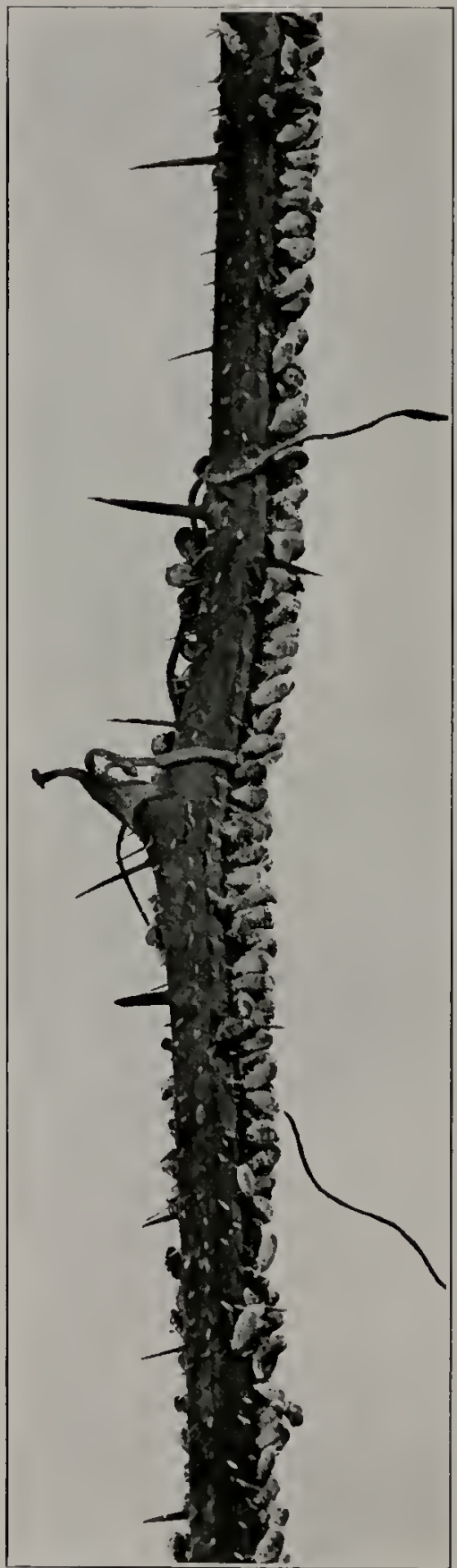

Fig. 47. Apterous viviparous females of Neompociphilus attemuatus (Osborn and Sirrine) clus. tered on lower side of stems of the smilax, smilar rotumlifolia: Urbana. November 4, 1929.
NEOPROCIPHILLS ATTENLATLS (OFBOR.X \& SIRRINE)

Fig. 47

Pemphigus attenuatus Osborn and Sirrine, Proceedings of the Iowa Academy of Sciences for 1892. Vol. I, part 3, (printed 18931. p. 100.

This species (Fig. $t^{*}$ ) is here recorded for the first time from Illinois. We have discovered that at Lrbana the nympls can successfully pass the winter under leaves at the base of the Smilur. vines on which they were produced. The life history of this species, as observed at Urbana (Frison and Ross), is as follows: continuation of species on infested Smilar for sever a 1 successive years: development of apterous viviparous females in spring and early summer from hibernating nymphs; production of alate viviparons females in latter part of August. which migrate: production of nymphs which hibernate by the apterous females produced in late stummer and fall. Just what becomes of the alate viviparous females which leave the Smila.1 in late stummer has not been definitely ascertained. but they certainly either migrate to other Suila.r vines, or an alternate host, to produce the sexual forms.

In some ways-the hibernating of the nymphs-the life history is suggestive of Prociphilus tesscllata (Fitch). l'atch (191:a) has figured the beakless oviparous female and best described the alate and apterous viviparous temales. Miss Pateh informs 11 , in answer to our query concerning this point. that these oviparous females may have been produced by the alate viviparous fonales atter being caught and she has no definite evidence they were collected on Smilur. sinec we have heen umable to find the sexual forms on Smilar, we beliese they are pro- 
duced elsewhere and that $N$. accris (Mlonell) may he another form of this species and the maple the primary host (see account of $N$, accris).

The genus Ncoprociphilus has been characterizerl as being withoul cornicles, iut cornicles are very much in evidence in the over-wintering ny'mplis.

Data associated with our specimens, collected on smilax rotundifolia. are as follows: Rock Island (June 24), 1928; Decatur (Oct. 5), Starved Rock State Park (Aug. 14), Urbana (Oct. 18, Nov. 7), 1929; Urbana (Feb. 15, Mar. 16, Apr. 4, May 3, 12, June 18, Aug. 25 and Sept. 18), 1930.

\section{Geñs PEMPHIGUS Hartig}

\section{Key to the species of the Genus Prmphigus}

1. Greatest diameter of fourth antenmal segment not distinctly less

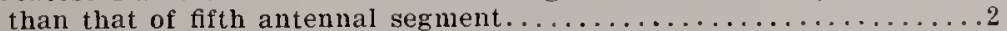

- Greatest diameter of fourth antennal segment distinctly less than that of fifth antennal segment; a large, membranous, irregularly shaped sensorium on distal half of both fifth and sixth antennal segments, these sensoria normally with small. more heavily chitinized, island-like areas bearing one or more setae (Fig. 240); from gall on petiole of poplar leaf, mature aphids escaping through a transverse slit (Fig. 49) ......... $\ldots \ldots \ldots \ldots \ldots \ldots$. [fundatrigeniae] populi-transversus Riley p. 367

2. Sixth antennal segment never with annular secondary sensoria......... Sixth antennal segment always with annular secondary sensoria......6

3. Sensorium on distal end of fifth antennal segment large and normally with a small, more heavily chitinized, island-like area in membranous area (Fig. 241); on roots of Cruciferae....... ...................... [sexuparae] populi-transversus Riley p. 367 and rubi Thomas p. 368

- Sensorium on distal end of fifth antennal segment small and without an island-like area in membranous area..............

4. Fifth antennal segment withont secondary sensoria..............

-. Fiftl antennal segment with secondary sensolia (Fig. 229); on roots of birch.............. [sexuparae] ephemeratus n. sp. p. 365

5. Fifth antennal segment about twice as long as greatest width and about as long as secord antenual segment (Fig. 228); on roots of solifago. Erigeron, etc... [sexnparae] brevicornis Hart p. 863

- Fifth antennal segment elongate, about three times as long as greatest width and conspicuously longer than second antennal

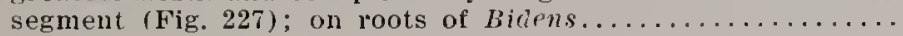

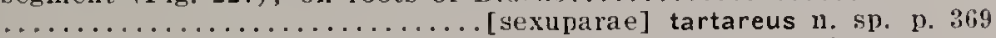

6. Fourth antennal segment with from one to three, rarely four, secondary sensoria; from cockscomb-like gall on upper surface of poplar leaf........ [fundatrigeniae] populi-venae Fitcl p. 368

- Fonth antenual segment usually with four or more secondary sensoria; from gall on petiole of poplar leaf, mature aphids

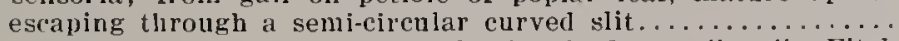
...................... [fundatrigeniae] populicaulis Fitch p. 366

\section{PENPHIGUS BREVICORNIS (HAIT) \\ Fici, 225}

Tychea brvicurnis Hart, Eighteenth Report of the State Eutomologist ou the Noxious and Beneficial Insects of the State of Illinois. March 4 , 1895. p. 97 .

Ever since the original alescription in 189.5 of Tychea bresicornis Hart. the relationships of this form lave been in doulst. Collections 
of root-frequenting aphids made during the fall of 1930 have proved, however, that this plant louse is a very common species on roots of Erigeron, Solidago, etc., in Illinois and that it belongs to the genus Pempligus as Cutright (1925) has placed it. Our information to date inclicates, too, that many or most of the sexuparae reach maturity before the ground is completely frozen and that they leave the soil for an alternate host. Those sexuparae that fail to leave the soil before it is frozen remain there during the winter and then in early. spring probably fly to the alternate host.

Although predictions are hazardous, we believe that the forms now called brezicornis Hart will eventually be found to be the sexuparae of populicaulis Fitch, the latter name having priority. Only one other species of Pcuphigus (populi-transicrsus Riley) approaches the abundance of populicaulis Fitch in Illinois, and the sexuparae of it have been made known by the excellent studies of Jones and Gillette (1918). The distribution and abundance of brecicornis Hart indicate that. if it has an alternate host, the gall which it forms on this host must be a common one: thus indicating by circumstantial evidence the gall of populicaulis Fitch. As already mentioned, the presence of numerous winged sexuparae in fall, the abdonens of which contain sexual forms, is indicative of an alternate host. Again, we have found in November in localities where hrcvicornis was abundant on roots, the sexuparae of a Pcmphigus, inseparable from breacornis Hart, in cracks in the bark and in scars on the trunk and branches of Populus dcltoides. Associated with these sexuparae we have found the sexual forms and eggs, and later (June) the galls of populicaulis.

Little mention has been made in literature of breaicornis Hart since the original description. Its assignment to Tycheoilcs cragrostidis Pass. by Theobald (1929) is obriously incorrect because breicornis is a true Pempligus. Although Cutright (1925) has sunk breaicornis as a synonym of lactucae Fitch, for the present we have not accepted this synonymy because of the possibility of the latter being sone other species. If Cutright's synonony is correct, and if our supposition about populicaulis is correct, the name of lactucac Fitch (185!) will have priority over botl other nanes. In any case, it seems that the nane brevicornis is doomed to synonymy as are most names applied to sexuparae.

Since there is no detailed description of the alate sexupara in literature, the following is given:

\section{A Inte Srxtrollit}

Size and general color.-Length from head to tip of anal plate. 1.70. Color of body, antennae, and legs dark brown, except abdomen, which is green. Wings almost hyaline, very slightly infuscate with gray; veins and stigma grayish brown.

Head and nppendages.-Average width of head across eyes, .36. Comparative lengths as follows: $111-.16$ to .23 , average .18 : $1 \mathrm{~V}-.0710 .11$. average $.09 ; \mathrm{V}-.06$ to 11 , average .08 ; V - .11 to .14 , average .12 plus .03. Sensoria (Fig. 22S) present on third and fourth segments, mumbering 5 to 6 , average 7 , on third, and 1 to 4 , average 2 , on fourth. Third segment wilh a spine-like process near base. Fourth and fifth segments imbricated, each with an oval primary sensorim without chitinous islands. 
Thorax and abdomen.-The pair of wax-pore plates on mesonotum oblique and oval, separated by slightly more than their greatest diameter (length), sometimes more nearly round and farther apart. Wax-pore plates on abdomen similar to those described for $P$. tartareus.

Data associated with our recent collections on roots of Erigeron and Solidago are as follows. Normal (July 28), 1SS4; Champaign (October 25), $1 S 86$ ) ; Beardstown (November 7), Effingham (Novenber 13), Flora (November 13). Golcouda (November 27), Herod (November 27), Oakwood (Octoher 22), Watson (November 13), Willow Springs (November 4), 1930. Forms inseparable from the true brevicornis Hart have been collected in Illinois irom crevices on trunks and branches of Populus deltoides as follows: Golcoda (November 27) and Watson (November 13), 1930. Males, oviparons females, and eggs were found associated with dead alate sexuparae from Watson on November 13.

The cotypic slides $(3171,7659,7666)$ are from Normal, lllinois, July 28, $1 S 84$, on corn roots, and Champaign, 1llinois, October 25, 18S6, in ant nest.

\section{PEMPHIGUS EPHEMERATUS new species}

\section{Ai.ate Viviparous feitale (Sextpali.i)}

Sizc and general color.-Average length from vertex to tip of cauda, 2.25. In life entire body with a downy wax coating. Specimens preserved on slide with head and thorax dark brown, abdomen yellowish-brown with seven small brownish lateral patches serially arranged. Antennae and beak concolorous with head or slightly lighter. Legs concolorous with antennae, slightly lighter than thorax, almost uniformly brown, tibiae sometimes slightly darker than femora. Stigma with posterior portion darkest, posterior dark portion extending to base of wings; veins very light bordered with light fuscous bands; posterior margin of wing brownish near junction with anal vein.

Head and appcndages.-Average width of head across eyes, .49. Antenal segments with the following comparative lengths: III- .17 to .21, average $.19 ; 1 V-.11$ to .13 , average $.12 ; V-.14$ to .17 , average $.15 ; \mathrm{VI}-.14$ to .19 , average .17 plus .03 to .06 , average .05 . Coefficient of antennal segment VI$1.19 \pm$; antennal coefficient $0.72 \pm$ (Maxson's formulae), Secondary sensoria (Fig. 229) present on third, fourth, and fifth antennal segments, numbering as follows: III -5 to 9 , average 7 ; IV -2 to 5 , average $3 ; \mathrm{V}-2$ to 5 , average 3. Secondary sensoria of the transverse type varying greatly in length and width, but never longer than the dianeter of the segment and always in a straight row. Primary sensorium on the sixth antennal segment without marginal sensoria. Third antennal segment with spine-like process on its inner side near base of segment (Fig. 229). The beak just fails to reach the mesothoracic coxae.

Thorax and appendages.-Prothorax with two transverse, narrow waxpore plates on the dorsum, one on each side of the meson. Mesothorax with two oblique, elliptical wax-pore plates on dorsum, separated by a distance about equal to their length and with two large oval wax-pore plates on the venter, situated immediately cephalad of the mesocoxae on the anteriormesal angle of the pleuron. Hind tarsi about twice as long as the fourth anteunal segment. Veins of tore wing ending a considerable distance before margin of wing; some fore wings with a sub-costal border.

Ibdomen.-Cornicles apparently absent. Dorsal wax-pore plates apuarently lacking or, if present, very indistinct; six large wax-pore plates situated on lateral margins of abdomen; a larger median wax-pore plate present just anterior to the cauda. Canda normal in shape.

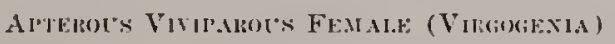

size und grnchul colur.-Average lengtl from vertex to tip of anal plate, 2.4. General color of body light yellowish-brown, except as lollows: antennae and anterior portion of head greyish-brown; mouthparts, legs, and pleural plates brown; tibiae slightly darker than the temora, as in tle alate viviparous female. 
Head and appenriages.-Average length of head across eyes, .43. Antennal segments with comparative lengths as follows: III - .10 to .13. average .11: IV- .04 to .06 , average $.05 ; \mathrm{V}-.09$ to .10 , VI- .13 to $.1 \%$, average .15 plus .03 to .04, average .04. Third and fourth antennal segments cylindrical, of almost uniform width, faintly imbricated, and without sensoria; the division between them often indistinct, represented only by a narrow contraction of the integument. Fifth segment faintly imbricate, distinctly cuneate, its diameter near apex twice that at base; apex with a circular primary sensorium fringed with hairs, subequal to sensorium on sixth segment. Sixth segment slightly imbricate, including the terminal filament longer thau seg. ments three and four together; the terminal filament distinctly defined, bearing at its apex a group of four or five short, stout spines; the single primary sensorium small, circular and fringed with hairs, its diameter subequal to that of the terminal filament. Eye small, composed of three bulging facets. Beak reaching just beyond middle coxae.

Thorax and abdomen.--Lengths of front legs average as follows: fenur .51 , tibia .45 , tarsus .18, claw .06 ; middle leg with femur .49. tibia .44, tarsus .18 , and claw .06 ; hind leg with femur .6S, tibia .70, tarsus .22, and claw .06. Femora smooth and bare, tibiae with scattered sloort spines. Cauda and anal plate broad and gently rounded.

Holotype.-Alate viviparous female (sexupara); Herod. Illinois, October 12. 192s, on roots, probably Betuta nigra. (Frison and Hottes). On slide witl a pupa. Slide No. 10773. Norphotype.-Apterous viviparous female; same data as holotype. On slide with alate viviparous females, pupae, and nymphs. Slide No. 10774. Paratypes.-Twelve slides of alate (sexuparae) and apterous viviparous temales, pupae, and nympls with the same data as holotype. two slides of apterous viviparous females with same data except date of November 27, 1930 (Frison and Ross). Slides Nos. 10775-107\$5 and others unumbered.

This species was collected on fine moss-like rootlets of Betula nigra where these had heen exposed lyy erosion along the bank of a small stream. The situation at the time was quite damp and dark. che to the previous high water and the slightly overhanging bank. It may be the lall migrant of an already described Pempligics. but the situation and apparently unusual host arld greatly to the possibility of its being entirely new. It is described with the hope that aiter its recognition others will interest themselves in investigating its life cycle. It differs from all other related species known to us by the combination of characters given in the key to the species of P'mplingus.

\section{PENPHIGUS POPULICAULIS FITCII}

Pemphigus populicaulis Fitch. Transactions of the New Jork State Agricultural Society, Vol. XV1II, $185 \mathrm{~S}$ (printed 1S59), p. 845 .

This plant louse has been previously recorded from Illinois he Walsh (186?), LeBaron (18:3), Thomas (18:9), and Davis (1914k). It causes a gall at the base of the leaves of poplar somewhat similar to $P$. populi-fromscersus except that opening is a semi-circular curved slit. Under a discussioin of $P$. brecicornis Hart we have already advanced our supposition that populicanlis is the aerial and gall-nahing form of the root-iecding plant louse described as hericormis Hart. and the nomenclatorial clanges that must result if this theory is sulystant iated.

Data associated with our specimens collected in galls on species of Populus are as follows: Cliampaign (July 16), 1SS5; Albion (May 26). Cave-in-Rock (May 30), Oakwood (July 1S), Sliawneetown (May 2i). I"r- 
bana (July 10), 1928; Eldorado (June 19). Elizabethtown (June 20), Kansas (June 17), Oakwood (June 1), Rock Jsland (July 7), Starved Rock State Park (July 5), 1929; Seymour (June 20), 1930.

\section{PEMPHIGUS POPLLI-TRANSVERSUS RILEY}

Fris. $48,98,240,241,330$

Pemphigus populi-trunsversus Riley, Bulletin of the United States Geological and Geographical Survey of the Territories, Vol. V, No. 1, January 22, 1879 , Article I, Part I, p. 15.

The details of the life history of this species are very well known because of the studies of Jones and Gillette (1918), who have shown that it alternates between poplars and the roots of various cruciferous plants. The winged migrants (funclatrigeniac) leave the galls (Fig.

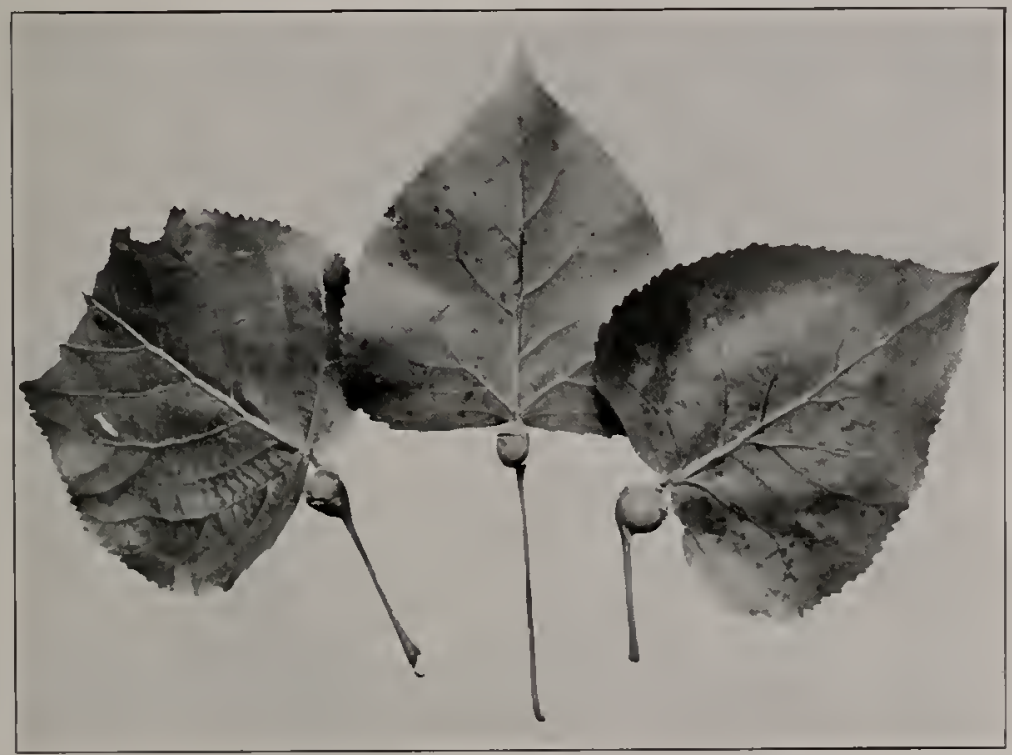

Fig. 48, Leaf petiole gall on the poplar, Populus rleltoides. caused by the migratory plant louse, Prmphigus populi-transversus Riley; Oakwood, July 22, 1929. The winged adults leave the gall through the trausverse slit.

fis) on poplars in spring or summer and fly to cruciferous plants, where the sexuparae are crentually produced. Fihe latter return to the trumks and branches of poplars in spring and produce the sexual forms which probluce eggs from which the stem mothers hatch. The stem mothers start the galls, each of which produces a large mumber of winged females or migrants.

We halve been mable to separate the cotypic specintens of $P$. rubi Thomas (185!), which arc sexuparac, from sexuparac of $P$. populitransecrsus kiley. The sinliarity in their antennac, which are quite 
different from the antennae of other sexuparae taken in Illinois. seems to us quite indicative that they are the same species.

Data associated with our Illinois material on Populus are as follows: Danville (Sept. 18), Elizabethtown (October 12), Golconda (October 13), Havana (June 21), Nahomet (October 2), Mt. CarmeI (May 26), Pekin (July 22), 1928; Farmer City (September 22), Herod (Sept. 27), Oakwood (October 13), Starved Rock State Park (JuIy 5), 1929; Fairmount (September 28), Watson (Nov. 13), 1930.

In addition, the sexuparae have been taken on roots of Lepidium virginicum at Mt. Carmel on May 26, 1928 . PreviousIy recorded from Iltinois by Davis (1910) and Gronemann (1930).

\section{PEMPHIGUS POPULI-VENAE FITCH}

FIg. 94

Pemphigus populi-venae Fitch. Transactions of the New York State Agricultural Society, VoI. XVIII, 1858 (printed 1S59), p. \$51.

Thomas (18:9), in the "Eighth Report of the State Entomologist of Illinois," lists a species of Pcmphigus under this name but without definitely recording it from Illinois. This species has been rarely recorded in literalure, and the only detailed description of its forms is that by Maxson and Knowlton (1929).

Our record establishing the occurrence of this species in Illinois is based upon the finding of the characteristic cockscomb-like galls upon the upper surfaces of leaves of Populus deltoides at Watson, Illinois, on Novem. ber 13, 1930 (Frison and Ross).

\section{PEMPHIGUS RUBI THOM.}

Pemphigus rubi Thomas, Eighth Report of the State Entomologist on the Noxious and Beneficial Insects of the State of Illinois, 1579. p. 147.

As mentioned in our remarks concerning $P$. populi-transicrsus Riley, we are unable to separate the cotypic specimens of rubi Thomas. which are sexuparae, from the sexuparae of the former and helieve that they are the same. Only the slight possibility of their being two different species of Pompligus with similar seximparac has prevented us from sinking one of the names in symnymy at this time. Ii later investigations prove these to be the same, the name of populi-fransicrsus Riley will have priority.

The statement of Jackson $(190 \%)$. that this species "canses at curling and twisting of the leaves" of raspberry, is evidently withou foundation. Jackson himself states he is not familiar with this species, and a check of all references known to us does not reveal stuch a statement hy others. Even Thomas, when he described rubi. stated that "it is possible that these specimens were accidentally on the rasj)lerry."

The cotypic slides, numbers $276 \pi$ and 2768 . are alate viviparous fenales (sexuparae) collected at Carbondale, Illinois. April 12. 187s, on rasplberry, by G. H. French. 


\section{PEMPHIGUS TARTAREUS new species}

F11. 227.

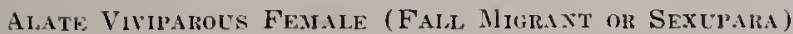

Size and general color.-Average length from vertex to tip of cauda, 2.38. Head, antemmae, beak, thorax, and legs, dark brown, with sutures paler. Abdomen pulverulent, pale whitish green, with spiracles, anal plate, and wax-pore plates greenish or brownish. Wings slightly infuscate with brownisls; front wings with costa, subcosta, stigma and posterior margin of wing in vicinity of anal vein deeply infuscate with brownish, remaining veins paler; hind wings with veins stll paler.

Head and appendages.-Average width of head across eyes. 41. Antennal segmeuts with comparative lengths as follows: III- .21 to .24, average .22; $\mathrm{IV}-.11$ to .13 , average $.13 ; \mathrm{V}-.10$ to .14 , average $.12 ; \mathrm{Vl}-.14$ to .19 , average .16 plus .04 . Coefficients determined according to Maxson's formulae are as follows: antennal coefficient, 0.825 ; and coefficient of sixth antennal segment, 0.909. Secondary sensoria (Fig. 227) restricted to third and fourth antennal segments, linear-oval, witl their margins wrinkled, arranged in a straight row on the dorsal side of the segment and numbering from 5 to 7 , average 6 , on the third segment, and 2 to 3 , average 2.5 , on the fourth. The third segment may have two or three small, round to oval, lateral sensoria. Primary sensorium on sixth antennal segment apparently without marginal sensoria. Third antennal segment with a very small, spine-like process on its inner side near base of segment. Flagellum of antenna imbricated. Beak reaching midway between pro- and mesothoracic coxae.

Thorar and appendages.-Prothorax with a lanceolate wax gland on each side of the dorso-meson. Mesothorax with an oval wax gland on each side of dorso-mesal line, separated by twice their greatest diameter, and in line with the base of the mesothoracic wings. Metathorax also with a pair of oval wax glands, in line with the other paired dorsal glands. Stigma of fore wings ending very abruptly, veins failing to reach margin of wing.

Abdomen.-Abdomen with seven pairs of lateral wax glands, those towards the posterior portion of abdomen very large. Dorsum typically with six pairs of wax glands, the basal ones largest, the posterior ones usually gradually decreasing in size, sometimes a pair coalescing, but varying greatly in shape and degree of coalescence. Seventh ahdominal segment with an extremely large, oval, wax gland on the mid-dorsal region. The single condition is presumably due to the confluence of two paired wax glands. Cornicles apparently absent. Cauda nornal and with but few hairs.

Holotype.-Alate viviparous female (sexupara); Decatur, lllinois, Oc. tober 21, 1929, on roots of Birlens sp, (F. C. Hottes). Slide No. 10708. Paratypes.-Fifteen slides in all, containing alate viviparous females and pupae; ten slides same data as holotype; one slide, Oak Park, Illinois, Octoher 9, 1909, on roots of Bidens. (J. J. Davis); four slides, Lafayette, Indiana, October 3, 1913, on roots of Billens, (J. J. Davis). Slides Nos. 1070910717 and others unnumbered.

When the complete life creles and seasonal forms of previonsly describerl species of Pemphigus become known, this species will likely be found to lie the sexupara of one of them. At present, however, fall migrants of only two species of Pempligus are authentically correlated with the spring, or gall making, forms. It is, therefore, impossible to place this form satisfactorily in our present system of classification, and it is best recorded as a new species. Mr. A. C. Maxson, to whom specinens were submitted for an opinion concerning their identity, concurs with this view. The specimcus in the paratypic series collected by Davis at ( )ak lark were recorded by bim (1911h) as P'. betac Doane. 
The characters given in the key to the species of the genus Pcmphigus arc sufficient to differentiate this species irom related and described forms.

\section{Genes PROCIPHILUS Kocil}

\section{Fey to the species of the Genus Prociphitus}

1. Wax-pore plates on mesonotum separated by a distance equal to several times their greatest diameter (Fig. 330); fore tibiae and antennae about equal in length; large species, body abont $4 \mathrm{~mm}$. in length; in congested colonies on branches of beech..

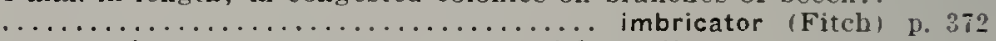

- Wax-pore plates on mesonotum separated by a distance less, or but slightly more, than their greatest diameter (Fig. 329): fore tibiae much shorter than length of antennae; smaller species, body rarely exceeding $2 \mathrm{~mm}$. in length; not found on

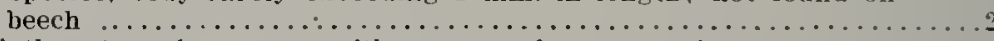

2. Sixth antennal segment with no secondary sensoria........... $\ldots \ldots \ldots \ldots \ldots \ldots$ [fundatrigeniae] corrugatans (Sirrinei p. 370

- Sixth antennal segment with one or more secondary sensoria..........

3. Third antennal segment usually with twelve or more secondary

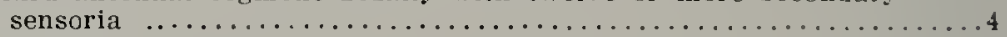

- Third antennal segment normally with less than twelve sec-

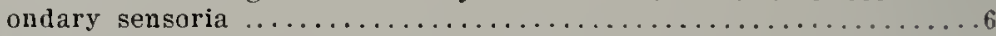

4. Wax-pore plates on dorsum of mesothorax triangular in outline

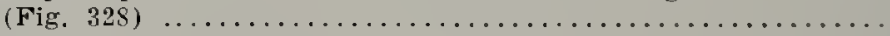
........ [fundatrigeniae and sexuparae] venafuscus (Paich) p. 373

- Wax-pore plates on dorsum of mesothorax oval in outline (Fig.

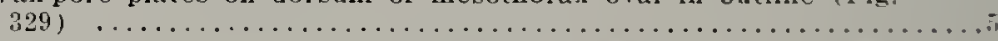

5. Veins of fore wing conspicuously margined with fuscous border: on roots of many plants.. [sexuparae] erigeronensis (Thomas) p. 371

-. Veins of fore wing not margined with fuscous border: on poma. ceous trees.............. [sexuparae] corrugatans (Sirrine)

6. Fourth and fifth antennal segments approximately the same length; fourth antennal segment about equal in length to front tarsi; wax-pore plates on mesonotum separated by a distance about equal to, or less than, their shortest diameter. .

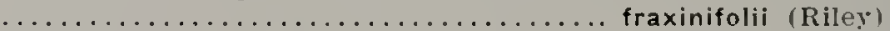

- Fourth antennal segment conspicuously shorter than the fifth: fourth antennal segment about equal in length to one-half length of front tarsi; wax-pore plates on mesonotum separated by a distance about equal to, or more than, their greatest

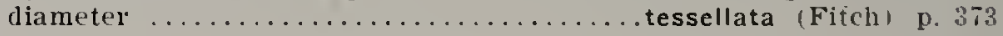

\section{PlROClPHILLS CORRUGATANS (SMIINE)}

Fia. 329

Pemphigus corrugatans Sirrine, Proceedings of the Iowa Acadeny of Sciences for 1893 , Vol. I, Part 4 , 1894, p. 130.

Davis (1910d) has recorded as questionably this species sume specimens that he collected on Crataegus. July i. 190i, at Lekoy. Illinois. At a later date of the same vear he changed this cletermination to Pcmphigus, sayng it "may be Fitch's $P$. pyri." A slide of this LeRoy material was very kindly sent to us for study hy . Mr. Davis. IVe fund. as Davis finally concluded. that the specinems undoubtedly helong to 
the genus Pcuphigus and, judging by Baker's (1916a) figures, are not pyri Fitch, which is a Prociplilus. "The life history of the species is but poorly understood.

The data associated with our two Illinois collections of this species are as follows: Antioch (June 15), 192s; Starved Rock State Park (May 13), 1930; collected on Crataegus and Amelanchier, respectively. The material from Antioch apparently represents stem mothers and nymplis, and that from Starved Rock State Park the alate (funclatrigeniae) and apterous viviparous females.

\section{PROCIPHILUS ERIGERONENSIS (THOAAS)}

Tychea erigeronensis Thomas, Eighth Report of the State Entomologist on the Noxious and Beneficial Insects of the State of Illinois, 1879, p. 168.

A study of the original description and probable cotypic specimens of Tychea crigcroncnsis Thomas, the studies of Forbes and Hart $(189.5)$. and recent collections of our own. all clearly indicate that one of our common subterrancan aphids in lllinois is the Tycliea crigeroncusis of Thomas. Furthermore, the studies of Patch (1918) and Cutright (19:5), and their drawings of the rare alate form, inclicate that this species is generically best placed as a Prociphilus; and this placement is supported also by an opinion expressed to us in a letter from Mr. A. C. Masson. It seems to us that Tychca radicola Oestlund (1886) and Tychca crigcroncnsis Thomas (1879) are the same species, as Forbes and Hart (1895) have previously stated. Maxson in a letter to us writes that "radicola Oestlund may be identical with the Tychea crigeroncnsis Thomas." The best account of the life-history of this species is that given by Cutright (1925). Ithether it migrates and produces aerial forms is still unknown.

Our Illinois host records for this root-feeding species are: Tararaeum officinale. Erigeron philadelphicus, and species of grass. Locality and seasonal records are as follows: Normal (April 24), 18s4; Urbana (March 19. Nov 25), 1890; Urbana (April 23, 26), 1892; Urbana (April 9-19), 1894; Urbana (Sept. 22, Oct. 25), 192s; Champaign (April 27), Urbana (April 2, May 1, July 22), 1929: Oakwood (Oct. 22), and Urbana (Sept. 22, Nov. 18), 1930. The data associated with probable cotypes (Slide No. 2769) are "roots of endive and Erigeron canalense, collector T. J. Burrill."

\section{PROCIPHILUS FRAXINIFOLII (RILEY)}

Fir. 49

Prmphigus frarinifolii Riley, Bulletin of the Inited States Geological and Geographical Survey of the Territories, Vol. V, No. 1, 1879, Art. 1, p $1 \%$.

This gremish and pulverulent aphid was described by both Riley (18:!) and Thomas (18:9) under the same name. The descrijtion of Riley, however, has priority over that of Thomas. It is a very common species in all parts of Illinois on ash (Frorimus) and has been previously recorderl from our state by Davis (1510k). It ma well be classed as an important pest of this tree because of the clirect injury that it causes and the monsighly appearance of trees infested with the psetuclo-leaf galls ( lig. I!1). According to Davis (1!)1(1), the sexual 
forms are produced in fall and the eggs laid in crevices of the bark of ash 1 rees. Definite information as to an alternate host of this plant louse is lacking. and it may be that the entire life cycle is spent upon the ash.

All the typic material of Pemphigus fraxinifolii Thomas, previously recorded by Davis (1913), is now mounted on two slides. Slide No. 2762 is designated as the lectotypic slide and Slide No. 7167 as a paratypic slide. Data associated with these slides are: Sauk City, Wisconsin, June, on Fraxinus quadrangulata, collected by Bundy.

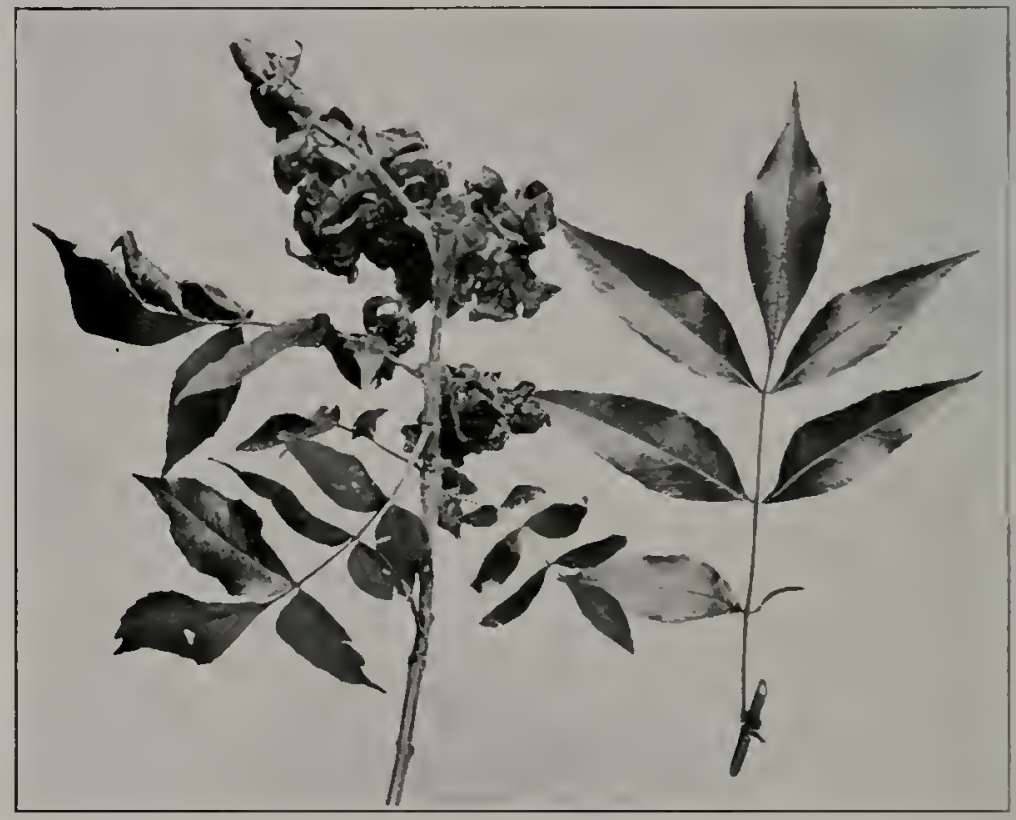

Fig. 49. Pseudo-gall on leaves of the white ash. Fraxinus americana, caused by Prociphilus frarinifolii (Riley); Crbana. June 16. 1929. Normal foliage on right and infested twig on left.

Data associated with our specimens, all collected ou ash (Frarinus sp.). are as follows: Freeport (June 20), 1920; Antioch (June 15). Bement (July 17), Champaign (July 8), Havana (Jume 22), Kankakee (June 29), Metropolis (June 11, Rock Island (June 23). St. Joseph (Aug. 5), Trhana (July 5), 1928: Anna (June 21). Cairo (June 22). Effingham (Jnne IS). Flizabethtown (Jume 20), El Paso (July 5). Grayville (June 19). Harris. burg (May 28), Jerseyvihe (June 25), Lisle (July 14), Mlaryville (Sept. 11), Newton (June 17), Oregon (July 10, 11). Rock Island (July T), 1929: Starved Rock State Park (May 13), 1930.

\section{I'ROCIPHILIS IMBRICATOR (FITCM)}

Fli, 97

Friosoma imbriealor. Fitch. Fourth Annual Report of the Regents of the University, on the Condition of the State Cabinet of Natural History. State of New York, January 14, 1\$51, p. 68 .

Apjarently this species las not been recorderl heretolore irom Illinois. Lilie many other species, it is mentioned in the Eighth Re. 
port of the State Entonologist of Illinois by Thomas (18i!9) lut not recorded or stated to be found in the state. The species is a large and exceedingly flocculent one, feeding and living in congested colonics on the larger branches of its host. the beech. Often it produces so much honey-dew that the ground beneath the infestation becones discolored. Alumost nothing has been published concerning the life history of this plant lonse, a species which is sonewhat of a misfit in cither the genus Prociphilus or Pemphigus.

Our specimens were taken on beech (Fagus grandifolia) at Jonesboro. Sept. 28, 1929.

\section{PROCIPHILU'S TESSELLATA (FITCII)}

Erinsomu icssellatu Fitch, Fourth Annual Report of the Regents of the University, on the Condition of the State Cabinet of Natural History, State of New York, January 14, 1\$51, p. 68.

This species was first recorded from Illinois by Davis (1910d), who cullected specinens on alders growing in the Chicago parks. According to Davis and several other authors. this plant louse is calpable of catusing injury to alders tused in ormamental plantings. Biologically this species is of special interest, in addition to its migratory habits, becanse it is one of the few aphicls known to hibernate in numbers in the nymplat stage. The sexual forms are produced on maples by migrants leaving the alclers in fall. The over-wintering eggs produce stem mothers in spring which prodnce generations (accrifolii Riley) destined to return in summer to alders. Although the life cycle is interrupted on its probable original host, the maple, the life cycle may continue withont interruption on alders. The first person to work out the life history of this species was l'atch (1!)(18, 1911b), whose findings were confirmed by the extensive stuclies of Pergande (1912).

Data associated with our specimens, all collected on alder (Almus sp.), are as follows: Herod (Nov. 29, 30), 1928; Herod (June 21), 1929.

\section{I'ROCIPHILUS VENAFU'SCUS (PATCI)}

Fiti. 328

l'mphigus v'nufusrus Patch, Eutomological News, Vol. XX, No. T, July, 1909, p. 319.

( nnly one specinen of this species, a fall migrant, has lecen talien in Illinois. Patch $(1 !(0) 1)$ ) has shown that in Maine the fall migrants maty le taken on lilac, chm. and ash, on all of which the sexual forms were proflucerl and winter egess subsequently laid. The spring forms were found to develop" "in the angles of the twigs or abont the swelling butls" of lilacs and ash. Besides ler first illustrations of this species, adclitional ligures of the curious wax-pore plates (Fig. 3est) of fle thorax, and of the antennae, are given in a later publication (191s).

Our sperimen, al sexupara, Was collected at Watson, lllino:s November $1: 3,19: 0$, on the bark of l'opulus delloilles. It may have been a "stray" on l'olullis. 


\section{GENLS THECABILS KOCH}

\section{THECABILS SPECIES}

Since we have been mable to secure alate specimens, the specific identification of our Thccabius material has been impossible. A British species of Thecabius, as well as T. populi-conduplifolius (Cowen) in the United States, is known to migrate between Populus and Ramuculus, the former being the over-wintering host.

Our apterous material has been examined by Mr. A. C. Maxson, who reports that specimens taken on the stems and crowns of fianunculus plants at Starved Rock State Park (August 14-September 10, 1929) are probably T. gravicornus Patch. What is apparently another species of this genus was collected in leaves of Lysimachia at the following places and dates: Kankakee (June 29, July 15), 1928; Beach (Aug. 28, 29), 1929. The apterous forms of all our material produced considerable flocculent secretions.

\section{Genus TRIFIDAPHIS Del Gcercio}

\section{TRIFIDAPHIS PHASEOLI (PASSERII)}

Tychea phascoli Passerini, Gli Afidi, 1860. p. 39.

This subterranean species has not been previously reported from Illinois. According to Gamman (1895) and Theobald (1929), it is capable of causing severe injury to garden beans. The best account in English of $T$. pliascoli is that given by Theobald (19:9). Mordvilko (1928a) has indicated that $T$. radicicola (Essig) is a synonym of phascoli and in certain parts of Europe other forms not thus tar found in America produce galls on Pistacia. According to our present information, this species is anolocyclic in Anerica.

Mr. A. C. Maxson has kindty determined our apterous specimens of this species. They were collected on the roots of sweet peas (Lathyrus sp.) in a greenbouse at Mlaywood, Illinois, on April 12, 1923, by Mlr. C. C. Compton.

\section{SCRFAMLL MINDARINAE \\ SUPERTRIBE MIND.ARE.A}

\section{Genes MINDARUS Kon}

\section{MINDARUS ABIETINLS KOOH}

Mindarus abietinus Koch. Die Pfanzenläuse Aphiden getreu nach dem l.eben abgebildet und beschrieben, Niirnherg, $1 \$ \overline{7}$, p. $2 i s$.

This species was described by Thomas (18\%9) in the "Eighth Report of the State Fontomologist of Ihinois." as a new species under the name of Schizoncura pinicola. Patch (1910b) and Davis (1913) have shown that the species described by Thomas is syonymous with M. abictinus Foch. It is rather strange that the species has not been 
recorded from Illinois since its collection by Thonns. According to Patch (1!)10h), who gives a good (lescriplion of the alate and apterous viviparous females, it developes in "curly tips of Abics balsumca Mill. and Picca canadensis Mill."

Data associated with the typic slide of $\$$. pinicola Thomas in the Survey collection (Slide No. 2774) are as follows: Carbondale, Illinois, April 20,1879 , on young white pine, by C. Thomas.

SUBFAMILY HORMAPIIDINAE

\section{SUPERTRIRE HORMAPHEA}

\section{Key to Genera}

1. Antennae of alate forms with five segments...... Hamamelistes p. 375

-. Antennae of alate forms with three segments........ Hormaphis p. 376

\section{GENUS HAMAMELISTES SHIMER}

\section{HANAMELISTES SIINOSUS SHIMER}

Fic. 50

Hamamclistes spinosus Shimer, Transactions of the American Entomological Society, Vol. I, 1867, p. 284.

Like Hormaphis hamamolidis (Fitch), this plant louse has a complicated and most interesting life history. It alternates, too, between the same two hosts-witch-liazel and birch. Its life history (Pergande, 1901) differs from that of $I I$. hamamclidis, as outlined under that species, principally as follows: the over-wintering eggs are laid on witch-hazel in spring or carly summer and do not hatch until the following spring: the galls on witch-loazel (Fig. jo) caused by the stem mothers are bud-galls of spiny appearance: in addition to the over-wintering eggs on witch-hazel there is a cocciliform (Fig. 33:) generation which over-winters on the birch and their offspring produce the common corrugations, or pseudo-galls. on the leaves; and the winged migrants produced on the birch return to the witch-hazel in late spring and produce the sexual generation.

Notypir slide.-Since this species was originally described by Shimer from specimens collected in Illinois (Mt. (arroll), and we have no knowledge that the types were ever preserved, a slide from the Survey collection is selected as the n'otypr. The data associated with the neotypic slide are as follows: Slide No. 8144, collected on witch-hazel, Starved Rock State Park, Illinois, August 14, 1929, by T. H. Frison and F. C. Hotles.

This species is very generally distributed over Illinois. We llave taken the galls and second-generation material on witeh-hazel (Hamamplis virgini(Im) at Irbana (July 26 and December 2, 1928, and July 23, 1929) and at Starved liock State l'ark (August 11, 1929). The pseudo-galls on birch and associated generations have been eollected as lollows: Autioch (June 15). Carbondale (June 4), East Jubuque (Iune 25), Galena (June 25), Kankakec (June 29), Oregon (June 28), Quincy (June 6), lRock lsland 
(June 24), 1928; Macomb (May 4), Wankegan (July 13), 1920. Davis (1910) has recorded the species from Chicago and Kankakee on witch-hazel, and Gronemann has sent us material from Elgin (September, 1930) upon which his "near Chicago" record (1930) is based.

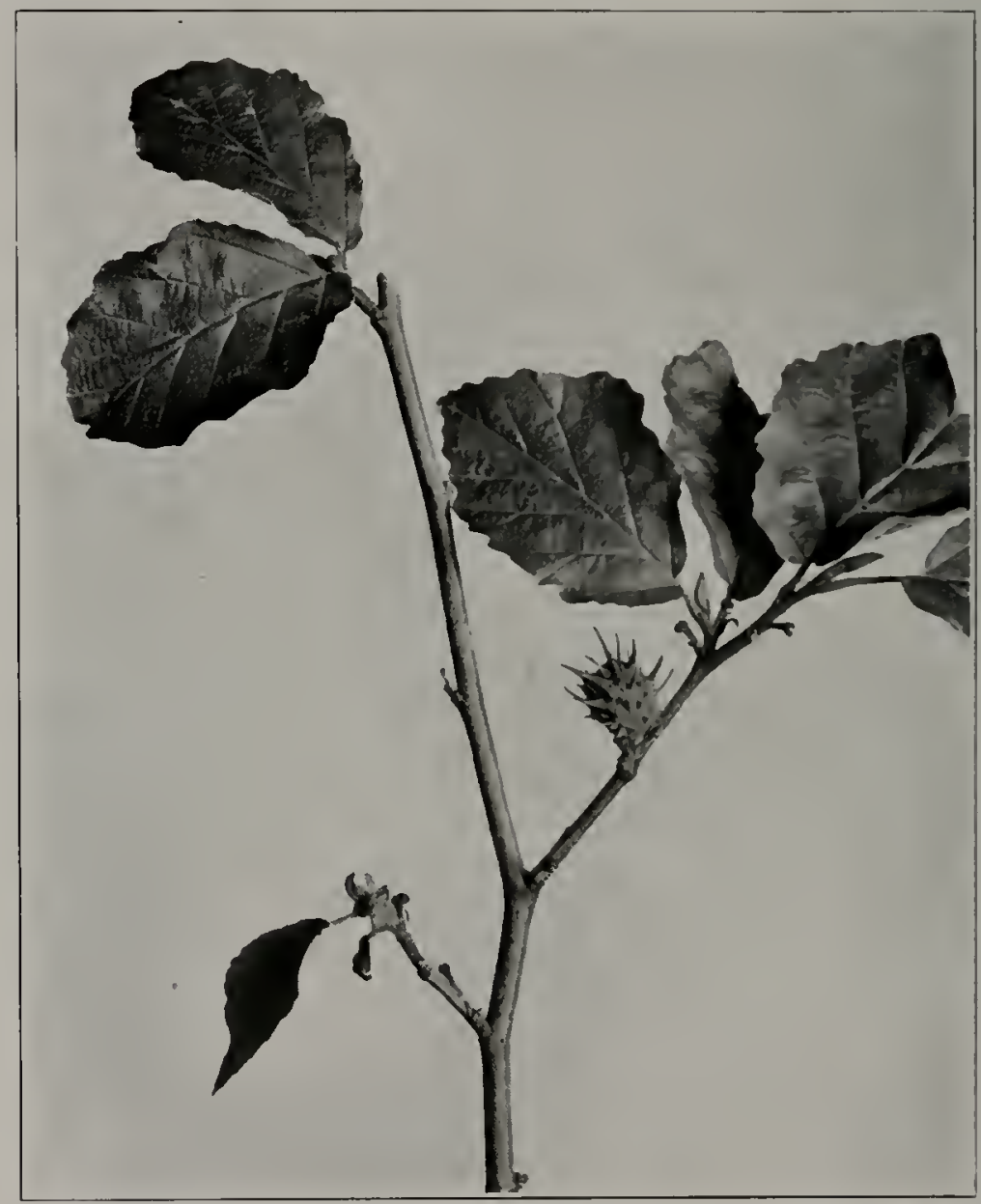

Fig. 50. Spiny bud gall on the witch-hazel. Hamamclis rirginiana, caused by Hamamelistes spinosus Shimer; Urbana, July 24, 1929.

\section{GENTS HORMALHIS OSTEN SACKF.X HORMAPHIS HAMAMELIUIS (FITCH)}

Brysurrypla hamamclidis Fitch. Fourth Amual Report of the Regents of the University on the Combition of the Siate ('abinet of Natural llis. tory, Jamuary 14. 1851. State of New lork, p 6!.

Few plant lice present a more remarkable or more diversified life cyele than this and the precedings species. Like Hamamedistes spinosus 
Shimer, it too, alternates between the witch-hazel and the birch. The complicated life history of this species was worked out ly Pergande (1901) and published after "nearly twenty-two years of patient labor." The winter is passed in the egg stage on witch-hazel. The stem mothers latching from these egrss in spring cause the formation of conical galls on the upper sides of the lenves. and in these galls they produce a second generation of aphids which are winged and migratory. These winged forms migrate to birches in late spring or early smmmer and produce generations which in their last stages are remarkalbly suggestive of the white-flies and are referred to in literature as alcurodiform generations. In late summer or early fall these aleurodiform generations, in turn, produce a generation of winged forms, or migrants, which return to the witch-hazel and produce the sexual forms that lay the over-wintering eggs.

This species has not been previously recorded from Illinois, except for the record by Gronemann (1930) from the "Chicago area." Mr. Gronemann has kindly supplied us with actual specimens of his collecting from Elgin, Illinois, on witch-hazel. During the past three years of collecting we have taken the species but once, at Starved Rock State Park, June 12-13,19.38, on witch-hazel (Hamamelis zirginiana). 


\section{PART III}

\section{KEYS TO SPECIES OF PLANT LICE GROUPED WITH REFERENCE TO HOST PLANTS}

For the convenicnce and use of workers in the field of economic entomology: and others interested only in naning a lew of the comnoner and nore important plant lice, we have prepared ten special keys. based upon natural or well-known artificial groupings of plants serving as losts for aphids. These keys have been made as simple as possible, and in most cases the characters used can be seen with the aid of a hand lens or a wirle-fielrl binocular microscope.

We have included in these keys only the species of plant lice most likely to be found in Illinois on certain natural or artificial groupings of plants, using the data assenbled by our field collecting in all parts of the state as the basis for the selection of the included species. In other geographical or political areas these lieys will require the incorporation of additional species. Even in Illinois they are not complete, because to make then so wonld entail the addition of numerous polypliagous species of very little economic importance and the expansion of the lieys to a point where they would be necessarily comparable to the nore technical leys in Part II.

\section{KEY TO THE SPECIES OF PLANT LICE LIKELT TO OCCLR ON} APPLE IN ILLINOIS

1. Secondary sensoria of antennal segments in the form of narrow ling-like structures almost encircling antennae. antennae therefore with a corrugated or notched appearance when seen from the side (Fig. 225); terminal filament of sixth segment shorter than basal portion (Fig. 244); covered in life with long white woolly secretions (Fig. 42); on trunks and roots of bost................... Eriosoma lanigera (Hausmann)

- Secondary sensoria of antemnal segments circular or oral (Figs. $262,266)$; terminal filament of sixth segment much longer than basal portion (Fig. 266): not covered in life with white woolly secretion although sometimes slightly" pulverulent (Fig. 30);

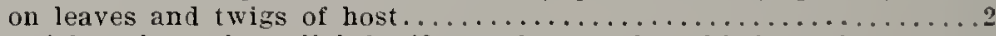

2. Cornicles short, but slightly if any longer than hind tarsi or basal portion of sixth antemul segment; dorsum of abdomen with a large dark-colored dorsal patch anterior to cornicles: miglating from apple to clovers and alfalfa...............

- Comicles of medium length, about twice as long as hind tarsi or basal portion of sixtl antennal segment: dorsum of abdomen with or without a large dark-colored dorsal patch anterior to

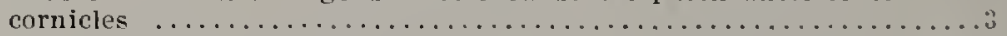

3. Abdomen with a large dark-colored spot on dorsum anterior to cornicles; third antennal segment much longer than width of head through the eyes; apterous forms slightly pruinose...

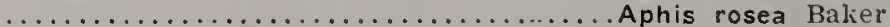

- Ablomen with dorsum essentially greenish. withont a clark-colored spot anterior to cornicles: third antennal sesment no longer than width of head through the eyes................. 
4. Cornicle distincty constricted before conspicuous flaring flange at apex (Fig. 134); secondary sensoria on fourth antenna] segment numerous; cauda stout and not sharply constricted near middle (Fig. 196)........Rhopalosiphum prunifoliae (Fitch)

- Cornicle not constricted before apex and without conspicuous flaring flange (Figs. 130, 133. 139); secondary sensoria on fourth antennal segment lacking or few; cauda sharply constricted near middle (Fig. 203)............ Aphis pomi DeGeer

\section{IEY TO THE SPECIES OF PLANT LICE LIKELY TO OCCLR ON} BERRIES IN ILLINOIS

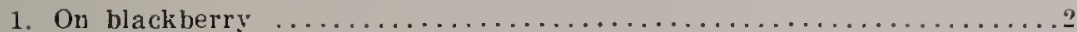

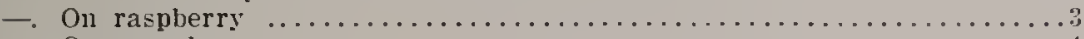

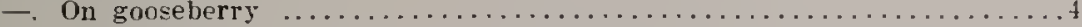

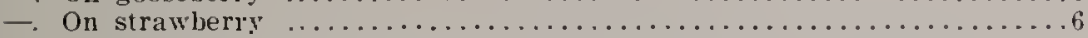

- On currant; pale yellowish aphid feeding on lower surface of leaves and causing them to become distorted and leddish (Fig. $34 \ldots \ldots \ldots \ldots \ldots \ldots \ldots$ Capitophorus ribis (Linnaeus)

- On grape; brownish aphid feeding on lower surface of leaves and on tendrils (Fig. 22) ...........Aphis illinoisensis Shimer p. 198

2 Antennae five-segmented; apterous forms yellowish white: causes curling of leaves particularly near tips of canes......

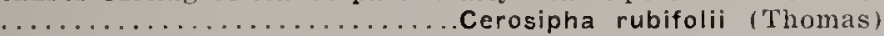

- Anteunae six.segmented; apterous forms greenish; beneath leaves and on stems.......................

3 Cornicles long and distinctly swollen (Fig. 121); species of large

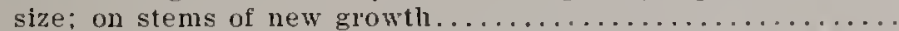
..................... Amphorophora sensoriata Mason p. 279 Cornicles cyliudrical and not swollen (Fig. 130); species of

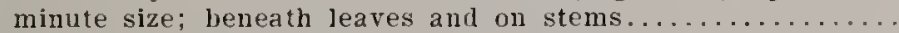

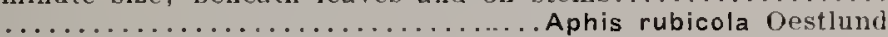

4. Third antennal segment much shorter than width of head through eyes; terminal filament short. not over three times as long as

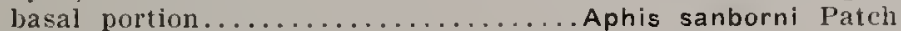

- Third antennal segment longer than width of head through eyes; terminal filament long, at least six times as long as basal

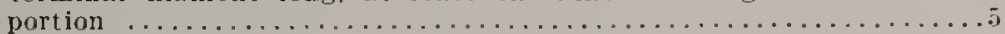

5. Fifth antennal segment with few secoudary sensoria (1) to 5 ).. ....................................

- Fifth antennal segment with secondary sensoria more uumerous

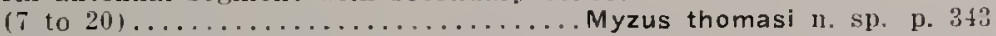

6. Black or bluish-black aphid; apterous forms without capitate setae (Fig. 324); on roots, crowns or stems...............

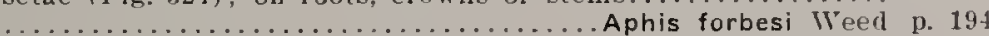

- Pale yellowish white or greenish aphid: apterous forms with capitate setae (Fig. 320 ); on undersides of leaves and stems.......7

7. Apterous forms with conspicuous capitate setae scattered over entire body; third antennal segment witl secondary sensoria widely scattered and numbering about thirty............. ............................. Capitophorus fragaefolii (Cockerell) Apterons forms with conspicuous capitate setae restricted almost entirely to head and anal regions of abdonen; third antennal segment with secondary sensoria less scattered and numbering about twenty........ Capitophorus minor (Forbes)

KEY TO THE SIECIES OF PLANT LICE LIKELY TO OCCUR ON COMMON GARDEN FOWERS IN ILLIXOIS

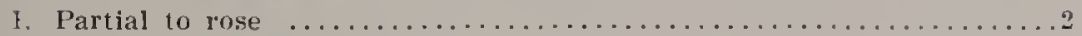

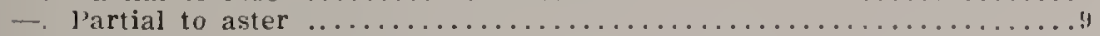

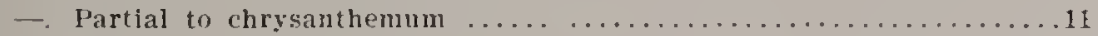




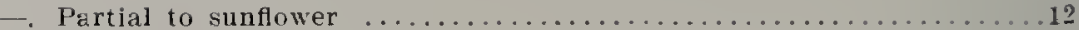

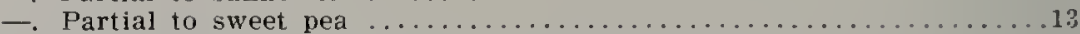

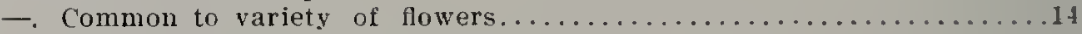

- Partial to columbine; medium-sized, yellowish green form with dark dorsal markings.........Myzus essigi Gillette and Palmer p. 33 i

-. Partial to nastertium; medium-sized, bluish to blackish form.

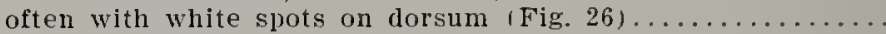

-. Partial to delphiniun ; medium-sized, reddish-brown to blackish species.....................Aphis rociadae Cockerell p. 214

-. Partial to golden glow; large reddish species (Fig. 38)........ ....................... Macrosiphum rudbeckiae (Fitch) D. 320

2. Apterous forms with numerous capitate or cluhbed setae over

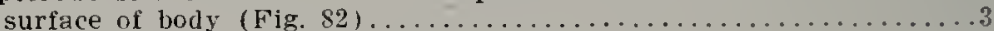

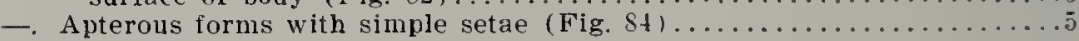

3. Alate forms with secondary sensoria present at least on third aud fourth antennal segments.......................

Capitophorus fragaefolii (Cockerell) p. 2\$3

- Alate torms with secondary sensoria restricted to third antennal

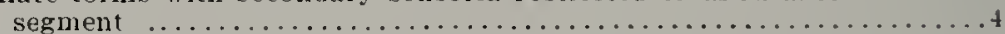

4. Coruicles much longer than fourth antennal segment. basal portion light shading to dark at apices; hind tibiae uniformly

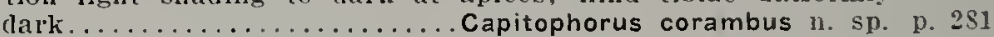

- Cornicles shorter or about same length as the fourth antenual segment, uniformly dark; hind tibiae mostly light-colored with

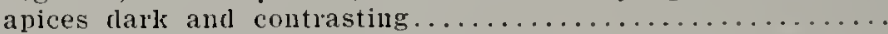

Capitophorus tetrarhodus (iValker) p. 291

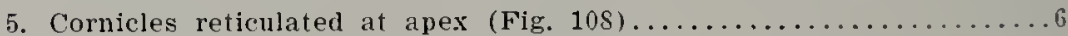

-. Cornicles not reticulated at apex (Fig. 129$) \ldots \ldots \ldots \ldots \ldots \ldots \ldots \ldots \ldots \ldots \ldots \ldots \ldots$

6. Cornicles black, strongly contrasting with color of abdomen.........

- Cornicles with at least basal portion concolorous with abdomen and not contrasting with it...........Macrosiphum gei (Koch) p. 306

7. Abdomen uniformly greenish or reddish; cornicles shorter than third antennal segment...... Macrosiphum pseudorosae Patch p. 318

-. Abdomen greenish with dark lateral patches; cornicles about as long as, or longer than, third antennal segment............ .....................................

S. Antenual tubercles well developed (Fig. S6); secondary sensoria on third antennal segment arranged approximately in a straight row...................Myzus porosus Sanderson

- Antennal tubercles poorly developed (Fig. 84 ): secondary sensoria on thircl antennal segment not arranged in a straight row

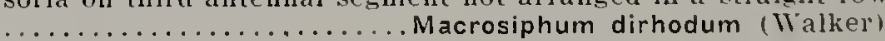

9. On roots...................... Aphis maidi-radicis Forbes p. 202

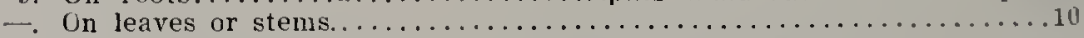

10. Cornicles much shorter than third antenual segment.......... ........................ Macrosiphum anomalae n. sp. p. $29 s$

- Cornicles approximately as long as third antennal segment.... ..................... Macrosiphum erigeronensis (Thomas) p. $30 t$

11. Predominantly dark retdish brown or blackish..............

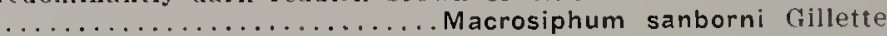

-. Predominantly greenish. Rhopalosiphum rufomaculatum (Wilson)

12. Cornicles very short, abont as long as hind tarsi: a small bluish

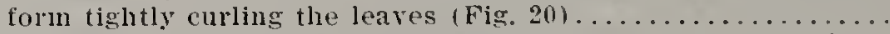
...................Aphis debilicornis Gillette and Palmer Cornicles at least twice as long as hind tarsi; a small yellowishgreen form on lower silles of leares.... Aphis helianthi Nonell

-. Comicles elongate, four or five times as long as hind tarsi: a large yellowish form with dark narkings on lower sides of leaves.........................Macrosiphum illini 1. sp. 
13. On roots: winged forn with media simple (Fig. 64); terminal filament of alate or apterous torms about as long as basal por-

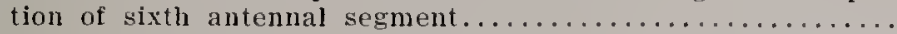
$\ldots \ldots \ldots \ldots \ldots \ldots \ldots$. . . . . . . . . . . . . . . . . . . . . . .

- On stems and leaves; winged form with media branched (Fig. 72); terminal filament of alate and aptelous torms much longer than basal portion of sixth antennal segment............

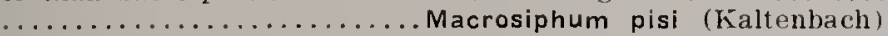

14. Cornicles minch shorter than width of head through eyes; medium sized bluish to blackish form, often with white dorsal

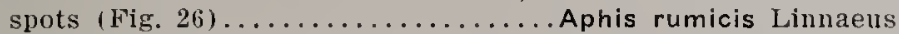

- Cornicles about as long or longer than width of head through eyes; medium to large. sized yellowish or greenish forms, sometimes with dark dorsal markings . ................. 5

15. Large greenish form, without dark markings on dorsum of abdomen: cornicles with closed reticulations at apices (Fig. 103); antennal tubercles poorly developed (Fig. 84 )............

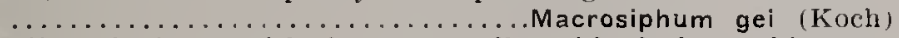

- Medium-sized gieenish forms, usually with dark markings on dorsum of abdomen; cornicles without closed reticulations at apices (Fig. 124); antemnal tubercles well developed (Fig.

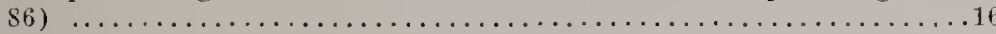

16. Cornicles slightly swollen near apex and about as long as width of head through eyes: apterous forms with dorsum of abdomen uniformly yełlowish green............Myzus persicae (Sulzer)

- Cornicles cylindrical, much longer than width of head through eyes; apterous forms usually with a dark horseshoe-shaped patcb on dorsum contrasting with ground color of yellowish

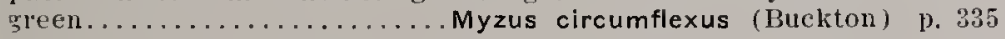

\section{KEY TO THE SPECIES OF PLANT LICE LIKELY TO OCCUR ON GRAIN CROPS IN ILLINOIS}

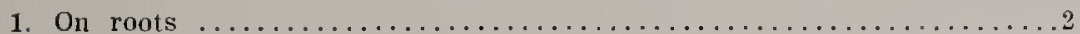

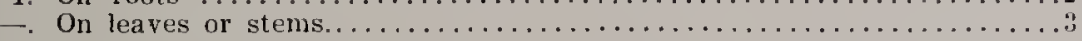

2. Cornicles present, about as long as hind tarsi, and cylindrical (Fig. 23); terminal filament of sixth antennal segnent much

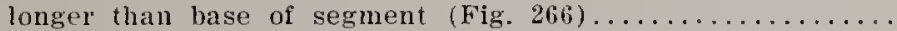

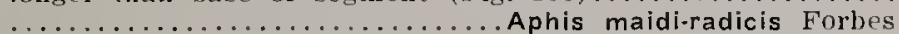

- Cornicles absent or ring-like and inconspicuous (Fig. 158); terminal filament of sixth antennal segment much shorter than base of segment (Fig. 241); several species of slight economic

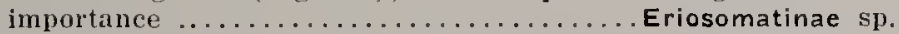

3. Body with numerous long, sharp, spine-like hairs; cornicles ring-

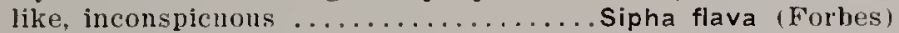

- Body without strong, spine-like hairs; cornicles cylindrical, conspicuous, at least as long as hind tarsi....................

4. Medial vein of front wing only once branched (Fig. 70$) \ldots \ldots$

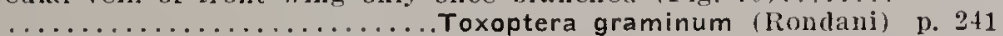

- Medial vein of front wings $t$ wice brancher (Fig. 72 ) ..........5

5. Terminal filament of sixth antennal segment about twice length of basal portion; hind tibiae unicolorous, brown or black.....

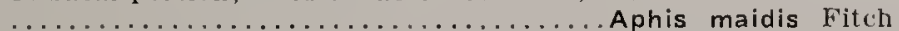

- Terminal filament of sixth antennal segment over three times length of basal portion: hind tibiae light yellowisl with apices

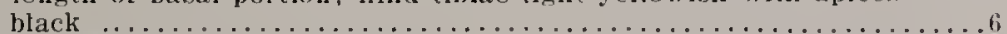

6. Cornicles long and slender, about as long as width of heart through eyes, slightly tapering to apex; apical thitl with closed reticulations (Fig. 114); cornicles and cauda greatly contrasting in color..........Macrosiphum granarium (Kirly)

- Cornicles sliorter aud stouter, much shorter than widti of head through eyes, constricted before apical flange; imbricate but without closed reticulations (Fig. 134): cornicles and cauda more or less concolorous, not contrastiug................

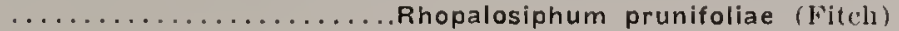




\section{KEY TO THE SPECIES OF PLANT LICE LIKELY TO OCCUR ON PLANTS IN GREENHOUSES IN ILLINOIS}

1. Wings with conspicuous dusky brown shading outlining all veins

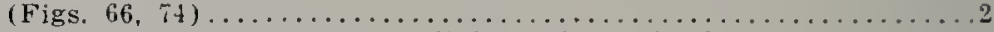

-. Wings without dark shading outlining veins $/$ Fig. $701 \ldots \ldots \ldots \ldots \ldots \ldots$

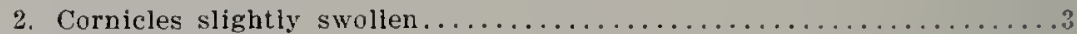

- Cornicles cylindrical and tapering towards apex: on fern...... .......................... Idiopterus nephrelepidis Davis p. 292

3. Hind wings normally with two oblique veins (Fig. 93): on violets ....................... Idiopterus violae (Pergandel p. 292

-. Hind wings normally with one oblique rein (Fig. 95); closed cell always present in fore wings and at least four-sided (Fig. if):

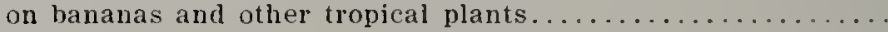

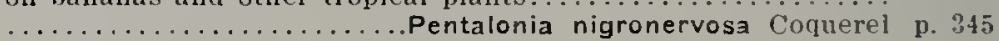

4. Predominant color some shade of brown or black.............. 5

-. Predominant color yellowish, pink, or some sbade of green......... \&

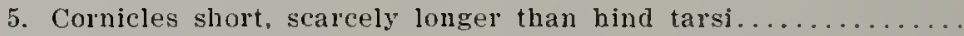

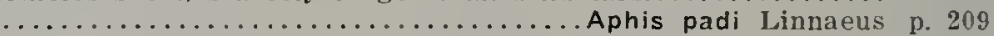

-. Cornicles longer, at least twice as long as hind tarsi..............6

6. Cornicles with apical portion conspicuously swollen (Fig. 148);

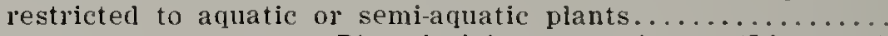

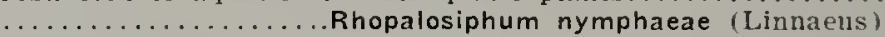

- Cornicles cylindrical or gradually tapering to apex, not swollen. or at most apex is but slightly enlarged (Fig. 106); not associated with aquatic or semi-aquatic plants................

7. Dark reddish brown; cornicles much wider at base than at apex, reticulate for much of their length; restricted to chrysanthemum......................Macrosiphum sanborni Gillette

- Black to bluish black, often with small white spots on dorsum; cornicles but stightiy wider at base than at apex. imbricated but not reticulated at apex; infesting a great variety of plants

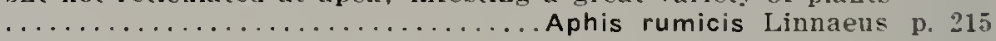

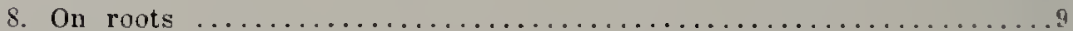

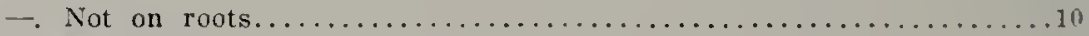

9. Medins of fore wing branched (Fig. 72 ); alate or apterons forms with terminal filament much longer than basal portiou of sixtl segment (Fig. 266): cornicles present in all forms; on roots

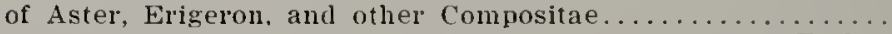

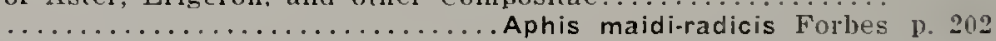

- Medius of fore wing simple (Fig. 64); alate or apterous forms with terminal filament shorter or at least not longer than hasal portion of sixth segment (Fig. 245): cornicles absent in all forms; on roots of sweet pea..Trifidaphis phaseoli (Passerini) p. 374

10. Cornicles short, less than width of head through the eves: spe-

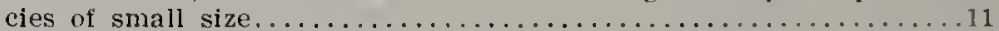

- Cornicles long, as long or much longer than width of head through the eyes; species of medium to large size.............. I?

11. Fourth antennal segment without secondary sensoria; likely to be found on a variety of plants........ Aphis gossypii Glover p. 195

-. Fourth antennal segment with secondary sensoria.................

12. Cornicles much longer than basal portion of sixth antennat seg. ment: cauda elongate and rather pointed: dorsum of abdomen

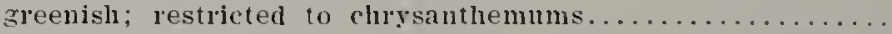
Cornicies about a. ang ans basat portion of sixth antennal segment; canda not elongate. rounded: dorsum of abdomen with dark markings on a greenish background: on Senecio cruentus Aphis padi Limmens 1) 209 
13. Cornicles exceedingly long, between one and one-half and two times as long as width of head through eyes; species of very

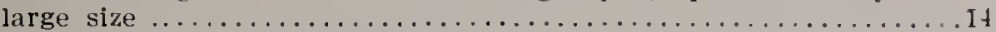

- Cornicles of moderate length, about as long as width of head through eyes; species of medium size..................... 6

14. Apex of cornicles without closed reticulations (Figs. 1IS, 119); body, legs, and cornicles almost uniformly greenish; on sweet

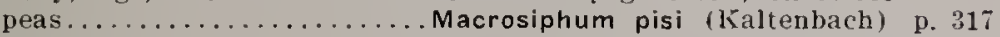

- Apex of cornicles with closed reticulations (Fig. 111); partial to

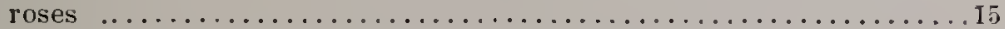

15. Secondary sensoria on third antennal segment approximately in a straight row (Fig. 293); cornicles uniformly tapering to apex (Fig. 111), with basal portion greenish and apices dusky;

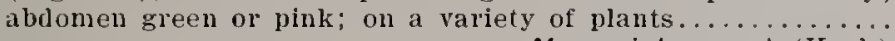

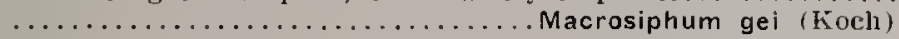

- Secondary sensoria on third antennal segment not approximately in a straight row (Fig. 288); cornicles somewhat constricted at apex before flange (Fig. 108), uniformly black; abdomen green with black lateral spots; on rose................ ntennal tubercles well developed (Fig. 86 ); cornicles cylindli-

16. Antennal tubercles well developed (Fig. 86 ); cornicles cylindri-
cal or but slightly swollen near apex; on a variety of plants...... I7
-. Antennal tubercles poorly developed (Fig. 80 ); a pical half of cornicles conspicuously swollen: on aquatic or semi-aquatic plants...............Rhopalosiphum nymphaeae (Linnaeus) p. 238

17. Cornicles slightly swollen near apex and about as long as width of head through eyes; apterous forms with dorsum of abdomen uniformly yellowish green....... Myzus persicae (Sulzer)

- Comicles cylindrical, much longer than width of head through eyes: apterous forms usually with a dark horseshoe-shaped patel on dorsum contrasting with ground color of yellowish green......................... circumflexus (Buckton)

\author{
.
}




\section{KEY TO THE SPECIES OF PLANT LICE LIKELY TO OCCLR ON ORNAMENTAL. SHRLBS IN ]LLINOIS}

1. On stems and leaves of elder berry (simbucus); a mediumsize blackish or bluish aphid witl a greenish tinge; cornicles

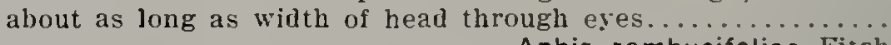

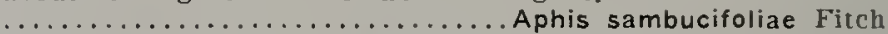

- On stems near base of snowberry and coralberry (simmphoricarpos): a large aphid covered with conspicuous white woolly secretion; cornicles short, shorter than length of basal por-

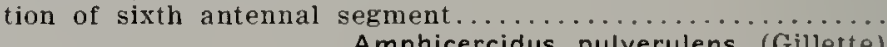
$\ldots \ldots \ldots \ldots \ldots$. . . . . . .

- On leaves of nine-bark (Physoc(r)us): a small dark brownish aphid; cornicles short, much shorter than width of head through eyes; third, fourth, and fifth antennal segments with numerous secondary sensoria..........Aphis neilliae Oestlund On twigs and leaves of buttonbush (Cephalunthus): a small greenish or reddish-brown aphid, somewhat pruinose; cornicles short, much shorter than willh of head through eves..

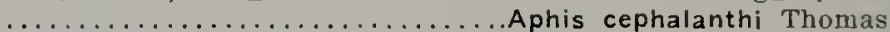
on stems and leaves of barbery (Berberis): a small yellowish aphid; cornicles about as long as width of head through eyes.

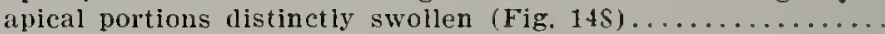

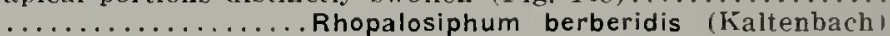

On stems and leaves of Evonymus; a small blackish or bluish aphid, often with white dorsal spots; cornicles much shorter than width of head through eyes...... Aphis rumicis Linnaeus

- On twigs and leaves of buckthorn (Rhammus), often causing them to curl; a very small greenish or blackish aphid; cornicles shorter than width of head through eyes............

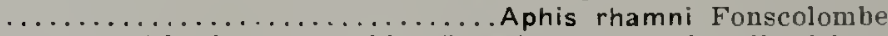

- On leaves of bush honeysuckie (Dimvilla); a snall yellowish or greenish aphid with dark cornicles; cornicles short. much

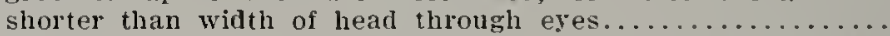

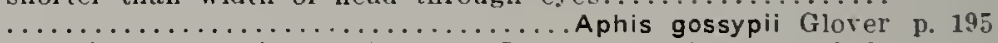
On species and varieties of roses (Rosa): (see key of aphids

likely to occur on garden flowers)................... p. 379

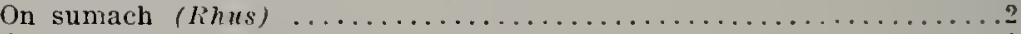

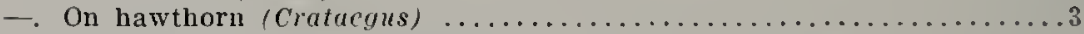

-. On suowball, highbush cranberry, and other shrubs helonging to

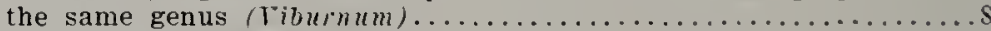

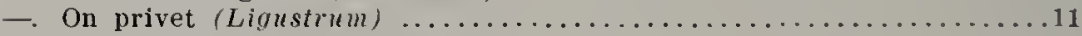

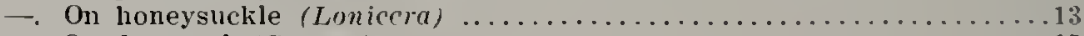

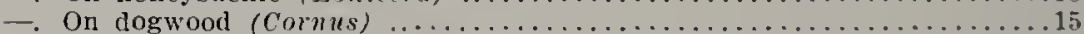

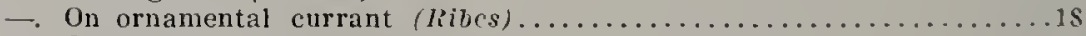

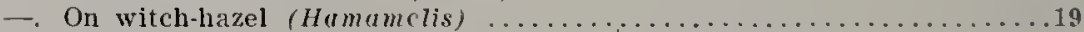

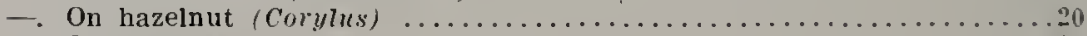

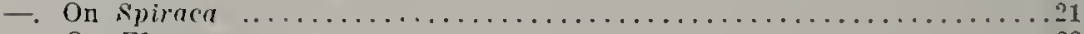

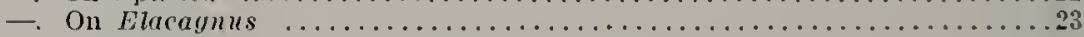

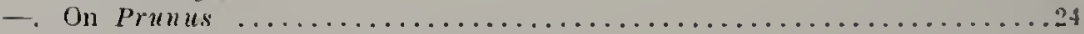

2. Cornicles present, swollen at apices (Fig. 14S), about as long as width of head through eyes: forming dense colonies on unlersides of leaves and stems: a mediun-size. reddish-brown

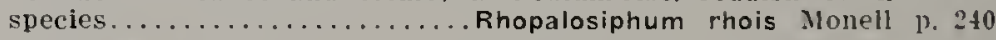

-. Cornicles absent; forming bag-like galls on upper surfaces of leaves; a very small species............ Melaphis rhois (Fitch) p. 359

3. Cornicles absent or not protruding conspicuously from abdomen......4

- Cornicles present and conspicuously protruding from abdomen........5

4. Antennae with anmular secondary sensoria. appearing notehed or corrugated from a side view (lig. 223); in flocculent colonies in curled leaves........Prociphilus corrugatans (Sirrine) p. 370 
- Antennae with oval or oval-transverse secondary sensoria, appearing mole cylindrical from a side view (Fig. 226); in flocculent colonies on undersides of stems and branches (Fig. 42)

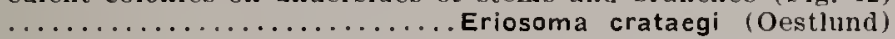

5. Cornicles longer than width of liead througl eyes; a large yellowish aphid..............Macrosiphum crataegi (Monell) Cornicles shorter than width of head through eyes; medium-

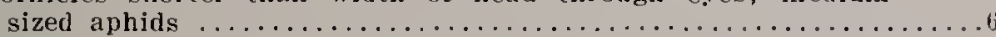

6. Cauda slort and rounded; secondary sensoria numerous on fourth and fifth antennal segments; head and thorax in life with a piuk or crimson tinge........ Aphis crataegifoliae Fitch

- Caula elongate; secondary sensoria few or wanting on fourth and fifth antenual segments; head and thorax in life brown or gleen ish brown, never pink or crimson ..................

7. Cornicles not swollen nor constricted before apices (Fig. 130)..

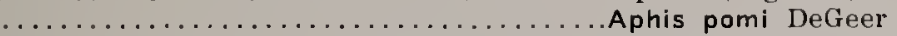

- Cornicles slightly swollen and constricted before apices (Fig.

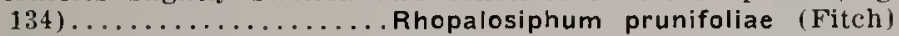

8. Apterous forms colored a pale bluish green, covered with a whitish powdery secretion; causing a severe curling of the leaves or pseudogall (Fig. 28)......Aphis viburnicola Gillette Apterous forms yellowish green, brown, or black, never covered with whitish powdery secretion; on stems and leaves and not

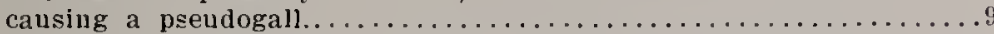

9. Apterous forns yellowish-green, alates with dark spots along sides of abdomen; third antennal segment usually with less than ten secondary sensoria.............. Aphis pomi DeGeer

- Apterous forms brownish or bluish black; third antennal segment usually with more than twelve secondary sensoria.........10

10. A bluish black species, often witl white spots on dorsum; apices of hind tibiae dark, sharply contrasting with lighter

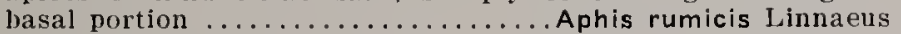

- A uniformly brownish species; hind tibiae more uniformly

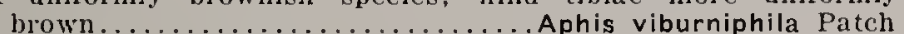

bluades of green or pink.............

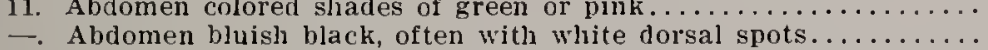

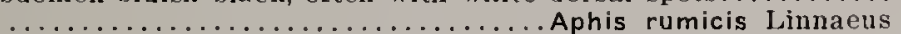

12. Cornicles cylinörical, much longer than width of head through eyes, reticulated at apex (Fig. 111); dorsum of abdomen uniformly some shade of green or pink; antennal tubercles poorly developed (Fig. 84).............Macrosiphum gei (Koch)

- Cornicles with apical portion often slightly swollen, ahout as long as width of head through eyes, not reticulated at apex (Fig. 129): dorsum of abdomen often with a large dark dorsal patch on a yellowish green background; antennal tubercles well developed (Fig. 86) .............Myzus persicae (Sulzer)

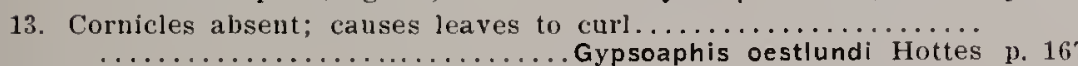

- Cornicles present and conspicuous......................

14. Longitudinal vein of hind wing once-forked, the second branched but partially developed (Fig. 89); fiftl antenual segment about twice as long as hind tarsi; causes leaves to curl.........

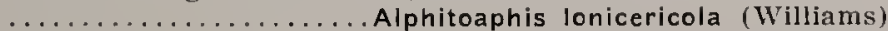

- Longitudinal vein of hind wing twice-forked (Fig. 93); fifth antennal segment and hind tarsi about equal in leugth; on leaves and flower hracts.. Rhopalosiphum melliferum (Hottes) p. 2:s

15. Terminal filament much sloorter than basal portion of sixth segment; cornicles on cone-shaped areas (Fig. 155)........

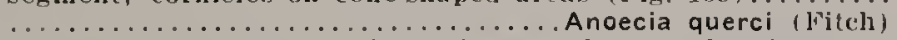

- Terminal filament two or three times as long as basal portion of sixtl segment; cornicles cylindrical (Fig. 133), prominently

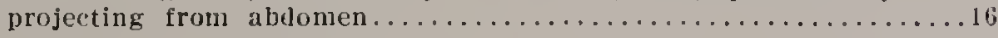


16. Apterous forms and abdomen of alate forms greenish; cornicles but slightly shorter than terminal filaments, secondary sensoria on thirl antennal segment numbering over twenty; of ten causing leaves of terminal branches to curl (Fig. 21).......

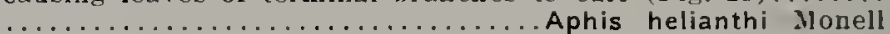

-. Apterous forms and abdomen of alate forms blackish or brownish; in cornicles about one-half or less as long as terminal filament; secondary sensoria on third antennal segment num. bering under twenty; on stems and under sides of leaves, sometimes causing the latter to curl........................

17. Cornicles much longer than basal portion of sixth antennal segment; a blackish form on the upper and lower sides of leaves

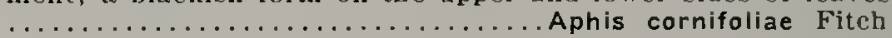

- Cornicles no longer than basal portion of sixth antennal seg. ment: a reddish-brown form on stems near tips........... $\ldots \ldots \ldots \ldots \ldots \ldots \ldots \ldots \ldots \ldots \ldots$. . . . . . . . .

18. Cauda elongate; secondary sensoria lacking or rare on fourth and fifth autennal segments: apterous forms without knobbed setae (Fig. 324); alates with dorsum of abdomen uniformly yellowish green .........................

- Cauda short and blunt; secondary sensoria numerous on fourth and fifth antennal segments; apterous forms with knobbed setae (Fig. 320); alates with a dark dorsal patch on abdomen

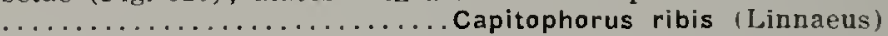

19. Antemnae with three segments; causing small conical galls on upper surfaces of leaves.... Hormaphis hamamelidis (Fitch)

- Antennae with five segments; causing a many-spined bud gall

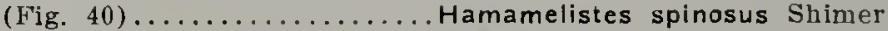

20. Cornicles very long and conspicuous, much longer than width of head between eyes; a large green and dark-colored species, black cornicles contrasting with abdomen................

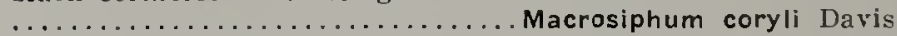

- Cornicles very short. much shorter than width of head through eyes, about as long as hind tarsi; a medium-size yellowish species, colnicles concolorous with abdomen..............

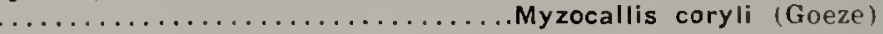

21. Abdomen essentially black or bluish-black and often with dorsal white spots; seconlary sensoria on tbird antennal segment

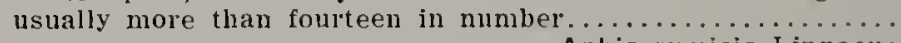

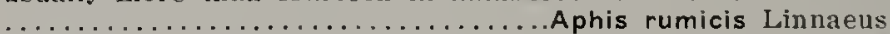

- Abdomen some shade of green or pinkish-brown; secondary sensoria on third antennal segment larely exceeding ten iu

22. Abdomen of alates and apterous forms yellowish.green. not pruinose; cornicles much longer thàn hind tarsi; recorded from several species and varieties of sipiraed as well as numerous other hosts.............................. pomi DeGeer

- Ahdomen of alates all apterous forms pinkish-green or reddishbrown. sliglitly pruinose; cornicles about as long as hind tarsi; recorded only from the meadowsweet (spiraca salicifolia)...

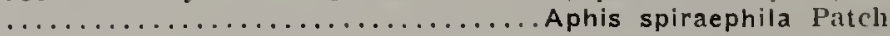

23. Colnicles with apical portion slightly swollen ............. $\ldots \ldots \ldots \ldots \ldots \ldots \ldots \ldots \ldots \ldots$. . . . . . . . .

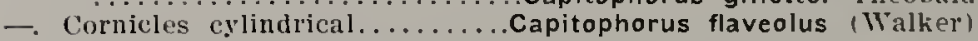

24. Hind wings witl longitudinal vein once-forked (Fig. 89): apterous forms and abdomen of alates a reddisl brown..........

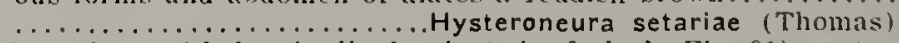

-. Hind wings with longitudinal vein twice-forked (Fig. 91); apterous forms and abdomen of alates some shade of green...... 
KEY TO THE SPEC]ES OF PLANT LICE LIKELY TO OCCUR ON PEACH, PLUM, OR CLLTIVATED CHEIRT IN ILLINOIS

1. Comicles very short, ahout as long as hind tarsi; secondary sensoria numerous on fourth antennal segment..............

- Cornicles long, at least several times as long as lind tarsi; secondary sensoria lacking or rare on fourth antennal segment.......3

2. Colnicles with a distinct flange (Fig. 137); cauda short and rounded; dorsum of abdomen with dark malkings on a yellowjsh or greenish background; apterous forms without a white woolly secretion; tiglitly curling leaves at ends of branches of peach and plun (Fig. 25)..............Aphis padi linnaeus

-. Colnicles without a flange (Fjg. 142); cauda elongate: dorsum of ablomen uniformly yellowish or greenish; apterous torms with a white woolly secretion; on lower sides of leaves and succulent stems of plum.........Hyalopterus pruni (Geollroy)

3. Hind wings with Jongitudinal vein with one brancl (Fig. 89); antennal tubercles not well developed (Fig. 79)............

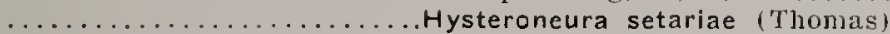

- Hind wings with longitudinal vein with two branches (Fig. 91); antenual tubercles well developed (Fig. 86$) \ldots \ldots \ldots \ldots \ldots \ldots \ldots \ldots \ldots$

4. Almost uniformly redılish brown; cornicles distinctly inbricated throughout; partial to c]erry (Fig. 39 )................

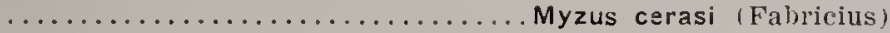

- Yellowish-green with dark markings; cornicles not distinct]y inbricaled throughout; partial to peach, causing leaves on shoots

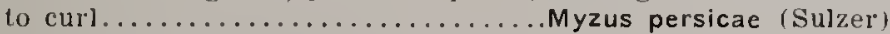

KEY TO THE SPECIES OF PLANT LICE LIKELY TO OCCUR ON TRUCK CROPS IN ILLINOIS

1. Cornicles much longel than width of head through the eye $\ldots \ldots \ldots \ldots 2$

- Cornicles not longer than width of head through eyes...............

2. Apical portion of cornicles reticulated (Fig. 111); speeies partial to potatoes and not likely to occur in numbers on other truck crops...................Macrosiphum gei (lioch) Apical portion of cornicles not reticulated (Fig. 129); species partial to peas and not likely to occur in numbers on other iruck crops......................... (Kaltenbach)

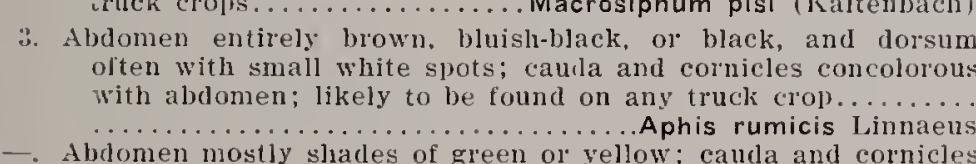

3. Abdomen entirely brown, bluish-black, or black, and dorsum
often with small white spots; caula and cornicles concolorous
with abdonen; likely to be found on any truck crop.........
.................................. Aphis rumicis Linnaeus

8. Abdomen entirely brown, bluish-black, or black, and dorsum
often with small white spots; caula and cornicles concolorou.
with abdomen; likely to be found on any truck crop.........
. Ab................................ Aphis rumicis Linnaens

3. Abdomen entirely brown, bluish-black, or black, and dorsum
often with small white spots; caula and cornicles concolorous
with abdonen; likely to be found on any truck crop.........
.................................. Aphis rumicis Linnaeus

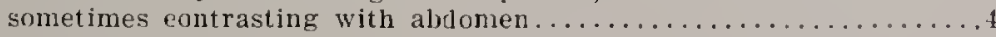

4. Colnicles approximately as long as width of head through eyes; dorsum of abdomen with a large solid brownisl patch anterior to cornicles; likely to cccur on any truck crop..............

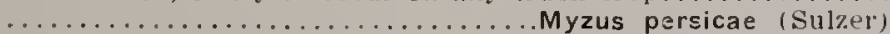

- Cornicles much shorter than width of head througl eyes; dorsum of ablomen without a large solid brownish patcli anterior to cornicles, although spots and transverse bars may be pres.

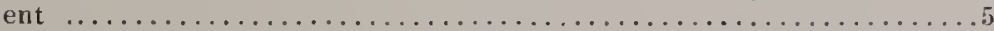

5. 'hird antennal segment as long as, or longer than, combined length of fourth, fifth, and basal portion of sixth; apterous forms thickly covered with whitish powder; partial to cluciferous plants, often rasing the leaves to blister or curl..... ....................... Brevicoryne brassicae (Limuaus) p. 228

Third antennal segment shorter than combined length of fourth. fifth, and basal portion of sixtl; afterous forms not covered

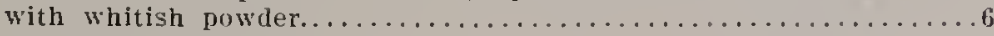


6. Veins of wings conspicuously outlined with fuscous; fourth alltennal segment with four or more secondary sensoria; partial to cruciferous plants.. Rhopalosiphum pseudobrassicae (Davis)

- Veins of wings normal, not conspicuously outlined with fuscous; fourth antennal segment with seconilary sensoria lacking, rarely one or two; partial to cucurbitaceous truck crops......

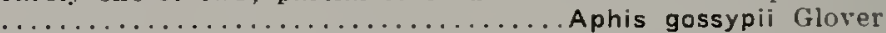

\section{KEY TO THE SPECIES OF PLANT LICE LIKELY TO OCCLR ON PLANTS USED AS VINES IN ILLINOIS}

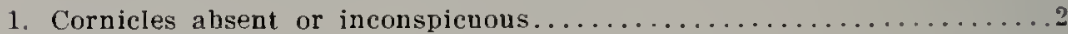

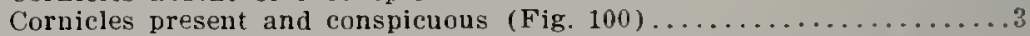

2. Alate and apterous forms essentially brownish, usually covered with a white flocculent secretion; sixth antennal segment with terminal filament much shorter than basal portion (Fig. $244)$; on stems and leaves of smilax (Fig. $\$ \$) \ldots \ldots \ldots \ldots \ldots$ $\ldots \ldots \ldots \ldots \ldots \ldots \ldots$ Neoprociphilus attenuatus $(0 . \&$ S.)

- Alate and apterous forms essentially greenish white, usually covered with a white flocculent secretion; sixth antennal segment with terminal filament much longer than basal portion (Fig. 248); on leaves and terminal shoots of honeysuckle

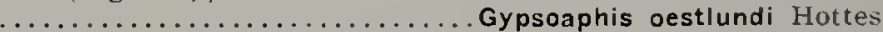

3. Abdomen essentially yellow or yellowish-green with some dark

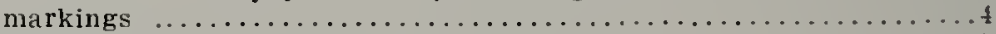

- Abdomen dark-brown, reddish-brown, or black................

4. Antennal tubercles with a finger-like inwarl projecting protrusion (Fig. 85); cornicles slender and smooth; many irregularly distributed secondary sensoria on third antennal segment; on

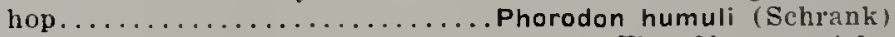

Antennal tubercles without a projection (Fig. So); cornicles stout and imbricated; secondary sensoria fewer and arranged more in a straight row; on angle-pod and morning glory.....

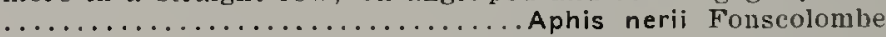

5. Black or bluisli-black, apterous forms with white spots on dorsum; on bittersweet...............Aphis rumicis Linnaeus

-. Alate anıl apterous torms essentially a uniform dark or reddisl

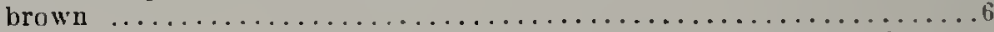

6. Third, fourth and fifth antennal segments of winged females of about the same Iengtl; on Boston ivy and Virginia creeper..

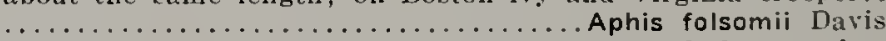
hird antennal segment of winged females much longer than

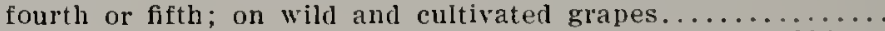

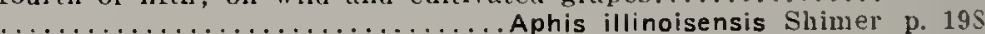




\section{HOST INDEX}

In this inclex are summarized all of our records of associations between plants and plant lice in lllinois. Under the scientific names of the plants are given lists of the species of plant lice found attacking them. The common names of many plants are inserted for convenience and references given to their scientific names.

The botanical and common names used in this paper are in accordance with the seventh edition of "Gruy's Nca' Manmal of Botany', except for the cultivated plants and some not included in Gray's Manual because of their extralimital origins. For the cultivated plants we have followed the nomenclature of the "Mamal of Cultizatcd Plants." by L. H. Bailey $(192 t)$. For other plants not covered by these references we have followed the "Dictionary of Plant Names," by H. L. Gerth van IVijk (1911).

Acer Negundo

Aphis rumicis $L$.

Aphis spiraecola Pateh

Periphyllus negundinis (Thomas)

Acer saccharinum

Clavigerus smithiae (Monell)

Drepanaplis acerifoliae (Thomas)

Drepanaphis monelli (Davis)

Neoprociphilus aceris (Monell)

Acer saccharum

Aphis rumicis $\mathrm{L}$.

Clavigerus smithiae (Monell)

Drepanaphis acerifoliae (Thomas)

Drepanaplis keslienae Granovsky

Drepanaphis monelli (Davis)

Drepanaplis sp.

Myzocallis ononidis (Kalt.)

Myzocallis punctata (Monell)

Neoprociphilus aceris (Monell)

Periplyllus lyropictus (Kessler)

Shenahweum minutum (Davis)

Achillea Millefolium

Capitophorus patonkus $H$. \& F.

Macrosiphum ambrosiae (Thomas)

Macrosiphum frigiclicola (G. \& P.)

Macrosiphum tapuskae H. \& F.

Actinomeris alternifolia

Macrosiphum ambrosiae (Thomas)

Maciosiphum ruralis $H$. \& $F$.

Aesculus glabıa

Drepanaphis monelli (Davis)

Alcler-see Alnus

Alfalfa-see Medicago

Alkanet-see Anclusa

Alnus sp.

Myzus alnifoliae (Fitch)

l'rociphilus tessellata (Fitch)

Alum-ront-see IIeuchera

Amaranth-see Amaranthus
Amaranthus paniculatus

Macrosiphum gei (Koch)

Amarantlus retroflexus

Macrosiphnm gei (lioch)

Amaranthus sp.

Macrosipluum gei (Koch)

Macrosiphum schranki Theobald

Ambrosia trifida

Macrosiphum ambrosiae (Thomas)

Ambrosia sp.

Macrosiphum ambrosiae (Thomas)

Macrosiphum rudbeckiae (Fitch)

Amelanchier sp.

Prociphilus corrugatans (Sirrine)

American aspen-see Populns tremuloicles

American elm--see Ulmus americana

Amphicarpa monoica

Microparsus variabilis Patch

Amsonia Tahelmaemontana

Aphis rhammi Fonsc.

Anchusa myosotidiflora

Aphis gossypii Glover

Myzus circumflexus (Buckton)

Angelica $\mathrm{sp}$.

Aphis signatis H. \& F.

Angle-pod - see Gonolobus

Anthemis cotula

Macrosiphum geí (lioch)

Apium graveolens var. dulce

Aphis gossypii Glover

Macrosiphum gei (Kocl)

Myzus lactucae (Schrank)

Myzus persicae (Sulz.)

Apocynum sp.

Aphis asclepiadis Fitch

Aphis spiraecola Patch

Macrosiphum gei (koch) 
Apple-see Pyrus Malus

Aquilegia canadensis

Aphis spiraecola Pateh

Myzus essigi $G$. \& $P$.

Myzus persicae (Sulz.)

Arabis Drummondi

Aphis gossypii Glover

Aretium minus

Aphis rumicis L.

Arctium sp.

Myzus persicae (Sulz.)

Arctostaphylos Uva-ursi

Amphorophora nervata (Gill.)

Tamalia coweni (Ckll.)

Arrow-wood-see Viburnum

Artemisia abrotanmm

Macrosiphum frigidicola (G. \& P.)

Artemisia pedemontana

Macrosiphum frigidicola (G. \& P.)

Artemisia sp.

Macrosiphum gei (Koch)

Macrosiphum ludovicianae (Oest].)

Aruncus sylvester

Macrosiphum pseudorosae Patch

Asclepias currassavica

Aphis nerii Fonsc.

Asclenias incarnata

Aplis nerii Fonse.

Asclepias sp.

Aphis asclepiadis Fitch

Aphis gossypii Glover

Aplis rumicis $\mathrm{L}$.

Aphis spiraecola patch

Macrosiphum gei (Fioch)

Myzocallis asclepiadis (Monell)

Myzocallis punctata (Monell)

Myzus persicae (Sulz.)

Ash-see Fraxinus

Aspen-see Populus

Aspidium sp.

Macrosiphum adianti (Oes|I.)

Asplenium Filix-femina

Macrosiphum ptericolens Patch

Asplenium sp.

Amphorophora laingi Mason

ldiopterus nephrelepidis Davis

Macrosiphum adianti (Oestl.)

Macrosiplum ptericolens Patch

Astel novae-angliae

Macrosiphum anomalae $H$. \& $F$.

Aster sp.

Macrosiphum ambrosiae (Thomas)

Nacrosiphum anomalae $H$. \& $F$.

Macrosiphum erigeronensis

(Thomas)

Macrosiphum gravicornis Patch

Avena sativa

Aphis madi-radicis Forbes

Forda olivacea Rolnwer

fieoica squamosa llart

Macrosiphum granarium (Khy.)

Rhopalosiphum prunifoliae (Fitch)

Toxoptera graminum (Rond.)

Avens-see Geum
Barberry-see Berberis

Basswood-see Tilia americana

Bearberry-see Arctostaphylos

Bedstraw-see Galium

Beech-see Fagus grandifolia

Beet-see Beta vulgaris

Beggar-ticks-see Bidens vulgata

Berberis Thunbergii minor

Rhopalosiphum berberidis (Kalt.)

Bergamot - see Monarda fistulosa

Beta vulgaris

Myzus persicae (Sulz.)

Betula alba var. papyrifera

Calaphis betulaecolens (Fitch)

Calaphis betulella Walsh

Euceraphis betnlae (koch)

Hamamelistes spinosus Shimer

Neosymydobius americanus

(Baker)

Betula nigra

Calaphis betulella Walsh

Hamamelistes spinosus Shimer

Pemphigus ephemeratus $H$. \& F.

Betula pendula

Calaphis betulaecolens (Fitch)

Hamamelistes spinosns Shimer

Neosymydobins ammulatus (koch)

Betula pumila

Cepegillettea befulaefoliae Granovsky

Hamamelistes spinosus Shimer

Birlens vnlgata

Aphis coreopsidis (Thomas)

Macrosiphum chrysanthemi (Oestl.)

Bidens sp.

Apli is ageratoidis Oestl.

Aphis coreopsidis (Thomas)

Macrosiphum chrysanthemi Oestl.

Pemphigus tartareus $H$. \& $F$.

Bindweed-see Conrolvulus

Birch-see Betula

Bittersweet-see Celastrus and Solanum Dulcamara

Blackberry-see Rubus

Black clierry-see Prunus serotina

Black currant-see Ribes nigrum

Plack-eyed susan-see Rudbeckia livita

Black gum-see Nyssa sylvatica

Black jack-see Quercus marilandica

Black larch-see Larix laricima

Black locust-see Robinia PseudoAcacia

Black mustard-see Brassica nigra

Black oak - see Quercus relutina

Blacki snakernot-see Sanicula

Black walnut-see Juglans nigra

Black willow-see Salix nigral

lazing star-see liatris squarrosa

Blephilia hirsuta

Aplis agertoidis Oestl. 
Rloodflower-see Asclepias curassavica

Bloodroot-see Sanguinaria canadensis

Blue beech-see Carpinus caroliniana

Blueberry-see Vaccinium

Boston ivy-see Parthenocissus tricuspidata

Bottle grass-see Setaria virjdis

Box elder-see Acer Negundo

Bramble-see Rubus

Brasenia Schreberi

Aphis maidis Fitch

Brassica nigra

Aphis maidi-radicis Forbes

Brassica oleracea

Brevicoryme brassicae (L.)

Myzus persicae (Sulz.)

Rlopalosiphum pseudobrassicae (Davis)

Brassica rapa

Myzus persicae (Sulz.)

Rhopalosiplum pseurlobrassicae (Davis)

Brassica sp.

Myzocallis asclepiadis (Monell)

Myzus persicae (Sulz.)

Rhopaiosiphum psendobrassicae (Davis)

Brickellia grandiflora

Aplis ageratoillis Oestl.

Bristly foxtail grass-see Setaria

Broom corn-see Holcus Sorghum var. technicus

Buclieye-see Aesculus

Buckthorn-see Rhamnus

Buffalo currant-see Ribes odoratum

Bull thistle-see Cirsium lanceolatum

Burdock-see Arctium

Bur marigold-see Bidens

Bul oak-see Quercus macrocarpa

Burning bush-see Evonymus atropurpureus

Bush honeysuckle-see Diervilla

Buttercup-see Ranunculus

Butter-weed-see Erigeron canadensis and Senecio glabellus

Buttonbush-see Cephalantlus

Button suakeroot-see Liatris

Buttonwood-see Platanus occidentalis

Cabbage-see Brassica oleracea

Calendula sp.

Macrosiphun gei (lioch)

Canada plum-see Prunus nigra

Canada thistle-see Cirsium arvense

Canoe birch-see Betula pendula and Betula alba var. papyrifer:a

Cape primrose-see Streptocarpus
Capsella IBursa-pastoris

Forda occiclentalis liart

Geoica squamosa Hart

Capsicum dulce

Aphis gossypii Glover

Marrosiphum gej (Koch)

Myzus persicae (Sulz.)

Carex sp.

Aphis mairlis Fitch

Aphis rumicis L.

Izipluya flabella (Samborn)

Macrosiphum pisi (Kalt.)

Rhopalosiphum enigmae var. parvae H. \& F.

Rhopalosiphum melliferun (Hottes)

Rhopalosiphum prunitoliae (Fitch)

Saltusaphis elongata Baker

Saltusaphis wanica H. \& F.

Sipla flava (Forbes)

Thripsaplis ballii (Gill.)

Thripsaphis producta Gill.

Thripsaphis verucosa Gill.

Toxoptera graminum (Rond.)

Carmation-see Dianthus

Carpiuns caroliniana

Macrosipluum carpinicolens Patch

Carrot-see Daucus Carota

Carya illinoensis

Longistigma caryae (Harris)

Monellia caryella (Fitch)

Monellia nigropunctata Granovsky

Carya ovata

Monellia caryella (Fitch)

Monellia costalis (Fitclu)

Monellia nigropunctata Granovsky

Carya sp.

Melanocallis fumipennella (Fitch)

Monellia caryae (Monell)

Monellia caryella (Fitch)

Monellia costalis (Fitch)

Monellia nigropunctata Granovsky

Myzocallis discolor (Monel\})

Myzocallis punctata (Monell)

Myzocallis walshii (Monell)

Tuberculatus punctatellus (Fitch)

Castalia sp.

Rhopalosiplum nymphaeae (L.)

Castanea dentata

Anoecia oenotherae Wilson

Calaphis castaneae (Fitch)

Longistigma caryae (Harris)

Catalpa speciosa

Aplis spiraecola Patch

Myzus persicae (Sulz, )

Catawba tree-see Catalpa

Cat brier-see Smilax

Cat mint-sec Nepeta

Catuip-see Nepeta

Cat spruce-see Picea canadensis

Cat-tail-see Typha latifolia

Cedar-see duniperus virginiana 
Celastrus scandens

Aphis rumicis L.

Aphis spiraecola Patch

Macrosiphum pisi (Kíalt.)

Celery-see Apium

Cephalanthus occirlentalis

Aphis ceplualanthi Thomas

Chamomile-see Anthemis

Chenopolium album

Hyalopterus atriplicis (L.)

Chenopodium sp.

Aphis gossypii Glover

Macrosiphum gei (Koch)

Myzus persicae (Sulz.)

Cherry-see Prunus

Chestnut-see Castanea

Chokeberry-see Pyrus arbutifolia var. atropurpurea

Choke cherry-sce Prunus virginiana

Chrysanthemum sp.

Macrosiphum sanborni Gill.

Myzus circumflexus (Buckton)

Rhopalosiphum rufomaculatum (TVilson)

Cineraria-see Senecio cruentus

Cinquefoil-see Potentilla

Cirsium arvense

Aphis rumicis L.

Cirsium lanceolatum

Aphis carduella Walsh

Aplis carclui $\mathrm{L}$.

Aphis rumicis L.

Capitophorus flaveolus (Walker)

Cirsium sp.

Capitophorus flaveolus (Walker)

Macrosiphum ambrosiae (Thomas)

Clearweed-see Pilea

Climbing bittersweet-see Celastrus

Climbing dogbane-see Traclielos. - perniun

Clotbur-see Xanthiun

Clover-see Melilotus and Trifolium

Coccoloba laurifolia

Aphis gossypii Glover

Coccoloba flendana

Aphis gossypii Glover

Cocklebur-see Ianthium

Columbine-see Aquilegia

Cone-flower-see Rudbeckia

Conioselinum chinense

Rhopalosiplım melliferum (Hottes)

Convolvulus sepium

Aphis nerii Fonse.

Convolvulus sp.

Aplis nelii Fonse.

Aphis spiraecola Patel

Macrosiphum gei (lioch)

Myzus persicae (Sulz.)

Coral-berry-see Symphoricarpos orbiculatus

Corn-see Zea Mays

Cornel-see Cornus

Cornelian cherry-see Cornus mas
Cornus mas

Aphis helianthi Monel.

Cormus stolonifera

Aphis cornifoliae Fitcl

Aphis helianthi Monel:

Cornus stricta

Aphis spiraecola Patch

Cornus sp.

Anoecia querci (Fitch)

Aplis caliginosa $\mathrm{H}$. \& $\mathrm{F}$.

Aplis cornifoliae Fitch

Aplis helianthi Monell

Aphis spiraecola Patch

Corylus americana

Macrosiphum coryli Davis

Myzocallis coryli (Goeze)

Cotton-see Gossypium

Cotton-wood-see Populus deltoides

Cowslip-see Dodecatheon

Cranberry-see Vacciuium

Cranberry-tree-see Viburnum opu. lus var. americanum

Cranesbill-see Geranium

Crataegus Crus-galli

Prociphilus corrugatans (Sirrine)

Rhopalosiphum prunifoliae (Fitch)

Crataegus tomentosa

Macrosiphum crataegi (Monell)

Crataegus sp.

Aphis crataegifoliae Fitch

Aphis pomi DeGeer

Eriosoma crataegi (Oestl.)

Macrosiphum crataegi (Nonell)

Rhopalosiphum prunifoliae (Fitch)

Tuberculatus ulmifolii (Monell)

Crocus sp.

Aphis gossypii Glover

Crowfoot-see Ranunculus

Cryptotaenia canadensis

Macrosiphum gei (lioch)

Rhopalosiphum melliferum (Hottes)

Cucumber-see Cucumis sativus

Cucumis melo

Apluis gossypii Glover

Cucumis sativus

Aphis gossypii Glover

Aplis spiraecola Patch

Cup plant-see Silphium perfolia. tum

Cuculbita maxima

Aphis gossypii Glover

Macrosipluum gei (Koch)

Cucurbita Pepo

Aplis gossypii Glover

Macrosiphun gei (loch)

Currant-see Ribes

Cut-leaf hirch-see Betula pendula

Crclamen indicum

Myzus persicae (Sulz.)

Crcioloma atriplicifolium

Macrosiphum gei (lioch)

Dahlia sp.

Aplis rumicis 1 . 
Dalisy-see Chrysantlemum

Daisy fleabaue-see Erigeron anumus

Dandelion-see Taraxacum

Daucus carota

Aphis tulipae Fonsc.

Rhopalosiphum melliferum (Hottes)

Delphinium tricorne Aphis rociadae Ckll.

Desmodium s].

Microparsus variabilis Pateh

Diauthus sp.

Aphis rumicis $\mathbf{L}$.

Myzus persicae (Sulz.)

Diervilla sp.

Apluis gossypii Glover

Dock-see Rumex

Dodecatheon Meadia

Aphis spiraecola Pateh

Doghane-see Apocynum

Dog fennel-see Anthemis cotula

Dogwood-see Cornus

Downy poplar-see Populus heterophylla

Duck's-meat-see Lemna

Duckweed-see Lemna

Easter lily-see Lilium

Egg-plant-see Solanum Melongena

Eichhornia sp.

Rhopalosiphum nymphaeae (L.)

Elaeagnus sp.

Capitophorus flaveolus (Walker)

Capitophorus gillettei Theobald

Elder-see Sambucus

Elecampane-see Imula

Eleusine indica

Anoecia querei (Fitch)

Elm-see Ulmus

Elymus sp.

Periphyllus negundinis (Thomas)

Erigeron annums

Macrosiphum erigeronensis ('Thomas)

Erigeron canadensis

Macrosiphum erigeronensis (Thomas)

Prociphilus erigeronensis (Thomas)

Erigeron philadelphicus Anoecia querci (Fitch)

Aphis maidi-radicis Forbes

Geoica squamosa Hart

Nacrosiphum erigeronensis (Thomas)

Macrosiphum gravicornis Patch

Pemphigus brevicornis (Hart)

Erigeron $\mathrm{sp}$.

Anoecia querci (Fitch)

Macrosiphum rigeronensis (Thomas)

Macrosiphum gravicornis Patclu

Eupatorium purpureum var. maculatim

Aplis vernouiae Thomas
Eupatorium urticaefolium

Aphis ageratoidis Oestl.

Aplis coreopsidis (Thomas)

Macrosiphum ambrosiae (Thomas)

Macrosiphum chrysanthemi (Oestl.)

Macrosiphum gei (Joch)

Nacrosiphum rucheckiae (Fitch)

Euphorbia marginata

Macrosiphum gei (Joch)

Euphorbia sp.

Aphis pulchella H. \& F.

Macrosiphum gei (Koch)

Evening primrose-see Oenothera biennis

Everlasting pea--see Lathyrus

Evonymus alatus

Aphis rumicis L.

Evonymus atropurpureus

Aphis rumicis L.

Fagus grandifolia

Prociphilus imbricator (Fitch) Phyllaphis fagi (L.)

Fern-see Aspiclium, Asplenium, and Nephrolepis

Fetid Buckeye-see Aesculus glabra

Figwort-see Scrophularia

Filhert-see Corylus

Fir-see Pinus sylvestris

Fleabane-see Erigeron

Fleur-de-lis - see Iris

Flowering almond-see Prunus japonica

Flowering cherry-see Prunus triloba

Forget-me-not-see Myosotis

Foxtail-see Setaria glauca

Fragaria sp.

Aphis forbesi Weed

Capitophorus fragaefolij (Ckll.)

Capitophorus minor (Forbes)

Fraxinus pennsylvanica var. lanceolata

Prociphilus fraxinifolii (Riley)

Fraxinls americana

Prociphilus fraxinifolii (Riley)

Fraxinus sp.

Prociphilus fraxinifolij (Riley)

Fuclisia sp.

Myzus circumflexus (Buckton)

Galium sp.

Aplis rumicis $L$.

Myzus cerasi (F.)

Rhopalosiphum nymphaea (l.)

Garland flower-see lledychium corouarium

Gaura bienmis

Macrosiphum pseudorosae Patch

Ciaura sp.

Macrosiphum pseudlorosae Patch

(ivranium maculatum

lacrosiplum geranii (Oestl.) 
Geranium sp., wild

Macrosiphum geranli (Oestl.)

Geranium sp., cultivated Myzus ciscumflexus (Buckton)

Gerardia pedicularia

Aphis rumicis var. gerardiae

Geum canadeuse

Ampliorophora rossi $\mathrm{H}$. \& $\mathrm{F}$.

Macrosiphmm pseudorosae Patch

Ginger-lily-see Hedychium

Goat's beard-see Aruncus

Golden alexanders-see Zizia aurea

Goldeu-glow-see Rudbeckia laciuiata val. hortensia

Golden-rod-see Solidago

Gonolobus laevis

Aphis nerii Fonse.

Gooseberry-see Ribes

Goosefoot-see Chenopodium

Goose grass-see Eleusine

Gossypium sp.

Aphis gossypii Glover

Gourd--see Cucurbita and Lagenaria vulgaris

Grape-see Vitis

Grass-see Setaria, Eleusine, Elymus, Panicum, aud Poa.

Grasses-(unidentified)

Amphoropliora singularis $H$. \& F.

Anoecia querci (Fitch)

Bracliycolus tritici Gill.

Colopha graminis (Monell)

Colopha ulmicola (Fitcli)

Forda occidentalis Hart

Forda olivacea Rohwer

Geoica squamosa Hart

Prociphilus erigeronensis (Thomas)

Rhopalosiphum prunifoliae (Fitch) Sipha flava (Forbes)

Great ragweed-see Ambrosia trifida

Green Amaranth-see Amaranthus retroflexus

Green ash-see Fraxinus pennsylvanica var. lanceolata

Green brier-see Smilax

Green foxtail grass-see Setaria viridis

Groundsel-see Senecio

Hackmatack-see Larix laricina

Hamamelis virginiana

Hamamelistes spinosus Slimer

Hamame]is sp.

Hamamelistes spinosus Sluimer

Hormaphis hamamelidis (Fitch)

Hard maple-see Acer saccharum

Hawliweed-see Hieracium

IIawthorn-see Crataegus

Hazelnut--see Corylus americana

Heart's ease-see Viola tricolor and Tiola

Jedge bindweed -see Convolvulus sepium
Hedychium coronarium

Pentalonia nigronervosa Coquerel

Helenium antumnale

Apluis gossypii Glover

Aphis vernoniae Thomas

Macrosiphum tardae H. \& F.

Helianthus sp.

Aphis debilicornis G. \& P.

Aphis helianthi Monell

Aplis rumicis $L$

Nacrosiphum ambrosiae (Thomas)

Macrosiphum gei (Koch)

Macrosiphum illini $H$. \& F.

llacrosiphum illini var. crudae $H$. \& $F$.

Macrosiplum illini rar. sangamonensis $H$. \& $F$.

Nacrosiphum rudheckiae Fitch

Jacrosiphum ruralis $H$. \& $F$.

IJyus persicae (Sulz.)

Helichrysum bracteatum

Aphis spiraecola Patch

Hemlock parsley-see Conioselinum

Heuchera sp.

Myzus heucherae (Thomas)

Hibiscus sp.

Aphis rhamni Fonse.

Hickory-see Carya

Hieracium venosum

Macrosiplum rudbeckiae (Fitch)

High-bush cranberry-see Viburnum opulus var. americanum

Hog peanut-see Amphicarpa

Holcus Sorghum var. saccharatus

Sipha flava (Forbes)

Holcus Sorglum var. technicus

Siplua flava (Forbes)

Honewort-see Cryptotaenia

Honeysuckle-see Diervilla a nd Lonicera

Hop-see Humulus

Hop clover-see Trifolium procumbens

Hornbeam-see Carpius

Horse chestmut-see Aesculus

Horse mint-see Monardia

Horse radish-see Radicula Armoracia

Horseweed-see Erigeron canadensis and Lactucil canadensis

Humulus Lupulus

Phorodon humuli (Schrauk)

Hydrangea sp.

Aplis rumicis $\mathrm{I}$.

Aphis spiraecola Pateh

Hypericum sp.

Hyalopterus hyperici (Monell)

Impatiens biflora

Aphis cephalanthi Thomas 
Impatiens sp.

Aphis cephalanthi Thomas

Iacrosiphum impatiensicolens

Patcli

Macrosiphum psendorosae Patch

Indian bean-see Catalpa

Indian hemp-see Apocynum

Inula royaleana

Capitophorus pakansus $H$. \& $F$.

Ipomoea batatas

Macrosiphum gei (Foch)

Ipomoea maxima

Myzns circumflexus (Buckton)

Iyzus persicae (Sulz.)

Iris sp.

Macrosiphum gei (Koch)

Iron oak-see Quercus stellata

lronweed-see Vernonia

Ivy. boston-see Parthenocissus tricuspiclata

Japanese barberry - see Rerberis

Jewelweed-see Impatiens

Joe Pye weed-see Eupatorium purpureum var. maculatum

Juglaus nigra

Monellia caryae (Monell)

Monellia caryella (Fitch)

Monellia costalis (Fitch)

Monellia nigropunctata Granovsky

Juneberry-see Amelanchier

June grass-see Poa pratensis

Juniper-see Juniperus

Juniperus virginiana

Cinara difficilis $H$. \& $F$.

Kentucky blue grass-see Poa pratellsis

Knotweed-see Polygonum

Lactuca canadensis

Macrosiphum sonchella (Monell)

Lactuca sp.

Amphorophora cosmopolitana Mason

Nacrosiplum ambrosiae (Thomas)

Macrosiphum gei (Jioch)

Macrosiplum gravicornis Patch

Macrosiphnm rudbeckiae (Fitch)

Macrosiphum sonchellum (Jonell)

Myzus lactucae (Schrank)

Prociphilus erigeronensis (Thonas)

Lady fern-see Asplenium Filixfemina

Lagenaria vulgaris Aphis gossypii Glover

Macrosiphnm gei (Koch)

Lamb's quarters-see Chenopodium album

Larch-see Larix

Large-tootlied aspen-see Populus grandidentata
Larix laricina

Cinara laricis (Hartig)

Iarkspur--see Delphinium

Lathyrus sp.

Macrosiphum gei (Koch)

Macrosiphum pisi (Kalt.)

Trifidaplis phaseoli (Pass.)

Lanrel oak-see Quercus imbricaria

Laurestimus-see Vibunum

Leafcup-see Polymnia

Lemna trisulca

Rliopalosiphum nympliaeae (L.)

Lepidium virginicum

Pempligus populi-transversus Riley

Rhopalosiphum pseudobrassicae (Davis)

Lettuce - see Lactuca

Liatris elegans

Aphis zilora H. \& F.

Liatris squarrosa

Aphis funesta $H$. \& F.

Aplis spiraecola Patch

Ligustrum vulgare

Aphis rumicis $\mathrm{L}$

Macrosiphum gei (lioch)

Myzus persicae (Sulz.)

Ligustrum sp.

Nacrosiphum gei (Koch)

Lilium sp.

Myzus circumflexus (Buckton)

Lily-see Lilium

Linden-see Tilia

Liriodendron Tulipifera

Macrosiphum liriodendri (Monell)

Locust-see Robinia

Lombardy poplar-see Populus nigra var. italica

Long-leaved pine-see Pinns palustris

Lonicera flava

Rhopalosiphum melliferum (Hottes)

Lonicera sempervirens

Rhopalosiphum melliferum (Hottes)

Lonicera sp.

Aphitoaphis lonicericola (WilJiams !

Gypsoaphis oestlundi Hottes

Rhopalosiphum melliferum ( Hottes)

Loosestrife-see Lysinachia

Lotus-see Nymphaeae

Low birch-see Betula punila

Lucerue-see Medicago

Lycopersicon esculentum Mill.

Amphoropluora solani (Thomas)

Nacrosijhum gei (Koch)

Myzus persicae (Sulz.)

Lysimalcitia productil

Thecaluius? sp. 
Mallow-see Hibiscus and Malva

Malva sp.

Aphis gossypii Glover

Maple-see Acer

Marigold-see Calendula

Marsilea quadrifolia

Myzus persicae (Sulz.)

Jay weed-see Anthemis cotula

Mazzard-see Prunus avium

Meadow grass-see Poa

Meadow rue-see Thalictrum

Meadow-sweet - see Spiraea

Medicago sativa

Macrosiphum pisi (lialt.)

Medick-see Medicago

Melilotus alba

Hysteroneura setariae (Thomas)

Macrosiphun pisi (Kalt.)

Melilotus officinalis

Macrosiphum pisi (Ka]t.)

Milfoil-see Achillea Millefolium

Milkweed-see Asclepias

Mimulus sp.

Myzus persicae

Missouri currant-see Ribes odoratum

Mock orange-see Philadelphus coronarius

Monarda fistulosa

Aphis monardae Oestl.

Myzus monardae (Williams)

Monarda sp.

Myzus monardae (Williams)

Monkey flower-see Mimulus

Morning glory-see lpomoea

Mossy-cup oak-see Quercus macrocarpa

Mountain ash-see Pyrus americana

Muskmelon-see Cucumis melo

Nustard-see Brassica

Myosotis sp.

Aphis padi $\mathbf{L}$.

Myzus persicae (Sulz.)

Nasturtium-see Tropaeolum majus

Necklace poplar-see Populus de]. toides

Nepeta Cataria

Aphis ageratoidis oestl.

Aplis rhamni Fonsc.

Aphis rumicis L.

Nephrolepis sp.

Idiopterus nephrelepidis Davis

Nettle-see Urtica

Nightsliade-see Solanum

Nime-barli-see Plissocarpus

Norway spruce-see Picea abies

Nympliaea castaleiflora (?)

Rhopalosiphum nymplateae (L.)

Nympliaea sp.

Aplis maiclis Fitch

Nyssa sylvatica

Aphis coreopsidis ('Thomas)
Oak-see Quercus

Oats-see Arena

Oenothera biennis

Anoecia oenotherae IVjlson

Anoecia setariae G. \& P.

Aphis oestlundi Gillette

Macrosiphum amhrosiae (Thomas)

Macrosiphum pseudorosae Patch

Oenothera sp.

Anoecia oenotherae Tilson

Anoecia setariae G. \& P.

Aphis oestlundi Gillette

Ohio buckeye-see Aesculus glabra

Orpine-see Sedum

Osier-see Salix

Over-cup oak-see Quercus macrocarpa

Ox-eye daisy-see Chrysanthemum

Oxyhaphus nyctagineus

Aphis rumicis $\mathrm{L}$.

Panic grass-see Panicum

Panicum sp.

Prociphilus erigeronensis (Thomas)

Pansy-see Viola tricolor.

Paper birch-see Betula alba var. papyifera

Parsuip-see Pastinaca

Parthenocissus tricuspidata

Aphis folsomii Davis

Partheuocissus sp.

Aphis folsomii Daris

Pastinaca sativa

Aplis decepta $H$. \& $\mathbf{F}$.

Aphis rumicis $L$.

Aphis spiraecola Patch

Macrosiphum gei (Koch)

Rhopalosiphum melliferum (Hottes)

Pea-see Lathyrus and Pisum

Peach-see Prumus persica

Peach-leaved willow-see Salix amygdaloides

Pear-see Pyus communis

Pecan-see Carya illinoensis

Pentstemon sp.

Macrosiphum gei (koch)

Pepper-see Capsicum

Peppergrass-see Lepidium

Pepperidge see Iyssa

Pepperwort-see Lepidium

Philadelphus coronarius

Aphis rumicis $L$.

Myzus persicae (Sulz.)

Pliramites $\mathrm{sp}$.

Hralopterus pruni (Geoffroy)

Plussocarpus opulifolius

Aphis neilliae Oestl.

Picea Ahies

Cinara pinjcolal (Kalt.)

Picea canadensis

Cimaria pinicola (kalt.) 
Picea sp.

Cinara palmerae (Gill.)

Cinala pinicola (Kalt.)

Pigeon grass-see Setaria glauca

Pigeon plum-see Coccoloba laurifolia

Pigweed-s e e Amaranthus retroflexus and Chenopodium album

Pilea pumila Asiphonaphis anogis $H$. \& $F$.

Pine-see Pinus

Pink-see Dianthus

Pin oak-see Quelcus palustris

Pinus echinata

Eulachnus rileyi (Williams)

Pinus palustris Eulachnus rileyi (Williams)

Pinus Strobus

Cinara strobi (Fitch)

Eulachnus rileyi (IVilliams)

Mindarus abietinus lioch

Pinus sylvestris

Cinara pini (L.)

Eulachnus rileyi (Williams)

Piqueria trinervia Myzus persicae (Sulz.)

Pisum sativum

Macrosipluum gei (Fioch)

Macrosiphum pisi (Kalt.)

Plantago sp.

Aphis maidi-radicis Forbes

Apluis roseus Baker

Myzus persicae (Sulz.)

Myzus plantagineus Pass.

Plaintain-see Plantago

Platanus occidentalis

Longistigma caryae (Harris)

Plum-see Prunus domestica

Plumed thistle-see Cirsium

Poa pratensis

Capitophorus poae (Gill.)

Poa sp.

Amphorophora nebulosa

Forda occidentalis Hart

Geoica squamosa Hart

Prociphilus erigeronensis (Thomas)

Rhopalosiplum prunifoliae (Fitch)

Polygonatum sp.

Macrosiphum gei (Koclu)

Macrosiphum kickapoo H. \& F.

Polygonum hydropipel

Aphis maidi-radicis Forbes

Aphis spiraecola Patch

Capitophrous gillettei Theohald

Polygonum Mullenbergii

Macrosiphum ambrosiae (Thomas)

Macrosiphum gei (Koch)

Macrosiphum pisi (Kalt.)

Polygonum sp.

Macrosipluum gei (Kocll)

Polymnia canadensis

Macrosiphum zinzalae 11 \& $F$.
Polymnia sp.

Capitophorus gillettei Theobald

Macrosiphum gei (Koch)

Pondweed-see Potamogeton

Poor robin's plantain-see Hieracium venosum

Poplar-see Populus

Populus deltoides

Asiphum pseudobyrsa Walsh

Cluaitophorus populifoliae Oestl.

Chaitophorus neglectus $H$. \& F.

Clavigerus smithiae (Monell)

Mordwilkoja vagabunda (Walsh)

Pemphigus nortoni Maxson

Pemphigus populicaulis Fitch

Pemphigus populi-transversus $\mathrm{Ri}$ ley.

Pempligus populi-venae Fitch

Periphyllus populicola (Thomas)

Prociphilus venafuscus (Patch)

Populus grandidentata

Chaitophorus neglectus H. \& F.

Chaitophorus populifoliae Oestl.

Clavigerus smithiae (Monell)

Populus heterophylla

Chaitophorus populifoliae Oestl.

Populus nigra var. italica

Periphyllus populicola (Thomas)

Populus tremuloides

Aphis maculatae Oestl.

Chaitopliorus populifoliae Oestl.

Periphyllus populicola (Tlomas)

Populus sp.

Asiplum pseudobyrsa Walsh

Pemphigus populi-trausversus $\mathrm{Ri}$ ley

Periphyllus populicola (Thomas)

Portulaca oleracea

Aphis gossypii Glover

Myzus persicae (Sulz.)

Portulaca sp.

Aplis maidi-radicis Forbes

Post oak-see Quercus stellata

Potamogeton natans

Rhopalosiphum nymphaeae (L.)

Potamogeton sp.

Rhopalosiphum nymphaeae (L.)

Potato-see Solanum tuberosum

Potentilla monspeliensis

Capitophorus fragaefolii (Ckll.)

Potentilla sp.

Capitophorus fragaefolii (Ckll.)

Macrosiphum psendorosae Patch

Prenanthes alba

Amplorophora nabali (Oestl.)

Macrosiphum ambrosiae (Tliomas)

Macrosiphum chrysanthemi (Oestl.)

prenantles sp.

Macrosiphum ambrosiae (T'lomas)

Prim-see Ligustum

Primrose-see Oenothera and Streptocarjus 
Privet-see Ligustrum

Prune-see Prunus domestica

Prunus anericana

Myzus persicae (Sulz.)

Prunus avium

Hysteroneura setariae (Thomas)

Myzus cerasi (Fabr.)

Myzus persicae (Sulz.)

Prunus domestica

Aphis pomi DeGeer

Hyalopterus pruni (Geofiroy)

Hysteroneura setariae (Thomas)

Myzus persicae (Sulz.)

Prunus japonica

Aphis pomi DeGeer

Rhopalosiphum prunifoliae (Fitch)

Prunus nigra

Aphis cerasifoliae Fitcl

Hysteroneura setariae (Thomas)

Prunus Persica

Aphis padi L.

Aphis persicae-niger Smith

Hysteroneura setariae (Thomas)

Myzus cerasi (F.)

Myzus persicae (Sulz.)

Prunus serotina

Aphis feminea Hottes

Myzus persicae (Sulz.)

Prunus triloba

Hysteroneura setariae (Thomas)

Prunus virginiana

Aphis cerasifoliae Fitch

uphis pomi DeGeer

Asiphonaphis pruni Wilson \& Davis

Hysteroneura setariae (Thomas)

Prunus sp.

Aphis cerasifoliae Fitch

Aphis chetansapa $H$. \& $\mathbf{F}$.

Asiphonaphis prumi Wilson \& Davis

Hysteroneura setariae (Thomas)

Pumpkin - see Cucurbita Pepo

Purple amaranth-see Amaranthus paniculatus

Purslane-see Portulaca

Pyrus americana

Aphis pomi DeGecr

Pyrus arbutifolia var. atropurpurea Aphis cerasifoliae Fitch

Pyrus communis

Aplris pomi DeGeer

Pyrus Nalus

Aplis maidis Fitch

Aphis pomi DeGeer

Aphis roseus Baker

Friosoma lanigera (Hausmann)

Rhopalosiplum prunifoliae (Fitch)

Pylus sp.

Aphis chetansapa $H$. \& F.

Aplis pomi DeGere

Quaking asp-see Populus tremuloides
Quercitron oak-see Quercus velutina

Quercus alba

Drepanaphis acerifoliae (Thomas)

Myzocallis alhambra Davidson

Iyzocallis discolor (Nonell)

Myzocallis walsbii (Monell)

Stegophylla quercicola (Baker)

Tuberculatus punctatellus (Fitch)

Quercus bicolor

Myzocallis alhambra Davidson

Iyzocallis walshii (Monell)

Quercus imbricaria

Myzocallis walshii (Monell)

Quercus macrocarpa

Chaitophorus quercicola (Monell)

Myzocallis albambra Davidson

Myzocallis discolor (Monell)

Neosymydobius albasiphus (Davis )

Stegophylla quercicola (Baker)

Tuberculatus punctatellus (Fitch)

Quercus marilandica

Myzocallis punctata (Monell)

Quercus palustris

Myzocallis discolor (Monell)

Myzocallis punctata (Monell)

Iyzocallis walshii (Monell)

Quercus stellata

Neosymydobius albasiphus (Davis)

Neosymydobius memorialis $H$. \& F.

Stegophylla quercicola (Baker)

Quercus velutina

Iyzocallis bella (Walsli)

Iyzocallis walshii (Monell)

Tuberculatus punctatellus (Fiteli)

Quercus sp.

Anoecia querci (Fitch)

Monellia carvella (Fiteb)

Myzocallis alhambra Daridson

Myzocallis bella (Walsh)

Myzocallis discolor (Monell)

Myzocallis puuctata (Monell)

Myzocallis walshii (Monell)

Neosymydobius albasiphus (Davis !

1 uberculatus punctatellus (Fitch)

Quince-see Prunus japonica

Radicula Armoracia

MIyzus persicae (Sulz.)

Radish-see Raphanus sativus

Ragweed-see Ambrosia

Ragwort-see Senecio

Ranunculus sp.

Thecabius gravicormus Patch

Raplianus sativus

Myzocallis asclepiadis (Monell)

Mlyzus pelsicae (Sulz.)

Rhopalosiphum psendobrassicae (Daris)

laspbery-see Rubus occidentalis 
Rattlesnake-root-see Prenanthes

Rattlesnake-weed-s e e Hieracium venosum

Red bircl-see Betula nigra

Red cedar-see Juniperus virginiana

Red clover-see Trifolium pratense

Red elm-see Ulmus fulva

Red-osiex dogwoor-see Cormus stolonifera

Reed-see Phragmites

Rlumulis lanceolata

Aphis rhamni Fonsc.

Rhus canadensis

Rhopalosiphum rhois (Monell)

Rhus glabra

Rhopalosiphum rhois (Monell)

Rhus sp.

Liosomaphis rhois (Monel])

Melaphis rhois (Fitch)

Ribes Grossularia

Aphis sanborni Patch

Capitophorus ribis (L.)

Myzus houghtonensis (Troop)

Ribes nigrum

Amphorophora cosmopolitana Ma. son

Aplis sanborni Patch

Capitophorus ribis (L.)

Ribes odoratum

Amphorophora cosmopolitana Mason

Capitophorus ribis (L.)

Macrosiphum ribiellum Davis

Myzus persicae (Sulz.)

Ribes sp.

Aplis sanborni Patch

Capitophorus ribis (L.)

Macrosiphum ribiellum Davis

Myzus houghtonensis (Troop)

Jyzus tlomasi $H$. \& $F$.

Ribwort-see Plantago

Riclsweed-see Pilea

River bircl - see Betula nigra

Robinia Pseudo-Acacia

Aphis laburni Kalt.

Aphis rumicis L.

Rock cress-see Arabis

Rock moss-see Sedum

Rosa rugosa

Capitophorus fragaefolii (Ckll.)

Myzus porosus (Sanderson)

Rosa sp.

Capitophorus corambus H. \& F.

Capitophorus fragaefolii (Ckll.)

('apitophorus tetrarhodus

(Walker)

Macrosiphum dirhodum (Walker)

Macrosiphum gei (Koch)

Macrosiphum pseudorosae Patch

Macrosiphum losae (l..)

Myzus circumflexus (Buckton)

Myzus porosus Sanderson

Rose-see Rosa

Rose mallow-see Hibiscus
Rosin-weed-see Silphium

Rubus sp.

Amphorophora sensoriata Mason

Aphis rubicola Oestl.

Cerosipha rubifolii (Thomas)

Rudbeckia lirta

Macrosiphum ambrosiae (Thomas)

Rudbeckia laciniata var. hortensia

Macrosiplum rudbeckiae (Fitch)

Rudbeckia sp.

Macrosiphum rudbeckiae (Fitch)

Rum cherly-see Prunus serotina

Rumex crispus

Aphis rumicis I.

Aplis spiraecola Patcli

Macrosiphum venaefuscae Davis

Rumex sp.

Aplis rumicis $\mathrm{L}$.

Macrosiphum gei (Koch)

Russian olive - see Elaeagnus

Saccharum officinarum

Sipha flava (Forbes)

St. John's wort-see Hypericum

Salix amygdaloides

Chaitophorus pusillus H. \& F.

Salix longifolia

Cavariella aegopodii (Scopoli)

Chaitophorus viminalis Monel]

Salix nigra

Aphis saliceti Kaltenbach

Chaitoplorus viminalis Monell

Clavigerus smithiae (Monell)

Salix sp.

Aphis saliceti Kaltenbach

Cavariella aegopodii (Scopoli)

Chaitophorus viminalis Mone]]

Clavigerus populifoliae (Fitch)

('lavigerus smithiae (Monell)

Macrosiphum laevigatae Essig

Myzus porosus Sanderson

Plocamaphis flocculosa (Weed)

Plocamaphis terricola H. \& F.

Tuberolachnus saligna (Gmel.)

Salvia leucantlia

Myzus persicae (Sulz.)

Sambucus canadensis

Aplis sambucifoliae Fitch

Myzus persicae (Sulz.)

Sambucus sp.

Aphis pomi DeGeer

Aphis sambucifoliae ritch

Sand bar willow-see Salix longifolia Sanguinaria canarlensis

Macrosiphum samguinarium H. \& F.

Sanicle-see Sanicula

Sanicula sp.

Aphis signatis II, \& 1 .

Saxifraga splentens

Aphis gossypii Glover

Macrosiplum gei (Kiorh)

Myzus persicale (Sulz.)

Saxifrage-sese Sixifraga 
Scrophularia leporella

Macrosiphum gei (Koch)

Scrophularia nodosa

Myzus scroplulariae (Thomas)

Scorpion-grass-see Myosotis

Scotch fir-see Pinus sylvestris

Scotch pine-see Pinus sylvestris

Scrub oak-see Quercus marilandica

Seaside grape - see Coccoloba

Sedge-see Carex

Sedum artissimum

Myzus persicae (Sulz.)

Sedum reflexum

Aphis gossypii Glover

Senecio cruentus

Aphis padi L.

Senecio glabellus

Aphis nyctalis $H$. \& F.

Senecio vulgaris

Macrosiphum gei (Koch)

Setaria glance

Geoica squamosa Hart

Hysteroneura setariae (Thomas)

Setaria viridis

Hysteroneura setariae (Thomas)

Myzus persicae (Sulz.)

Setaria sp.

Anoecia querci (Fitch)

Pemphigus populi-transversus Riley

Shag-bark hickory-see Carya ovata Sheepberry-see Viburnum lentago

Shell-bark hickory-see Carya ovata

Shepherd's purse-see Capsella Bursa-pastoris

Shield fern-see Aspidium

Shingle oak-see Quercus jmbricaria

Shooting star-see Dodecatheon Meadia

Shrubby bitter-sweet-see Celastrus

Silphium integrifolium

Macrosiphum pallens $H$. \& F.

Silphium perfoliatum

Macrosiphum ludbeckiae (Fitcli)

Silver maple-see Acer saccharinum

Sky-flower-see Senecio

Slippery elm-see Ulmus fulva

Smartweed-see Polygonum

Smilax rotundifolia

Neoprociphilus acelis (Monell)

Neoprociphilus attemuatus (O. \& S.)

Smooth sumach-see Rhus glabra

Snakeroot-see Eupatorium urticaefoliun, Liatris, and Sanicula

Sneezeweer-see Helenium

Snowbery-see Symphoricarpos

Snow-onthe-nountain-see Euphorbia marginata

Soft maple-see Acer saccharinum

Solanum dulcamara L.

Macrosiplum pisi (Kalt.)
Solanum melongena

Macrosiphum gei (lioch)

Myzus persicae (Sulz.)

Solanum tuberosum

Macrosiphum gei (lioch)

Myzus persicae (Sulz.)

Solanum sp.

Aphis rumicis L.

Solidago canadensis

Aphis solidagiuifoliae Williams

Macrosiphum erigeronensis (Thomas)

Macrosiphum gravicornis Patcl

Macrosiphum rudbeckiae (Fitch)

Solidago nemoralis

Macrosiphum rudbeckiae (Fitch)

Soliclago sp.

Aphis solidaginifoliae Williams

Macrosiphum ambrosiae (Thomas)

Nacrosiphum chrysanthemi (Oestl.)

Macrosiphum erigeronensis (Thomas)

Macrosiphum gravicornis Patch

Macrosiphum rudbeckiae (Fitch)

Pemphigus brevicolnis (Hart)

Solomon's seal-see Polygonatum

Sonchus arvensis

Amphorophora cosmopolitana Mason

Sonchus oleraceus

Amphorophora cosmopolitana Mason

Sonchus sp.

Aphis rumicis L.

Amphorophora cosmopolitana Ma. son

Capitophorus flaveolus (Walker)

Macrosiphum ambrosiae (Thomas)

Sorghum-see Holcus Sorghum var saccharatus

Sorrel-see Rumex

Sour gum-see Nyssa

Southernwood-see Artemisia abrotanum

Sow thistle see Somchus arvensis

Spanisl bayonet-see Yucca

Spatter-dock-see Nrmploea

Spear grass-see Poa

Spinach-see Spinacia oleracea

Spinacia oleracea

Aphis gossypil Glover

Macrosiplium gei (Koch)

Myzus persicae (Sulz.)

Spindle tree-see Eronymus

Spiraea latifolia

Aphis spiraecola Patch

Aphis spiraephila Patch

Spiraea salicifolia

Aphis spiraeplila Patch

Spiraea Vanhouttei

Aphis spiracola Patch

Spiraea sp.

Aphis spiraecola Patch 
Spleenwort-see Asplenium

Spotted touch-me-not-see lmpatiens biflora

Spruce--see Picea

Spurge-see Euphorbia

Spurgewort-see Salvia

Squash-see Cucurbita maxima

Squaw-weed-see Senecio

Stafi tree-see Celastrus

Stick-tight-see Bidens vulgata

Stiff cornel-see Cornus stricta

Stonecrop-see Sedum

Strawbery - see Fragaria

Strawflower-Helichrysum

Streptocarpus sp.

Myzus circumflexus (Buckton)

Sugar cane-see Saccliarum officinarum

Sugar maple-see Acer saccharum

Sumach-see Rhus

Sunflower-see Helianthus

Swamp birch-see Betuła pumila

Swamp milkweed-see Asclepias incarnata

Swamp spanish oak-see Quercus palustris

Swamp white oak-see Quercus hicolor

Sweet cherry-see Prunus avinm

Sweet clover-see Melilotus

Sweet pea-see Lathyrus

Sweet pepper-see Capsicum dulce

Sweet potato-see lpomoea batatas

Sweet viburnum-see Viburnum Lentago

Sword fern-see Nephrelepis

Sycamore-see Platanus occidentalis

Symphoricarpos orbiculatus

Amphicercidus pulverulens (Gill.)

syringa-see Philadelphus coronarius

Tamarack-see Larix laricina

Taraxacum officinale

Aplis knowltoni H. \& F.

Macrosiphum ambrosiae (Thomas)

Macrosiphum taraxaci (Kalt.)

Prociplilus erigeronensis (Thomas)

Tare-see Vicia

Thalictrum sp.

Macrosiphum purpurascens (Oestl.)

Thistle-see Cirsium, Piqueria, and Sonchus

Thoroughwort-see Eupatorium

Tick trefoil-see Desmodium

Tilia americana

Hysteroneura setariae (Thomas)

Longistigma caryae (Harris) Macrosiphum tiliae (Monell) Myzocallis tiliae (L.)

Tomato-see Lycopersicon esculentuin
Touch-me-nol-see lmpatiens

Trachelospermum difforme

Macrosiphum gei (lioch)

Trefoil-see Trifolium

Trifolium pratense

Aphis bakeri Cowen

Aphis cerasifoliae Fitch

Aphis crataegifoliae Fitch

Maclosiphum granarium ( Kby.)

Macrosiphum pisi (Kalt.)

Myzocallis ononidis (Kalt.)

Sipha flava (Forbes)

Trifolium procumbens

Macrosiphum pisi (Kalt.)

Myzocallis ononidis (kalt.)

Trifolium repens

Macrosiphum gei (lioch)

Macrosiphum pisi (Kalt.)

Trifolium sp.

Geoica squamosa Hart

Macrosiphum pisi (Kalt.)

Myzocallis ononidis (Kalt.)

Triticum aestivum

Nacrosiphum granarium (Kby.)

Triticum sp.

Macrosiphum granarium (Kby.)

Myzocallis discołor (Monell)

Rhopalosiphum prunifoliae (Fitch)

Sipla flava (Forbes)

Toxoptera graminum (Rond.)

Tropaeolum majus

Aphis rumicis L.

Trumpet weed-see Eupatorium purpureum

Trumpet honeysuckle - see Lonicera sempervirens

Tulip-see Tulipa

Tulip tree-see Liriodendron

Tulipa sp.

Aphis rumicis $\mathrm{L}$.

Tupelo-see Nyssa

Turnip-see Brassica rapa

Typha latifolia

Rhopalosiphum enigmae H. \& F.

Ulmus atata

Georgiaphis $u 1 m i$ (Wilson)

Tuberculatus ulmifolii (Monell)

Ulmus americana

Colopha ulmicola (Fitch)

Eriosoma lanigera (Hansmann)

Tuberculatus ulmifolii (Monell)

Ulmus lulva

Colopla graminis (Monell)

Coloplia nlmicola (Fitch)

Eriosoma crataegi (Oestl.)

Eriosoma mimica H. \& F.

Eriosoma rileyi (Thomas)

Georgiaphis umi (Wilson)

Gobaishia ulmi-tusus (Walsh)

Macrosiphum rei (lioch)

Tuberculatus ulmitolii (Monell) 
Llmus sp

Colopha graminis Monell

Colopha ulmicola (Fitch)

Eriosoma lanigera (Hausmann)

Gobaishia ulmi-fusus (Walsh)

Tuberculatus ulmifolii (Monell)

Urtica sp.

Aphis rumicis L.

Vaccinjum vacillans

Amphorotshora vaccinii Mason

Verbena sp.

Myzus persicae (Sulz.)

Vernonia fasciculata

Aphis vernoniae Thomas

Vernonia sp.

Aphis spiraecola Patch

Vervain-see Verbena

Vetch-see Vicia

Vetchling-see Lathyrus

Viburnum Lentago

Aphis viburnicola Gill.

Viburnum Opulus var. americanum Apbis rumicis L.

Aphis viburnicola Gill.

Aphis viburuiphila Patch

Viburnum sp.

Aphis bakeri Cowen

Aphis crataegifoliae Fitch

Aphis rumicis L.

Aphis spiraecola Patch

Aphis viburnicola Gill.

Aphis vilurniphila Patch

Vicia sp.

Macrosiphum pisi (Kalt.)

Viola tricolor

Myzus persicae (Sulz.)

Viola sp.

Idiopterus violae (Pergande)

Violet-see Viola

Virginia creeper-see Parthenocissus

Vitis labrusca

Aphis illinoisensis Shimer

Vitis sp.

Aphis illinoisensis Shiner

Aphis spiraecola Patch

Waahoo -see Evonymus atropurpureus

Wahoo-see ITlmus alata

Waluut-see Juglans nigra

Water beech-see Carpinus caroliniana

Water cress-see Rallicula

Watel hyacinth-see Eichholnia

Watel lily-see Castalia and Nym. phaea

Water pepper-see Polygomum hyropipel

Water shield-see Brasenia

Waswolk-see Celastrus scandens

Weeping birch-see Betula pendula

Wheat-sce Triticum
White Birch-see Betula pendula and Betula alba var. papyrifera

White clover-see Trifolium repens

White elm-see Ulmus americana

White lettuce see Prenanthes alba

White melilot-see Melilotus alba

White oak-see Quercus alba

White Pine-see Pinus Strobus

White snake-root-see Eupatorium urticaefolium

White spruce-see Picea canadensis

White tholn-see Crataegus

White water lily-see Castalia

Whitewood tree-see Liriodendron tulipifer'a

Wild bergamot-see Monarda fistulosa

Wild black cherry-see Prunus serotina

Wild cranesbill-see Geranium maculatum

Wild lettuce-see Lactuca canadensis

Wild plum-see Prunus nigra and Pruuus americana

Wild lye-see Elymus

Willow-see Salix

Winged elm-see Llmus alata

Winged pigweed-see Cycloloma

Witch hazel-see Hamamelis

Woorbine-see Parthenocissus

Wood fern-see Aspilium

Wood mint-see Blephilia hirsuta

Wormwood-see Altemisia

Xanthium canadense

Hacrosiphum ambrosiae (Thomas)

Yard grass-see Fleusine

Yarrow-see Aclillea

Yellow barked oak-see Quercus relutina

Yellow daisy-see Rudbeckia hirta

Fellow dock-see Rumex crispus

Yellow honeysuckle-see Lonicera flavir

Yellow melilot-see Melilotus ofticinalis

Fellow pine-see Pinus echinata and pinus palustris

Yellow pond lily-ser X̃mphaea

Fellow poplar-see Liriodendrou tu. lipifela

ruecu sp.

Aphis jumicis L.

Zea Mays

Anoecia querci (Fitch)

Aphis maili-radicis Forbes

Athis maidis Fitch

Colopha graminis ( Monell)

Geoica squamosa Hart

Aacrosiphum granarium (kis.)

lemphigus brevicoruis (Hart)

Sipha flava (Forbes) 
The Playt Lice, or AmHible, of IlJixols

Zizia aurea

Aphis luridis H. \& F.

Aphis signatis H. \& F.
Zizia sp.

Aphis luridis $H$. \& $F$.

Aphis signatis H. \& F. 


\section{BIILIOGRAPHY}

The following list of publications includes the papers to which direct citations are made in the text. Many additional references to the literature dealing with plant lice are contained in some of the papers here listed.

AsIIMEAI, W. H.

1881-2. On the Aphididae of Florida, with Descriptions of New Species. Canadiau Entomologist: Part i. Vol. 13, No. 7. July. pp. 154-156; part ii, Vol. 13, No. 11, November, pp. 220-225: part iii. Vol. 14, No. 5, May, pp. $88-93$.

BAKER, A. C.

1915. The Woolly Apple Aphis. L. S. Department of Agriculture. Report No. 101, pp. 1-55, pls. 1-15, figs. 1-3.

1916a. Identity of Eriosoma pyri. Journal of Agricultural Research. Vol. V, No. 23, March 6, pp. 1115-1119, I pl.

1916b. A Review of the Pterocommini (Aphididae, Hom.) Canadian Entomologist, Vol. 4S, No. S, August, pp. $280-290$.

1916c. The Identity of Eriosomu querei Fitch (Aphidadae, Hom.). Entomological News, Vol. XXVII, No. S, October, pp. 359-366, figs. $1-10$.

1916d. A Synopsis of the Genus Culaphis. Proceedings of the Entomological Society of Washingtou, Vol. XVlll, No. 3, November 27. pp. 1S4-189.

1917a. Synopsis of the Genus Saltusaphis (Aphididae, Hom.). Canadian Entomologist. Vol. XLIX, No. 1, January, pp. 1-9, pls, 1. 2, 3.

1917b. Eastern Aphids, New or Little Known, Part II. Journal of Economic Entomology, Vol. 10. No. 4, August, pp. 420-433, fig. 21.

1917c. Life History of Macrosiphum illinoisensis. the Graperine Aphis. Journal of Agriculuural Research, Vol. XI. No. 3, October 15. pp. $\$ 3-89$, pls. 8,9 .

1917d. Some Sensory Structures in the Aphididae. Canadian Entomologist. Tol. XLIX, No. 11. November. pp. 37s-3\$4. pl. xw11.

1918. Our Birch symulobius Distinct from the European (Aphididae, Hom.). Canadian Entomologist, Vol. L, No. 9, September, $318-320$.

1919a. A Meluphis from Moss (Hom.). Eutomological News. Vol. XXX. No. 7, July, pp. 194-196, figs. a-d.

1919b. Neoturoptera violae. Theo., and Its Allies. Bullerin of Entomological Research, Vol. 10, Pt. 1, November, pp. $45-46$, pl. 1.

1919c. The Houghton Goosebery Aphis. Journal of Economic Ento. mology, Vol. 12, No. 6, December, pp. 433-437.

1920. Generic Classification of the Hemipterous Family Aphididae. U. S. Department of Agriculture, Bulletin No. \$26, August 10, pp. $1-109$, pls, $1-3 \mathrm{TI}$.

1921a. Note on the Rosy Aphis. Canadian Entomologist. Vol. Llll. No. 1. April, 1). 95.

1921b. On the Family Name for the Plant Lice. Proceedings of the Entomological Socjety of Washington, Vol. 23, No, 5, May. pp. 101-103.

192:. Tribe Callipterini, in the Hemiptera or Sucking Insects of Connecticut, Connecticut State Geological and Natural History Survey Bulletin No. 34, pp. 271-290. 
BAkER, A. C., and W. F. TLR.Yk

1916. Morphology and Biology of the Gieen Apple Aphis. Journal of Agricultural Research. Department of Agriculture, Vol. V, No. 21, February 21, pp. 955-994, figs. 1-4, pls. 1.xv11-1,xxv.

1919. Apple.grain Aplis. Journal of Agricultural Research, Vol. XVili, Börxir, C. No. 6, December 15, pp. 311-324, one table.

1930. Beiträge zu einem neuen System der Blattläuse. Archiv für klassifikatorische und phylogenetische Entomologie, Band 1. Heft 2, March 14, pp. 115-194.

Висктох, G. B.

1876. Monograph of the British Aphides, Vol. 1, London, pp. i-iii, 1-193, pls. I-xxxint.

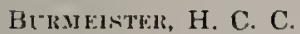

1839. Handbuci der Eutomologie. 5 Bde. Berlin, Reimer. Bd. 2. Abteil 1, 1835. Hemiptela, 12 w. 400 p. Abteil 2, 1, Hälfte. 1838. Ortboptera. 8 p. v. p. $397-756$ w. 2 p. Verbess.; Abteil 2 , 2. Hälfte, 1S39. Neuroptera. p. 757-1050.

CL.IRKE, IV. T.

1903. A List of California Aphididae. Canadian Entomologist, Vol. XXXV. No. 9, September, pp. 247-254.

Cockerklt, T. D. A.

1901. A New Plant-louse Injuring Strawberry Plants in Arizona. Canadian Entomologist. Vol. XXXI1I, No. 4, Apri1, p. 101.

1903. Aplididae. Transactions of the American Entomological Society, Vol. XXIX, pp. 114-116.

1905. A Gall on Bearberry (Arctostaphylus). Canadian Entomologist, Vol. XXXI1, No. 11, November, pp. 391-392.

Coqtekis, CInAki.ks

1859. Note sur quelques Insectes de Madagascar et de Bourbon. Annales Société Eutomologique de France, Ser. 3, Vol. VII, pp. $239-260,2$ Taf.

Cowr., J. H

1895. [Aphididae] in Gillette and BAkF: A Preliminary List of the Hemiptera of Colorado. Agricultural Experiment Station of Colorado State Agricultural College, Bullet in No. 31, Technical Series No. 1. May, pp. 115-124.

Cétright, Clamin R.

1925. Subterranean Aphids of Ohio. Onio Experiment Station, Bulletin 387. September, pp. 175-238, pl. 1-r1.

D.Musox, W. M.

1914a. Plant Louse Notes from California. Journal of Economic Entomology, Vol. VII, No. 1. Febiuary, pp. 127-136, figs. 1-8.

1914h. Walnut Aphides in California. U. S. Department of Agriculture, Bulletin No. 100, August 31. pp. 1-4S, pls. 1-1N. figs. 1-18, tables I-Xi1.

1915. Little-known Western Plant-lice. 1. Journal of Economic Entomology, Vol. S, August 15, pp. 419-429, p1. 25, 26, 27.

1917a. little-known Western Plant lice. JJ. Journal of Economic Entomology, Vol. 10, No. 2, April, pp, 290-297, figs. 1-28.

1917b. The Reddish-Brown Plum Aphis (Rhopalosimhum nymphere 1,inn.). Journal of Economic Eutomology, Vol. X, No. 3, June, pp. $350-353$, fig. 19 (figs. 1-12).

1919. Life History and Habits of the Mealy Plum Aphis. 1. S. Depart. ment of Agriculture, Professional Paper, Bulletin No. 774, April 28. pl). 1-16, pls. 1. 2.

1920. A New Mysocallis (Aphididae: Homoptera). Canadian Entomologist. Vol. LII, No. 6, August, pp. 176-17i.

1921. Biological Studies of . phis rumicis Linn. I3ulletin of Entomological Research, Vol. XII, I't, 1, June, pp. 81-89, figs. 1-6. 
D.Ivis, J. J.

1908a. A New Aphid on the Virginia Creeper. Entomological News, Vol. XIX, No. 4, April, pp. 143-146, pl. v11.

1908b. Notes on the Life History of the Leafy Dimorph of the Boxelder Aphid, Chatophorus negundinis Thos. Annals of the Entomological Society of America, Yol. 1, No. 2, June, pp. 130-132.

190sc. Studies of Apluididae I. Annals of the Entomological Society of America, Columbus, Ohio. Vol. 1, No. 4, Decenber, pp. 251-264. pls, $x \times 1, x \times 11, x \times I 1$.

1909a. Biological Studies on Three Species of Aphididae. L. S. Department of Agriculture, Bureau of Entomology, Technical Series, No. 12, Pt. \&, February, pp. 123-168.

1909b. Studies on Aplididae II. Annals of the Entomological Society of Anerica, Vol. 2, No. 1, Marcb, pp. 30-42, pls. r-ru.

1909c. Two New Genera and Species of Aphidiclae. Annals of the Entomological Society of America, Vol. IJ, No. 3, September, pp. 196-200, pl. xxvis, figs. 9-15.

1910a. Chaitophorus negundinis Thos, vs. C. aceris Linn. Entomological News, Vol. XX1, No. 1, Jamuary, pp. 14-16, figs.

1910b. Two Curious Species of Aphididae from Illinois. Entomological News, Vol. XXI, No. 5, May, pp. 195-200, pl. vin.

1910c. Aphis aquaticus Jackson Vs. Rhopalosiphum nympharae Linn. Entomological News, Vol. XX1, No. 6. June, pp. 245-247.

1910d. A List of the Aphididae of lllinois, with Notes on Some of the Species. Journal of Economic Entomology, Vol. 3. October, pp. 407-420, pis. 27, $2 \mathrm{~s}$.

1910e. A List of the Aphididae of Jllinois, with Notes on Some of the Species. Journal of Economic Entomology, Vol. 3, December, pp. 482-499, pls. 31,32 .

1911a. The Woolly Aplis of Oak (Phyllaphis? querci Fitch) (Hemip.) Entomological News, Vol. XXII, No. 6, June, pp. 242-245, pl, 111.

1911b. A List of the Aphididae of Illinois, with Notes on Some of the Species. Journal of Economic Entomology, Vol. 4. No. 3, Jume, pp. 325-331, pl. 10, fig. 10.

1911c. Williams" "The Aphididae of Nebraska."-A Critical Rerien: Nebraska University Studles, Vol. 11, No. 3. July, pp. 253-292, pls. 1-rili.

1913. The Cyrus Thomas Collection of Aphididae, and a Tabulation of Species Mlentioned and Described in His Publications. Bulletin of the lllinois State Laboratory of Natural History. Vol. X. Art. 11, September, pp. 97-121, with 2 pls.

1914a. New or Little Known Species of Aphididae. Canadian Entomologist, Vol. XLV1, No. 2, February, pp. 41-51, pl. 11, figs. 10-12: No. 3 , March, pp. 77-87, pl. 11, 1 ; No. 4, April, pp. 121-134, figs, 14-17, pl. vir; No. 5, May, pp. 165-173, fig. 18; No. T, July, pp. 226-235, pl. xinl, figs, $21,22$.

1914b. The Yellow Clover Aphis. U. S. Department of Agriculture, Bureau of Entomology, Technical Series, No. 25. Part 1I, November, pp. $17-40$, figs. 1-15.

1915. The Pea Aphis with Relation to Forage Crops. U. S. Department of Agriculture, Bulletin No. 276, September 29, pp. 1-6\%, figs. 1-17, tables I-vi1.

1917. The Corn-Root Aphis and Methods of Controlling it. [־. S. Department of Agriculture, Farmers Bulletin \$91. December, pp. 1-12, figs. 1-5, (reprint Jume, 1921).

1919. Miscellaneous Aphid Notes 1. Canadian Entomologist, Vol. Ll, No. 10, October, pp. 22s-234. pl. xx, figs. $26 \cdot 30$.

\section{DrGeklz, CAlit,}

1773. Mémoires pour servir à l'histoire des Insectes. Stockholm. Hosselberg. Tome 3.2 et $696 \mathrm{pp} ., 44$ Taf. 
DELoxi, D. M., and A. A. MATHlEwso.

1925. The Intluence of Temperature and Humidity upon the Development of Hyzus houghtonensis Troop. Journal of Economic Entomology, Vol. 1S, No. 2, February, pp. 172-176.

DELoxi, D. M., and M. P. Joxes

1926. Control Mleasures for the Houghton Gooseberry Aplis with Special Reference to Plant Resistance. Journal of Economic Entomolo. gy, Vol. 19, No. 1, February, pp. $40-43$, pl. 1.

Essic. E. O.

1911a. Aphididae of Soutlern California-V. Pomona College Journal of Entomology, Vol. IIJ, No. 1, February, pp. 400-403, fig. 135-141.

1911b. Aphididae of Southern California-VII. Pomona College Journal of Entomology, Vol. JII, No. 3, September, pp. 523-557, figs. 169186.

1915. Aplididae of California-XI. Journal of Entomology and Zoology. Vol. 7. No. 3, September, pp. 180-200, figs. 1.9.

1917. Aphididae of California. University of California Publications, Technical Bulletins, Entomology, Vol. I, No. 7, July 20, pp. 301 346, figs. $1-30$.

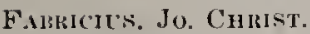

1775. Systena Entomologiae. Fleusburgi et Lipsiae, Korte. $\$ 32$ pp. FELT, E. P.

1909. Twenty-fourth Report of the State Entomologist on Injurjous and Other Insects of the State of New York. N. Y. State Museum, Albany, Bulletin 134. (Education Department, Bulletin No. 455) September 15 , pp. 19-22, figs. 6-9.

Fitc11, As:

1851. Catalogue with References and Descriptions of the Insects Collected and Arranged for the State Cabinet of Natural History. Fourth Annual Report of the Regents of the University on the Condition of the State Cabinet of Natural History, Albany, New York, pp. 3\$5-413.

1854. Report on the Noxious, Beneficial and Other Insects of the State of New York. Transactions of the New York State Agricultural Society, Vol. XIV, pp. 705-880, $2 S$ figs., (printed 1855).

1856. Insects Infesting Fruit Trees. Third Report on the Noxious and Otber Insects of the State of New York. Transactions of the New York State Agricultural Society, Vol. XVI, pp. 490, pls. 4.

1958. Fifth Report on the Noxious and Other Insects of the State of New York: Insects Infesting Deciduous Forest Trees. Transactions of the New York State Agricultural Society, Vol. XVIll, pl). 1-74.

1566. Cabbage Aphis, Aphis brassicae Linn. (Homoptera, Aphidae). Eleventh Report on the Noxious, Beneficial, and Other Insects of the State of New York. Transactions of the New York State Agricultural Society, Vol. XXVI, August, pp. 511-514, figs. \$-9.

Folson, J. W.

1909. The Insect Pests of Clover and Alfalfa. Twenty-fifth Report of the State Entomologist on the Noxious and Beneficial Insects of the State of lllinois, pp. 41-124, figs. 1-35, pls, 11, 11.

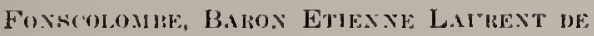

1841. Description des Pucerous qui se trouvent aux environs d'Aix. Annales de la Société Entomologique de France, Tome X, pp. $157-198$.

Forkisi, S. A.

1883. The delon Plant Louse (Aphis cucumeris n. sp.). Twelfth Jeport of the State Entomologist on the Noxious and Beneficial Insects of the State of lllinois, for the year 1882, pp. 83-91. 
15S4. Recent Observations. Plant-Lice-Aphides. Thirteenth Report of the State Entomologist on the Noxious and Beneficial Insects of the State of Illinois, May 31, jp. 1-203, pls. 1-xv.

1591. A Summary History of the Corn-Root Aphis. Seventeenth Report of the State Entomologist on the Noxious and Beneficial Insects of the State of Illinois, for the years 1589 and 1S90, pp. $64-70$, pl. II (figs, 2,4 ).

1900. Twenty-first Report of the State Entomologist on the Noxious and Beneficial Insects of the State of Illinois, pp. 1-184 and i-xxvili, pls. I-1x.

Folibes, S. A., and C. A. HAl:T

1895. Eighteenth Report of the State Entomologist on the Noxious and Beneficial Insects of the State of Illinois. Mtarch, pp. 1-149, pls. $\mathrm{I}-\mathrm{Xr}$.

Frisox, T. H.

1927. A List of the Insect Types in the Collectious of the 1llinois State Natural History Survey and the University of lllinois. Illinois State Natural History Survey Bulletin, Vol. XVI, Art. 1\%, February, pp. $137-309$.

GaRMAx, H.

1595. The Bean Root-louse. Seventl Annual Report of the Fentucky Agricultural Experiment Station, for the year 1894, pp. xxilxxirt, figs, 2,3 .

Gillette, C. P.

1907. New Species of Colorado Aphididae, with Notes upon Their LifeHabits. Canadian Entomologist, Vol. Nixix, No, 12. Decem her, pp. 3\$9-396. pl. xi.

190Sa. New Species of Colorado Aphididae, with Notes upon Their Lifehabits. Canadian Entomologist, Vol. XL. No. 1. January, pp. 17-20, pl. 1; Vol. Xl, No. 2, February, pp. 61-68, pl. 111.

1908b. Notes and Descriptions of Some Orchard Plant Lice of the Family Aphididae. Journal of Economic Entomology, Vol. 1. No. 5. October, pp. 302-310, pls. 5, 6; Vol. I, No. 6, December, pp. 359-36.. pls. S, 9.

1909a. Phyllaphis coweni Ckll. Canadian Entomologist, Vol. NLl, No 2, February, p). 41-45, pl. 1 .

1909b. Two Little-known Aphids on Carer s]. Entomological News. Vol. XX, No. 3. March, pp. 119-121, pl. vill.

1909c. American Snowhall Louse, Aphis viburnicola n. sp. Entomological News, Vol. NX, No. 6, June, pp. 2S0-2S5, pl. xi.

1909d. Plant Louse Notes, Family Aphididae. Jourual of Economic Entomology, Vol. 11. October, No. 5, pp. 351-35s, pl. 12; Vol. Il, No. 6, December, pp. 3\$55-3\$\&, pl. 13.

1910. Plant Louse Notes, Fanily Aphididae. Journal of Economic Entomology, Vol. Ill, No. 4, Allgust, pl), 367-371, pl. 24; Vol. 11 I. No. 5, October, pp. 403-407, pl. 26.

1911a. Plant Louse Notes, Family Aphididac. Journal of Economic Entomology, Vol. IV, No. 4, Angust, pp. 3\$1-3\$5, pl. 16.

1911b. Two Rhophlosiphum Species and thhis muterulens n. sp. Journal of Economic Entomology, Vol. IV, No. 3, June, pp. 32(1-325, pl. 9.

1911c. A New Genus and Fonr New Species of Aphidisae. Entomological News, Vol. XX11, No. 10, December. np. 440-444, figs. 1-16. i). $x$ iा.

1914. Two Colorado Plant Lice (Hemip.-Homop.). Entomological News, Vol. XXV, No. 6, lune, pp. 269-275, pl. XI.

1915. Confusion of Rhomalosiphum himpohaes lioch and $u y z u s$ mragoii Gillette. Journal of Economic Entomology. Vol. Vill. So. ¿. Jule, p). 375-379, pls. J7-IS.

19]7a. Some Colorado Species of the Genus lachnus. Annals of the Entomological Society of America, Vol. X, No. 2, June, pp. 13:3144. pls, x, xi. 
1917b. Two New Aphid Genera and Some New Species. Canadian Entamologist, Vol. XLIX, June, pp. 193-199, pl. xI.

1915. Some Grass-root Aphids (Hem., Hom.). Entomological News, Vol. XXix, No. 8, October, pp. 2\$1-2\$4, pl. xis.

1927. Notes on a Few Aphid Species and the Genus Illinoia Wilson. Annals of Entomologica! Society of America, Vol. 20, No. 3, September, pp. 344-348, figs. 1-2.

Gil.htti., C. P'., and L. C. Br.igg

1915. Notes on Some Colorado Aphids Having Alternate Food Habits. Journa] of Economic Entomology, Vol. Vlll, No. 1, February, pp. 97-103.

1917. The Migratory Habits of Myzus ribis (Linn.). Journal of Economic Entomology, Vol. 10, No. 3, June, pp. 3is -340 , figs. 1-17.

1918. tphis saliceti (Kaltenbach), siphocoryne pastinarae (Linn.), and Allied Species. Canadian Entomologist, Vol. 50. No. 3, March, pp. 89.94 , figs. 1-20.

Gillette, C. P., and M. A. Paliei

1924. New Colorado Lachnini. Annals of the Entomological Society of America, Vol. XVlI, No. 1, January, pp. 1-44, pls. 1-xill.

1928. Notes on Colorado Aphididae. Annals of the Entomological Society of America, Vol. XXJ, No. 1, March, pp. 1-24, pls. I-11.

1929. New Colorado Aphididae. Annals of the Entomological Society of America, Vol. XXII, No. 1, Warch, pp. 1-32, pls. I-rilr.

Gidist:, C. P., and E. P. TAYiok

1908. A Few Orchard Plant Lice. Agricultural Experiment Station of the Colorado Agricultural College, Bulletin 133, September, pp. $1-48$, pls. $1-4$, fig. 1 .

GLovis, T.

1877. Report of the Entomologist and Curator of the Museum. Report of the Commissioner of Agriculture of the Operations of the Department for the year 1876, Government Printing Office, Washingtoll, D. C., pp. 17-46, figs. $37-44$.

Gumix, Juhix Frienricu

1790. See Limnaeus, Systema Naturae, 1790.

Gorzl:, J. A. E.

1778. Entomologische Beyträge zu des Ritter Linnẻ zwölften Ausgabe des Natursystems. Band II, Leipzig. pp. 1-352.

Gruxossis, A. A.

192Sa. A New Genus and Species of Aplididae (Homoptera). Proceedings of the Entomological Society of Washington, Vol. XXX, No.

7. Oetober, pp. 113-119.

1925h. A Review of Myzocallis Species Inlabiting $4 \ln u s$. With Description of a New Species (Homoptera. Alliidae). Annals of the Entomological Society of America, Vo!. XXI, No. 4, December, pp. 546-565, pl, xxxt.

Groxmani, C. F.

1930. Fifty Common Plant Galls of the Chicago Area. Field Musenm of Natural History, Botany Leaflet No. 16, pp. 1-29, figs.

H.IRI:IS, T. W.

1841. A IReport on the Insects of Massachusetts. Injurious to Vegetation. pp. 1-45.9. (1S42 Reprint: A Treatise on Some of the Insects of New England, Which Are Injurious to Vegetation. Cambridge.).

H.1:T1G, G. I.

1839. Jaluresberichte über die Fortscluritte der Fortwissenseliaft und fortslichen Naturkunde in Jahre 1836 und 1837 nebst Origina]Abhandlungen aus dem Gebiete dieser Wissensclaften. IBerlinFörstner. Abhandlungen, I, Heft 4 , pp. 640-646. 
HATSAIAXX, J. F. L.

1802. Beiträge zu den Mlaterialien für eine künftige Bearbeitung der Gattung der Blattläuse. Illiger's Mlagazin für Insektenkunde. Braunschweig. Vol. I, pp. 426-446.

HaYHLRT, Pall

1909. Observations on a Gall Aphid (Aphis atriplicis L.). Annals of the Entomological Society of America. Vol. 1I. Xo. 11, June, pp. 88.99 , pl. $x i$.

Heririck, G. W., and J. W. Hixidte

1911. The Cabbage Aphis. Cornell University Agricultural Experiment Station of the College of Agriculture, Bulletin ..o. 300. Mlay. pp. $717-746$, figs. $286-292$.

Hongriss, H. E

1919. Control of Green Apple Aphis in Bearing Orchards. Tew Iork Agricultural Experiment Station. Bulletin 461. June, pp. 97-134. pls. I-X.

HORSFALI, J. L.

1925. The Life History and Bionomics of tphis rumicis. University of Iowa. Studies in Natural History, Vol. XJ, Xo. 2 (new series No. 87), February 15 , pp. 1-57, pls. I-1X.

HotTES, F. C.

1930a. Aphid Homonyms. Proceedings of the Biological Society of Washington, Vol. 43, October 7 , pp. 179-IS4.

1930b. The Name Cinart versus the name Lachnus. Proceedings of the Biological Society of Washington, Vol, 43 , Norember $\bar{i}$, pp. 185-18S.

Huxtek, S. J., and P. A. Giexs

1909. The Green Bug and Its Enemies. Bulletin of the Lniversity of Kansas, Vol. IX, No. 2, pp. i-ix, 1-22I, pls. I-111 (colored), pls. I-1X (half-tone and line), text figs. 1-65.

JACKsox, C. F.

1907. A Synopsis of the Genus Pemphigus witl Notes on Their Economic Importance, Life History, and Geographical Distribution. Proceedings of the Columbus Horticultural Society. Vol. 22. pp. $160-218$, 3 figs.

1908. Notes on the Aphididae. (I) Observations on a Semiraquatic Aphid, Aphis uquaticus n. sp. The Ohio Naturalist. Vol. VIII. No. 3, January, pp. 243-249. pl. xirı.

JoHAxxisex, O. A., and E. M. PATCu

1911. Insect Notes for 191I. Maine Agricultural Experiment Station. Bulletin No. 195, December, pp. 229-24i, 2 pls.

Joxes, C. R.

1929. Ants and Their Relation to Aphids. Colorado Agricultural College, Bulletin 341. February, pp. 1-96.

JoNks. T. H., and C. P. GH.LETTE.

1918. Life History of Penphigus mopuli-transmersus. Journal of Agri-

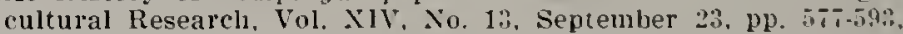
fig. 1 , pls. $\$ 1-\$ 5$.

K.LTEXIACH, J. H.

1843. Mlonographie der Familien der Pflanzenlänse (Pluytophthires). Aachen. In Commission der Roschüt z'schen Buchlıandlung (P. Fagot), pp. 1-222, pl. 1.

I846. Fünf nene Species ans der Familie der Pllanzenlăuse. Entomologische Zeitung. Hcrausgegeben von den entomologischen Vereine zu Stettin, Vol. VII, pp. 169-1i5. 
lítisteli, H. F.

1SS6. Die Entwickelungs und Lebensgeschichte von Chaitophorus aceris Koch, Chaitophorus testurinatus Thorn., und Chaitophorus lyropictus Kessler. Nova Acta Academie Caesareae LeopoldinoCarolinae Germanicae Naturae Curiosorum. Band L.I, No. 2. pp. $149-180, \mathrm{pl}$. $\mathrm{x} \times \mathrm{N}$.

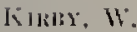

179S. History of Timula tritici and lchneumon tipulac. with Some observations upon Other Insects That Attend the Wheat, in a Letter to Thomas Marsham. Transactions of the Linnean Society of London, Vol. IV, pp. $230-239$.

lixowltux, G. F.

1929a. Notes on a Few Species of Mlyzini (Aphididae) from Utah with Descriptions of Two New Species. Canadian Entomologist, Vol. LX1, No. 1. January, pp. 9-15, figs. 1-7.

1929b. Aphid Notes from Utah. The Pan-Pacific Entomologist, Vol. VI, No. 1, July, pp. 33-42, figs, 1-7.

Focir, C. L.

1857. Die Ptlanzenläuse, Aphiden, getren nach dem Leben abgebildet und beschrieben. Nürnberg, Latzbeck, Heft 8 , u. 9, pp. 237 . 335,12 Taf.

LEB.1:0.5. W'.

1871. Insects Injurious to the Willow. Second Report on Noxious Insects in Illinois, pp. 1-70, 23 figs.

1S73. Insects Injurious to the Cottonwood. Third Annual Report on the Noxious Insects of the State of Illinois, Springfield, pp. 193 . 199, 1 fig.

L.IXXkts, C.

175s. Systema Naturae, Editio Decima, umgearbeitet u. sehr vermehrt. Holmiae, Laur. Salvii, Bd. 1, 8, 2 u. $\$ 24$ p.

1761. Fauna Suecica, Editio Altera, Auctior, Stockholm, 578 pp., 2 pls.

1790. Systema Naturae, Thirteenth Edition, Lipsiae (Gmelin, J. F.), Impensis Georg. Emanuel, Beer, Tomus 1, Pars. IV, 2224 pp.

Ml s. X. P. Wr.

1923. The Raspberry Cane Aphid (Hom.). Proceedings of the Entomological Society of Washington, Vol. 25, No. 9, December, pp. $1 S 8-190$.

1925. A Revision of the Insects of the Aphid Genus Amphorophora. Proceedings of the ['nited States National IIuseum, Vol. 67, Art. 20 , September 23, pp. 1-73, pls. 1-18.

IH.ATIESOX, R.

1919. A Study of the Plant Lice Injuring the Foliage and Fruit of the Apple. Cormell University Agricultural Experiment Sta. tion, Nemoir 24, June, pp. 679-762, figs. 111-120, pls. vil-xxix.

Ilsisiox, A. C.

192:. Subfamily Pemphiginae. In The Hemiptera or Sucking Insects of Connecticut. Bulletin No. 34, Connecticut State Geological and Natural History Survey, pp. $311-229$.

M.xinox, A, C., and F. C. Huttr:s

1!26a. A New Tribe and a New Species in the Subfamily Pemphiginae (Homop.: Aphididae), Entomological News, Vol. XXxVI, Io. 5, May, pp. 129-133, pl. V.

1926b. Georgiaphis Nom.n. for (Feornia (Aphididae, Homop.). Entomological News, Vol. XXXVil, No. 8, October, pp. 266, 267.

MAxiox, A. C., and G. F. KNowito.

1029. The Tribe Pemphigini in Utah. Annals of the Entomological Society of America, Vol. XXIl, No. 2, June, pp. 251.271, figs. 1-8. 
MFtC.U.F. C. L., and WT, P. Flixt

1928. Destructive and Useful lnsects. McGraw-Hill Book Company, New York. xii +918 pp., 561 figs.

MIUHETON. NETTIE

1878. A New Species of Aphis, of the Genus Colopha. Bulletin of the Illinois State Laboratory of Natural History, Vol. I, No. 2. June, p. 17 .

Moxel., J. T., and C. V. Rusr

1579. Notes on the Aphididae of the Inited States with De-criptions of Species Occurring West of the Mississippi. Part 1I: Notes on Aphidinae, witl Descriptions of New Species by Monell. Bulletin of the United States Geological and Geographical Survey of the Territories, Vol. V. No. 1, Art. 11, January 22, pp. 1-32.

MOXELL, J. T.

1582. Notes on Aphididae. Canadian Entomologist, Vol. XiV, No. 1, January, pp. $13-16$.

Monnvilko. A.

1924. Eriosoma lanigera. Biology and Distribution. Transactions of the Department of Applied Entomology, Leningrad, Vol. XII. No. 3,110 pp., 4 pls.

1928a. Les Pemphigiens des Pistachiers et Leurs Formes Anolocycliques. Bulletin de la Société Zoologique de France. Tol. 53. Julỵ 10, pp. $358-366$.

1928b. The Evolution of Cycles and the Origin of Heteroecy (Migrations) in Plant Iice. Annals and Magazine of Natural History, Series 10. Vol. II, December, pp. 570-5 $\$ 2$.

Nevili, V. P.

1929. Aphids of Central Asia. Uzbekistan Experimental Station of Plant Protection, Tashkent Pub. XVI, 424 pp.. $10 S$ figs.

Oestruxu, O. W.

18S6. List of the Aphididae of Minnesota, with Descriptions of Some New Species. Fourteenth Annual Report of the State Geologist of Minnesota, March, pp. 17-56.

1887. Synopsis of the Aphididae of Minnesota. Geological and Natural History Survey of Minnesota, Bulletin No, 4, pp. 1-97.

1922. A Synoptical liey to the Aphididae of Minnesota. Nineteenth Report of the State Entomologist of Nimnesota. pp 114-1.i.

OEstixn, O. W., and F. C. HotTes

1926. A Chapter in the Life History of Morluilkoja "aqabundus (Aphidiclae). Annals of the Entomological Society of America. Fol. XIX, No. 1, March, pp. $75-81,1$ pl.

Osisols, H., and F. A. Sikis.x:

1892. Notes on Aphididae. Insect life. Vol. V. pp 235-237.

PAck. H. J., and G. F. Kxแmatox

1929. A Few Match Brush Aplids from ['tah. Canalian Entomologist. Tol. LAl, No. 9, September, pp. 199-204. figs. 1-5.

l'mork. F. B.

1915. The Turnip Louse. Texas Agricultural Experimeat Station. Bulletin $1 \mathrm{~s} 0$, October, pp, $7-7 \tau, 10$ figs., 5 pls.

I’ภkки, J, R,

1916. The Western Wheat Aplis (Brachy/ulus tritici Gill.), Journal of Economic Entomology, Tol, 9. No. 1. February, pp. 152-15:. pl. $x$.

P.Al: Ki:L, II, 13 .

19): The Hop Aphis in the l'ucific Region. $l^{*} \mathrm{~S}$. Department of Agriculture, Bureau of Entomology, Bulletin Xo. 111, May 6, pl). 1.4:. figs. 1-8, pls. $1-x$. 
P.Issekixl. Giovasi

1860. Gli Afidi. Con un prospet to dei generi ed alcune specie italiane. 2nd ed., Parma, 1S60, 40 pp.

P.тси, Euitii M.

1908. Pemphigus tessellata: Alternate Host, Migrants and True Sexes. Entomological News, Vol. XIX, No. 10, December, pp. 484-488, pl. $\mathrm{xxil}$.

1909a. Homologies of the Wing Veins of the Aphididae, Psyllidae, Aleurodidae, and Coccidae. Aunals of the Entomological Society of America, Vol. 2, No. 2, June, pp. 101-129, pls. xir-xxi.

1909b. Pemphigus venafuseus n. sp. Entomological News, Vol. XX, No. 7, July, pp. 319-322, pl. xin.

1909c. The Desmodium Aphid, Micropursus variabilis n. sp. Entomological News, Vol. XX, No. 8, October, pp. 337-341, figs. 1-6, pls. Xi1II, xix.

1910a. Gall Aphids of the EIn. Maine Agricultural Experiment Station, Bulletin No. 181, Mlay, pp. 193-240, figs. 126-197.

1910b. Four Rare Aphid Genera from Maine. Maine Agricultural Experiment Station. Bulletin No. 1S2, June, pp. 241-24S, 6 pls.

1911a. Two Species of Macrosiphum. Maine Agricultural Experinent Station, Bulletin 190, June, pp. 81-92, figs. 59-72.

1911b. Insect Notes for 1911. Maine Agricultural Experiment Station, Bulletin No. 195, December, pp. 229-248, 2 pls.

1912a. Aphid Pests of Maine. Maine Agricultural Experinent Station, Bulletin No. 202, July, pp. 159-178, figs. 269-315.

1912b. Elm Leaf Curl and Woolly Apple Aphid. Maine Agricultural Experiment Station, Bulletin No. 203, August, pp. 235-25s, figs. 438-462.

1913a. Aphid Pests of Maine-11. Willow Family. Maine Agricultura] Experiment Station, Bulletin No. 213, June, pp. 73-100, figs 20-51.

1913b. Woolly Aphid of the Elm. Maine Agricultural Experiment Station. Bulletin 220, November, pp. 259-29S, figs. 119-143.

1914a. Currant and Gooseberry Aphids in Maine. Maine Agricultural Experiment Station, Bulletin 225, February, pp. 49-68, figs. 5-37.

1914b. Maine Aplids of the Rose Family. Maine Agricultural Experi. ment Station, Bulletin 233, November, pp. 253-2S0, figs. \$9-97.

1915a. Two Clover Aphids. Journal of Agricultural Research, Vol. III, No. 5, February 15, pp. 431-433, figs. 1-3.

1915b. The Pond-Lily Aphid as a Plum Pest. Science, (new series), Vol. XLII. No. 1074, July 30, p. 164.

1915c. Pink and Green Aplid of Potato. Maine Agricultural Experiment Station, Bulletin 242, October, pp. 205-223, figs. 47-49.

1917. Eastern Aphids, New or Little Known, Part I. Journal of Economic Entomology, Concord, Vol. 10, No. 4, August, pp. $\$ 16-420$, fig. 20 .

1918. Eastern Aphids. A Few Species of Prociphilus. Maine Agricul. tural Experiment Station, Bullet in 270, pp. 45-99, figs. 4, 5.

1919. Three Pink and Green Aphids of the Rose. Maine Agricultural Experiment Station, Bulletin 2S2, pp. 206-24S.

1920. The Life Cycle of Apbids and Coccids. Annals of the Entomological Society of America, Vol. XI11, No. 2, June, pp. 156-167.

1923a. The Sumner Food Plants of the Green Apple Aphid (Aphis pomi). Maine Agricultural Experiment Station. Bulletin 313, October, pp. $45-68$, figs. $15-22$.

19231. Family Aphididae. Connecticut Geological and Natural History Survey. Bulletin 34, Guide to the Insects of Condecticut. Part IV. The Hemiptera or Sucking insects of Connccticut. pp. $290-311$.

1924. The Buckthorn Aphid. Maine Agricultural Experiment Statiou. Bulletin 317, April, pp. 24-52, figs. 6-8. 
1925. The Melon Aphid. Maine Agricultural Experiment Station. Bull. 326, September, pp. 185-196, figs. 13-15.

1927. Two Current Aphids that lligrate to Willow-Herbs. Maine Agricultural Experiment Station, Bulletin 336 (Entomologr No. 120), January, pp. 1-8, figs. 1, 2.

1929. The Apple Aphid and the Citrus Aphid: Aphis pomi DeGeer and A. spiraecola Patch. Journal of Economic Entomology, Vol. 22, No. 4, August, pp. 698-699.

Pergaxde, T.

1900. A New Species of Plant-Louse Injurious to Violets. Canadian Entomologist, Vol. XXX11, No. 2, Fehruary, pp. 29-30.

1901. The Life-history of Two Species of Plant-lice Inhabiting Both the Witch-liazel and Birch. U. S. Department of Agriculture, Dirision of Entomology, Technical Series, No. 9, pp. 1-44. figs. 1-23.

1904. On Some of the Aphides Affecting Grains and Grasses of the United States. Department of Agriculture, Division of Entomology, Bulletin No. 44, pp. 1-23, figs. 1-4.

1912. The Life History of the Alder Blight Aphis. Department of Agriculture, Bureau of Entomology. Technical Series, No. 24. April 29 . pp. 1-2S, figs. 1-12.

PIIILLIS. IV. J.

1916. Macrosibhum granarium, the English Grain Aphis. Journal of Agricultural Research, Vol. XI, No. 11, December 11, pp. 463480 . fig. 1, pls. B, 33, 34, tables I-III.

QUAITANCE, A. L., and A. C. BAkER

1917. Aphids Injurious to Orchard Fruits, Currant, Gooseberry, and Grape. U. S. Department of Agriculture, Farmers' Bulletin sot. April, pp. 1- $\$ 2,30$ figs. (Also Farmers' Bulletin 1128, June, 1920. pp. 1-48.)

RıLEY, C. V.

1869. First Annual Report on the Noxious, Beueficial, and Other Insects of the State of Missouri. Jefferson City. pp. 1-1\$1, two colored plates, many woodcuts.

1579. Notes on the Aplididae of the United States, with Descriptions of Species Occurring West of the Mississippi, by Mlonell and Riley. Part 1: Biological Notes ou the Pemphiginae, with Descriptions of New Species, by Riley. Bulletin of the U. S. Geological and Geographical Survey of the Territories, Vol. V. No. 1, Art. 1. pp. 1-32.

ROIIWEI:, S. A.

1908. The Aphid Genus forda. Psyche, Vol. XY. August. pp. 67-6S.

RoxuAx, C.

1852. Lettera al S. Prof. G. Bertoloni: Nota sopra una specie di Afide. volante in numerosa torma vella citta di Parma. Nuovi annali delle scienze naturali. Bologna, ser, 3, Vol. VI, pp. 9-12.

Rosis. W. A.

1917. The Secondary Host of $M y=u s$ ecrasi. Canadian Entomologist, Vol. XIIX, No. 12, December, p. 434.

S.хиокх, C. E.

1904. liansas Aphididae with Catalogue of Nortl American Aphididae and Host-Plant and Plant Host List. Kansas ["niversity Science Bulletiu, Vol. III. No. 1, July, pp. 3-S2. pls. 1-xiı.

S.INUERSOX, E. D.

1900. The Strawbery Root Louse. Delaware College Agricultural Experiment Station, Bullet in XLIX, December, pp. 3-13.

1901. Report of the Entomologist. Twelfth Annual Report of the Dela. ware College Agricultural Experiment Station. pp. 142.23S. figs. $1-14$, pls. I-r. 
1902. Report of the Eutonologist. Thirteenth Annual Report of the Delaware College Agricultural Experiment Station, pp. 127-199, figs. 13-33.

SCHot'TEDEx, H.

1906. Catalogue des Aphides de Belgiqque. Memoires de la Société Entomologique de Belgique, Tome Xil, pp. 189-246.

Scimaxk, Finaz vox Payla

179s. Fauna Boica, Durchgedachte Geschicte der in Baiern einheintischen und zolnwen Thiere, Nurnberg (Ingalstadt, Landshut), Band 1, Teil 1, pp. 1-292; Teil 2, pp. 293-720.

1S01. Ibil. Band II, Teil 1,374 pp. (durche Druckfeller 274); Teil 2, $1802,412 \mathrm{pp}$.

1803. Ibid. Band III, Teil 1, 272 pp.; Teil 2, 1904, 372 pp.

SHIIIEI: H.

1866. A New Grape Aphis. Prairie Farmer, Vol. 1S, No. 20, November 17, p. 316.

1867. On a New Genus of Aphidae. Transactions of the American Entomological Society, Vol. I, pp. 283-285.

SHILI. A. F.

1925. The Lite Cycle of Macrosiphum solanifolii with Special Reterence to the Genetics of Color. The American Naturalist, Vol. LIX, No. 663, July-August, pp. 289-310, tables 1-5.

Sirin, E. F.

1590. The Black Peach Aphis. Entomologica Americana, Vol. VI, No. 6. Brooklyn, June, pp. 101-103, and pp. 201-20s.

SMITII, L. B.

1919. The Life History and Biology of the Pink and Green Aphid (.1)acrosiphum solanifolii Ashmead). Virginia Truck Experiment Station, Bulletin 27, April 1. pp. 27-79, figs. 3-11, tables I-V.

S.IIII. R. L.

1921. Anuraphis helichrysi Kalt., a Pest of Prune, Plum, and Red Clover in Idaho. Journal of Economic Entomology, Vol. 14. No. 5, October, pp. $422-423$.

Sim.tux, L. B.

1927. A Comparative Study of the Structural Characters Used in the Classification of the Genus Macrosiphum of the Family Aphididae, with Special Reference to the Species Found in California. University of California Publications in Entomology, Vol. 4, No. 6. pp. $89-158,77$ figs.

SILZHK, J. H.

1776. Abgekürzte Geschicte der Insecten nach dem Linneischen System. Winterthur, H. Steiner u. Co. Teile 1, $27+274$ pp.; Teile 2. $71 \mathrm{pp} ., 32$ Taf.

Siw.11, A. F.

1919. A Synopsis of the Aplididae of California. University of California Publications in Entomology, Tol. 111, No. 1, November 1. pp. 1-221, pls. 1-17.

T.MIIIASII, R.

1430. List of the Aphid Genera Proposed as New in Recent Years. Proceedings of the Entomological Society of Washington, Vol. 32. No. 1, January, pp. 1-24.

T11:013.11), F. V.

1912. A New Strawberry Aphis, Entomologist, Vol. X1X. Xo. 591, August, p. 223.

1926. The Plant Lice, or Aphididae, of Great Britain, Headley Brotlers, London. Vol. 1, 372 pp., 196 figs.

1927. Ibirl. Vol, 11, 411 pp., 182 figs.

1929. Jhirt. Vol. III, 364 pp., 213 figs. 
THoMAS, CYRLS

1877. Notes of the Plant-lice Found in the Cnited Staces. Transactions of the Illinois State Horticultural Society for 1876., pp. 137-212, figs. $1-8$.

1878. A List of the Species of the Tribe Aphidini, Family Aphididae, Found in the [nited States, Which Have Been Heretofore Named, with Descriptions of Some New Species. Bulletin 1lli. nois State Laboratory of Natural History, Vol. I, No. 2, June, pp. 3-16.

1579. Eighth Report of the State Entomologist on the Noxious azd Beneficial Insects of the State of Illinois. Third Annual Report by Cyrus Thomas. 212 pp., 47 figs.

Troor, J.

1906. A New Aphid. Entomological News, Vol. XVII, No. 2, February, pp. $59-60,3$ figs.

V.IN DEI Goot, P.

1915. Beitråge zur Kemntnis der Holländischen Blattåuse. Eine morphologisch-systematische Studie. Haarlem, H. D. Tjeenk IIillink \& Zoon. 600 pp., \& Tafel.

Vicisiry, R. A.

1908. A Comparative Study of the External Anatomy of Plant Lice. Twelfth Report of the State Entomologist of Minnesota for the years 1907-1908, December, pp. 178-191, figs. 94-9s.

1910. Contributions to a Knowledge of the Corn Root-Aphis. (Aphis maidi-radicis Forbes). $\mathrm{U}$. S. Department of Agriculture, Bur. eau of Entomology, (Cereal and Forage Insects Investigations). Bulletin 85, Part V. July 12, pp. 97-11S, figs. 54-59.

W.M.Kin, F.

184S. Descriptions of Aphides. The Annals and Nagazine of Natural History, (second series) Vol. I, No. 4, Art. XxIr, pp. 249-260, April; No. 5, Art. xxxis. pp. 32s-345, May; Vol. II. No. T. Art. v1. pp. 43-53, July; No. 8, Art. x, pp. 95-109, Angust; No. 9, Art. xxiI, pp. 190-203, September; No. 11, Art. xlin, pp. 421-431, November.

1849a. Descriptions of Aphides. The Annals and Magazine of Natural History, Second Series, Vol. III, No. 13, Art. 111, pp. 43-53, January; No. 16. Art. xxxv, pp. 295-304, April; Vol. IT, No. 19. Art. v11, pp. 41-4S, July; No. 21, Art. xxil1, pp. 195-202, September.

1S49b. Descriptions of New British Aphids. Zoologist, Vol. VIl, (appendix), pp. (il-(').

1850. Descriptions of Aphides. The Anmals and Iagazine of Natural History, Second Series, Vol. V, No. 25, Art. 111, pp. 14-2S. Jan. uary; No. 28, Art. xxin, pp. 269-2s1, April; No. 29, Art. xxxv. pp. 3S\$-395. May; Vol. Vl, No. 31. Art. VI, pp. 41-4S, June; No. 32, Art. xil, pp. 11 \&-12:, July.

W.ISII, B. D.

1S62. On the Genera of Aphidae Found in the Lnited States. Proceed ings of the Entomological Society of Philadelphia, Vol. 1, December, pp. 294-311, 8 figs.

W.us11, B. D., and C. I. Rur.

1569. Galls and Their Architects. The American Entomologist, Vol. I. No. 6. February, 1S69, p). 101-110, figs.

Wristr.k, F. Ml., and W. J. P111.1.1P'

1912. The Spring Grain Aphis or "Green Bug." [?. S. Department of Agriculture, Bureau of Entomology, Bull. No. 110. September. pp. 1-15i, figs. $1-4 \$$, pls. $1-1 \mathrm{x}$.

WEAsTris, R. L.

1917. The Box Elrler Aphid. Agricultural Experiment Station of the Iowa State College of Agriculture and Alechanic Arts. Bulletin No. 17i, October, p|j, 95-121, figs. 
WEED, A.

1927. Metamorphosis and Reproduction in Apterous Forms of Myzus persicue Sulzer as Influenced by Temperature and Humidity. Journal of Economic Entomology, Vol. XX, No. 1, Felsruary, pp. 150-157, figs. 6-7, 2 tables.

WEen. C. M.

1888. Contribution to a Knowledge of the Autumn Life-history of Certain Little-known Aphididae. Psyche, Vol. V. November-December, pp, 123-134.

1859. Third Contribution to a Knowledge of the Life-history of Certain Little-known Plant Lice (Aphididae). Bulletin of the Ohio Agricultural Experiment Station, Vol. II, No. 6 (second series, No. 13), September, pp. 133-170, pl. i.

1891. Fifth Contribution to a Knowledge of Certain Little-known Aphididae. Insect Life, Vol. 11 I, No. 6, Narch, pp. 285-293, figs. 23-26, pl. i.

WhLLAMS, T. A.

1911. The Aphididae of Nebraska. University of Nebraska Studies, Vol. X, No. 2, March, pp. 1-91.

Wucsox, H. F.

1908. The Green Aphis of the Chrysanthemum-Aphis rufomaculata n. sp. Entomological News, Vol. XIX, No. 6. June, pp. 261-262.

1910a. A Key to the Geuera and Notes on the Synonymy of the Tribe Callipterini, Family Aphididae. Canadian Entomologist, Tol. XLII, No. S, August, pp. 253-259.

1910b. A Second Paper on the Genera in the Subfamily Callipterinae. Canadian Entomologist, Vol. XLI1, No. 12, Decenber, pp. 3\$4388.

1911. Two New Genera and Seven New Species of the Family Aphididae. Canadian Entomologist, Vol. XLIII, No. 2, February, pp. 59-65.

1923. Tribe Lachnini. In The Hemiptera or Sucking Insects of Connecticut. Connecticut State Geological and Natural History Survey, Bnlletin No. 34, pp. 256-271.

Whsox, H. F., and J. J. D.wis

1919. A New Genus and Species of Aphid (Hem., Hom.). Entomolog. ical News, Vol. Xxx, No. 2, February, pp. 39-40.

W1.MMIMIRT, F. 11 .

1925. The Cherry Black Fly (1/yzus crrasi). Bulletin of Entomological Research, Vol. 16. Pt. I, July 13, pp. 85-94, figs. 1-6.

Wi.NTKR, J. D.

1929a. The Identity of Aphis muirnln Oestlund and Aphis rubiphila Patcl. Entomological News, Vol. 40. No. 6. June, pp. 193-194.

1929b. A Preliminary Account of the Raspberry Aphids. Nlinnesota Agricultural Experiment Station, Technical Bulletin 61, Septeniber, pp. 1-30, figs. 1-3.

Zerk, E. H., and H. W. E.ıтTाool

1929. The Banana Aphid (Pentalonia nigronereos' Coq.). Agricultural Gazette of New South Wales, Fol. 40, No. 9, pp. 675-680. 3 figs. 
Explanition of Plate I

\section{WINGS}

Fig. 51 Mindarus abietinus Koch.

Fig. 52 Tuberolachnus saligna (Gmelin).

Fig. 53 Hormaphis hamamelidis (Fitch).

Fig. 54 Periphyllus populicola (Thomas).

Fig. 55 Parlucia antennatum (Patch).

Fig. 56 Tuberculatus punctatellus (Fitch).

Fig. 57 Calaphis castaneae (Fitch).

Fig. 58 Idiopterus neplurelepidis Davis.

Fig. 59 Longistigna caryae (Harris).

Fig. 60 Eulachnus rileyi (Williams).

Fig. 61 Myzocallis discolor (Monell).

Fig. 62 Chaitophorus quercicola (Nonell).

Fig. 63 Myzocallis bella (Walsh).

Fig. 64 Colopha graminis (Monell).

Fig. 65 Calaphis betulella Talsh.

Fig. 66 Idiopterus neplnelepidis Davis.

Fig. 67 Cinara strobi (Fitch).

Fig. 68 Anoecia querci (Fitch).

Fig. 69 Colopha ulmicola (Fitch).

Fig. 70 Chaitoplsorus pusillus Hottes and Frison.

Fig. 71 Myzocallis punctata (Monel]).

Fig. 72 Euceraphis betulae (Koch).

Fig. 73 Melaphis rhois (Fiteh).

Fig. 74 Pentalonia nigronervosa Coquerel. 

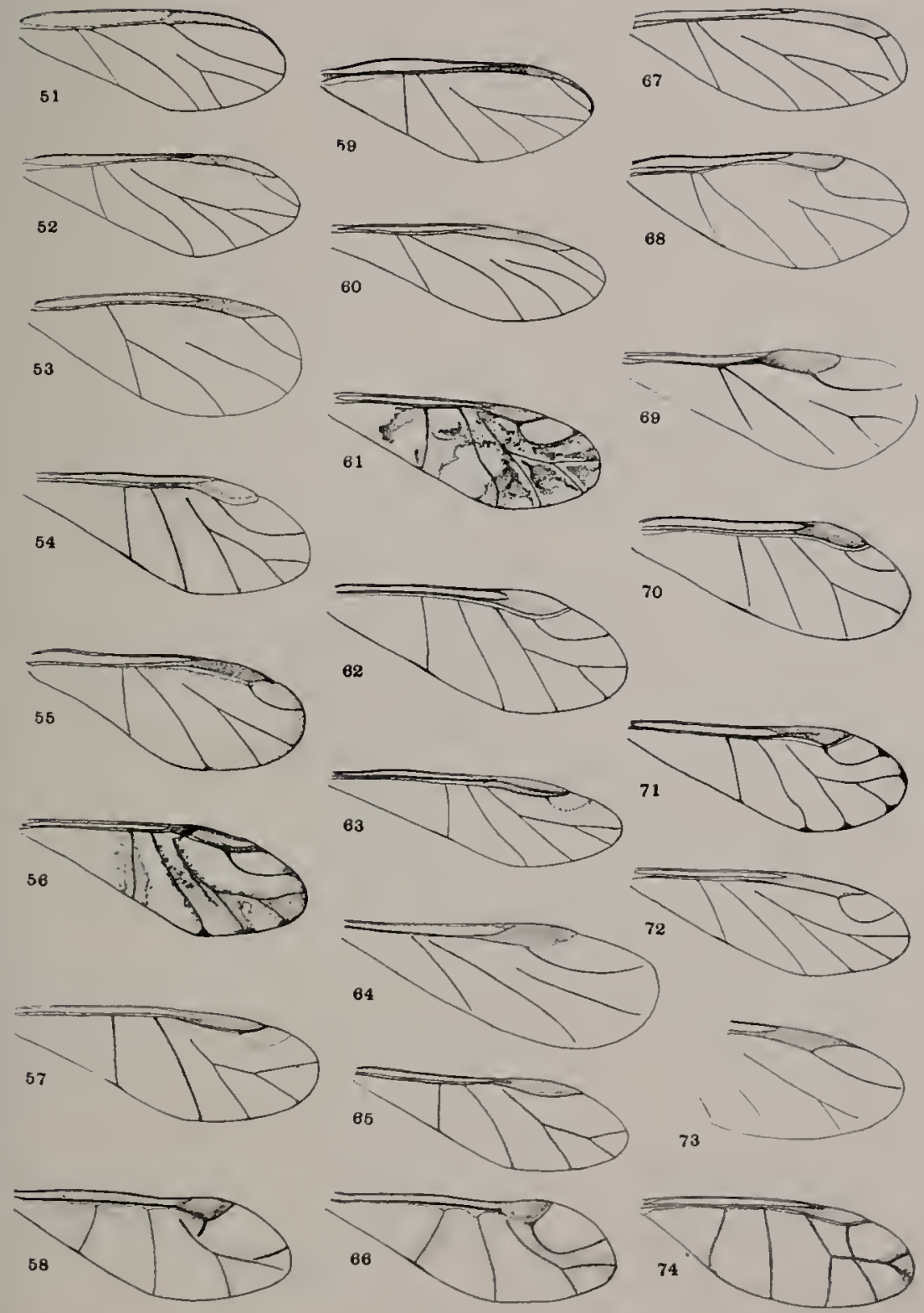

PI. ITF I 


\section{Explanation of Plate II}

\section{HEADS AND WINGS}

Fig. 75 Paducia antennatum (Patch), head, alate, viviparous female.

Fig. 76 Paducia antennatum (Patch), head, alate viviparous female.

Fig. 77 Clavigerus populifoliae (Fitch), head, alate viviparous female.

Fig. 78 Calaphis betulella Walsh, head, alate viviparous female. female.

Fig. 79 Alphitoaphis lonicericola (WVilliams), head, alate viviparous

Fig. So Aphis rumicis Linnaeus, head, alate viviparous female.

Fig. 81 Neosymydobius memorialis Hottes and Frison, head, alate riviparous female.

Fig. 82 Capitophorus patonkus Hottes and Frison, lead, alate viviparous female.

Fig. S3 Tamalia coweni (Cockerell), head, alate viviparous female.

Fig. 84 Macrosiphum rosae (Linnaeus), head, alate viviparous female.

Fig. 85 Phorodon humuli (Schrank), head, alate viviparous female.

Fig. 86 Myzus monardae (Davis), head, alate viviparous female.

Fig. 87 Gobaishia ulmi-fusus (Walsh), hind wing.

Fig. Ss Colopha graminis (Monell), hind wing.

Fig. 89 Hysteroneura setariae (Thomas), hind wing.

Fig. 90 Aphis crataegifoliae Fitch, fore wing.

Fig. 91 Myzus persicae (Sulzer), hind wing.

Fig. 92 Eriosoma crataegi (Oestlund), hind wing.

Fig. 93 Alplnitoaphis lonicericola (Williams), hind wing.

Fig. 94 Pempligus populi-venae Fitch, hind wing.

Fig. 95 Pentalonia nigronervosa Coquerel, hind wing.

Fig. 96 Microparsus variabilis Patch, hind wing.

Fig. 97 Prociphilus imbricatol (Fitch), portion of fore wing.

Fig. 95 Pemphigus populi-transversus Riley, portion of fore ning.

Fig. 99 Aphis bakeri Cowen, portion of fore wing. 

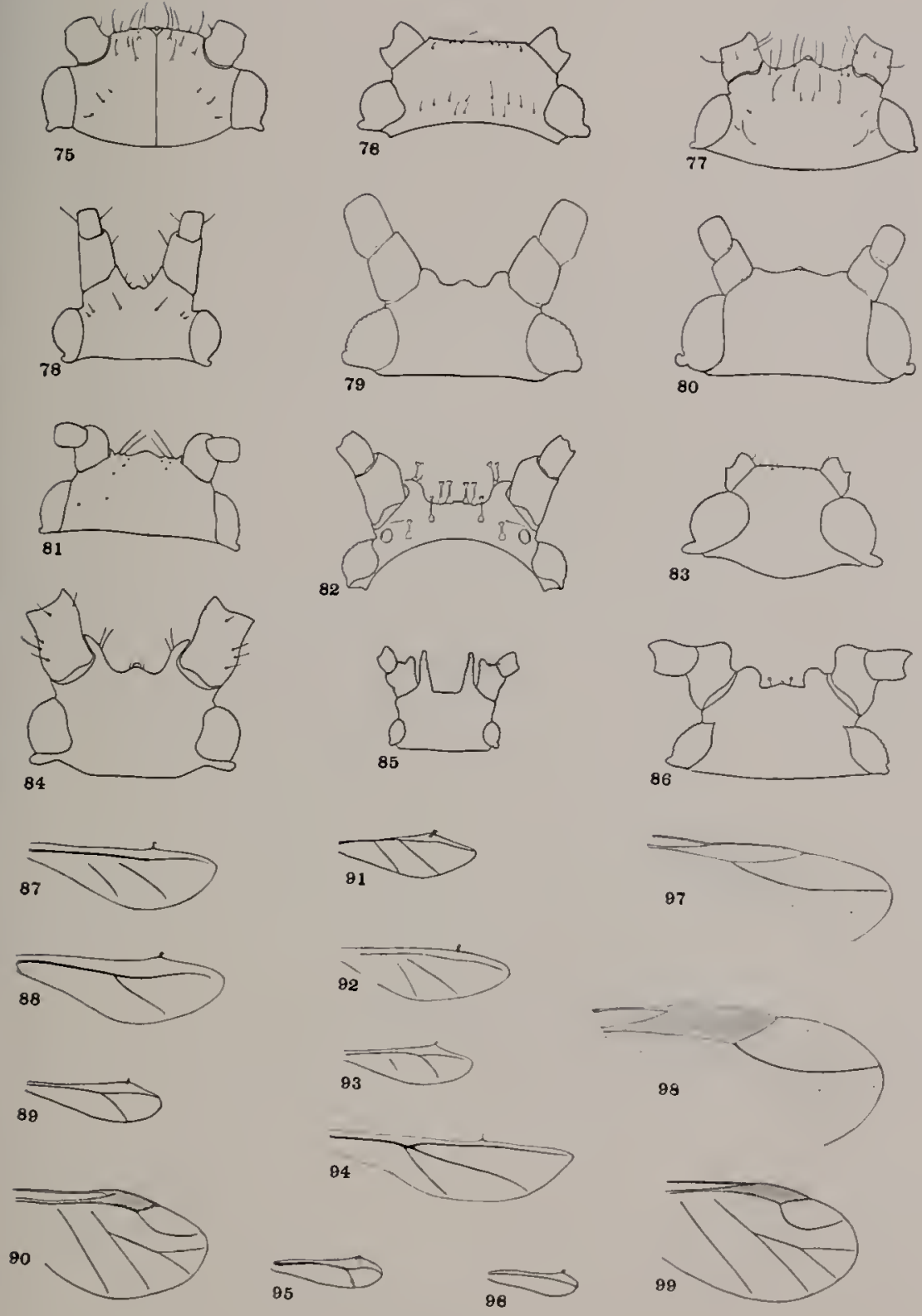

7

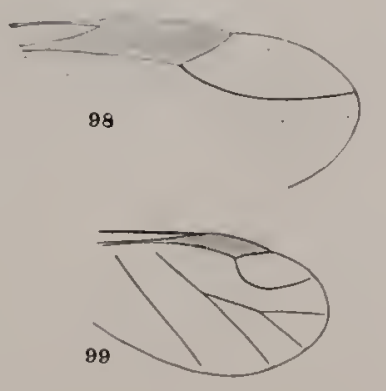

PLATE II 
ExpLANATION OF I'LATE III

\section{CORNICLES}

Alate Vivipanols Fraldite

EXCEIT FIG. 104, WHICII IS APTEROt'S

Fig. 100 Macrosiphum frigidicola (Gillette aud Paimer).

Fig. 101 Macrosiphum adianti (Oestlund).

Fig. 102 NIacrosiphum carpiuicolens Patch.

Fig. 103 Macrosiphum illini Hottes and Frison.

Fig. 104 Macrosiphum soncliella (Monell.

Fig. 105 Macrosiphum sauguinarium Hottes and Frisou.

Fig. 106 Macrosiphum sanborni Gillette.

Fig. 107 Macrosiphum tardae Hottes and Frison.

Fig. 108 Macrosiphum rosae (Linnaeus).

Fig. 109 Macrosiphum kickapoo Hottes and Frison.

Fig. 110 Macrosiphum liriodendri (Moneli).

Fig. 111 Macrosiphum gei (Ǩoch).

Fig. 112 Macrosiphum pallens Hottes and Frison.

Fig. 113 Macrosiphum sonchella (Monell).

Fig. 114 Nacrosiphnm ambrosiae (Thomas).

Fig. 115 Macrosiphum ruralis Hottes and Frison.

Fig. 116 Macrosiphum anomalae Hottes and Frison.

Fig. 117 Macrosiphum tapuskae Hottes and Frison.

Fig. 118 Macrosiphum schranki Theobald.

Fig. 119 Capitophorus pakansus Hottes and Frison.

Fig. 120 Mlacrosiphum zinzalae Hottes and Frison.

Fig. 121 Amphorophora rossi Hottes and Frison.

Fig. 122 Amphorophora singularis Hottes and Frison.

Fig. 123 Amphorophora nervata (Gillette).

Fig. 124 Myzus houghtonensis (Troop), lectotye.

Fig. 125 Capitophorus corambus Hottes and Frison.

Fig. 126 Amphorophora vaccinil Mason.

Fig. 127 Amphorophora nebulosa Hottes and Frison.

Fig. 128 Capitophorus patonkus Hottes and Frison.

Fig. 129 Myzus porosus Sanderson. 


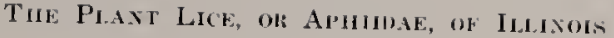

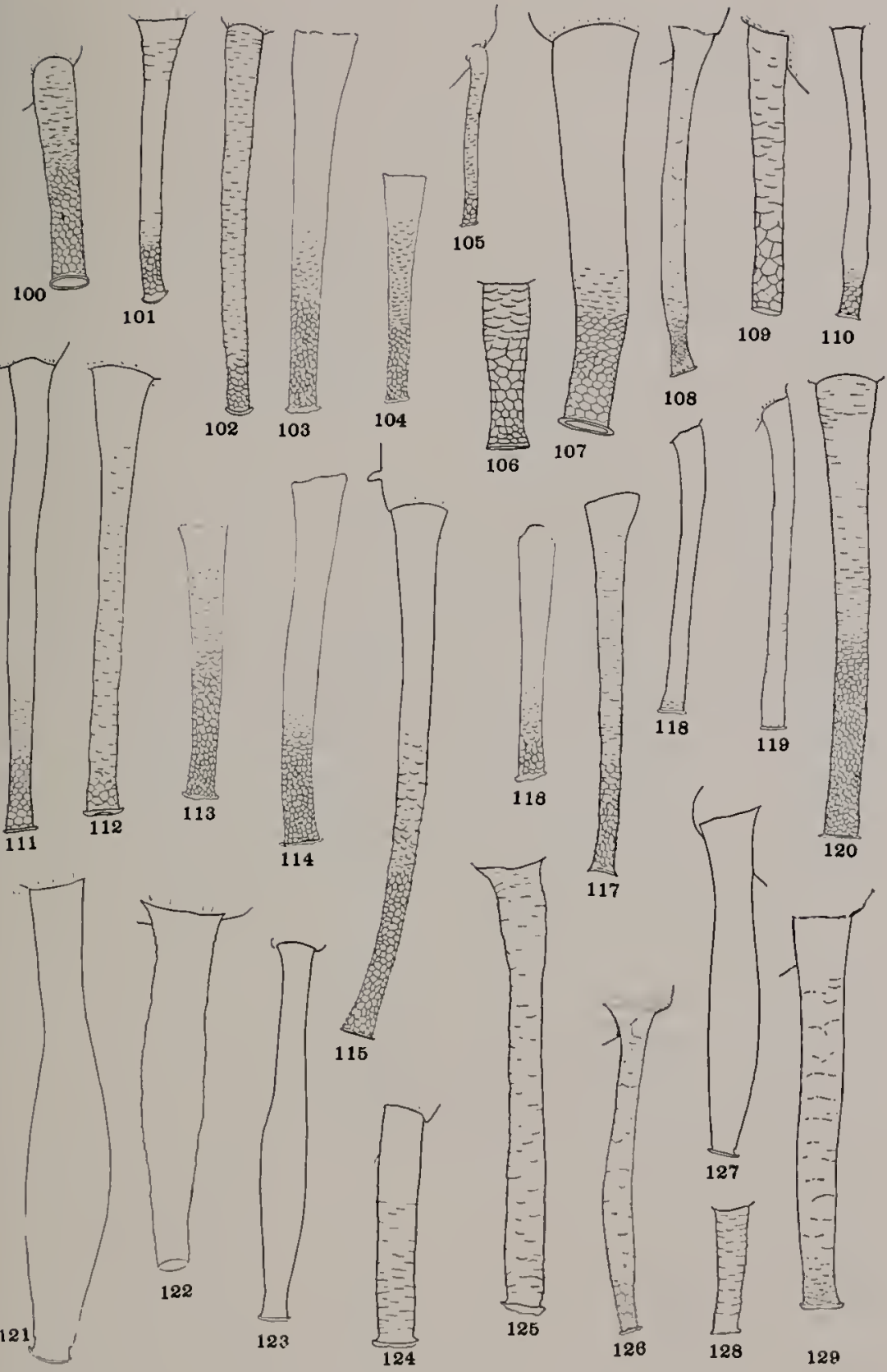

I'I,ATE; III 


\section{Explanation of Plate IV}

\section{CORNICLES}

\section{Alate Vinparous Fealales}

Fig. 130 Aphis decepta Hottes and Frison.

Fig. 131 Aphis funesta Hottes and Frison.

Fig. 132 Aphis carduella Walsh.

Fig. 133 Aphis cornifoliae Fitch.

Fig. 134 Rhopalosiphum enigmae Hottes and Frison.

Fig. 135 Hysteroneura setariae (Thomas).

Fig. 136 Alphitoaphis lonicericola (Villiams).

Fig. 137 Aphis nyctalis Hottes and Frison.

Fig. 138 Cerosipha ruhifolii (Thomas).

Fig. 139 Aphis roseus Baker.

Fig. 140 Aphis caliginosa Hottes and Frison.

Fig. 141 Aphis pulchella Hottes and Frison.

Fig. 142 Aphis chetansapa Hottes and Frison.

Fig. 143 Aphis zilora Hottes and Frison.

Fig. 144 Amphicercidus pulverulens (Gillette).

Fig. 145 Clavigerus smithiae (Monell).

Fig. 146 Clavigerus populifoliae (Fitch).

Fig. 147 Clavigerus populifoliae (Fitch).

Fig. 148 Rhopalosiphum herheridis (Kaltenbach).

Fig. 149 Paducia antennatum (Patch).

Fig. 150 Neosymydohius memorialis Hottes and Frison.

Fig. 151 Chaitophorus pusillus Hottes and Frison.

Fig. 152 Periplyllus negundinis (Thomas).

Fig. 153 Cinara laricis (Hartig).

Fig. 154 Drepanaphis acerifoliae (Thomas).

Fig. 155 Monellia costalis (Fitch).

Fig. 156 Melanocallis fumipennella (Fitch).

Fig. 157 Monellia caryelia (Fitch).

Fig. 158 Eriosoma lanigera (Hausmann).

Fig. 159 Phyllaphis fagi (Linnaeus).

Fig. 160 Brevicoryme hrassicae Linnaeus.

Fig. 161 Plocamaphis terricola Hottes and Frison.

Fig. 162 Plocamaph is flocculosum (Weed). 
Tiie Plaxt Lice, ok APHIDole, of IILINOIA
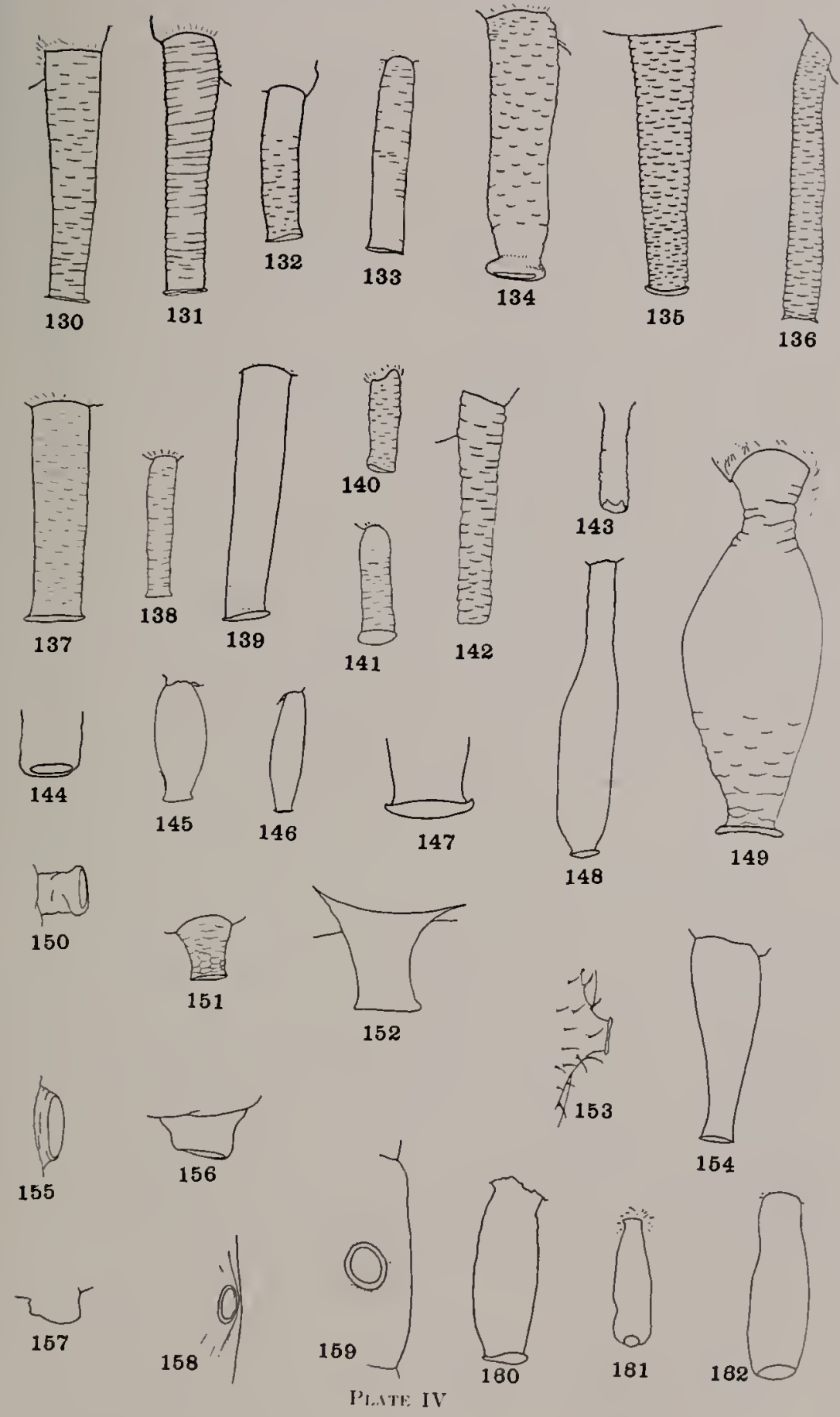


\section{Explanation of Plate l \\ CAUDAE AND ANAL PLATES}

Fig. 163 Capitophorus pakansus Hottes and Frison, cauda, alate vivi. parous female.

Fig. 164 Amphorophora nebulosa Hottes and Frison, cauda, alate viviparous female.

male.

Fig. 165 Macrosiphum adianti (Oestlund), cauda, alate viviparous fe-

Fig. 166 Macrosiphum carpinicoleus Patch, apterous viviparous female. fundatrix.

Fig. 167 Capitophorus ribis (Linuaeus), cauda, alate viriparous female. male.

Fig. 168 Myzocallis discolor (Mouell), anal plate, alate viviparous fe-

Fig. 169 Capitophorus patonkus Hottes aud Frison, cauda, alate viviparous female.

male.

Fig. 170 Macrosiphum carpinicolens Patch, cauda, alate viviparous fefemale.

Fig. 171 Macrosipluum illini Hottes aud Frison, cauda, alate ririparous

Fig. 172 Macrosiphum kickapoo Hottes and Frison, cauda, alate riviparous female. male.

Fig. 173 Euceraphis betulae (Koch), anal plate, alate viviparous fe-

Fig. 174 Capitophorus corambus Hottes aud Frison, cauda, alate viriparous female.

Fig. 175 Macrosiphum pallens Hottes and Frison, cauda, alate vivi. parous fenale.

Fig. 176 Jacrosiphum tapuskae Hottes and Frison, cauda, apterous viviparous female.

Fig. 177 Amplorophora rossi Hottes and Frison, cauda, alate rivipar. ous female.

Fig. 178 Myzocallis discolor (Monell), cauda, alate viviparous female.

Fig. 179 Macrosiphum frigidicola (Gillette and Palmer), cauda, alate viviparous female.

Fig. 180 Macrosiphum anomalae Hottes and Frison, cauda, alate viri. parous female. male.

Fig. 181 Iacrosiplum pisi (Kaltenbacli), cauda, alate viviparous fe-

Fig. 182 Macrosiphum tardae Hottes and Frison, cauda, alate viviparous female.

Fig. 1S3 Cepegillettea betulaefoliae Granovsky, cauda, alate viviparous fenale.

Fig. 184 Macrosiphum ambrosiae (Thomas), cauda, alate viviparous female, lectotype.

Fig. 185 Macrosiphum ruralis Hottes and Frison, cauda, alate viviparous female.

Fig. 186 Macrosiphum zinzalae Hottes and Frison, cauda, alate viviparous female.

Fig. 187 Byzus houghtonensis (Troop), cauda, alate riviparous feuale. lectotype.

Fig. 1ss Chaitophorus viminalis Monell. cauda, alate viviparous female. 

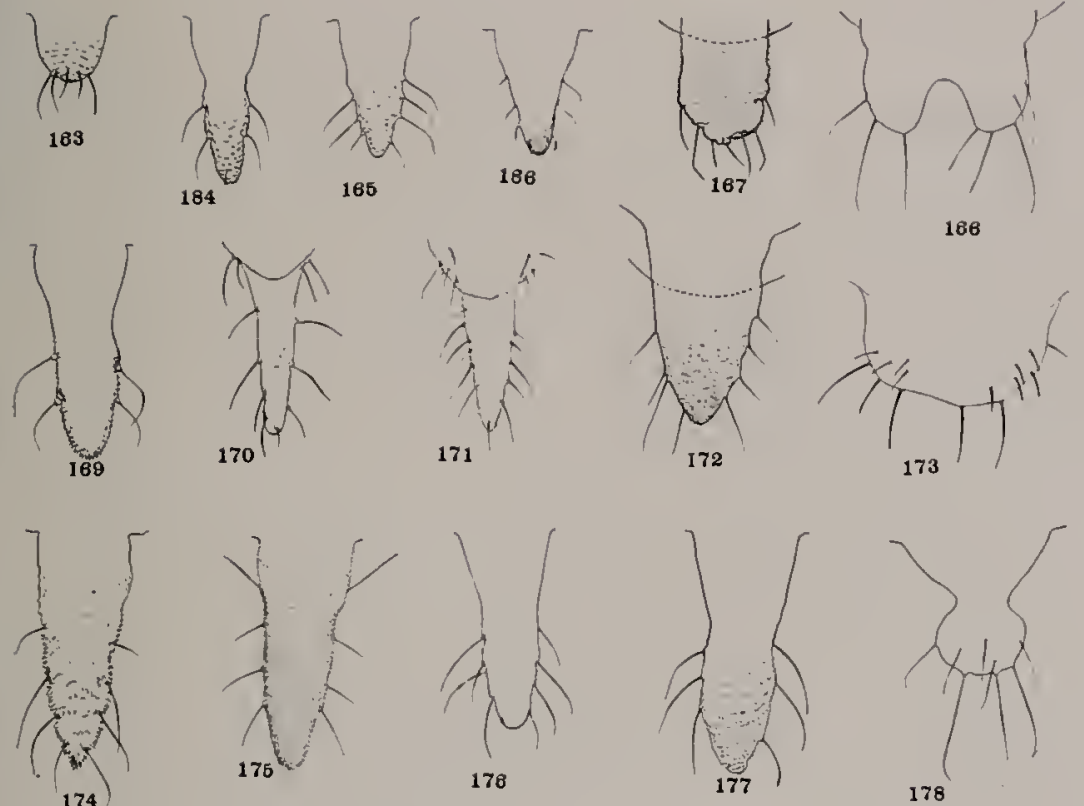

174
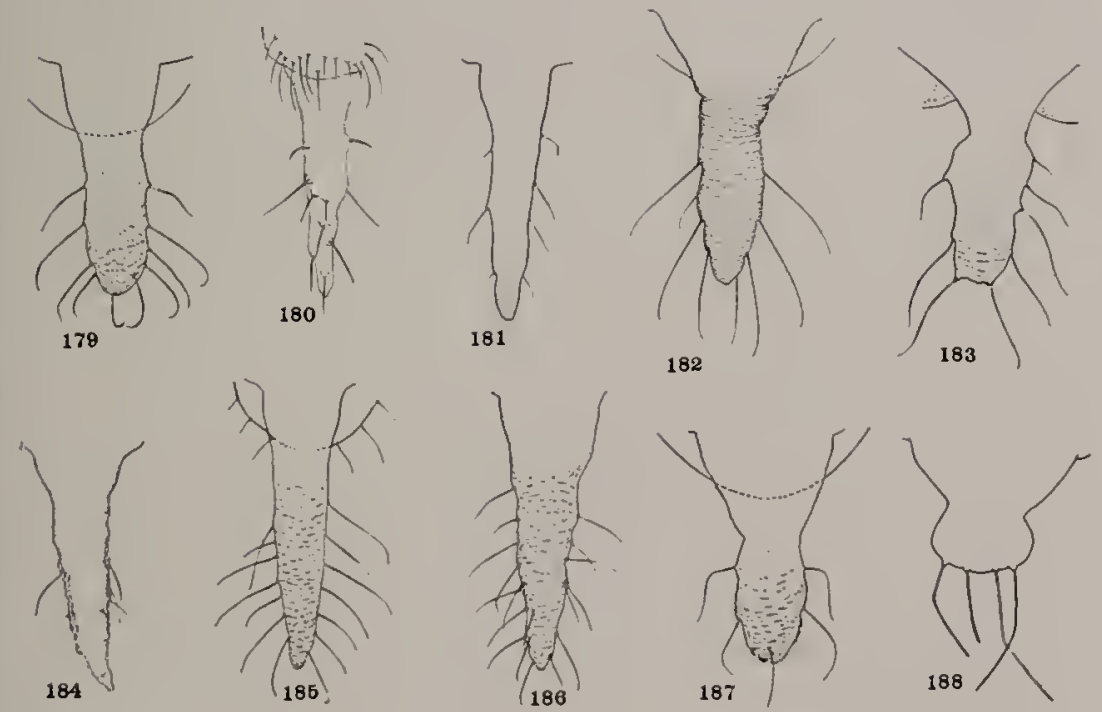

Pi.n'E: V 


\section{Explanation of Plate lit}

\section{CAUDAE AND ANAL PLATES}

Fig. 190 Paducia antennatum (Patch), cauda, alate viviparous female. Fig. 191 Aphis rociadae Cockerell, cauda, alate viviparous female.

Fig. 192 Cerosipha rubifolii (Thomas), cauda, alate viviparous female. feniale.

Fig. 193 Aphis chetansapa Hottes and Frison, cauda, alate viriparous

Fig. 194 Aphis zilora Hottes and Frison, cauda, alate viviparous female.

Fig. 195 Aphis carduella Walsh, caucla, alate viviparous female. male.

Fig. 196 Rhopalosiphum prunifoliae (Fitch), cauda, alate viviparous female.

Fig. 197 Aphis nyctalis Hottes and Frison, cauda, alate viriparous fe-

Fig. $19 \mathrm{~S}$ Aphis illinoisensis Shimer, cauda, alate viviparous female.

Fig. 199 Hyalopterus pruni (Geoffroy), cauda, alate viviparous female.

Fig. 200 Rhopalosiphum enigmae Hottes and Frison, cauda, alate riviparous female.

Fig. 201 Aphis folsomii Davis, cauda, alate viviparous female.

Fig. 202 Aphis caliginosa Hottes and Frison, canda and anal plate, alate viviparous female. male.

Fig. 203 Aphis funesta Hottes and Frison, cauda, alate viriparous female.

Fig. 204 Brevicoryne brassicae Limnaeus, cauda, alate viviparous fe-

Fig. 205 Asiphonaphis anogis Hottes and Frison, canda, alate riviparous female.

Fig. 206 Cavariella aegopodii (Scopoli), cauda and supra-anal process, alate viviparous female.

Fig. 207 Rhopalosiphum enigmae Hottes and Frison, cauda, oriparous female.

Fig. 208 Aphis spiraephila Patch, cauda, alate viviparous female. male.

Fig. 209 Gypsoaphis oestlundi Hottes, anal plate, alate viviparous fe-

Fig. 210 Aphis padi Linnaeus, anal plate, alate vivifarous female.

Fig. 211 Neosymydobius memorialis Hottes and Frison. cauda, alate viviparous female.

Fig. 212 Thripsaphis ballii (Gillette), apical dorsal abdominal segment. canda, and anal plate, alate viviparous female.

Fig. 213 Cinara laricis (Hartig), anal plate, alate viviparous female.

Fig. 214 Plocamaphis terricola Hottes and Frison, cauda and anal plate, alate viviparous female.

Fig. 215 Saltusaphis elongatus Baker, apical dorsal abdominal segment, cauda, and anal plate, apterous viviparous female.

Fig. 216 Cinara laricis (Hartig), cauda, alate riviparous female. female.

Fig. 217 Drepanaphis acerifoliae (Thomas), anal plate, alate viviparous

Fig. 218 Thripsaphis producta Gillette, apical dorsal abdominal segment, cauda, and anal plate, alate viviparous female.

Fig. 219 Saltusaplis wanicus Hottes and Frisou, apical dorsal abdominal segment, cauda, and anal plate. apterous viviparous female.

Fig. 220 Calaphis betulella Walsh, anal plate, alate viriparous female.

Fig. 221 Eriosoma lanigera (Hausmann), cauda and anal plate, alate viviparous temale.

Fig. 222 Hormaphis hamamelidis (Fitch), cauda and aual plate, alate viviparous female. 

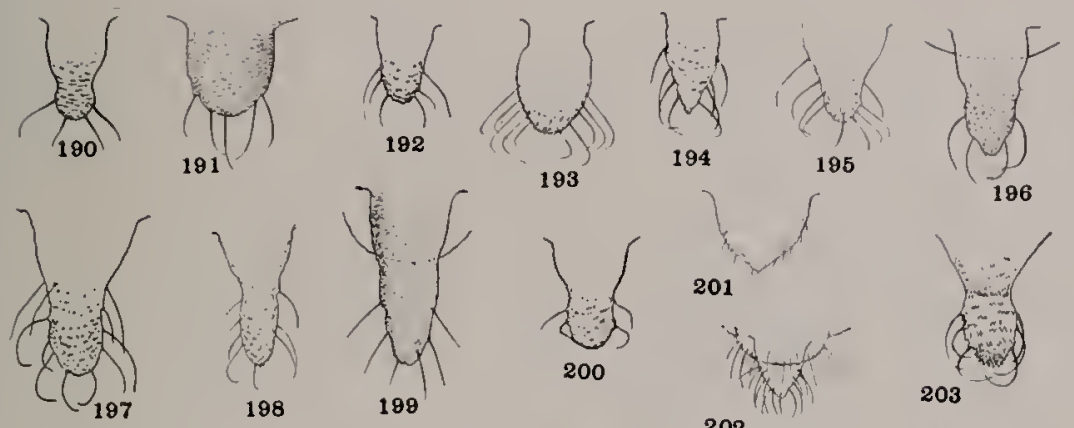

196
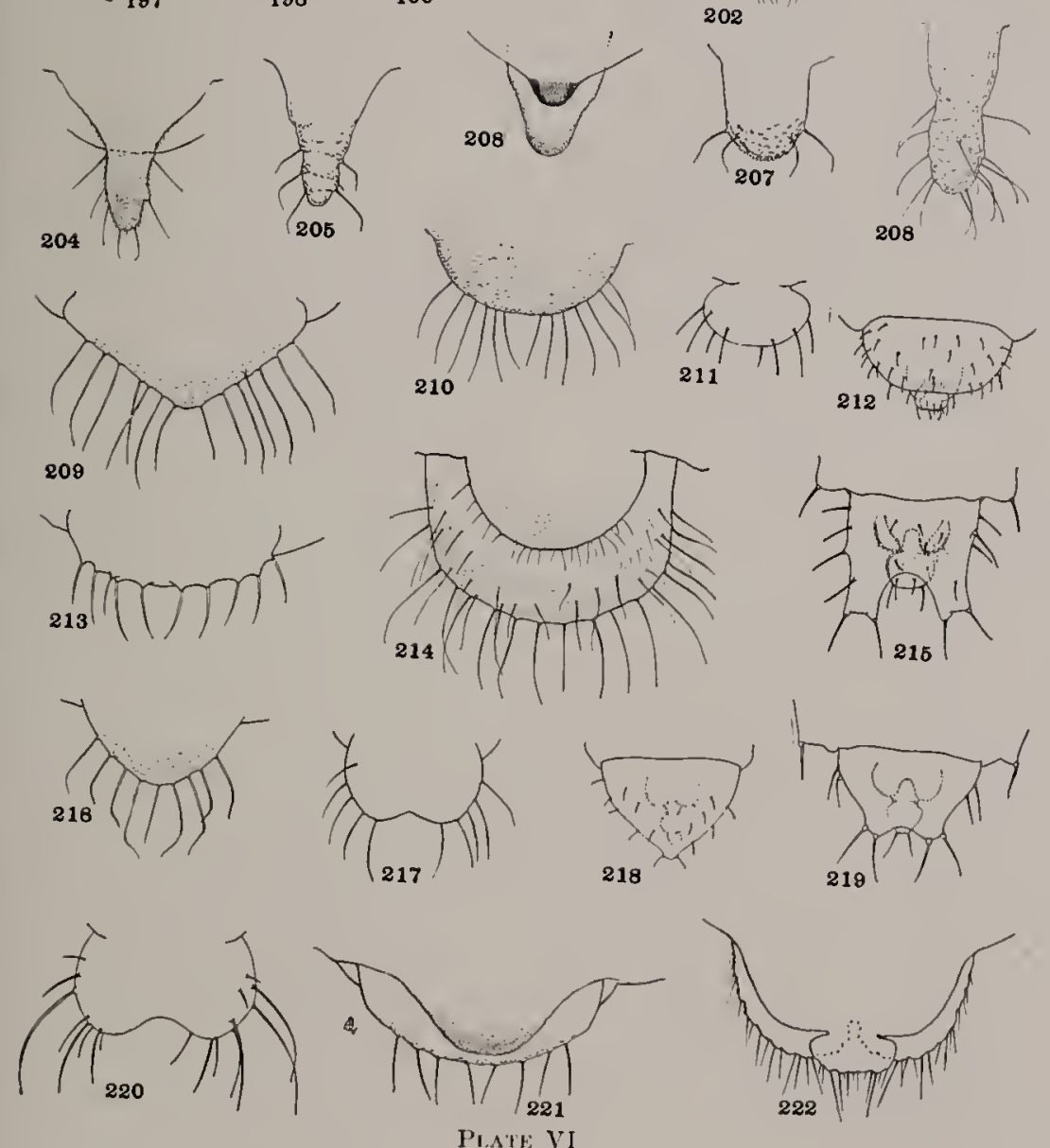


\section{Explanation of Plate VII}

\section{ANTE.VAE}

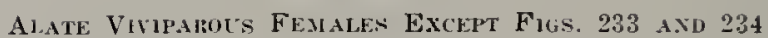

Fig. 223 Eriosoma mimica Hottes and Frison, flagellum.

Fig. 224 Hormaphis hamamelidis (Fitch), three-segmented antenna.

Fig. 225 Eriosoma lanigera (Hausmann), third segment.

Fig. 226 Georgiaphis ulmi (Wilson), third segment.

Fig. 227 Pemphigus tartareus Hottes and Frison, sexupara, flagellum.

Fig. 225 Pemphigus brevicornis (Hart), sexupara, flagellum. lum.

Fig. 229 Pemphigus ephemeratus Hottes and Frison, sexupara, flagelments.

Fig. 230 Paducia antennatum (Patch), third and fourth antennal seg-

Fig. 231 Cinara difficilis Hottes and Frison, flagellum.

Fig. 232 Sipha flava (Forbes) five-segmented antenna.

Fig. 233 Saltusaphis elongatus Baker, apterous male, third, fourth. and fifth antennal segments.

Fig. 234 Melanocallis fumipenniella (Fitch), alate male, flagellum.

Fig. 235 Calaphis castaneae (Fitch), third segment.

Fig. 236 Calaphis betulaecolens (Fitch), third segment.

Fig. 237 Saltusaphis wanicus Hottes and Frison, third segment.

Fig. 238 Neoprociphilus aceris (Monell), third segment. ment.

Fig. 239 Mordwilkoja vagabunda (Walsh), fundatrigenia, sixth seg-

Fig. 240 Pemphigus populi-transversus Riley, fundatrigenia, sixth segment.

Fig. 241 Pemphigus populi-transversus Riley, sexupara, fifth and sixth segments.

Fig. 242 Saltusaphis wanicus Hottes and Frison, sixth segment.

Fig. 243 Drepanaphis acerifoliae (Thomas), sixth segment.

Fig. 244 Tamalia coweni (Cockerell), sixth seguent.

Fig. 245 Neosymydohius albasiphus (Davis), sixtl segment.

Fig. 246 Melanocallis fumipennella (Fitclu), sixth segment.

Fig. 247 Neosymydobius memorialis Hottes and Frison, sixth segment.

Fig. 248 Amphicelcidus puiverulens (Gillette), sixth segment.

Fig. 249 Myzocallis alnifoliae (Fitch), third segment.

Fig. 250 Chaitophorus populifoliae Oestlund, third segment.

Fig. 251 Monellia costalis (Fitch), third segment.

Fig. 252 Chaitophorus pusillus Hottes and Frison, third segment.

Fig. 253 Chaitophorus neglectus Hottes and Frison, third segment.

Fig. 254 Neosymydohius annulatus (Koch), third segment.

Fig. 255 Neosymydobius memorialis Hottes and Frison, flagellum.

Fig. 256 Plocamaphis terricola Hottes and Frison, third segment. 


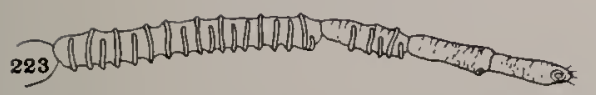

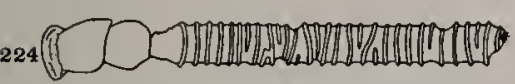
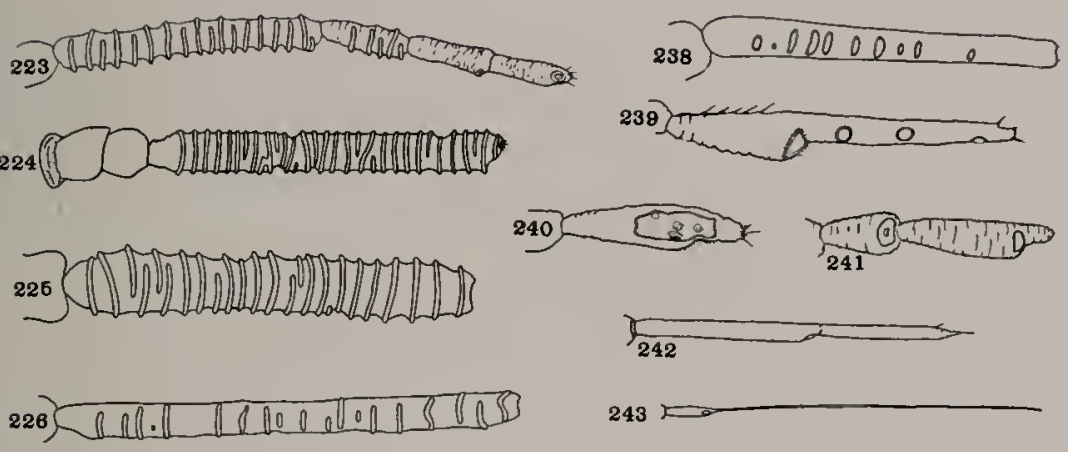

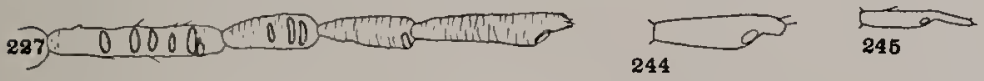

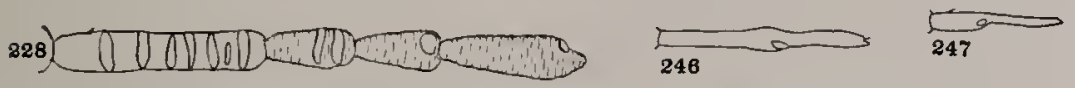

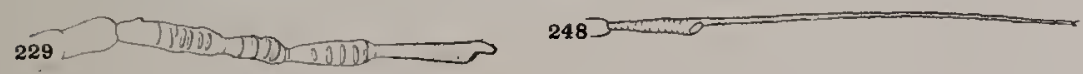

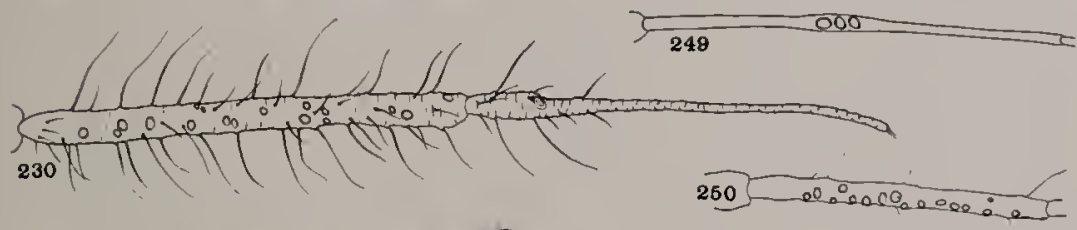

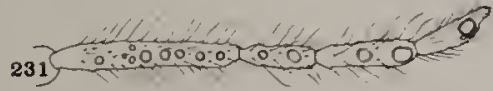
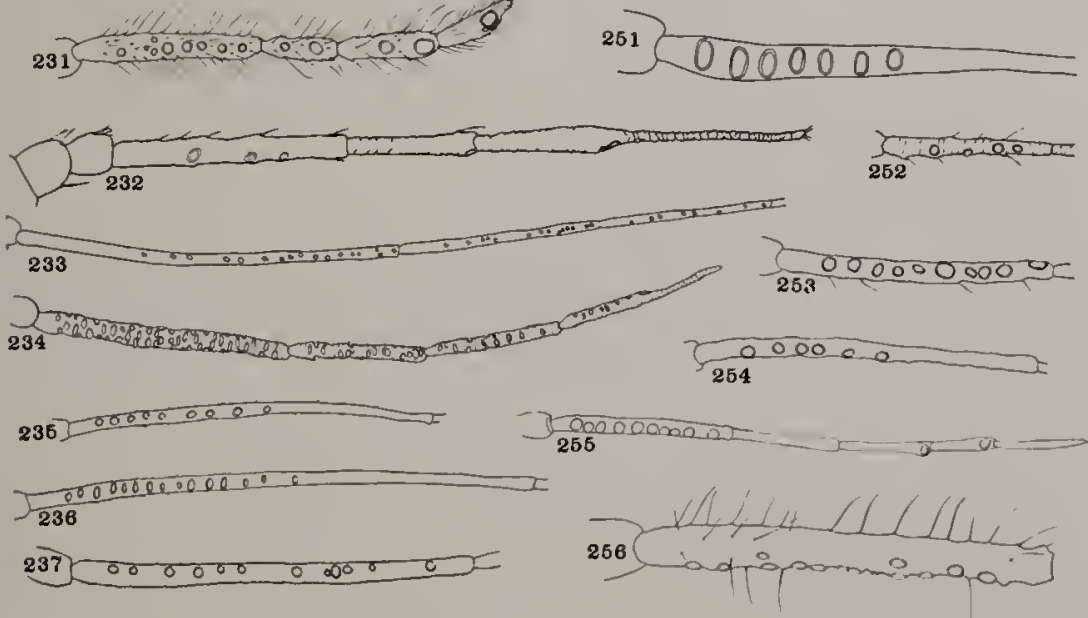

Plite VII 


\section{Explanation of Plate lili}

\section{ANTENNAE}

Fig. 25 Capitophorus pakansus Hottes and Frison, alate viviparous female, third and fourth antennal segments.

Fig. 258 Capitophorus pakansus Hottes and Frison, male, third, fourth. and fifth antennal segments.

Fig. 259 Capitophorus coramhus Hottes and Frison, apterous viviparous female, third antennal segment.

Fig. 260 Capitophorus coramhus Hottes and Frison, alate viviparous female, third antennal segment.

Fig. 261 Myzus thomasi Hottes and Frison, alate viviparous female, third, fourth, and fifth antennal segments.

Fig. 262 Rhopalosiphum enigmae Hottes and Frison, alate viviparous female, third and fourth antennal segments.

Fig. 263 Rhopalosiphum enigmae Hottes and Frison, male, third, fourth, and fifth antennal segments.

Fig. 264 Myzus thomasi Hottes and Frison, apterous viriparous female. third, fourth and fifth antennal segments.

Fig. 265 Aphis signatis Hottes and Frison, alate viviparous female, third and fourth antennal segments.

Fig. 266 Aphis nyctalis Hottes and Frison, alate viviparous female, third, fourth, fifth, and sixth antennal segments.

Fig. 267 Aphis nyctalis Hottes and Frison, apterous viviparous female. third and fourth antennal segments.

Fig. 268 Aphis luriclis Hottes and Frison, alate viviparous female, third, fourth, and fifth antemnal segments.

Fig. 269 Aphis coreopsidis (Thomas), alate viviparous female, third. fourth, and fifth antennal segments.

Fig. 270 Asiphomaphis anogis Hottes and Frison, alate viriparous fe. male, third and fourth antennal segments.

Fig. 271 Aphis cornifoliae Fitch, alate viviparous female, third antennal segment.

Fig. 272 Capitophorus patonkus Hottes and Frison, apterous viviparous female, third antennal segment.

Fig. 273 Myzus houghtonensis (Troop), alate viviparous female, lectotype, third antennal segment.

Fig. 274 Capitophorus patonkus Hottes and Frison, alate viviparous female, third antennal segment.

Fig. 275 Cerosipha rubifolii (Thomas), alate viviparous female, third antennal segment.

Fig. 276 Aphis pulchella Hottes and Frison, alate viviparous female. third antennal segment.

Fig. 277 Macrosiphum illini Hottes and Frisou, apterous viviparous female, third and fourth antennal segments.

Fig. 278 Aphis zilora Hottes and Frison, alate viviparous female, third antennal segment.

Fig. 279 Aphis carduella Walsh, alate viviparous female, third antennal segnient.

Fig. 2S0 Aphis chetansapa Hottes and Frison, alate viviparous female, third antenual segment.

Fig. 281 Aphis decepta Hottes and Frison, alate viriparous female, third antennal segment.

Fig. 282 Aphis funesta Hottes and Frison, alate viviparous female. third antennal segment.

Fig. 283 Hysteronenra setariae (Thomas), alate viviparous female. third antennal segment.

Fig. 284 Aphis caliginosa Hottes and Frison, alate viviparous female. third antennal segment. 


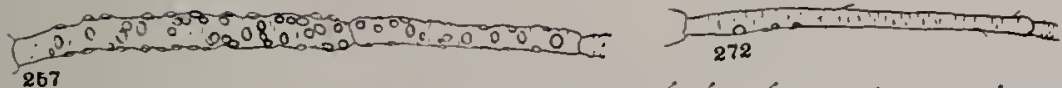

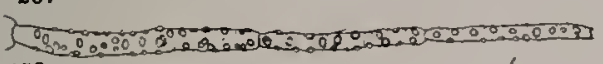

$\sqrt{600}+00000=2$

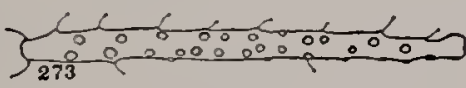
258 00000008000003 is

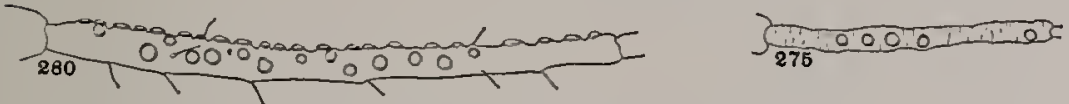

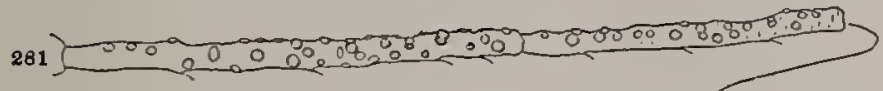

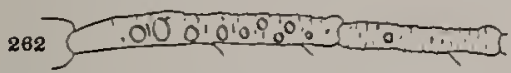

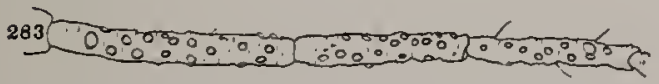

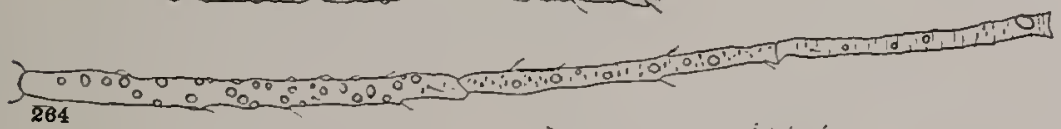

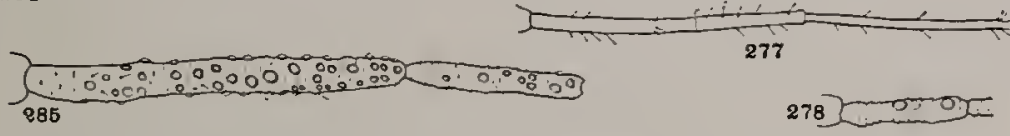

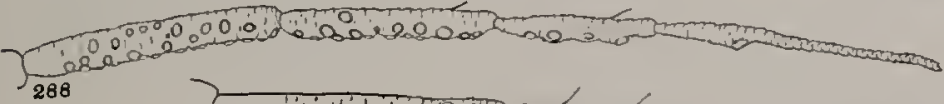

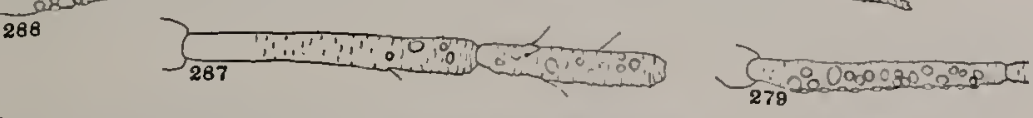

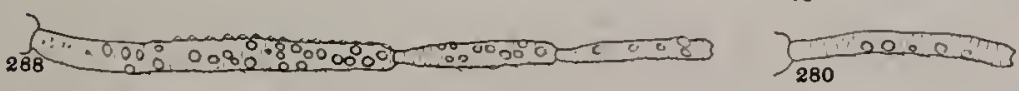

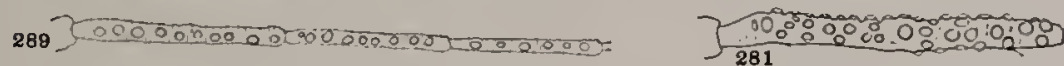

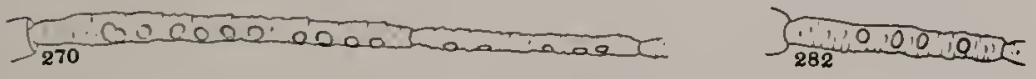

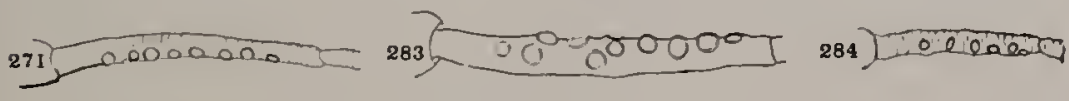

Pi.tTE: VIII 


\section{Explanation of Plate IX}

\section{ANTENIAE}

Fig. 285 Macrosiphum illini Hottes and Frison, male, third. fourth, and fifth antennal segments.

Fig. 286 Mlacrosiphum ruralis Hottes and Frison, alate viviparous female, third antennal segment.

Fig. 287 Macrosiphum sanguinarium Hottes and Frison, alate viviparous female, third antennal segment.

Fig. 2SS Macrosiphum tardae Hottes and Frison, alate viviparous female, third antennal segment.

Fig. 289 Macrosiphum pallens Hottes and Frison, alate viviparous female, third antenual segment.

Fig. 290 Macrosiphum zinzalae Hottes and Frison, apterous viviparous female, third antennal segment.

Fig. 291 Macrosiphnm zinzalae Hottes and Frison, alate viviparous female, third antennal segment.

Fig. 292 Mlacrosiphum carpinicolens Patch, alate viviparous female. third antennal segment.

Fig. 293 Macrosiphum adianti (Oestlund), alate riviparous female. third antennal segment.

Fig. 294 Macrosiphum kickapoo Hottes and Frison, alate viviparous female, third and fourth antemnal segments.

Fig. 295 Macrosiphum gravicornis Patch, oviparous female, third antennal segment.

Fig. 296 Macrosiphum erigeronensis (Thomas), oviparous female, third antennal segment.

Fig. 297 Macrosiphum frigidicola (Gillette and Palmer), alate viviparous female, third antennal segment.

Fig. 298 Macrosiphum soncliella (Monell), apterous viviparous female. third and fourth antennal segments.

Fig. 299 Mlacrosiphum tapuskae Hottes anil Frison, apterous viviparous female, third antenual segment.

Fig. 300 Macrosiphum illini Hottes and Frison, alate viviparous female. third antennal segment.

Fig. 301 llacrosiphum ambrosiae (Thomas), apterous viviparous fe. male, lectotype, third antennal segment.

Fig. 302 Macrosiphum ambrosiae (Thomas), alate vivipurous female. lectotype, third antennal segment. tibia.

Fig. 303 Macrosiphum illini Hottes and Frisom, oviparons female, hind

Fig. 304 Macrosiphum tapusliae Hottes and Frison, alate viviparous female, third antennal segment.

Fig. 305 Anplorophorat nebulosa Hottes and Frison, alate viviparous temale, third antennal segment.

Fig. 306 Amphorophora singularis Hottes and Frison, alate viviparous female, third antemnal segment.

Fig. 307 Amplorophora rossi Hottes and Frison, nlate riviparous fe. male. third antennal segment.

Fig. 3us Macrosiphum anomalae Hottes and Frison. alate viriparous female, third antenual serment. 


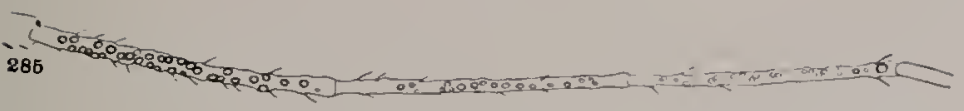
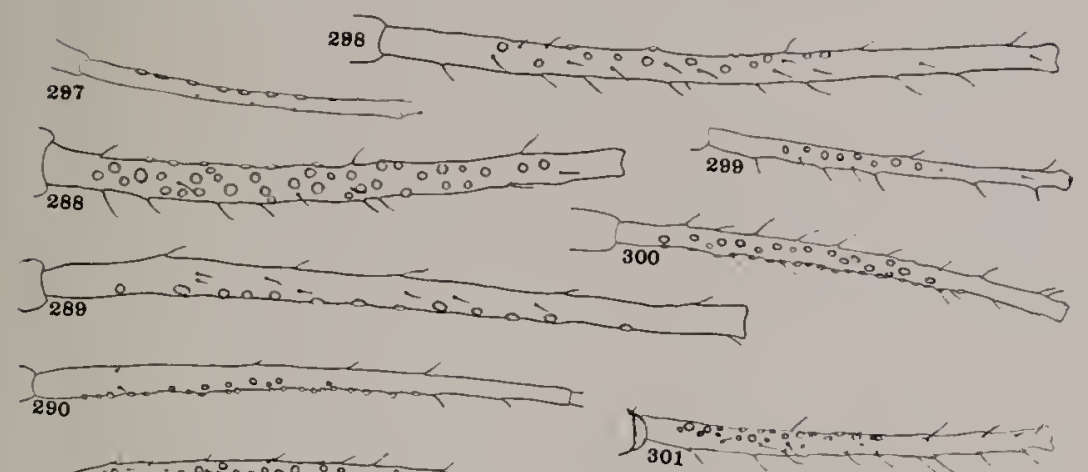

$S_{291} 0.000000006000$
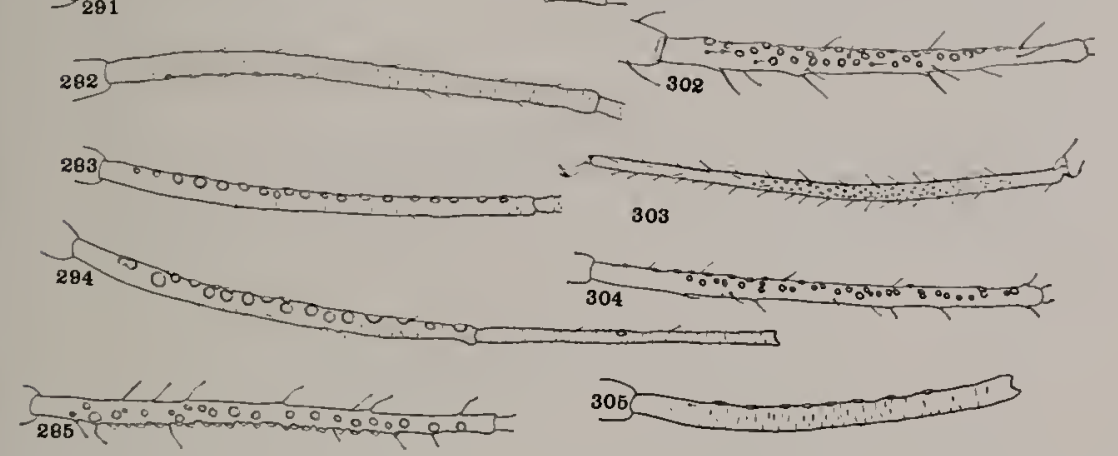

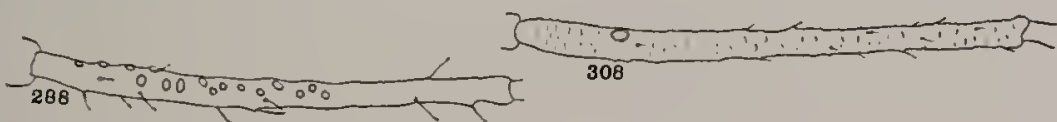

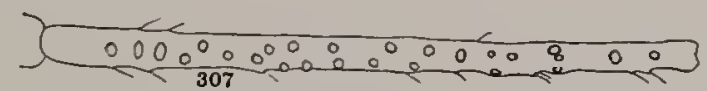

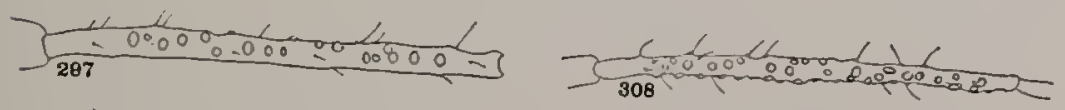

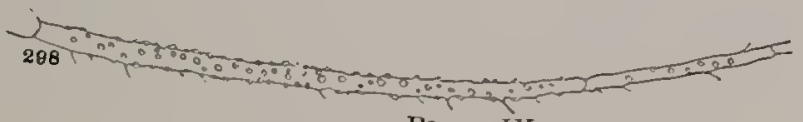

Plate IX 


\section{Exilhanaton of Plite $\mathrm{X}$}

TUBERCLES, SETAE, ETK:

Fig. 309 Aphis caliginosa Hottes and Frison, alate riviparous female, laleral tubercles.

Fig. 310 Nelanocallis fumipennella (Fitch), alate riviparous female, lateral tubercles.

Fig. 311 Myzocallis asclepiadis (Mouell), alate viriparous female, lateral tubercles.

Fig. 312 Asiphonaphis pruni Witson and Davis, alate riviparous female, latera] tubercles.

Fig. 313 Paducia antennatum (Patch), alate viviparous female, lateral tubercles.

Fig. 314 Gypsoaphis oestlundi Hottes, lateral tubercles.

Fig. 315 Asiphonaphis anogis Hottes and Frison, apterous viviparous female, lateral tubercles.

Fig. 316 Jziphya flabellus (Sanborn), alate viviparous female. modified setae.

Fig. 317 Geoica squamosa Hart, apterous viviparous female, to] view of modified setae.

Fig.318 Geoica squamosa Hart, apterous viviparous female, lateral view of modified setae.

Fig. 319 Tuberculatus punctatellus (Fitch), alate viviparous female. dorsal abdominal tubercles.

Fig. 320 Capitophorus fragaefolii (Cockerell), apterous vivijuarous female, globate setae.

Fig. 321 Saltusaplis elongatus Baker, apterous viriparous female. com. pound eyes without ocular tubercles.

Fig. 322 Thripsaphis rerucosa Gillette. apterous riviparous female. cauda, anal plate and telminal abdominal segment.

Fig. 323. Drepanaphis monelli (Davis), alate viviparous female, dorsal abdominal tubercles.

Fig. 324 Thripsaphis ballii (Gillette), alate viviparous female, unmodified setae.

Fig. 325 Sheuahweum minutus (Davis), alate viviparous female. fore femola.

Fig. 326 Cepegillettea betulaetoliae Granovsky, alate viviparous female. fore femora.

Fig. 327 Drepanaphis acerifoliae (Thomas), alate viviparous female. dorsal abclominal tubercles.

Fig. 328 Prociphilus venafuscus (Patch), (sexupara), dorsal wax-pore plates of mesothorax.

Fig. 329 Prociplilus col'ugatans (Sirrine), (fundatrigenia), dorsal waxpore plates of mesothorax.

Fig. 330 Pemphigus populi-transrersus Riley (fundatrigenia), dorsa] wax-pore plates of mesothorax.

Fig. 331 Periphylus negundinis (Thomas), dimorphic form.

Fig. 332 Hamamelistes spinosus Slimel. coccidiform generation.

Fig. 333 Myzocallis walslii (Monell), oviparous female, showing color pattern and setal arrangement.

Fig. 33t Myzocallis alhambra Davidson, oviparous female, sliowing color pattern and setal arrangement.

Fig. 3:5 Chaitophorus neglectus Hottes and Frison, alate viviparous female, showing color pattern.

Fig. $3: 36$ Chaitophorus populifoliae Oesthund. alate viviparous female. showing color pattern. 
The Plaxt Lice, or Almilde. ol Ii lixols
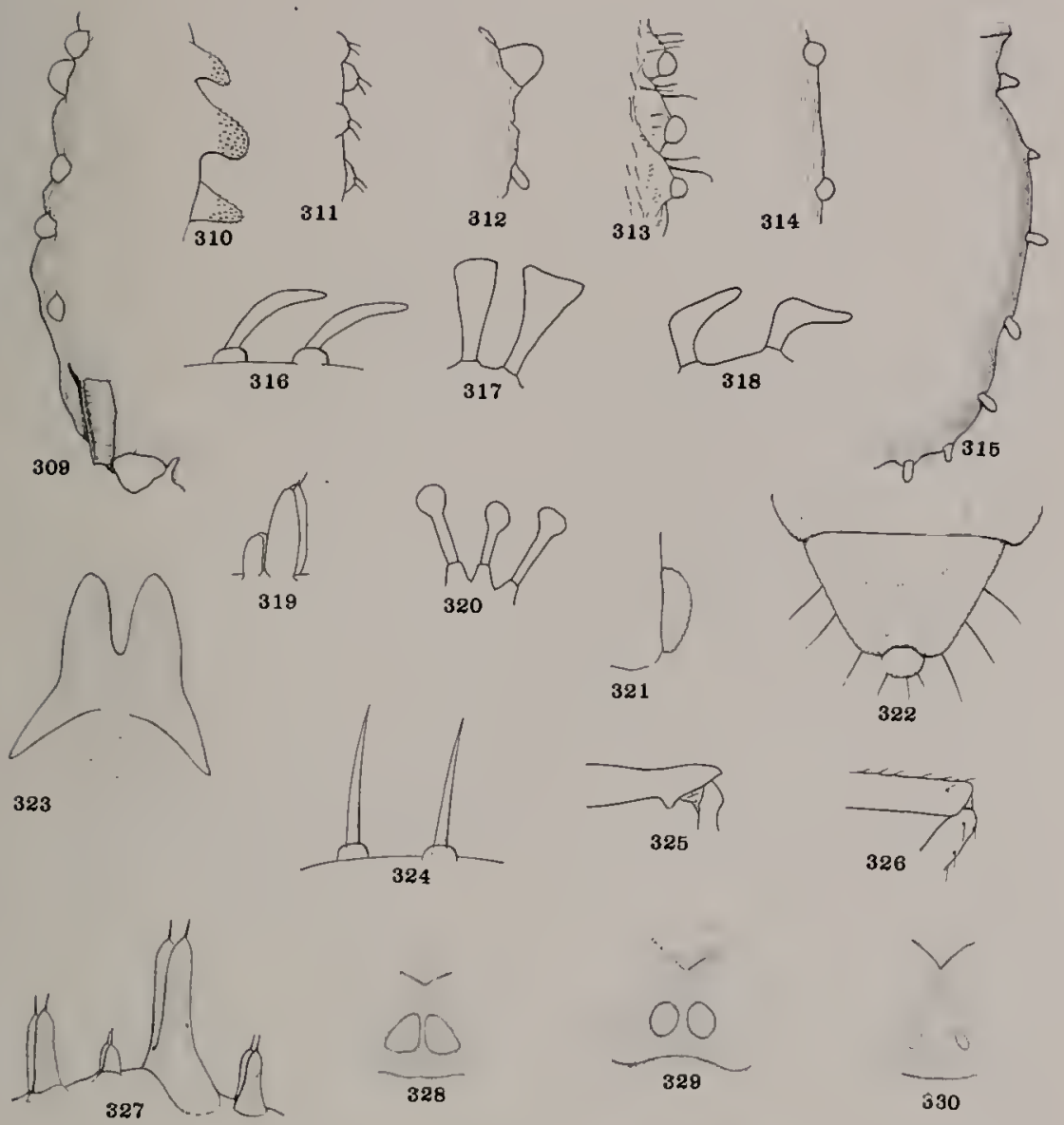

323
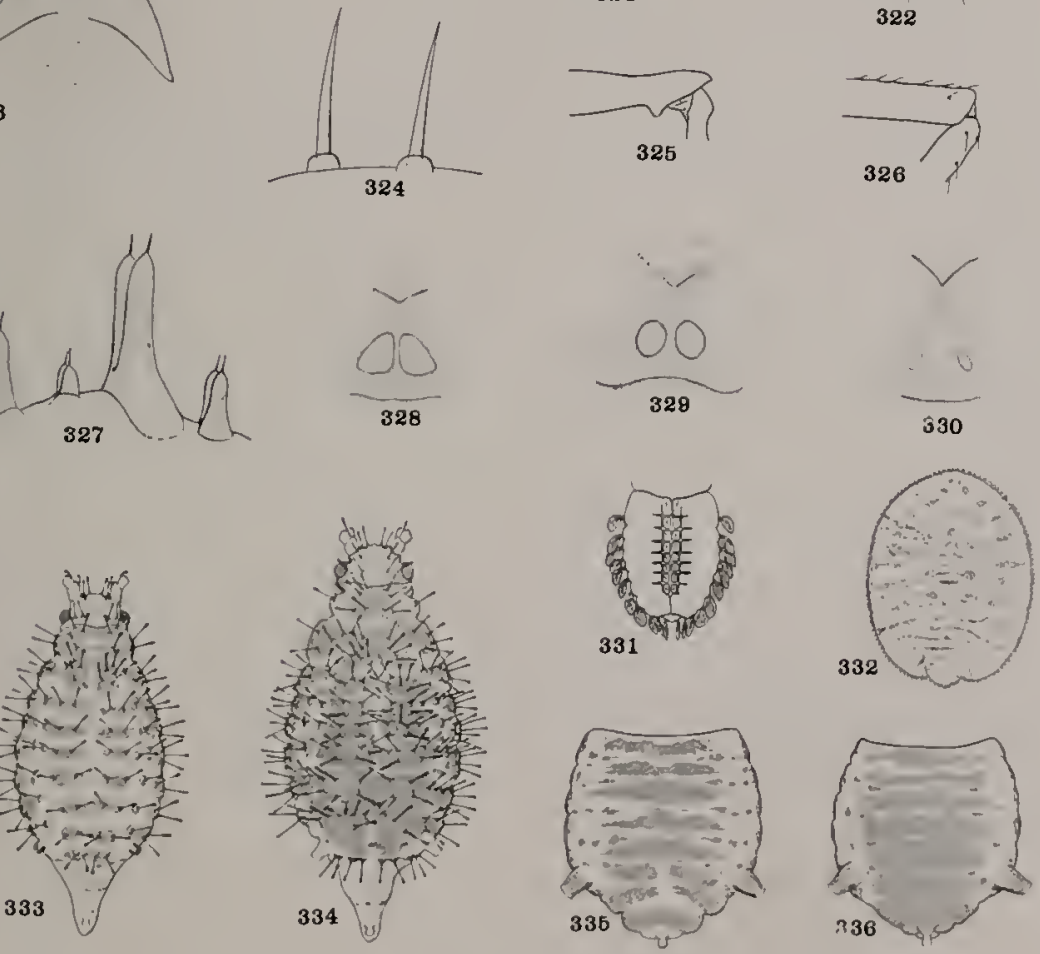

Puate 


\section{ADDENDA}

\section{Species Not Recogitized}

There exist a few original descriptions of species of aphids. based upon specimens collected in Illinois. which are not recognized in the body of this paper. This situation is due to the fact that to date no one has been able to definitely associate particular species of aphids with these descriptions, probably because of their linitations or vagueness. These descriptions are as follows:

Aphis quercifoliae Walsh. Proc. Ent. Soc. Phil., Vol. 1, No. 9. 1862, p. 298. Eriosoma? fungicola Walsh, Proc. Ent. Soc. Phil., Vol., 1. No. 9, 1862, p. 304. Pemphigus formicarius Walsh, Proc. Ent. Soc. Phil., Vol. 1, No. 9, 1S62, p. 30 s. Pemphigus formicetorum Walsh, Proc. Ent. Soc. Phil., Vol. 1, Xo. 9, 1S62, p. 308.

Siphonophora verbence Thomas, Bulletin Illinois State Laboratory of Natural History, Vol. 1, No. 2, June, 1878, p. 8 .

\section{APHIS SYMPHORJCARPI THOMAS}

Among the recently recovered types of aphids originally described by Thomas, and not discussed in the body of this article becanse of their collection in Iowa, are specimens of Aphis symphoricarpi Thomas. These cotypic specimens, in poor condition, are monnted on Slides Nos. $2: 5 \%$ and $8: 56$, and the following data are associated with them: Fort Dodge. Iowa, September 1, 18\%i, on Simphoricarpus aulgaris. Both slicles contain apterous viviparous fenales, which may unquestionably be recognized as parasitized specimens of the species now known as albipcs (Oestlund). The parasitized condition of the specimens accomnts for the statements: "Bodies rather broally osoid, and very" convex. Abdomen distinctly acuminate at the apex, but no tail apparent," which were used in the original description, and for the misleading color notes.

\section{CEDOAPHIS INCOGNITA new name}

We find that Aphis albipes Oesthund is a synonym of Aphis symphoricarpi Thomas. As a result of this symonymy, the species referred to by Oestiund (1922) as Ccdoaphis symphoricarpi is without a name, and we therefore have proposed incognita as a new name ior this species. 


\section{INDEX}

The names of all species and varieties are here listed under the generic names to which the various species have been assigned $i_{11}$ this paper, and also in alphabetical order. Those reduced to synonyny, preoccupied, of changed generic assignment, or representing previous Illinois records based upon misidentifications are indicated lyy italic type, and new names by bold-faced type.

abbreviata Patch, Aphis, 214

abietinus lioch, Mindarus, 374 acerifolii Riley, Pemphigus, 373

acerifoliae (Thomas), Drepanaphis, 246

aeerifoliae Thomas, Siphonophora, 246

aceris (Monell), Neoprociphilus, 361 aceris Monell, Pemphius, 361

adianti (Oestlund), Macrosiphum, 296 adianti Oestlund. Siphonophora, 296 aegopodii Scopoli, Aphis, 229

aegopodii (Scopoli), Cavariella, 229 ageratoidis Oestlund, Aphis, 181

ayilis (lialtenbach), Eulachnus, 157

albasiphus (Davis), Neosymydobius, 261

albasiphus Davis, Symydobius, 261 albifrons Essig, Hacrosiphum, 333 albipes Oestlund, Aphis, 438

allambra Davidson, Myzocallis, 255

alni DeGeer, Aphis, 256

alni (DeGeer), Myzocallis, 256

alnifoline Fitch, Lachnus, 256

alnifoliae (Fitch), Myzocallis, 256

Alphitoaphis Hottes, 175

lonicericola (Williams), 175

ambrosiae (Thomas), Macrosiphum, 298

ambrosiae Thomas, Siphonophora, 298 americanus (Baker), Neosymydobius, 261

americunus Baker, Symydobius, 261

Amphicercidus Oestlund, 160

pulverulens (Gillette), 160

Ampliorophora Buckton, 273

cosmopolitana Mason, 274

laingi Mason, 275

nabali (Oestlund), 275

nebulosa Hottes and Frison, 275

nervata (Gillette), 227

rossi Hottes and Frison, 277

sensoriata Mason, 279

singularis Hottes and Frison, 279

solani ('Thomas), 280

vaccinii Nason, 280

ampullita Buckton, Amphorophora, 275

annulatus Kocl., Chaitophorus, 262

annulatus (Koch). Neosymydobius, 262
Anoecia Koch. 151

oenotherae Wilson. 151

querci (Fitch), 152

setariae Gillette and Palmer, 151

anogis Hottes and Frison, Asiphonaphis, 225

anomalae Hottes and Frison, Macrosiphum, 298

antennata (Patch), Paducia, 168

antennatum Patch, Melanoxantherjum, 168

Anuraphis Del Guercio, see Aphis, 176

Aphis Linnaeus, 176

ageratoid is Oestlund, 181

asclepiadis Fitch, 181

bakeri Cowen, 181

caliginosa Hottes and Frison, 182

carduella Walsh. 18:

cardui Linnaeus, 185

cephalanthi Thonas, 185

cerasifoliae Fitch, 186

chetansapa Hottes and Frison, 186 coreopsidis (Thomas), 188

cornifoliae Fitch, 189

crataegifoliae Fitch, 190

debilicornis (Gillette and Palmer), 191

decepta Hottes and Frison, 192

feminea Hottes, 193

folsomii Davis, 19?

forbesi Weed, 194

funesta Hottes and Frison, 194

gossypii Glover, 195

helianthi Monell, 196

illinoisensis Shimer, 198

knowltoni Hottes and Frison, 199

lahurni Kaltenhach, 199

luridis Hottes and Frison, 200

maculatae Oestlund, 201

mairli-radicis Forhes, 202

maid is Fitch, 205

middletonii Thomas, 203

monardae Oestlund, 205

neilliae Oestlund, 205

nerii Fonscolonbe, 206

nyctalis Hottes and Frison, 206

oestlundi Gillette, 208

padi J innaeus, 209

persicae-niger Smith, 209

pomi DeGeer, 210 
pulchella Hottes and Frison, 212 rhamni Fonscolombe, 214 rociadae Cockerell, 214 rosea Baker, 214

rubicola Oestlund, 215 rumicis linnaeus, 215 rumicis var, gerardiae (Thomas), 217

saliceti Kaltenbach, 217 sambucifoliae Fitch, 218 sanborni Patch, 218

signatis Hottes and Frison, 219 solidaginifoliae Williams, 220 spiraecola Patch, 220 spiraephila Patch, 222 tulipae Fonscolombe, 222 vernoniae Thomas, 222 viburnicola Gillette, 22 ? viburniphila Patch, 224

zilora Hottes and Frison, 224

apocymii Koch, Aphis, 181

aquatifus Jackson, Rhopalosiphum, $23 \mathrm{~S}$

aquilegiae Essig, Myzus, 337

arundinis (Fabricius), Hyalopterus, 232

asclepiatis Cowen. Nectarophora, 306 asclepiadis Fitch, Aphis, $1 S 1$ asclepiatis Nonell, Callipterus, 256 asclepiadis (Monell), Myzocallis, 256 Asiphonaphis Wilson and Davis, 225 anogis Hottes and Frison, 225

pruni Wilson and Davis, 227

Asiphum Koch. 348

pseudobyrsa (Walslı). 345

atriplicis Linnaeus, Aphis, 231

atriplicis (Linnaeus), Hyalopterus, 231

attenuatus (Osborn and Sirrine). Neoprociphilus, 362

attenuatus Osboru and Sirrine, Pemphigus, 362

avenae Fabricins, Aphis, 239

bakeri Cowen, Aphis, $1 \$ 1$

ballii Gillette, Brachycolus, 270

ballii (Gillette), Thripsaphis, 270

bella Walsh, Aphis, 257

bella (Walsh), Myzocallis, 257

berberidis Kaltenbach, Aphis. 235

berberidis (KaItenbach), Rhopalosiphum, 235

betar Doane, Pemphigus, 369

betulue Limnaeus, Aphis, 249

betulae (Linnaeus). Euceraphis, 249

brtulaccolens (Fitch), Aphis, $2 \notin t$

betulaecolens (Fitch), Calaphis, 244

betulaefoliae Granovsliy, Cepegillettea, 246

betulella Walsh, Calaphis, 244

Brachycolus Buckton, 22S

tritici Gillette, $22 \mathrm{~S}$

bra!nit Gillette, Myzus, $2 \$ 2$ braggij Gillette and Palmer, Plocamaphis, $17 t$

hrassicae (Linnaeus), Brevicoryne, $22 \mathrm{~S}$

brassicae Linnaeus, Aphis, 228

brevicornis (Hart), Pemphigus, 363

brevicornis Hart, Tychea, 363

Brevicoryne Van der Goot, $22 S$

brassicae (Linnaeus), 228

brevis Sanderson, Aphis, 190

Calaph is Walsh, 243

betulaecolens (Fitch), 244

betulella Walsh. 244

castaneae (Fitch), 245

californica (Clarke), Macrosiphum, 314

caliginosa Hottes and Frison, Aphis. 182

Capitophorus Vtan der Goot, 2so

corambus Hottes and Frison, 2S1

flaveolus (Walker), 282

fragaefolii (Cockerell), $2 \$ 3$

gillettei Theobald, 2S4

minor (Forbes), 284

pakansus Hottes and Frison. 286

patonkus Hottes and Frison. 2ST

poae (Gillette), 290

ribis (Linnaeus), 290

tetrarhodus (Walker). 291

carduella Walsh, Aplis, 153

cardui Linnaeus, Aphis, 185

carpinicolens Patch, Macrosiphum, 301

caryate Harris, Aphis, 157

caryae (Harris), Longistigma, 15\%

caryar Monell. Callipterus, 251

caryae (Monell). Monellia, 251

caryaefoline Davis, Callipterus, 250

carlyplla Fitch, Aphis, 252

caryella (Fitch), Monellia. 252

caryclla var. costalis Fitch, Aphis, 252

castaneae (Fitch), Calaphis, 245

castancar Fitch, Callipterus, 245

Catamergus Oestlund, see Macrosiphun, 293

Cavariella Del Guercio, 229

aegopodii (Scopoli), 229

Cepegillettea Granovsky, 246

betulaefoliae Granorsky. 246

cephalanthi Thomas, Aphis, 155

cerasi Fabricius, Aphis, 335

cerasi (Fabricius). Myzus, 335

crosiculens (Fitch). Euceraphis. 249

cerasifoliae Fitch, Aphis, 186

eprealis (kaItenbach), Macrosiphum, $30 \mathrm{~s}$

Cerosipha Del Guercio, 229

rubifolii (Thomas), 229

Chaitophorus liocli, 160

neglectus Hottes and Frison, 161 populifoliae Oestlund, 163

pusillus Hottes and Frison, 163

quercicola (Monell), 164

viminalis dlonell, $16: \mathrm{i}$ 
chetansapa Hottes and Frison, Aphis, $156^{\circ}$

chrysanthemi (Oestlund), Macrosiphum, 302

chrysanthemi Oestlund, Siphonophora, 302

Cinara Curtis, 153

difficilis Hottes and Frison, 153

laricis (Hartig), 155

palmerae (Gillette), 156

pini (Linnaeus), 156

pinicola (Taltenbach), 156

strobi (Fitch), 157

circumfiexus (Buckton), Myzus, 335

circumflexa Buckton, Siphonophora, 335

Clavigerus Szepligeti, 165

populifolize (Fitch), 165

smithiae (Monell), 166

Colopha Monell, 348

graminis (Monell), 348

ulmicola (Fitch), 349

Colophella Börner, see Colopha, 348

Coloradoa. Wilson, 241

corambus Hottes and Frison, Capitophorus, 281

coreopsidis (Thomas), Aphis, $18 \mathrm{~S}$

coreopsidis Thomas, Siphonophora, 188

corni auctt., Anoecia, 152

cornicola Walsh, Eriosoma (?), 152

cornifoliae Fitch, Aphis, 189

comugatans Sirrine, Pemphigus, 370

corrugatans (Sirrine), Prociphilus, 370

coryli Davis, Macrosiphum, 303

coryli Goeze, Aphis, 257

coryli (Goeze), Myzocallis, 257

cosmopolitana Mason. Anphorophora, 274

costalis (Fitch), Monellia, 252

courni Cockerell. Pemphigus, 268

coweni (Cockerell), Tamalia, 268

crataegi (Monell), Macrosiphum, 304

crataegi Monell, Siphonophora, 304

crataegi (Oestlund), Eriosoma, 351

cratregi Oestluud, Schizoneura, 351

crataegifoliae Fitch, Aphis, 190

Cryptomyzus van der Goot, see Capitophorus, 280

cucumeris Forbes, Aplisis, 195

cucurbilue Thomas, Siphonophora, 306

cymosbati (Oestiund), Myzus, 316

duvisi Patch, Aphis, 201

lebilicornis Gillette and Palmer, Anuraphis, 191

debilicornis (Gillette and Palmer), Aphis, 191 .

decepta Hottes and Frison, Aplís, 192

rentatus le Baron, Larlinus, 159 difficilis Hottes and Frison, Cinara, 153

diospyri Thomas, Aphis, $1+2$

rirhorlum Walker, Aphis, 304

dirholum (Walker), Macrosiphum, 304

liscolor Monell, Callipterus, 258

discolor (Monell), Myzocallis, 258

Urepanaphis Del Guercio, 246

acerifoliae (Thomas), 246

keshenae Granovsky, $24 \mathrm{~s}$

nonelli (Davis), 249

claeagni Del Guercio (Davis), Myzus, 283

eleusinis Thomas, Rhizobius, 152

elongata Baker, Saltusaphis, 265

enigmae Hottes and Frison. Rhopalosiphum, 235

enigmae var. parvae Hottes and Frison, Rhopalosiphum, 237

ephemeratus Hottes and Frison, Pemphigus, 365

erayrostial is Middleton, Colopha, 349

erigeronensis (Thomas), Macrosiphum, 304

erigeronensis (Thomas), Prociphilus, 371

erigeronensis Thomas, Siphonophora, 304

erigeronensis Thomas, Tychea, 371

Eriosoma Leach, 350

crataegi (Oestlund), 351

lanigera (Hausmann), 351

mimica Hottes and Frison, 353

rileyi Thomas, 354

essigi Gillette and Palmer, Chaitophorus, 163

essigi Gillette and Palmer, Nyzus, 337

Euceraphis Walker, 249

betulae (Linnaeus), 249

Eulachnus Del Guercio, 157

rileyi (IVilliams), 157

euphorbiar Thomas, Siplonophora, 306

cuphorbicole Thomas, Siphonophora, 306

evansi Theobald, Amphorophora, 278

fagi Limnaeus, Aphis, 264

fagi (Linnaeus), Phyllaphis, 264

feminea Hottes, Aphis, 193

flabella (Sanborn), Iziphya, 250

flubellus Sanborn, Chaitophorus, 250

faveolu Walker, Aphis, 282

flaveolus (Walker). Capitoplorus, 282

flava (Forbes), Sipha. 1it

furus Forbes, Chaitophorus, 174

flocrulosum Weed, Melanoxauthus, 173 
flocculosus ( Weed), Plocamaphis, 173 folsomii Davis, Aphis, 193

forhesi Weed, Aplis, 194

Forda Heyden, 354

occidentalis Hart, 356

olivacea Rohwer, 356

formicaria Heyden, Forda, 356

formicarius Walsh, Pemphigus, 438

formicetorum Walsh, Pemphigus, 438

formosana Takahashi, Amphorophora, 280

fragaefolii (Cockerell), Capitophorus, 283

fragaefolii Cockerell, Myzus, 283

fragariae Theohald. Myzus, 283

fragariae var. immaculata Riley. Macrosiphum, 284

fraxinifolii Riley, Pemphigus, 371

fraxinifolii Thomas, Penuphigus, 372

fraxinifolii (Riley), Prociphilus, 371

frigiticola Gillette and Palmer, Macrosiphoniella, 305

frigidicola (Gillette and Palmer), Macrosiphum, 305

frondosae Oestlund, Aphis, 181

fumipennella Fitch, Aphis, 250

fumipennella (Fitch), Melanocallis, 250

funesta Hottes and Frison, Aplis, 194

fungicola Walsh, Eriosoma(?), 438

galeopsiais (Kaltenbach), Phorodon, $28 t$

gei (Jioch). Macrosiphum, 306

gci lioch, Siphonophora, 306

Geoica Hart, 356

squamosa Hart, 356

Georgiaphis Maxson and Hottes, 357

nlmi (Wilson), 357

geranii (Oestlund), Macrosiphum, 307 geranii Oestlund. Nectarophora, 307

gerariliae Thomas, Siphonophora, 217

yillettei Mlaxson and Hottes, Georgia, 357

gillettei Theobald, Capitophorus, $2 \$ 4$ gladioli Felt, Aphis, 222

Gobaishia Matsumura, 359

nlmi-fusus (Walsh and Riley), 359

gossypii Glover, Aphis, 195

granaria Kirby, Aphis, 308

granarium (Kirby), Macrosiphum, 308

graminis (Monell), Colopha, 348

graminis Mlonell, Tetraneura, 348

graminum Rondani. Aphis, 241

graminum (Rondani), Toxoptera, 241

gravicornis Patch. Macrosiphum, 308 gravicornis Patch, Thecabius, :7t

Gypsoaphis Oestlund, 167

oestlundi Hottes, 167

hamamelidis Fitch, Brysocrypta, 376 hamamelidis (Fitch), Hormaphis, 376
Hamamelistes Shimer, 375

spinosus Shimer, 375

helianthi Oestlund, Aphis, 191

helianthi Monell, Aphis, 196

helichrysi Kaltenhach, Aphis, 203

heucherae (Thomas), Myzus, 337

heucherae Thomas. Siphonophora, 337

Hormaphis Osten Sacken. 376

hamamelidis (Fitch), 376

houghtonensis Troop, Aphis, 335

houghtonensis (Troop), Myzus, $33 \mathrm{~s}$

houardii Wilson, Amplorophora, 240

humuli Schrank, Aphis, 345

humuli (Schrank), Phorodon. 345

Hyadaphis lirkaldy, see Rhopalosiphum, 234

Hyalopterus Koch. 23I

atriplicis (Linnaeus), 231

lyperici (Jlonell), 232

pruni (Geoffroy). 232

hypeici Thomas, Myzocallis, $2: 2$

hyperici Ionell, Aphis, 232

hyperici (Mlonell), Hyalopterus, 232

hyperici Thomas, Myzocallis, 232

Hysteroneura Davis, 232

setariae (Thomas), 232

1diopterus Davis. 292

nephrelepidis Davis, 292

violae (Pergande), 29:

illini Hottes and Frison. Macrosiphum, 309

illini var. crudae Hottes and Frison. Macrosiphum. 311

illini var. sangamonensis Hottes and Frison, Macrosiphum, 312

Illinoia IVilson. see Macrosiphum, 293

illinoisensis Shimer, Aphis, $19 \mathrm{~S}$

imbricutor Fitch, Eriosoma, 372

imbricator (Fitch), Prociphilus, 372

impatiensicolens Patch, Macrosiphum, 312

impatientis Thomas, Aplis, $1 \$ 5$

incognita Hottes and Frison. Cedoaplis, 138

inulae (Walker), Capitophorus, 2ST

lziphya Nersky, 250

flabella (Sanborn), 250

Kakimia Hottes and Frison. $34 t$

keshenae Granorsky, Drepanaplis, 248

kickapoo Hottes and Frison, Macrosiplium, 312

knowitoni Hottes and Frison, Aphis. 199

laburni Kalteubach, Aplis, 199

Lachnus Bnrmeister. see Cinara, 153

lactucae Fitch, Pemphigus, 364

lactucar (Linnaeus). Siphomophora. $33 \mathrm{~s}$

lactucer Schrank, Aphis, Bss 
lactucae (Schrank). Myzus, 338

laevigatae Essig, Macrosiphum, 314

laingi Mason, Amphoropliora, 275

lanigera Hausmann, Aphis, 351

lanigera (Hausmann), Eriosoma, 351

laricifex Fitch, Lachnus, 156

laricis (Hartig), Cinara, 155

laricis Hartig. Lachnus, 155

laricis Walker, Aphis, 155

Liosomaphis Walker, see Rhopalosiphum, 234

liriodendri (Monell), Macrosiphum, 314

liriodendri Monell, Siphonophora, 314

lonicerae Nonell, Aphis, 167

lonicericola Williams, Aphis, 175

lonicericola (Willians). Alphitoaplís, 175

Longistigma Wilson, 157

caryae (Haryis). 157

ludovicianae (Oestlund), Macrosiphum, 315

ludovicianae Oestlund, Siplonophora, 315

luridis Hottes and Frison, Aphis, 200 lutescens Monell, Aphis, 206

lyropictus Kessler, Chaitophorus, 170 lyropictus (Kessler), Periphyllıs, 170

maculatae Oestlund, Aphis, 201

Macrosiphum Passerini, 293

adianti (Oestlund), 296

ambrosiae (Thomas), 298

anomalae Hottes and Frison, 298

carpinicolens Patch, 301

chrysanthemi (Oestlund), 302

coryli Davis, 303

crataegi (Monell), 304

dirlodum (Walker), 304

erigeronensis (Thomas), 304

frigidicola (Gillette and Palmer), 305

gei $($ Koch $), 306$

geranii (Oestlund), $30 \bar{i}$

granarium (Kirby), 308

gravicornis Patch, 308

illini Hottes and Frison, 309

illini var. crudae Hottes and Frison, 311

illini var. sangamonensis Hottes and Frison, 312

impatiensicolens Patch, 312

kickapoo Hottes and Frison, 312

laevigatae Essig. 314

liriodendri (Monell), $\$ 14$

ludovicianae (Oestlund), 315

pallens Hottes and Frison, 315

pisi (Kaltenhach), 317

pseudorosae Patch, 318

ptericolens Patcli, is

purpurascens (Oestlund), 318

ribiellum Davis, 319

rosae (Linnaeus), $\$ 20$ rudbeckiae (Fitch), 320

ruralis Hottes and Frison, 321

samborni Gillette, $: 23$

sanguinarium Hottes and Frison, 323

schranki Theobald, 326

sonchellum (Nonell), 326

tapuskae Flottes and Frison, 327

taraxaci (Kaltenbach), 329

tardae Hottes and Frison, 329

tiliae (Nonell), 331

venaefuscae Davis, 332

zinzalae Hottes and Frison, 332

Macrosiphoniella Del Guercio, see Macrosiphum, 293

nuadia Swain, Macrosiphum, 333

maidi-radicis Forhes, Aphis, 202

maidis Fitch, Aphis, 205

mali Fabricius, Aphis, 210

malifoliae Fitcl, Aphis, 214

meticaginis Koch, Aphis, 199

Melanocallis Oestlund, 250

fumipennella (Fitch), 250

Melaphis Walsh, 359

rhois (Fitch), 359

mellifera Hottes, Hyadaphis, 238

melliferum Hottes, Rhopalosiphum, 238

memorialis Hottes and Frison, Neosymydohius, 262

Microparsus Patcl, 333

variabilis Patch, 333

middletonii Thomas, Aphis, 203

niddletonii Knowlton, Chaitophoroides, 199

mimica Hottes and Frison, Eriosoma, 353

Mindarus lioch, 374

abietinus Koch, 374

minor (Forbes), Capitophorus, $2 \$ 4$

minor Forbes, Siphonophora, 284

minutus Baker, Nelaphis, 360

minutus Davis, Drepanaphis (?), 268

minutum (Davis), Shenaweuns, 268 monardae Oestlund, Aphis, 205

monardae (Williams), Myzus, 339

monarlac Williams, Phorodon, 339

monarlne (Williams), Rliopalosiphum, 339

monelli (Davis), Drepanaphis, 249

monelli Davis, Phynatosiphum, 249

Monellia Oestlund, 251

caryae (Monell), 251

caryella (Fitch), 252

costalis (Fitcli), 252

nigropunctata Granorsky, 252

Mordwilkoja Del Guercio, 360 vagabunda (Walsh), 360

Myzocallis Passerini, 254

alhambra Davidson, 255

alni (DeGeer), 256

alnifoliae (Fitch), 256

asclepiadis (Monell), 256 ; 
bella (Walsh), 257

coryli (Goeze), 257

discolor (Mlonell), 258

ononid is (Kaltenbach), 258

punctata (Ionell), 259

tiliae (linnaeus), 259

walshii (Monell), 259

Myzus Passerini, 334

cerasi (Fabricius), 335

circumflexus (Buckton), 335

essigi Gillette and Palmer, 337

heucherae (Thomas), 337

houghtonensis (Troop), 338

lactucae (Schrank), 338

monardae (TVilliams). 339

persicae (Sulzer), 339

plantagineus Passerini, 340

porosus Sanderson, 340

scroplulariae ('Thomas), 343

thomasi Hottes and Frison, 343

nabali (Oestlund), Amphorophora, 275

nabali Oestlund, Rhopalosiphum, 275

nebulosa Hottes and Frison. Amphoropliora, 275

neglectus Hottes and Frison, Chaitophorus, 161

negundinis Thonias, Chaitophorus, 170

negundinis ('Thomas), Periphyllus, 170

neilliae Oestlund, Aphis, 205

Neomyzus Van der Goot, see Myzus, 334

Neoprociphilus Patch, 361

aceris (Mlonell), 361

attenuatus (Osborn and Sirrine). 362

Neosymydobius Baker. 261

albasiphus (Davis). 261

americanus (Baker), 261

annulatus (Koch), 262

memorialis Hottes and Frison, 262

Neothomasia Baker, see Periphyllus, 170

nephrelepidis Davis, Idiopterus, 292

nerii Fonscolombe, Aplis, 206

nervata (Gillette), Amphorophora, 277

ncrvatum. Gillette, Rhopalosiphum, 277

nigrae Oestlund. Chaitophorus, 165

nigronervosa Coquerel, Pentalonia. 345

nigropunctata Granovsly. Monellia. 252

nyctalis Hottes and Frison, Aplis, 206

nymphaeac Limnaeus, Aphis, $23 S$

nymplnaeae (Linnaeus), Rhopalosiphtwm, 238 oblongus Heyden, Symydobius, 261

occidentalis Hart, Forda, 356

oenotherae Oestlund, Aphis, $20 \mathrm{~S}$

aenotherae Wilson, Anoecia, 151

oestlundi Gillette, Aphis, 208

oestlundi Hottes, Gypsoaphis, 16

olivacea Rohwer. Forda, 356

onoridis Kaltenbach, Aphis, $25 \mathrm{~S}$

ononidis (Kaltenbach), IIyzocallis, $25 \mathrm{~S}$

padi Linnaeus, Aphis, 209

Paducia Hottes and Frison, 167

antennata (Patch), 168

pakansus Hottes and Frison. Capitophorus, $2 S 6$

pallens Hottes and Frison, Macrosiplum, 315

pallida (Oestlund), Macrosiphum, $31 \mathrm{~s}$

pallilu (Walker), Macrosiphum. $31 \mathrm{~S}$

palmerae (Gillette), Cinara, 156

palmerae Gillette. Lachnus, 156

panici Thomas, Tychea, 143

panicola Thomas, Schizoneura, 152

parvae Hottes and Frison, Rhopalosiplum enigmae var.. 237

prastinacae Davis, Hyadaphis, 229

patonkus Hottes and Frison. Capito. phorus, 2ST

pelargonii (Kaltenbaclı), IJacrosiphum, 316

Pemphigus Hartig. 363

brevicornis (Hart). 363

ephemeratus Hottes and Frison, 365

populicaulis Fitch, 366

populi-transversus Riley, 36i

populi-venae Fitch, $36 \mathrm{~S}$

rubi Thomas, $36 \mathrm{~s}$

tartareus Hottes and Frison. 369

Pentalonia Coquere], 345

nigronervosa Coquerel, 345

Periplylius Vau der Hoeven, 170

lyropictus (Jiessler). 170

negundinis (Thomas), 170

populicola (Thomas), 172

persicae Sulzer, Aplis, 339

persicae (Sulzer), Myzus, 339

persicae-niger Smith, Aphis, 209

phaseoli (Passerini). Trifidaphis. 374

phascoli Passerini. Tychea. 374

'horodon Passerini, 345

lumuli (Schrank). 345

Phyllaphis Koch, 264

fagi (Linnaeus). 264

pini Linnaeus, Aphis, 156

pini (linnaeus), Cinara. 156

pinicola (Jialtenbach), Cinara, 156

pinirola kalteubach. Lachuus, 156

pinicola Thomas. Schizoneura, 374

pisi Kaltembach. Aphis, 317

pisi (Kaltenbach), Macrosiphum, 317 
plantagineus Passerini, Myzus, 340

Plocamaphis Oestlund, 172

floccnlosa (Weerl), 173

terricola Hottes and Frison, 173 poae (Gillette), Capitophorus, 290

poue Gillette, Rhopalosiphum, 290

poae Thomas, Rhizobius, 142

pomi DeGeer, Aphis, 210

populella Gillette and Palmer, Chaitophorus, 163

populicaulis Fitch, Pemphigns, 366

populicola Thomas, Chaitophorus, 172

populicola (Thomas). Periphyllus, 172

pomulifolige Davis, Aphis, 202

populifoliae Fitch, Aphis, 165

populifoliae (Fitch), Clavigerus, 165

populifolice Inowlton, Chaitophoroides, 199

populifoliae Oestlund, Chaitopliorus, 163

populi-transversus Riley, Pemphigus, 367

populi-venae Fitch, Pemphigus, $36 s$

porosus Sanderson, Myzus, 340

Prociphilus Joch. 370

corrugatans (Sirrine), 370

erigeronensis (Thomas), 371

fraxinifolii (Riley), 371

imbricator (Fitch), 372

tessellata (Fitch), 373

venafuscus (Patch), 373

producta Gillette. Thripsaphis, 270

pruni Geoffroy, Aphis, 232

pruni Geoffroy, Hyalopterus, 232

pruni Jioch, Aphis, 185

pruni Vilson and Davis, Asiphonaphis, 227

munifoliae Fitch, Aphis, 185, 239

prunifoliae (Fitch), Rhopalosiphum, 239

"1seurlobrassicne Davis, Aphis, 240

pseudobrassicae (Davis), Rhopalosiphum, 240

pseudobyrsa (Walsh), Asiphum, 348 iseurlobyrsa Walsh, Byrsocrypta, 348 pseudorosae Patch, Macrosiphum, 318 ptericolens Patch. Macrosiphum, :18 pulchella Hottes and Frison, Aphis. 212

pulverulens (Gillette), Amphicercidus, 160

loulrerulens Gillette, Aphis, 160

junclatr Monell, Callipterus, 259

punctata (Monell). Myzocallis, 259

punctatell Fitch, Aphis, 271

punctatella (Fitch), Tuberculatus, 271

punclatus (Bnrmeister), Tuberolach. กus, 159

purpurascens (Oestlund), Macrosiplium, 318 purpurascens Oestlund, Nectarophora, 318

pusillus Hottes and Frison, Chaitopholus, 163

pyri Fitcl, Pemphigus, 370

querci (Fitch), Anoecia, 152

querei Fitch, Eriosoma, 152

quercicola Honell, Callipterus (?), 164

quercicola (Mlonell), Chaitophorus, 164

quercicola Baker, Phyllaphis, 268 quercicola (Baker), Stegophylla, 265 quercifoliae Walsh, Aphis, 438

rudieicola Essig, Tychea, 374

radicola Destlund, Tychea, 371

rhamni Fonscolombe, Aphis. 214

rhois Nonell, Rhopalosiphum, 240

rhois Fitch, Byrsocrypta, 359

rloois (Fitcli), Melaphis, 359

Rhopalosiphum Koch, 234

berberidis (Jialtenbach), 235

enigmae Hottes and Frison, 235

enigmae var. parvae Hottes and Frison, 237

melliferum Hottes, 298

nymphaeae (Linnaeus), 238

prunifoliae (Fitch), 239

pseudobrassicae (Davis), 240

rhois Monell, 240

rufomacnlatum (Wilson), 241

ribiellum Davis, Macrosiphum, 319

ribis Linnaeus, Aphis, 290

ribis (Liunaeus), Capitophorus, 290

rileyi Thomas, Eriosoma, 354

rileyi (Williams), Eulachmus, 157

rileyi Williams, Lachnus, $15-$

rociadae Cockerell, Aplis, 214

rosae Linnaeus. Aphis, 320

rosae (Linuaeus), Macrosiphum, 220

rosarum (TFaltenbach), Myzus, 283

rosec Baker. Anuraphis, 214

rosea (Baker), Aphis, 214

rossi Hottes and Frison. Amphorophora, 277

rubecula Haldeman, Aphis, 215

rubi Thomas, Pemphigus, 368

rubicola Oestlund, Aphis, 215

rubicunda (Wilson), Cinara. 155

rubifolii (Thomas), Cerosipha, 229

rubifolii Thomas, Sipla, 229

rubiphilu l'atch, Aphis, 215

rudbeckiac Fitch, Aphis, 320

rudbeckiae (Fitch), Macrosiphum, 320

rufa Mnnell, Macrosiphum liriodendri var., 315

rufomaculatum (W'ilson), Rhopalosiphum, 241

rumicis l,innaeus, Aphis, 215 
ruralis Hottes and Frison, Macrosiphum, 321

salicicola Thomas, Siphonophora, 217 saliceti Kaltenbach, Aphis, 21\% saligna Gmelin, Aphis, 159 saligna (Gmelin), Tuberolachnus, 159

Saltusaphis Theobald, 265

elongata Baker, 265

wanica Hottes and Frison, 266 sambuci Linnaeus, Aphis, $21 \mathrm{~S}$ sambucifoliae Fitch, Aphis, 218 sanborni Patch, Aphis, 218 sanborni Gillette, Macrosiphum, 323 sanguinarium Hottes and Frison, Macrosiphum, 323

schranki Theobald, Macrosiphum, 326 scrophulariae (Thomas), Myzus, 343 scrophulariae Thomas, Phorodon, 343 senecionis Williams, Aphis, $20 \mathrm{~S}$ sensoriata Mason, Amphorophora, 279 setariae Gillette and Palmer, Anoecia, 151

setariae (Thomas), Hysteroneura, 232 setariae Thomas, Siphonophora, 232 Shenahweum Hottes and Frison, 267 minutum (Davis), $26 \mathrm{~s}$

signatis Hottes and Frison, Aphis, 219

similis Van der Goot, Capitophorus, 287

singularis Hottes and Frison, Amphorophora, 279

Sipha Passerini, 174

flava (Forbes), 174

smithiae Nonell, Chaitophorus, I66 smithiae (Monell), Clavigerus, 166 solani (Thomas), Amphorophora, 280 solani Thomas, Megoura, 2SO

solunifolii (Ashmead), Macrosiphum, 306

solidaginifoliae Williams, Aphis, 220 sonchellum (Monell), Macrosiphum. 326

sonchella Monell, Siphonophora, 326 sonchi Davis, Rhopalosiphum, 274 sorbi Kaltembach, Aphis, 214

spicalus Hart, Rhizobius, $34 \mathrm{~s}$ spinosus Oestlund, Chaitophorus, I64 spinosus Shimer, Hamamelistes, 375 spiraecola Patch, Aphis, 211, 220 spiraeclla Schouteden, Aphis, 2 II, 220 spiraeplila Patch, Aphis, 222 squamosa Hart, Geoica, 356

Stegophylla Oestlund, 268 quercicola (Baker), $26 \mathrm{~s}$

strobi (Fitch), Cinara, 157

strobi Fitch, Eriosoma, 157

symphoricarpi Oestlund, Cedoaphis, 438

symphoricarpi Thomas, Aphis, I42. 438 symphoricarpi (Thomas), Thargelia, 142

Tamalia Baker, $26 \mathrm{~S}$

coweni (Cockerell), 265

tapuskae Hottes and Frison, Macrosiphum, 327

taraxaci Kaltenbach, Aphis, 329

taraxaci (Kaltenhach), Macrosiphum, 329

tardae Hottes and Frison, Macrosiphum, 329

tartareus Hottes and Frison, Pemphigus, 369

terricola Hottes and Frison, Plocamaphis, 173

tessellata Fitch, Eriosoma, 373

tessellata (Fitch), Prociphilus, 373

tetrarhorla Walker. Aphis, 291

tetrarhodus (Walker), Capitophorus, 291

Tetraneura, see Colopha, 348

Thecabius Koch, $37 \pm$

gravicornis Patch (?), 374

species (?), 37t

Therioaphis Walker, see Myzocallis, 254

thomasi Hottes and Frison. Mrzus, 343

Thomasia Wilson, 172

Thripsaphis Gillette. 270

ballii (Gillette), 270

producta Gillette. 270

verrucosa Gilette. 271

tiliae Linnaeus, Aphis, 259

tiliae (Linnaeus), Myzocallis, 259

tiliae (Monell), Macrosiphum. 331

tiliae Monell, Siphonophora, 331

Toxoptera Koch, 241

gramiuum (Rondani), 241

tritici Gillette, Brachycolus, $22 \mathrm{~s}$

trifolii Monell, Callipterus. $25 \mathrm{~S}$

Trifidaphis Del Guercio, 3.4 phaseoli (Passerini), 374

tuberculata Patch, Aphis, 193

Tuberculatus Mlordvilko, 271 punctatella (Fitch), 27 ulmifolii (Monell), 272

Tuberolachnus Mordvilko, 159 saligna (Gmelin), 159

tulipae Fonscolombe, Aphis. 22.2

tulipac Thomas, Rhopalosiphum. 339

แlmi (Linnaeus), Eriosoma, 353

ulmi Riley, Eriosoma, 354

ulmi VIilson, Georgia, 35i

ulmi (Wilson), Georgiaphis, 357

ulmicola (Fitch), Coloplia. 34 ?

ulmicola Fitch, Byrsocrypta, 349

ulmicola Thomas, Callipterus. $2: 2$

ulmifolii Monell, Callipterus, 272

ulmifolii (Monell). Tuberculatus, 272 
ulmi-fusus (Walsh and Riley), Gobaishia, 359

ulmi-fusus Walsh and Riley, Pem. phigus, 359

urticae Schrank, Aphis, 326

utricularia (Passerini), Geoica, 357

vaccinii Mason, Amphorophora, 280 vagabunda Walsh, Byrsocrypta, 360 vagahunda (Walsh), Mordwilkoja, 360

variahilis Patch, Microparsus, 333

venaefuscae Davis, Macrosiplum, 332 venafuscus Patch, Pemphigus, 373

venafuscus (Patch), Prociphilus, 373 verbenae Thomas, Siphonophora, 143, $43 \mathrm{~S}$

vernoniae Thomas, Aphis, 222

verrucosa Gillette, Thripsaphis, 271

vihurni Scopoli, Aphis, 224

viburnicola Gillette, Aphis, 223 viburniphila Patch, Aphis, 224

viminalis Mlonell, Chaitophorus, 165 vincae Gillette, Myzus, 336

violae Pergande, Rhopalosiphum, 292

violae (Pergande), Idiopterus, 292

violae Theobald, Neotoxoptera, 292 viticola Thomas, Siphonophora, 198 vitis (?) Scopoli, Aphis, 199

ualshii Mlonell, Callipterus, 259

walshii (Mlonell), Myzocallis, 259

wanica Hottes and Frison, Saltusaplis, 266

xylostei Schrank, Aphis, 298

rylostci (Schrank), Rhopalosiphum, 238

zilora Hottes and Frison, Aphis, 224 zinzalae Hottes and Frison, Macrosiplum, 332 